
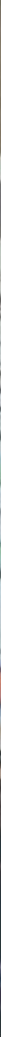

Jannis Julien Grimm

\title{
Contested Legitimacies
}

Repression and Revolt in

Post-Revolutionary Egypt 
Contested Legitimacies 


\section{Protest and Social Movements}

Recent years have seen an explosion of protest movements around the world, and academic theories are racing to catch up with them. This series aims to further our understanding of the origins, dealings, decisions, and outcomes of social movements by fostering dialogue among many traditions of thought, across European nations and across continents. All theoretical perspectives are welcome. Books in the series typically combine theory with empirical research, dealing with various types of mobilization, from neighborhood groups to revolutions. We especially welcome work that synthesizes or compares different approaches to social movements, such as cultural and structural traditions, micro- and macro-social, economic and ideal, or qualitative and quantitative. Books in the series will be published in English. One goal is to encourage nonnative speakers to introduce their work to Anglophone audiences. Another is to maximize accessibility: all books will be available in open access within a year after printed publication.

\section{Series Editors}

Jan Willem Duyvendak is professor of Sociology at the University of Amsterdam. James M. Jasper teaches at the Graduate Center of the City University of New York. 


\section{Contested Legitimacies}

Repression and Revolt in Post-Revolutionary Egypt

Jannis Julien Grimm

Amsterdam University Press 
Cover photo: Graffiti on Youssef El-Gendy Street in Cairo with caption "we will implement Sharia, even if we violate it ourselves"

Photo by Hossam el-Hamalawy

Cover design: Coördesign, Leiden

Typesetting: Crius Group, Hulshout

ISBN $\quad 978946372265^{\circ}$

e-ISBN $\quad 9789048553457$ (pdf)

DOI $\quad 10.5117 / 9789463722650$

NUR $\quad 697$

(c) Jannis Julien Grimm / Amsterdam University Press B.V., Amsterdam 2022

All rights reserved. Without limiting the rights under copyright reserved above, no part of this book may be reproduced, stored in or introduced into a retrieval system, or transmitted, in any form or by any means (electronic, mechanical, photocopying, recording or otherwise) without the written permission of both the copyright owner and the author of the book.

Every effort has been made to obtain permission to use all copyrighted illustrations reproduced in this book. Nonetheless, whosoever believes to have rights to this material is advised to contact the publisher. 


\section{Table of Contents}

Preface

1 Introduction 13

$\begin{array}{lr}\text { History in the Making } & 15\end{array}$

Interactionist Approaches and the Arab Uprisings 20

The Egyptian Revolution as the Result of a Hegemonic Crisis $\quad 24$

Political Subjectivation and the Emergence of New Contentious

$\begin{array}{ll}\text { Alliances } & 26\end{array}$

Situating this Project $\quad 28$

2 Conceptual Choices and Theoretical Framework 43

$\begin{array}{lr}\text { Players and Arenas } & 46\end{array}$

Contentious Interaction at Critical Junctures $\quad 49$

Making Events Transformative $\quad 5^{2}$

A Discourse Theoretical Perspective on Contentious Politics $\quad 55$

3 Brothers and Rebels $\quad 69$

$\begin{array}{ll}\text { The Polarization of Egyptian Society } & 71\end{array}$

$\begin{array}{ll}\text { Rebellion against Mursi } & 78\end{array}$

$\begin{array}{ll}\text { The June } 30 \text { Uprising } & 81\end{array}$

$\begin{array}{lr}\text { A Crisis of Legitimacy } & 84\end{array}$

4 Coup and Anti-Coup $\quad 89$

From Government to Opposition 90

The Constitution of the Anti-Coup Alliance as a Political Player $\quad 94$

Constructing the Antagonist Other 100

The Republican Guard Massacre 109

$\begin{array}{lr}\text { A Popular Mandate for Repression } & 118\end{array}$

$\begin{array}{lr}\text { Setting Course for Violence } & 126\end{array}$

5 Myths and Martyrs 133

The Making of a Massacre 134

$\begin{array}{lr}\text { The Rabaa Salute } & 139\end{array}$

The Rabaa Martyrs $\quad 145$

Backlash to the Rabaa Massacre $\quad 159$ 
$\begin{array}{ll}\text { Tactical Adaptation } & 167\end{array}$

Discursive Path Dependencies 179

6 New Sheriff in Town $\quad 189$

Anti-Coup Resistance from Abroad $\quad 191$

Victors' Justice 194

The Rehabilitation of the Armed Forces 197

$\begin{array}{ll}\text { Shrinking Spaces } & 203\end{array}$

A Winning Formula for Popular Support $\quad 207$

7 A Tale of Two Islands $\quad 213$

Reshaping the Protest Arena $\quad 215$

$\begin{array}{ll}\text { The Limits of Securitization } & 217\end{array}$

The Popular Campaign to Protect the Land 224

$\begin{array}{ll}\text { Sinai Liberation Day } & 229\end{array}$

Turning the Nationalist Discourse Inside Out 240

Harnessing the Memory of January 25 for Coalition Building 253

8 Conclusion and Implications $\quad 271$

Autocratic Restoration through the Lenses of Contentious Politics 273

From a Relational to an Interactionist Perspective on Protest and

$\begin{array}{ll}\text { Repression } & 278\end{array}$

Conceptualizing the Discursive Arena of Contentious Politics $\quad 282$

Prospects for Resistance in Egypt $\quad 285$

Appendix: A Mixed-Method Approach to the Study of

Contentious Interaction 295

Combining Protest Event and Discourse Analyses in a Nested Research Design $\quad 296$

Event Data and their Limitations $\quad 298$

Political Discourse Analysis $\quad 301$

$\begin{array}{ll}\text { Source Selection } & 305\end{array}$

Data Collection and Ethical Dilemmas $\quad 307$

$\begin{array}{ll}\text { Bibliography } & 313\end{array}$

$\begin{array}{ll}\text { Index } & 343\end{array}$ 


\section{List of Figures and Tables}

\section{Figures}

$\begin{array}{lll}\text { Figure } 1 & \text { Trajectory of Anti-Coup protests and state repression } & 92\end{array}$

Figure 2 Antagonist frontier in the Anti-Coup discourse 95

Figure 3 Construction of legitimacy and corresponding AntiCoup action strategy

Figure 4 Construction of antagonist other in the Anti-Coup discourse

Figure 5 The coup as a mirror image of the Anti-Coup resistance 106

Figure 6 Construction of antagonist other after the Republican Guard Massacre

Figure 7 Evolution of Anti-Coup demands in response to repression 122

Figure 8 Construction of antagonist other after Mandate Friday $\quad 125$

$\begin{array}{lll}\text { Figure } 9 & \text { The Rabaa salute } & 140\end{array}$

Figure 10 Construction of the moral qualities of the Anti-Coup protesters

Figure 11 Construction of the moral corruption of the coup forces 155

Figure 12 Political violence throughout the protest cycle $\quad 165$

Figure 13 Impact of transformative events on protest turnout $\quad 168$

Figure 14 Impact of transformative events on protest rates $\quad 168$

Figure 15 Timing of the Anti-Coup protests 172

Figure 16 Impact of leadership decapitation on protest frequency $\quad 176$

$\begin{array}{lll}\text { Figure } 17 & \text { Evolution of the Anti-Coup repertoire } & 177\end{array}$

$\begin{array}{lll}\text { Figure } 18 & \text { PCPL protest rate and turnout } & 225\end{array}$

Figure 19 Repression of PCPL protest events $\quad 225$

$\begin{array}{lll}\text { Figure 20 } & \text { PCPL protest repertoire } & 227\end{array}$

Figure 21 Meaning of the island deal in the PCPL discourse 242

Figure 22 Tiran and Sanafir as a bridge between revolutionary and nationalist discourses $\quad 256$

Figure 23 Antagonist frontier in the PCPL discourse 262

$\begin{array}{ll}\text { Figure } 24 \text { Nested research design } & 297\end{array}$

Figure 25 Temporal fixation of meaning in a discourse 304

Figure 26 Alternative fixation of meaning based on identical signifiers

Tables

Table $1 \quad$ List of Anti-Coup miliuniya protests, Fridays highlighted 171

Table 2 Comparison between official casualty figures and Wiki Thawra 301

Table 3 Key terminology of discourse theory 302 



\section{Acknowledgments}

Our texts are indebted to our intellectual encounters with other people and their works. I am grateful to all those colleagues, mentors, and friends who have so graciously shared their ideas and insights with me. Your engagement with my work has been a privilege. It made writing this book a rewarding experience. To begin with, I thank Cilja Harders, Carola Richter, and Donatella Della Porta for their guidance and mentorship throughout this challenging project. This book would not exist without your encouragement and belief in my work. I am also particularly grateful to James Jasper and Jan Willem Duyvendak for welcoming me into this inspiring series, and to AUP's Maryse Elliott, Irene van Rossum, Julie Benschop-Plokker, Mike Sanders, and Jaap Wagenaar for their editorial support. Particularly Jim's kind advice and practical suggestions to improve earlier versions of this book cannot be overestimated. Likewise, special thanks go to Swen Hutter for his constructive engagement with my manuscript.

This work was supported by the Berlin Graduate School Muslim Cultures and Societies, the Center for Middle Eastern and North African Politics and the Center for Interdisciplinary Peace and Conflict Research at Freie Universität Berlin, the German Institute for International and Security Affairs (SWP), the Institute for the Study of Protest and Social Movements (ipb), COSMOS / SNS Florence, and the Orient Institute Istanbul. I was furthermore able to present and discuss my work in Athens, Berlin, Bochum, Cairo, Florence, Frankfurt, Gothenburg, Istanbul, London, New York, Oslo, Oxford, Pisa, and Washington.

In each of these places, I enjoyed the help and support of numerous friends and colleagues. Their willingness to give their time so generously during the planning and development of this project was crucial. For their care, commitment, and countless inspiring exchanges, I am particularly grateful to Nadine Abdalla, Schirin Amir-Moazami, Amro Ali, Felix Anderl, Khalil Al-Anani, Muriel Asseburg, Nagwan Al-Ashwal, Abdelrahman Ayyash, Hanan Badr, Erika Biagini, Jan Boeddeling, Lorenzo Bosi, Elias Steinhilper, Teije Hidde Donker, Marie Duboc, Tine Gade, Max Gallien, Nick Gjorvad, Ellis Goldberg (Rest in Power), Lisel Hintz, Andrea Jud, Gudrun Krämer, Vickie Langohr, Aleksandra Lewicki, Marc Lynch, Stefan Malthaner, Danilo Marino, Mohammed Masbah, Lars Ostermeier, Stephan Roll, Ilyas Saliba, Dina El-Sharnouby, Simon Teune, Mareike Transfeld, Laura Turiano, Giorgos Venizelos, Dina Wahba, Annette Weber, Isabelle Werenfels and Allison West. The personal toll of doing research on violence and suffering is rarely 
talked about, but it is all too real. Therefore, I am grateful for being part of such a kind and supportive community.

Equally as important for the conclusion of this project was the unwavering moral support of my family. I cannot begin to express my thanks to my love Johanna who accompanied me on this journey from its very beginning. You stood by me in times of doubt, helped me stay on track, and kept my curiosity alive. Your care and commitment make me forever grateful.

Finally, my gratitude goes to the activists, protesters, and citizen reporters who were willing to share their memories, and sometimes their flats and offices with me. Our commitment as researchers pales in the light of your engagement for a better future. Because of potential repercussions or agreed-upon confidentiality, your names remain unmentioned here. But I am confident that you know who you are. Importantly, I know who you are, and I am deeply thankful for your trust. 


\section{Preface}

Accounts of revolutions are necessarily situated and partial. As Jack Shenker (2016) writes, "What defines a revolution - where it can be located on a calendar and a map, what it includes, who speaks for it, the things it seeks to change - is never a neutral question" (p. 11). Accordingly, this book is political by default: for its perspective, which honors the premise that "the vision is better from below" (Haraway, 1988, p. 584); for its choice of topic - an investigation of struggle and contention within a regime that professes unity and concordance; and for its source archive, which gives voice to the mobilized people as the agents of change.

Many of the crises described and investigated in this book are rooted in group-based forms of inequality. These inequalities are not just testing grounds for refining and elaborating theory. On the contrary, they are real arenas of struggle that affect the livelihoods of real people. Critical research must recognize these struggles as such by taking them as the point of departure and by aiming towards their solution. Discourse analytical projects, such as this book, have a particular responsibility in this regard because power relations that cement inequalities and legitimize oppressive modes of domination have a vital discursive basis of reproduction - in Egypt as much as elsewhere. Accordingly, I hope that this book remains not just an academic treatise, evaluated only by methodological quality criteria, but one that also provides some insights for activists on how to maintain their resistance in the darkest hour. The presented cases demonstrate that even when the physical space is limited for protest, there often remains discursive space for contesting oppressive power relations.

Different stories could have been explored in this book about Egypt's post-revolutionary trajectory. One could think about exploring how the Rabaa massacre has produced embodied memories that still leave an imprint on Egyptians' fears, desires, and action choices today. One could explore how Egyptians have grappled with individual and collective memories of bloodshed. One could investigate how the nationalist turn has catalyzed the emergence of an affective regime to govern the desires that were born out of the revolutionary experiences of 2011. Or, more modestly, one could explore how emotions in Egypt, up until today, are subjected to a friend-foe binary to support the antagonizing of all those who dare articulate dissent.

Given the constraints of this book, I am unable to follow up on these and many other threads. Nor am I able to write about the variety of actors who have been mentioned in this book in passing and whose voices have not been 
explored with the same level of detail. To reach a better understanding of those fateful months after the military coup in Egypt, it would be necessary to explore these silences in more detail. Aware of these constraints, I don't claim to provide an exhaustive account of Egypt's bloody summer of 2013. The presented truths must be taken as "positioned truths" (Abu-Lughod, 2014, p. 468). Many more stories could be told without providing a complete picture. I believe that putting these different perspectives into dialogue with one another is what gives our individual subjective accounts value and worth. 


\title{
$1 \quad$ Introduction
}

The lessons of the Arab Spring for the study of protest in Egypt

\begin{abstract}
The Arab Spring left a deep imprint on Middle Eastern and North African societies, but also on social movement scholarship. In particular, three lines of inquiry provide vantage points for investigating protest in the region today: critical approaches that avoid the structuralist bias of early analyses of the Arab Spring and, instead, focus on the imaginative terrain of social protest; constructivist approaches that retrace how political subjectivation processes enabled innovative revolutionary alliances; and relational approaches that investigate the interactions between different players during the 2011 uprisings. This book is situated at the intersection of these strands of literature. It is an attempt to map contentious politics in post-revolutionary Egypt and show how different social arenas, street politics, and the politics of signification, interrelated, and informed the country's transition.
\end{abstract}

Keywords: Arab Spring, Egypt, social movements, alliances, political arenas, contentious dynamics

A decade after the popular uprising of 2011, Egyptians are witnessing an authoritarian comeback under the auspices of a military-backed government, a politicized judiciary, and a weak shadow parliament. This restoration of autocracy is all the more astounding as it was first initialized by a military coup that was backed by millions of Egyptians marching in the streets and then enforced by a fierce crackdown on the supporters of the deposed president. Spearheaded by the Egyptian Muslim Brotherhood (MB), several groups had organized themselves in a broad coalition that rejected the coup against President Mohammed Mursi, himself a Brotherhood member, as an illegitimate intervention into the country's democratic transition. The so-called National Alliance in Support of Legitimacy (NASL),

Grimm, Jannis Julien, Contested Legitimacies: Repression and Revolt in Post-Revolutionary Egypt. Amsterdam: Amsterdam University Press 2022 DOI: 10.5117/9789463722650_CHO1 
commonly referred to as the Anti-Coup Alliance, defied authorities with country-wide peaceful protest marches. The alliance organized the largest wave of Islamist mobilization in Egyptian history, occupying several public squares in the capital with large camps, not unlike the earlier sit-ins on Tahrir Square.

This protest campaign was met with fierce repression by the Egyptian security forces, which cracked down on protesters indiscriminately and with utmost brutality. But other than during the 2011 Tahrir uprising, this time, they were successful. Even as police violence peaked in mid-August with several massacres, authorities drew scant criticism on a national level. On the contrary, state violence came with vigorous attempts by media and public figures to justify the killings (Grimm, 2013). Many defended the massacres as a legitimate police operation against terrorist forces. Others did not necessarily welcome the violence but justified it as a necessary evil to end the Muslim Brotherhood's grip on power, and as a corollary of the mass protests that had ousted President Mursi who hailed from the group. Declarations of solidarity with the victims of the massacres thus remained limited to the Islamist segment of society.

The "coup-volution" (Hamada, 2014, p. 37) against President Mursi several weeks earlier had set the stage for this muted reaction to unprecedented bloodshed. In an overwhelming show of political determination, large masses of Egyptians, including many groups that had been key in the mobilization against the Mubarak regime, had welcomed Mursi's removal from office on July 3, 2013. In their eyes, Mursi had derived his legitimacy from a narrow victory in a contentious election, where the choice, for most of the Tahrir activists, had been between two evils. Not realizing this predicament, he had done little to placate his opponents' fears of the advent of an Islamic state in Egypt. He pursued an exclusivist winner-takes-all policy and alienated the revolutionary opposition along the way. The various new political forces that had entered the scene with the Tahrir revolution were not provided with platforms for dialogue or inclusion. Instead, the government and its supporting Freedom Justice Party took Mursi's marginal electoral victory in the presidential runoffs with 51.73 percent of the cast votes as grounds for uncompromising policymaking. They also took to discrediting all dissent as an illegitimate disruption of the democratic process. When the Tamarod [rebel] campaign filled Tahrir Square with hundreds of thousands of angry protesters, his uncompromising stance had undermined President Mursi to such a degree that any insistence on his democratic legitimation held little credibility outside of his core constituency. 


\section{History in the Making}

At times, it is not until decades later that observers or participants of historical events recognize the meaning of what they were part of, and experienced. History, by nature, emerges only in retrospect. What makes historical events meaningful - and what they signify for the course of history - is mostly visible only when attention is turned to it with hindsight. This is true particularly for the protagonists of longue-durée social movements, like the struggle for women's rights or the pacifist anti-war movement, who have sometimes not even lived to reap the fruits of their efforts. At times, however, it is already as events unfold that spectators realize that they are witnessing history in the making. The question of what makes such events historic; what compels people to grasp the liminal character of what they are witnessing, has been answered philosophically by Wilhelm Hegel (1910). He generally affiliated historical breaks with violent eruptions of social and political contestation - as crucial elements in a sequential chain of successions of wars and victors. Building on this thought, Robin Wagner-Pacifici (2010) has affirmed the conditioning nature of violence for the individuals who populate history. But he also contends that violence inheres not only in the material sequence of events:

It inheres as well in the naming, appropriating, and displacing of this violence as cultural artefacts do the work of constituting history. This work of constituting history takes enormous effort. Events must force their way into historical subjects' fields of attention and action, and while violence is not an essential ingredient of all historic transformations, it is a condition of many of them. Great things are at stake, including the remaking of social and political identities and the redistribution of power and resources. (p. 1358)

In Egypt, the well-studied January 25 uprising against Husni Mubarak has been described as such a crucial moment of experiencing history live unfolding - and as one conditioned and accompanied by levels of political violence in the streets which were unprecedented in the country's republican history. The historic impact of this violence as a precipitating force manifested itself in Mubarak's ouster after close to three decades in power. But it also showed itself through the emergence of new ways of doing politics in a country where decision-making had always been a prerogative of the regime and its cronies. The brutal repression unleashed upon those who occupied Tahrir Square marked the beginning of the end of this top-down 
approach. When authorities began to treat every walking Egyptian citizen as a potential enemy, this decisively undercut Mubarak's claim to political legitimacy. As state violence reached unprecedented levels, his regime increasingly resembled "an occupying force, an authority whose legitimacy is based, above all, on naked power" (Naeem, 2019).

It is no coincidence that the quest for political legitimacy and the struggle over its sources took center stage in post-revolutionary Egypt. As Nicola Pratt (2015) has argued, since the 2011 uprising, "the most significant contest revolves not around institutions or political party programs, but conceptions of Egyptian identity" (p. 44). During the so-called "18 days of Tahrir," the place where the people gathered, the square itself, had replaced Egypt's state institutions as the incarnation of the Egyptian populace, and thus as the ultimate source of all political legitimacy. But this consensus eroded in the months after, and a vicious struggle began over the nature, source, and consequences of political legitimacy in the post-Mubarak era. Thanassis Cambanis (2013) has summarized the implications of this struggle:

What grants legitimacy to a leader? The question usually arises in the abstract realm of political theory, but in today's Egypt, it has become one of visceral, daily importance. How big does a crowd of protesters have to be to indicate an elected leader is no longer the voice of his people? When do self-interested or authoritarian policy decisions go so far as to invalidate the mandate of an elected government? On the streets of Cairo, these questions have come to occupy the center of a serious, messy conversation about how to build a healthy and accountable new state.

In retrospect, the 2011 Tahrir occupation can be interpreted as the first episode of this conversation. This episode has been at the center of countless studies of the so-called Arab Spring. Equally significant, but significantly less studied, are the episodes at the heart of this book. The massacres of Rabaa al-Adawiya and Al-Nahda two and a half years after the Tahrir uprising were a watershed moment in the history of modern Egypt. ${ }^{1}$ Like the Tahrir uprising, this critical juncture represented a violent moment of history in the making. Hardly anyone witnessing the events unfolding on August 14,

1 For better accessibility, I have refrained from making use of various complex scholarly systems of rendering written and spoken Arabic in the Latin script. Instead, throughout this study, Arabic has been transliterated according to a simplified version of the system employed by the International Journal of Middle East Studies, available at https://ijmes.chass.ncsu.edu/ docs/TransChart.pdf. All translations are my own. 
2013, either live, on television, or through social media, failed to notice the liminality inherent in what they saw. Horrific images emerged of the Egyptian army and police troops brutally cracking down on protesters in the streets and squares that had witnessed an iconic uprising against authoritarian governance only two years earlier. These images were broadcasted in infinite loops over the following weeks and supplemented by gruesome footage from Cairo's morgues. They left a deep imprint on those who saw them. Egypt, after Rabaa, would never be the same. As Dina Wahba (2017) wrote in her powerful recapitulation of the events in the fourth year after,

Rabea cannot be seen as a singular event but should be viewed as a key moment within almost two-and-a-half years of state-sponsored violence up until that moment, in which Egyptians had to a great extent normalized images and videos of violence and death, from Tahrir to Maspero, to Mohamed Mahmoud, to Port Said.

At the time of the crackdown, I had been working on the mobilization efforts by the National Alliance in Support of Legitimacy (NASL), commonly referred to as the Anti-Coup Alliance, for several weeks. The mostly Islamist protest alliance had defied authorities with country-wide peaceful marches since President Mursi's removal from office. I had talked with participants of the protest camps in Nasr City in the weeks before the massacres. And I followed up on these conversations in their aftermath. The central aim of these conversations was to try to make sense of the counter-intuitive effects of the massacre on Egypt's political public. Unlike after the experience of disproportionate state violence on Tahrir, a backlash to the repression, in terms of dissident mobilization across ideological and social cleavages, had failed to materialize (Grimm \& Harders, 2018). The repression was condemned by local and international human rights defenders as crimes against humanity. But it barely drew any criticism at the national level - let alone popular outrage that could have materialized in protests. The overwhelming majority, including public intellectuals of all political persuasions, welcomed the security forces and their strongman's resolve against the Islamists. Those protesting the violence were shamed, expelled from parties, and chastised on social and public media. It was disturbing to witness many of those who had been victimized by repression only two years earlier now relativize or even cheer for the very same kind of state violence. Amongst those supporting the repression were respected journalists, activists, and the leaders of several ostensibly pro-democratic and liberal parties and social movements. 
Moreover, the witnessed sequence of events also ran counter to much of what sociological theory suggested about the impact of brutal police violence on protesters: driven by the question of why repressions worked in some instances, but not in others, social movement scholars had explored the mobilization-repression nexus for over four decades. While this body of research found the empirical link between mobilization and coercive response to be so stable that it assumed a law-like character (Davenport, 2007 b, p. 7), a heated debate had been fought over the effect of repression on mobilization, with a variety of conflicting correlations being statistically established over time. In an attempt to refine their models, scholars had turned to the material qualities of repressions to explain the diverging reactions on the protester's side: repressions were found to be effective when applied pre-emptively and selectively (M. Hafez, 2003; Mason \& Krane, 1989), when violence was not employed indiscriminately against opponents and regardless of their rank (Khawaja, 1993), and when the level of repression did not surpass a certain threshold (Alimi, 2009; Hess \& Martin, 2006). Otherwise, regime forces risked a "moral shock" (Jasper \& Poulsen, 1995, p. 498) to society that raised such a sense of public outrage that individuals became inclined to act, even in the absence of prior networks of recruitment and mobilization.

Such a moral shock failed to materialize after Rabaa, even though repression was applied reactively and indiscriminately against opponents. Contrary to what social movement theorists would have expected, since the military overthrow of President Mursi, rather than protest, Egypt witnessed a rapid counterrevolution. Ten years after the popular uprising, national security and the "war on terror" have become the dominant frameworks for the implementation of ever more restrictive domestic policies in Egypt. They have replaced the coalition-enabling revolutionary slogan of "bread, freedom, and social justice" of 2011 in the mobilization of the political public. Gradually, the security discourse constructed by state officials has been extended from including only the Islamist segment of society to all actors voicing criticism of the regime or the security forces' handling of street protests. Today, mobilization efforts have all but ceased.

This book essentially attempts to retrace how Egyptians got to this point. Starting from the puzzle of absent repression backlash despite ideal-typical conditions, it examines the patterns of contention in Egypt since the summer of 2013. It thereby seeks to provide an answer to the pertinent question asked by Donatella Della Porta (2016) in a recent intervention: "Where did the revolution go?" In other words, this study closely traces the unfolding waves of mobilization and repression in Egypt after the extensively 
investigated revolutionary period of the so-called Arab Spring (2011-2012). Broadly speaking, the topic of this book is thus the issue of mobilization in an authoritarian setting. More specifically, it is the interaction processes between different political players in Egypt's post-revolutionary arena that takes center stage - between protesters of different colors, and between today's rulers and their former contenders.

The eight chapters of this book narrate Egypt's post-revolutionary history through the lenses of contentious politics. This narration begins in late 2012, with the wave of dissent that emerged in Egyptian streets against the policies of Egypt's first freely elected president Mohammed Mursi which were widely perceived as erratic and despotic. Popular discontent with the administration's performance manifested in country-wide street protests and culminated in the iconic Tamarod [rebel] uprising on June 30, 2013, which paved the way for Mursi's ouster. It then moves to the mass protest against the military coup, on July 3, 2013, which arguably represents the most significant wave of mobilization since the iconic mass protests on Tahrir Square in January 2011. As one of the first academic works, this book takes a closer look at this episode, illustrating how it established path dependencies for a powerful counterrevolution that reversed most of the achievements of the 2011 uprising.

The way how this counterrevolution and authoritarian restoration unfolded in the months after Rabaa is the topic of another episode discussed in this book. It covers the post-coup period in Egypt and reconstructs the emergence of a new hegemonic consensus that legitimized the restoration of the most repressive regime in Egypt's republican history - embodied in the leadership of General Abdel Fattah Al-Sisi. Alive to the debate about the general's prospects as Egypt's new "president-for-life" (R. Owen, 2012), the narration ends on a positive note. The final episode of contention covered in this study shifts attention back to Egypt's streets to show that the new authoritarian order in Egypt is far from consolidated. The popular protests against the transfer of a small Red Sea archipelago to Saudi Arabia illustrated how the seeds of resistance have already been planted: When certain historic events made it apparent that authorities did not walk their talk, mobilizing players were provided with an opportunity to subvert the securitizing discourses that sustained the status quo. This opened windows for mobilization and facilitated oppositional alliance building in a seemingly closed context.

Zooming in on these different contentious episodes, this book emphasizes the performative and discursive interaction of diverse coalitions of contenders and their authoritarian counterparts as key for understanding the trajectory of Egypt's post-revolutionary transformation. Above all, three 
different lines of inquiry in social movement studies of the Arab Spring provided the conceptual basis for this project.

\section{Interactionist Approaches and the Arab Uprisings}

The contentious relationship between protesters and policing agents has been investigated extensively by social movement studies with the help of case studies from across the globe. From this work, as Christian Davenport (2005: vii) noted, we have a sense of what tactics will be used on both sides and what provokes violent behavior; we have some insights into what consequences are likely when movements take to the street, or when protests are crushed by repression, and we have some idea of where to look for information. For the most part, however, investigations of what is varyingly called the mobilization-repression nexus (e.g., Davenport, 2005; Johnston, 2012; Tilly, 2005) or the repression-dissent nexus (e.g., Lichbach, 1987; Tilly, 2005) rarely transcended the study of aggregate accounts. Attempts to establish causality and derive action-reaction models black-boxed the interaction process itself, effectively reducing the study of protest and repression to an endless correlation of the total aggregate level of one output (repression) with another (protest) (see Lichbach, 1987, p. 288). As a result, and with few recent exceptions (Moss, 2014; Soudias, 2015; Della Porta \& Tarrow, 2012), the current state of research on protest-repression-dynamics broadly consists of two separate strands, with each investigating either of the two sides of the interaction.

By contrast, the volatile situational dynamics of the Arab Spring in late 2010 and early 2011 clearly illustrated the need to move beyond such unidirectional analyses. The sudden appearance of mass protests against authoritarian rule in the Middle East and North Africa caught scientists by surprise as it posed a major puzzle for both, movement and regime scholars. The grievances of Arab societies caused by the "lingering political, social, and economic crises" (Harders \& König, 2013, p. 7) had been known for more than a decade and fueled the notion of Arab exceptionalism from the supposed global democratization trend (Valbjørn \& Volpi, 2014). These old crises of the Arab regimes held little explanatory power for the wave of new protests across the region. Besides, in the run-up to the popular uprisings, neither the cohesion among regime elites, nor the composition and permeability of their polities, nor the capacities of their coercive apparatuses had undergone significant changes. In the light of quite stable political opportunity structures, political players and their choices seemed to hold 
answers to the puzzle of how regime-threatening popular protest could erupt in a context of authoritarian contraction. During the Arab Spring, it was both, regime agents and mobilizing groups that created new windows of opportunity for social transformation in their highly dynamic interaction (Davenport \& Moore, 2012; Harders \& König, 2013; Ketchley, 2014; Shokr, 2015; Volpi \& Clark, 2019).

Particularly in the Egyptian January 25 Revolution, increased mobilization efforts and the radicalization of protesters' demands can be attributed to short-dated interaction effects (see El Chazli, 2018, p. 150). When the authorities awakened to the fact that the turnout during the first days of protests was unprecedented in that 'for the first time in most protesters' memory, they outnumbered police" (El-Amrani, 2011, p. 3), they hastily shut down the cell phone and internet networks across the country to undermine online mobilizing structures. Contrary to their intention, however, this only sparked more demonstrations - largely by people who had until then abstained from participation, but were now disrupted by the shutdown and dragged into the confrontation (Hassanpour, 2011, p. 28). Anti-regime protests culminated on January 28, 2011, dubbed by activists the Friday of Rage. Unable to control the masses, police forces eventually withdrew from the streets, ceding the first victory to the protesters on Tahrir Square. The 18 days of Tahrir thus clearly demonstrated the need to closely study the patterns of interaction between different political players including state institutions and social movement organizations on a day-to-day basis.

It is hence not surprising that the aftermath of the Arab Spring saw relational and interactionist approaches make their way into the study of protest in the Middle East (Berriane \& Duboc, 2019; Bishara, 2015; Grimm, 2019; Grimm \& Harders, 2018; Volpi \& Clark, 2019; Volpi \& Jasper, 2018). Earlier studies of the uprising had overwhelmingly focused on the economic, social, or technological conditions, and hence the macro-structural environment of the uprisings. As Frederic Volpi (2014) laments, one was hard-pressed to find an account of the Arab uprisings that did not include "a lengthy account of the social, economic, and political structures that underpinned the uprisings" (p. 154). By contrast, studies of protest in the post-revolutionary period recognized the explanatory power of interaction, confirming an overall trend in the study of social mobilization "away from vague macro-level structures that are posited by the observer but are otherwise invisible, toward concrete micro-level phenomena that are commonsensical and visible to anyone" (Jasper \& Volpi, 2018, p. 17). These contributions centered on the interactive and situated processes of mutual orientation between different players as 
central explanatory variables for investigations of social movements and social mobilization processes (see Jasper, 2012).

Notably, the new cultural-interactionist turn in the research of protest in the Arab World was championed by researchers that resorted to the vocabulary of players and arenas as building blocks of their analysis. Developed by James Jasper and Jan Willem Duyvendak in several articles (Jasper, 2010; McGarry et al., 2016) as well as two complementary volumes with examples of empirical application (Duyvendak \& Fillieule, 2015; Jasper, 2015a, $2015 \mathrm{~b}$ ), the "players and arenas"-framework emphasizes the situatedness and contingency of social change. It posits a "strategic-interactive picture of politics, full of actions and reactions, expectations and calculations, and also emotions" (Jasper, 2015a, p. 20). At the core of this approach are thus not the far-reaching and long-term changes in the structure of society or the emergence of social crises or new conflict cleavages, but the behaviors, strategies, and emotions of the actors at the center of these macro-processes. As Frédéric Volpi and Janine Clark argue (2019, p. 2), this fine-grained view of contentious politics facilitates transcending the common but limiting dualist focus on the outcomes of political processes and an orientation towards the micro-interactions that drive them. Sequences of interactions by strategic social players in different social arenas are attributed special importance in explaining social movements and revolutionary processes, such as the Arab Spring. They help explain the emergence of powerful coalitions of contenders, such as those between marginalized workers, disenfranchised Islamists, professional liberal activists, and organized Youth groups that were tantamount to the success of the Arab uprisings. But they also help explain the failure and success of autocrats in repressing these coalitions and their actions.

The events of the Arab Spring exemplified, for instance, how repressive measures can backfire on their agents, and have even a catalyzing effect on mobilization (see Grimm \& Harders, 2018; Holmes, 2012; Shokr, 2015). Strategic interactionist perspectives, in turn, help understand how such backfire effects come about or why protests, in response, may turn violent (see Ketchley, 2014; Nassauer, 2016, 2019). Above all, they conceptualize regimes as complex compound players and hence help to decompose, or "break down" (Duyvendak \& Jasper, 2015) states, as the uniform actors they are often assumed to be. Instead, the state is deconstructed into its constituent actors and arenas, into fragmented units, such as different executive institutions, different branches of government, and different policing agents - for instance, the riot police or the armed forces in the case of Egypt. In complex social arenas, such as the protest setting of post-coup 
Egypt, these different players meet, interact strategically with each other, and negotiate their boundaries. At times, these interactions even manage to blur the boundaries between movement and state actors (see Verhoeven \& Bröer, 2015), such as in those cases where players defect and change sides in the struggle of the people vs. the state.

Such defections have been the topic of ample discussion with a view to the Arab Spring (see Grewal, 2018; Holmes \& Koehler, 2020; Nepstad, 2013). Especially for the Tahrir uprising, countless articles have investigated the process by which the army and the people became "one hand" (Ketchley, 2014), thus setting the stage for the breakdown of the ruling coalition and Mubarak's ouster. The Egyptian case seemed to prove that it was particularly the perceived violation of moral codices (e.g., of a people's dignity) which inspired rifts and defections within the ranks of formerly unified players (see Khosrokhavar, 2018, p. 169ff.). Previous works from other geographical areas supported this line of argument. They suggested that, regardless of regime type, structural disposition, or repressive capacity, any state conduct could mobilize opposition if it was only considered illegitimate or disproportionate concerning their expectation of how authorities should behave (e.g., Almeida, 2003; Hess \& Martin, 2006; Opp \& Roehl, 1990).

Yet, how is it that something comes to be perceived as unjust, illegitimate, disproportionate, or abusive by a critical mass? How does this perception translate into action? Our expectations of situations, after all, are culturally mediated, as Jim Jasper has stressed (2018):

How people understand the world around them - including other players, arenas, and even themselves - is central to any theory of action that aspires to go beyond the simplistic, self-interested individuals of rational choice theory. There is an objective world outside our interpretations of it, but it only affects how we act when it is filtered through those interpretations. Meaning is unavoidable. (p. 13)

This is equally true for the meaning that is attributed to witnessed interactions. Different political players are audiences for each other's actions, hence their maneuvers must be investigated through an interpretive and cultural lens (Jasper, 2015a, p. 10). Yet, the link between what happens, how the people make meaning of it, and how this meaning is acted upon - partly guided by cognitive schemas, scripts, and ideologies, and partly conditioned by reflex, urges, mores, and affective commitments - remains largely understudied. 


\section{The Egyptian Revolution as the Result of a Hegemonic Crisis}

The bulk of literature on contentious dynamics has focused on the material features of repression and collective action. Much less has been said about the interpretation of events on the ground or the discursive and emotional subjectivation processes by which, as Farhad Khosrokhavar (2018) put it, "what was accepted as a sad fact of life becomes unbearable due to heightened indignation, shared and amplified" (p. 16o). Only a few studies have acknowledged that the popular protest of the so-called Arab Spring was situated in an "imaginative terrain" (Chalcraft, 2014, p. 179) and hence, if it was to be adequately understood, attention had to be given to the role of symbolic contestation.

Significantly, those that did, built largely upon a Gramscian reading of the revolutionary events of 2011. This is evident in their attempts to account for the observation that, during the 18 days of Tahrir, social subjects interpreted the world around them in a political way and subsequently acted on these interpretations "in a disruptive, transgressive, and collective fashion" (Chalcraft, 2014, p. 159; see also Chalcraft \& Noorani, 2007, pp. 1-19; Pratt, 2015). In their reading of the Egyptian uprising, January 25 represented a rupture that enabled counter-hegemonic forces to come to the fore and challenge the status quo, maintained by dominant players and legitimized through their narratives. ${ }^{2}$

The January 25 uprising took place in a context of entrenched authoritarianism and thus a tightly controlled and largely static political arena. What was commonly referred to as the Mubarak regime effectively represented an authoritarian hegemonic block with remarkable stability. Aside from the presidency, it included the armed forces, domestic intelligence, as well as members of the country's business elite. For several decades, this block was sustained and its dominance over the country's political affairs naturalized by a hegemonic "national modernization" discourse (see Pratt, 2012). After the demise of the grand ideologies (Anti-Colonialism, Pan-Arabism, Socialism), which had supplied legitimacy to different regimes in the region, this discourse relied largely on a social contract of informality (Harders, 2009, p. 300). It promised Egyptian citizens a certain degree of social welfare and a fair share of economic development in exchange for a waiver of political representation and social demands, and for their political acquiescence of the status quo. ${ }^{3}$

2 Gramsci (1971) has referred to this superstructure as "hegemony" (p. 161). The concept denotes a consensus on the naturalness of existing relations of power, backed by the coercion of the state apparatus.

3 If anything, after the fall of the bipolar world order, of the grand old ideologies only political Islam and its notion of Islamic unity were still able to inspire popular support and establish 
The legitimacy of this informal social contract, however, had eroded in the years before the uprising as a consequence of a massive social "transformation without transition" (Harders, 2015, p. 148). These social dynamics manifested in the shape of demographic change, increasing digitalization (and thus enhanced popular access to information), unequal economic development, and the proliferation of civic mobilizing structures (see Chalcraft, 2014, 2016; Joya, 2011). Since the late 1980s, this erosion was additionally catalyzed by the implementation of economic liberalization policies and the Mubarak regime's tawrith [succession] crisis.

Roberto Roccu (2013a) argues that neoliberal economic reforms promoted the emergence of a capitalist oligarchy at the expense of social cohesion and the integrity of the ruling hegemonic bloc (see also Achcar, 2013; Hanieh, 2013). Neoliberal reform may have been a necessary structural condition to deliver on the promises of economic prosperity. But the implementation of reforms impoverished and alienated vast strata of the Egyptian population, eroding the political hegemony that hitherto sustained Egypt's ruling class. As Brecht de Smet $(2015,2016)$ argued, one of the reasons why Mubarak's regime fell was because his neoliberal business cronies failed to gather enough consent for their project. Andrea Teti and Gennaro Gervasio (2011) come to a similar conclusion:

In short, having sacrificed remnants of its populist revolutionary legitimacy on the altar of its narrower self-interest, and alienating increasingly large swathes of the population in the process, the ruling elite found it impossible to compensate politically for its economic choices. (p. 323)

At the same time, alternative visions that could have been incorporated by the regime to reform the incumbent governance culture and reinvigorate the hegemonic order could not be expressed publicly given the tightly controlled political space and the severe limitations in freedom of speech. Consequently, a counter-hegemonic culture developed only in the shape of several alternative political grassroots projects. Their claims remained primarily confined to the private sphere or the few pockets of political activism that were tolerated by the Mubarakist security state. Until the 2011 uprising, with the notable but short-lived (2005-2007) exception of the 
Kefaya movement (Chalcraft, 2014, p. 162), most of these discourses were unable to travel beyond the boundaries of these secluded counter-publics.

Thus, such discourses failed to resonate among Egyptians in a way that could have challenged the hegemonic social order. Recourse to the repressive apparatus effectively prevented the widening gap between Egyptian society and its ossified regime from being addressed in the public sphere. In the long-term, however, the dissonance between the hegemonic superstructure that meant to legitimize and naturalize the exclusionary rule of an elitist clique (see Roll, 2010), aggravated the latent crisis of legitimization (see Herrera \& Mirshak, 2018) laying the ground for the urban middle-class revolt of 2011. As Chalcraft (2014) argues, in 2010, the governing regime was factually a case of "dominance without hegemony - a situation in which coercion outweighed consent in the political order at large" (p. 165). The performative disruption of the tacit hegemonic consensus of the Mubarak era through the first protest marches on January 25, 2011, in this view, became the tipping point that brought the latent crisis to the fore. According to Nicola Pratt (2015), it demonstrated that "Egyptians rejected the domination and coercion of Mubarak's regime and that the latter had lost its hegemony over a large part of society" (p. 46).

Similarly, Chalcraft (2014) contends that the sight of demonstrators overpowering riot police across the country and exhausted policemen deserting their posts signaled that "even the regime's instruments of domination - as opposed to its long-defunct forms of hegemony - were now vulnerable" (p. 175). As the symbolic "barrier of fear" crumbled, empowering disenfranchised Egyptians to speak their minds about long-held grievances, the Tahrir uprising triggered a proliferation of countless new competing political projects with contending visions for the country's political future (see Wessel, 2017, Chapter 3). By debunking the hollow protectionist rhetoric of the Mubarak regime, it set the precedent for new forms of mobilization that would dominate the following 18 days until Mubarak's ouster, and the years to come.

\section{Political Subjectivation and the Emergence of New Contentious Alliances}

The Tahrir protests also triggered a range of political subjectivation processes that "transformed passive moods into active emotions that promote action, in particular, social protest" (Khosrokhavar, 2018, p. 160). Leaning on poststructuralist notions of collective identity, subjectivation in the context of collective mobilization is defined here as the discursive articulation of togetherness, a sense of belonging, or a political collectivity to identify with, within an ongoing 
antagonist political struggle. As Khosrokhavar (2018) has argued, subjectivation processes open up the possibility of individuals asserting themselves as "a person who participates in politics through street protests" (p. 163).

The initial protests on Tahrir Square provided the spark for such processes. They were a box-opener for contesting the dominant political players through a "new political language" (Filali-Ansary, 2012) that emphasized personal and collective freedom, human dignity, social justice, and political selfdetermination over statist conceptions of centralized and authoritarian ruling for the common good. During these expressions of resistance "a particular social imaginary was generated, a symbolic identity, forming around the unified position of alterity" (Smaldone, 2015). Bridging political divides by drawing the ultimate antagonist frontier in Egypt's political struggle not between different social or ideological factions, but between the people and the regime, this discourse allowed political groups and their respective mobilizing goals to re-emerge which had been largely repressed or discredited in the public sphere.

Moreover, the joint experience of protesting on Tahrir and confronting security forces during the defense of the protest camps led to the emergence of more durable affective commitments between the players on the square that supported the resilience of the protest movement against repression and disappointment. Combined, the political and emotional subjectivation processes enabled what Roberto Roccu $(2013 \mathrm{~b})$ has referred to as "embryonic forms of alliance between the dispossessed and the discontented" (p. 423). Significantly, the Egyptian January 25 Revolution has been attributed by many authors to this successful alliance formation - not only between the mobilized streets and the elites within state institutions, such as the military (Nepstad, 2011; Roll, 2016; Barany, 2011) but also between various oppositional groups in a process of cross-movement mobilization that blurred former social and ideological divides (Beissinger et al., 2015; Durac, 2015; Goldstone, 2011; Harders \& König, 2013). This ties in with the studies of social uprisings in other regions of the world, where scholars also identified the emergence of cross-class and cross-movement coalitions as a precondition for successful mass mobilizations against authoritarianism and an active precursor for almost all popular-driven revolutions in the 2oth century (Foran \& Goodwin, 1993; Goldstone, 2011; Van Dyke \& McCammon, 2010; Goldstone, 2009).

It is important to note that this process of coalition-forming, in the Egyptian case, was not ad-hoc but built on prior groundwork (see Beinin \& Vairel, 2011; Clarke, 2011; El-Ghobashy, 2011). Mark Beissinger, Amaney Jamal, and Kevin Mazur (2015) have shown how, across the Arab world, different regime 
strategies vis-à-vis domestic socio-demographic and political pressures had laid the foundation for contentious coalitions in the run-up to the 2011 Arab uprisings by creating "sites of heightened grievance and configurations of opposition mobilizing structures" (p. 2). In Egypt, these sites gave rise to formal organizations and mobilizing structures which were tested, for instance, in the Kefaya campaign of 2005 (see El-Mahdi, 2009), but they also promoted the spread of informal ties and networks which Asef Bayat (2010) has referred to as the "quiet encroachment of the ordinary" (p. 33). These long-term developments provided the parameters for coalition building in the Egyptian case. Yet, as Gilbert Achcar (2013, p. 151) stressed, until 2011 the desolate state of organized civil society gave little hope for cross-class collective action.

In effect, the emergence of objective structural grievances is rarely enough to precipitate eventful sequences of action that actuate a revolution. In Egypt, only the emergence of players that aggressively articulate the unfavorable status quo as a legitimacy crisis of their rulers provided the subjective factor that tipped off further mobilization potentials and catalyzed the emergence of a new coalition of contenders. The shared experience of victimization by state repression then galvanized oppositional identity. Atef Said (2014) argued that particularly the case of Egypt seems to illustrate that "how coalitions are weakened or strengthened, or the very choice of making coalitions, are shaped by and occur in response to state actions or control in the political sphere." He is right. But at the same time, only joint participation in demonstrations created personal bonds and forged crucial affective ties of mutual trust and care between protest participants (Harders \& König, 2013). These subjectivation processes were tantamount to the success of 2011. The diversity of the protest movement that resulted from successful coalition-building provided political legitimacy to the uprisings and offered some protection by increasing the repression costs for security forces. Through their coactions, the mobilized people then produced their own windows of opportunity for social transformation (Kurzman, 2012).

\section{Situating this Project}

Contested Legitimacies is situated at the juncture of these three strands of literature and their central concepts: strategic interaction, discursive contestation, and political subjectivation. As a key for understanding the highly volatile mobilization dynamics in Egypt, in an era of authoritarian contraction, the book explores the competing narratives articulated by the 
contending political players since the 2013 military coup and investigates how they informed their struggle for moral leadership and political legitimacy. The contentious struggle for legitimacy in Egypt is thus conceived of as one over people's "hearts and minds" (Pratt, 2015, p. 46). In this struggle, different players - both civil society and from the ranks of the regime - reinforced or challenged prevailing relations of power with the end to influence the conditions of possibility for their mobilization. Depending on which of many competing narratives about contentious events prevailed and were able to affect people cognitively and emotionally, ${ }^{4}$ police forces adopted different postures when facing disorder, and protesters evaluated their available choices of repertoire differently. Depending on which interpretation prevailed, players' actions inspired revolt or created windows of opportunity for repression.

Accordingly, this book concentrates on what Stuart Hall (1982) has referred to as the "politics of signification" (p. 64), that is, the competing and changing meaning that contending players construct and voice about specific events to discredit political opponents, rally support for their cause and advance their struggle in a contingent and highly dynamic political arena. It focuses on the outcome of the constantly fought discursive battles over interpretation in Egypt after the 2013 military coup and systematically traces their effects on the action choices of different contending players (e.g., their repertoires, their mobilizing strategies, their proneness to violence, or their composition). It is argued that contested perceptions and interpretations of the dynamics of contention on the ground, captured in the post-structuralist notion of articulation, crucially account for variances in the reaction of social movements to regime action, and potentially mobilizable publics to both protest and repression.

The Egyptian case is a prodigious one to study in this regard. Over several episodes of contention related to the construction of legitimacy for political power, it very much illustrates the role of the symbolic and the intervention of the discursive sphere into processes of both, political mobilization, and state repression. At the same time, the Egyptian case provides an opportunity to analyze these processes in a highly contested political realm with several collective actors frantically interacting with each other in shifting alliances and political constellations. The challenge of this case study, accordingly, lay

4 In line with Jasper (2018), emotions are here understood as causal mechanisms that relate to the transforming capacity of protest as well as the transformation and permutation of movements themselves. Paired with and partly conditioning cognitive processes, they help explain "how one action leads to another in politics" (p. 12). 
in the volatility of the competing and often partly overlapping discourses that emerged as a product of Egypt's early post-revolutionary struggles. These meaning ascriptions, rather than becoming sedimented, were re-signified, incorporated, and re-appropriated by different players in their struggle for normative discursive hegemony.

As regards the questions that drive this research, I thus investigate first, how collective actions and state responses to mobilization were represented in opposing discursive projects by political contenders after the military coup on July 3, 2013. How were central themes of Egyptian politics - revolution, nation, dignity, legitimacy - discursively renegotiated to inform both contentious claim-making or and repression? At the heart of these questions is an outline of the constitutive myth that surrounds the post-coup regime. It was a certain symbolism and discourse that empowered the new regime to articulate, implement, and create widespread consent to state violence and policies that aimed to suppress other political players and their projects. But black-boxing this relation of dominance by referring to it as "hegemony" will not take us any further in understanding its emergence, its functions, as well as its cognitive and emotional drivers. Accordingly, the investigations in this book are more concerned with the question of how exactly this discourse was manufactured to mobilize emotions; how cultural work managed to transform popular anger about the unruliness of the post-coup situation into indignation about the protesters and support for the post-coup regime; and how it naturalized repression and authoritarian relations of dominance after the deposition of President Mursi.

The second complex of questions at the heart of the following analyses relates to the impact of what William Sewell (1996b) has referred to as "transformative events" on this discursive struggle. On the one hand, the question is here whether we can discern certain historical events that managed to dislocate established meaning structures, thus shattering affective commitments and cognitive schemes established to interpret the political arena since the 2011 uprising. Did these disruptions allow for the emergence of new commitments among central players, thus catalyzing oppositional subject formation - and if so, how?

On the other hand, understanding why certain events - including some of the most mediatized and violent ones, such as the Rabaa massacre - failed to exert a transformative effect on the trajectory of contention in Egypt is equally important. William Gamson (1992) reminds us that "there are many political movements that try in vain to activate people who, in terms of some allegedly objective interest, ought to be up in arms" (p. 6). No matter 
how passionate and how significant the collective claims and individual commitments of protesters, public manifestations of opposition do not automatically inspire people to join a cause. Equally, even the most brutal and indiscriminate repression does not automatically produce protests. Accordingly, several chapters of this book try to understand why certain instances succeeded or failed to mutate into transformative events. They retrace how the interactions of certain key players contributed to either outcome.

Furthermore, this book retraces what such critical junctures meant for contentious politics: What was the impact of shifts in the discursive and emotional architecture of contentious politics on opportunities for political repression or social mobilization? Could the subversion of players' established patterns of thinking of, feeling through, and talking about the world produce relations that favored coalition building and cross-movement mobilization? How did it affect different contentious players' horizon of expectations and or their perception of opportunities for action? And how did these players, through their actions, then transform the rules and parameters or reify the regularities of the political arena?

In its attempt to answer these questions, this project is inspired by and seeks to integrate works from the political sociology of social movements as well as ideas from the post-structuralist Essex School of discourse theory. The realization that the relationship between protesters and agents of repression is a dynamic one that works both ways (i.e., in which causal effects can be identified on both sides), which defines the conceptual perspective of this research project, is indebted to interactionist approaches from the field of social movement studies (a.o., Duyvendak \& Jasper, 2015; Jasper \& Duyvendak, 2015; Volpi \& Jasper, 2018). Instead of ascribing the success or failure of protest cycles to structural conditions, unilinear ascriptions, or the idiosyncratic features or resources of a given protest movement, I follow these authors and their research program in their conceptualization of protest cycles as the results of complex interactive processes on the micro-level and in different strategic arenas.

This strategic interaction takes place on a material level, where it manifests in observable protest-repression-dynamics. And it takes place on a discursive level, too, where different readings of social reality are crafted and strategically promoted by the contending players. To conceptualize this discursive arena, this book draws strongly from discourse theory and the works of the so-called Essex School (a.o., Howarth et al., 2000; Howarth 
\& Torfing, 2005; Laclau, 2005; Laclau \& Mouffe, 2001)..$^{5}$ By emphasizing language's constitutive aspect, such a perspective helps to recall that the meaning attached to material events has immediate and tangible real-world effects. It constitutes the boundaries of responses by contending actors. My mixed-method analysis of textual communication, semiotic representation, and physical interaction in Egypt's post-revolutionary arena, whose methodology and sources are detailed in the Appendix, is guided by the premise that contentious claim-making is not only influenced by or influential on public discourse. Players' discourses, instead, constitute the conditions of possibility for social claims. Changing discourses about physical events thus provide the context for interpreting the diverging findings on the interactional effects of states and contenders on each other.

\section{Outline}

This book consists of six chapters, in addition to this introduction and some concluding remarks. Of these, one chapter is concerned with developing a theoretical framework and outlining the methodological choices of this book. This entails a meso-level approach to the study of contention, a relational and interactionist framework of analysis, and special attention to the discursive arena of contentious politics. Five chapters are of an empirical and analytical nature. Structurally, the second chapter, after this introduction, describes the conceptual framework and theoretical underpins, embedding this paper in the broader research tradition of social movement studies. First, it introduces the idea of social mobilization as a population of contentious events (see Della Porta, 2011). These events can be viewed as the visible traces of the strategic interactions of different individual and compound social players, such as protest movements, police forces, or army units, who face each other in a complex and dynamic social arena (see Jasper, 2015b, 2015a; McGarry et al., 2016). At the same time, players themselves, too, represent arenas for internal struggles among their constituting individuals.

By adopting such a social interactionist and relational perspective, this case study compliments Charles Tilly's (2008) call for more refined evidence on contentious performances that, "look inside individual episodes to analyze

5 Named after a graduate program at the University of Essex, the Essex School became the breeding ground for a generation of scholars who contributed to establishing their mentors' approach as a research tradition (e.g., Glynos et al., 2009; Howarth, 1998, 2013; Howarth et al., 2000; Howarth \& Torfing, 2005; Torfing, 1999). 
the interplay of actors, interactions, and contentious claims" (p. 35, see also Tilly, 2005, p. 222). As Tilly famously argued, protest episodes are not activists' solo performances. They involved a high degree of social interaction: spectators can become sympathizers or opponents that support or reject protesters' demands; they can become activists themselves or join forces with the agents of repression. Della Porta $(2014 \mathrm{~b})$ has referred to this fluid and dynamic nature of contentious politics as a "dance" (p. 165) between challengers of authority, power, and privilege, and those who seek to retain and extend it. Building on this thought, this book conceives social movements as systems of relations between different individual and compound social players, whose political subjectivities and contentious performances are conditioned by and embedded in their strategic interactions with others.

Finally, the second chapter suggests that discourse theory, by accounting for both linguistic meaning and the material event, can contribute to developing the concept of protest arenas by theorizing the discursive layers of interaction that accompany contentious struggles. Drawing on the works of Ernesto Laclau and Chantal Mouffe (above all, Laclau \& Mouffe, 2001; Laclau, 2005), it illustrates how discursive arenas can be thought of as the sites of players' struggles over key signifiers. The outcomes of these struggles condition what can be said, what problems can be named, who can be held accountable, and what solutions appear viable. This combination of strategic interactionist and discourse theoretical approaches allows for a methodology that combines protest event analysis, a tested method from the toolkit of social movement studies, and discourse analysis in a nested research design. This innovative nested research design is described in more detail in the Appendix, in the hope that it can serve as an inspiration for other scholars of contentious politics to adopt a disaggregated framework of analysis that pays equal attention to the production and the interpretation of protest and repression.

The empirical part of this book begins by retracing the chain of events that led to the uprising on June 30, 2013, and the ouster of President Mursi (Chapter 3). These events, I argue, can be interpreted as disruptive, transformative events that caused an irrevocable rift in the social order. This period of Egypt's post-revolutionary history has been the subject of much discussion by scholars of political Islam investigating the trajectory of one of the largest Islamic movements in the modern world, from its sudden rise to power to its quick demise and near extinction (El-Amrani, 2013), as well as by others assessing the impact of Mursi's short rule on the country's political transition (N. J. Brown, 2013; Stein, 2012). More recently it has attracted the attention of social movement scholars, with several authors reconstructing the dynamics of contention leading up to the 2013 military coup and those 
following it (Biagini, 2017; Grimm \& Harders, 2018; Ketchley, 2017a). While methodologically diverse, these accounts agree that Mursi's presidency had been riddled with conflict from the outset. ${ }^{6}$ Chapter 3 explores how this conflict unfolded, polarized society, and catalyzed a clash between two competing hegemonic projects which culminated in Mursi's deposition by the military on July $3,2013$.

The next two empirical chapters (Chapters 4 and 5) explore the dynamics of contention in Egypt directly after the 2013 military coup, above all, the wave of Islamist mobilization by the Muslim Brotherhood and its supporters which came to be known as the Anti-Coup campaign. Unlike the January 25 Revolution that has been discussed in extenso, the protests staged by the National Alliance in Support of Legitimacy (NASL) - commonly known as Anti-Coup Alliance - have been scarcely investigated. This is partly due to the rapid authoritarian regression and the restoration of autocratic modes of governance in Egypt that followed the contentious dynamics in mid-2013 and drew considerable scholarly attention. Partly it is because the brutal repression that accompanied the protests affected first and foremost demonstrators that could be counted to the Islamist spectrum of Egyptian society. Brutal massacres by state security forces against civilians, such as that on Rabaa al-Adawiya Square, could thus be signified as a reasonable, albeit failed attempt by Egypt's authorities to confront radical Islamic groups.

At the same time, the contentious dynamics in the summer of 2013 can be considered as one of the most formative episodes for Egyptian politics of the last decades, equaling only that of January 25 in recent years. It enabled the emergence of what has become one of the most brutal authoritarian regimes not only in the region but across the globe. An interlude chapter (Chapter 6) thematizes this autocratic restoration in the aftermath of the 2013 military coup. It describes how a new discourse took hold of Egypt in which national defense and the fight against terrorism replaced self-determination and civilian rule as the central signifiers. This discourse enabled the rehabilitation of the armed forces as representatives of the people's will and their inclusion into a new hegemonic bloc, an alliance of political forces with the ability to exert power through consensus, not only coercion (Gramsci, 1971, p. 365f.).

The contentious episode discussed in the last empirical chapter shows, however, that the post-coup regime's very reliance on a nationalist discourse for legitimizing its actions sowed the seeds for new resistance. Chapter 7 investigates how the transfer of the Egyptian archipelago of Tiran and Sanafir to Saudi Arabia in early 2016 became a catalyst for oppositional

6 For a summary of Mursi's first year in office, see http://www.jadaliyya.com/Details/29146. 
subject formation and the emergence of a strange bedfellow coalition under conditions of extreme repression. Drawing on another protest event catalog and an analysis of the competing discourses on the protests, the chapter illustrates how the Egypt is not for sale!-campaign [Hamlat-masr mish li-l-bia'a] undermined the regime's nationalist lingo, thus changing the perception of opportunities for mobilization and creating the conditions for innovative coalitions. Placing its campaign in the trajectory of the Egyptian revolution, the coalition established solidarity between liberals, leftists, and the nationalist youth who had so far toed the regime's line.

The final concluding chapter (Chapter 8) discusses the overall empirical findings critically in light of ongoing theoretical debates on the power of nationalism. An Appendix deals with methodological concerns. It covers the sources used in this investigation and presents the embedded research design of this study in detail. For the sake of reproducibility, it details the methods-mix employed for empirical analysis, namely a combination of protest event data, discourse analysis, and interviews; it discusses source selection and coding procedures, and it describes the procedure by which discourses are visualized as semantic networks in the empirical chapters of this study. An additional section in the Appendix deals with epistemological concerns and issues of positionality.

In sum, this book can be considered an attempt to map Egypt's postrevolutionary contentious politics. It includes tracing the unfolding protest dynamics during the above-mentioned contentious episodes in an event database that documents the scope and repertoire of the unfolding events. But it also includes tracing the effect of contested discourses on the performances and repertoires of different social players in the highly dynamic arena of Egypt's embattled streets. Thereby, a new narrative of Egypt's post-revolutionary history is developed. It contends that the story of President Mursi's fall and President Sisi's rise is not one of a journey back to square one. Nor is it the story of a failed revolution that was undermined by the wit of Egypt's elites and the machinations of a deep state, and that - once more - testifies to the structural resilience of authoritarianism in the Arab World. Instead, the trajectory of the Egyptian uprising and its aftermath is portrayed as the contingent rise and fall of competing players and their political projects in a highly dynamic political setting arena. These players, as will be shown, have all risen, struggled, and, at times, fallen over questions of legitimacy and over attempts to incarnate the will of the people and monopolize representations of the nation's interest. In this book, I retrace how this contest over legitimacy unfolded, and how it inspired repression and revolt in post-revolutionary Egypt. 


\section{References}

Abu-Lughod, L. (2014). Writing against culture. In H. L. Moore \& T. Sanders (Eds.), Anthropology in theory: Issues in epistemology (2nd ed., pp. 466-479). Wiley Blackwell.

Achcar, G. (2013). The people want: A radical exploration of the Arab uprising. University of California Press.

Alimi, E. Y. (2009). Mobilizing under the gun: Theorizing political opportunity structure in a highly repressive setting. Mobilization, 14(2), 219-237. https://doi.org/10.17813/ maiq.14.2.u210745765568737

Almeida, P. (2003). Opportunity organizations and threat-induced contention: Protest waves in authoritarian settings. American Journal of Sociology, 1og(2), 345-40o. https://doi. org $/ 10.1086 / 378395$

Barany, Z. (2011). Comparing the Arab revolts: The role of the military. Journal of Democracy, 22(4), 24-35.

Bayat, A. (2010). Life as politics: How ordinary people change the Middle East. Stanford University Press.

Beinin, J., \& Vairel, F. (2011). Social movements, mobilization, and contestation in the Middle East and North Africa. Stanford University Press.

Beissinger, M. R., Jamal, A. A., \& Mazur, K. (2015). Explaining divergent revolutionary coalitions: Regime strategies and the structuring of participation in the Tunisian and Egyptian revolutions. Comparative Politics, $48(1), 1-21$.

Berriane, Y., \& Duboc, M. (2019). Allying beyond social divides: An introduction to contentious politics and coalitions in the Middle East and North Africa. Mediterranean Politics, 24(4), 399-419. https://doi.org/10.1080/13629395.2019.1639022

Biagini, E. (2017). The Egyptian Muslim Sisterhood between violence, activism and leadership. Mediterranean Politics, 22(1), 35-53. https://doi.org/10.1080/13629395.2016.1230943

Bishara, D. (2015). The politics of ignoring: Protest dynamics in late Mubarak Egypt. Perspectives on Politics, 13(4), 958-975. https://doi.org/10.1017/S153759271500225X

Brown, N. J. (2013). Egypt's failed transition. Journal of Democracy, 24(4), 45-58.

Cambanis, T. (2013, July 21). What will give Egypt's ruler 'legitimacy'? Boston Globe. https://www. bostonglobe.com/ideas/2013/07/20/what-will-give-egypt-ruler-legitimacy/sNmW2ruHKkm8tFOuPTlg8H/story.html

Chalcraft, J. (2014). Egypt's 25 January uprising, hegemonic contestation, and the explosion of the poor. In F. A. Gerges (Ed.), The new Middle East: Protest and revolution in the Arab World (pp. 155-179). Cambridge University Press.

Chalcraft, J. (2016). The Arab uprisings of 2011 in historical perspective. In A. Ghazal \& J. Hanssen (Eds.), The Oxford handbook of contemporary Middle-Eastern and North African history. Oxford University Press. https://doi.org/10.1093/oxfordhb/9780199672530.013.13

Chalcraft, J., \& Noorani, Y. (2007). Counterhegemony in the colony and postcolony. Palgrave Macmillan. http://www.palgrave.com/us/book/9780230019188

Clarke, K. (2011). Saying 'enough': Authoritarianism and Egypt's Kefaya movement. Mobilization: An InternationalJournal, 16(4), 397-416. https://doi.org/10.17813/maiq.16.4.m728m673p734ol23

Davenport, C. (2005). Introduction: Repression and mobilization: Insights from political science and sociology. In C. Davenport, H. Johnston, \& C. Mueller (Eds.), Repression and mobilization (pp. vii-xli). University of Minnesota Press.

Davenport, C. (2007). State repression and political order. Annual Review of Political Science, $10(1), 1-23$. https://doi.org/10.1146/annurev.polisci.10.101405.143216 
Davenport, C., \& Moore, W. H. (2012). The Arab Spring, winter, and back again? (Re)introducing the dissent-repression nexus with a twist. International Interactions, $38(5), 704-713$. https:// doi.org/10.1080/03050629.2012.726187

De Smet, B. (2015). A dialectical pedagogy of revolt: Gramsci, Vygotsky, and the Egyptian Revolution. Brill. https://doi.org/10.1163/9789004262669

De Smet, B. (2016). Gramsci on Tahrir: Revolution and counter-revolution in Egypt. Pluto Press.

Della Porta, D. (2011). Eventful protest, global conflicts: Social mechanisms in the reproduction of protest. In J. M. Jasper \& J. Goodwin (Eds.), Contention in context: Political opportunities and the emergence of protest (pp. 256-276). Stanford University Press.

Della Porta, D. (2014). On violence and repression: A relational approach (the Leonard Schapiro memorial lecture, 2013). Government and Opposition, 49(2), 159-187. https://doi.org/10.1017/ gov.2013.47

Della Porta, D. (2016). Where did the revolution go? Contentious politics and the quality of democracy. Cambridge University Press.

Della Porta, D., \& Tarrow, S. (2012). Interactive diffusion: The coevolution of police and protest behavior with an application to transnational contention. Comparative Political Studies, 45(1), 119-152. https://doi.org/10.1177/0010414011425665

Durac, V. (2015). Social movements, protest movements and cross-ideological coalitions: The Arab Uprisings re-appraised. Democratization, 22(2), 239-258. https://doi.org/10.1080/13510 347.2015.1010809

Duyvendak, J. W., \& Fillieule, O. (2015). Conclusion: Patterned fluidity: an interactionist perspective as a tool for exploring contentious politics. In J. W. Duyvendak \& J. M. Jasper (Eds.), Players and arenas: The interactive dynamics of protest (pp. 295-318). Amsterdam University Press. https://doi.org/10.2307/j.ctt16vj285.16

Duyvendak, J. W., \& Jasper, J. M. (Eds.). (2015). Breaking down the state: Protestors engaged. Amsterdam University Press.

El Chazli, Y. (2018). It takes two (or more) to tango. In F. Volpi \& J. M. Jasper(Eds.), Microfoundations of the Arab uprisings: Mapping interactions between regimes and protesters (pp. 135-158). Amsterdam University Press.

El-Amrani, I. (2011). Popular protest in North Africa and the Middle East (I): Egypt victorious? (Middle East/North Africa Report No. 101). International Crisis Group. http://www.crisisgroup. org/en/regions/middle-east-north-africa/north-africa/egypt/101-popular-protest-in-northafrica-and-the-middle-east-i-egypt-victorious.aspx

El-Amrani, I. (2013). Marching in circles: Egypt's dangerous second transition (Middle East/North Africa Briefing No. 35). International Crisis Group. http://www.crisisgroup.org/ /media/ Files/Middle\%2oEast\%2oNorth\%2oAfrica/North\%2oAfrica/Egypt/bo35-marching-incircles-egypts-dangerous-second-transition.pdf

El-Ghobashy, M. (2011). The praxis of the Egyptian revolution. Middle East Report (MER), $41(258)$. http://www.merip.org/mer/mer258/praxis-egyptian-revolution

El-Mahdi, R. (2009). The democracy movement: Cycles of protest. In R. El-Mahdi \& P. Marfleet (Eds.), Egypt: The moment of change. Zed Books.

Filali-Ansary, A. (2012). The languages of the Arab revolutions. Journal of Democracy, 23(2), 5-18. https://doi.org/10.1353/jod.2012.0035

Foran, J., \& Goodwin, J. (1993). Revolutionary outcomes in Iran and Nicaragua: Coalition fragmentation, war, and the limits of social transformation. Theory and Society, 22(2), 209-247.

Gamson, W. A. (1992). The social psychology of collective action. In A. D. Morris \& C. Mueller (Eds.), Frontiers in social movement theory (pp. 53-76). Yale University Press. 
Glynos, J., Howarth, D., Norval, A., \& Speed, E. (2009). Discourse analysis: Varieties and methods (ESRC National Centre for Research Methods Review Paper No. 14). http://eprints.ncrm. ac.uk/796/1/discourse_analysis_NCRM_014.pdf

Goldstone, J. A. (2009). Rethinking revolutions: Integrating origins, processes, and outcomes. Comparative Studies of South Asia, Africa and the Middle East, 29(1), 18-32.

Goldstone, J. A. (2011). Cross-class coalitions and the making of the Arab revolts of 2011. Swiss Political Science Review, 17(4), 457-462.

Gramsci, A. (1971). Selections from prison notebooks. Lawrence and Wishart.

Grewal, S. (2018). Explaining military defection and loyalty in the Mediterranean. Mediterranean Politics, 23(3), 427-432. https://doi.org/10.1080/13629395.2017.13060oo

Grimm, J. J. (2013, August 26). Riding the tiger [Carnegie Endowment for International Peace]. Sada. http://carnegieendowment.org/sada/2013/o8/26/riding-tiger/gkgr

Grimm, J. J. (2019). Egypt is not for sale! Harnessing nationalism for alliance building in Egypt's Tiran and Sanafir island protests. Mediterranean Politics, 24(4), 443-466. https://doi.org/10 $.1080 / 13629395.2019 .1639024$

Grimm, J. J., \& Harders, C. (2018). Unpacking the effects of repression: The evolution of Islamist repertoires of contention in Egypt after the fall of President Morsi. Social Movement Studies, $17(1), 1-18$. https://doi.org/10.1080/14742837.2017.1344547

Hafez, M. (2003). Why Muslims rebel: Repression and resistance in the Islamic world. Lynne Rienner Publishers.

Hall, S. (1982). The rediscovery of 'ideology': Return of the repressed in media studies. In M. Gurevitch, T. Bennett, J. Curran, \& J. Woollacott (Eds.), Culture, society, and the media (pp. 56-9o). Methuen.

Hamada, A. (2014). Understanding the military role in the Egyptian revolution: Comparing February 2011 and July 2013. In N. Belakhdar, I. Eickhof, A. el Khawaga, O. el Khawaga, C. Harders, \& S. Sandri (Eds.), Arab revolutions and beyond (pp. 29-40). Center for Middle Eastern and North African Politics.

Hanieh, A. (2013). Lineages of revolt: Issues of contemporary capitalism in the Middle East. Haymarket Books.

Haraway, D. (1988). Situated knowledges: The science question in feminism and the privilege of partial perspective. Feminist Studies, 14(3), 575-599. https://doi.org/10.2307/3178066

Harders, C. (2009). Politik von unten - Perspektiven auf den autoritären Staat in Ägypten. In M. Beck, C. Harders, A. Jünemann, \& S. Stetter (Eds.), Der Nahe Osten im Umbruch (pp. 299-323). Springer VS.

Harders, C. (2015). "State analysis from below" and political dynamics in Egypt after 2011. International Journal of Middle East Studies, 47(1), 148-151.

Harders, C., \& König, C. (2013). Mobilization, repression and coalitions: Understanding the dynamics of the Arab Spring [Discussion Paper]. Center for Middle Eastern and North African Politics. https://www.polsoz.fu-berlin.de/polwiss/forschung/international/vorderer-orient/publikation/working_papers/dp_o6/index.html

Hassanpour, N. (2011). Media disruption exacerbates revolutionary unrest: Evidence from Mubarak's quasi-experiment (SSRN Scholarly Paper ID 1903351). Social Science Research Network. http:// papers.ssrn.com/abstract $=190335^{1}$

Hegel, G. W. F. (1910). Vorlesungen über die Philosophie der Geschichte. Philipp Reclam jun.

Herrera, L., \& Mirshak, N. (2018, August 11). Hegemony is never complete: Using Gramsci to understand the Arab uprisings. Truthout. https://truthout.org/articles/hegemony-is-nevercomplete-using-gramsci-to-understand-the-arab-uprisings/

Hess, D., \& Martin, B. (2006). Repression, backfire, and the theory of transformative events. Mobilization, $11(2), 249-267$. 
Holmes, A. A. (2012). There are weeks when decades happen: Structure and strategy in the Egyptian revolution. Mobilization, 17 (4), 391-410. https://doi.org/10.17813/maiq.17.4.905210228n564037

Holmes, A. A., \& Koehler, K. (2020). Myths of military defection in Egypt and Tunisia. Mediterranean Politics, 25(1), 45-70. https://doi.org/10.1080/13629395.2018.1499216

Howarth, D. R. (1998). Discourse theory and political analysis. In E. Scarbrough \& E. Tanenbaum (Eds.), Research Strategies in the Social Sciences (pp. 268-310). Oxford University Press.

Howarth, D. R. (2013). Poststructuralism and after: Structure, subjectivity and power. Palgrave Macmillan UK.

Howarth, D. R., Norval, A., \& Stavrakakis, Y. (Eds.). (2000). Discourse theory and political analysis: Identities, hegemonies and social change. Manchester University Press.

Howarth, D. R., \& Torfing, J. (Eds.). (2005). Discourse theory in European politics: Identity, policy, and governance. Palgrave Macmillan.

Jasper, J. M. (2010). Social movement theory today: Toward a theory of action? Sociology Compass, 4(11), 965-976. https://doi.org/10.1111/j.1751-9020.2010.00329.x

Jasper, J. M. (2012). Introduction: From political opportunity structures to strategic interaction. In J. Goodwin \& J. M. Jasper (Eds.), Contention in context: Political opportunities and the emergence of protest (pp. 1-36). Stanford University Press.

Jasper, J. M. (2015a). Introduction: Players and arenas formerly known as the state. In J. M. Jasper \& J. W. Duyvendak (Eds.), Breaking down the state: Protestors engaged (pp. 9-24). Amsterdam University Press. https://doi.org/10.2307/j.ctt196315k.3

Jasper, J. M. (2015b). Introduction: Playing the game. In J. M. Jasper \& J. W. Duyvendak (Eds.), Players and arenas: The interactive dynamics of protest (pp. 9-32). Amsterdam University Press. https://doi.org/10.2307/j.ctt16vj285.3

Jasper, J. M. (2018). The emotions of protest. The University of Chicago Press.

Jasper, J. M., \& Duyvendak, J. W. (Eds.). (2015). Players and arenas: The interactive dynamics of protest. Amsterdam University Press.

Jasper, J. M., \& Poulsen, J. D. (1995). Recruiting strangers and friends: Moral shocks and social networks in animal rights and anti-nuclear protests. Social Problems, 42(4), 493-512. https:// doi.org/10.2307/3097043

Jasper, J. M., \& Volpi, F. (2018). Introduction: Rethinking mobilization after the Arab uprisings. In F. Volpi \& J. M. Jasper (Eds.), Microfoundations of the Arab uprisings: Mapping interactions between regimes and protesters (pp. 11-40). Amsterdam University Press.

Johnston, H. (2012). State violence and oppositional protest in high-capacity authoritarian regimes. International Journal of Conflict and Violence, 6(1), 55-74.

Joya, A. (2011). The Egyptian revolution: Crisis of neoliberalism and the potential for democratic politics. Review of African Political Economy, $38(129), 367-386$. https://doi.org/10.1080/03056 244.2011.602544

Ketchley, N. (2014). "The army and the people are one hand!" Fraternization and the 25 th January Egyptian Revolution. Comparative Studies in Society and History, $56(1)$, 155-186. https://doi. org/10.1017/Soo10417513000650

Ketchley, N. (2017). Egypt in a time of revolution: Contentious politics and the Arab Spring. Cambridge University Press.

Khawaja, M. (1993). Repression and popular collective action: Evidence from the West Bank. Sociological Forum, 8(1), 47-71.

Khosrokhavar, F. (2018). Violence, social actors, and subjectivation in the Egyptian revolution. In F. Volpi \& J. M. Jasper (Eds.), Microfoundations of the Arab uprisings: Mapping interactions between regimes and protesters (pp. 159-182). Amsterdam University Press.

Kurzman, C. (2012). The Arab Spring uncoiled. Mobilization: An International Quarterly, 17(4), 377-39o. https://doi.org/10.17813/maiq.17.4.10326742no556v15 
Laclau, E. (2005). On populist reason. Verso.

Laclau, E., \& Mouffe, C. (2001). Hegemony and socialist strategy: Towards a radical democratic politics (2nd edition). Verso.

Lichbach, M. I. (1987). Deterrence or escalation? The puzzle of aggregate studies of repression and dissent. Journal of Conflict Resolution, 31(2), 266-297.

Mason, T. D., \& Krane, D. A. (1989). The political economy of death squads: Toward a theory of the impact of state-sanctioned terror. International Studies Quarterly, 33(2), 175-198. https:// doi.org/10.2307/2600536

McGarry, A., Davidson, R. J., Accornero, G., Jasper, J. M., \& Duyvendak, J. W. (2016). Players and arenas: Strategic interactionism in social movements studies. Social Movement Studies, 15(6), 634-642. https://doi.org/10.1080/14742837.2016.1199320

Moss, D. M. (2014). Repression, response, and contained escalation under 'liberalized' authoritarianism in Jordan. Mobilization, 19(3), 261-286. https://doi.org/10.17813/ maiq.19.3.q508v72264766u92

Naeem, M. (2019). In Egypt, nothing has changed - But perhaps everything has. Mada Masr. https://www.madamasr.com/en/2019/11/13/opinion/u/in-egypt-nothing-has-changed-butperhaps-everything-has/

Nassauer, A. (2016). From peaceful marches to violent clashes: A micro-situational analysis. Social Movement Studies, 15(5), 515-530. https://doi.org/10.1080/14742837.2016.1150161

Nassauer, A. (2019). Situational breakdowns: Understanding protest violence and other surprising outcomes. Oxford University Press.

Nepstad, S. E. (2011). Nonviolent resistance in the Arab Spring: The critical role of military-opposition alliances. Swiss Political Science Review, 17(4), 485-491. https://doi. org/10.1111/j.1662-6370.2011.02043.x

Nepstad, S. E. (2013). Mutiny and nonviolence in the Arab Spring: Exploring military defections and loyalty in Egypt, Bahrain, and Syria. Journal of Peace Research, 5o(3), 337-349. https:// doi.org/10.1177/0022343313476529 Article information

Opp, K.-D., \& Roehl, W. (1990). Repression, micromobilization, and political protest. Social Forces, 69(2), 521. https://doi.org/10.2307/2579672

Owen, R. (2012). Rise and fall of Arab presidents for life. Harvard University Press.

Pratt, N. (2012, May 25). Old state, new rules: From war of manoeuvre to war of position [University of Oxford Podcast]. https://podcasts.ox.ac.uk/panel-4-old-state-new-rules-war-manoeuvrewar-position?qt-media_player=o\#qt-media_player

Pratt, N. (2015). After the 25 January Revolution: Democracy or authoritarianism in Egypt? In R. Abou-el-Fadl (Ed.), Revolutionary Egypt: Connecting domestic and international struggles. Routledge.

Roccu, R. (2013a). The political economy of the Egyptian revolution: Mubarak, economic reforms and failed hegemony. Palgrave Macmillan.

Roccu, R. (2013b). David Harvey in Tahrir Square: The dispossessed, the discontented and the Egyptian revolution. Third World Quarterly, 34(3), 423-440. https://doi.org/10.1080/0143659 7.2013 .785338

Roll, S. (2010). 'Finance matters!' The influence of financial sector reforms on the development of the entrepreneurial elite in Egypt. Mediterranean Politics, 15(3), 349-370. https://doi.org/ 10.1080/13629395.2010.517098

Roll, S. (2016). Managing change: How Egypt's military leadership shaped the transformation. Mediterranean Politics, 21(1), 23-43. https://doi.org/10.1080/13629395.2015.1081452

Said, A. (2014, December 10). Regimes and movements: Thoughts on contentious politics and the Arab Spring. Mobilizing Ideas. https://mobilizingideas.wordpress.com/2014/12/10/ regimes-and-movements-thoughts-on-contentious-politics-and-the-arab-spring/ 
Sewell, W. H. (1996). Three temporalities: Toward an eventful sociology. In T. J. McDonald (Ed.), The historic turn in the human sciences (pp. 245-248). University of Michigan Press.

Shenker, J. (2016). The Egyptians: A radical story. Penguin.

Shokr, A. (2015). The 18 days of Tahrir. Middle East Report, $41(258)$, 14-17.

Smaldone, T. (2015). The Arab uprisings and the blossoming of a 'global imaginary'. Inquiries Journal, $7(6), 1-3$.

Soudias, D. (2015). Policing January 25: Protest, tactics, and territorial control in Egypt's 2011 uprising. Middle East - Topics \& Arguments, 4(1), 170-182. https://doi.org/10.17192/meta.2015.4.2669

Stein, E. (2012). Revolution or coup? Egypt's fraught transition. Survival, 54(4), 45-66. https://doi. org/10.108o/oo396338.2012.709388

Teti, A., \& Gervasio, G. (2011). The unbearable lightness of authoritarianism: Lessons from the Arab uprisings. Mediterranean Politics, 16(2), 321-327. https://doi.org/10.1080/13629395.2011.583758

Tilly, C. (2005). Repression, mobilization, and explanation. In C. Davenport, H. Johnston, \& C. Mueller (Eds.), Repression and mobilization (pp. 211-226). University of Minnesota Press.

Tilly, C. (2008). Contentious performances. Cambridge University Press.

Torfing, J. (1999). New theories of discourse: Laclau, Mouffe, and Z̆ ižek. Blackwell Publishers.

Valbjørn, M., \& Volpi, F. (2014). Revisiting theories of Arab politics in the aftermath of the Arab uprisings. Mediterranean Politics, 19(1), 134-136. https://doi.org/10.1080/13629395.2013.856185

Van Dyke, N., \& McCammon, H. J. (Eds.). (2010). Strategic alliances: Coalition building and social movements. University of Minnesota Press.

Verhoeven, I., \& Bröer, C. (2015). Contentious governance: Local governmental players as social movement actors. In J. W. Duyvendak \& J. M. Jasper (Eds.), Breaking down the state: Protestors engaged (pp. 95-110). Amsterdam University Press. https://doi.org/10.2307/j.ctt196315k.7

Volpi, F. (2014). Framing political revolutions in the aftermath of the Arab uprisings. Mediterranean Politics, 19(1), 153-156. https://doi.org/10.1080/13629395.2013.856186

Volpi, F., \& Clark, J. A. (2019). Activism in the Middle East and North Africa in times of upheaval: Social networks' actions and interactions. Social Movement Studies, 18(1), 1-16. https://doi.or g/10.1080/14742837.2018.1538876

Volpi, F., \& Jasper, J. M. (Eds.). (2018). Microfoundations of the Arab uprisings: Mapping interactions between regimes and protesters. Amsterdam University Press.

Wagner-Pacifici, R. (2010). Theorizing the restlessness of events. American Journal of Sociology, 115(5), 1351-1386. https://doi.org/10.1086/651299

Wahba, D. (2017). Rabea: How do we live with ourselves after witnessing a massacre? Mada Masr. https:/www.madamasr.com/en/2017/o8/17/opinion/u/rabea-how-do-we-live-with-ourselvesafter-witnessing-a-massacre/

Wessel, S. (2017). The making of political representation. Processes of claim-making and receiving during the Egyptian transformations (2011-2014) [Doctoral Dissertation]. Universität Hamburg. 



\title{
2 Conceptual Choices and Theoretical Framework
}

\author{
Eventful history, interaction dynamics, and discursive \\ arenas
}

\begin{abstract}
This chapter outlines the conceptual choices and develops the theoretical framework of this inquiry. This includes a micro-level approach to the study of contention, an interactionist framework of analysis, and special attention to the discursive arena of contentious politics. It introduces the idea of social mobilization as populations of contentious events by compound players who interact with their counterparts in complex protest arenas. The emergence of political subjectivities, as well as players' strategic choices on alliance-building, mobilization, and employed tactical repertoires, are all embedded in and contingent on these interactions. This chapter illustrates how discourse theory, by accounting for both linguistic meaning and the material event, can contribute to developing the concept of protest arenas further by theorizing the discursive layers of interaction that accompany contentious struggles.
\end{abstract}

Keywords: eventful protest, players, arenas, discourse theory, transformative events

With its focus on symbolic interaction and contested interpretations of contentious politics, this book deals primarily with the discursive interactions that accompany and shape both, state repression and social protests. A discourse is defined here as "a particular way of representing certain aspects of the world, whether physical, social or psychological" (Rear \& Jones, 2013, p. 375). About physical interactions, such as distinct protest gatherings or the repressive measures taken by security forces on a specific date against the people in the streets, there are always different representations that

Grimm, Jannis Julien, Contested Legitimacies: Repression and Revolt in Post-Revolutionary Egypt. Amsterdam: Amsterdam University Press 2022 DOI: $10.5117 / 978946372265^{\circ}$ _CHO2 
compete for meaning. This has been true for Egypt ever since the outbreak of the political struggle in 2011, as Khaled Abdalla (2016) illustrates in his discussion of the shifting fault lines of the revolution:

Is 25 January the anniversary of the revolution, or a day commemorating the police? Did we have two revolutions? Were the events of June 30 , 2013, a revolution or a coup? Can the Muslim Brotherhood's program be considered "secular"? Who killed who on what day? Who is conspiring to destabilize the country? Is it our duty to obey or to challenge? (p. 37)

How these questions are answered by individuals is, and always was, more than a question of representation. According to Pratt (2015), the struggles over the meaning and objectives of the January 25 Revolution represent "struggles over 'the hearts and minds' of the Egyptian people and the definition of the future polity" (p. 48). Due to language's constitutive aspects, the meanings attached to material events have immediate and tangible real-world consequences. By constituting the boundaries of responses by contending players, they are significant for the course of events during phases of contention. Discourses and the physical events they signify are thus a two-way street, or as Marianne Jørgensen and Louise Phillips (2002) stress, "discourse is a form of social practice which both constitutes the social world and is constituted by other social practices" (p. 61).

The theoretical framework presented in this chapter builds on these considerations. It bridges the discourse theoretical research tradition and the contentious politics research program. It subscribes to the idea of social mobilization as a population of collective action events, and thus to a "constructivist" approach to social movements. Based on this thought, it is claimed that political players, such as social movements or authoritarian regimes, are not static and uniform actors, endowed with certain features and traits that can be inferred based on their ideology, culture, or religious affiliation. Instead, they are complex compound and (inter-)active social players and themselves the products of a contingent social context.

Procedural and interactional approaches have attempted to make sense of this relation by investigating the relational subjectivation processes within different social arenas that give rise to compound players such as social movements that challenge the status quo. Foregrounding the short-term effects of the interactions between regimes and their contenders, above all scholars of political violence and repression (a.o., Della Porta, 2014b; Earl \& Soule, 2010; Francisco, 2004; Hess \& Martin, 2006; Jasper \& Poulsen, 1995; McCarthy \& McPhail, 2005) first illustrated how windows for mobilization 
were often situational, and emerge spontaneously and unexpectedly from contentious interaction. Hanspeter Kriesi (2004), for instance, noted that "episodes of contentious interaction are likely to modify the relevant configuration of actors and, thus, to change the specific opportunities for future options for collective action" (p. 79). In a similar vein, Della Porta (2011) talks about the "eventfulness" of protest to describe how social movements can create opportunities for themselves or other players that follow. ${ }^{1}$

The Arab Spring was a prime example of this generative process. It demonstrated the necessity to move beyond structuralist and taxonomic accounts in what Lawson (2016) has referred to as the "fourth generation" of revolutionary theory. Like the collapse of the Soviet regime in 1989, the Arab Spring is often portrayed as a "structurally overdetermined drama" (Beissinger, 2009, p. 335). But actually, it depended on countless acts of contention whose outcomes were hardly predetermined, as each event altered the "constellation of possibilities in the future" (Alimi \& Meyer, 2011, p. 477). Della Porta (2014a, pp. 29-32) has drawn parallels between this eventful character of the upheaval in the Arab World and the popular uprisings in the GDR and former Czechoslovakia: It was in their dynamic interaction that innovative coalitions of contenders produced relations that favored mobilization and transformation. In both protest waves, she notes, social mobilization "fueled itself: it did not so much respond to emerging political opportunities as it created and broadened them in the struggle" (Della Porta, 2014a, p. 191).

Her comparative historical approach to the analysis of the Arab Uprisings as a process of democratization from below is one of the few attempts to establish bridges between the disciplinary perspectives of transition and democratization studies, on the one hand, and those of social movement scholars on the other. The prognosis of democratization in Egypt may have been disproven by the bleak political reality of a counterrevolution and a protest-driven democratic roll-back from below. The merit of Della Porta's

1 The work of both authors reverberates William Sewell's conception of an eventful temporality of protest, which highlights how social structures, thought durable and resilient, can effectively be transformed through collective agency. Sewell recognized a necessity to relocate the focus of historical sociology to the analysis of events, making a head start with his study of the publication of Abbé Sieyes' Qu'est que c'est le tiers état? and the storming of the Bastille in 1789 - two events at the outset of a most decisive contentious episode in European history (see Sewell, 1996a). In a later essay with Doug McAdam (2001), he identifies four different temporal rhythms that each grasped different aspects of social movement and revolution: 1) cultural epochs/master templates; 2) long-term changes that destabilize existing power relations; 3 ) protest cycles, which denote the temporally narrow and most active phase of social movements; and 4) transformative events, unique moments of collective creativity. 
analysis, however, lies in her dynamic conception of contentious politics as more than a context variable for elite decision-making. She and others have stressed how it was effectively a sequence of responsive and interactive events that had a transformative impact on mobilization in Egypt. These dynamics provided the trigger for translating long-existing structural conditions for cross-class and cross-ideological mobilization into effective collective action coalitions.

In a similar vein, several more recent studies of the Arab Spring aftermath have underscored that the puzzle of successful mass mobilization amid stable authoritarianism can be solved only by adopting a procedural and relational perspective and by focusing on micro-level dynamics, rather than macro-level structural shifts (e.g., Grimm \& Harders, 2018; Harders \& König, 2013; Jasper \& Volpi, 2018; Volpi \& Clark, 2019; Weipert-Fenner, 2021). After all, what is conventionally understood as political opportunity structures underwent little change at the forefront of the 2011 uprisings. Neither the cohesion of regime elites, nor the permeability of their polities, nor the capacities of their coercive apparatuses had experienced significant change. But during the 18 days of Tahrir, authorities, and contenders changed the perception about these structures through their interactions, thus creating new openings themselves.

\section{Players and Arenas}

Few authors have been more vocal in their critique of an exclusive focus on the macro conditions of social change than Jeff Goodwin and James Jasper. In their now seminal critique of the structural reductionism inherent in the political opportunities approach Goodwin and Jasper (1999) noted that political process theory, despite its inherent tautological bias, had become hegemonic in the field of social movement studies to the extent that analyses increasingly portrayed political opportunities as the necessary and sufficient conditions for mobilizations while failing to assess how individuals recognized, realized or created these opportunities. Recent contributions to the political opportunities paradigm may have taken the constructed nature of opportunities more seriously (see Giugni, 2009; Koopmans \& Olzak, 2004). However, they equally fell short of accounting for the volatility of social interaction and the contingency of its effects, mostly black-boxing public discourse as a mere resonance chamber.

Jim Jasper's later works then attempted to overcome the stalemate between structural and cultural studies of protests (Jasper, 2015a, p. 9). In two 
complementary edited volumes, he and his collaborators offered an attempt at theoretical bridge building by focusing on the strategic interactions that accompany and define situations of mobilization and contestation (see Duyvendak \& Jasper, 2015; Jasper \& Duyvendak, 2015). ${ }^{2}$ Three elements are central to this approach: players, arenas, and strategic interaction. Players can be thought of as individuals or groups of individuals who engage strategically with each other for specific purposes (Jasper, 2015b, p. 1off.). These purposes may vary among different factions of one compound player and they also vary over time. Jasper refers to the different circumstances and places where players interact as arenas thus taking up a Latin term that is usually employed to literally or metaphorically designate a combative stage that is designed to accommodate a multitude of spectators. According to Jasper, it is by engaging each other in such arenas that different actors become political players in the first place.

Beyond constituting merely a physical space, arenas can be thought of as sets of rules, norms, and resources that allow for the interaction of several individual or compound actors (Jasper, 2015b, p. 14f.). Jasper and Duyvendak prefer the metaphor of the arena over the resembling term "field" used by a range of other approaches that aim to balance the tendencies in sociological theory toward either structural determinism or an exclusive focus on contingency and agency, the "agency-structure behemoth" (McGarry et al., 2016, p. 635), and to define a middle ground between micro and macro scales of analysis (Bourdieu, 1993; DiMaggio \& Powell, 1983; Fligstein \& McAdam, 2015; Martin, 2003). One of the reasons for this is that they aim to distance themselves from notions of the field as an epistemic construct. For Jasper and Duyvendak, arenas are not merely imagined and constructed by the researcher in the process of data gathering and analysis. Instead, they are built by the interacting players themselves. For social scientists this means that they can "take a seat" in them and observe the interactions, such as when watching political talk shows on $\mathrm{TV}$, attending court sessions, or following debates on Twitter. In other words:

Arenas help stabilize chains of interactions by providing physical constraints, formal rules, and informal traditions. They offer places to sit or

2 The two editions engage in a division of labor, of sorts: While Players and Arenas analyses a multitude of social players, such as movement factions, foundations, companies, trade unions, and intellectuals, Breaking Down the State centers mainly on the different arenas of the state, including a.o. courts, political parties, police, military, and international organizations, such as the United Nations. 
stand, to observe or participate. They have transmission and recording devices to preserve the actions and decisions or to convey them to audiences not physically present. Their lighting and acoustics also shape the actions. (Jasper, 2018, p. 165)

Just like players, arenas are dynamic and malleable. They are always "emerging, changing, and recombining" (Jasper, 2015b, p. 13). Their transformative potential stems from the fact that rules and norms are constantly being strategically interpreted, contested, ignored, and broken. These interactions are part of the third conceptual pillar which, building on Goffmann (1986) and Blumer (2009), describes the strategic and culturally mediated interaction dynamics of players and arenas. These dynamics create, define, and change actors, arenas, and the entire social world. Strategy, in this context, denotes all conscious efforts by individual or compound actors to "get their way" (Jasper, 2008), that is, to force, convince or compel other players to do what they want them to do.

With a view to contentious politics, this model naturally begs the question of whether social movements and their counterparts should be conceived of as players or as arenas? The answer is both: According to Duyvendak and Jasper, in empirical reality, social movements (as well as states) often claim (or are attributed) a high level of internal coherence and unity. This unity represents a "necessary fiction" (Jasper, 2015b, p. 14) and can be explained through the rules of antagonist subject formation discussed in depth later in this chapter. But factually it often does not exist. Instead, players are usually highly heterogeneous, dynamic, and overlapping. Additionally, they often become arenas for social conflict or coordination themselves (see Polletta \& Kretschmer, 2015). They are thus arenas themselves but engage as players with a larger social theater.

The advantage in conceiving of movements through these lenses lies in the ability to capture also processes of mobilization that do not conform to the classical image of a social movement organization engaging in a campaign. Furthermore, a players-arenas perspective avoids homogenizing contentious actors by investigating them through essentialist analytical categories (like the youth, the workers, the Islamists, etc.). These categories often invoke a certain historical agency (e.g., of the working class in revolutions) that may not be empirically warranted for the investigated case. Moreover, in empirical reality, camps are rarely static or strictly demarcated. Especially broad mass mobilizations are better understood as "assemblages of diverse people and groups that in an exceptional moment come to apprehend a common goal" (Schwedler \& Harris, 2016, p. 4) than as social movements 
with discernible boundaries, memberships, and clear cut distinctions. As Goodwin, Jasper, and Khattra (1999, p. 31) stressed, "A social movement does not simply presuppose, but is itself an expression of the associated activities of some group or field of actors" (p. 31).

Accordingly, a methodological perspective on the individual (and its decisions and micro-interactions) should be at the basis of inquiries into macro-processes of change. Social movements are central to such change. But they must be understood as compound players composed of countless individuals who are driven not only by idiosyncratic interest or different layers of "Zweckrationalität" but also by emotions, urges, affective commitments, and long-forged moral identities (Jasper, 2018, p. 4ff.; see also Polletta \& Kretschmer, 2015, p. 47). The same holds for structural categories, such as class or ideology. While not denying the relevance of class or identity politics in determining the course of contentious politics, these phenomena are better understood as symptoms of subjectivation processes that are rooted in the reproduction of historical relations - hence, in players' interactions, rather than some essentialist substructure of the social (Bourdieu, 1987; Wacquant, 2019; see also Della Porta \& Atak, 2017, p. 37).

The analyses in this book build on these considerations. In my narration of Egypt's post-revolutionary history, I subscribe to a view of protest cycles as the results of complex relations between autonomous individuals on a micro-level. Accordingly, the analytical focus lies on the strategic, that is, goal-oriented practices of human interaction (Jasper, 2015b, p. 19). The trajectory of the investigated protest cycles is not ascribed to structural conditions or the idiosyncratic features of given movements, such as their supposedly static ideological predisposition. Instead, protest cycles are viewed as products of complex interactions between authorities, coalition partners, competitors, and the public. These interactions are captured and observed symptomatically through the investigation of events, which provide moments of structuring that harmonize the individual struggles of different players.

\section{Contentious Interaction at Critical Junctures}

As conceived by McAdam and Sewell (2001), events may be thought of as "unique happenings, full of accident, contingency, and sudden, unexpected transformations" (pp. 100-102). They are "punctual and discontinuous rather than cyclical, linear, or continuous" (p. 102). McAdam and Sewell find commonalities between events during revolutionary times and the conventional 
temporal registers of social movements. But they are careful to underscore the importance of a few historic events, lamenting that sociological analysts had, so far, left their analysis to historians. Events such as the taking of the Bastille explored by McAdam and Sewell exert a transformative effect on people as they created "hitherto unimagined categories of political action" (Tarrow, 2001, p. 106). It is during these events that we can observe "concentrated moments of political and cultural creativity when the logic of historical development is reconfigured by human action" (McAdam \& Sewell, 2001, p. 112).

The authors capture these crucial turning points in the history of social movements in their notion of transformative events. The idea of a transformative event is that of a short-term temporality that opens a new temporal register wherein "a new future becomes possible, a new founding" (Schwedler, 2016). Time becomes fateful because it comes to be seen as "irreversible, in the sense that an action, once taken, or an event, once experienced, cannot be obliterated" (Sewell, 2009, p. 6). They cannot be undone and unthought, propelling an impression of liminality. Donatella Della Porta and Kivanc Atac (2017) have related this experienced liminality, which is characterized by political contingency and a high level of uncertainty among social players, to the notion of critical junctures. Critical junctures are structurally undetermined in that their impact highly depends on how players perceive the exceptional movement and adjust their course of action accordingly. Rather than creating rigid path dependencies, critical junctures usually expand the horizon of possibilities and thus the range of plausible action choices (Della Porta \& Atak, 2017, p. 32f.). As Della Porta (2014b) writes elsewhere, the exceptional moment is often seen "as requiring exceptional commitment" (p. 178), which can catalyze innovation and lead to the emergence of wholly new forms of political action. Usually heralding a cascade of temporally compressed contentious events, these key events are both unique in their underlying dynamics and their transformative potential. Becoming part of the cultural stock of a movement, they also provide moral reference points and create new possibilities for framing. Thereby they can become resources for the formation of new subjectivities, for meaning-making, and - ultimately - for recruitment and backlash mobilization (Jasper \& Poulsen, 1995, p. 497f.; Olesen, 2009, p. 26).

Transformative events and the critical junctures they heralded played a vital role in the uprisings across the MENA region. Jillian Schwedler has argued that the initial acts of the uprisings - despite the idiosyncratic differences between the various cases of mass protest across the region - were akin in their symbolism and effect to the events described by Sewell: "Just 
as taking the Bastille helped transform the self-understandings of French subjects into citizens, the early days of the Arab uprisings were necessary to make imaginable actually thinkable" (Schwedler, 2016). When 26-year old Mohamed Bouazizi set himself aflame in the town of Sidi Bouzid on December 17, 2010, his self-immolation became a transformative event that "sparked the fire in millions like him" (Chatterji, 2013, p. 96). In the Egyptian case, in turn, the torture and the killing of the Alexandrian teenager Khaled Said by police officers in late 2010, became a transformative event (Della Porta, 2014a, p. 101). Not only was Khaled Said's portrait a recurrent image during all kinds of protests against state violence in 2011, but his murder also served as a trigger for a massive backlash that drove the number of young people who sympathized with Said's ordeal and were willing to show their solidarity by protesting to new heights.

What is more, the Arab Spring demonstrates the ability of such transformative events to impact even geographically distant sites. Khaled Said and Mohamed Bouazizi became icons not only in Egypt and Tunisia. Their images and corresponding narratives traveled across borders to enter the cultural stock of movements beyond the region. The new culture of resistance developed during the Tunisian and Egyptian uprisings easily connected to and fueled through its success story a globally shared desire for direct participation in politics (see El-Sharnouby, 2018b). Miniya Chatterji (2013, p. 101), for instance, has explored how the "dignity uprisings" in the Arab world served as transformative events for struggles in India, where they provided strength and legitimacy to the local anti-corruption movement. In a similar vein, Sarah Kerton (2012) has argued that the successful defense of the protest camps on Tahrir Square played a crucial role in initiating and shaping Europe's Occupy movement. Even long after protesters had emptied the square, the aura of Tahrir lasted on for European activists, influencing the forms of what was thinkable and possible in their spatial present.

When it comes to the aftermath of the Arab Spring, together with Cilja Harders (2018), I have explored the decisive impact of transformative events on the trajectory of contention in Egypt. We pointed out how they were recurrently followed by "moral shocks" (Jasper \& Poulsen, 1995, p. 498) which compelled formerly contention-averse people to take to the street in large numbers. Generated by blatant acts of state violence, these moral shocks raised such a sense of public outrage that individuals were mobilized, even in the absence of prior networks of recruitment, and although structural conditions were not ripe for protest. For this recurrent unintended consequence of state repression, Ronald Francisco (1995) has coined the term "backlash protest" (p. 263). The risk of backlash mobilization following repression 
is generally found to increase when repression is applied reactively and indiscriminately against all opponents regardless of their rank (Della Porta, 2014b, p. 169; Khawaja, 1993), instead of selectively targeting leading cadres of a movement or agents provocateurs, thus causing the individual costs of participating in a protest to approximate those of non-participation (M. Hafez, 2003; Mason \& Krane, 1989). Moreover, backlash becomes likely when the level of repression, that is, police brutality or the severity of restrictions, surpasses a certain threshold (Francisco, 2004).

Prominent examples referred to in the literature as transformative and highly mobilizing backlash events are the Bloody Sunday Massacre in Northern Ireland, or the Sharpeville Massacre in South Africa (Hess \& Martin, 2006, p. 251). In turn, during the January 25 Revolution, the vicious attempt by the Mubarak regime to disperse the crowds on Tahrir Square with the help of hired thugs on camelback was such a transformative event. The violent attack on February 2, 2011, recalled as the Battle of the Camel during the occupation of Tahrir, strengthened the determination of those defending the square and triggered massive backlash mobilization (Holmes, 2012, p. 399).

\section{Making Events Transformative}

Like during other confrontations on Tahrir Square, a range of complex emotional dynamics worked together to turn the Battle of the Camel into a transformative moment. Several observers have described how, before the attack, the Tahrir occupation had become a sort of protest carnival despite the massive risks and protesters' victimization by police forces (see Jasper, 2018; Ayata \& Harders, 2018; Said, 2015). They contend that the bodily copresence, joint practices, and collective performances during the prolonged occupation of Tahrir Square (and other squares in the region that witnessed large-scale occupations, such as Taksim Square in Istanbul or the Pearl Roundabout in Manama, Bahrain) led to the emergence of multi-layered affective dynamics. These included aspects of joy, excitement, and liberation and served to catalyze processes of solidarization. In their interplay, they "enabled outright antagonistic actors to protest together" (Ayata \& Harders, 2018, p. 116). But they were also key in sustaining resistance when the camps were attacked. As Jasper (2018) argues, "with that exhilaration as background, each attack - verbal or physical - by Mubarak's thugs and spokespersons created more indignation than fear. Or rather, indignation turned the reflex fear into a useful moral feeling of outrage" (p. 78). This 
moral outrage vitalized the protest movement, shored up its resilience, and contributed to a continuous influx of protesters until Mubarak resigned.

Violent events such as massacres have a particularly intense emotional impact on society. These encounters give rise to "intense emotions, such as excitement, and strengthened commitment to radical politics" (Della Porta, 2008, p. 172). However, moral outrage may also be triggered by different kinds of structural contradictions and implosions that disrupt players' perception of their lifeworld, thus eliciting an intense emotional response (Pearlman, 2013; Benski \& Langman, 2013; Benski et al., 2013). Large ruptures in the life cycle of social movements are easily recognizable, but small ruptures can be equally meaningful and indicate "a pushing of boundaries by defiance of a previously honored red line, whether done by the security services or by protesters" (Schwedler, 2018, p. 72). Disruptions of "the quotidian," that is, of the taken-for-granted routines and attitudes of everyday life, can be a highly productive force as regards mobilization.

A recently published volume, edited by Jim Jasper and Frederic Volpi (2018), explores the dynamics of meaning-making on a micro-level. Therein Schwedler (2018) convincingly argues for a closer study of protest events, not only as a component of a larger protest cycle which helps to piece together a larger study but especially in terms of the meaning that people attribute to them. Methodological nationalism and a macro focus on the larger protest waves or cycles, she contends, have led scholars to overlook the vital question of how meaning is generated by the actors involved in the protests themselves throughout even a single event: "What political work is done in the course of a protest or set of protests, and for and by whom?" (Schwedler, 2018, p. 71). Centering her analysis on the regularities and ruptures in the micro-practices of the "Kaluti protests" against the Israeli embassy in Jordan she shows how, at times, even small ruptures can become very meaningful events for collective actors. It is whether these events on the ground develop affective power and touch people's hearts and minds that decides if they inspire backlash or not.

Even when events involve violence, the creation of "myths and martyrs" (Della Porta, 2006, p. 161) is not an automatism. Shocking violence may sometimes become a "summary symbol" that intensifies the meaning of resistance (Cremer-Schäfer, 1992, p. 24). But often brutal violence also deters dissent and prevents the emergence of strong political players. Either outcome is highly dependent on the discursive embedding of events and how audiences make meaning of their feelings towards the events they witness by placing them in certain narratives over others. As Margaret Archer (2003) asserts, "courses of action are produced through the reflexive 
deliberations of agents who subjectively determine their practical projects in relation to their objective circumstance" (p. 165). Even concrete physical experiences - the tear gas and batons of the police, the injustices suffered at the hands of the state, the strenuous resistance against an overwhelming deployment of security forces - must be embedded in symbolic structures to attribute a certain meaning to them

For instance, Youssef El Chazli (2018, p. 140ff.) has argued that the abuse and killing of Khaled Said in itself was not an extraordinary event. Torture and police brutality were commonplace in Mubarak's Egypt. Hence there was nothing inherently significant about Said's murder. What made it transformative was that several political players seized the event as a public case to define a political enemy. The murder of the Alexandrian teenager cleft a political chasm between Egypt's people and its police. Beyond the immediately suffered experience, the (re)construction of the event was thus imperative for subsequent mobilization (Della Porta, 2014b, p. 177).

In line with this reasoning, Colin Hay (1996, p. 424) has argued on a more general level that the effects of political crisis events are always dependent on their discursive mediation through narratives. Narratives can be understood as "the representation of an event or a sequence of events, real or fictitious, through thematically connected (as opposed to merely chronologically listed) words and images" (Jasper et al., 2020, p. 20). Crises and critical junctures are accessed in and through such narratives. The interaction between the state and contenders thus also takes place in the discursive arena, in addition to the material arena of the street where police forces shoot their tear gas canisters, and where demonstrators answer with stones and roadblocks (see Jasper \& Duyvendak, 2015). Emotionality and affect play an important role in this process. They help explain "why some symbols and meanings grab us and others leave us cold" (Jasper et al., 2020, p. 251), and thus, ultimately, the resonance of certain narratives over others. To subvert dominant codes, movements must construct compelling sets of representations that are not only convincing but also able to touch people's feelings.

Social movement scholars have attempted to capture this interpretive process in the concept of framing. According to this influential strand of research, diverging readings of demonstrators' physical interactions with, for instance, police forces emerge from the contested framing of events by the contending players. Framing works on discourse in a similar fashion as a frame around a picture does (Noakes \& Johnston, 2005, p. 2), concurrently highlighting and excluding certain items and features, establishing clearly what is to be taken as relevant in the artistic composition and what as redundant. In essence, framing implies two dimensions: First, it captures 
the cognitive process through which players make sense of the events they witness. Adding to this encoding of reality, framing embodies the discursive work by which actors communicate the meanings they attach to events (G. Brown, 2014, p. 143). The perceived causes of, reasons for, or solutions to certain events are thereby translated into specific symbolic structures and positioned within strategically manufactured narratives.

Yet how does this process influence the conditions for mobilization or repression? The framing perspective recognized social movements as signifying agents and no longer reduced them to carriers of extant ideas that are rooted in their structural positions (Benford \& Snow, 2000, p. 613). But it failed to conceptualize the link between players' discourses and their impact on the arenas of protest in a compelling way. Like in the opportunities approach, the prominence of some narratives over others is explained in purely structural terms: Depending on people's economic dispositions, their ideology, or their access to resources, movement narratives may end up stuck in dead-end streets or assume a favorable symbolic position and facilitate mobilization. By contrast, discourse theoretical approaches give the struggle over meaning as the constitutive element of the social center stage.

\section{A Discourse Theoretical Perspective on Contentious Politics}

At the foundation of discourse theory lies the assumption that society cannot be understood as a structured totality and cannot be described through any unifying principle. This does not mean that there is not some form of social order which structures daily life. There is just no necessary one. All social orders - just like social identities - are necessarily contingent. Ernesto Laclau and Chantal Mouffe (2001), who are commonly viewed as the founders of the so-called Essex School of discourse theory, call this the "constitutive openness" of the social (p. 96).

In their founding text, they contest the "lingering class essentialism" (Keucheyan \& Elliott, 2013, p. 240) of Marxist theory and defend an antiessentialist view of social struggles. The classical Marxist position had assumed that a subject's social position, despite its empirical variations and tendencies on the surface, could always be traced back to its position as a partial element in an essential social order. The social had been presented as "a structural totality with its own identifiable and intelligible positivity" (Hall, 1988, p. 43) enabling all those able to read the code that structured "the social" - that is, of course, the laws of capitalist production - to identify the position of all of society's elements. Ultimately, social players' role in 
politics was always defined by their position in the capitalist relations of productions. The working class was therefore ascribed with the natural role of the revolutionary subject and consequently the greatest hegemonic potential.

Against this backdrop, Gramsci's lifework constituted a turning point for Laclau and Mouffe (Laclau \& Mouffe, 2001, p. 67). His conception of hegemony replaced the static and often essentializing concept of ideology in Marxist thought. It enabled Gramsci to grasp the increasing significance of culture in social relations. For Gramsci, political subjects were not strictly speaking class subjects. Gramsci viewed political rule as more than a mere mirror image of material realities bound by inextricable economic laws. Instead, those in power constantly had to manufacture social consent and acquiescence for their rule through discursive processes of articulation (see Gramsci, 1971, pt. 2). Gramsci referred to this political logic as hegemony. It denotes the creation of consensus by persuasion and the enforcement of power asymmetries without resorting to force.

Gramsci's social theory maintained an essentialist core that tied hegemony to the naturalization of class divisions (Keucheyan \& Elliott, 2013, p. 240). As adopted by Laclau and Mouffe, however, hegemony describes the naturalization of all kinds of power relations, of which class is but one possible option. In a world that is radically heterogeneous, fragmented, and volatile, they argue, social identity is anything but defined a priori. ${ }^{3}$ Instead, the coherence of social players is highly contingent on (and constructed by) the dynamics of a struggle (Shantz, 200o, p. 92f.). In this sense, social life had to be interpreted as a continually shifting surface of inscription of a variety of meanings.

Building on this though, Laclau and Mouffe suggest conceiving the social as a hegemonic terrain. This terrain finds its expression in the strategic interactionist notion of a discursive arena. In it, many players attempt to convince others of their reading of social reality to widen their room for maneuver. In protest arenas, the competitive nature of this discursive layer is evident. As part of their power struggle, contenders constantly assign

3 Their deconstruction of historical materialism built on the empirical observation that the social world has become more complex than forecast by Marxism. Far from consolidating, class cleavages have become ambiguous and supplemented by other layers of identity. This cast doubts on workers' objectively antagonist relationship to capital and on the link between structural positions and the constitution of interests. Rather than the workers assuming their revolutionary role, researchers were witnessing the emergence of new social movements who no longer focused exclusively on economic demands and whose mobilizing structures and resources were not organized along class divides. 
protest and repression events with competing meanings to claim moral authority and garner support: police forces vilify demonstrators to undercut their social base and legitimize repression; demonstrators expose state violence to trigger reflex emotions and elicit sympathy and action from other political players (see Jasper, 2018, p. 55). They often represent social reality in mutually exclusive ways. These constructions have consequences for the trajectory of contentious politics. They give the social a specific form that may allow or prevent certain courses of action.

The most significant consequence of this constitutive openness of the social is the realization that the meaning of objects, including contentious phenomena such as protests, cannot be objectively determined. According to Hay (2013), events are "what we make of them; and what we make of them determines how we respond" (p. 23). Discourse analyses thus cannot aim to discover the truth about social reality. Instead, they can only describe how the discursive interactions of social players construct this reality "so that it appears natural and neutral" (Rear, 2013, p. 5) and in line with common sense. This construction occurs through strategic acts of articulation by social players in different arenas of struggle. ${ }^{4}$ Laclau and Mouffe (2001) define the essential dimensions of this process of meaning-making as follows:

We will call articulation any practice establishing a relation among elements such that their identity is modified as a result of the articulatory practice. The structured totality resulting from the articulatory practice, we will call discourse. The differential positions, insofar as they appear articulated within a discourse, we will call moments. By contrast, we will call element any difference that is not discursively articulated. (p. 105)

Underlying their conception of discourse is the notion of a discursive field consisting of a multitude of signifiers. None of these signifiers themselves are fixed to a particular signified. Their identity stems from the discourse in which it is located. This makes them open to different meaning ascriptions (Torfing, 1999, pp. 98-99). Through their messages, slogans, and communicative practices, different players attempt to fix a web of meanings within a particular domain by structuring these signifiers into meaningful relations to the exclusion of others.

We can thus imagine discourses as webs of multiple "floating" elements that are interconnected through players' articulations. In these discourses,

4 For an overview glossary of Laclau and Mouffe's specific terminology, see Table 3 in the Appendix. 
different elements are grouped around nodal points, eminent signifiers that structure the discursive field (Laclau \& Mouffe, 2001, p. 112). According to Jørgensen and Phillips (2002), a nodal point is "a privileged sign around which the other signs are ordered; the other signs acquire their meaning from their relationship to the nodal point" (p. 26). A popular example of such a nodal point is the signifier "people" within populist discourses (Laclau, 2005, p. 153). From this nodal signifier, technical terms such as "border," but also terms with multi-layered meanings such as "nation" or "elite," derive their specific meaning. The practice of articulation ultimately consists in the construction of relational webs of meaning around such nodal points.

The relation by which elements are linked can be one of difference or equivalence (Laclau, 2005, p. 78). It is at the level of these relations that the crucial contests over meaning take place. For instance, police forces often place small-scale melees with demonstrators, the destruction of property during protests, and large-scale riots into a relation of equivalence through their common definition as protester violence. By contrast, within social movement discourses, these phenomena may assume differential positions when they are framed either as self-defense, as a disruption of the capitalist means of production, or as legitimate resistance against structural oppression, respectively. These clashing interpretations represent the points of crystallization lines along which collective identities are developed and the fault lines along which political actors can rally support.

\section{Disruptive Events and the Articulation of Antagonism}

Processes of political subjectivation are usually triggered by disruptive events that challenge established knowledge and open up opportunities for new political rationalities to evolve (see Nabers, 2017). As Schwedler (2016) underscored, a single event "can fundamentally transform the horizon of what people believe is possible" and thus enable new articulatory projects. For those participating in or witnessing them, these events reveal their transformative character by significantly disrupting, altering, or violating the taken-for-granted assumptions governing routine political and social relations. Laclau and Mouffe refer to these ruptures as "dislocations" (Laclau and Mouffe 2001, 49f.; Laclau 1990, 41ff.).

Dislocation, according to the authors, describes the need for the re-arrangement of discourses to incorporate new events. It is caused by those events that cannot immediately be incorporated into the current horizon of expectations. That is, those events that cannot be symbolized or made sense of within the prevailing discourse, or as Marchart (2014) states, they are "something we 
did not expect and which therefore threatens the sedimented routines and processes of social institutions" (p. 277). By uprooting the sedimented meaning of nodal signifiers, these events reveal the contingency of the social order.

For contentious politics, such ruptures can be a productive force. By shattering interpretations of social reality that had gone unquestioned they create possibilities for activists to renegotiate the limits of what is thinkable, in terms of political alternatives, and doable, in terms of actions on the ground. Colin Hay (1996), who has produced some of the most insightful works on the effects of political crises, has therefore described critical junctures that lay bare the precariousness of the social order as moments of decisive intervention. These interventions can take different directions. They can reify existing power relations, such as, after the September 11 attacks, when the widespread impression that the United States was experiencing a liminal moment streamlined mainstream discourses and closed the space for alternative interpretations (see Bail, 2012). But they can also challenge the status quo. It is usually in moments of dislocation when processes of disidentification with the prevailing order and those that sustain it begin. Contenders can react to this crisis by attempting to "hegemonize the gap" (Nabers, 2017, p. 422) and by forging resistance around political alternatives.

From the perspective of discourse theory, this resistance operates according to relational rules of subject formation - the We is defined vis-à-vis the Other. It is this differential relation to a constitutive outside (who I am not) that confirms and fixates social identity (who I am). ${ }^{5}$ According to Laclau (2006), to constitute a popular political subjectivity a player "has to discursively construct the enemy - the oligarchy, the establishment, big money, capitalism, globalization" (p. 655). If manifold sectors of society join a protest movement in rejection of government policy, this is made possible not by their mutual solidarity based on their common adherence to the same class, gender, etc., but by their common rejection of the constructed other - in many cases the government. In the absence of any pre-discursive features uniting them, the mobilized populace has at least one thing in common: the antagonism between their subject position and that of their adversary.

5 Laclau and Mouffe draw on Georges Sorel's conception of a world based on the primacy of conflict. However, unlike Sorel they do not see this conflict as one that follows any essential qualities or pre-discursive features of the social. For instance, class struggles are but one of many articulations of social antagonism. This rigorous abandonment of a class perspective finds its correlate in the notion of ubiquitous antagonisms as constitutive features of subject formation: if "no 'essence' underlies the social, the entities that develop in it are necessarily relational - that is to say, they are constructed with respect to one another or against one another" (Keucheyan \& Elliott, 2013, p. 241). 
In framing approaches to social movement studies this differential process has been captured in the concepts of "boundary framing" and "adversarial framing" (Benford \& Snow, 2000, p. 616; see also Hunt et al., 1994), attributional processes that construct and delineate between movement protagonists and antagonists. This construction process cuts across different dimensions of the framing process: Players usually adopt a diagnostic frame when they portray their political antagonists. Through this act of naming and shaming, they define the problem and appoint responsibility. By contrast, their self-portrayal usually reproduces a prognostic frame by designating who should act, and how. Moreover, antagonizing narratives usually involve an additional motivational component that aims to justify action against the designated enemy. The motivational frame typically stresses urgency and a duty to act. It often adds a moral dimension to the hitherto rational line of argument (Noakes \& Johnston, 2005, p. 2). Appeals to tradition, values, and belief systems target the emotional drivers of a movement's audience. In sum, there are, at least, three antagonisms that pervade the communications of protest players and can be investigated through discourse analyses:

1 one that pits the agents of injustice against their victim, and the agents of change,

2 one that contrasts the deeds of the former with the demands and strategies of the latter as a plan to solve an impasse or crisis,

3 and one that juxtaposes the moral superiority of the collective subject with the moral corruption of the antagonists other.

Each of these levels is equally important for the cohesion and recruitment of a social movement and thus for processes of collective identity formation. James Jasper, Michael Young, and Elke Zuern have dedicated an entire book to exploring how social groups build solidarities, policies, and social movements out of such clear-cut divisions - admiration for heroes and outrage for villains - that require diligent character work (Jasper et al., 2020, p. 2).

The emergence of a positive collective subject, such as a social movement, is achieved by the articulation of a link between its elements that is not shared by the enemy. This chain of equivalence dissolves the differential relations among the individual movement components through common reference to an external other. The specificity of their demands dissolves once they meet with rejection from a common enemy, paving the way for alliance-building and collective identity formation (Keucheyan \& Elliott, 2013, p. 242). The logic of difference that previously defined their interrelation 
is functionally replaced by a logic of equivalence; sectoral particularisms are transformed into a collective rejection of an antagonist other.

This process was illustrated by the Arab Spring: Part of the recipe for the success of the 2011 mass protests was their rejection of a unitary ideology and their dissolution of social differences in an equivalential chain of demands, with "neither a unitary subject to act as a signifier nor any metanarrative to contain its message" (Hale, 2014). The emergence of such a compound player resisting the status quo represented a subjectivation process that related different individuals to what Farhad Khosrokhavar (2018) has referred to as a "would-be social movement" (p. 163). A subsequent affective process of emotional affiliation, termed the "Midan Moment" by Ayata and Harders (2018), forged the multiple elements into a unified struggle:

In the Egyptian Revolution, the loose association of individuals with disparate social conditions gave birth to collective action against the Mubarak regime. This was made possible through 'subjectivation': the latter compensated for the heterogeneous conditions of the people, creating a unity of emotions autonomous from their "objective" social conditions (Khosrokhavar, 2018, p. 163).

This subjectivation was paralleled and reinforced by a dichotomization of the political spectrum into two antagonist camps, as the revolutionaries from different class backgrounds and conflicting ideologies found solidarity in their shared rejection of the Mubarakist state (see Smaldone, 2015). The iconic slogan "al-sha'ab yurid isqat al-nizam" [the people want the fall of the regime] evidences this antagonist formation (see Svendsen, 2014, p. 46). It articulates a commonality between all those taking to the streets and establishes the regime and its stooges as the main obstacles for transformation. Laclau (2005) describes this as the emergence of an "internal frontier, a dichotomization of the local political spectrum through the emergence of an equivalential chain of unsatisfied demands" (p. 74). This antagonist frontier separates the people from power, enabling a plurality of demands to constitute a broader social subjectivity.

\section{Synthesis}

Meanings are not produced in a vacuum but through sharing and exchange of argument. And they are both realized through and respond to interaction. Analyses must account for how discourses are produced and engaged within a framework of understanding that is being shaped through broader 
processes of social interaction. Unfolding events leave traces in contenders' discourses and contribute to the emergence, permutation, and demise of political subjectivities. Vice-versa, discourses come to constitute and redefine social reality by altering conditions of possibilities for action. Cultural interactionist frameworks of analysis are suited to capture these dynamics by conceptualizing the relation between social players and the social arenas in which they interact as a two-way street. This makes it possible to conceive of the interactions among the main contenders in Egypt's post-coup theater as contingent reactions to a series of critical junctures and, at the same time, as constitutive practices that turned these junctures into transformative events, reshaped parameters of the political game, and gave rise to antagonist struggles over meaning.

Laclau and Mouffe's concept of dislocation aptly captures the discursive character of those events that social movement scholars have referred to as transformative, precipitating, or turning point events. As Nabers (2017) recapitulates:

These "events" are never situated outside of a discourse. They neither have a temporal nor a spatial location outside of the discursive frame that translates it from a "pure event" - with all its ambiguities, displacements, and disruptions - into a "historical event" (p. 425).

It is the way how activists articulate their meaning and how they weave them into counter-hegemonic narratives that provides these events with a transformative character. This process generates texts, speeches, and other products of articulatory practices which can be collected as "snapshots" of certain players' discourses at a specific point of time and analyzed in relation to the social situation they are inserted. It also implies agency: In analogy to the study of protest performances, discourse is viewed as an iterative process, constituted by countless acts of articulation on the part of the contending players. Through these interactions, the latter can create opportunities for themselves and other players, but also influence the trajectory of unfolding events. According to Hay (2013, p. 425), the collective mobilization of popular perceptions at moments of crisis is crucial in influencing the trajectory of contentious dynamics. They open or foreclose windows for mobilization, provide fertile ground for, or impede the emergence of new political alliances, and bridge or reify preexisting social and ideological cleavages.

Discourse theory provides the analytical vocabulary for describing the process by which antagonisms are constructed in this process; how chains of equivalence are established that delineate between those who are part of 
a movement and those who are not; and how differences among different players are moderated by a common relation to central signifiers. In turn, framing approaches point out those layers of social movement discourses where political subjectivation processes can sensibly be analyzed. Through the coaction of these layers, signifying players supply both the We who should act collectively as an agent of change and the antagonist Other who should be acted against. Thereby, the discursive space is dichotomized, between those who are part or allies of the movement and those who are not.

Establishing clear-cut antagonisms on all three levels can help mobilize people and their passions and forge strong alliances between political players. At the same time, as will be shown in later chapters of this book, these antagonisms may also constrain players' actions. Jasper and his collaborators underscored a dilemma also faced by the Egyptian Muslim Brotherhood after becoming the target of state repression: "If you have demonized your opponent as malevolent and unreliable, it may be hard for you to justify negotiations with them" (Jasper et al., 2020, p. 9).

As the remaining chapters of this book illustrate, thinking of the interpretive battles after key events as a contentious struggle at the level of individual signifiers, between dynamic players in a changing discursive arena allows for an analysis of contentious politics that transcends the structural determinism of classical discourse theoretical approaches and reconstructs contenders' identities in more nuanced ways, and in relation to the dynamics of their struggle.

\section{References}

Abdalla, K. (2016). Changing frames and fault-lines. In M. Baker (Ed.), Translating dissent: Voices from and with the Egyptian Revolution (pp. 33-44). Routledge.

Alimi, E. Y., \& Meyer, D. S. (2011). Seasons of change: Arab Spring and political opportunities. Swiss Political Science Review, 17(4), 475-479. https://doi.org/10.1111/j.1662-6370.2011.02041.x

Archer, M. S. (2003). Structure, agency and the internal conversation. Cambridge University Press.

Ayata, B., \& Harders, C. (2018). Midān moments: Conceptualizing space, affect and political participation on occupied squares. In B. Röttger-Rössler \& J. Slaby (Eds.), Affect in relation: Families, places and technologies (pp. 115-133). Routledge.

Bail, C. A. (2012). The fringe effect: Civil society organizations and the evolution of media discourse about Islam since the September 11th attacks. American Sociological Review, 77 (6), 855-879. https://doi.org/10.1177/0003122412465743

Beissinger, M. R. (2009). Nationalism and the collapse of Soviet Communism. Contemporary European History, 18(3), 331-347.

Benford, R. D., \& Snow, D. A. (2000). Framing processes and social movements: An overview and assessment. Annual Review of Sociology, 26, 611-639. 
Benski, T., \& Langman, L. (2013). The effects of affects: The place of emotions in the mobilizations of 2011: Current Sociology. https://doi.org/10.1177/0011392113479751

Benski, T., Langman, L., Perugorría, I., \& Tejerina, B. (2013). From the streets and squares to social movement studies: What have we learned? Current Sociology, 6r(4), 541-561. https:// doi.org/10.1177/0011392113479753

Blumer, H. (2009). Symbolic interactionism: Perspective and method. University of California Press.

Bourdieu, P. (1987). What makes a social class? On the theoretical and practical existence of groups. Berkeley Journal of Sociology, 32, 1-17.

Bourdieu, P. (1993). The field of cultural production (R. Johnson, Ed.). Columbia University Press.

Brown, G. (2014). Does framing matter? Institutional constraints on framing in two cases of intrastate violence. Mobilization, 19(2), 143-164. https://doi.org/10.17813/maiq.19.2.j13338h544l20720

Chatterji, M. (2013). The globalization of politics: From Egypt to India. Social Movement Studies, 12(1), 96-102. https://doi.org/10.1080/14742837.2012.698132

Cremer-Schäfer, H. (1992). Skandalisierungsfallen. Einige Anmerkungen dazu, welche Folgen es hat, wenn wir das Vokabular 'der Gewalt' benutzen, um auf gesellschaftliche Probleme und Konflikte aufmerksam zu machen. Kriminologisches Journal, 24(1), 23-36.

Della Porta, D. (2006). Social movements, political violence, and the state. Cambridge University Press.

Della Porta, D. (2008). Eventful protest, global conflicts. Distinktion, 9(2), 27-56.

Della Porta, D. (2011). Eventful protest, global conflicts: Social mechanisms in the reproduction of protest. In J. M. Jasper \& J. Goodwin (Eds.), Contention in context: Political opportunities and the emergence of protest (pp. 256-276). Stanford University Press.

Della Porta, D. (2014a). Mobilizing for democracy: Comparing 1989 and 2011. Oxford University Press.

Della Porta, D. (2014b). On violence and repression: A relational approach (the Leonard Schapiro memorial lecture, 2013). Government and Opposition, 49(2), 159-187. https://doi.org/10.1017/ gov.2013.47

Della Porta, D., \& Atak, K. (2017). The spirit of Gezi: A relational approach to eventful protest and its challenges. In Global diffusion of protest: Riding the protest wave in the neoliberal crisis (pp. 31-58). Amsterdam University Press. https://doi.org/10.1515/9789048531356-003

DiMaggio, P. J., \& Powell, W. W. (1983). The iron cage revisited: Institutional isomorphism and collective rationality in organizational fields. American Sociological Review, 48(2), 147-160. https://doi.org/10.2307/2095101

Duyvendak, J. W., \& Jasper, J. M. (Eds.). (2015). Breaking down the state: Protestors engaged. Amsterdam University Press.

Earl, J., \& Soule, S. A. (2010). The impacts of repression: The effect of police presence and action on subsequent protest rates. In P. G. Coy (Ed.), Research in social movements, conflicts and change (pp. 75-113). Emerald Group Publishing Limited.

El Chazli, Y. (2018). It takes two (or more) to tango. In F. Volpi \& J. M. Jasper (Eds.), Microfoundations of the Arab uprisings: Mapping interactions between regimes and protesters (pp. 135-158). Amsterdam University Press.

El-Sharnouby, D. (2018). New social movements: The case of youth's political project in Egypt. Middle East Law and Governance, $10(3)$, 264-29o. https://doi.org/10.1163/18763375-01003003

Fligstein, N., \& McAdam, D. (2015). A theory of fields (First issued as an Oxford University Press paperback). Oxford University Press.

Francisco, R. A. (1995). The relationship between coercion and protest: An empirical evaluation in three coercive states. The Journal of Conflict Resolution, 39(2), 263-282.

Francisco, R. A. (2004). After the massacre: Mobilization in the wake of harsh repression. Mobilization: An International Quarterly, 9(2), 107-126. 
Giugni, M. (2009). Political opportunities: From Tilly to Tilly. Swiss Political Science Review, 15(2), 361-367. https://doi.org/10.1002/j.1662-6370.2009.tboo136.x

Goffman, E. (1986). Strategic interaction (3rd ed.). University of Pennsylvania Press.

Goodwin, J., Jasper, J. M., \& Khattra, J. (1999). Caught in a winding, snarling vine: The structural bias of political process theory. Sociological Forum, 14(1), 27-54.

Gramsci, A. (1971). Selections from prison notebooks. Lawrence and Wishart.

Grimm, J.J., \& Harders, C. (2018). Unpacking the effects of repression: The evolution of Islamist repertoires of contention in Egypt after the fall of President Morsi. Social Movement Studies, 17(1), 1-18. https://doi.org/10.1080/14742837.2017.1344547

Hafez, M. (2003). Why Muslims rebel: Repression and resistance in the Islamic world. Lynne Rienner Publishers.

Hale, S. (2014). The new Middle East insurrections and other subversions of the modernist frame. Journal of Middle East Women's Studies, 10(3), 40-61. https://doi.org/10.2979/ jmiddeastwomstud.10.3.40

Hall, S. (1988). The toad in the garden: Thatcherism among the theorists. In C. Nelson \& L. Grossberg (Eds.), Marxism and the interpretation of culture (pp. 35-57). Macmillan Education UK.

Harders, C., \& König, C. (2013). Mobilization, repression and coalitions: Understanding the dynamics of the Arab Spring [Discussion Paper]. Center for Middle Eastern and North African Politics. https://www.polsoz.fu-berlin.de/polwiss/forschung/international/vorderer-orient/publikation/working_papers/dp_o6/index.html

Hay, C. (1996). From crisis to catastrophe? The ecological pathologies of the liberal - democratic state form. Innovation: The European Journal of Social Science Research, 9(4), 421-434. https:// doi.org/10.1080/13511610.1996.9968500

Hay, C. (2013). Treating the symptom not the condition: Crisis definition, deficit reduction and the search for a new British growth model. The British Journal of Politics \& International Relations, 15(1), 23-37. https://doi.org/10.1111/j.1467-856X.2012.00515.X

Hess, D., \& Martin, B. (2006). Repression, backfire, and the theory of transformative events. Mobilization, $11(2)$, 249-267.

Holmes, A. A. (2012). There are weeks when decades happen: Structure and strategy in the Egyptian revolution. Mobilization, 17(4), 391-410. https://doi.org/10.17813/maiq.17.4.905210228n564037

Hunt, S. A., Benford, R. D., \& Snow, D. A. (1994). Identity fields: Framing processes and the social construction of movement identities. In E. Laraña, H. Johnston, \& J. R. Gusfield (Eds.), New social movements: From ideology to identity (pp. 185-208). Temple University Press.

Jasper, J. M. (2008). Getting your way: Strategic dilemmas in the real world. University of Chicago Press.

Jasper, J. M. (2015a). Introduction: Players and arenas formerly known as the state. In J. M. Jasper \& J. W. Duyvendak (Eds.), Breaking down the state: Protestors engaged (pp. 9-24). Amsterdam University Press. https://doi.org/10.2307/j.ctt196315k.3

Jasper, J. M. (2015b). Introduction: Playing the game. In J. M. Jasper \& J. W. Duyvendak (Eds.), Players and arenas: The interactive dynamics of protest (pp. 9-32). Amsterdam University Press. https://doi.org/10.2307/j.ctt16vj285.3

Jasper, J. M. (2018). The emotions of protest. The University of Chicago Press.

Jasper, J. M., \& Duyvendak, J. W. (Eds.). (2015). Players and arenas: The interactive dynamics of protest. Amsterdam University Press.

Jasper, J. M., \& Poulsen, J. D. (1995). Recruiting strangers and friends: Moral shocks and social networks in animal rights and anti-nuclear protests. Social Problems, 42(4), 493-512. https:// doi.org/10.2307/3097043 
Jasper, J. M., \& Volpi, F. (2018). Introduction: Rethinking mobilization after the Arab uprisings. In F. Volpi \& J. M. Jasper (Eds.), Microfoundations of the Arab uprisings: Mapping interactions between regimes and protesters (pp. 11-40). Amsterdam University Press.

Jasper, J. M., Young, M. P., \& Zuern, E. (2020). Public characters: The politics of reputation and blame. Jørgensen, M., \& Phillips, L. (2002). Discourse analysis as theory and method. Sage.

Kerton, S. (2012). Tahrir, here? The influence of the Arab uprisings on the emergence of Occupy. Social Movement Studies, n1(3-4), 302-308. https://doi.org/10.1080/14742837.2012.704183

Keucheyan, R., \& Elliott, G. (2013). Left hemisphere: Mapping critical theory today (2nd ed.). Verso.

Khawaja, M. (1993). Repression and popular collective action: Evidence from the West Bank. Sociological Forum, 8(1), 47-71.

Khosrokhavar, F. (2018). Violence, social actors, and subjectivation in the Egyptian revolution. In F. Volpi \& J. M. Jasper (Eds.), Microfoundations of the Arab uprisings: Mapping interactions between regimes and protesters (pp. 159-182). Amsterdam University Press.

Koopmans, R., \& Olzak, S. (2004). Discursive opportunities and the evolution of right-wing violence in Germany. American Journal of Sociology, no(1), 198-230. https://doi.org/10.1086/386271

Kriesi, H. (2004). Political context and opportunity. In D. A. Snow, S. A. Soule, \& H. Kriesi (Eds.), The Blackwell Companion to Social Movements (pp. 67-9o). Blackwell.

Laclau, E. (1990). New reflections on the revolution of our time. Verso.

Laclau, E. (2005). On populist reason. Verso.

Laclau, E. (2006). Why constructing a people is the main task of radical politics. Critical Inquiry, 32(4), 646-68o. https://doi.org/10.1086/508086

Laclau, E., \& Mouffe, C. (2001). Hegemony and socialist strategy: Towards a radical democratic politics (2nd edition). Verso.

Lawson, G. (2016). Within and beyond the "fourth generation" of revolutionary theory. Sociological Theory, 34(2), 106-127. https://doi.org/10.1177/0735275116649221

Marchart, O. (2014). Institution and dislocation: Philosophical roots of Laclau's discourse theory of space and antagonism. Distinktion:Journal of Social Theory, 15(3), 271-282. https://doi.org /10.1080/1600910X.2014.966272

Martin, J. L. (2003). What is field theory? American Journal of Sociology, $109(1)$, 1-49. https://doi. org/10.1086/375201

Mason, T. D., \& Krane, D. A. (1989). The political economy of death squads: Toward a theory of the impact of state-sanctioned terror. International Studies Quarterly, 33(2), 175-198. https:// doi.org/10.2307/2600536

McAdam, D., \& Sewell, W. H. (2001). It's about time: Temporality in the study of social movements and revolutions. In R. Aminzade, D. McAdam, E. Perry, W. H. Sewell, S. Tarrow, \& C. Tilly (Eds.), Silence and voice in the study of contentious politics (pp. 89-125). Cambridge University Press.

McCarthy, J. D., \& McPhail, C. (2005). Protest mobilization, protest repression, and their interaction. In C. Davenport, H. Johnston, \& C. Mueller (Eds.), Repression and mobilization (pp. 3-32). University of Minnesota Press.

McGarry, A., Davidson, R. J., Accornero, G., Jasper, J. M., \& Duyvendak, J. W. (2016). Players and arenas: Strategic interactionism in social movements studies. Social Movement Studies, 15(6), 634-642. https://doi.org/10.1080/14742837.2016.1199320

Nabers, D. (2017). Crisis as dislocation in global politics. Politics, 37(4), 418-431. https://doi. org/10.1177/0263395716661341

Noakes, J. A., \& Johnston, H. (2005). Frames of protest: A road map to a perspective. In H. Johnston \& J. A. Noakes (Eds.), Frames of protest: Social movements and the framing perspective (pp. 1-29). Rowman \& Littlefield Publishers.

Olesen, T. (2009). Social movement theory and radical Islamic activism. In Islamism as social movement (pp. 7-33). CIR Aarhus Universität. 
Pearlman, W. (2013). Emotions and the microfoundations of the Arab Uprisings. Perspectives on Politics, 11(2), 387-409. https://doi.org/10.1017/S1537592713001072

Polletta, F., \& Kretschmer, K. (2015). Movement factions: Players and processes. In J. M. Jasper \& J. W. Duyvendak (Eds.), Players and arenas: The interactive dynamics of protest (pp. 35-54). Amsterdam University Press. https://doi.org/10.2307/j.ctt16vj285.4

Pratt, N. (2015). After the 25 January Revolution: Democracy or authoritarianism in Egypt? In R. Abou-el-Fadl (Ed.), Revolutionary Egypt: Connecting domestic and international struggles. Routledge.

Rear, D. (2013). Laclau and Mouffe's discourse theory and Fairclough's critical discourse analysis: An introduction and comparison. Critical Policy Studies, 7(4), 375-394.

Rear, D., \& Jones, A. (2013). Discursive struggle and contested signifiers in the arenas of education policy and work skills in Japan. Critical Policy Studies, 7(4), 375-394. https://doi.org/10.1080 /19460171.2013.843469

Said, A. (2015). We ought to be here: Historicizing space and mobilization in Tahrir Square. International Sociology, 3o(4), 348-366.

Schwedler, J. (2016). Taking time seriously: Temporality and the Arab uprisings. Project on Middle East Political Science. https://pomeps.org/2016/06/1o/taking-time-seriously-temporalityand-the-arab-uprisings/

Schwedler, J. (2018). Routines and ruptures in anti-Israeli protests in Jordan. In F. Volpi \& J. M. Jasper (Eds.), Microfoundations of the Arab uprisings: Mapping interactions between regimes and protesters (pp. 67-88). Amsterdam University Press.

Schwedler, J., \& Harris, K. (2016). What is activism? Middle East Report, 281, 2-5.

Sewell, W. H. (1996). Historical events as transformations of structures: Inventing revolution at the Bastille. Theory and Society, 25(6), 841-881. https://doi.org/10.1007/BFoo159818

Sewell, W. H. (2009). Logics of history: Social theory and social transformation. University of Chicago Press.

Shantz, J. (2000). A post-Sorelian theory of social movement unity: Social myth reconfigured in the work of Laclau and Mouffe. Dialectical Anthropology, 25(1), 89-108.

Smaldone, T. (2015). The Arab uprisings and the blossoming of a 'global imaginary'. Inquiries Journal, $7(6), 1-3$.

Svendsen, K. D. (2014). The articulation of resistance and the Arab 'Spring': A post-structuralist perspective [Thesis in global studies]. Roskilde University.

Tarrow, S. (2001). Silence and voice in the study of contentious politics: Introduction. In R. Aminzade, D. McAdam, E. Perry, W. H. Sewell, S. G. Tarrow, \& C. Tilly (Eds.), Silence and voice in the study of contentious politics (pp. 1-10). Cambridge University Press.

Torfing, J. (1999). New theories of discourse: Laclau, Mouffe, and Ž ižek. Blackwell Publishers.

Volpi, F., \& Clark, J. A. (2019). Activism in the Middle East and North Africa in times of upheaval: Social networks' actions and interactions. Social Movement Studies, $18(1)$, 1-16. https://doi.or g/10.1080/14742837.2018.1538876

Volpi, F., \& Jasper, J. M. (Eds.). (2018). Microfoundations of the Arab uprisings: Mapping interactions between regimes and protesters. Amsterdam University Press.

Wacquant, L. J. D. (2019). Making class: The middle class(es) in social theory and social structure. In S. G. McNall (Ed.), Bringing class back in: Contemporary and historical perspectives. Routledge. https://doi.org/10.4324/9780429033612

Weipert-Fenner, I. (2021). Go local, go global: Studying popular protests in the MENA post-2011. Mediterranean Politics. 



\title{
3 Brothers and Rebels
}

\author{
Mursi's legitimacy crisis, popular grievances, and the \\ Tamarod protest coalition
}

\begin{abstract}
This chapter retraces the lead-up to the Tamarod uprising on June 30, 2013, and the ouster of President Mursi. It illustrates how the "quiet entente" between the army and the Muslim Brotherhood, the two most powerful organized players in post-Mubarak Egypt, had tarnished the new president's image from the start. The conflicted interactions between his administration and an alliance of opposition players during a phase of rapid political transition cemented the image of an Islamist president who attempted to monopolize his grip on power. In this context, a new powerful player emerged in the shape of the Tamarod campaign. Its performative disruption of the status quo through mass protest on June 30 brought the government crisis to the fore and paved the way for a military coup.
\end{abstract}

Keywords: Mursi, Tahrir Square, Tamarod, military coup, revolution, Islamism

Mohamed Mursi's presidential oath set the stage for conflict. The formal installation of Egypt's first civilian president was scheduled for June 30, 2012. But on the day before his formal oath of office, the Muslim Brotherhood and its political arm, the Freedom and Justice Party (FJP), organized an informal inauguration ceremony on Tahrir Square. There, Mursi stood defiantly before his followers and declared from a podium the conclusion of the tumultuous revolutionary period and the beginning of a new, democratic era in Egypt. ${ }^{1}$ Accompanied by frantic cheers from the crowd, many of whom hailed from the once-banned Islamist Muslim Brotherhood, the president-elect unbuttoned his jacket to prove that he was speaking without a protective vest.

1 For a full record of the speech see https://www.youtube.com/watch?v=LGoxgvkcLYo.

Grimm, Jannis Julien, Contested Legitimacies: Repression and Revolt in Post-Revolutionary Egypt. Amsterdam: Amsterdam University Press 2022 DOI: 10.5117/9789463722650_CHO3 
Then he went on to read the official oath of office: I swear by God that I will sincerely protect the republican system and that I respect the constitution and the rule of law. [...] I will look after the interests of the people and protect the independence of the nation and the safety of its territory." On the next day, Mursi repeated his oath to the 17 Mubarak-appointed judges of the Supreme Constitutional Court (SCC).

Mursi's popular oath on Tahrir Square was widely perceived as a message of defiance to the Supreme Council of Armed Forces (SCAF) that, thus far, had steered the fate of the republic since the ouster of Husni Mubarak. It was also a clear nod to those who were demanding restitution of popular sovereignty. Traditionally, the Egyptian President is sworn in at the Parliament. The logical site for the presidential inauguration would thus have been the Majlis al-Sha'ab, the People's Assembly. In the last parliamentary elections in January and February 2012, the FJP had secured a sweeping majority in this assembly. But the lower house had been dissolved shortly before Mursi's inauguration. Faced with the prospect of the Muslim Brotherhood and its FJP dominating all major institutions within Egypt's constitutional architecture, the then-ruling SCAF had asked the Supreme Court to disband the house, based on alleged faults in Egypt's electoral procedures. The upper house, the so-called Shura Council, which had been elected based on the same faulty electoral law, faced similar legal challenges.

Against this backdrop, Mursi's informal oath in Midan Tahrir marked, if not a legal, then at least a symbolic challenge to the SCAF's guardianship over the transition process. This test of the army's resolve alarmed those who had seen the dissolution of the Parliament a necessary attempt by the military and the judiciary to provide checks and balances to the Brotherhood's sweeping takeover of Egypt's governing institutions - an alleged akhwana [Brotherhoodization] of the Egyptian state (Haenni, 2016, pp. 28-30). The newly elected president's first moves further nourished their fears: Merely a week in office, on July 9, 2012, Mursi decreed that the dissolution of the Shura Council was not legal and asked it to convene in its original composition. He furthermore entrusted the council with a parliamentary caretaker function until a new constitution would pave the way for a fresh round of elections.

While short-lived in their immediate effect - shortly after, another SCC ruling overturned the president's decree - the mark left on the Mursi's public image by the popular oath and his defiance of the judges was longerlasting. For Mursi's opponents, both actions represented bold attempts of the president to place himself above the judiciary. They also exemplified the new president's priorities: His policies targeted not primarily those who had driven the country to the brink of civil strife, the feloul [remnants] of 
the old regime. Instead, they aimed to disempower those who could curb the Brotherhood's influence on the country's transition.

\section{The Polarization of Egyptian Society}

A range of symbolic steps may be read as attempts by the new president to counter and eradicate this narrative and position himself as a legitimate representative of the revolutionary and democratic forces. Shortly after taking office, Mursi established two committees in charge of overseeing transitional justice measures. One committee was tasked with examining all cases of civilians tried in military courts after the revolution, whose number had surpassed 12,00o by the end of 2011. A second fact-finding committee was tasked with investigating the killing of unarmed protesters during the 18 days of Tahrir and the ensuing rule of the SCAF.

Mursi also moved quickly to answer the calls of the popular campaign No to Military Trials, a coalition of revolutionary youth groups, human rights advocates, and leftist and liberal political parties, for releasing those who had been detained in the course of the January 25 Revolution and the months after under the rule of the SCAF. On July 19, 2012, 572 political detainees were released and cleared of their indictments as part of a Ramadan amnesty. Moreover, a range of old-guard figureheads was sent into forced retirement. Amongst those replaced on August 5, 2012, was the head of the military police, General Hamdy Badeen, as well as the notorious intelligence chief Mourad Mouwafi, who had been appointed and served in his position under Mubarak. The replacements were officially framed as the consequence of a security lapse that had enabled a deadly jihadist assault on Egyptian troops near Rafah on August 5, 2012. But since most of the dismissed officers were hardly involved in decisions about troop movements in Sinai, they were widely interpreted as an attempt by the president to purge the security sector from the confidants of the Mubarak regime (S. A. Cook, 2012; Fahim, 2012).

The purges in the domestic security establishment were soon followed by a reshuffle of the military leadership, in defiance of a SCAF decree that had stripped authority over military personnel from the presidency. On August 12, 2012, both Defense Minister and SCAF head Field Marshal Mohammed Hussein Tantawi and the Army Chief of Staff Sami Anan were asked to resign. Tantawi and Anan represented the two highest-ranking officers in the Supreme Council of Armed Forces. They had also been the public faces of the army throughout the entire transitional period since the fall of Mubarak. Later in Autumn, Mursi additionally ordered retrials 
for former President Mubarak and his Minister of Interior Habib al-Adly, stripping them of their double jeopardy protection.

However, this entire transitional justice process was plagued by allegations of politicization and victors' justice. Most measures were implemented selectively and largely spared members of the armed forces (Van Leuven, 2014). First, the fact-finding committee comprised not only judges, lawyers, and various prominent public figures, but also the assistant minister of interior, a military general, and an officer of Egypt's intelligence apparatus. By contrast, six relatives of slain or injured protesters were appointed as observers only. The doubts cast by its composition on the committee's independence were reinforced by its final report, which remained classified after its completion in December 2012. According to leaked excerpts, the 700-page document implicated the military in incidents of torture, death in detention, and forced disappearances (Hill \& Mansour, 2013). However, the full text was never made public but referred to the prosecution as a classified document. It remains there until today. Tellingly, Mursi's new expanded list of defendants in the retrial of the killings during the January 25 Revolution did not include any military officers either.

This selective enforcement of transitional justice nourished suspicions that the Muslim Brotherhood and President Mursi were colluding with the military. Even the political pardons did not sway this image. Those who portrayed Mursi as an Islamist wolf in sheep's clothing dismissed them as revolutionary window-dressing. The pardons furthermore cemented the image of a president intent on collaboration with the old guard to guarantee privileges for his supporters (Shenker, 2016, p. 259). After all, the first of a total of nine presidential pardons, granted by Mursi on July 26, 2012, went exclusively to Islamist convicts. The list included senior Brotherhood leaders residing abroad who had been tried in absentia as well as 18 presumed veterans of the Gama'a al-Islamiya's armed Islamist insurgency of the $1980 \mathrm{os}$ and 1990s. Some of the latter had received death sentences from state security courts for their involvement in an assassination attempt against Husni Mubarak in Addis Ababa. Only much later, on the $100^{\text {th }}$ day of his presidency, Mursi issued a general pardon for all citizens arrested for protesting since January 25, 2011.

In truth, the number of Islamists released during Mursi's rule was small (27) compared to the more than 800 released members of Islamist or jihadist organizations during the rule of the SCAF in 2012 (Bahgat, 2014). Nevertheless, misinformation and leaked statements by senior officers construed the image of a president who favored, above all, his ideological kin and who had irresponsibly pardoned dangerous convicted extremists. These accusations 
thwarted the president's attempts to portray himself as receptive to the goals of the January 25 Revolution. Instead, they reinforced the narrative that the Muslim Brotherhood and its representatives "preferred to deal and bargain with the deep state; that is, it worked through traditional channels such as the military and the Ministry of Interior, rather than accommodating and allying with the young revolutionaries and activists who sparked the uprising" (Al-Anani, 2015a, p. 535).

\section{The Shadow of the "Quiet Entente"}

Notably, the narrative of a tacit coalition between the Islamists and the officers resulted from the early post-revolutionary interactions among Egypt's key political players. Above all, the Muslim Brotherhood's initial hesitance to join the 2011 Tahrir protests against Husni Mubarak cast a long shadow on its revolutionary credentials. ${ }^{2}$ This was despite the subsequent contribution of Islamist demonstrators in making the 18 days of Tahrir successful with the help of the organization's logistical infrastructure and by providing dedicated protection units to the occupiers. Having the most to lose, as the experience of violent oppression of Islamists during the past decades had proven (see Pargeter, 2010; Wickham, 2013), the organization's Guidance Bureau had initially warned of the disruptive and destabilizing potential of a popular revolt (Muslim Brotherhood, 2011).

Only after witnessing how the demonstrators successfully claimed Midan Tahrir as their site of representation, they re-evaluated the stakes in the ongoing conflict and decided to join the rallying calls for a Friday of Anger on January 27, 2011. Up to 100,000 Muslim Brotherhood members participated in the subsequent countrywide protests (Wickham, 2013, p. 162), which constituted the turning point for the uprising against Mubarak (Harders \& König, 2013, p. 27). Nevertheless, the Brotherhood's initial rejection of the protests and hesitant support for the uprising had left a mark.

This badge of shame was reinvigorated by the organization's pragmatic decision to demobilize its constituents, shortly after Mubarak's ouster on

2 Young Brotherhood members had been at the forefront of the Tahrir protests since January 25 . Some Brotherhood youth activists had also been active in the planning phase of the protests. During two visits to Midan Tahrir on January 25 and 26, I spoke with several young Brothers who had taken to Tahrir jointly with fellow members of the Zamalek soccer fan club. These Ultras would soon gain notoriety for their physical defense of the Tahrir sit-ins against police incursions and attacks by state-hired thugs. The Brotherhood's guidance bureau tolerated this level of individual participation but remained hesitant to endorse the uprising against Mubarak (Interview with former Brotherhood member, Istanbul, November 12, 2017). 
February 11, 2011, and embrace dialogue with the remnants of his regime. After the downfall of Mubarak's National Democratic Party (NDP), the Brotherhood and its newly founded political arm, the nominally independent but factually subordinated Freedom and Justice Party (FJP), ${ }^{3}$ became the strongest organized player in Egypt's post-revolutionary arena. In the subsequent months, they took a conciliatory stance vis-à-vis the ruling SCAF. With the newly founded Salafist Nour-Party, first, they supported the SCAF's constitutional referendum. Then, they neglected calls from most smaller opposition factions for a postponement of parliamentary elections considering the prospects of easy electoral victories. This nonconfrontational and accommodative stance - discussed as a "quiet entente" between Brotherhood and army (see Al-Anani, 2015a) - characterized the Muslim Brotherhood's strategy throughout the entire transition period. It also tainted the new President's revolutionary credentials.

Even Mursi's far-reaching purge of security sector officials was not able to rehabilitate this public image. Praised by spontaneous crowds on Midan Tahrir as a de facto end to military rule in Egypt, the sacking of the SCAF leaders, in addition to the leadership of several army branches, was not unambiguous. It left the military's privileges intact, including the right to prosecute civilians in military courts. Furthermore, it provided those responsible for crimes and massacres during the SCAF rule with a safe exit and amnesty from legal prosecution (Achcar, 2013, p. 272ff.). When leaving office, Hussein Tantawi was fittingly honored by Mursi with Egypt's highest state medal, the Order of the Nile. The former SCAF chairman and his chief of staff were also awarded posts as presidential advisors.

Moreover, their positions were filled with officers who enjoyed even deeper support from within military ranks. Tantawi and Anan were intimately connected to the former Mubarak regime and, thus, resented by other leading army officers as magnets of public criticism. In contrast, the new Defense Minister Abdel Fattah al-Sisi and Chief of Staff Sedki Sobhi hailed from a new generation of army leaders. Untainted by the hands of the former regime, they provided the military with the opportunity for a fresh

3 From its foundation, the FJP encompassed countless Egyptians who did not belong to the group. Formal membership in the Brotherhood requires an intensive training process, known as tarbiya, including a five-to-eight yearlong gradual ascendency from an initial status as a prospective member (for a description of this incubation process see Al-Anani, 2016, pp. 82-98). Becoming an FJP member was substantially easier. The party thus became a mechanism for extending the boundaries of the populace under the clout of the Brotherhood, while maintaining the rigid internal structures that had ensured the MB's coherence and resilience over decades of repression. 
start and a chance to whitewash its political image. The new appointments also allowed the military to restore its prestige as an impartial protector of the nation, above factional politics. From his first commission as an officer in 1977, above all, Al-Sisi had mainly stuck to a traditional military career path while advancing through the ranks of Egypt's mechanized infantry. Only in 2010, he assumed a more political role through his appointment to the post of director of military intelligence, after serving a stint as its deputy director. In this capacity, he joined the SCAF as the council's youngest member, where he served as the liaison officer between the armed forces and Egypt's political parties. Accordingly, the SCAF reshuffle represented an entrenchment of the status quo, rather than a step towards civilian governance.

Mursi's image as a reformer indebted to the spirit of the revolution was further undermined by his appointment of Major General Mohamed Ibrahim, a former assistant minister in the prisons department, as minister of interior. Ibrahim replaced Ahmed Gamal El-Din, who had come under criticism for his role as deputy minister for general security during the deadly Mohamed Mahmoud clashes in November 2011. Like Tantawi's retirement, this cabinet reshuffle was intended to signal a fresh start. However, with Ibrahim - an old hand of the Mubarak regime - taking office, it appeared as a return to the old days.

\section{Mursi's Constitutional Declaration as a Watershed}

These ambivalent actions severely damaged Mursi's legitimacy from his early days. The breaking point came with a fierce battle between the presidency and the Egyptian judiciary. This conflict culminated on November 22, when Mursi issued a controversial constitutional declaration that shielded him from judicial interference and effectively put the executive beyond the supervision and control of the judiciary. The decree aimed to end the legal battle over the appointment of a new prosecutor-general as well as the ongoing struggle between the Mursi administration and leading opposition members over the composition of the Constitutional Assembly: The newly instated assembly had been exclusively appointed by the Brotherhooddominated upper house and included many prominent Islamists. This raised fears within the liberal camp that the constitutional drafting process if left unchecked, would produce the foundations for a theocratic regime. As the dialogue between Mursi and opposition leaders stalled, the risk increased that the way the assembly had been elected could be ruled illegal in court. Mursi's constitutional declaration prevented this by shielding not only the 
presidency but also the Constitutional Assembly and the lower house of parliament from potential judicial interference and dissolution.

Mursi attempted to hedge his bets by introducing a transitional justice passage into his declaration, which intended to pave the way for retrials of all defendants accused of harming protesters during 2011. Moreover, he made the first use of his new legislative powers by dismissing the Mubarak-appointed Prosecutor General Abdel Meguid Mahmoud. But rather than placating the opposition, the declaration antagonized not only the political opposition but also members of the administration and the usually supine elite. Regardless of any potential rationales for the constitutional declaration (N. J. Brown, 2013, p. 49), ${ }^{4}$ the disempowerment of the judiciary by the executive soon came to symbolize the frontier in a struggle for interpretive predominance over the country's democratic transition. Consequently, it became the reference point for tumultuous disputes over the meanings of constitutionality, the separation of powers, sovereignty, and democratic legitimacy. Several public figures who had been appointed by Mursi as presidential advisors resigned and large sections of the Egyptian public took to the street in what quickly turned into nationwide protests.

Popular anger at Mursi overstepping his institutional boundaries manifested most visibly in a series of protests in front of the Ittihadiya presidential palace on December 5,2012 . These protests were organized by the so-called National Salvation Front (NSF). This loose alliance of the main opposition parties and several revolutionary youth movements threw the growing dissent into sharp relief. According to Zaid Eyadat (2015, p. 169), the structure of the NSF mirrored the decentralized resistance against authoritarian encroachment witnessed during the January 25 Revolution. Above all, it illustrated how Mursi's divisive policies had led to the emergence of a new dominant antagonism in Egypt's protest arena which effectively blurred the formerly salient divisions that had fragmented Egypt's opposition in the aftermath of 2011. The NSF did not forward any positive vision for better governance (Dworkin, 2013, pp. 6, 20). However, the coalition included players of every political stripe who were bound together by their shared

4 Several analysts, including law professors Noah Feldman (2012) and Mohammad Fadel (2014), have defended Mursi's decree as well-intentioned, albeit miscommunicated. They argue that a failure to issue the decree would have led to the collapse of the entire transition process by jeopardizing the near-completion of the draft constitution and thus preventing parliamentary elections. Without the decree, accordingly, Egypt would have returned to de facto indirect military rule. Their reasoning, however, reveals a purely legalist view of democratic transitions. Whether Mursi's policies were "legitimate" or not, depended not on legal arguments but popular perception. 
opposition to Mursi. Its initial 35 members comprised liberals and socialists, but also several centrist and reactionary parties that were populated by old regime elites. ${ }^{5}$

When these groups converged at the presidential palace to demand Mursi's resignation, police forces collectively disobeyed Mursi's orders to step in. As the crowds grew larger, they were confronted, instead, by civilians, armed with sticks and chains, who had been mobilized by the Muslim Brotherhood to disperse the protests and protect the seat of the presidency. The ensuing fervent clashes between both camps resulted in a dozen casualties and hundreds of injured on both sides.

The Ittihadiya clashes became a transformative event for Egypt's postrevolutionary dynamics. They set the stage for a return of violence to Egypt's streets. For the first time since the 2011 uprising, deadly violence was not only deployed by police forces or hired thugs against civilians but developed in a confrontation between Egyptians and their fellow citizens: at the presidential palace, pro- and anti-Mursi demonstrators clashed in brutal melees; across Egypt's provinces, angry mobs set FJP party offices and Brotherhood branch offices ablaze.

More importantly, the clashes polarized the already fragmented Egyptian public into two camps, with each defending a partisan notion of legitimacy and democratic due process. This dichotomization of the public sphere laid path dependencies for how different players would support, defend, fight, or come to terms with the "coup-volution" (Hamada, 2014, p. 37) that would soon sweep Mursi from office. Ittihadiya thus became a catalyst for the emergence of two competing compound players in Egypt's post-revolutionary scene:

On the one hand, the Muslim Brotherhood's decision to systematically engage in street politics through a mobilizing mechanism can be traced back to the experience of Ittihadiya (Ketchley, 2017a, p. 135). The clashes left eight members of the group dead. The security forces had stood by and watched Muslim Brothers being chased through Cairo's streets without intervening. Consequently, the Brotherhood decided that hereafter, it would confront all protests directed against their president with counter-demonstrations.

5 Initially, it comprised 35 political parties and revolutionary groups, with the April 6 Youth Movement, the National Progressive Unionist Party, the Dignity Party, the Socialist Popular Alliance, the Social Peace Party, the Egyptian Communist Party, the Egyptian Popular Current, and the Maspero Youth Coalition occupying the left-wing; the Kefaya Movement, the National Association for Change, the Reform and Development Misruna Party, the Social Democratic Party and the Constitution Party taking the liberal wing; the New Wafd and the Free Egyptians representing the centrist currents; and the Freedom Party and the Amr Moussa's Conference Party occupying the right-wing. 
Dedicated protection units within the lower Brotherhood ranks were charged with the protection of street protests against opponent attacks and, potentially, against the police should it side with the former. ${ }^{6}$

On the other hand, the Brotherhood's deployment of armed troops to disperse the protests also galvanized support for the coalition against Mursi's presidency as it confirmed the reproaches that the Brotherhood and its president were placing themselves above the law. As a participant of the Ittihadiya protests in December recalls: "The massacre of Ittihadiya revealed the Brotherhood's true face. They could no longer hide their bloody hands. [...] The Central Security Forces [Egypt's notorious riot police] did nothing to defend us, so we had to defend ourselves." ${ }^{7}$

Mursi did little to counteract this impression. On the contrary, his rush to complete and pass the new constitution through a popular referendum on December 15, 2012, further alienated his critics who felt dismayed that the Islamists had monopolized the drafting process and produced a document that cemented the status quo. Following several resignations from the Constitutional Assembly as well as boycotts from underrepresented liberals, the draft constitution was finalized by an exclusively Islamist body. None of the oppositional players who had rallied for the Ittihadiya protests felt ownership over the proposed document.

\section{Rebellion against Mursi}

The aftermath of Ittihadiya witnessed a loss of appetite for further violent agitation. The brutal clashes left a mark on the public mood, and further instances of major political violence remained absent during the remainder of Mursi's tenure until the protests of June 30, 2013. Dissent within the security apparatus grew, nonetheless. Additionally, the socio-economic crisis propelled discord to new heights, fueled by violent repression on the anniversary of January 25,2011 . This violence served to catalyze street politics: By April 2013, youth groups launched a grassroots campaign to collect signatures for the resignation of Mohamed Mursi, a revocation of the 2012 constitution, and a temporary return to the 1971 constitution pending the drafting of a more inclusive constitutional document. The idea of the campaign, which gave itself the name Tamarod [Rebellion], was to gather and submit 15 million signatures to the constitutional court on the anniversary of 
Mursi's assumption of Egypt's presidency. This way it attempted to assemble a critical quorum that quantitatively surpassed the 13 million votes by which Mursi had won the election. A petition in colloquial Arabic was distributed across the country and declared the goals of the campaign:

Because security has not been restored since the 2011 revolution... we do not want you

Because the poor still have no place... we do not want you

Because we are still begging for loans from abroad... we do not want you Because there is no justice for the martyrs... we do not want you Because there is no dignity for me and my country... we do not want you Because the economy has collapsed and depends only on begging... we do not want you

Because Egypt is still following the footsteps of the USA... we do not want you

The petition also assigned responsibility to the president for the country's misery. The lack of physical and social security was held up as proof of his lack of suitability for office. Signatories declared that they were of sound mind and demanded the destitution of President Mursi as well as early presidential elections.

Tamarod adopted this modus operandi from the prominent opposition leader Mohamed El-Baradei who had championed a popular petition for constitutional reforms in February 2010 (see Elyachar, 2014). His sevenpoint list of demands was mirrored by Tamarod's sevenfold justification for rejecting Mursi. However, in contrast to El-Baradei who had spent "more time outside of Egypt in 2009-10 than he did within the country" (Kamrava, 2014, p. 268), the Tamarod campaign drew from the experience of community advocacy groups such as Askar Kazeboon [The military are liars] and maintained a firm grassroots infrastructure throughout the country (Alexander \& Aouragh, 2014, pp. 902-903). This way, it avoided the mistakes of revolutionary youth groups in 2011, whose mobilization had been heavily focused on social media and blogs.

At first, the group was hardly taken seriously. Most of its members knew one another from Kefaya [Enough!], a grassroots campaign that had once mobilized against the re-election of former President Husni Mubarak. But the leaders of the campaign, the activists Mohammed Abdel Aziz, Mahmoud Badr, Moheb Doss, Walid El-Masry, and Hassan Shahin were hardly known. Once the signature campaign gathered pace in the countryside, it nevertheless garnered the attention of prominent players, such as the domestic 
security services and the Ministry of Interior. Over the ensuing weeks, the Tamarod initiative was provided with logistical and financial support from different players within the ranks of state security (see Ketchley, 2017b; Springborg, 2018) and rhetorical backing by prominent opposition leaders: "Ministry officials and police officers helped collect signatures for the petition, helped distribute the petitions, signed the petition themselves, and joined the protests" (Alsharif \& Saleh, 2013). One of my interviewees, who took part in the initial Tamarod mobilization in the coastal city of Alexandria, recounts how the logistical support of the local police ranged from assistance in printing flyers and petition forms to physical protection of demonstration marches against counter-demonstrations of Mursi supporters. ${ }^{8}$

As a consequence of this intimate connection, several authors have analyzed Tamarod as a creation of the "deep state" to undermine the rule of President Mursi (see Springborg, 2018)..$^{9}$ Others have pointed to the scarcity of reliable non-partisan information about any systematic support for Tamarod by the military, beyond individual shows of solidarity by some of its members (Roll, 2016, p. 33). At any rate, Tamarod's success was not solely due to the state support that it received. Growing hardship and a bottleneck in the supply of cooking gas, car fuel, and basic food staples further catalyzed the movement's growth. In June 2013 queues of cars waiting for diesel at gas stations often stretched for several blocks creating traffic jams and bringing city life to a near standstill. The fuel shortage also manifested in frequent power outages, often several times a day and during peak business hours. Likewise, fuel and foodstuffs experienced massive price hikes. The prices for cooking oil, sugar, and wheat, for instance, increased by half compared to the previous year (Westall \& Perry, 2013).

As the crisis culminated, the official reaction ranged from a deflection of responsibility to outright denial. Even after the head of the Egyptian Gas and Petroleum Company publicly acknowledged that petroleum consumption was exceeding the available stock, the Mursi administration downplayed the situation. As late as June 25, 2013, it continued to deny the existence of a

8 Interview with former Tamarod organizer, London, March 2018.

9 In several interviews, former Tamarod campaign members, including its founding member Moheb Doss, indicate close coordination with several military officers and security agencies throughout the signature campaign. Above all, Badr, Aziz, and Shahin reportedly attended several meetings with the Ministry of Interior and with the then-head of the armed forces Abdel Fattah al-Sisi (Atef \& Frenkel, 2014). Former military and security officers, in turn, served as the intermediaries between the protest organizers within the Tamarod campaign and the armed forces during the preparations for June 30. 
crisis and, instead, attributed the supply gap to ineffective distribution and misappropriation. Such statements were parroted by government supporters who blamed a covert alliance of former regime cronies for manufacturing the crisis (N. Brown, 2013).

But the deflective attitude also pitted the Mursi administration and its supporters further against those opposing the president. Fueled by growing feelings of insecurity and hardship, above all, in the countryside, Tamarod had grown in strength. By June, the campaign claimed to have gathered a total of 22 million signatures. ${ }^{10}$ Significantly, this count surpassed the number of votes cast for Mursi in the presidential elections. Critics of the government and activists felt empowered by this silent majority. ${ }^{11}$ Consequently, the pace of collective action accelerated until, on June 30, 2013, Egyptians took their protest to Tahrir Square.

\section{The June 30 Uprising}

In the run-up to President Mursi's first year in office, clashes erupted across the country between supporters of the Tamarod campaign and members of the Muslim Brotherhood and its FJP. In reply to Tamarod's protest calls for June 30, the latter had mobilized an "open-ended" sit-in in the capital and called for a nationwide miliuniya [million man march] in defense of Mursi's legitimacy a week before the Tamarod-protest on Tahrir Square. ${ }^{12}$ To avoid further bloodshed and potentially ensuing repression by the security forces, the Brotherhood avoided Tahrir Square which had been claimed by the Tamarod campaign as its main theater. Instead, the pro-Mursi marches were to concentrate on Al-Nahda Square in the district of Giza and on the surroundings of the Rabaa al-Adawiya Mosque in the Cairene suburb of Nasr City.

These protest sites were first announced by a loose coalition of Islamist parties and movements allied with the Brotherhood and its FJP. On June 27,

10 Several polls cast doubt on this signature count. A poll from late May 2013, for instance, indicates that, even when Mursi's approval hit rock bottom at 32 percent, roughly 40 percent of Egyptians had never heard of Tamarod, and only half of those aware of the campaign were amenable to signing it (see Osman, 2013a).

11 Interview with a member of the NSF organizing committee, Berlin/Cairo, June 2014, via Jitsi Meet.

12 The term miliuniya recalls the transformative power of the first million-man march in $21^{\text {st }-c e n t u r y ~ E g y p t ~ o n ~ J a n u a r y ~} 27,2011$, which, as Aoudé (2013) has put it, managed to derail "much of the machinations of the reactionary forces" (p. 249). As a protest tactic, the miliuniya was part of the repertoire of nearly all protest alliances in Egypt since the 2011 uprising, including the Revolutionary Youth Coalition, Tamarod, and the Anti-Coup Alliance. 
2013, this group was officially established as the National Alliance in Support of Legitimacy (NASL, later on, more commonly known as the Anti-Coup Alliance). Besides the Freedom and Justice Party, it comprised more than 40 organizations, ranging from moderate religious movements to ultraconservative Salafi groups. Prominently placed in this alliance were the Building and Development Party - the political arm of the Gama'a al-Islamiya, the Salvation and Development Party - the political arm of the Egyptian Islamic Jihad, the moderate Islamic Wasat [Center], as well as Al-Raya [the Flag], the party of Salafist preacher Hazem Salah Abu Ismail. ${ }^{13}$ Over the coming weeks, the shared experiences of confronting police forces and opponents would forge this loose coalition into an efficient protest alliance.

As the guiding frame for its first joint demonstration, the alliance chose the slogan "Legitimacy is a red line." Like the group's name, this slogan not only underscored the centrality of Mursi as the only legitimate president for the alliance's political position. It also directly referenced Mursi who had claimed in an aggressive speech on June 26 that all constitutional and legal powers had been vested in him as the head of the state - and that his legitimacy exceeded that of any mass mobilization in the streets. Mursi had also underscored that social movements, including revolutionary ones, could no longer provide a mandate to anyone, not even the president, other than through the means defined in the constitution:

Revolutionary legitimacy has a range, limits, and a time, after which nations then move to constitutional legitimacy. We are under this constitutional legitimacy now. Wake up people, we have constitutional legitimacy. We have a constitution, a constitution according to which we can be held accountable. ${ }^{14}$

Delivered to a crowd of supporters in front of the Cairo Stadium, this speech reacted to the military's warning that it would consider intervening should turmoil in Cairo's streets persist. After the NASL had announced

13 The NASL additionally comprised the New Labor Party, the Virtue Party, the Reform Party, the Arab Tawhid Party, the Islamic Party, the Homeland Party, the Asala [Originality] Party, the People's Party, the Coalition of Arab Tribal Union in Egypt, the Revolutionary Trustees Council, the Union of Professional Syndicates (comprising 24 trade unions), the Union of Preachers, the General Union of Farmers of Egypt, the Al-Azhar University Students Union, The Labor Centre, the General Association of Street Vendors, as well as a group of retired officers. See https://www. scribd.com/document/394191292/NASL-Founding-Statement.

14 A speech transcript can be accessed at https://de.scribd.com/document/378807384/ Mursi-Speech-26-June-2013. 
its counter-demonstrations to the Tamarod protests on June 30, Defense Minister Al-Sisi called on all players to reach a settlement through civic dialogue. But he also emphasized the army's constitutional role as guarantor of national security as he spoke in a large auditorium directly to close to a thousand officers. ${ }^{15}$ His insistence that the armed forces would not "stand by if Egypt descends into violence" was ambiguous enough to be welcomed by all sides. But it was widely understood as an ultimatum to the acting government to compromise and give in to the opposition's demands for change. Empowered by this perceived backing of the armed forces, Egyptians took to the streets on June 30, 2013, in numbers comparable to those of the January 25 uprising. When armored vehicles deployed to Cairo's streets, they were adorned by Tamarod protesters with spray paint slogans that revived the fraternization myth of the January 25 Revolution about the people and the army as "one hand."

Estimates of how many people participated in the June 30 demonstrations vary. ${ }^{16}$ While a military source indicated an estimated turnout of 14 million to Reuters (Fayed \& Saleh, 2013), Tamarod spokesmen were quick to claim that 33 million Egyptians - over one-third of the entire population - had taken to the street. Albeit hardly credible, this count was adopted by the country's major media outlets and made it into international reporting. Regardless of the actual turnout, the demonstrations caused a shift in the balance of power also due to their demographic diversity and social and geographical spread to all corners and classes of the republic. Those who marched on June 30 came "from all walks of life; secular and devout, liberal and leftist, revolutionary and reactionary" (Mogahed, 2013; see also Schielke, 2017, p. 209).

Accordingly, the National Salvation Front styled its first statement on the June 30 protests as Revolutionary Communique No.r. Therein, it declared the victory of the revolutionary movement and underscored that the Egyptian people had affirmed the downfall of the regime of Mohamed Mursi and the Muslim Brotherhood. In light of the massive show of protest, June 30 also witnessed the resignation of ten ministers from Mursi's cabinet. Additionally, several state players openly stated their

15 A partial recording of the speech is available at https://youtu.be/rBBmQry7nc8.

16 For instance, Jack Brown suggests a commensurately lower turnout, based on an evaluation of helicopter shots broadcasted by Egyptian state television. The two biggest gatherings in Cairo may have encompassed less than half a million people (J. Brown, 2013). More generous calculations indicate that between 500,000 and 700,000 protestors could have been on the streets of Cairo and, by extension, a maximum of 3 million could have been protesting throughout the whole of Egypt (S. Ismail, 2013). 
support for the protesters: The police forces announced that they would not stand with the Muslim Brotherhood. The Interior Ministry pledged that its policemen would protect the demonstrators against potential assaults (see El-Rashidi, 2013). And the armed forces, in turn, showed their support by canceling the festivities for the 44th anniversary of the air force, where Mursi was due to speak on the same day. According to Adel Abdel Ghafar (2013), the military also provided the necessary logistics to mediatize the scenes on Tahrir: carried by an army helicopter, an anti-Mursi director was permitted to record aerial shots of the protests which were soon broadcast by Egyptian media.

In addition, different army units paraded their armored vehicles on Midan Tahrir, projected elaborate laser graphics onto the Mogamma administration building, and flew cordons of battle helicopters carrying the Egyptian flag over the heads of the protesters. These spectacles converted Tahrir into the site a carnivalesque celebration of patriotism. As Maged Atef and Sheera Frenkel (2014) recollect:

In the skies above Tahrir Square, military planes began to conduct elaborate flying stunts, painting the colors of the Egyptian flag or drawing hearts in the blue summer sky. The stunts were neither easy to perform nor cheap, but they sent the clear message that both the army and police were behind Tamarod.

Therefore, it came as no surprise when the armed force issued an explicit ultimatum to the president on the following day. Signed by the entire central command of the armed forces, a top brass body of roughly 50 decorated officers, including the SCAF, and read out by a military spokesman on state television, the statement called for the government to meet the people's demands and settle its differences with the opposition within the next 48 hours (see Reuters, 2013). Otherwise, the army would intervene and enact a roadmap for the country's future.

\section{A Crisis of Legitimacy}

With hindsight, it seems obvious that the Tamarod campaign successfully subverted the discourse sustaining Mohamed Mursi's rule. As Seppe Malfait (2014, p. 16) contends, the popular campaign had succeeded in constructing a new narrative, grouped around the contested signifiers of the "revolution," of "democracy," and of "legitimacy." By fixing the meaning 
of these floating signifiers in a discourse that drew a sharp line between the Muslim Brotherhood, on the one hand, and all other elements of Egyptian civil society, on the other, Tamarod's discourse established a new political frontier: To one side were those representing the popular will - including the anti-Mursi demonstrators, oppositional parties and initiatives such as the NSF and Tamarod, as well as key state institutions such as the armed forces and the Ministry of Interior. On the other side of the political divide was the antagonist Other of the incumbent Islamist government and its supporting organizations who, supposedly, were defying this will.

This discourse lionized the Tamarod protesters and aimed to recreate the revolutionary momentum of 2011 where a variegated coalition of state and non-state actors had stood side by side against the authoritarian incumbent regime. It also vilified President Mursi as a peon in the Islamists' larger plan to establish an authoritarian theocracy. Diligent character work was part and parcel of this dichotomizing narrative: From his first day in office, different opposition players had portrayed Mursi as a mere puppet of the Muslim Brotherhood. This caricature was reinforced by subsequent events, such as Mursi's constitutional declaration, which represented just another tile in the larger mosaic of a weak and malevolent president. It became the dominant cognitive scheme for understanding Mursi's actions. Jim Jasper and his co-authors (2020) have aptly described this process of characterization: 'Once a character trait becomes a hook for stories (a 'heuristic' for reporters and the public to understand the world), it is difficult to dislodge it from media discourse" (p. 10).

By the time that the Tamarod campaign filled Tahrir Square, it had undermined President Mursi to such a degree that his claims to democratic legitimation failed to resonate outside of his constituency. Mursi had effectively been portrayed as a minion to the evil villain of the Brotherhood, whose only legitimacy stemmed from a narrow victory in a contentious election - one where the choice for many had been one between two evils [Mursi, an uncharismatic Islamist, on the one side, and Ahmed Shafik, Mubarak's last prime minister, on the other]. This discourse created not only the conditions for an explicit civic alliance against Mursi's rule across the divisions of class, ideology, and movements. It also enabled the formation of an implicit coalition between Mursi's political contenders and the armed forces.

This coalition blurred the hitherto relatively sharp boundaries between state and social players in Egypt's post-revolutionary arena. As a state institution, the military saw its constitutionally guaranteed privileges endangered 
by the prospect of civil strife. Through its support for the Tamarod campaign, it saw a chance to restore its role as a protector of social peace and as a defender of the nation. The powerful "flank effect" (Haines, 2013) created through this integration of variegated players in a political campaign first benefitted mobilization by some of the bloc's members against the precarious status quo and then paved the way for a military coup by others against the first freely elected president Egypt's republican history.

The solidarity of its key allies, but also most Salafi parties and movements (with the notable exception of the Nour Party) as well as other non-religious organizations may have contributed to the Mursi administration's overestimation of its political leeway in the face of credible threats of military intervention and growing momentum for the June 30 demonstrations. Furthermore, the victories at the ballot box since the 2011 uprising - first in the March 2011 referendum on constitutional amendments to the 1971 constitution, then in the December 2011 parliamentary elections, and finally in the presidential elections and constitutional referendum of 2012 - had made the Brotherhood and its president over-confident of their popular backing. As Nicola Pratt (2015) rightly noted:

Indeed, one of the fundamental errors of the Muslim Brotherhood was to assume that their plurality in the first parliamentary elections and their victory in the first presidential elections indicated their hegemony over the vast majority of the population. (p. 46)

In truth, the elections had done little to satisfy popular aspirations for political participation. Hence Mursi met little sympathy when he addressed the nation on June 26,2013 , only to discredit the opposition as reactionary forces and to stress that the ballot box represented the sole legitimate means to gauge the popular will (see Mursi, 2013a).

While media reports indicated growing support for the Tamarod campaign and predicted a massive turnout for the June 30 protests, both President Mohamed Mursi and cadres of the Egyptian Muslim Brotherhood declined not only to bow to the opposition's demands but also rebuffed several mediation offers. In an attempt to mitigate the risk of open conflict and civil strife, among others, the Salafi Nour-Party - the FJP's former coalition partner in parliament - attempted to broker a deal between the Brotherhood and the opposition. However, the armed forces' symbolic deadline passed without an agreement, and without Mursi giving in to the opposition's demands. In the early afternoon of July 3,2013 , the army took sides against the acting government and took over the leadership of the country. 


\section{References}

Abdel Ghaffar, A. (2013, August 7). Egypt's framing wars of June 3oth. OpenDemocracy. http:// www.opendemocracy.net/adel-abdel-ghafar/egypts-framing-wars-of-june-3oth

Achcar, G. (2013). The people want: A radical exploration of the Arab uprising. University of California Press.

Al-Anani, K. (2015). Upended path: The rise and fall of Egypt's Muslim Brotherhood. The Middle East Journal, 69(4), 527-543.

Al-Awadi, H. (2013). Islamists in power: The case of the Muslim Brotherhood in Egypt. Contemporary Arab Affairs, 6(4), 539-551. https://doi.org/10.1080/17550912.2013.856079

Alexander, A., \& Aouragh, M. (2014). Egypt's unfinished revolution: The role of the media revisited. International Journal of Communication, 8, 890-915.

Alsharif, A., \& Saleh, Y. (2013, October 10). Special report: The real force behind Egypt's 'revolution'. Reuters. https://www.reuters.com/article/us-egypt-interior-specialreport/ special-report-the-real-force-behind-egypts-revolution-of-the-state-idUSBRE99908D20131010

Atef, M., \& Frenkel, S. (2014, April 15). How Egypt's rebel movement helped pave the way for a Sisi presidency. BuzzFeed. https://www.buzzfeed.com/sheerafrenkel/how-egypts-rebelmovement-helped-pave-the-way-for-a-sisi-pre

Bahgat, H. (2014, February 16). Who let the jihadis out? Mada Masr. https://www.madamasr.com/ en/2014/02/16/feature/politics/who-let-the-jihadis-out/

Brown, N. (2013, July 17). Egypt's wide state reassembles itself. Foreign Policy. https://foreignpolicy. com/2013/o7/17/egypts-wide-state-reassembles-itself/

Brown, N. J. (2013). Egypt's failed transition. Journal of Democracy, 24(4), 45-58.

Cook, S. A. (2012, August 9). Brother knows best. Foreign Policy. https://foreignpolicy. com/2012/o8/og/brother-knows-best/

Dworkin, A. (2013). The struggle for pluralism after the North African revolutions (ECFR Policy Brief No. 74). ECFR. http://www.ecfr.eu/page/-/ECFR74_PLURALISM_REPORT.pdf

El-Rashidi, S. (2013, June 27). Egyptian police divided in run-up to 30 June anti-Morsi rallies. Ahram Online. http://english.ahram.org.eg/NewsContent/1/64/74399/Egypt/Politics-/ Egyptian-police-divided-in-runup-to--June-antiMors.aspx

Elyachar, J. (2014). Upending infrastructure: 'Tamarod', resistance, and agency after the January 25th Revolution in Egypt. History and Anthropology, 25(4), 452-471. https://doi.org/10.1 080/02757206.2014.930460

Eyadat, Z. (2015). A transition without players: The role of political parties in the Arab revolutions. Democracy and Security, n1(2), 160-175. https://doi.org/10.1080/17419166.2015.1043080

Fahim, K. (2012, August 8). Morsifires intelligence chiefand Sinai governor over soldiers'killings. The New York Times. https://www.nytimes.com/2012/08/og/world/middleeast/egypt-sinaiattacks.html

Fayed, S., \& Saleh, Y. (2013, June 30). Millions flood Egypt's streets to demand Mursi quit. Reuters. https://www.reuters.com/article/us-egypt-protests-idUSBRE95QoNO20130630

Haenni, P. (2016). The reason for the Muslim Brotherhood's failure in power. In B. Rougier \& S. Lacroix (Eds.), Egypt's revolutions: Politics, religion, and social movements (pp. 19-40). Palgrave Macmillan.

Haines, H. H. (2013). Radical flank effects. In D. A. Snow, D. D. Porta, P. G. Klandermans, \& D. McAdam (Eds.), The Wiley-Blackwell encyclopedia of social \& political movements (pp. 10481049). Wiley-Blackwell. https://doi.org/10.1002/9780470674871

Hamada, A. (2014). Understanding the military role in the Egyptian revolution: Comparing February 2011 and July 2013. In N. Belakhdar, I. Eickhof, A. el Khawaga, O. el Khawaga, C. 
Harders, \& S. Sandri (Eds.), Arab revolutions and beyond (pp. 29-40). Center for Middle Eastern and North African Politics.

Harders, C., \& König, C. (2013). Mobilization, repression and coalitions: Understanding the dynamics of the Arab Spring [Discussion Paper]. Center for Middle Eastern and North African Politics. https://www.polsoz.fu-berlin.de/polwiss/forschung/international/vorderer-orient/publikation/working_papers/dp_o6/index.html

Hill, E., \& Mansour, M. (2013, April 10). Egypt's army took part in torture and killings during revolution, report shows. The Guardian. http://www.theguardian.com/world/2013/apr/10/ egypt-army-torture-killings-revolution

Jasper, J. M., Young, M. P., \& Zuern, E. (2020). Public characters: The politics of reputation and blame.

Kamrava, M. (2014). Beyond the Arab Spring: The evolving ruling bargain in the Middle East. Oxford University Press.

Ketchley, N. (2017a). Egypt in a time of revolution: Contentious politics and the Arab Spring. Cambridge University Press.

Ketchley, N. (2017b, July 3). How Egypt's generals used street protests to stage a coup [Washington Post].Monkey Cage. https://www.washingtonpost.com/news/monkey-cage/wp/2017/07/03/ how-egypts-generals-used-street-protests-to-stage-a-coup/

Malfait, S. (2014). An Islamist Caesar in Egypt's passive revolution? A discourse theoretical analysis of Morsi's hegemonic project [Master Thesis in Conflict and Development]. Universiteit Gent.

Mogahed, D. (2013, July 25). Deep runs the divide [Carnegie Endowment for International Peace]. Sada. http://carnegieendowment.org $/$ sada/index.cfm?fa $=$ show\&article $=52493 \&$ solr_hilite $=$

Mursi, M. (2013, June 26). Address to the nation on the anniversary of his inauguration [Arabic, on file].

Muslim Brotherhood. (2011, January 26). Statement from the Muslim Brotherhood regarding the events of January 25 and their aftermath [Arabic]. IkhwanWiki. https://bit.ly/1lıDUj

Pargeter, A. (2010). The Muslim Brotherhood: The burden of tradition. Saqi Books.

Pratt, N. (2015). After the 25 January Revolution: Democracy or authoritarianism in Egypt? In R. Abou-el-Fadl (Ed.), Revolutionary Egypt: Connecting domestic and international struggles. Routledge.

Reuters. (2013, July 1). Egyptian armed forces chief sets ultimatum. https://www.reuters.com/ article/us-egypt-protests-army-text-idUSBRE96014420130701

Roll, S. (2016). Managing change: How Egypt's military leadership shaped the transformation. Mediterranean Politics, 21(1), 23-43. https://doi.org/10.1080/13629395.2015.1081452

Schielke, S. (2017). There will be blood: Expectation and ethics of violence during Egypt's stormy season. Middle East Critique, 26(3), 205-220. https://doi.org/10.1080/19436149.2017.1336023

Shenker, J. (2016). The Egyptians: A radical story. Penguin.

Springborg, R. (2018). Egypt. Polity.

Van Leuven, D. (2014, May 25). Morsi and transitional justice: Peace vs. justice \& implications for a post-Brotherhood Egypt. Al Nakhlah. https://alnakhlah.org/2014/05/25/morsi-and-transitionaljustice-peace-vs-justice-implications-for-a-post-brotherhood-egypt-by-dallin-van-leuven/

Westall, S., \& Perry, T. (2013, March 13). Food price rises put restive Egypt on edge. Reuters. https://www.reuters.com/article/us-egypt-food/food-price-rises-put-restive-egypt-onedge-idUSBRE92CoPW20130313

Wickham, C. R. (2013). The Muslim Brotherhood: Evolution of an Islamist movement. Princeton University Press. 


\title{
4 Coup and Anti-Coup
}

\author{
Islamist resistance and the National Alliance in Support of \\ Legitimacy
}

\begin{abstract}
The military coup was a constitutive event. It triggered political subjectivation processes both within the Islamist camp and within the coalition of players who had asked for Mursi's deposition. This chapter shows how the coup virtually dichotomized Egypt's political arena. This new societal division cut across the formerly salient division between the people and the regime by pitting an alliance of civic and state forces against an equally variegated coalition of anti-coup forces. In this contest, both sides articulated competing conceptions of legitimacy to discredit their respective opponents and lionize their allies. They thereby unwittingly conditioned alliance-building, authorities' means of responding to protest as well as how the public would come to evaluate the contending players and their actions and goals.
\end{abstract}

Keywords: Anti-Coup, coalition building, counter-mobilization, Islamist movements, legitimacy, repression

General Abdel Fattah al-Sisi announced Mursi's arrest and the coming changes in government on July 3, 2013, at 7 p.m. local Egyptian time. His speech signaled that the army had learned from past mistakes: Rather than assuming power itself, it installed a civilian transition government. Led by Adly Mansour, a respected judge and the former head of the Supreme Constitutional Court, as interim president this government was charged with implementing a transitional roadmap. Aside from new elections and the formation of a national reconciliation commission, this roadmap included the elaboration of a new constitution, a reformation of the electoral law, and the implementation of a new ethical codex for the country's media outlets. An interim cabinet was authorized to rule by decree.

Grimm, Jannis Julien, Contested Legitimacies: Repression and Revolt in Post-Revolutionary Egypt. Amsterdam: Amsterdam University Press 2022 DOI: $10.5117 / 978946372265^{\circ}$ _CHO4 
For his televised address, Al-Sisi was joined by representatives of Egypt's religious institutions, opposition party leaders, and high-ranking officers in a carefully stage-managed visual framing process (see Abdel Ghaffar, 2013). The sheik of Al-Azhar Ahmed Al-Tayyeb and Coptic Pope Tawadros followed Al-Sisi at the podium with speeches of their own, confirming their support for the steps taken by the army. National Salvation Front leader Mohamed El-Baradei and Tamarod spokesman Mahmoud Badr spoke last. Significantly, a leading member of the Salafist Nour Party attended the announcement as well, letting the military intervention appear as a broad consensus of Egyptian society, rather than an antiIslamist coup.

Aside from creating tangible facts on the ground - such as the arrest of Egypt's first freely elected President alongside 250 mid and upper ranks of the Brotherhood and its Freedom and Justice Party (FJP) - the coup d'état had also a symbolic side. As a discursive event, it provided a constitutive myth for two opposing political projects whose competition would dominate the political arena in the years to come. The coup dichotomized Egypt's political public by delimiting the frontier between two opposing camps of players. In this struggle, both sides derived their legitimacy from competing conceptions of democracy, legality, and the country's revolutionary heritage; both sides claimed to represent the popular will and to speak for the people; and both sides engaged in vicious vilification of their respective other, depicting it "as an existential threat, yet paradoxically also as a minuscule fringe side-lined by their clear majority" (Mogahed, 2013). Most importantly, Mursi's deposition became the catalyst for the largest wave of Islamist mobilization in Egypt's republican history, and paved the way for the emergence of a complex and powerful new player in the shape of the so-called "Anti-Coup Alliance."

\section{From Government to Opposition}

The National Alliance in Support of Legitimacy (NASL) had been demonstrating in support of President Mursi since mid-June. But after July 3, 2013, this alliance transformed rapidly from an advocacy coalition in support of the incumbent Mursi government into a street movement and the central oppositional player to the consolidating post-coup regime. The coup bestowed upon the alliance a new role as the primary pressuring mechanism for a broad coalition of mostly Islamist players who rejected the military intervention as an illegitimate coup against the country's democratic transition. 
The coalition honored the president's last speech and made opposition to the coup and the restoration of shar'aiya [legitimacy] the epicenter of its campaign. As it added the suffix "in Rejection of the Coup" to its original name and called for country-wide protest marches, it soon came to be known as the Anti-Coup Alliance. The myth of a national initiative for the restoration of constitutional, democratic, and revolutionary legitimacy became the surface for the inscription of a variety of demands and meaning constructions under the umbrella of the Anti-Coup Alliance. As the central nodal signifier, this specific conception of legitimacy also defined the boundaries of the Anti-Coup movement's collective identity.

Rabaa al-Adawiya Square in the Cairene neighborhood of Nasr City became the epicenter of this movement's activities. By squatting on Rabaa Square, the Brotherhood and its allies adopted a contentious repertoire that, according to Carola Richter (2017) has become "a global signifier for staging anti-establishment protest" (p. 106). Across borders, especially major urban roundabouts have become eminent sites of confrontation between revolutionary and reactionary groups (see McCurdy et al., 2016; Weizman et al., 2015). The symbolism of these occupations, as Jonathan Liu (2011) notes, is almost jokingly obvious: "What better place to stage a revolution, after all, than one built for turning around?"

As Mona Abaza (2014) has argued, the choice of Rabaa al-Adawiya was not a "last resort" (p. 165) but deliberately contrasted with Tamarod-occupied Midan Tahrir. The latter is a site that is not only heavily loaded with revolutionary symbolism but has also served, for decades, as the site of annual parades to celebrate the 1952 military coup (Weizman et al., 2015, p. 37). If Tahrir Square provided some sort of public voice to those who supported military intervention into civilian politics, Midan Rabaa provided something of a counter-public. ${ }^{1}$ Located on a major intersection of Nasr City, the square offered several advantages: First, Nasr City is charged as a symbol of the military's embedding into Egyptian society. The urban conglomerate was planned and built in the late 1950s and early 1960 s under the auspices of Gamal Abdel Nasser and houses Egypt's Al-Azhar University. Next to Rabaa al-Adawiya Square is the Tomb of the Unknown Soldier on Al-Nasr Road. Across the street, facing the tomb is the Minassa [tribune] memorial for the assassination of former President Sadat. Several military clubs and the principal military parade street are close by (Abdelbaseer, 2016). The occupation of a major square in the vicinity of these sites challenged the coup leaders' interpretive authority over the role and function of the armed forces in Egyptian politics. 
In addition to Midan Rabaa, a second large camp was created on Midan Al-Nahda [Renaissance Square] in the vicinity of the Cairo University, on the other bank of the Nile. Until their dissolution by police in mid-August, these two sites in the capital geographically concentrated most of the unseated president's supporters. Moreover, the two squares served as hubs for a large portion of the demonstrations in Cairo and Giza, where different marches originated and converged. But contention did not remain limited to the capital. During the period investigated in this book, the decisive first 100 days after the coup against Mursi, I have documented 2,433 discrete protest events that can be attributed to the Anti-Coup Alliance. These events took place in all provinces, albeit with a clear focus on the governorates' capitals.

Figure 1 Trajectory of Anti-Coup protests and state repression

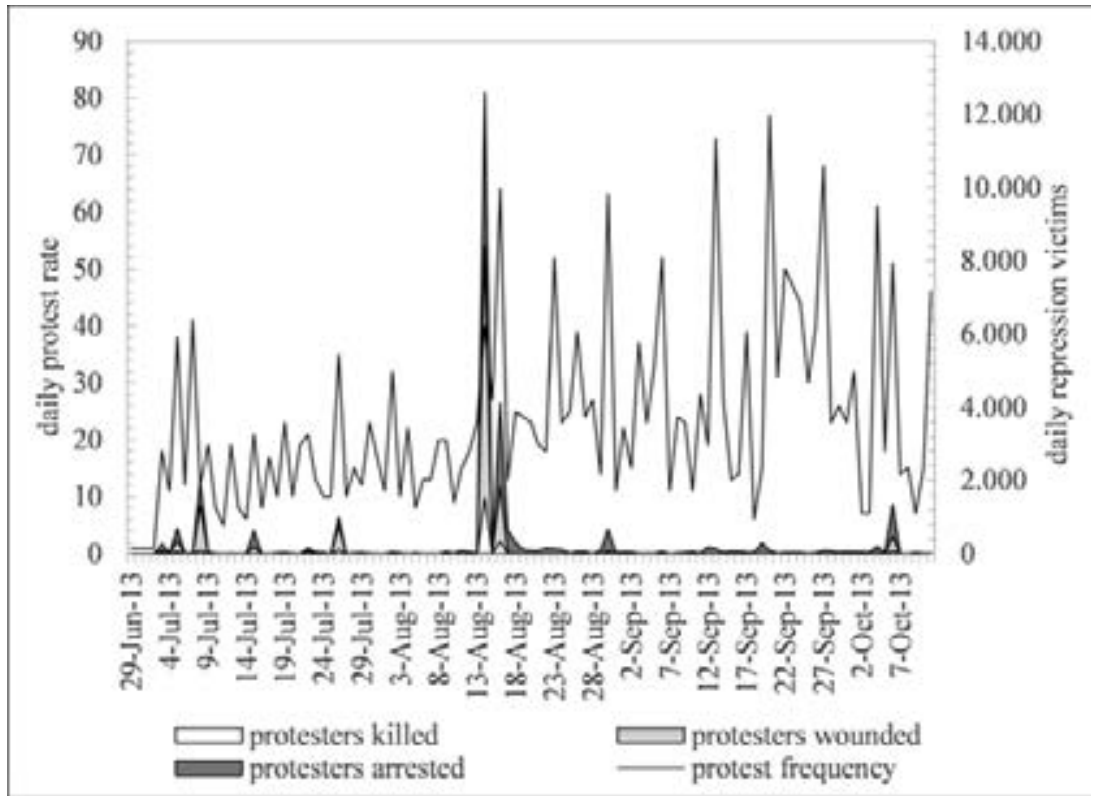

Protest events were not normally distributed across the investigation period. Several instances of condensed event data point to episodes of accelerated mobilization and an escalation of contentious interaction. These findings correlate with the available data on victims of state repression: For the investigation period, Wiki Thawra has documented the violent deaths of 2,305 and the physical injury of 11,517 people by violence from security forces including police, riot police, and army units. 14,442 people were arrested. Significantly, most peaks in the dataset correspond with those 
phases that were marked by an intensification of protest. Combined, the diagrams highlight four distinctive episodes of contentious interaction between protesters and security forces:

1 First, the deposition of Mohamed Mursi triggered an initial phase of collective action that concentrated on the surroundings of Midan Rabaa al-Adawiya, on Al-Nahda Square in Giza, and Salah Salem Street in downtown Cairo.

2 Second, the first mass killing of demonstrators in front of the Republican Guard headquarters on July 8, 2013, precipitated a cascade of regular daily marches that contributed to the institutionalization of the AntiCoup Alliance as a coherent player.

3 Third, the public call by then-Defense Minister Al-Sisi for a popular mandate to confront terrorism, followed by a mass protest on July 26 , 2013, marked a turning point for the regime's dealing with the protest and resulted in the deadly clashes on Nasr Street.

4 Finally, fourth, the simultaneous raids of the camps on the Rabaa and Al-Nahda Squares on August 14, 2013, became the constitutive event for an authoritarian regression in the coat of nationalism. But they also strengthened the resolve of the Anti-Coup protesters who continued to protest in the face of death, albeit in smaller frequency and numbers.

These episodes were all defined by a precipitating event that included a massive deployment of indiscriminate and lethal state violence against protesters. These instances became "turning point events" (Pearlman, 2018) for the trajectory of the Anti-Coup movement and were usually followed by an immediate escalation of protest activities.

Significantly, aside from altering conditions on the ground, these events were also important as discursive events and became resources for identity formation. More than just reference points for collective action frames, they entered the cultural stock of the Anti-Coup movement as nodal signifiers. Thereby they were able to usher a new understanding of political reality and its possibilities (see Schwedler, 2016), exerting a precipitating effect on the Anti-Coup campaign. At the same time, the competing narratives promoted by the contending players about the events constituted the conditions of possibility for these players' actions, that is, for subsequent protest performances and repressive responses.

Especially the battle over the definition of legitimacy in the context of a democratic transition laid path dependencies for how players responded to each other's demands and actions early on. References to his constitutional legitimacy had been a constant feature of the former president's discourse. At the same time, the meaning of this nodal signifier had been undermined 
time and again by Mursi's actions. This made it a delicate topic around which to mobilize. By the time the Anti-Coup movement took to the streets, "legitimacy" had become a hollow shell - an empty signifier that was filled with different meanings by opposing camps.

\section{The Constitution of the Anti-Coup Alliance as a Political Player}

Mursi's rule had revealed the contingency of the Brotherhood's conception of democratic legitimacy. It had also paved the way for a hegemonic struggle, in which both Tamarod and the Brotherhood aimed to conclusively determine the meaning of the floating signifiers of legitimacy, democracy, revolution, and popular sovereignty. By mid-2013, this struggle had resulted in a stalemate with no faction able to expand its reading of the world into a broader social imaginary. The coup broke this stalemate and reshuffled the cards. For the Anti-Coup Alliance, it provided a founding myth that enabled alternative possibilities of collective identification vis-à-vis an antagonist other.

This is illustrated by the body of statements issued by the National Alliance in Support of Legitimacy and Rejection of the Coup (NASL) after the military intervention on July 3 which split the political arena into two opposing camps. The manner in which these statements were created reflected in many ways the consensus establishing procedures within the NASL. ${ }^{2}$ Typically, a skilled editor drafted these releases by picking up the cues from the last agreed-on and uncontested Anti-Coup statement. New events were placed in relation to these cues. Selected individuals from the NASL leadership then reviewed the resulting statement before publication. Once released, the statements expressed the alliance's common denominator, including who was to be considered an insider and who an outsider, who a potential ally, and who a coupist and thus an irrevocable enemy.

Unsurprisingly, this discourse juxtaposed the protagonists of the coup and its victims as nodal signifiers. As Helen Underhill (2016) stressed, this binary became a core element of the NASL narrative which aimed to depict the June 30 uprising and its aftermath as "a rupture in the revolution, the antithesis of democracy" (p. 53). By framing the events of July 3 not only as a coup against Mursi but as one against popular will, a frontier was constructed between the people who had been deprived of their legitimate electoral choice and the coupists who had illegitimately deposed the people's 
Figure 2 Antagonist frontier in the Anti-Coup discourse

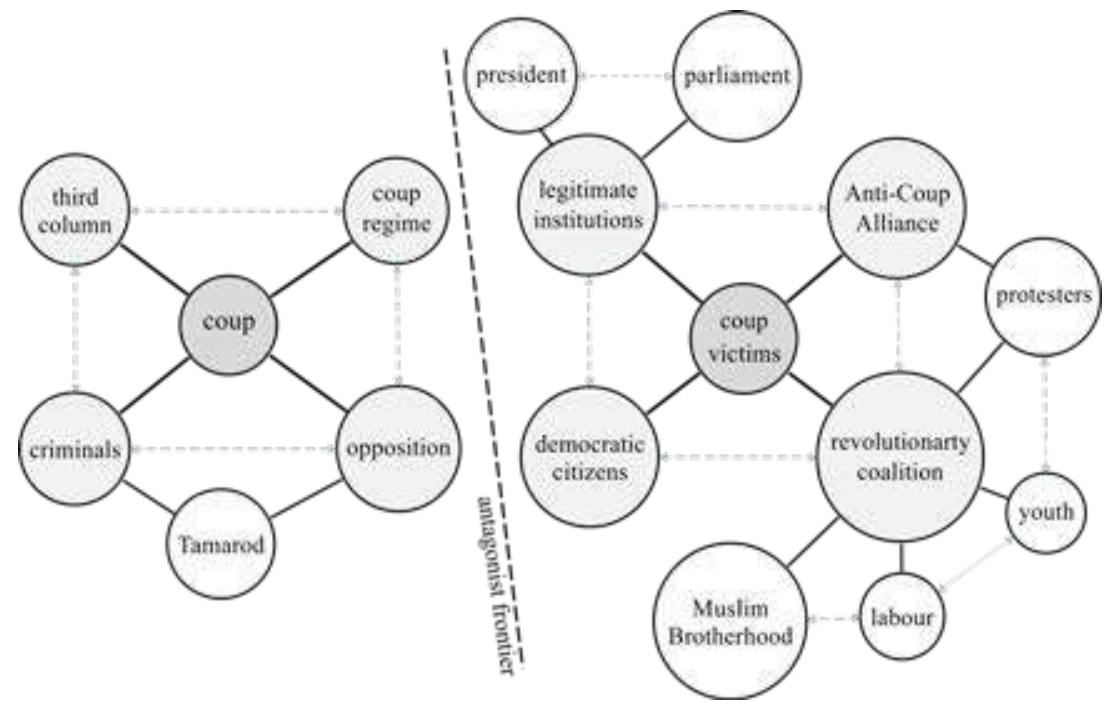

representative. The semantic network in Figure 2 illustrates this symmetric structuration of the Anti-Coup discourse. ${ }^{3}$ Therein, the coup and its victims are depicted as the nodal points for two opposing chains of equivalence that connect different clusters of discourse elements and delimited those players who were to be considered part of the Anti-Coup coalition and their actions from its opponents.

This dividing line served as a reference for juxtaposing a range of players in a differential relation: The coup leaders were constructed as the antagonist to the elected President Mursi the country's democratic leader. In a similar vein, the institutions that had backed Mursi's ouster, such as the Ministry of Interior or the domestic security apparatus, found their differential counterpart in those institutions that had supported his presidency. Those players from the ranks of the former political opposition who had welcomed Mursi's removal, in turn, were juxtaposed to the democratic citizens who shared the principles and goals of the Anti-Coup campaign. Those who had shown their support for the military intervention through street protest, including the Tamarod campaign, were portrayed as nothing more than a bunch of criminals who had been instrumentalized by the so-called third

3 In this and the following figures, a dashed line demarks the antagonist frontier separating different camps of players; dotted lines with arrowheads illustrate differential relations; these differences are dissolved by mutual relations of equivalence (simple lines) to a nodal signifier. 
column - an ostensive conspiracy of the deep state, remnants of the old Mubarak regime, and foreign powers aiming to destabilize the country (see Gribbon \& Hawas, 2012, p. 122). They were contrasted with labor and youth movements as well as Islamist groups who had made possible the January 25 uprising, in the first place.

\section{Articulating a Collective Identity}

In their exploration of the techniques by which social players, collectives or individuals, identify social problems, and reconstruct political allegiance, Jasper, Young, and Zuern (2020) emphasize the character work that goes into the articulation of social identities: "Politics is about the pursuit of power," they argue, "but one central way to get power is to persuade others that you are competent, courageous, and benevolent while your opponents are none of these" (p. 2). When it comes to compound players facing oppression and injustice, the articulation of victimhood takes an essential role in this process. It usually precedes the diagnosis of an antagonist other who is made responsible for the injustice, and the hero whose duty it is to seek a redress of grievances: "If character work can establish that there is a victim, then there must be a wrong to be righted" (Jasper et al., 2020, p. 195).

Realizing that President Mursi's earlier attempt to fraternize with the Egyptian public and present himself as a people's man had failed, the AntiCoup coalition refrained from establishing a direct link between the people and the deposed president but, instead, constructed a relation of equivalence between both only via their common victimization by the coup. Individual players' demands without necessary prior relations were thereby grouped into a popular demand for the abolition of the coup. This shared linkage as victims reproduced a common trait of political meaning work for the purpose of social mobilization.

To lend credibility to this self-characterization, the protest coalition also worked hard to alter the image of the Anti-Coup campaign as an extended arm of the Brotherhood. Albeit present on the Rabaa al-Adawiya podium and at street rallies, the NASL's official communication largely evaded any religious symbolism. Samuli Schielke (2017) claimed that Mursi's supporters, in their attempt to discredit their political rivals, produced a strongly sectarian narrative about their opponents as "Christians, godless liberals, or corrupt old regime elites - thus, once again, not the true Muslim Egyptian people" (p. 209). But this narrative was mainly produced by agitated speakers on the Rabaa stage. 
When it came to its official communication, neither the Anti-Coup Alliance's nor the Brotherhood's statements after July 3 exhibited a strong sectarian - or even religious - language. Albeit derived from the same Arabic root, the Anti-Coup discourse centered not on sharia, the religious law derived from the precepts of Islamic scripture, but on Mursi's shar'iya, his worldly legitimacy, and the legality of his actions. There was a conspicuous absence of typical Brotherhood tropes, such as the traditional slogan "Islam is the solution" (Imad, 2014, p. 239). While the coup forces were likened to the feloul, the remnants of the old regime, neither their confession nor their piety played a central role. This can be understood as a strategy to leave the movement permeable to outside support by non-Islamist political groups. During Mursi's presidency, opposition parties had regularly accused the Brotherhood of abusing religion for political gains. Well aware of their image as tujjar ad-din [religion brokers] (Monier \& Ranko, 2013, p. 116), the NASL thus adopted broader references to democratic legitimacy, in an effort to dissolve pre-existing antagonisms and bridge social polarization.

The notions of democratic citizenship and faithfulness to the goals of the revolution became key in the Anti-Coup campaign's attempts at coalition building and at linking its struggle to broader struggles against authoritarianism. The military coup, an NASL statement on July 4, 2013, stressed, had been one against "the legitimacy derived from the will of the people and revolution of January 25" (NASL, 2013d). This legitimacy had been granted via elections and referenda - democratic procedures that had been established as a result of the joint revolutionary protests of youth, workers, and Islamists. In this logic, all those players who either supported democratic due process or those who had shared the goals of the glorious revolution of January 25 were bound together through their victimization by the coup. In this perspective, solidarity with Mohamed Mursi, as the prime victim of the coup also became a matter of principle for the Anti-Coup coalition, as their communiqués illustrate (e.g., NASL, 2013g).

In essence, the Anti-Coup Alliance conceived legitimacy as based on four pillars: national security, revolutionary glory, electoral democracy, and constitutionality (see Figure 3). These four pillars defined the movement leaders' views of how to legitimately respond to the coup, and it conditioned their instructions to their followers regarding the desired repertoire of action and demands to be voiced at protest marches. From the primacy of restoring constitutionality derived the demand for restitution of the elected president, the reinstatement of the disbanded parliament, and the restoration of the rule of law. From the claim to defending the popular will derived the appeal to break the coup and protect Egypt's transition. From 
Figure 3 Construction of legitimacy and corresponding Anti-Coup action strategy

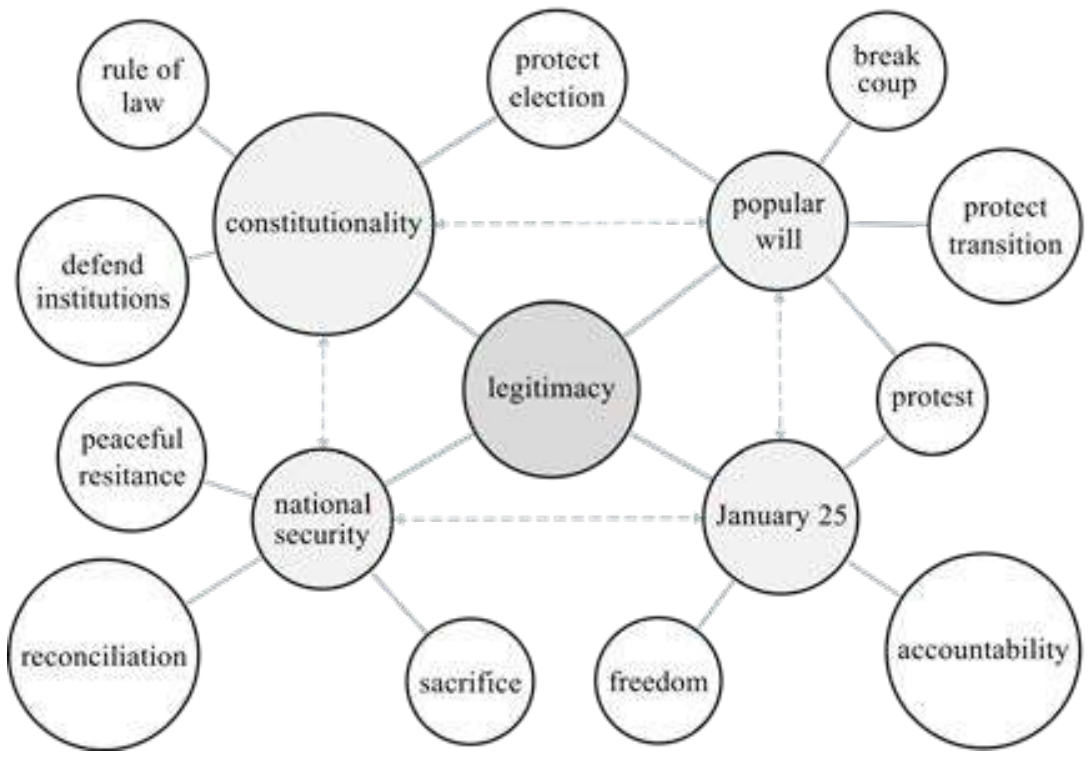

the nationalist-inspired reference to the defense of legitimacy as a service to national security, in turn, derived the strong insistence on peacefulness and the (at least official) support for reconciliation. And from the definition of legitimacy as one rooted in the January 25 Revolution derived demands for freedom, social justice, and accountability, as well as an insistence on protest as a mechanism for leveraging popular support.

The alliance's prognosis of what was to be done and how it was to be done, hence of the appropriate strategies of resistance reflected these convictions. This is exemplified by the fourth NASL statement, which was released shortly before Mursi's ouster on July 3 and stressed that adherence and protection of these pillars of legitimacy would ensure that there would be "no fighting or violence or any kind of bloodshed" (NASL, 2013b).

\section{Pillars of Legitimacy}

The NASL realized that it had been the narrow conception of popular will as the periodic formal expression of voting preference at the ballot, which had undermined first Mubarak's and then Mursi's claim of representing the people. It therefore additionally drew on conceptions of revolutionary legitimacy which had been developed via street politics during the 20112012 uprising. References to the January 25 Revolution recall, above all, a 
range of historical descriptions of who acted how towards whom during the 18 days of the Tahrir Square occupation in 2011. However, January 25 can also be conceived of as the signifier for a more abstract belief system and a repertoire of interpretive frames loaded with cultural and affective meaning. Tarek Ghanem (2016) has deployed the metaphor of religion to describe this symbolic layer of January 25 . He points to the ideals of agency, autonomy, and moral consistency, the emotions, and affective memories, and the rituals and iconography (embodied in the martyrs and their stories and legacies), which the term evokes.

Though the metaphor is debatable, the Tahrir revolution, as a symbolic marker, has come to embody the essential elements of a belief system with enormous mobilizing power. By arguing that "the great revolution continues all the areas and quarters of Egypt until achieving its goals and making it clear that it will never allow the defunct former regime to return" (NASL, 2013a), the Anti-Coup campaign drew on this belief system to reinforce its claims. The alliance thereby placed its resistance to the coup in the trajectory of the Egyptian revolution against authoritarianism: as a committed coalition of Egyptian citizens who continued to uphold the spirit of the revolution, the NASL would neither allow legitimacy to be overturned nor a return to "the age of dictatorship, corruption, and tyranny" (NASL, 2013b).

Betting on the power of collective memories about the 2011 uprising, the alliance moreover drew parallels between its victimization and the violent crackdown on Midan Tahrir. It emphasized that, in 2011, thousands of Egyptians had fallen victim to the same kind of violence that its members were now experiencing (see NASL, 2013d). This effectively likened the Anti-Coup martyrs to the canonized martyrs of the Tahir uprising. After instances of violence and bloodshed, these references became more explicit, such as on the day before Mursi's ouster on July 3 , when clashes between demonstrators, residents, and police forces at a pro-Mursi rally near Cairo University left 18 dead (see Human Rights Watch, 2013a). The Alliance reacted to these clashes by extending its condolences to the families of all those who had been killed, both supporters and opponents of its cause. In its letter of condolence, it portrayed the fatalities as martyrs and ignored the fact that the violence had resulted from civil strife. Instead, it highlighted that the clashes had unraveled "under the eyes and ears of the security apparatus" (NASL, 2013d). Additionally, it pointed out the similarities with Mubarak's infamous attempt to disperse the crowds on Tahrir Square with the help of hired thugs on camelback on February 2, 2011 - one of the most iconic events of the Tahrir occupation. 
Such parallels between the early days of the 2011 uprising and the beginning of the crackdown on the Anti-Coup campaign were not only drawn by the public relations professionals within the NASL but also at the movement's grassroots level. Several interview partners have acknowledged that the violence in the summer of 2013 was premeditated given the climate of anxiety, dehumanization of opposing sides (see also Schielke, 2017). However, they also stressed that initially their perception of the struggle was shaped by the categories of their prior revolutionary experience. One research participant recalled that he and his comrades had stood "as one" on Abdel Moneim Riyad street, one of the entrances to Tahrir Square, against the hired thugs in 2011. In 2013 he felt like he and his comrades were standing against them once more, only this time in Gizah, the site of the Al-Nahda encampment. ${ }^{4}$

Lastly, the defense and protection of national security also became a nodal signifier in the Anti-Coup Alliance's discourse on legitimate resistance. This was undertaken to counter the coupists' attempts to monopolize the prerogative of interpretation over what was to be considered sensitive to national security and which elements were a threat to it. Furthermore, such rhetoric also served to discredit alternative resistance strategies against the coup which were not primed on nonviolence. The adoption of a prognostic frame that stressed peaceful protest as the only legitimate means of resistance had a strong prefigurative component in that it expressed the political ends of the Anti-Coup campaign - a return to civil rule and a peaceful rotation of power - through its means (see Yates, 2015). From the outset of their campaign, the alliance thus affirmed its "full commitment to the principle of peacefulness established by the glorious January Revolution." Bloodshed was a "red line" that was not to be crossed (NASL, 2013a).

\section{Constructing the Antagonist Other}

This red line divided the NASL from its antagonist other. This adversary was constructed around the nodal signifier of the coup. Mursi's last presidential address had set the parameters for who was to be considered to be part of this coup. Only moments after General Al-Sisi had announced Mursi's ouster, the president released a hastily recorded video clip on an official Website, in which he denounced the coup attempt. Moments later, the website was shut down, and the record disappeared, as official media channels refused

4 Group discussion with two young Muslim Brothers and the son of a Gamaa Islamiya member, July 2014 . 
to televise Mursi's statements without permission from the armed forces. ${ }^{5} \mathrm{~A}$ shortened transcript was later e-mailed to selected reporters and researchers. It asserted that the actions of the leadership of the armed forces represented a military coup. In his capacity as the high commander of the armed forces, the president insisted that all citizens, "whether civilian or military, both commanders and soldiers" should adhere to the constitution and reject this coup that only led Egypt backward. ${ }^{6}$

He also affirmed his earlier view that an unholy alliance between remnants of the old regime and a fifth column of criminals, corrupt instigators, and secretive groups had colluded to sabotage Egypt's democratic experiment. In his anniversary speech on June 26 , Mursi had alleged that this nefarious counterrevolutionary coalition was supported from abroad (see Mursi, 2013b). After Mursi's deposition, the NASL adopted this definition of the national enemy as an axis of four different counterrevolutionary players (see Figure 4). These included:

1 The coup regime, which denoted the coup leaders on the institutional level and the public figureheads of the military intervention, Defense Minister Abdelfattah Al-Sisi, Interior Minister Mohamed Ibrahim, the state security institutions, as well as the Ministry of Interior and its subordinate law enforcement and policing bodies.

2 A clandestine fifth column consisting of old regime remnants, the remaining fractions of Mubarak's National Democratic Party, and their domestic and foreign financiers, which were trying to cause chaos and sectarian strife to destabilize the country and enable a return to the pre-revolutionary order.

3 The opposition forces, including the Tamarod movement and the parties and initiatives bundled in the National Salvation Front, who had violated the constitution by voicing their dissent outside of the institutional channels for democratic expression; as well as the larger part of private and state media who, according to the NASL, were abrogating their professional ethics for a role as a public address system for the coup forces.

4 Criminals and hired thugs, including the so-called baltagiya who, in Mubarak's time, used to swarm Egypt's neighborhoods during elections to intimidate opposition candidates, and who developed into key agents of state repression since the 2011 uprising.

5 Neither an official record nor a full original transcript of the speech exists. This is the primary reason why this "last stand" is usually overlooked by analysts who mistakenly refer to Mursi's address on June 2, 2013 as his last speech.

6 A copy of the e-mail received on July 3, 2013, at approximately 10 p.m. Cairo time, is on file with the author. 
Figure 4 Construction of antagonist other in the Anti-Coup discourse

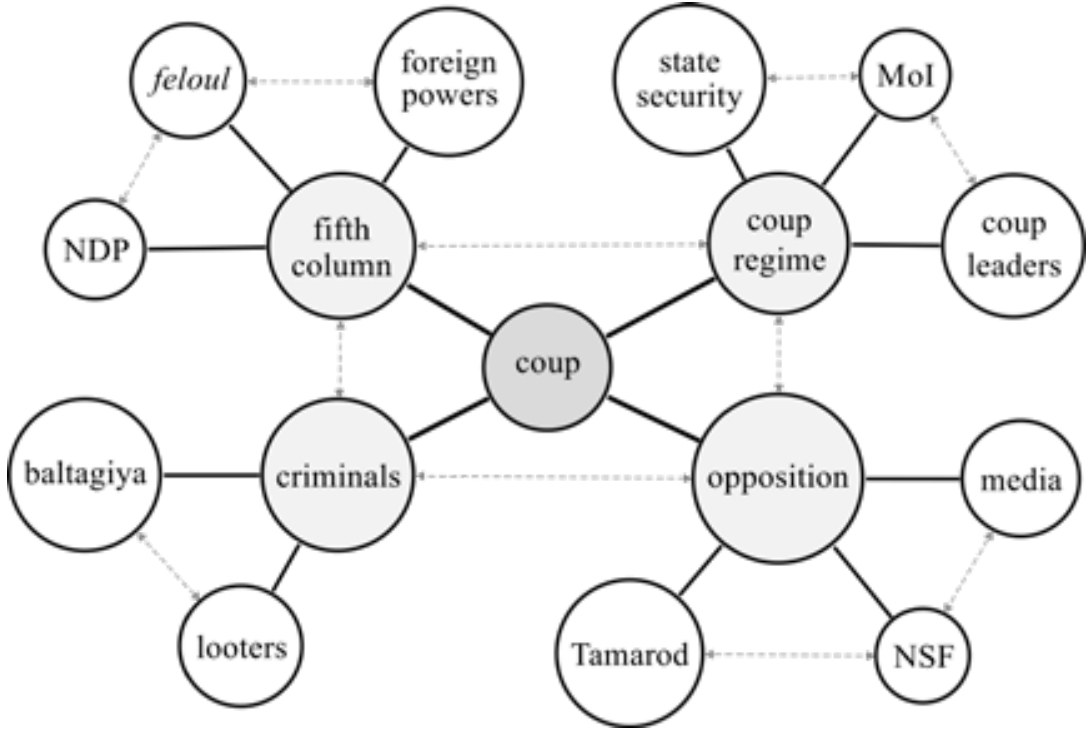

Significantly, the armed forces were not included in this nefarious quartet. Quite the contrary, at first, the NASL explicitly welcomed the army's presence in the street and called upon the troops to prevent attacks on protesters just as they had done during the Tahrir uprising. The alliance even downplayed prior confrontations between Islamist protesters and army forces as mere misunderstandings that the NASL was keen to avoid from now on (see NASL, 2013c). Many of the NASL statements addressed the members of the armed forces as "fellow officers" thus deliberately constructing a relation of equivalence between the soldiers and the members of the Anti-Coup campaign. This conciliatory tone was surprising, as the alliance concurrently framed the cascade of events between June 30 and July 3 as an inqilab 'askariy - a military coup d'état - making use of a terminology that implied the armed forces' involvement. Explicitly, however, it refrained from calling out the generals as the chief perpetrators and, instead, emphasizes the military's role as a people's army.

\section{People's Army versus Police State}

This reluctance to alienate the military can be explained by the NASL's lack of allies within the security sector. Numerous media sources had 
documented the resentment that had permeated the officers' corps of the Ministry of Interior during Mursi's year in office (Alsharif \& Saleh, 2013). Furthermore, police officers had assisted in the collection of signatures for the Tamarod petition and adopted a wait-and-see approach vis-à-vis the Mursi administration. At times, the police had even openly opposed the Mursi administration, such as during the Ittihadiya Palace clashes discussed in the previous chapter. In June 2013, it also refused to protect the Brotherhood's headquarters in Cairo's Moqattam district as well as FJP premises across the country from looting and arson. ${ }^{7}$ The Ministry of Interior's partisan stance against the acting government became obvious during the coup itself when it unilaterally deployed against the pro-Mursi demonstrators. In a division of labor of sorts, a command within the Egyptian armed forces took Mursi into custody, while the police cracked down on the Brotherhood's demonstrations and relieved the armed forces of the need to make use of their arms.

The NASL's congenial stance towards the armed forces thus partly resulted from its sheer lack of alternatives. Hoping for army units to act as a buffer between Egypt's notorious riot police and the demonstrators, the square leadership of the Rabaa and Al-Nahda camps invited the soldiers to join the sit-ins as brothers and fend off attacks on a constitution that, in the view of the NASL, had preserved the army's central role in Egyptian politics. Keenly aware of its lack of sympathies in the upper army leadership - laid bare by recurrent informal meetings between army officers and Ministry of Interior officials at their social clubs throughout spring (see Alsharif \& Saleh, 2013) - the alliance turned, above all, to the mid and lower ranks:

We harbor only love and appreciation for the officers, the non-commissioned officers, and the soldiers of the armed forces ... you are always an object of honor and pride. We do not forget your role in the recuperation of Sinai in the 1973 war, and we do not forget your support for the glorious Egyptian Revolution on January 25. (NASL, 2013c)

The glory of the armed forces was juxtaposed in opposition to the savagery of the police forces who were portrayed as foot soldiers of the coup. Through the term dawla bulisiya [police state] the alliance characterized the Ministry of Interior as the central villain (NASL, 2013d, p. 6). In addition to domestic security and the coup leaders around Al-Sisi, the NASL also blamed hired

7 A record of the press conference is available at https://www.youtube.com/watch?v=EArLLae99Jw. 
thugs for the violence. As the looting and arson of Brotherhood premises increased and clashes in the vicinity of the Cairo University left 18 dead, the NASL began to refer to the police forces as mugrimin muhtarifin [professional criminals].

Moreover, in an aggressive demarcation of bodies, the NASL vilified as baltagiya all civilians engaged in clashes with its supporters. The term baltagiya originally refers to the Mafia-like structures in many of Cairo's settlements which exist largely outside the supervision of the state. In the past, these structures reliably produced muscles-for-hire, whose services could be contracted by state institutions, local public servants as well as private businessmen (Amar, 2011, p. 308). During the January 25 Revolution, these groups transformed into an instrument of state repression in a dual sense. On the one hand, the baltagiya became a tool to anonymously attack protesters after police forces had retreated to their barracks (Hanafi, 2015). This repression by proxy enabled the regime to confront protesters without corroborating their claims of oppression (see Schwedler, 2018, p. 81). It also allowed the regime to deny responsibility for the violence on the ground. At the same time, the presence of para-state producers of violence in public spaces could be used as a pretext to extend the security apparatus's use of force.

On the other hand, the baltagiya-label became an expedient label to discredit social movements, vilify political currents, and undermine subaltern politics. As Paul Amar (2011) argues, "protesters were re-signified as crazed mobs of brutal men, vaguely 'Islamist' and fiercely irrational" (p. 308). The politics of signification during the revolutionary moment in Egypt effectively blurred the lines between who was a thug and who a revolutionary: "Since all protestors were outlaws, everyone became a thug" (Wahba, 2020, p. 84). However, the delegitimizing essence of the baltagiya label remained intact despite its politicization and was reproduced in Egypt's post-revolutionary arena by a variety of players. After the 2013 coup, both camps attempted to monopolize usage of the derogatory term to discredit their adversaries' policies as a relapse into the barbarism of the Mubarak era.

The NASL alluded, furthermore, to the machinations of a fifth column, a clandestine subversive faction that aimed to undermine the nation's unity by any means at their disposal. In line with Pratt's findings (2015, p. 49), this domestic fifth column that threatens the fabric of the nation through its particularistic interests found its complementary counterpart in the hidden hands of dangerous foreign forces. Unspecific hints to external actors as a "third hand" or as "foreign fingers" - today common tropes in 
the xenophobic discourses that are promoted by nationalist TV shows and official statements in Egypt - were a characteristic feature of the NASL statements.

As Wessel (2018) has suggested these "third hand"-claims represented a particularly powerful rhetorical vehicle: "Since the 'enemy' or the 'other' is so elusive and depends on the interpretation of the individual, it enables the incorporation of a wide range of competing and even opposing collective imaginaries" (p. 353). According to the NASL, the nefarious alliance plotting against the people consisted of both, remnants of the old regime, such as Mubarak's National Democratic Party, as well as foreign powers, including Zionist agents, who collaborated to destabilize the country and prepare the return to the pre-revolutionary order.

In a press release on the eve of June 30, the NASL leadership alleged that the Tamarod movement was colluding with these forces. The statement not only decried the political violence and killings, and the looting of the FJP's offices during the past weeks. It also bemoaned that the attacks with blades, live bullets, birdshot, and Molotov cocktails clearly showed that the "NDP thugs and their NSF and Tamarod allies [...] had no respect for the sanctity of homes and private property" (Muslim Brotherhood, 2013a). It claimed that supporters of the Tamarod campaign had attacked NASL leaders' houses and shops across Egypt and even laid siege to mosques. Other players were complicit in these attacks, the statement stressed, by remaining quiet and implicitly condoning this violence. This also included the media which, according to the NASL, had failed to adhere to professional standards by not covering the attacks.

Here the NASL picked up Mursi's cue. In the last speech before his deposition, Mursi had alleged that the media was playing a crucial role in the counterrevolutionary efforts that, ultimately, would lead to his demise. After Mursi's ouster, the alliance elaborated on this role in a statement about the "coupist media broadcasting" which accused Egypt's publishing houses and television broadcasters of slander and intentional misrepresentation of the peaceful Anti-Coup protests (NASL, 2013f.). The statement also called on the remaining free media in the country to attend the demonstrations as neutral observers and to oppose the skewed image that the coup forces were promoting.

\section{Mirror Images}

The depiction of the coup forces mirrored the NASL's self-portrayal (see Figure 5). This was particularly so on the diagnostic level where the 
Figure 5 The coup as a mirror image of the Anti-Coup resistance

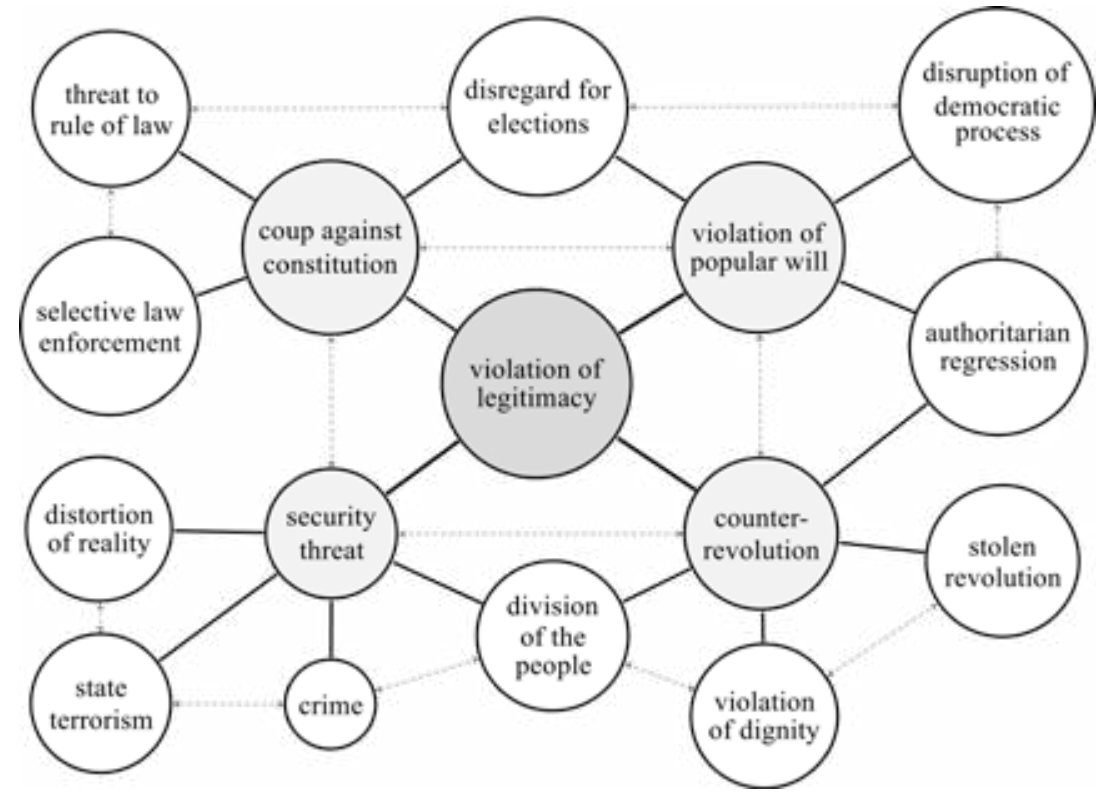

Anti-Coup Alliance enumerated the coup forces' actions. Here the popular will, constitutionality, national security, and the January 25 Revolution again assumed the roles of nodal signifiers. According to the NASL, the players that supported the coup had undermined precisely these foundations of legitimate rule by acting against the popular will to champion a counterrevolution, and by setting themselves above the roles provisioned for them in the constitution. Above all, the state institutions aligned with the coup were neglecting their constitutional purpose: Security forces were failing to protect protesters as well as FJP offices from attacks. The media were not abiding by the norms of professionalism and decency as stipulated in article 215 of the constitution by spreading misinformation. And the armed forces were overstepping their mandate to protect the homeland by adopting a partisan role and partaking in a vicious defamation campaign against one group.

On the other hand, the NASL claimed, the coup forces were threatening the rule of law. By forcibly deposing President Mursi, they had ignored the constitutional process to replace the head of state, either via democratic elections or via impeachment. Article 152 specified that the removal of Egypt's head of state was conditional on a motion signed by at least one-third of the members of the Council of Representatives and a two-thirds majority vote. 
Aside from a threat to the rule of law, the NASL referred to the coup also as an imminent threat to the integrity and security of Egyptian society. National security effectively became another central signifier in the alliance's discourse about its antagonist other. The NASL based this diagnostic framing crucially on three arguments: First, it asserted that the coup was pitting "the people against the army on the one hand, and against each other, on the other hand" (NASL, 2013j), thus eroding the popular unity achieved through the joint revolutionary struggle as well as the social contract between the Egyptian people and its armed forces. Second, it warned that the incitement of civil strife during this critical juncture would only benefit Egypt's domestic and foreign enemies (see NASL, 2013g). And third, it underscored that the use of state violence against protesters provided a pretext for a return of the security state and a rollback of the rights and freedoms that had been won during the 2011 uprising.

Within this security frame, the security service's (in)actions were interpreted as symptoms of reemergent state terrorism. These symptoms included the closure of Islamist media channels, the illegal arrest of opposition politicians, a campaign of lawsuits against Brotherhood members, and former government officials, as well as the restriction of public spaces for protest. This rhetoric only hardened when clashes between Anti-Coup protesters and their opponents intensified, and the police started to confront protest marches more forcefully. When riot police brutally cracked down on the Anti-Coup demonstrations on Friday, July 5, 2013, the NASL began to openly accuse the coup forces of murder (see NASL, 2013e, 2013f.).

\section{First Blood}

The Friday of Rejection on July 5, 2013, became the first turning point event for the Anti-Coup campaign. The NASL had called for nationwide protests on this day. In Cairo, these protests concentrated on the periphery of Salah Salem Street, which houses the Republican Guard headquarters. Ostensibly, the Republican Guard is directly subordinate to the president of the Republic, but it had been members of this military division that had taken President Mursi into custody. Consequently, Anti-Coup demonstrators believed the deposed President Mursi was held in their headquarters and erected tents in front of the barracks directly after Mursi's deposition was announced. After the Friday sermon, thousands of additional demonstrators marched to the barracks, answering calls by the Brotherhood's murshid [supreme leader] Mohammed Badie who had unexpectedly appeared at a rally in eastern Cairo and insisted that street mobilization would continue until Mursi's 
reinstatement. Overwhelmed by this mobilization, riot police resorted to live ammunition to confront the marches, killing at least three and injuring several more.

Violence also intensified at other demonstrations as Mursi supporters clashed with their opponents in central Cairo, Alexandria, Beni Suef, Damanhur, and Luxor. In most of these situations, the police forces sided with Mursi's opponents. At times, they merely provided cover and shielded anti-Mursi demonstrators with their vehicles (Escobales et al., 2013). In other instances, they engaged in physical violence themselves. In many cases, police simply remained absent from the scene for hours. As a result, the clashes lasted until the early morning hours and left dozens of protesters dead and over a thousand injured.

Investigations have highlighted that violence on the night of July 5 emanated from all sides (Human Rights Watch, 2014, p. 108ff.). But the consequences were particularly severe for the Anti-Coup Alliance. Graphic videos of Mursi supporters stabbing their opponents and throwing them off the roof of a building in the city of Alexandria undermined the NASL's insistence on peaceful resistance. On Rabaa Square, these videos were relativized as self-defense or denounced as false flag operations. To rectify its public image, the NASL even alleged that the security services had paid bearded baltagiya to wreak havoc in an attempt to frame Mursi's supporters as extremists (see NASL, 2013g). But outside of the NASL support base, these justifications did not resonate. Most Egyptians were simply appalled by the brutality they had witnessed.

Consequently, the events on July 5 contributed to the development of a siege mentality within the Islamist camp. They confirmed the worst fears of the Anti-Coup organizers who had repeatedly cautioned against an upsurge in violence, should its demonstrators remain unprotected. At the same time, their aftermath substantiated the NASL's perception of its adversary as an alliance of security forces and media in the cover of a popular uprising. For the Anti-Coup members, their collusion was evidenced by the fact that neither the army nor police had intervened for hours to prevent factional violence, and by the fact that the media had assigned responsibility for the clashes solely to the Anti-Coup protesters.

These suspicions were additionally fed by Tamarod and the National Salvation Front who responded to the July 5 clashes with statements that portrayed the Anti-Coup campaign as a violent revolt against the glorious second revolution on June 30. For the NASL, this appropriation of the revolution metaphor whitewashed the coup on July 3, 2013. In an attempt to counter this narrative, it insisted that Tamarod had violated the people's 
dignity by inviting the army to return to the political playing field and asserted that it would not allow a return to the age of dictatorship. As the NASL adopted this diagnosis of July 3 as a regression to autocracy, the depiction of Mursi's opponents as counterrevolutionaries became central to the Anti-Coup resistance discourse.

\section{The Republican Guard Massacre}

The internal frontier constructed by the NASL between the supporters of legitimate democratic rule, on the one hand, and the counterrevolutionary coup forces, on the other, crumbled as it became increasingly evident that the armed forces could not be relied upon as a neutral mediator. The army's partiality was apparent on July 5, 2013, when many of the tanks that were deployed across the country carried anti-Mursi demonstrators on their roofs to the frontlines. But it became undeniable when army units, for the first time since Mursi's ouster, deployed lethal violence against protesters themselves. Supported by riot police, they began to clear the Anti-Coup sit-ins in front of the Republican Guard headquarters on the night of July 7-8, 2013. It is estimated that, at the time, some 2,00o people were camping on Salah Salem Street (Kingsley \& Green, 2013). Hundreds of these Anti-Coup protesters were injured or arrested during the raids. In addition, more than 90 protesters were killed by live ammunition - fired from the rifles of elite army units. ${ }^{8}$

To justify this deadly use of force, the military claimed that the security forces had only acted in self-defense against armed protesters who had tried to break into the barracks. ${ }^{9}$ But video evidence and eyewitness interviews tell a different story, namely that of a coordinated assault of Republican Guard units and the paramilitary Central Security Forces (CSF) on the protesters (Amnesty International, 2013a). Videos uploaded by neighbors of the sit-in contained only a few images of protesters hurling stones and Molotov cocktails towards the security forces. ${ }^{10}$ But they clearly document

8 Wiki Thawra has documented a total of 93 victims, 1,200 injured, and more than $65^{\circ}$ arrests.

9 According to a police report by the Cairo General Investigative Bureau (No. 9134/2013), armed terrorists had attacked the Republican Guard with motorcycles, shooting live ammunition and birdshot and throwing stones from neighboring buildings toward the Republican Guard base. In response to this attack, the army and CSF units protecting the base had used sound bullets and teargas to disperse the responsible groups. The report is available at https://nchrl.org/sites/ default/files/Police\%2opreparator.pdf.

10 See, for instance: https://youtu.be/A31XI7_wl-s; https://youtu.be/-iND9GsCGhU; https:// youtu.be/kKrqk2P4Bvo. 
the use of automatic weapons by uniformed and plainclothes officers and army units against the protesters.

This use of deadly force sparked harsh criticism even among those players who had backed Mursi's ouster. The Salafi Nour Party - a former ally of the Muslim Brotherhood who had sided with the army on July 3 - announced its retreat from the negotiations about an interim government. Shortly thereafter, Hazem Qandil stepped down as interim prime minister. Tellingly, his resignation letter included an apology to the deposed President Mursi for not having resigned directly after his ouster. Even players closely aligned with the armed forces, such as the representatives of Misr Qawiyya [Strong Egypt], Tamarod, and the National Salvation Front demanded an impartial investigation into the shootings.

\section{The Specter of the Deep State}

The killings that are commonly referred to as the "Republican Guard massacre" (P. Owen \& McCarthy, 2013) heralded a new phase in the Anti-Coup Alliance's political subjectivation process. Most importantly, they created a dislocation in the Anti-Coup discourse (Figure 6, new elements shaded in grey). Thus far, the alliance had deliberately excluded the armed forces from the portrayals of its adversary. But the sight of army units shooting unarmed protesters was an event that could not be incorporated into the horizon of expectations evoked by this discourse. The "betrayal" of the armed forces came as a shock to many Anti-Coup protesters. It impacted heavily on protesters' affective loyalties in that it undermined trust and disenthralled long fostered feelings of love and belonging (see Jasper, 2018, p. 103ff.). It also seriously challenged the NASL's narrative of the armed forces as a neutral people's army.

To suture this rift, the Anti-Coup discourse needed to shift. On July 8, 2013, for the first time, the Anti-Coup Alliance explicitly called out the armed forces for their actions:

The hideous massacre was committed by the Egyptian Army and police against peaceful protesters from among the sons of the great Egyptian people, praying the Fajr, in a crime that is unprecedented in Egyptian History. It resulted in dozens of martyrs, including children and infants who died at the breasts of their mothers, and hundreds of injured. (NASL, 2013h)

In this characterization of the events, we have the unprotected pious victim of the children and mothers, who are attacked by the powerful villain of the coup forces, aided by the minions of the army and police. In later statements, 
Figure 6 Construction of antagonist other after the Republican Guard Massacre

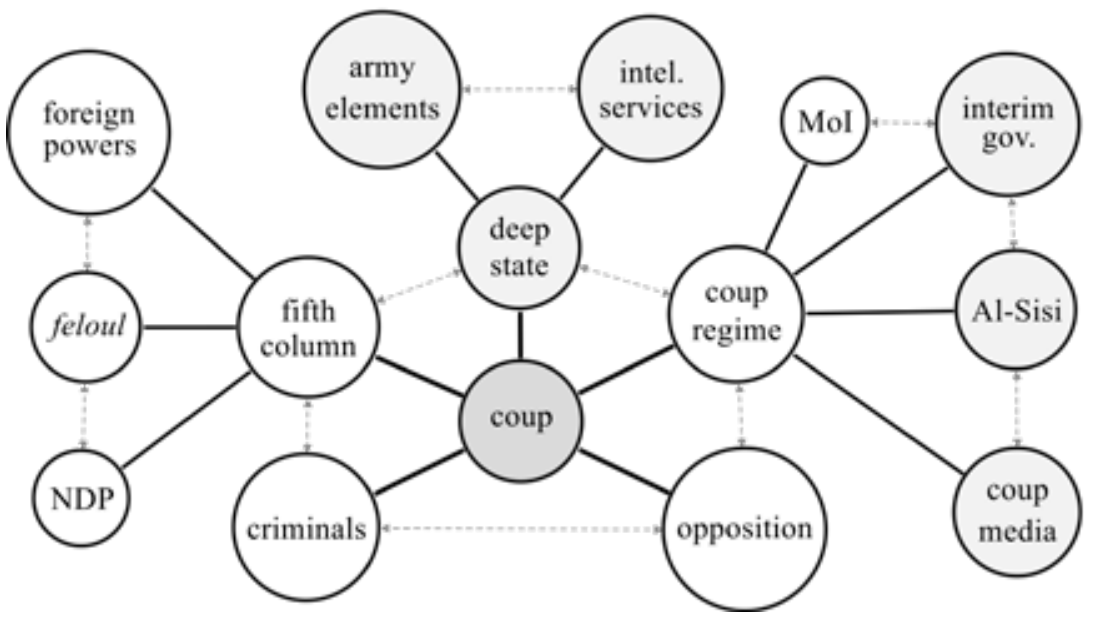

this cast was completed by the heroes of the Egyptian people whom the Anti-Coup Alliance called upon to join the ranks of the opposition. This topical character work provided an organizing principle by which the actions of players on both sides of the antagonist divide could be linked together and made sense of (see Jasper et al., 2020, p. 2ff.). The Anti-Coup press releases about the massacre were also unprecedented in their moral excoriation of the armed forces. They stressed that the army had dishonored itself by violating all religious values and moral norms. Not thugs or gangsters but soldiers and officers had fired live bullets into crowds of worshipers. This repugnant crime made the army an accomplice of the coup and placed it on the opposite side of the frontier drawn by the protesters between the coup forces and the resistance. Over the coming weeks, the armed forces moved from the least questioned player to the most prominent foe in the Anti-Coup narrative.

Notably, even after the Republican Guard massacre, the Anti-Coup discourse retained a backdoor for reconciliation - at least, with the lower ranks of the army. It categorically distinguished between those giving and those merely acting upon orders. In several letters to their "brother officers and soldiers," the NASL organizers stressed that its protesters had no quarrel with the members of the armed forces themselves. Their conflict was with those commanders who involved the army in politics and aimed for a return to direct military rule:

We are all Egyptian citizens, military and civilian, we are all brothers in our homeland. Among you are some brothers of kin. We were also part of 
the military during our military service. We were proud of the uniform and proud to belong to this ancient national institution. You will become civilians again after the end of your service. You are part of us, and we are part of you. (NASL, 2013l)

To maintain this strategic distinction, even when army operations against street protests became more frequent, the Anti-Coup organizers concentrated on their framing of Abdel Fattah Al-Sisi and his aides - the coup leaders - as the main culprits. During the July 3 coup, the Republican Guard had acted under Al-Sis's direct orders when it took Mursi into custody. That the elite unit was now also involved in the killing of protesters facilitated framing the General as the mastermind behind the democratic rollback. In addition, the NASL exculpated the military rank and file by adopting vague references to the machinations of an alleged deep state that was controlling the state's actions.

The term deep state [ad-dawla al-'amiqa] carries multiple connotations. On the one hand, it has traditionally denoted a secretive authoritarian substructure of republican politics behind institutional façades. As such it aptly described how power was exerted in Egypt's "officer republic" (Sayigh, 2012) until the fall of Mubarak. Since the 1950s, a quiet entente between the presidency, the security services, and the army had functioned as a political gatekeeper. As Springborg (2018, p. 71) argues, power shifted marginally between the three legs of this tripod, but the tripod itself remained remarkably stable. This power balance allowed the alternating political regimes governing the country to protect the interests of a narrow elite to the exclusion of the majority population. However, it also undermined the separation of power and prevented accountability, thus stalling the much-needed economic modernization.

On the other hand, the deep state represents a discursive figure that belies the scarcity of reliable information about the actual power relations in post-revolutionary Egypt. As an empty signifier, it has become a scapegoat for players on both sides of the political divide. For power-holders, the deep state functions as a bogeyman who is invoked to deflect from their shortcomings. The different republican regimes from Sadat to Mubarak routinely blamed the deep state for Egypt's economic underperformance. ${ }^{11}$

11 Sarah Wessel (2016, p. 18ff.) has discussed a particularly striking example of how the narrative of the deep state was instrumentalized by the Supreme Council of Armed Forces to tarnish the revolutionary movement. In 2012, its government produced two segments for state and private television which cautioned Egyptians against interacting with foreigners. These spots spread 
Parroted by state television and newspapers the term securitized politics by creating the perception of a country under threat of exploitation by conspiring domestic and foreign forces. For contenders, in turn, referrals to the deep state functioned as a vehicle for pointing out the accountability gap before the 2011 uprising. After the Arab Spring, it turned into a prominent excuse for social movements to explain the resilience of authoritarian structures (see Hanafi, 2015).

Alongside similar expressions, such as the "third hand" or the "fifth column," the term also became an effective rhetorical tool to discredit specific players and their actions as controlled by foreign powers (Wessel, 2016). During Mursi's time in office, references to the deep state became such common currency that not only progressive activists, but also Mursi's conservative supporters claimed that the president was constrained in his policies and reform efforts by the tight grip of a counterrevolutionary deep state alliance. Mursi himself adopted this trope in his last public speeches (Mursi, 2013c).

The NASL hence drew on a well-established archive by invoking the deep state as the master puppeteer who was pulling the strings in Egypt's political theater - and to discredit the interim regime which was solidifying rapidly: Only a few days in office, interim President Adly Mansour issued a timetable for the transition period. He also swiftly appointed a technocratic transition government led by the respected economist Hazem El-Beblawi. ${ }^{12}$ NSF leader Mohamed El-Baradei was appointed to the post of vice-president. These swift attempts to institutionalize the new status quo can be understood as an attempt to curry favor with those social players whose protests had paved the way for Mursi's ouster. Additionally, they meant to alleviate fears of a return to direct military rule.

Among the Anti-Coup protesters, however, these steps were discounted as mere window-dressing. A dedicated statement on the day the interim cabinet was sworn in portrayed the new government as an autocratic dictatorship in disguise and highlighted popular elections as the only legitimate means for the Egyptian people to choose their representatives (NASL, 2013k). This

fears of conspiracies by alleging that youth movements were dealing with foreign spies. The clips can be viewed at https://youtu.be/GuclyK94RwI and https://youtu.be/poaHa7Jkxa4.

12 Aside from Prime Minister Hazem Al-Beblawi, the interim cabinet comprised 34 members, including two military and two police representatives. In addition to Al-Sisi, who remained defense minister, Air Marshall Reda Mahmoud Hafez joined the cabinet as minister of military production. Major General Mohammed Ibrahim retained his post as interior minister, and General Mohamed Abu Shady assumed responsibility for supply and domestic trade. 
narrative placed the interim government within the realm of the coup forces, further narrowing the room for compromise in favor of consolidation of political antagonisms.

\section{Closing Ranks}

The victimization by state repression gradually closed the window for reconciliation between the key players in Egypt's protest arena. It also complicated attempts by third parties to act as mediators between the interim authorities and the Muslim Brotherhood. Before the Republican Guard massacre, Egypt's Al-Gama'a Al-Islamiya - a staunch political ally of the Brotherhood - had attempted to break the polarizing political stalemate by calling for reconciliation and negotiations about a general amnesty for all contending factions. After the massacre, such a conciliatory course of action became much harder to justify within the Anti-Coup Alliance. As several exiled participants of the demonstrations in early July 2013 confirmed when I interviewed them in Istanbul, the shared experience of facing police brutality effectively streamlined the narrative within the originally diverse protest coalition. Conversely, the divisions between the antagonist camps became more pronounced, as the alliance resorted to a portrayal of the struggle as a zero-sum game:

The current conflict is not political between parties with different visions, but a struggle between the dream of achieving a civil democratic state and brutal military rule that never in the entire global history has kept a clean slate. (NASL, 2013i)

Aside from galvanizing the Anti-Coup Alliance's collective identity, the Republican Guard massacre also triggered a significant backlash on the part of the Anti-Coup protesters. Collective action notably gained pace with the start of Ramadan on July 10, 2013. During the fasting month, Anti-Coup protesters across the country used mosques as gathering points for their marches and central stages for their rallies (on a comparable function of mosques in other contexts see Olesen, 2009, p. 19; M. Hafez, 2003, p. 36). In the weeks after the Republican Guard incident, protest rates increased steadily until settling at around one hundred larger protest marches per week.

As argued more extensively elsewhere (Grimm \& Harders, 2018), this protest backlash was driven, above all, by the lack of selectivity and the brutality of the security forces. Many victims of the Republican Guard crackdown had been hospitalized with bullet wounds in their thorax, neck, and head regions. 
Investigations suggest that these wounds were caused by both, targeted sniper fire and indiscriminate machine gun use (EIPR, 2014, p. 44f.; Human Rights Watch, 2014, p. 113f.). Moreover, CSF units had poorly timed their operations so that they coincided with the morning prayers, and used heavy weaponry against the demonstrators, causing the death of several women and children (see EIPR, 2014; Human Rights Watch, 2014; Kingsley \& Green, 2013).

Notably among the victims of the massacre were not only members of the Anti-Coup Alliance - let alone armed protesters, as the security forces affirmed - but also residents of the surrounding neighborhoods. Some of these residents had joined the protesters for the morning prayer or had gone to pray in the Mustafa and Sayyida Safiya Mosques which are both close to the Republican Guard barracks. Doctors reported that the bulk of the victims had been barefoot upon their arrival at the hospital - an indication that the attack had coincided with the prayer (El-Dabh, 2013a). This enabled the Anti-Coup organizers to frame the assault as a slaughter of devoted Muslims and to draw comparisons to Syria where an army attack on the Umari mosque in Deraa had precipitated a civil war (see Pearlman, 2018). An Anti-Coup slogan soon branded Al-Sisi as a butcher and compared him to Syrian President Bashar al-Assad (Rahin, 2013).

\section{Burning Bridges}

These narratives, however, never reached the broader Egyptian public. They were thus scarcely able to evoke solidarity or to convince non-aligned political players of the peaceful nature of the Anti-Coup protests. Against the background of a media blackout against the NASL, the massacre narrative generated little resonance. Instead, many in the anti-Mursi camp underreported or relativized violence as a necessary evil to defend public security. As Fatima El-Issawi (2014) argued, "journalists' self-identification as advocates for the 'national interest', translated into the defense of the regime's survival, and prevailed over the timorous movement among journalists after the uprising who lobbied for independent and professional journalism" (p. 302).

Others chose to ignore the killings in their reporting as part of a survival strategy to appease the military (Bolliger et al., 2016). ${ }^{13}$ The few independent newspapers that published evidence that supported the protesters' side

13 Several journalists interviewed during a 2015 field trip to Cairo describe how they were asked by their board or editor-in-chief to tune down the tone of their articles to avoid repercussions. Two recounted that their online articles were taken offline shortly after the release of the army's press statement which contradicted parts of their stories. 
of the story - even against their political stances - found their articles censored or blocked from access (see A. A. Mohsen, 2013). This included the Brotherhood's English and Arabic websites, which served as the NASL's main public relations tools (Richter, 2017), as well as the Brotherhood's Huriyya \& Adala newspaper whose print edition was discontinued by the Al-Ahram Publishing House after the Republican Guard killings. ${ }^{14}$

Meanwhile, state television published a series of video clips released by the military and the Ministry of Interior which rivaled the images circulated by the NASL via social media. ${ }^{15}$ They showed protesters hurling stones from rooftops and bearded men with shotguns and make-shift firearms near the Republican Guard barracks. Albeit heavily edited, these clips fed into the state narrative that depicted the sit-in as a threat, which had been neutralized by the security forces. What is more, the authorities categorically denied the use of lethal violence and denounced all evidence to the contrary as a skilled falsification. According to army spokesman Ahmed Adly, the clips released by the NASL were part of "psychological warfare" against the armed forces. ${ }^{16}$

These and similar claims supported a strategic securitization of the AntiCoup protests on the part of the interim authorities. Coined by a group of researchers of the University of Copenhagen (Buzan et al., 1998; Waever, 1995), the term describes the process of discursive construction that aims at fundamentally altering the public perception of a social player so that she becomes relevant in a security context. Internalized norms and values, as well as the institutionalized rules of peaceful coexistence, are thereby be altered or replaced by new modes of action that follow a strict security logic: In the name of security, extraordinary measures are legitimized that would otherwise be unacceptable - for instance, the domestic deployment of troops against protestors. This is because an issue complex, once successfully securitized, comes to be regarded as an isolated subsystem, where norms and rules that govern society do not apply (see Amar, 2013). The security complex becomes anarchy in its own right. Processes of securitization are supported by certain linguistic structures.

After the Republican Guard clashes, Egypt's "securocratic" institutions (see Abdelrahman, 2017) sought to establish legitimacy for their actions by controlling the rhetoric surrounding the events. To accomplish this task,

15 Wiki Thawra has collected these videos as well as pictures and clips released by third parties on YouTube and different social media at http://bit.ly/2RqRhpW.

16 A full video of the press conference is available at https://youtu.be/xugyag81soM. 
the SCAF and the Ministry of Interior unleashed a propaganda campaign. Claims of an armed attack were soon followed by allegations that weapons were stored at the Rabaa camp and that the Anti-Coup protest sites were harboring radical Jihadist foreign fighters. State television became the interim regime's mouthpiece and increasingly portrayed the Anti-Coup Alliance as an alien body and as a problem that required a security solution.

Such discourses were fueled by the rising number of confrontations in the weeks after the Republican Guard killings. Clashes between AntiCoup protesters and counter-demonstrators as well as organized baltagiya escalated. On July 19, 2013, they culminated in bloody street battles in the city of Mansoura that left several women dead (EIPR, 2014, p. 50). Their deaths tarnished the image of the NASL as a peaceful civic coalition. July 2013 also saw a significant increase in terrorist attacks on police stations and checkpoints within the Nile Valley and on the Sinai Peninsula, as well as an assault on Coptic Christians in Southern Egypt. Though the Muslim Brotherhood condemned this spike of sectarian violence (NASL, 2013p), the attacks nourished suspicions that the group, in a division of labor, had joined forces with Jihadi groups to destabilize and bring down the government.

More significantly, the growing feelings of vulnerability and insecurity among the Egyptian population gradually turned the general atmosphere against the protests (see Osman, 2013b). This, in turn, lowered the costs of policing: As collective actions continued to disrupt urban transport, blocked major thoroughfares, and forced business activity to a near halt, authorities could argue that the police only fulfilled its mandate to restore law and order when it took action against protesters (see Rivera Celestino, 2012, p. 6). Rumors that the NASL was hoarding weapons and operating torture chambers, in turn, became the pretext for raids of the FJP party premises across the country. Sanctions against critics of this crackdown were justified as measures against disinformation and incitement (M. Mohsen, 2013).

The securitization of the Anti-Coup protest was backed by judicial proceedings against the NASL leadership which was declared the principal suspect of an investigation into the Republican Guard killings. According to General Prosecutor Hisham Barakat, the Anti-Coup leaders had incited violence against demonstrators on several occasions and "ordered armed groups to cut off highways and threaten violence" (Abedine \& Abdelaziz, 2013). This accusation paved the way for the imposition of far-reaching travel bans and asset freezes. It also clearly aimed at isolating the protest leadership from its base.

This attempt to drive a wedge into the movement was flanked by conciliatory remarks vis-à-vis the Anti-Coup grassroots. Army spokesman Ahmed 
Ali addressed the squatters on Midan Rabaa and Midan Al-Nahda as brothers and signaled general willingness to engage in reconciliatory measures. ${ }^{17}$ In a similar vein, Interim President Mansour took the anniversary of the July 23, 1952 revolution as an occasion to invite Egypt's political players to set aside their hatred and divisions and join a national dialogue to "turn a new page" in the country's history. ${ }^{18}$ But these reconciliation initiatives were emphatically rejected by the Anti-Coup organizers who stressed that Mursi was the only legitimate host for any sort of national dialogue (Nagi, 2013b). The movement would not contribute to a consolidation of the status quo by accepting the interim institutions as dialogue partners. Following this rebuke, the president's conciliatory rhetoric gave way to more confrontative discourse that vilified all protesters as enemies of the state.

\section{A Popular Mandate for Repression}

Abdel Fattah Al-Sisi's speech on July 24, 2013, at a military graduation ceremony marked the turning point for the government's strategy vis-à-vis the Anti-Coup movement. Delivered in response to a deadly bomb attack on the Mansoura police station and broadcast live by state media, the general's remarks turned into a rallying cry. In an attempt to restage the dynamics that had empowered the army to depose Mursi, the speech emphasized the inseparable relationship between the Egyptian people and their armed forces, summoning the revolutionary myth of the army and the people as "one hand" (see Ketchley, 2014). Festooned in full military regalia, Al-Sisi urged Egyptians to celebrate this unity by taking to the streets in support of the security forces once more on June 26,2013 :

I ask all trusted and honorable Egyptians to come out next Friday to give me the authority to face violence and terrorism. I have not asked anything of you before, but now I ask you to come out and remind the world that you have demands. [...] Please Egyptians shoulder your responsibility with me, the army, and the police. Show your steadfastness in the face of what is going on. ${ }^{19}$

17 A full video of the press conference is available at https://youtu.be/xugyag81soM.

18 See full speech at https://youtu.be/GxI31_ICOmA.

19 For a full record of Al-Sisi's speech visit https://youtu.be/RXYOq47fvAs. A transcript is available at https://archive.is/wip/ZDKmm. 
This call for a popular mandate to confront violence and terrorism capitalized on the widespread feelings of fear and uncertainty and aimed to turn these reflex emotions into affective commitments that supported the authorities' course of action. It can also be interpreted as the first comprehensive effort to present a counter-narrative to the NASL's legitimatization of resistance through street protests. Al Sisi's appeal exemplified how two different conceptions of legitimacy were effectively clashing in Egypt's divided public sphere (Al-Awadi, 2013, p. 549). Whereas the Muslim Brotherhood and its alias invoked the input legitimacy, granted to its President and party through the electoral ballot, Al-Sisi justified the military's intervention into politics with the Mursi administration's missing throughput and output legitimacy.

The signifier of irada al-sha'abiya, the popular will, played a central role in Al-Sisi's attempt to challenge the Anti-Coup discourse: From his first day in office, according to the general, Mursi had failed to rule as a "president of all Egyptians." He had refused initiatives to contain the political crisis through inclusive consultations among all political players. At last, Mursi had also ignored the massive turnout on June 30, 2013, which, according to Al-Sisi, equaled ignoring the will of the people (see Abdel Ghaffar, 2013). The implications of this exclusive rule were clear: Mursi had forgone his right to govern in the name of the people. This right had been revoked through a popular revolt on June 30. Millions of protesting Egyptians had left the military - the guardian of popular sovereignty - with no choice but to intervene.

Al-Sisi's speech reproduced the antagonist logic that had governed political subjectivation within the Anti-Coup camp. His remarks did not explicitly name any one political faction. But they portrayed Egypt's protest arena as one populated by two irreconcilable antagonists - the people and a group of religious fanatics who were turning Egypt into "a battlefield between those claiming to fight in the name of God and others who were allegedly standing against God's religion." Like the NASL's statements, Al-Sisi's words demarcated a frontier between the legitimate body of the nation and its external antagonist other. This frontier pitted "the people" against "the people" (Mogahed, 2013). The Anti-Coup Alliance and its supporters, according to Al-Sisi, were on the one side of this divide. The honorable Egyptian people whom he asked to take to the streets on July 26 , were on the other.

While it is arguable, if Al-Sisi's speech reflected a personal recognition of his role as the dominant player in the post-coup order, the Mandate Speech indeed became an indicator of popular support for the general. On the evening of the defense minister's speech, presidential spokesman Ahmed al-Muslimani confirmed the interim president's support for Al-Sisi's “war 
on terrorism," and welcomed Al-Sisi's call to protect the revolution and the state (Fahim \& Sheikh, 2018a). Within hours after Al-Sisi's speech, the armed forces declared a nationwide state of alert and deployed additional troops in all provinces. State television channels added the tagline didda al-irhab [against the Terrorism] as a banner to their news broadcasts. Soon all six of the major private satellite channels also adopted variations of the banner, reading "Egypt against terrorism," "together against terrorism" or "the people's word against extremism" (Bradley, 2014). Moreover, the Tamarod movement echoed Al-Sisi's call to the streets and declared its full support for the armed forces to confront the terrorism of the Muslim Brotherhood (see Saleh, 2013). The National Salvation Front toed the line and emphatically urged the government to disband the Anti-Coup sit-ins.

By contrast, the NASL perceived Al-Sisi's address as an announcement of another massacred and a prelude to a civil war (see RNN, 2013a). Furthermore, the different parties represented in the NASL seized on the general's speech as evidence that Egypt was returning to fascist military rule. On behalf of all players in the alliance, the Muslim Brotherhood released a statement on July 24 that likened Al-Sisi's speech to that of Bashar al-Assad on March 30 , 2011 (see Muslim Brotherhood, 2013b). In this much-anticipated speech before to the Syrian People's Assembly, the Syrian president had requested a similar mandate to confront plots to destroy the nation.

\section{Mandate Friday}

Walter Armbrust (2015, p. 105) has interpreted the protests on July 26, 2013, as the decisive moment of Al-Sisi's ascension to power. After Mandate Friday, as the protests responding to Al-Sisi's speech are commonly known, the general separated from his prior institutional function as a mere arbiter of social unrest and assumed a more political role. Hundreds of thousands of Egyptians had answered the general's call and demanded action against the Anti-Coup protest camps. Aside from the NASL, only the Nour Party and the April 6 Movement had boycotted the protests.

Mandate Friday thus effectively became a barometer for the Egyptians' willingness to support a crackdown on the Islamist demonstrations. Encouraged by the broad support, the prosecution brought charges of murder and conspiracy with the Palestinian Hamas against Mohammed Mursi that same day (Pioppi, 2013, n. 6o). Moreover, the Ministry of Interior announced that the occupied squares would soon be cleared in an orderly and legal way. The following night, the police moved against the Rabaa al-Adawiya sit-in for the first time (Chayes, 2013). The offensive mirrored that at the Republican 
Guard barracks three weeks earlier: After barraging the surroundings of the Rabaa camp with teargas, the CSF advanced on Nasr street, the slip road to the Rabaa camp, with army units as a backup. The ensuing clashes in front of the Minassa [podium] memorial of former President Sadat lasted until the early next morning. They left over 100 people dead and many more injured.

The clashes on Nasr Street were the hitherto worst single mass killings in the republic's history. Many of the corpses, examined by journalists and human rights defenders in the surrounding morgues, exhibited head wounds from sniper fire and multiple bullet holes in their torsos which pointed to heavy machine gun use (EIPR, 2014, p. 57; Human Rights Watch, 2014, p. 124ff.). The figures released by Wiki Thawra confirm that security forces had stepped up their use of lethal violence: While the killed-injured ratio stood at an average of one killed versus 13 injured in the Republican Guard killings, this ratio moved to 1:7 during the clashes on Nasr Street. Uploaded videos confirm the uncontrolled use of live ammunition which Egyptian authorities deny up to the present day. ${ }^{20}$ By contrast, there is little evidence for the use of firearms by NASL demonstrators (see Human Rights Watch, 2014, p. 128f.). The observation that CSF and army units captured on film neither wore ballistic vests nor took cover from enemy fire suggests that protesters were mostly unarmed.

Against this background, the nightly operation on Nasr Street failed to achieve its intended effect. The excessive and disproportionate police violence not only nourished protesters' grievances and strengthened their affective commitments. It also granted legitimacy to demands for legal recognition of all mass killings. After the Republican Guard massacre, seeking justice for the victims of state repression, the release of detained protesters, and the impartial investigation of army and police crimes had become part of the campaign's demands. These demands became more central following the clashes on Nasr Street. They soon ranked equally to the calls for Mursi's reinstatement (see Figure 7, new elements shaded in grey).

On August 7, 2013, FJP General Secretary Mohamed Al-Beltagy announced on the Rabaa-podium that the sit-ins would no longer end with the return of the elected president to his office. Anti-Coup protesters would not demobilize until those responsible for shedding the martyrs' blood were tried in court and the judiciary had undergone a reform to safeguard against another counterrevolution (RNN, 2013c). According to Al-Beltagy and his allies in the NASL, a comprehensive transitional justice process would need to include not only investigations into the killing of protesters but also into 
Figure 7 Evolution of Anti-Coup demands in response to repression

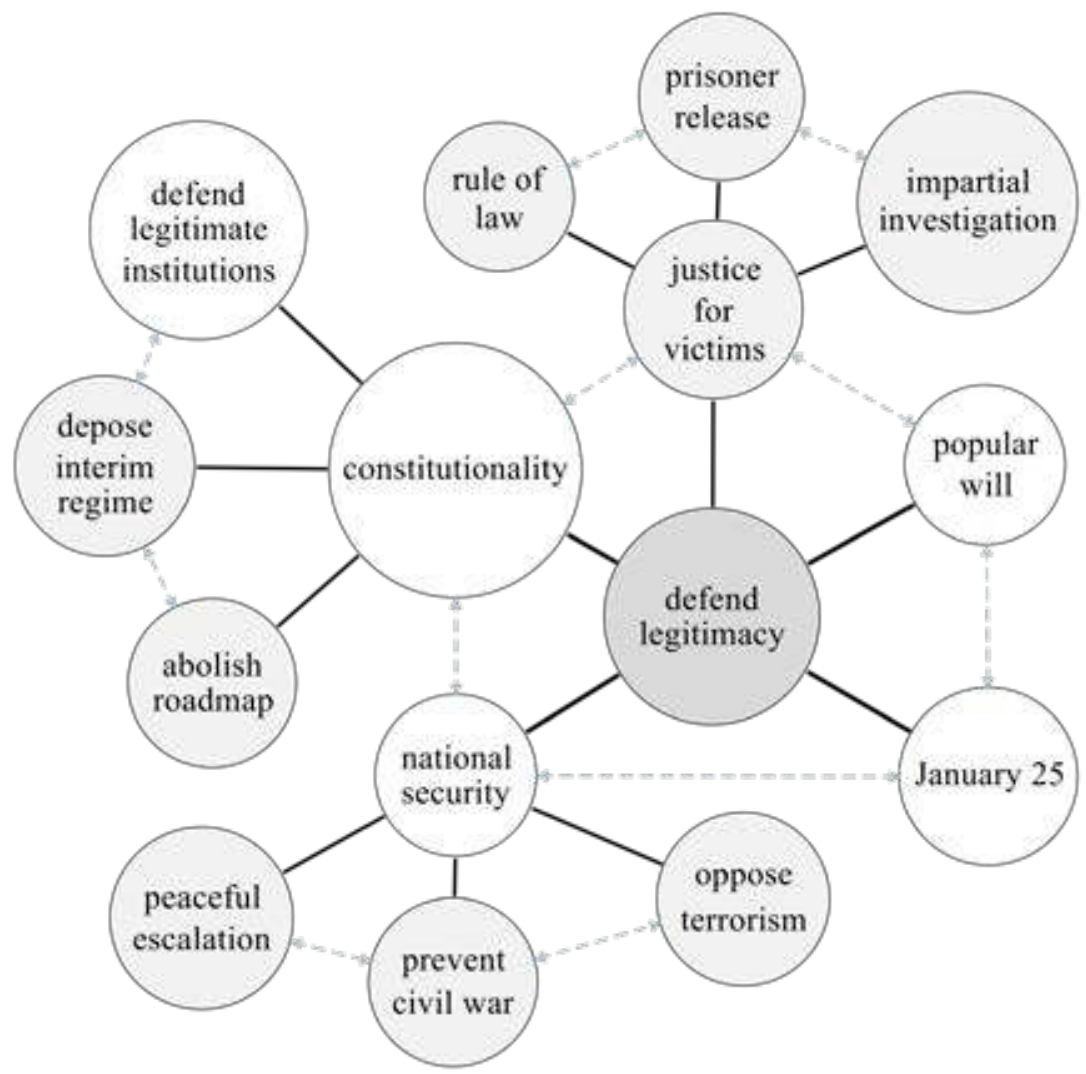

the fabrication of criminal charges and the censorship of Brotherhoodaffiliated media outlets (see NASL, 2013r, 2013s). The alliance additionally called on the International Criminal Court to prosecute Al-Sisi for crimes against humanity (Muslim Brotherhood, 2013b).

This turn towards the international community marked a shift from prior communications which had mostly framed foreign governments and international organizations as accomplices of the coup. It partly responded to the growing international criticism of the Egyptian security forces' conduct in Cairo. The NASL saw the notes of concern by the UN General Secretary and High Commissioner for Human Rights as opportunities to lobby their agenda in an international arena and parallelly to the domestic arenas where the dialogue processes with other political forces had come to a standstill.

On a domestic level, by contrast, Anti-Coup statements concentrated on evoking sympathies among the broader Egyptian public. The indiscriminate 
use of automatic weapons on Nasr Street allowed the NASL to liken the police operation to the infamous massacre of Coptic demonstrators by army units in front of the Maspero television building in October 2011 - an event that is firmly engrained in Egyptians' collective memory about military rule after 2011 (see M. Youssef et al., 2014). Like the Maspero killings, the alliance stressed, the Minassa massacre pointed to an evident collapse of the rule of law. According to the Anti-Coup Alliance, a "law of the jungle" had taken over the protest arena and was enforced by the "henchmen" of the military coup (NASL, 2013n).

At the same time, Anti-Coup representatives tried to reshape the image of their camps as incubators for terrorism through a PR offensive. A Rabaa tour with visits to the field hospital and the main stage aimed to counter the securitization of the protests by state media (Johanson, 2013). Launched by several young NASL supporters in early August, the daily tours with the motto "Heard enough, time to see!" meant to dispel rumors of extremism, kidnapping, and torture inside the camp. A promotional text, which was widely shared on social media, invited Egyptians and international observers to visit the sit-ins and verify their peacefulness themselves. ${ }^{21}$ But the PR offensive city failed to generate much resonance (Holmes, 2013). An official Rabaa sit-in tour bus (NASL, 2013t) fared no better.

\section{Competing Conceptions of Terror}

Furthermore, the NASL attempted to counter the regime's vilification at demonstration marches themselves by appropriating the terrorism label as a nodal signifier in its discourse. After the Minassa massacre, new protest chants directly referenced Al-Sisi's mandate speech and stressed the protesters' principled nonviolence. Slogans such as, "to those standing at the window, we are your brothers, not terrorists" (Nagi, 2013c), featured prominently in the Anti-Coup marches, alongside regular rhythmic references to silmiya [peacefulness]. Many protesters began to carry posters in Arabic and English - thus addressing both a domestic and international crowd - which rejected the terrorism label and highlighted the victimization of protesters by police brutality. The dissemination of such counter-narratives to the vilification by authorities turned into a central motivation for the protests.

21 The full statement is available at https://archive.is/wip/fonRi. It was followed shortly by a professionally edited promotion video which can be viewed at https://www.youtube.com/ watch?v=C2j6GopsL3s 
To subvert the securitization of its campaign, the NASL additionally gave further weight to its prior framing of repression as state terrorism. In several statements, it denounced Al-Sisi's talk about a war on terrorism as a cover for his own criminal conduct (e.g., NASL, 2013p). Visits by human rights organizations to the Anti-Coup protest sites would reveal that the coup forces were the ones who were practicing "terrorism, extermination, murder, threats, and intimidation of the oppressed" (NASL, 2013q). This state terrorism in disguise was replicating Mubarak's way of ruling, but it would not prevent the alliance from protesting - just as smear campaigns and police repression had not stopped the January 25 Revolution.

Some within the Anti-Coup Alliances advanced this narrative more zealously than others, such as FJP Secretary-General Mohamed AlBeltagy who was quoted as asking the crowds in Rabaa to "prepare for a second jihad" (ABC/AFP, 2013). In its official communication, however, the NASL was wary of any religious subtext and avoided framing its resistance as a jihad-like zero-sum game between believers and infidels (see Alimi, 2009, p. 226; Olesen, 2009, p. 9). The exception was a recurrent reference to the fifth surah of the Quran. According to the cited verse no. 32, whenever someone killed another human being, this was as if he had killed all mankind. Moreover, many Anti-Coup statements appealed to the security forces' conscience by quoting the Prophet Mohammed, according to whom there was no duty to obey any leader if this meant disobeying Allah.

Apart from such abstract appeals to its antagonist's moral emotions, the NASL notably curbed its efforts to persuade members of the armed forces to support its cause. Condemnations of the military became less differentiated after the Minassa massacre. According to the NASL, army units had partaken in the coup forces' "eradication policy" by supporting the police forces with gas bombs and providing cover for snipers (NASL, 2013m). The armed forces were given a final choice:

The question to the Supreme Council of the Armed Forces remains: is it looking for political solutions to the crisis of the homeland [...] or has it accepted the language of genocide, murder, kidnapping, fabrication of charges, and muffling of mouths practiced by some of the leaders of the armed forces as a solution for any crisis. (NASL, 20130)

The forces in the Anti-Coup Alliance also ran out of patience with other social players. After the mandate speech, the NASL reached out to third parties - including the Grand Imam of Al-Azhar Ahmad al-Tayyeb - in an 
Figure 8 Construction of antagonist other after Mandate Friday

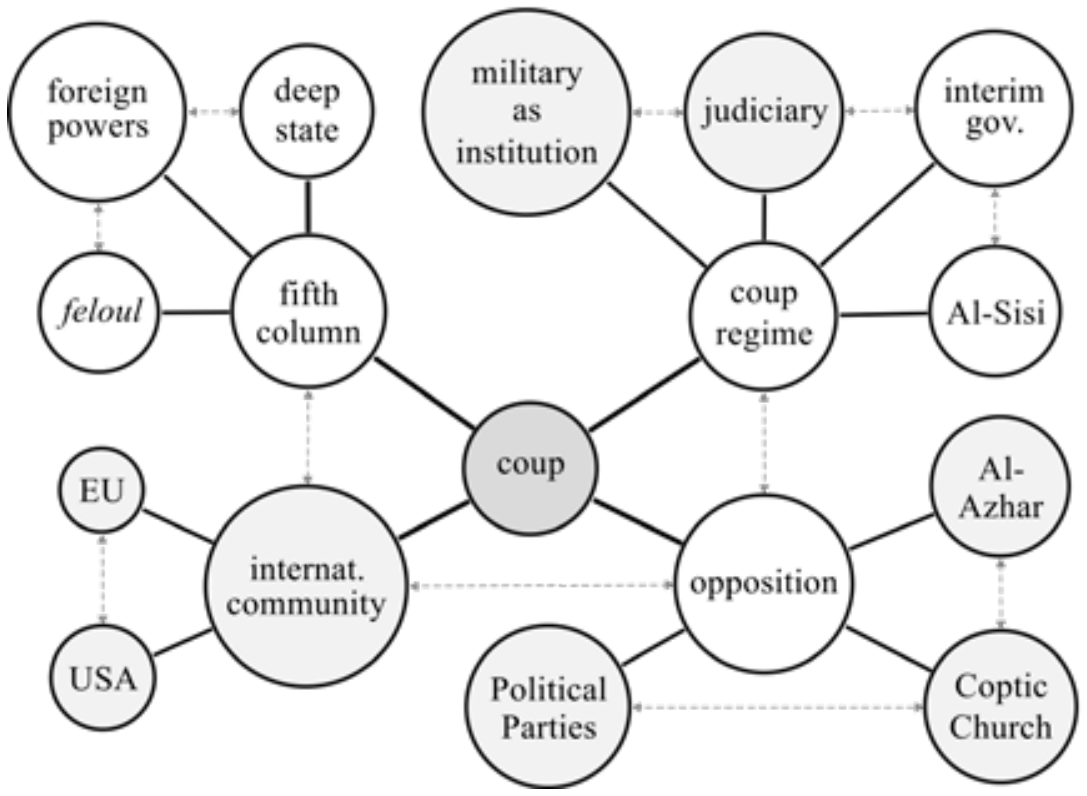

attempt to restart reconciliation efforts (see Muslim Brotherhood, 2013b). But considering many of these players' blessing of Al-Sisi's words and their justification of the ensuing violence as ugly but necessary efforts at curbing the growing instability, these discussions became increasingly obsolete. After the killings, the NASL asserted, it would not engage in any more talks with either of the parties who had lent their support to the interim government, because they were no longer "unbiased mediators but partners in the putschists' crime" (Muslim Brotherhood, 2013d). This included Sheikh Ahmed al-Tayyeb who, according to the NASL (2013c), had tolerated the presence of snipers on the premises of Al-Azhar University, as well as a range of foreign players who had remained silent over the mass violence (NASL, 2013q). Particularly the U.S. administration and the European Union had supposedly abetted the killing of unarmed civilians by recognizing and financing the post-coup regime.

With the list of enemies growing (see Figure 8, new elements shaded in grey), the odds of turning the Anti-Coup movement into a broader alliance dwindled, as did the chances for a peaceful mediation of the conflict. Accordingly, the NASL abandoned prior thoughts about reconciliation and turned toward a portrayal of the campaign as a fight of one against all. Henceforth, this narrative remained the dominant tenor of the Anti-Coup 
campaign and imbued the protesters with what Jasper (2018) has referred to as a "deontological pride" (p. 5). In a massive backlash, this feeling of moral superiority provided fresh impetus to the protest campaign. Protest rates increased continuously. By the middle of August, the two camps in Rabaa and Al-Nahda Square had developed into entire tent cities. These were replete with functioning internal infrastructure, constantly harboring an average of 85,000 protesters. ${ }^{22}$

\section{Setting Course for Violence}

Among those players who backed Al-Sisi's call for a war on terror, the Minassa clashes equally marked a point of no return. The clashes were still ongoing when Interior Minister Ibrahim declared that the units on Nasr Street were unarmed and had "never pointed a weapon towards the chest of a protester."23 Instead, he portrayed the clashes as fighting between demonstrators and residents of the Nasr City neighborhood. During the following days, the prevention of such clashes became a pretext for expanding the security forces' room for maneuver in preparation of a raid against the Anti-Coup camps. These preparations included the transferal of emergency powers to Prime Minister Hazem al-Beblawi and the authorization of civilian arrests by army forces. President Mansour also authorized the deployment of military infantry against the protest camps and, in a highly contentious move, restored the infamous anti-Islamist units of the State Security Service. A symbol of Mubarak's police oppression, these units had supposedly been dissolved in March 2011.

On July 29, 2013, the National Defense Council (NDC), Egypt's highest body on matters of domestic security, then announced that evidence was growing that the Anti-Coup sit-ins posed a threat to national security (Dakroury, 2013). Its statement no longer differentiated between most peaceful demonstrators and individual violent elements within the NASL. Instead, it collectivized the blame for the escalating street violence and placed it on the entire contentious alliance. On July 31, 2013, the cabinet followed

\footnotetext{
22 Participant counts based on satellite photographs of an average night at the sit-in suggest that between 71,000 and 100,000 protesters camped on Rabaa Square alone (see Human Rights Watch, 2014, n. 32). Other calculations suggest that the total occupied area housed around 300,000 protesters, with an additional 245,000 protesters on Al-Nahda Square (see S. Ismail, 2013). These variances can partly be explained by the fact that turnouts varied significantly between Friday and regular weekdays.

23 For a video of the press conference see https://www.youtube.com/watch?v=yblonfpcHıU.
} 
suit and empowered the Ministry of Interior to take steps against such threats to public security. A deployment plan was signed off by the NDC a few days later.

After a week of escalating rhetoric, on August 7, 2013, President Mansour declared that all mediation efforts had failed and a decision had been taken to clear the sit-ins after the end of Ramadan. ${ }^{24}$ This sealed a spiral of violence that culminated in the "worst mass unlawful killings in the country's modern history" (Human Rights Watch, 2013b). However, the security forces' indiscriminate and disproportionate application of force also provided the Anti-Coup Alliance with a new motive for continued resistance. It created myths and martyrs which began to figure strongly in the Anti-Coup resistance discourse as embodiments of the movement's righteousness and moral superiority. As the following chapter shows, it was the strong intertwining of these moral emotions with the principled commitment to peaceful resistance that explains the Anti-Coup Alliance's resilience in the face of unprecedented repression. At the same time, it prevented the protesters from turning to a more violent contentious repertoire - and thus from following in the footsteps of predecessor cases of Islamist coup-ousting in the region.

\section{References}

Abaza, M. (2014). Post January revolution Cairo: Urban wars and the reshaping of public space. Theory, Culture \& Society, 31(7-8), 163-183. https://doi.org/10.1177/0263276414549264

ABC/AFP. (2013, July 25). Egypt's military, Muslim Brotherhood call for protests. ABC News. https://www.abc.net.au/news/2013-07-25/egypts-defiant-muslim-brotherhood-leaderurges-27stand27-a/4844700

Abdel Ghaffar, A. (2013, August 7). Egypt's framing wars of June 3oth. OpenDemocracy. http:// www.opendemocracy.net/adel-abdel-ghafar/egypts-framing-wars-of-june-3oth

Abdelbaseer, M. (2016, January 25). Cairo's Rabaa massacre: Between a murderous army and urban failure. FA: Failed Architecture. https://www.failedarchitecture.com/ cairos-rabaa-massacre-between-a-murderous-army-and-urban-failure/

Abdelrahman, M. (2017). Policing neoliberalism in Egypt: The continuing rise of the 'securocratic' state. Third World Quarterly, $38(1), 185$-202. https://doi.org/10.1080/01436597.2015.1133246

Abedine, S., \& Abdelaziz, S. (2013, July 25). Pro-Morsy group calls for Egypt protests, warns of violence. CNN. https://edition.cnn.com/2013/o7/24/world/africa/egypt-unrest/index.html

24 Several international organizations and a range of prominent Egyptians from the liberal as well as the Islamist spectrum tried to avert the looming confrontation. Amongst others, the EU, the African Union, the US State Department, the former Brotherhood member Abdel Moneim Aboul-Futuh and the acting vice president and Nobel Peace Prize laureate Mohammed El-Baradei. 
Al-Awadi, H. (2013). Islamists in power: The case of the Muslim Brotherhood in Egypt. Contemporary Arab Affairs, 6(4), 539-551. https://doi.org/10.1080/17550912.2013.856079

Alimi, E. Y. (2009). Mobilizing under the gun: Theorizing political opportunity structure in a highly repressive setting. Mobilization, 14(2), 219-237. https://doi.org/10.17813/ maiq.14.2.u210745765568737

Alsharif, A., \& Saleh, Y. (2013, October 10). Special report: The real force behind Egypt's 'revolution'. Reuters. https://www.reuters.com/article/us-egypt-interior-specialreport/ special-report-the-real-force-behind-egypts-revolution-of-the-state-idUSBRE99908D20131010

Amar, P. (2011). Turning the gendered politics of the security state inside out? International Feminist Journal of Politics, 13(3), 299-328. https://doi.org/10.1080/14616742.2011.587364

Amar, P. (2013). The security archipelago: Human-security states, sexuality politics, and the end of neoliberalism. Duke University Press.

Amnesty International. (2013, July 10). Egypt:Damning evidence points to security forces' failures. https://www.amnesty.org/en/press-releases/2013/o7/egypt-damning-evidence-pointssecurity-forces-failures/

Armbrust, W. (2015). The iconic stage: Martyrologies and performance frames in the January $25^{\text {th }}$ revolution. In R. Abou-El-Fadl (Ed.), Revolutionary Egypt: Connecting domestic and international struggles (pp. 43-64). Routledge.

Bolliger, R., Elmenshawy, M., \& Weilandt, R. (2016). The military, the media and public perceptions in Egypt: Communication and civil-military relations (Egypt Civil-Military Relations Conference Paper Series No. 3). Geneva Centre for the Democratic Control of Armed Forces. https://www.dcaf.ch/sites/default/files/publications/documents/Egypt_Civil_Paper3_ENG. pdf

Bradley, M. (2014, May 29). Egyptian TV swayed public against Morsi, in favor of Sisi. Wall Street Journal. http://www.wsj.com/articles/egyptian-tv-swayed-public-against-morsi-in-favorof-sisi-1401330765

Buzan, B., Wæver, O., \& Wilde, J. de. (1998). Security: A new framework for analysis. Lynne Rienner Pub.

Chayes, S. (2013, August 1). The Egyptian Restoration. Carnegie Endowment for International Peace. http://carnegieendowment.org/2013/08/o1/egyptian-restoration/gh3o

Dakroury, N. (2013, July 29). National Defence Council closely monitoring Rabaa and Al-Nahda sit-ins. Daily News Egypt. https://www.masress.com/en/dailynews/207454

EIPR. (2014). The weeks of killing: State violence, communal violence and sectarian attacks in the summer of 2013. Egyptian Initiative for Personal Rights. https://eipr.org/sites/default/files/ reports/pdf/weeks_of_killing-en.pdf

El-Dabh, B. (2013, July 8). Sorrow and anger at Rabaa Al-Adaweya. Daily News Egypt. https:// dailynewsegypt.com/2013/07/08/sorrow-and-anger-at-rabaa-al-adaweya/

El-Issawi, F. (2014). The role of Egyptian media in the coup. In IE Med. Mediterranean Yearbook 2014 (pp. 299-304). http://www.iemed.org/observatori/arees-danalisi/arxius-adjunts/anuari/ anuari-2014/ElIssawi_egypt_media_military_coup_IEMed_yearbook_2014_EN.pdf

Escobales, R., Holpuch, A., \& Weaver, M. (2013, July 5). Egypt's 'day of rejection' - Friday 5 July as it happened. The Guardian. https://www.theguardian.com/world/middle-east-live/2013/ jul/o5/egypt-braced-day-of-rejection-live

Fahim, K., \& Sheikh, M. E. (2018, October 19). Egyptian general calls for mass protests. The New York Times. https://www.nytimes.com/2013/07/25/world/middleeast/egypt.html

Ghanem, T. (2016, May 30). O brother, what is prison? On Malek Adly. Mada Masr. http://www. madamasr.com/opinion/o-brother-what-prison-malek-adly

Gribbon, L., \& Hawas, S. (2012). Signs and signifiers: Visual translations of revolt. In S. Mehrez (Ed.), Translating Egypt's revolution: The language of Tahrir (pp. 103-142). Oxford University Press. 
Grimm, J. J., \& Harders, C. (2018). Unpacking the effects of repression: The evolution of Islamist repertoires of contention in Egypt after the fall of President Morsi. Social Movement Studies, $17(1), 1-18$. https://doi.org/10.1080/14742837.2017.1344547

Hafez, M. (2003). Why Muslims rebel: Repression and resistance in the Islamic world. Lynne Rienner Publishers.

Hanafi, A. (2015). Qamos Al-Thawra: A dictionary of the revolution. http://qamosalthawra.com/en

Holmes, A. A. (2013, August 16). Before the bloodletting: A tour of the Rabaa Sit-in. The Cairo Review of Global Affairs. https://www.thecairoreview.com/tahrir-forum/before-the-bloodletting-atour-of-the-rabaa-sit-in/

Human Rights Watch. (2013a, July 5). Egypt: Deadly clashes at Cairo University. https://www. hrw.org/news/2013/07/05/egypt-deadly-clashes-cairo-university

Human Rights Watch. (2013b, August 19). Egypt: Security forces used excessive lethal force. https:// www.hrw.org/news/2013/o8/19/egypt-security-forces-used-excessive-lethal-force

Human Rights Watch. (2014, August 12). All according to plan: The Rab'a massacre and mass killings of protesters in Egypt. https://www.hrw.org/report/2014/o8/12/all-according-plan/ raba-massacre-and-mass-killings-protesters-egypt

Imad, A. G. (2014). Islamists between revolution and the state: An epilogue. Contemporary Arab Affairs, 7(2), 283-298.

Ismail, S. (2013, July). Mathematics and Egyptians don't mix: June 30 protests figures. The Revolution Fails. https://therevolutionfails.tumblr.com/post/56565464162/mathematicsand-egyptians-dont-mix-june-3o

Jasper, J. M. (2018). The emotions of protest. The University of Chicago Press.

Jasper, J. M., Young, M. P., \& Zuern, E. (2020). Public characters: The politics of reputation and blame.

Johanson, M. (2013, August 7). 'Rabaa tours' seeks brave tourists for trips into Cairo's Pro-Morsi Protest Camp. International Business Times. https://www.ibtimes.com/rabaa-tours-seeksbrave-tourists-trips-cairos-pro-morsi-protest-camp-1374953

Ketchley, N. (2014). “The army and the people are one hand!” Fraternization and the 25th January Egyptian Revolution. Comparative Studies in Society and History, 56(1), 155-186. https://doi. org/10.1017/Soo10417513000650

Kingsley, P., \& Green, L. (2013, July 18). Killing in Cairo: The full story of the Republican Guards' club shootings. The Guardian. http://www.theguardian.com/world/interactive/2013/jul/18/ cairo-republican-guard-shooting-full-story

Liu, J. (2011, February 20). Roundabouts and revolutions: The "Arab street" begins and ends in a circle. https://www.vice.com/en_us/article/788d7e/roundabouts-and-revolutions-the-“arabstreet"-begins-and-ends-in-a-circle

McCurdy, P., Feigenbaum, A., \& Frenzel, F. (2016). Protest camps and repertoires of contention. Social Movement Studies, 15(1), 97-104. https://doi.org/10.1080/14742837.2015.1037263

Mogahed, D. (2013, July 25). Deep runs the divide [Carnegie Endowment for International Peace]. Sada. http://carnegieendowment.org/sada/index.cfm?fa=show\&article $=52493 \&$ solr_hilite $=$

Mohsen, A. A. (2013, July 9). The killing of Islamist protesters: State censorship or self-censorship? Mada Masr. https://madamasr.com/en/2013/o7/og/news/u/the-killing-of-islamist-protestersstate-censorship-or-self-censorship/

Mohsen, M. (2013, July 10). Arrest warrants for Badie and nine others for Republican Guard clashes. Daily News Egypt. /node/1542?language=en

Monier, E. I., \& Ranko, A. (2013). The fall of the Muslim Brotherhood: Implications for Egypt. Middle East Policy, 20(4), 111-123. https://doi.org/10.1111/mepo.12050

Mursi, M. (2013a, June 26). Address to the nation on the occasion of the anniversary of his inauguration [Arabic, on file]. 
Mursi, M. (2013b, July 2). Urgent statement by the presidency of the republic [Arabic, on file].

Muslim Brotherhood. (2013a, June 29). National Alliance in Support of Electoral Legitimacy's speech to the Egyptian people on the eve of 30 June. Ikhwanweb. http://www.ikhwanweb. com/article.php?id $=31062$

Muslim Brotherhood. (2013b, July 25). Statement by the Anti-Coup Alliance in response to Al-Sisi's speech. Ikhwanweb. https://archive.vn/wip/uVAHa

Muslim Brotherhood. (2013c, August 3). Anti-Coup Alliance statement condemns security forces attack on Friday 2 August. Ikhwanweb. http://www.ikhwanweb.com/article.php?id=31211

Muslim Brotherhood. (2013d, August 6). Anti-Coup Alliance statement affirms no invitation to dialogue received. Ikhwanweb. http://www.ikhwanweb.com/article.php?id=31233

Nagi, M. (2013a, July 15). No meetings between military and Muslim Brotherhood: FJP spokesperson. Daily News Egypt. http://www.dailynewsegypt.com/2013/07/15/ no-meetings-between-military-and-muslim-brotherhood-fjp-spokesperson/

Nagi, M. (2013b, July 26). Pro-Morsi march jovial at Al-Nahda Square. Daily News Egypt. https:// dailynewsegypt.com/2013/07/26/pro-morsi-march-jovial-at-al-nahda-square/

NASL. (2013a, July 2). The text of the statement of the National Alliance in response to the statement of the army. https://alaam25o.blogspot.de/2013/o7/blog-post.html

NASL. (2013b, July 3). Statement 4 [Arabic, on file].

NASL. (2013c, July 4). From the field command of the sit-ins to our brothers in the armed forces [Arabic, on file].

NASL. (2013d, July 4). Statement 6 [Arabic, on file].

NASL. (2013e, July 5). On the events of the Friday miliuniya [Arabic]. Facebook. https://archive. vn/wip/ZeiXt

NASL. (2013f, July 7). Statement 9 [Arabic, on file].

NASL. (2013g, July 7). To the Egyptian people [Arabic]. https://archive.vn/wip/XcvSh

NASL. (2013h, July 8). Statement 10 [Arabic]. https://archive.vn/wip/R39Gf

NASL. (2013i, July 11). Statement 12: Principles of the January 25 revolution [Arabic]. Facebook. https://archive.is/wip/lHSRE

NASL. (2013j, July 15). National Alliance in Support of Legitimacy statement condemns coup; calls for peaceful protests. Ikhwanweb. http://www.ikhwanweb.com/article.php?id=31144

NASL. (2013k, July 16). On the formation of the fake government [Arabic]. Facebook. https:// archive.vn/wip/jVhUC

NASL. (2013l, July 16). To the armed forces [Arabic]. Facebook. https://archive.vn/wip $/ 7 \mathrm{H}_{4} \mathrm{QE}$

NASL. (2013m, July 26). On the massacre of Rabaa al-Adawiya [Arabic]. Facebook. http://bit. $\mathrm{ly} / 2 \mathrm{PZfxD} 6$

NASL. (2013n, July 26). Statement 37 [Arabic]. Facebook. https://archive.vn/wip/MuACe

NASL. (20130, July 27). Regarding the efforts and initiatives put forward within the framework of constitutional legitimacy [Arabic]. Facebook. http://bit.ly/2Q Q1RaVi

NASL. (2013p, July 29). Statement 42: The National Alliance responded to the allegations of the National Defence Council [Arabic]. Facebook. https://archive.vn/bItCH

NASL. (2013q, August 1). Statement 47 [Arabic]. Facebook. http://bit.ly/2Q1Lv1o

NASL. (2013r, August 3). Anti-Coup Alliance statement on US delegation meeting on Saturday. Ikhwanweb. http://www.ikhwanweb.com/article.php?id=31215

NASL. (2013s, August 3). Statement 49: On the meeting with the US delegation [Arabic]. Facebook. https://archive.vn/wip/2iK 3 m

NASL. (2013t, August 6). Come join the Rabaa sit-in tour bus [Arabic]. Facebook. https://archive. vn/wip/rgDp3

Olesen, T. (2009). Social movement theory and radical Islamic activism. In Islamism as social movement (pp. 7-33). CIR Aarhus Universität. 
Osman, M. (2013). Baseera public opinion poll on Egyptians' living conditions and their expectations for the future. Baseera. http://baseera.com.eg/baseera/pdf_poll_file_en/Expectations\%20 for\%2othe\%2oFuture-en.pdf

Owen, P., \& McCarthy, T. (2013, July 8). 51 Morsi supporters killed in shooting at Republican Guard compound. The Guardian. http://www.theguardian.com/world/middle-east-live/2013/ jul/o8/egypt-34-killed-in-shooting-at-compound-where-morsi-is-being-held-live-coverage

Pearlman, W. (2018). Contingency and agency in a turning point event: March 18, 2011, in Daraa, Syria. In F. Volpi \& J. M. Jasper (Eds.), Microfoundations of the Arab uprisings: Mapping interactions between regimes and protesters (pp. 111-134). Amsterdam University Press.

Pioppi, D. (2013). Playing with fire: The Muslim Brotherhood and the Egyptian Leviathan. The International Spectator, 48(4), 51-68. https://doi.org/10.108o/03932729.2013.84768o

Pratt, N. (2015). After the 25 January Revolution: Democracy or authoritarianism in Egypt? In R. Abou-el-Fadl (Ed.), Revolutionary Egypt: Connecting domestic and international struggles. Routledge.

Rahin, A. (2013, July 17). Al-Arian told Al-Hayat: The army contacted us and al-Sisi refused to negotiate with Qandil [Arabic]. Al-Hayat. https://bit.ly/2HhisLD

Richter, C. (2017). Mobilize, justify, accuse: The Egyptian Muslim Brotherhood and changing media practices. In S. Foellmer, M. Lünenborg, \& C. Raetzsch (Eds.), Media practices, social movements, and performativity: Transdisciplinary approaches (pp. 100-113). Routledge.

Rivera Celestino, M. (2012). Violence breeds violence: How violent crime affects repression in democratic regimes [Paper presented at the Workshop 'Advancing the Scientific Study of Conflict and Cooperation: Alternative Perspectives from the UK and Japan', 20-21 March 2012]. http://privatewww.essex.ac.uk/ ksg/esrcjsps/Rivera.pdf

RNN. (2013a, July 24). National Alliance: Al-Sisi speech is a call for civil war [Arabic]. Rassd News Network. https://archive.vn/wip/hmZx9

RNN. (2013b, August 7). Al-Beltagy states three demands after the return of Morsi [Arabic]. Rassd News Network. https://archive.vn/wip/NodXo

Saleh, Y. (2013, July 24). Egypt's Tamarud youth group backs army call for protests. Reuters. https:// www.reuters.com/article/us-egypt-protests-youth-idUSBRE96NoHV20130724

Sayigh, Y. (2012). Above the state: The officers'republic in Egypt. Carnegie Endowment for International Peace. http://carnegieendowment.org/2012/08/o1/above-state-officers-republic-in-egypt/ $\mathrm{d}_{4} \mathrm{l}_{2}$

Schielke, S. (2017). There will be blood: Expectation and ethics of violence during Egypt's stormy season. Middle East Critique, 26(3), 205-220. https://doi.org/10.108o/19436149.2017.1336023

Schwedler, J. (2016). Taking time seriously: Temporality and the Arab uprisings. Project on Middle East Political Science. https://pomeps.org/2016/06/10/taking-time-seriously-temporalityand-the-arab-uprisings/

Schwedler, J. (2018). Routines and ruptures in anti-Israeli protests in Jordan. In F. Volpi \& J. M. Jasper (Eds.), Microfoundations of the Arab uprisings: Mapping interactions between regimes and protesters (pp. 67-88). Amsterdam University Press.

Springborg, R. (2018). Egypt. Polity.

Underhill, H. (2016). Translating and diaspora politics: Narrating the struggle at 'home' and 'abroad'. In M. Baker (Ed.), Translating dissent: Voices from and with the Egyptian Revolution (pp. 45-59). Routledge, Taylor \& Francis Group.

Waever, O. (1995). Securitization and desecuritization. In R. D. Lipschutz (Ed.), On security (pp. 46-86). Columbia University Press.

Wahba, D. (2020). A thug, a revolutionary or both? Negotiating masculinity in post-revolutionary Egypt. Middle East - Topics \& Arguments, 14, 56-65. https://doi.org/10.17192/meta.2020.14.8265

Weizman, E., Fisher, B., \& Moafi, S. (2015). The roundabout revolutions. Sternberg Press. 
Wessel, S. (2016). Grey-scales: Negotiating the civil state in post-revolutionary Egypt (CARPO Study: The Dawla Madaniyya Series No. 3). CARPO. https://carpo-bonn.org/ wp-content/uploads/2016/12/CARPO_Study_03_2016_Wessel.pdf?fbclid=IwAR1xw91dRRjp9wRIW_oxoPdhQK $7 \mathrm{Y}_{2}$ GoMo-id_V7MoslqGV5zRjKbWifoFw

Wessel, S. (2018). The 'third hand' in Egypt. Middle East Law and Governance, 10(3), 341-374. https://doi.org/10.1163/18763375-01003006

Yates, L. (2015). Rethinking prefiguration: Alternatives, micropolitics and goals in social movements. Social Movement Studies, 14(1), 1-21. https://doi.org/10.1080/14742837.2013.870883

Youssef, M., Arafa, H., \& Kumar, A. (2014). Arab revolutions: Breaking fear: Mediating discourse of democratic uprising in Egypt: Militarized language and the "battles" of Abbasiyya and Maspero. International Journal of Communication, 8(1), 871-889. 


\title{
$5 \quad$ Myths and Martyrs
}

The Rabaa al-Adawiya massacre as a critical juncture

\begin{abstract}
The Rabaa massacre represented a pivotal event for the contending players and a turning point for Egypt's post-coup politics. After Rabaa, the anti-Mursi camp needed to rationalize the violence deployed against the protesters. It thereby unwittingly paved the way for an authoritarian restoration. At the same time, the victimized protesters were unable to abandon their unsuccessful claims to legitimacy. This precluded broader popular solidarity with those killed in Rabaa Square. The massacre also set the conditions for future protests: as the Anti-Coup Alliance defined itself in antithesis to coup forces, it responded not by adopting violent resistance, but by diversifying its contentious repertoire. This chapter thus exemplifies the conditioning effect of battles in the discursive arena on players' protest performances and action strategies.
\end{abstract}

Keywords: martyrs, massacres, political violence, repression, tactical adaptation, contentious repertoire

The Rabaa al-Adawiya massacre (hereafter referred to simply as Rabaa) heralded a new phase of political subjectivation within the Anti-Coup Alliance. As regards police brutality and arbitrary conduct, the raids set a record. Alongside the massacres of Tiananmen in 1989 and Andijan in 2005, they are among the biggest mass killings of demonstrators in a single event. The civilian death toll was also unprecedented in Egypt's modern history. However, unlike in precedent cases of Islamist coup-ousting and large scale state violence against Islamist forces (M. Hafez, 2003), and in contrast to prior findings on the increase of disruptive tactics in response to repression (Alimi et al., 2012; Morris, 1993), Rabaa did not cause a radicalization of the Anti-Coup protesters' contentious repertoire. Instead, state violence triggered mechanisms of adaptation inside the National Alliance in Support of

Grimm, Jannis Julien, Contested Legitimacies: Repression and Revolt in Post-Revolutionary Egypt. Amsterdam: Amsterdam University Press 2022 DOI: 10.5117/9789463722650_CHO5 
Legitimacy (NASL) that ensured the continuation of the Anti-Coup campaign despite heavy policing. State repression also produced a limited backlash effect as regards the campaign's internal mobilization levels.

This chapter illustrates how the NASL successfully turned the massacres at the Republican Guard headquarters, on Nasr Street, Rabaa al-Adawiya Square, and Al-Nahda Square into ideational commodities that invigorated the Anti-Coup uprising in the face of repression. By relying on a discourse that portrayed those killed in the massacres as martyrs and the survivors of Rabaa as "heroes of endurance" (Jasper et al., 2020, p. 214ff.), thus turning them from passive and weak victims of violence into heroes who sacrificed themselves for the cause, the NASL was able to transform the horror of the brutal mass killings into a moral commitment to the alliance. The killings became a source of indignation that encouraged resilience and resistance, rather than demobilization. This counteracted the defeating blows dealt by Egypt's security forces and partly compensated for its destructive effect on mobilization levels and the internal cohesion of the Anti-Coup movement.

Confirming previous findings on the effects of indiscriminate state repression (Francisco, 1995, 2004; Khawaja, 1993; Hess \& Martin, 2006), the arbitrariness exhibited by those policing the Anti-Coup protests had an unintended mobilizing effect. However, this backlash was more complex than unidimensional backlash models suggest. It did not mechanically follow from the deployed violence but was contingent on the articulation of events by the key players in the Anti-Coup coalition. Furthermore, it transcended binary notions of escalation vs. de-escalation. Finally, the backfire from state violence remained mostly peaceful as the NASL made nonviolent resistance a core component of its group identity. The legitimacy discourse that was propagated by the coalition in the weeks before the massacre hence constrained radicalization and prevented a shift towards more violent repertoires of contention. At the same time, it also constrained potential alliance-building and forestalled public shows of solidarity by other political players when the Anti-Coup protesters were brutally killed on Rabaa and Al-Nahda Square.

\section{The Making of a Massacre}

The mass killings of mid-2013 were the subject of three independent investigations by Human Rights Watch (2014), the Egyptian Initiative for Personal Rights (2014), and the Egyptian rights-based organization Nazra for Feminist Studies (2013). All three attributed the responsibility for the unprecedented 
death toll to the excessive force deployed by the Central Security Forces (CSF) and army against mostly unarmed demonstrators in a premeditated attack. Eyewitness testimonies confirm that the security forces had operated an indiscriminate shoot-to-kill policy, deployed snipers against civilians, and abstained from firing warning shots. Many of the victims showed severe head, neck, and thorax injuries, as well as bullet holes from large caliber weapons. The total body count of the raids and the ensuing street battles in Cairo, Alexandria, and other provincial capitals stands at over 1,50o dead, and almost 7,00o injured, with an even higher estimated number of unreported cases (EIPR, 2014, p. 65). In the area of the Rabaa-camp alone, at least 969 people were killed. ${ }^{1}$ Tens of thousands were arrested. At the conclusion of the raids, so many people had been detained by police and army forces in the vicinity of Midan Rabaa al-Adawiya that prisoners were temporarily rounded up at the Cairo International Stadium until space became available at the surrounding police stations (see Kingsley, 2014).

The catastrophic course of the raids, which lasted a total of 12 hours, was partly due to their timing and, relatedly, to the spatial makeup of the Rabaa and Al-Nahda campsites at the time of the police incursion. It is apparent that security forces reacted to the sit-ins far too late. By the time the squares were raided, they had been occupied for 47 days. During this period, they were enlarged and fortified with makeshift barricades. Particularly the Rabaa camp had expanded its radius from the intersection of Nasr Street and Tayaran Street to include a large part of the Rabaa al-Adawiya neighborhood (Abdelbaseer et al., 2014).

The urban structure of the area made Midan Rabaa an ideal space of contention. ${ }^{2}$ Unlike the Tahrir roundabout, Rabaa Square lies at the intersection of several major commuter arteries. The encampment thus significantly interrupted everyday work life and traffic in the capital. Besides, it was easily accessible from all sides. In addition to the four central gates on the opposing ends of the Nasr and Tayaran Streets, three peripheral entrances on Yousef Abbas Street and Anwar al-Mufti Street lead into the camp, each equipped with checkpoints. Over the weeks a considerable influx of protesters led to the expansion of the protest camp along these principal axes: to the East, the tent city soon reached the Tiba Mall at the intersection of Nasr and

1 Independent human rights organizations note that the figures released by the Egyptian National Council of Human Rights (632 casualties) excluded the counts from several morgues and hospitals in the vicinity of Rabaa Square. Human Rights Watch (2014, p. 13) assumes a death toll far above 1,000 people for the raid of Midan Rabaa alone. The NASL, by contrast, stated a death toll of 5,000, with 20,000 wounded (see NASL, 2013ab).

2 For a scalable map of the protest camps, based on field notes, see http://u.osmfr.org/m/224774/. 
Ahmed Taysir Street; to the West, barricades stretched on Nasr Street until the Minassa memorial of former president Sadat; to the North, rows of tents lined Tayaran Street until close to the Ministry of Defense.

While initially helpful in concentrating a significant crowd in the center of Cairo, the geospatial makeup of Rabaa Square also allowed authorities to isolate the protesters from the neighboring quarters. In the morning hours of August 14, 2013, CSF units and army special forces started their assault from several directions. Army snipers were deployed on top of many military buildings surrounding the square, tanks, and armored personnel carriers blocked the camp's main entrances, and helicopters targeted all side exits from the square. After establishing a "no-go buffer zone around the sit-in" (Abdelbaseer, 2016), security forces moved in with bulldozers to destroy the makeshift barricades surrounding the square. When they closed in on the Rabaa al-Adawiya mosque, the demonstrators found themselves trapped within the area of the assault. The square, an open stage with little cover, offered no place to hide, and the perimeter established by the police forces prohibited demonstrators from escaping safely.

By keeping the timing of the raids secret, the police also precluded unarmed participants from leaving the campsite before the upcoming assault. The authorities issued a clearance order via public media and helicopters dropped flyers over the camp asking the protesters to leave the camps peacefully lest the army disperses them. But they had not specified their schedule to prevent the squatters from organizing their defense. Hence unarmed protesters found themselves in the crossfire between militant protesters and advancing troops. Met with strenuous resistance - mostly stone-throwing but also Molotov cocktails and sporadic gunshots ${ }^{3}$ - the CSF randomly opened fire, condoning civilian casualties.

\section{After the Massacre}

Prior research on violent repression events and massacres showed how their emotional impact can translate into symbolic moments that give meaning to social struggles. For instance, Della Porta (2014b) demonstrated through life cycle interviews how the fascist massacre in Piazza Fontana in Milan in 1969 left a lasting mark on the collective memory of Italian leftists, sparked

3 Compared to the number of participants in the sit-ins, the number of confiscated weapons was relatively small. According to the Ministry of Interior, 55 Molotov cocktails, nine rifles and pistols, and around two dozen make-shift guns were found in Al-Nahda Square. In the bigger Rabaa tent city, 15 handguns were found (see EIPR, 2014, p. 64). 
interest in and solidarity with ongoing militant mobilization activities, and moved to the center of leftist discourses:

The mobilization after the massacre and the death of an anarchist, Pinelli, while being interrogated by police during the investigation represented very intense experiences for many activists. In death, comrades became heroes. Extreme emotions were aroused by the memory of the "April days of 1975." (p. 173)

In a similar vein, Rabaa and its victims moved to the center of the Anti-Coup resistance discourse. Sharply contrasting their prior experiences of everyday life in the sit-ins, the massacres became a "collective biographical landmark" for the protesters (Demmelhuber, 2014, p. 42). For many of those protesting on Rabaa and Nahda Square, the weeks of occupation had not only been a strategic tool but had also enabled the organization of alternative and ideal-typical miniature societies. Particularly the Rabaa sit-in with its sophisticated internal logistics, functional differentiation, work-sharing, community activities, and social support structures had a strong prefigurative character. Several research participants described their time at the sit-ins as a unique personal experience that changed their understanding of solidarity and meaningful life. Their glorifying descriptions effectively echoed previous accounts by protesters of their experiences during the 18 days on Tahrir Square in 2011 (see Telmissany, 2014, p. 4off.; Van de Sande, 2013).

Certainly, the Anti-Coup camps neither harbored an equally pluralist cross-ideological coalition as Tahrir had during the Arab Spring nor did they give voice to the aspirations of as many different segments of Egyptian society. But Ahmad Shokr's (2015) descriptions of the square's identityestablishing communitarian dynamics, if complemented by a strong religious component, to a large part captures what the tent cities represented for the Anti-Coup supporters. They were experienced by their participants as utopic spaces, where an idealized vision of society could be construed and lived that drew on Islamist discourses as much as the cultural stock of the 2011 camps. Over 47 days of occupation, particularly Rabaa "turned into a veritable polis, where people were bound together by more than a common political demand" (Shokr, 2015). Midan Rabaa al-Adawiya and Al-Nahda housed a society under construction where people with different socio-economic, ideological, and demographic backgrounds met in collective resistance against the installation of a new historical block in the shape of the military-backed coup forces. 
Against conventional wisdom, the sit-ins were not only populated by rank and file Muslim Brothers and their families. According to several interlocutors, like Tahrir, Rabaa represented an egalitarian utopia that cut across classes, age groups, and organizational boundaries. Albeit shunned by liberal and secular players - some of whom were, in principle, sympathetic to the rights of the Mursi supporters to freely voice their opinion but did not join the sit-ins, because they disagreed with the protesters' goals - the tent cities were populated by Egyptians from all walks of life. A study of the socio-economic profiles of those who were killed in the Rabaa dispersal shows that the protest participants came from more than half of the country's districts, including the more prosperous and urbanized parts of the country (Ketchley \& Biggs, 2015). In a sense, the camp was not so much pro-Brotherhood as it was anti-coup.

Conversations with participants of the Anti-Coup campaign pointed to the presence of, at least, two factions of players on Rabaa and Al-Nahda Square. The first encompassed actual supporters of deposed President Mursi. By contrast, the second comprised citizens who were not necessarily pro-Mursi but, above all, opposed to the way he had been removed from office. Among the latter, some shared the conviction that the former president should have stepped down or that he should, at least, have been removed from office through impeachment as described in the constitution. This bifurcation of motivations for being anti-coup represents a major difference to the June 30 protest coalition, whose major factions welcomed military intervention as a way to not only depose the president but also repeal a disliked constitution.

It certainly was in the NASL's interest to portray the Rabaa sit-in as a horizontally organized and diverse community, as this narrative blurred the de facto existent hierarchies between Ikhwan [Muslim Brothers] and non-Ikhwan among the camp's members. In truth, Brotherhood members and Freedom and Justice Party (FJP) functionaries played a leading role in most committees on the square and were crucially involved in the logistical efforts necessary for the smooth functioning of this utopian social order, including the provision of basic necessities and the organization of security. However, among the NASL grassroots, the Brotherhood activists only made up between a quarter to a third, as several interviewees stressed who attended the sit-ins. Eyewitnesses who toured the campsite in the days before their dissolution came to a similar conclusion (see Bedier, 2014; Holmes, 2013). Accordingly, most participants of the sit-in were not formal members of either organization.

For weeks, Midan Rabaa and Al-Nahda became "social laboratories" (Van de Sande, 2015, p. 190) where the variegated forces allied in the NASL 
negotiated, tested, and shaped their new ideal political community. From the political debates on the Rabaa-podium to the mundane acts, such as cleaning the streets, re-painting the surrounding walls, distributing food, or organizing the night shifts, the everyday practices of collectively sustaining an alternative order, which rivaled that of the post-coup state, provided moments of inspiration for the formation of a strong collective identity that overran the political distinctions between the movements aligned in the NASL.

On August 14, 2013, this "effervescent community" (Khosrokhavar, 2018, p. 166) was abruptly shattered. The Anti-Coup movement's coherence, however, endured. The collective experience of brutal state violence endowed further sense and identity to the protesters' subsequent struggle: Framed by the coalition as a "crime against humanity in the holy month of Ramadan" (NASL, 2013u), the massacres became the central theme for the campaign, dominating the imagery and collective action frames in the second half of the examined timeframe. As Dawn Perlmutter (2013) noted, the critical juncture of Rabaa and all of its corresponding actors, figures, imagery, and symbols were virtually "endowed with supernatural qualities."

The dispersals also caused a moral shock that transcended the geographical boundaries of the raided squares. Similar to Guantanamo or Abu Ghraib becoming symbols for the ubiquitous violations of human rights in the name of the global war on terror, Rabaa became a symbol for authorities' disdain for civil opposition, civic rights, and the peaceful solution of political conflict. The massacres resonated strongly with universalized norms of human dignity and civil rights. Therefore, they quickly turned into a transnational symbol for state abuse of repressive powers.

\section{The Rabaa Salute}

The moral indignation generated by the mass killings became encapsulated in a four-fingered hand gesture, made by raising four fingers with the thumb resting on the palm, the Rabaa-salute. The Rabaa al-Adawiya Square is named after the $8^{\text {th }}$-century Muslim saint Rabia Al-Adawiya, whose forename in Arabic means fourth, hence the four-fingered hand gesture. Before the massacre, the gesture was used by Cairo's microbus drivers to let commuters know where they were heading. After August 14, its meaning expanded to include not only a location but also a collective that was being victimized. The corresponding graphic sign comprised a black right hand with four fingers raised and thumb folded on a yellow background over the capital letters R4BIA, Rabaa, or less common Rabiza. 


\section{Figure 9 The Rabaa salute}

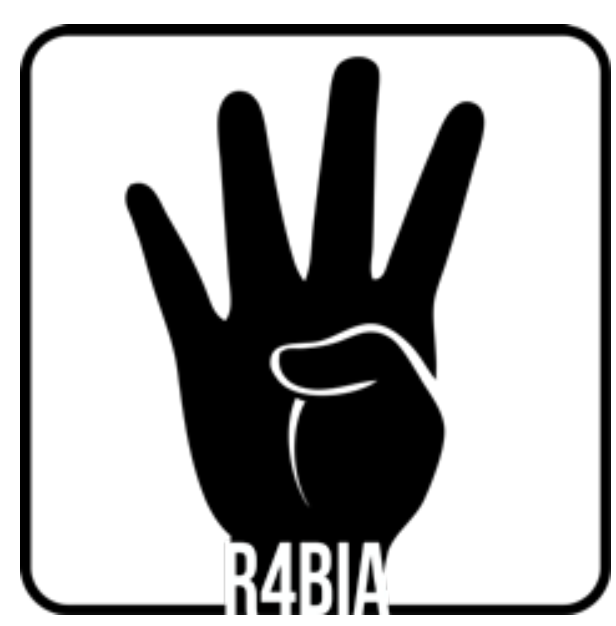

A dedicated website, set up by sympathizers of the Anti-Coup campaign shortly after the massacre, described the sign's meaning as follows:

$\mathrm{R}_{4} \mathrm{BIA}$ is a symbol of freedom; $\mathrm{R}_{4} \mathrm{BIA}$ is the birth of a new movement for freedom and justice; $\mathrm{R}_{4} \mathrm{BIA}$ is the birth of a new world; $\mathrm{R}_{4} \mathrm{BIA}$ is the return of Muslims to world stage; R4BIA means justice, freedom and conscience; R4BIA is the place where the so-called values of the West collapsed; R4BIA means the Egyptian heroes who became free by dying; R4BIA is Egypt, Syria, Palestine and the whole geography of Islam; R4BIA is the name of those who wake all the Islamic world with their death; $\mathrm{R}_{4} \mathrm{BIA}$ is the place of people who show the death is a revival; $\mathrm{R}_{4} \mathrm{BIA}$ is our daughter Asma [daughter of Brotherhood leader Mohammed al-Beltagy, killed on Midan Rabaa]; R4BIA is the grandchildren of Hasan Al Banna [founder of the Muslim Brotherhood, killed by secret police in 1949]; R4BIA is the new name of our children who will change the world; $\mathrm{R}_{4} \mathrm{BIA}$ is a new breath to humanity; $\mathrm{R}_{4} \mathrm{BIA}$ is justice for everyone against rotten Western values; $\mathrm{R}_{4} \mathrm{BIA}$ is the soul of a free man and a free woman; $\mathrm{R}_{4} \mathrm{BIA}$ is the tear, the sadness, the sobbing; $\mathrm{R}_{4} \mathrm{BIA}$ is the joy, the happiness, the good news; R4BIA is the child, the woman, the young, the old; $\mathrm{R}_{4} \mathrm{BIA}$ is a man like a man; $\mathrm{R}_{4} \mathrm{BIA}$ is straight as an Aleef, humble as Waw [the first and the $27^{\text {th }}$ letter of the Arabic alphabet]; $\mathrm{R}_{4} \mathrm{BIA}$ is a pure martyrdom; $\mathrm{R}_{4} \mathrm{BIA}$ is a new world; $\mathrm{R}_{4} \mathrm{BIA}$ is Ummah; R4BIA is solidarity, togetherness, brotherhood; R4BIA is unification of Islamic World; R4BIA is the shame of the accomplice of the massacres; 
$\mathrm{R}_{4} \mathrm{BIA}$ is the end of munafiqeen [hypocrites] who support the massacres; $\mathrm{R}_{4} \mathrm{BIA}$ is the end of oil sheikhs; $\mathrm{R}_{4} \mathrm{BIA}$ is the end of capitalists; $\mathrm{R}_{4} \mathrm{BIA}$ is the end of Zionists; R4BIA is the end of immoral press; RABIA is the arena of martyrdom; $\mathrm{R}_{4} \mathrm{BIA}$ is the mother of martyrs; $\mathrm{R}_{4} \mathrm{BIA}$ is a smiling martyrdom. (R4bia, 2013)

The NASL did not necessarily share all these meanings. In fact, the website administrators, who remained anonymous until years after, admitted on their site that their answers to the question "what is R4BIA?" was a compilation of interpretations from across the world. ${ }^{4}$ But in many ways, these explanations exemplify the affective power that the R4BIA-salute carried, as an empty signifier that could be filled with different meanings by the diverse sympathizers of the NASL, in Egypt and abroad.

The R4BIA-sign turned into a powerful mobilizing symbol, precisely because it could be associated with both, a religious imaginary and the now globalized symbolism of civil rights movements: On the one hand, its black and yellow colors referenced those of the holy sites of Islam, the golden Dome of Rock shrine in Jerusalem and the black cloth covering the Kaaba in Mecca (Eren, 2017; Hamama, 2016), making it possible to perceive the sign as a marker of the Anti-Coup Alliance's Islamic identity. On the other hand, they also resonated well with the visual language of international human or civil rights campaigns. For instance, Amnesty International, Black Lives Matter, or the Human Rights Campaign all employ a contrasting black stencil on yellow canvas as campaign logos to convey a sense of urgency and alarm for their goals. This similarity helped the Anti-Coup campaign surpass linguistic and cultural barriers. As a powerful visual image in the age of social media, the stylized R4BIA-salute went viral quickly (Richter, 2017).

Beyond Egypt's borders, the sign was adopted by solidarity groups across the region and Europe, and by a range of prominent critics of the Al-Sisi regime. This includes politicians, as well as self-declared spokesperson of Islam. The sign gained particular popularity in Turkey, where it was adopted by then-Prime Minister Recep Tayyip Erdogan during his public rallies (Tharoor, 2016). After vocally condemning the massacres in Cairo and offering asylum to persecuted Brotherhood members, Erdogan appropriated the symbol for domestic politics. Given its origins, the salute represented a powerful Islamic alternative to the "grey wolf"-salute of the

4 Several reports place the Rabaa sign's origin in Turkey, portraying the graphic designers Saliha Eren and Cihat Döleş as the creators of the sign. For a short documentary of the creation story, visit https://youtu.be/Ex_kztHc8S4. 
ultra-nationalist Turkish Bozkurtlar (Hürriyet Daily News, 2017). Erdogan's Justice and Development Party (AKP), therefore, soon developed the Rabaa sign into its trademark. After the failed coup attempt in Turkey on July 15, 2016, it fully uncoupled the salute from its Egyptian origin and established it as a symbol of resistance against military rule. Today, the AKP bylaws describe the four-fingered hand as a symbol of the party's guiding principles: "one homeland; one state; one flag; one nation" (Birgün Daily, 2017).

In Egypt too, the R4BIA symbol developed into an object of contestation. The salute's "codes of connotation," as Barthes (1993) has referred to the rhetoric of images, were understood radically differently by different communities. On the one hand, the salute became the unifying signifier of the Anti-Coup campaign. A simple shape, the sign could easily be reproduced by supporters. Across the country, Mohammed Mursi's picture was replaced with placards showing the R4BIA emblem (Werbner et al., 2014, p. 22). Many supporters of the campaign also used the sign as a spray-painted stencil to mark urban spaces. Through this graffiti as well as through posters adorned with the R4BIA emblem, the NASL could make its presence felt in residential neighborhoods where police deployments impeded protest marches.

As a powerful "condensing symbol" (Jasper \& Poulsen, 1995, p. 498) the R4BIA-sign encapsulated the essence of what Rabaa had meant to many protesters. First, it directly referred to deposed President Mursi who had been the fourth republican president of Egypt, following Gamal Abdel Nasser, Anwar al-Sadat, and Husni Mubarak in the presidential office. ${ }^{5}$ Furthermore, the similarity with the victory sign connoted the protesters' resilience against repression, while setting them apart from those mobilized by Tamarod on Tahrir Square who had welcomed the Mursi's deposition on June 30, 2013, with the V-sign. Finally, its implicit reference to the Sufi saint Rabaa al-Adawiya, also fit the Anti-Coup narrative, as the historical figure of Rabaa, conveniently, was often associated with the values of steadfastness and the struggle for freedom through faith.

Announced to her father in a vision, Rabaa was born in 715 in Basra. After a youth in poverty and the death of her father, she endured a life of suffering, hardship, and slavery only due to her strong faith. As the legend goes, this very piety prompted her master to set her free at the end (Salbi, 2013). The parable of the Sufi saint was embodied by the Anti-Coup protesters who saw it as an allegory of their struggle. As Jasper and his colleagues (2020, 
p. 216) write, saints such as Rabaa "are heroes of example, parallel to heroes of endurance in that they find non-traditional sources of strength, indeed turning some of their weaknesses into strengths, moral strengths" (p. 216). They accomplish an important task in helping victims endure sufferance by showcasing that the "suffering itself has a transcendent value" (Jasper et al., 2020, p. 216). Particularly Brotherhood members who had lived through decades of persecution before the Arab Spring could find consolation in Rabaa's story of victory through endurance and piety.

Most importantly, however, the Rabaa-salute conveyed emotional solidarity with those massacred on Rabaa Square. Protest signs articulate the individual demands of their carriers. Several research participants recollect wearing T-Shirts with the R4BIA -sign at protests to pay their respects to the martyrs without singling out and heroizing individual protesters for their roles in the square. ${ }^{6}$ Given the multifaceted meaning of the $\mathrm{R}_{4} \mathrm{BIA}$-emblem, these banners themselves turned into an articulation of the demands and desires of the Anti-Coup movement, thus performatively reconstructing the movement's collective identity in contrast to its external other. The mass resort to the R4BIA-sign by protesters, in this sense, reflected a "conscious participation in a specific culture of resistance" (Gribbon \& Hawas, 2012, p. 104). Just as the Tahrir protesters had unremittingly reproduced the iconic slogan "bread, freedom, human dignity" in 2011 and thereby reinforced a "distinct and categorical connection between the police state and their decades-long economic dispossession" (Gribbon \& Hawas, 2012, p. 112), NASL protesters now resorted to the R4BIA-salute as a powerful means of relating to one another while challenging the dominant narrative about the raids. The signs encapsulated and conveyed different emotional layers that resonated with the movement's narrative of Rabaa and included grief and sorrow, pride about the movement's steadfastness and resilience, anger and outrage about the regime's boldness and brutality, and a desire for retribution.

Unsurprisingly, for those who reproduced a securitizing narrative that portrayed the NASL as a terrorist entity, the self-referential nature of the Rabaa-salute was taken as evidence for the fact that the Muslim Brotherhood and its allies were disassociating from the Egyptian public. The veneration of the Rabaa martyrs by the Islamist movement and corresponding slogans such as "RABIA is the arena of martyrdom, R4BIA is the mother of martyrs, $\mathrm{R}_{4} \mathrm{BIA}$ is a smiling martyrdom" on NASL-associated websites aggravated

6 Interview with Anti-Coup protest organizer in the Mohandessin district, November 2013, via Jitsi Meet. 
their fears of radicalization and the adoption of jihadist positions by the protesters. Others claimed that the protesters were capitalizing on bloodshed they were themselves responsible for. Consequently, many Egyptians took to social media to edit the four-fingered salute and create counter-symbols that either showed support for General Al-Sisi or turned the Islamist symbol of solidarity into a joke (see Ibrahim, 2013).

Among the most prominent signs shared on Facebook and Twitter was a hand whose fingertips ended in Kalashnikov rifles. Stamped with the term silmiya [peacefulness], it highlighted the hypocrisy of the Anti-Coup protesters who emphasized nonviolence but had used firearms to defend Rabaa Square. Another version of the salute connected the fingertips with a black standard bearing the shahada [testimony of Islamic faith]. This insinuated similarities between the Anti-Coup Alliance and jihadist terrorist groups who have used the black banner since the late 199os. Other popular images displayed the crest of the armed forces or showed two hands curved in the shape of the letters CC - a popular abbreviation for General Al-Sisi based on the English pronunciation of his name.

Salafi groups also appropriated the salute. Their version brandished only the index finger in a tawhid [the indivisible oneness of God]. As Martijn De Koning (2013) has argued, for some groups the original R4BIA-sign represented forbidden idolatry and bid'ah [innovation], because it did not originate in Islamic tradition and divided the Islamic ummah. The Rabaa sign thus became a symbolic marker "of the boundary between insiders and outsiders creating both difference and similarity on different sides of the boundary but also across the boundary" (Martijn de Koning, 2013). Through this process of symbolic differentiation and collective self-assertion, Rabaa provided a mythical closure to the hitherto still relatively open subjectivation processes that had been set in motion within the Anti-Coup Alliance by the coup on July 3, 2013. As all attempts by the regime to hold the movement in check by criminalizing the R4BIA-salute sign failed (Shamni 2013). ${ }^{7}$ Instead, Rabaa developed into a central signifier in the Anti-Coup resistance discourses. It provided unity and irrevocably demarcated the frontier between coup and anti-coup.

7 From December onwards, those flashing the Rabaa-salute were charged under Article 86 of the Penal Code. The article regulated the designation of political groups as terrorist entities. After the designation of the Muslim Brotherhood as a terrorist organization in December 2013, displaying the R4BIA sign was taken as evidence for belonging to the criminalized group and charged with up to five years imprisonment. 


\section{The Rabaa Martyrs}

Redemption for the souls of the Rabaa martyrs' as a motive for protest dislodged even the restitution of President Mursi from the list of primary Anti-Coup objectives. Not only did the presence of posters and banners commemorating the victims of state repression become a prominent phenomenon at Anti-Coup marches, but the slain supporters of President Mursi were bestowed with almost sacred status. Perlmutter (2013) has described the mythical qualities of the Rabaa al-Adawiya massacre as follows: "A new Islamist legend was born out of the blood of Egyptian protesters. It would not be surprising if pilgrimages to Rabia al-Adawiya Mosque to commemorate the new martyrs occur each year on the anniversary of the violence."

This sacralization of protest was difficult for the regime to oppose. Even before the Rabaa events, the commemoration of martyrs had been a central part of the NASL's resistance myth. The so-called "panorama tent" on Midan Rabaa al-Adawiya had displayed the portraits of fallen members of the movement. Centrally located at the intersection of Youssef Abbas and Al-Nasser Road in front of a Mobil gas station, its walls were covered with photographs of killed protesters. Tables within the tent showcased some of the martyrs' possessions for visitors, and LCD televisions screened documentaries and video snippets of the clashes during which they were killed. This prominent representation of killed protestors served the strategic aim of the NASL to extend the Anti-Coup coalition across ideological divides. It showed how ordinary Egyptian citizens including women and youth were selflessly sacrificing their lives vis-à-vis security forces and thus evoked collective memories of popular resilience against state violence during the January 25 uprising.

In presenting those killed by security forces as martyrs, rather than victims, the Anti-Coup campaign attempted to overcome passivity and the hitherto dominant narrative of victimhood that, albeit successful in fostering internal cohesion, had failed to mobilize broader public support. Jasper, Young, and Zuern (2020) describe the reasons for this ambiguous effect of victimization in their discussion of the feelings of pity and horror experienced by those witnessing the suffering of others:

We can empathize with their pain, but we cannot appreciate their subjective point of view. Victimhood creates a gap between viewer and viewed, objectifying the victim and freezing her outside the possibility of will or reasoned action. Victims lack agency. They speak only to narrate their victimhood. They are objects, not subjects. (p. 197) 
Rendering the killed Anti-Coup protesters as martyrs, in this sense, not only paid the last honor to the dead. It also served a tactical purpose. By turning victims into heroes, the Anti-Coup Alliance reasserted their - and by extension its own - agency. At the same time, it sought to overcome the dilemma of retaining public sympathy as a victim of oppression while also crafting images of strength (see Jasper et al., 2020, p. 231). After the Republican Guard killings, the NASL already tried unsuccessfully to liken the killing of Anti-Coup protesters to the suffering of Khaled Said at the hands of the police in late 2010; as this revolutionary frame failed to inspire sympathies, it then resorted to a more religious framing of the Republican Guard victims by stressing how they had been killed insidiously during the act of prayer. These framings, albeit unsuccessful in mobilizing popular support, were primarily strategic attempts to evoke solidarity with the movement's cause among the Egyptian masses. After Rabaa, by contrast, martyrdom turned into a central internal theme of Anti-Coup Alliance, representing "a rhetorical call" (Peterson, 2015b) to the living members of the movement to change, through their resistance, the context in which the martyrs' death had occurred.

The notion of martyrdom plays a crucial role in most social movements, as do their visual depictions (see Askanius, 2013). The articulation of victims as martyrs invests their slain bodies with meaning. Their visual depiction, in turn, indexes the circumstances of their death and, thereby, symptomatically points to the greater injustice that their respective movement seeks to encounter. The martyrs of a social movement are symbols of the experienced injustice and multiplicators of the movement's raison d'être. "Martyrs are heroes made from victims" (Jasper et al., 2020, p. 214). They embody a link between grievances, indignation, and political action: as victims, they testify to unjust treatment and social problems; as heroes, they testify to the moral worth of a cause and the importance of acting, even against great odds and even at the price of self-sacrifice.

Martyrs also give movement audiences a powerful interpretive frame by providing clear points of condensation to identify friends and foes: "By defining martyrdom as any death delivered at the hand of the oppressor, the nation's collectivity is reaffirmed vis-à-vis the oppressor" (Khalili, 2009, p. 141). Martyrs can thereby serve as the foundation or reinforce the boundaries of what Asef Bayat (2005), with a view to Islamist social movements, has referred to as "imagined solidarities" (p. 891).

Both the original Greek term martyrios and the Arabic term shahid, in their literal signification, mean "witness." In an abstract sense, the martyr who suffers witnesses injustice and testifies to the truth of the cause by virtue of her suffering: 
Social movements get an enormous boost from martyrs who give their lives for the cause. They testify to the importance of the issue, as important to them as life itself. Plus, they demonstrate how viciously repressive and brutal the other side, or the police, are. Death raises deep emotions and forces people to ask what their deepest values are, what they might consider dying for. (Luker, 2009, p. 157)

In this sense, Khaled Said, the young Alexandrian who was brutally beaten to death in police custody and then framed as a drug dealer in June 2010, was not only one of the sparks of the 2011 uprising in Egypt but also one of its first martyrs (see A. Ali \& El-Sharnouby, 2014). ${ }^{8}$ In juxtaposition to the security state's moral corruption, Said's innocence elevated him to the status of a martyr. Likewise, Mohamed Bouazizi, a street vendor whose self-immolation triggered the 2010 uprising in Tunisia, has been discussed as the first martyr of the Arab Spring, despite the unpolitical nature of his suicide (see Halverson et al., 2013). As Jasper, Young, and Zuern (2020) noted, Bouazizi "could be recast as a martyr, even if his personal motives differed somewhat from those of the movement he inspired. But that movement benefited from portraying him as an intentional martyr and from describing his motives to match their own" (p. 215).

\section{Mobilizing Martyrdom in Egypt}

In the Egyptian context, the theme of martyrdom constitutes today one of the few "fil rouge" that continues to connect the Arab uprisings to religion (Di Donato, 2012, p. 2). ${ }^{9}$ On the one hand, the idea of martyrdom has deep historical roots within Islamic dogma (see D. Cook, 2007). Notably, the three radicals that make up the Arabic term shahid (martyr) are also at the base of the word shahada, the Islamic testimony of faith. Albeit appearing only once in the Qur'an in its political meaning, the term shahid frequently appears in the Hadith literature, often in relation to the discussion of jihad (see Afsaruddin, 2016; D. Cook, 2012). An ample research tradition has thus developed around the exploration of the martyr theme in jihadist ideology and the political practices of radical Islamic movements, both Shia and Sunni and including Hamas, Hizbullah, or the Egyptian Islamic Jihad (a.o.,

8 It is noteworthy that the URL of the renowned "We are all Khaled Saeed" Facebook page (https://www.facebook.com/elshaheeed.co.uk/) even contains the Arabic word Shaheed [martyr]. 9 For a discussion of the history of martyr narratives in North Africa, see Halverson et al. (2013, p. $322 \mathrm{ff}$.$) .$ 
D. Cook, 2002; Euben, 2002; Litvak, 2010; Moghadam, 2014). Beyond their role as summary symbols for injustices, martyrs assume an additional purifying role for many of these movements. Here the term not only designates the death for a political cause, but it furthermore refers to pious individuals who, in dying for a religious cause, transfer their moral qualities to the entire group of believers.

On the other hand, in Egypt especially, the martyr narrative has diffused from a traditionally religious context with its associated identities into the nationalist terrain, extending what Walter Armbrust (2015) has referred to as Egypt's "martyr-scape" (p. 89). The anti-colonial struggle for independence, as well as decades of war over Sinai, including several devastating defeats at the hands of Israel, effectively catalyzed a nationalist appropriation of the longstanding religious martyrdom narrative. Today, Egyptians celebrate a National Day of the Martyr on March 9 to commemorate the death of military commander in chief Abdel Moneim Riyad during the 1969 war; and fallen soldiers and policemen, as well as the victims of militant attacks and assaults, are regularly referred to as national martyrs. It is noteworthy that also January 25-a day mostly recalled as the start of the 2011 uprising against Mubarak - originally marked a national holiday in remembrance of the sacrifices made for national independence: Declared by Mubarak himself in 2009, National Police Day commemorates 50 officers of the Ismailiya police station who were killed by British troops on January 25, 1952, for their insubordination (see Thornhill, 2006, p. 56). Today, the incident is portrayed as the spark of the popular revolt that brought down the Egyptian monarchy half a year later.

In the propaganda of Egypt's republican regimes, martyrdom assumed, above all, the distinctive image of the shahid al-harb [martyr of the war]. The theme perfectly embodied the military ideal of heroism in the face of the enemy, as well as the perception of death in the service of the nation as the ultimate patriotic duty. The veneration of national martyrs made the abstract national struggle for territorial sovereignty graspable and tangible for civilian citizens. As Dalia Mostafa (2016) has stressed, "it is through the martyr's image that the people and the army are united in grief for the wounded nation" (p. 56). Informed by the nationalist identity formation processes that informed political projects throughout the MENA region in the mid-1950s, the divine promise of a better tomorrow, that is, individual recompense and elevation of the martyrs in the afterlife, thereby turned into the promise of a better today for Egyptians. This image worked successfully in the service of the incumbent players and their aspirational identities because it prepared citizens for sacrifice and self-abandonment for the greater weal. 
The trope of sacrifice for the nation met its limits in early 2011 when Egyptian youth visibly refused to accept any more humiliation in the name of patriotism and at the hands of its police. Armbrust (2015) has noted the irony of this historical twist on National Police Day. In his last public speech, Mubarak's claims to "military honor, allegiance, and sacrifice" were met with dismay; instead, crowds waved the bottoms of their shoes in a gesture of disgust (Shadid \& Kirkpatrick, 2011). In contrast to Mubarak's presidency, the theme of people's sacrifice for the nation survived and even invigorated the uprising (Pratt, 2020), illustrating how the image of the martyr turned into an ideational commodity that different groups instrumentalized to garner support and legitimacy for their causes (Gribbon, 2013). Social movements resorted to the martyrdom theme to enliven their members, to link their grievances to those of other oppositional players, and to assert the steadfastness of their mobilization in the face of state violence.

As could be observed during the 18 days of Tahrir, the notion of death for a political cause continuously found its expression in the theme of martyrdom (see Armbrust, 2013, 2015; Gribbon, 2013; Mittermaier, 2015; Zakarevičiūtè, 2015). Some of these enactments of the martyr theme notably drew on a religious archive. For instance, in January 2011, Coptic protestors arrived at Tahrir Square brandishing crosses and wearing stickers that read "a martyr is available here" to indicate their readiness to die for the revolution (Ramzy, 2015, p. 649). Other religiously inspired performances of martyrdom on Tahrir Square included protesters wearing the kafan, a white Islamic burial shroud (Gribbon \& Hawas, 2012, pp. 110, 112), as well as commemorative graffiti of fallen protesters and "living martyr" photographs that resembled the well-known iconography of Islamic resistance movements (Halverson et al., 2013, p. 326).

For the most part, however, the 2011 revolutionaries avoided religious connotations that could have contributed to a sectarian reading of the uprising. Instead, they largely built on a nationalist archive that bridged confessional differences and emphasized Egyptianness as a unifying frame of reference. For instance, the systematic commemorations of the victims from the Battle of the Camel or the clashes on Mohamed Mahmoud Street in photographs and through the graffiti portraits in downtown Cairo, which achieved global fame alongside other spectacular revolutionary wall art, were mostly devoid of religious references (Armbrust, 2015, p. 88).

Many murals reproduced ancient Egyptian imagery, instead (Abaza, 2016, p. 116; Telmissany, 2014, p. 44). Depictions of martyrs as Queen Nefertiti, as pharaohs wearing the striped Nemes-headcloth, or adorned with the wings of the ancient Egyptian god Horus (see Pratt et al., 2012), enabled identification 
and commemoration across ideological cleavages. They underscored protesters common belonging to a people whose culture and legacy predated contemporary political antagonisms. This frame facilitated cross-ideological alliance-building against a regime that was, conversely, often depicted as a many-headed snake, or as Anubis, the ancient Egyptian god of death. For its unifying frame, the pharaonic imagery was also reproduced by subsequent mobilization attempts, such as during the campaign against military trials in the summer of 2011, or the 2012 mass protests against the rule of the SCAF.

Even the Coptic movements in 2012 resorted to commemorating the martyrs of the Maspero massacre - a deadly crackdown of army units on Coptic demonstrators in Cairo on October 9, 2011 - by reviving ancient Egyptian themes (El Gendi, 2017, p. 47f.). In the aftermath of the massacre, commemorative protest marches employed Christian symbols, such as makeshift crosses and pictures of Christ, but also extended their martyr frame in an attempt to collectivize the outrage over repression to other segments of society. Through nationalist performances, the Coptic community reasserted its identity as Egyptian, attempting to counter the media's vilification of the demonstrators. Furthermore, it linked Coptic grievances to those of other oppositional groups, trying to evoke compassion among the wider Egyptian public.

The common denominator of these different adoptions of the martyrdom signifier across the ideological spectrum is the theme of death at the hand of the enemy - a theme that catalyzes political subjectivation processes by reinforcing the antagonist boundaries of the community. What Laleh Khalili (2009) has noted for the context of Palestine can be transferred to the Egyptian context: "Islamists and secularists emphasize the act of injustice which results in martyrdom, such that any activity of the oppressor or enemy which results in the death [...] transforms that potential senseless death into a redemptive self-sacrifice for the nation" (p. 140).

Given the multilayered roots of the martyrdom theme in Egyptian culture and collective memory, the NASL drew on Islamic, nationalist, and revolutionary discourses in its reproduction of the martyrdom narrative as a metaphorical carrier of meanings. The rendering of killed protestors as martyrs added a transcendental element to its protest, which elevated it to a morally and spiritually superior struggle above mere factional politics.

\section{The Moral Righteousness of the Anti-Coup Protesters}

The systematic integration of the Rabaa martyrs into the imagery of the Anti-Coup movement, with the online R4BIA platform, several social media 
sites, and a dedicated magazine Sawt al-Shahid [Voice of the Martyr ${ }^{10}$ collecting pictures and stories about the massacre as a sort of "virtual reliquary" (Halverson et al., 2013, p. 320), had a galvanizing effect on the protest alliance. Anti-Coup supporters may have been "shocked into action" (Jasper, 2018, p. 142) based on the moral outrage generated by Mursi's ouster and the clearing of Rabaa. But they continued their protest due to the affective bonds created by performative shows of compassion and solidarity, and the moral commitments they fostered. Like those who had died at the hands of the state on Tahrir, the Rabaa martyrs turned into powerful symbols of the need for change. As Mark Allen Peterson (2015a) noted:

Their deaths put new steel into the will of many protesters who argued that going home - no matter how deeply entrenched and willing to ignore them the regime appeared to be - had become morally impossible. It was unthinkable that these men and women should have shed their blood for an uprising that failed. (p. 168)

The interrelation of moral emotions and protesters' motives is also confirmed by surveys, according to which the solidarity with victims of earlier protests was one of the most relevant sources of inspiration for Anti-Coup demonstrators (see Ketchley \& Biggs, 2014). More than 90 percent of respondents indicated that a close friend or acquaintance had been arrested since the military coup and almost 75 percent personally knew someone killed while protesting.

With each fallen protester that could be elevated from its individualized mortal existence into an embodiment of the movement's values and aims, the discursive structure defining the external frontier between the Anti-Coup Alliance and its foes was fortified. In this sense, Rabaa represented a physical, but not an ideational defeat. Albeit brutal in its effect on the logistic capacities of the movement, for the Anti-Coup Alliance, the gruesome massacre also revealed the protesters' moral superiority to the coup forces. This perceived moral superiority, which set the movement apart from the coupists, manifested in the Anti-Coup discourses as a triad of patriotism, religious piety, and principled peacefulness (see Figure 10).

10 The magazine was distributed in print at rallies and online as a PDF-file via the now-closed website www.shahidmasr.com. A copy of the magazine's first edition is available at https:// de.scribd.com/document/158718621/Shahid-Mag-Issue1. 
Figure 10 Construction of the moral qualities of the Anti-Coup protesters

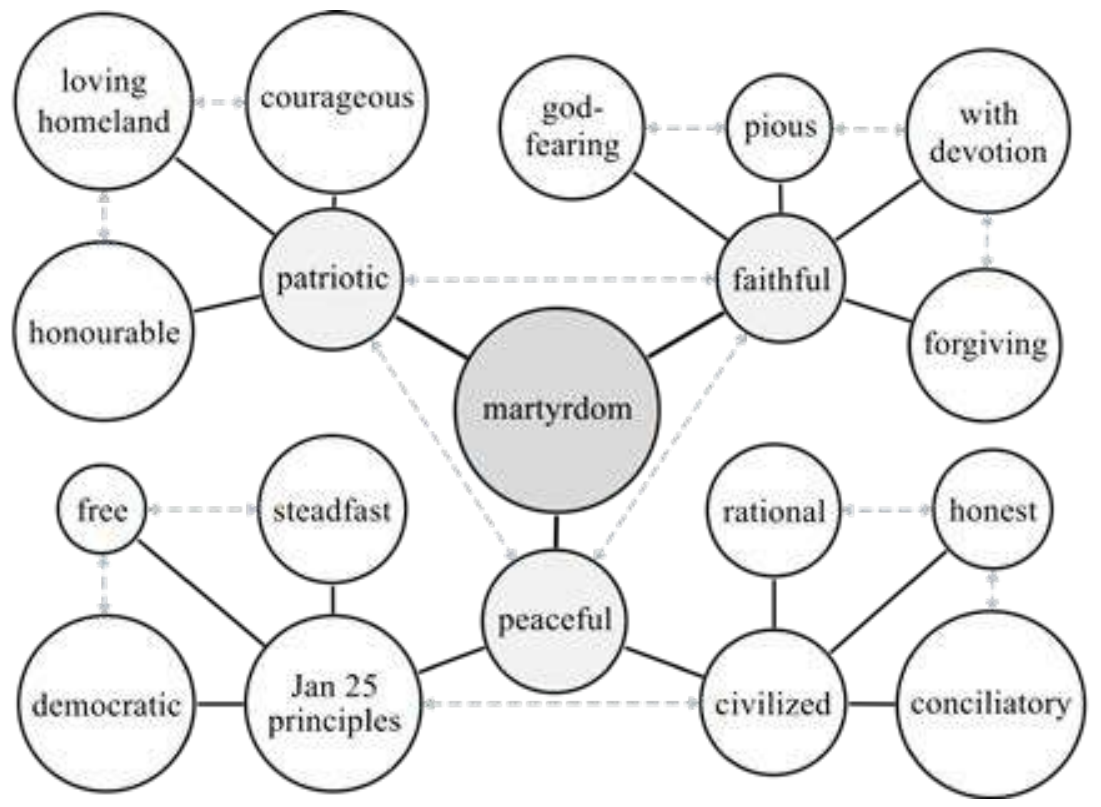

This tripod effectively mirrored the alliance's portrayal of the coup forces. According to the NASL, the latter's moral decay was evidenced by the unprecedented police brutality on Rabaa Square:

They burnt peaceful protesters' tents as women and children sought shelter inside from the effect of teargas, thus causing them horrific burns and excruciatingly painful injuries. Meanwhile, security apparatus sniper-fire targeted journalists, photographers, and reporters, as well as unarmed civilians [...]. Even worse, the putschists' forces prevented ambulances from taking badly injured citizens to nearby hospitals, after the field hospital was unable to cope with this enormous number of casualties. (Muslim Brotherhood, 2013e)

The massacre was still unfolding when the NASL declared that it would not be drawn into a spiral of violence by this brutal and heinous attack. Its resistance would remain non-violent. Drawing on the debatable mythical narrative of the January 25 Revolution as a completely peaceful uprising famously captured by the iconic chant silmiya, silmiya (peaceful, peaceful) (see Abaza, 2016, p. 120) - the NASL released a statement that asserted that its revolution would continue to build on the peaceful power of the street. In a symbolic reference to the January 25 Revolution, the alliance announced 
a Friday of Anger (see NASL, 2013v), thus aiming to reproduce the backlash moment of the 2011 revolution (see Harders \& König, 2013, p. 27). Like the original Friday of Anger on January 28, 2011, also the Anti-Coup rallies were meant to be strictly peaceful.

Principled peacefulness was not only invoked to place the Anti-Coup protests in the trajectory of the Egyptian 2011 revolution. It also served to showcase the civilized nature and conciliatory character of the AntiCoup protesters in contrast to the savageness of the coup forces. The NASL thereby favored a potential long-term gain on the emotional level (gaining compassion from other audiences), over the short-run disadvantage of refusing to defend itself against repression (see Jasper, 2018, pp. 55-56). In contrast to the "scorched-earth" crackdown on the Rabaa and Nahda vigils (NASL, 2013y), the Anti-Coup demonstrators would remain civilized and refrain from taking revenge. According to the NASL, peacefulness would "prevail over bullets" in the long term (NASL, 2013x). Martyrdom on the path of peaceful protest, accordingly, only symbolized protesters' moral superiority and bolstered the legitimacy of their aims:

The precious blood of peaceful protesters that flowed and is still being spilled is watering the tree of liberty in Egypt and is arousing the spirit of the January 25 Revolution - resistance to injustice, corruption, and rejection of the coup, repression, and tyranny. (NASL, 2013w)

At the same time, the alliance strategically welcomed any new reconciliation initiatives, including a temporary ceasefire, to prevent further bloodshed, while denouncing the security forces' unwillingness to engage in negotiations as a symptom of their bloodthirst. Recognizing that after Rabaa, Egypt's streets had turned into an unlevel playing field, the alliance furthermore turned to patriotic nationalist as well as religious lingo to motivate its sympathizers to continue protesting despite their defeat on Rabaa Square. On the one hand, new NASL rallying calls glorified the demonstrators who continued to resist after Rabaa as true patriots who displayed "heroic bravery" and their love for the Egyptian homeland by facing the regime's bullets unarmed (NASL, 2013w). On the other hand, the alliance emphasized their pious character thus complementing the protesters' nationalist credentials by their moral elevation as true believers: The protesters had selflessly given their lives "to please Allah," their blood had nourished "the pure land of Egypt" in Rabaa, Al-Nahda and at the Republican Guard (NASL, 2013ae).

The amalgamation of nationalist and religious tropes is exemplified in a statement on the Friday of Anger protests. Therein the coalition stressed 
that "despite all the pain and wounds caused by the loss of the martyrs and by the suffering of the wounded and injured," the crimes of the coup forces were only strengthening the movement's determination to pursue its quest for an "Islamic, national, moral and human duty" (NASL, 2013v). What is more, the alliance resorted to framing the goals of its campaign not only in worldly terms but increasingly pointed to the rewards that awaited protesters in the hereafter. Many statements released after Rabaa ended with inflections that God would save Egypt and its people and "reward the honorable martyrs in the afterlife" (NASL, 2013u); or with a quote from the last verse of surah 226 from the Qur'an, roughly translating, "those who do wrong will come to know by what a (great) reverse they will be overturned!" (NASL, 2013z).

Placed within the Anti-Coup discourse, these phrases reinforced the subjectivation of the Anti-Coup protesters as the righteous and morally superior political player in Egypt's streets. They also served as a reminder - or perhaps a threat - that those on the other side of the antagonist divide would eventually pay for their deeds. The alliance moreover appealed to the consciences of policemen and soldiers by quoting the Prophet Mohammed. According to the quoted hadith, related by Al-Bukhari (6820) and Muslim (1840), there was no duty to obey a leader if this meant disobeying Allah. Similarly, the alliance cited a passage of surah 5 reading, "if someone kills a human being, except as a punishment for murder or for causing turmoil in the land, it is as if he has killed all mankind" (Verse No. 32) (e.g., Muslim Brotherhood, 2013d).

The growing importance of such Islamic references for the motivational dimension of the Anti-Coup discourse was reflected in contentious performances on the ground: in the week after the Rabaa killings, the NASL announced that demonstrators, as an act of protest, would perform their Maghrib [sunset] and ' Isha' [nightfall] prayers on Ramses Square to commemorate those killed during a siege on the neighboring Al-Fateh Mosque on August 17, 2013. During the gatherings, protesters would pray for the souls of these innocent martyrs (NASL, 2013w). In neighborhoods with strong support for the Islamists' cause, the movement furthermore organized symbolic processions to the graves and former residences of killed demonstrators. These processions as well as the funerals of martyrs, which were often attended by thousands of sympathizers, provided occasions for new protest marches.

\section{The Moral Corruption of the Coup Regime}

The moral qualities of those affiliated with the coup - in the eyes of the NASL all players who failed to condemn the massacres - were articulated as the very antithesis of this pious, patriotic, and civilized self-image of the Anti-Coup 
Figure 11 Construction of the moral corruption of the coup forces

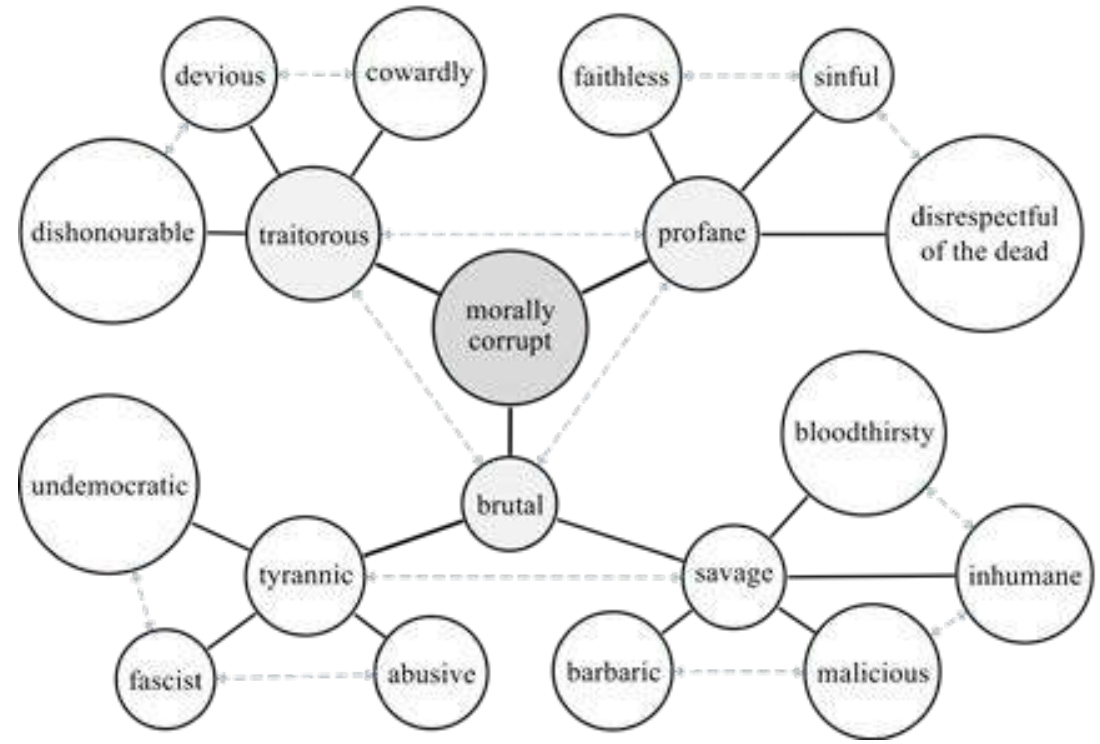

movement (see Figure 11). A week after the massacre, the coalition published a "blacklist" of all those who were complicit in the atrocities of the "coup regime" (NASL, 2013ad). The list included respected political figures, public intellectuals, media professionals, revolutionary activists, as well as representatives of labor and professional associations. This narrowed down the NASL's potential allies and, in truth, foreclosed any chances for the creation of a larger coalition of contenders. The charges leveled by the NASL against these players were no longer related only to the sabotage of the democratic transition. After Rabaa, they also encompassed the complicity in crimes against humanity (NASL, 2013z) and the acquiescence to a "war of annihilation" (Muslim Brotherhood, 2013e) and "genocide" (NASL, 2013aa) at the hands of the army and police.

A barrage of fervent Anti-Coup statements in the second half of August summarized the events of August 14-17, 2013, and articulated a strategic path forward. According to the statements, Rabaa had epitomized the coup forces' profanity and loss of humanity: the coupists had operated an "unholy practice of violating the sanctity of the dead by mutilating the bodies of the martyrs" (NASL, 2013x), and they had desecrated several houses of worship - including the Rabaa al-Adawiya mosque, which was burned down while protesters were sheltering inside. On August 16, 2013, the NASL stressed, they had furthermore attacked a provisional field hospital established inside the Al-Fateh Mosque, close to Ramses Square in downtown Cairo. When 
riot police from the nearby Al-Azbakeya police station opened fire on the mosque and armed protesters holed up inside the building responded with gunfire, the clashes developed into a full-blown siege that lasted until the protesters' surrender on the evening of the next day.

The standoff at the Fateh Mosque marked the first use of large-caliber stationary weapons against the Anti-Coup protesters (Carr, 2013). Dozens were killed by machine-gun fire (see Fahim \& Sheikh, 2013). Significantly, the victims also included the son of the Brotherhood's spiritual leader, Mohamed Badie, as well as a grandson of the group's founder, Hassan alBanna. Their deaths added to the list of prominent NASL members killed during the crackdown on the Anti-Coup protests on the previous days. Most symbolically, Asmaa al-Beltagy, the outspoken teenage daughter of FJP Secretary-General Mohamed al-Beltagy, was shot during the raid of the Rabaa encampment. In the following weeks, Asmaa turned into one of the movement's most venerated martyrs (Sherlock \& Samaan, 2013).

The Fateh Mosque becoming a flashpoint of the countrywide clashes in the Rabaa aftermath (which cost 137 lives), fit the motivational frame of the NASL discourse which characterized the coup forces as faithless sinners. For the alliance, the shelling of one of the most famous houses of worship in Egypt perfectly exemplified the coupists' disregard for moral standards and their sacrilegious disrespect for the pillars of the Islamic religion (NASL, 2013z). In its $78^{\text {th }}$ statement on August 25, 2013, the alliance even branded the coupists as heretics in an implicit act of takfir [declaring an individual as an apostate]. Released in response to the death of 37 detained Anti-Coup members in the back of an overcrowded police van, ${ }^{11}$ the statement declared that the coup force - like the Mubarak regime - had distorted Islamic teachings to justify state violence:

They returned to the ways of the deposed [Mubarak] and his disciples and elicit people to legitimize bloodshed and rivalry under false pretenses and through falsified fatwas that have no relation to true religion, its ethics, or values. (NASL, 2013ad)

In a follow-up statement, the alliance called upon the military to refuse the government's kill order, as well as all orders to storm houses of worship,

11 Investigations by the British Guardian newspaper based on the leaked proceedings of an official inquiry and the testimonies of survivors and prison guards suggest that 37 of 45 prisoners died from exposure to CS gas after hours of suffering from a lack of oxygen in an overcrowded vehicle with broken ventilation (see Kingsley, 2014). 
because such actions were considered haram [forbidden] by Islamic law (NASL, 2013z). A quote from the Quranic Verse 4:39 at the end of the statement highlighted that whoever intentionally killed a believer would be punished in hell. For their heresy, the NASL stressed, the coup forces would encounter god's revenge in this world and the Hereafter.

This and similar subsequent statements served a triple purpose: First, they addressed the security forces as believing Muslims by accentuating the brutality of the coup forces as a violation of the teachings of Islam. This appeal to moral conscience meant to alienate individuals in the police and armed forces from their commanding officers. Second, they addressed the wider public, whom they aimed to convince of the government's broken promise to protect the integrity of the Egyptian people. Finally, they also projected internal cohesion by morally elevating the Anti-Coup supporters above their antagonists.

For the same reasons, several statements contrasted the protesters' patriotism and courage with the dishonorable politics of those backing the interim authorities (NASL, 2013x). In analogy to the martyr-narrative, the NASL characterized its supporters as "pure Egyptians" who had faced bullets with their bare chests; by contrast, the coupists had engaged in a cowardly "war of annihilation" against the people which was not worthy of the Egyptian army as an institution (Muslim Brotherhood, 2013e). This latter reproach - that the army had turned against the people - was particularly powerful because it directly challenged the justifications of Mursi's deposition and the ensuing crackdown against his supporters. Al-Sisi himself had portrayed the military's mission as the protection of the Egyptian nation and its free will, and as one above electoral politics or factional struggles. The Anti-Coup Alliance's discourses opposed this claim. Accordingly, the atrocities committed by soldiers and policemen against civilians evidenced the authorities' partiality and counterrevolutionary intentions, nullifying their political legitimacy.

Significantly, the Arabic term batil [void, false, vain], by which the NASL declared the regime's claim to legitimacy null and void, has a double connotation: in its literal meaning, it describes a phenomenon that does not fulfill what is expected of it, does no longer fulfill its original and proper purpose and does not properly fit into its assumed fitting place in the order of things. The term thus aptly symbolized how the NASL viewed the interim authorities and their transitional roadmap, namely as groundless, ineffective, and thus invalid. Beyond this literal meaning, however, the term also transports an additional affective dimension, referencing Yousef Chahine's iconic The Land about the unsuccessful struggle of a peasant 
village against the oppression of feudal landowners (see Mostafa, 2016, p. 67). In the 1968 movie, the fellahin organize themselves in a series of collective actions to protect their land and their crops, repeatedly making use of the term to denounce the landlords' machinations. During the 2011 Tahrir protests, this pop-cultural reference was adopted as a protest chant that declared the political system and all its representatives void: the respective call and response chant involved a protest leader shouting the name of a prominent regime figure (such as, Husni Mubarak, his son Gamal Mubarak, Interior Minister Habib al-Adly, or steel tycoon and crony Ahmed Ezz) and the chorus responding "batil!" in one voice.

By appropriating this symbolism, the NASL drew parallels between authorities' response to the Anti-Coup campaign and Mubarak's attempt to defuse the Tahrir protests, two and a half years earlier. Many people would probably have accepted Mubarak's announcement, on January 31, 2011, to step down by the end of his term. But his attempt to clear Tahrir Square with the help of hired thugs two days later made the offer null and void. In the Anti-Coup version of events, like Mubarak's assault on Tahrir, the massacres in the summer of 2013 demonstrated the regime's lacking confidence that they could break popular resistance by peaceful means. Though significantly more brutal, the Rabaa massacre paralleled Mubarak's helpless response to the uprising - by turning to deadly violence, the putschists admitted their ideational defeat.

After Rabaa, pointing out similarities between the authoritarian practices of the Mubarak regime and the post-coup government became a prominent method by the NASL to discredit the transitional authorities as harbingers of a counterrevolution and a return to tyranny (NASL, 2013z). The authorities reinforced these analogies on their part by imposing a state of emergency. In an assessment of its options after the Rabaa massacre, the NASL declared on August 20, 2013, that its opponents had coalesced with the feloul, the remnants of the former regime, to "wreak terror on our revolution and seek revenge for the old regime" (NASL, 2013aa). This framing produced a new rationale for the ongoing violence, and for continuing resistance. Accordingly, no longer only the democratic transformation and the constitutional rule of President Mursi was at stake. Instead, the NASL signified the repression of the Anti-Coup campaign as an attempt by the ancien régime to retaliate against those who had ousted Mubarak and to restitute the old order with "all its symbols, institutions and nefarious practices" (NASL, 2013ad).

Significantly, this narrative complemented the systematic integration of the martyr theme into Anti-Coup rhetoric and imagery. As Jasper, Young, and Zuern (2020) have noted, "endurance and martyrdom are contrasting 
reactions to oppression; one is resistance by living, the other by dying. In one case you are available to take care of others, in the other you hope to live on as a symbol. Or to find glory in the afterlife" (p. 221). The Anti-Coup discourse after Rabaa was shaped by both tendencies, thus harnessing the mobilizing and empowering effect of both narratives: Whereas the Rabaa victims were recast as martyrs for legitimacy and as shining examples of sacrifice for democratic principles, those who had survived the killings turned from heroes of endurance into heroes of resistance - into revolutionaries who represented the last bastion of democracy and bulwark against tyranny. Both discourses aimed to make sense of the experienced violence and gave purpose to the continued Anti-Coup campaign. This new raison d'être counteracted the worsening collective morale after the defeat on Rabaa Square and provided a boost to street protests too.

\section{Backlash to the Rabaa Massacre}

The extent to which the confrontation on Rabaa Square backfired, not only on the regime but also on the Anti-Coup Alliance's hitherto largely peaceful campaign, was most visible on the second day after the massacres. In a massive backlash, Anti-Coup demonstrators took to the streets across the country in numbers unparalleled since July 3, 2013. This backlash stabilized the campaign's mobilization levels, which had plummeted after the loss of the two main protest sites in the capital. Until mid-August, the tent cities, with their coherent protest repertoire, strict hierarchies, and unified message, provided a model that Anti-Coup sympathizers emulated across the country. The raids on August 14 proved this model to be unsustainable. Isolated attempts to occupy new squares, including Midan Mustafa Mahmoud and Midan Suares in the Cairene quarters of Mohandessin and Maadi, were thwarted by police forces (see Miller \& Gulhane, 2013).

Consequently, the Anti-Coup organizers concentrated on protest marches as the preferred post-Rabaa tactic to carry on the campaign, initially with success: As regards protest rates, the Antic-Coup Friday of Anger even exceeded its 2011 precursor. August 16, 2013, witnessed the highest number of collective actions on a single day during the whole investigation period. In Cairo alone, 28 protest marches converged in Downtown's Ramses Square, where they were met with teargas. The ensuing clashes between militant protesters, police forces, counter-demonstrators, and residents lasted until the next day. These confrontations expanded to provincial capitals, above all, the canal cities of Ismailiya and Damietta, and villages in the Nile Delta. 
Aside from producing a surge of demonstrations, the Rabaa-backlash also manifested in the form of more radical expressions of dissent and a surge of incidents involving collective violence against security forces and minorities. Dozens of assaults on police stations and army checkpoints were reported in all Egyptian governorates, with 15 officers killed in the village of Kerdasa alone (Human Rights Watch, 2014, pp. 104-107) Particularly the provinces of Assiut, Minya, Fayoum, and Sohag were rocked by confessional violence for several days following the massacres (EIPR, 2014, pp. 94-98). The Eshhad Center for the Protection of Minorities (2018) confirmed at least 143 attacks on churches, Coptic priests, and Christian properties in the period under examination. Tellingly, more than 120 of these attacks occurred in the immediate Rabaa aftermath. In some provinces, residents reported that their houses or shop fronts were marked with a cross in the night after Rabaa. Many of these marked properties were ransacked or firebombed in the following weeks. ${ }^{12}$ In most cases, neither the police nor the military intervened to prevent or end the respective attacks.

These attacks were not unpremeditated. They were foreshadowed by weeks of sectarian agitation by extremist elements within the Anti-Coup Alliance at the Al-Nahda and Rabaa al-Adawiya sit-ins. It is reasonable to presume that this hate speech contributed to the spike of sectarian violence. A close examination of the public Anti-Coup rhetoric reveals that sectarian narratives never made it into the NASL mainstream. As demonstrated in the previous chapter, religious references or theological justifications were not central to the Anti-Coup resistance discourse. The antagonism toward the coup regime was mainly articulated around the signifiers of popular, democratic, constitutional, and revolutionary legitimacy, rather than in terms of a struggle of believers against infidels. However, the NASL had tolerated sectarian agitation on the grassroots levels to maintain the support of more radical Islamist constituents. It also welcomed prominent Salafist speakers to their rallies who insinuated links between Mursi's ouster and the alleged machinations of the Coptic Church (Human Rights Watch, 2013c). Most of these speakers pointed to the fact that Coptic Patriarch Tawadros II. had closed ranks with the military leadership as evidence of this claim. Assam Abdel Maged, a leading member of the Gama'a al-Islamiya, even alleged that a new Christian "crusade" against the Islamic state-building project was on its way (EIPR, 2014, p. 9of.).

The alliance thus practiced a certain degree of doublespeak by publicly denouncing violence and calling for national unity, while sharing the Rabaa 
podium and other stages across the country with extremists who blamed the Egyptian Christians for the bloodshed since July 3, 2013. To appeal to radical Islamist supporters while avoiding alienation among the general public, NASL cadres, too, spoke with a forked tongue: On the Rabaa podium, for instance, FJP Vice-Chairman Essam El-Erian made vague insinuations that thousands were standing by, ready to sacrifice themselves for their legitimate president (RNN, 2013b). Furthermore, FJP Secretary-General Mohammed al-Beltagy claimed that the terrorist attacks would not stop until Mursi was reinstalled (Nagi, 2013a). Such statements were widely covered in the Egyptian press, where they were interpreted as an implicit admission of guilt and a smoking gun.

In the context of rising sectarian violence, some players in the Anti-Coup Alliance further embraced divisive language. It is noteworthy that their press releases in the days after the massacres in the capital often rivaled the official Anti-Coup communiqués, illustrating that that alliance itself represented a dynamic arena for internal struggle among closely aligned yet autonomous social players. While the NASL leadership, for instance, framed the arson and lootings across the country as spontaneous eruptions of anger (see Muslim Brotherhood, 2013e), some Anti-Coup subgroups and local Brotherhood chapters implicitly sympathized with the perpetrators by claiming that the police and the Copts had brought it upon themselves by insulting Islam and closing ranks with the coup regime. An infamous post on the FJP Helwan's Facebook page voiced surprise that people were still asking why churches were being burned. It alleged that militant groups sponsored by the Coptic Church had used the chaos in the aftermath of the July 3 coup to vandalize Islamic houses of worship. The statement nominally condemned the ongoing sectarian attacks. But it also justified them as a comprehensible response to the Churches behavior: "Burning houses of worship is a crime. And for the Church to declare war against Islam and Muslims is the worst offense. For every action, there is a reaction" (FJP Helwan, 2013). Such blunt relativizations of violence were often complemented by rumors that the Coptic Church had collaborated with the police to repress the Anti-Coup protest marches. These rumors were also spread through NASL-affiliated media platforms, including the Muslim Brotherhood's Ikhwanonline websites (see Muslim Brotherhood, 2013f.).

This dissemination of hate speech by members of the Anti-Coup Alliance created the impression that the movement had mutated from its initial function as a protest coalition into a coordinating mechanism for militant action. In truth, the NASL never adopted violence as a political strategy. On the contrary, after experiencing deadly police violence, those 
Anti-Coup leaders who were not arrested during the raids categorically distanced themselves from any form of political violence. Realizing the risk of fragmentation into a moderate wing and a more radical basis, the NASL combined the announcement of a new political vision with a categorical renunciation of political violence as a legitimate expression of dissent. NASL statement 72 condemned not only the mass killings of Anti-Coup protesters but also "the acts of violence, arson, and looting against certain churches, several provincial public buildings, as well as police stations" (NASL, 2013aa). The FJP, the NASL's largest contributor, even explicitly addressed the radicalization tendencies at the movement grassroots by stressing there was no justification for "any attack, even verbal, against Copts, their churches or their property" (FJP, 2013a), regardless of whether Copts had supported or participated in the July 3 coup.

This vocal renunciation of violence by the NASL and one of its main tributaries can be understood as a strategic choice. As prior research including on previous social mobilizations in Egypt showed, popular support for state repression depends strongly on whether the threat posed by protesters exceeds the parameters of what is deemed legal and accepted by social practice (Davenport, 2007a, p. 69; Earl, 2003, p. 57). By disassociating themselves from radical resistance tactics, the campaign organizers aimed to sway public opinion in its favor and eliminate new pretexts for repression. Possibly, they also realized how the portrayal of the Coptic Church as part of the coup forces had fostered sectarian antagonism and thus contributed to the violent outbursts. After an initial period of contradictory statements from within the ranks of the alliance, most Anti-Coup members fell in line with this choice.

Aware of the polarization of Egyptian society along ideological fault lines, also Muslim Brotherhood cadres condemned the arson attacks as the acts of criminals who instrumentalized the peaceful protests as a stalking horse for vandalism and terror. Some even accused the police of planting the bombs and staging the assaults on Coptic property to discredit the Islamist movement and legitimize a crackdown (see FJP, 2013b). The NASL parroted these accusations and likened the attacks to the deadly 2011 bombing of the Two Saints Church in Alexandria (NASL, 2013aa). This attack on New Year's Eve was repeatedly portrayed as a false flag operation under the auspices of former Interior Minister Habib al-Adly (F. Ismail, 2011).

\section{Nonviolent Resistance as a Strategic Choice}

These clear rejections of violence as a political means by the Anti-Coup leadership constrained the radicalizing effect of the repression deployed 
against the protesters. Consequently, aside from the horrific arson attacks and assaults in the period between August 14-17, nonstate violence remained a marginal phenomenon on the fringes of the contentious struggle. One of the reasons for this was that the Anti-Coup Alliance had closely tied its conception of legitimacy to the notion of nonviolent resistance. This principled insistence on peacefulness was born out of necessity and initially simply reflected the balance of power on the ground. Brotherhood cadres were keenly aware of their inferior manpower, compared to the Tamarod street protesters, and firepower, compared to the security forces. But it dominated the Anti-Coup discourse even when the protesters found themselves with their backs against the wall. This discourse set the conditions of possibility for contentious performances on the ground, precluding the adoption of tactics that were more disruptive but not primed on nonviolence as a viable strategy.

That the Anti-Coup Alliance retained an almost exclusively nonviolent repertoire of action was indeed surprising. Usually, state repression and oppositional violence are closely related, as research on protest policing has shown (Della Porta, 2014b). With a view to Hamas, the Muslim Brotherhood's Palestinian affiliate, Eitan Alimi (2009) argued that "extreme repression, systematic victimization, and exclusion from the political system can lead certain groups to adopt extreme political agendas and, consequentially, an action strategy for creating political making [sic] opportunities that allow an external struggle against the system" (p. 232). Especially when the costs of staying nonviolent in the face of harsh repression begin to equal the costs of taking up arms - why should players stay peaceful and not defend themselves? Anti-Coup members had faced this question after the dispersal of their camp: as the crackdown intensified, any affiliation with the Brotherhood put even those at risk that ceased protesting.

Moreover, from the outset of the Tamarod campaign, activists in both camps had believed that violence was unavoidable. Even one of Tamarod's founding members Ahmed Adel anticipated a violent escalation of the June 30 protests (Chang, 2013). As Samuli Schielke (2017) recalls, the expectation among Egyptians in May and June 2013 was "that the Brotherhood would not go voluntarily. They would fight back fiercely. They would need to be forced" (p. 210). In describing this anticipation of impending confrontation, some analysts even claim that the ousted Islamists actually welcomed the massacres, "expecting to produce martyrs who would win them international support" (Abaza, 2016, p. 116). While hardly grounded in solid evidence, these speculations testify to the polarized public mood in early summer 2013 . Interestingly, members of both antagonist camps, whom I interviewed for 
this book, confirm these expectations of bloodshed. Some admitted that they craved some sort of tension release, given the strained public mood. On both sides of the political divide, those engaged in mobilizing expected a burst of violence should either the army or counter-demonstrators confront the Anti-Coup sit-ins.

These expectations were nourished by signs that the protesters made use of the weeks-long occupation to prepare for an upcoming battle with the security forces. The perimeters of both sit-ins were visibly fortified with makeshift barricades of paving stones, metal bars, and car wrecks to slow down potential police incursions. Furthermore, dozens of videos uploaded to YouTube, and the reports of visitors to the Rabaa encampment evidenced the organization of self-defense units within the NASL. ${ }^{13}$ These units were charged with protecting marches and patrolling the occupation sites (Kingsley \& Chulov, 2013). Far from a professional militia, they were mostly armed with sticks, wooden planks, and makeshift shields, and carried a hotchpotch of crash helmets and hardhats. Nevertheless, they pointed to a gradual militarization of the alliance's organizational structures.

Even so, the Anti-Coup movement consciously avoided further alienating the Egyptian public by choosing a nonviolent approach. The protest event catalog illustrates how it succeeded in mobilizing its supporters in an almost exclusively non-violent campaign throughout the entire summer of 2013. Against expectations, the constant need to adapt to deteriorating conditions for voicing dissent did not entail a gradual radicalization of the Anti-Coup Alliance's repertoire. The weak convergence of repression and protester violence might be attributable to the relatively short timeframe under scrutiny, as the historical precedents of Islamist coup-ousting have demonstrated. In Algeria, for instance, the radicalization of Islamist groups in the civil war period was preceded by a phase of peaceful mobilization that lasted for multiple years (M. Hafez, 2003, p. 200). During the examined timeframe, however, the charge that Anti-Coup Alliance turned violent after Rabaa is not supported by facts.

Each of the violent events discussed in the previous chapters provoked a temporary flash of violence. But the analysis reveals no lasting influence of police repression on the Anti-Coup repertoire of contentions (see Figure 12). After the Republican Guard massacre on July 7 and the clashes of Nasr street on July 27 , protester violence was short-dated and stayed spatially limited to the immediate confrontation site. It subsided in the early morning of the 
Figure 12 Political violence throughout the protest cycle

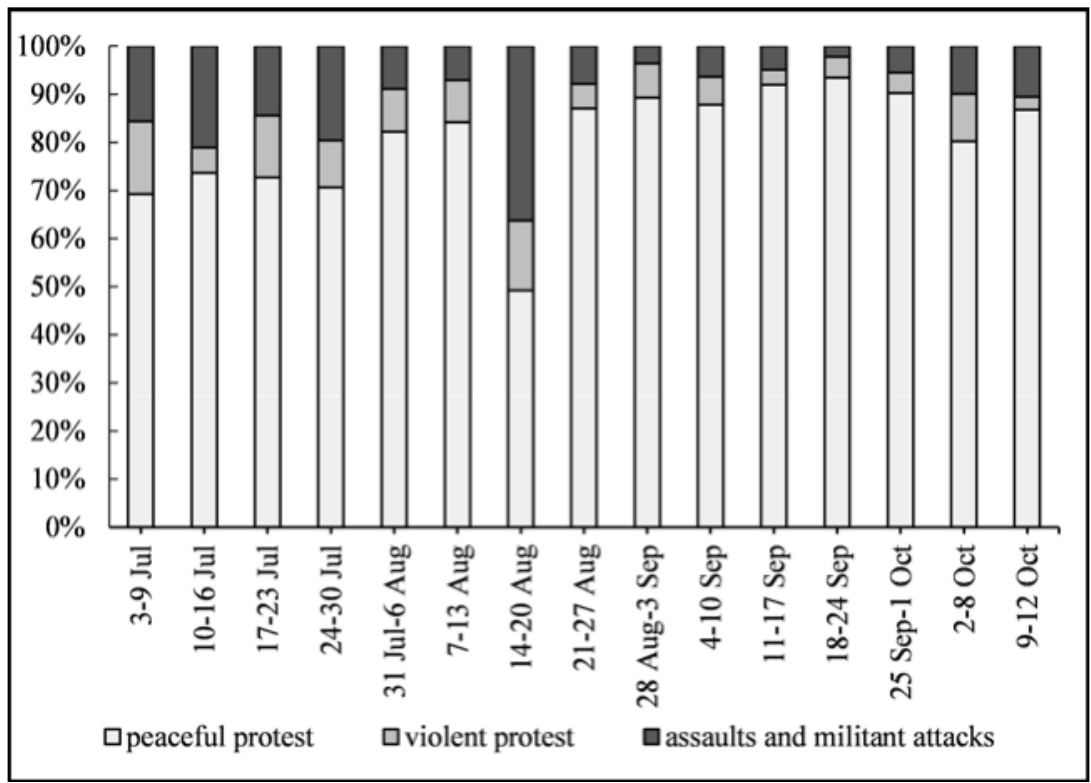

following day (Kingsley \& Green, 2013). Only in mid-August did repression provoke violent outbursts that transcended the immediate surroundings of the raids. Except for this short period in the Rabaa aftermath, protester violence remained confined to scattered incidents.

Notably, in most of these cases, violence remained highly situational. In some cases, it originated from baltagiya who interrupted Anti-Coup protest marches to provoke a violent response. In others, it resulted from the escalating tensions between rival protesters. On Mandate Friday, for example, Anti-Coup supporters clashed with nationalist demonstrators who had heeded Al-Sisi's call for protest. The ample street battles that ensued caused heavy casualties on both sides (EIPR, 2014, pp. 53-56). The overall picture of the protest cycle, however, shows that political violence was neither a strategic component nor a dominant concomitant feature of the Anti-Coup campaign. Violent behavior by protesters rather decreased over the investigation period. Particularly after the Nasr Street clashes on July 26,2013 , in the second half of the reviewed period, the protest organizers exerted a moderating influence on their followers.

The same is true for assaults on police and army personnel. If anything, their rate rather declined. Given that no direct link could be established between these attacks and the Anti-Coup campaign on a logistical level, 
it is likely that their perpetrators acted on their initiative and against the strategic interest of the protest campaign. Notably, these findings contradict the narrative produced by the Egyptian authorities who justified their declaration of martial law and the curtailing of civic freedoms with the threat posed by the Anti-Coup militias (Dworkin \& Michou, 2014, p. 6). In particular, the state's loss of its monopoly of power in the North Sinai province, evidenced by a sharp increase of bombings and assaults on checkpoints, was quoted as evidence for the Muslim Brotherhood's growing militancy - even after the jihadist Majlis Shura al-Mujahid and Ansar Bayt al-Maqdis claimed responsibility for the attacks (Gold, 2014). It is probable that the Anti-Coup leaders consciously chose a nonviolent approach to disassociate themselves from these extremist groups and their respective ideological and logistical ties to Al-Qaeda and the Islamic State. But the adoption of a nonviolent repertoire and a prognostic frame that stressed peaceful resistance as the only legitimate means of campaigning had also a strong prefigurative element as it reflected the NASL's broader conception of legitimacy.

This is not to say that Mursi's supporters did not resort to violence at all. Video evidence, as well as interviews conducted with Anti-Coup protesters, confirm that the players allied in the NASL resorted to stonethrowing and condoned the use of Molotov cocktails (and occasionally also of handguns and makeshift firearms). In addition, punctual outbursts of violence accompanied some of the larger protest events. In one widely mediatized incident on July 21, 2013, supporters of the ousted president carrying a black Salafist banner pushed opponents off the roof of a water tower in the Sidi Gaber area of Alexandria (Hawksley, 2013). Moreover, human rights organizations presented evidence that some participants of the Anti-Coup sit-ins had forcibly held and tortured suspected state security informants at the campsites in Cairo, including under one of the podiums of the Rabaa al-Adawiya sit-in (Amnesty International, 2013b). But these brutal outbursts largely point to transgressions committed by protesters individually, rather than a characteristic feature or strategic choice of the Anti-Coup Alliance. For the most part, they were deplored (albeit not punished) by the broader protest collective. As a result, such violent behavior remained the exception rather than the rule. Against expectations, the constant need of adapting mobilizing structures and contentious repertoire to worsening protest policing, the restriction of public spaces for the public articulation of political dissent, and the suppression of peaceful means of resistance did not entail a radicalization of the Anti-Coup Alliance. 


\section{Tactical Adaptation}

Rather than general behavioral laws, situational mechanisms of adaptation dominated the alliance's reactions to repression. These findings are in line with Neil Ketchley's (2017a) analysis of the evolution of protest in the years after the 2011 uprising. While our databases differ, both reveal the same adaptive trends, thus demonstrating the benefits of a disaggregated approach to the study of the protest-coercion-nexus. Rather than binary notions of escalation vs. de-escalation, what could be witnessed were processes of decentralization and diversification within the Anti-Coup movement's contentious repertoire. Violent encounters, instead of precipitating a mechanical shift towards or away from violence, were learning occasions for police forces and protesters, who both adapted their behavior to each other after these confrontations (see Della Porta \& Tarrow, 2012; McAdam, 1983).

In contrast to Charles Tilly's (2008) controversial claim that "contentious performances change incrementally as a result of accumulating experience," and not because of "great events" (p. 5), it was precisely such great events - a coup, a mass shooting, and two massacres - which acted as triggers for tactical innovation in the summer of 2013. Especially after the pivotal massacres in mid-August 2013, adaptation and the development of an innovative contentious repertoire enabled the protesters to cope with the loss of their operational bases.

\section{Decentralization and Temporal Concentration}

After the brutal skirmishes in late July, participation levels had recovered gradually, but following the massacres of Rabaa and Al-Nahda, the turnout rates abruptly dropped to the lowest level since early July (see Figure 13). This setback can be attributed, above all, to spatial decentralization processes as protesters quickly adapted to the destruction of their operational bases in the capital. In a call to the free people of Egypt, the NASL explicitly stated this decentralization as one of its six campaign principles to cope with the increasing challenges of maintaining organizational coherence. These principles included the rejection as illegitimate of all acts carried out by the coup government in the frame of its fight against terrorism, the escalation of civil disobedience tactics, the duty to continue mobilization without interruption, and the decentralization of the protest campaign, on the spatial level, to different villages, districts, and neighborhoods, and on the organizational level, to women, youth and girls (NASL, 2013ac). 
Figure 13 Impact of transformative events on protest turnout

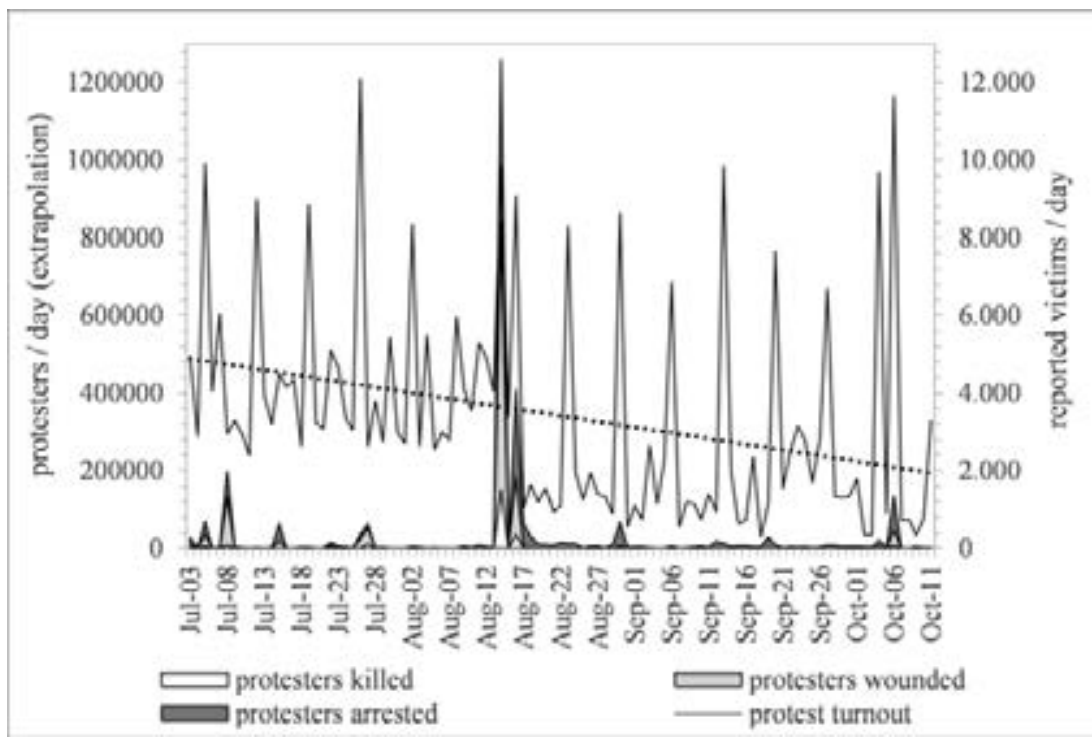

Figure 14 Impact of transformative events on protest rates

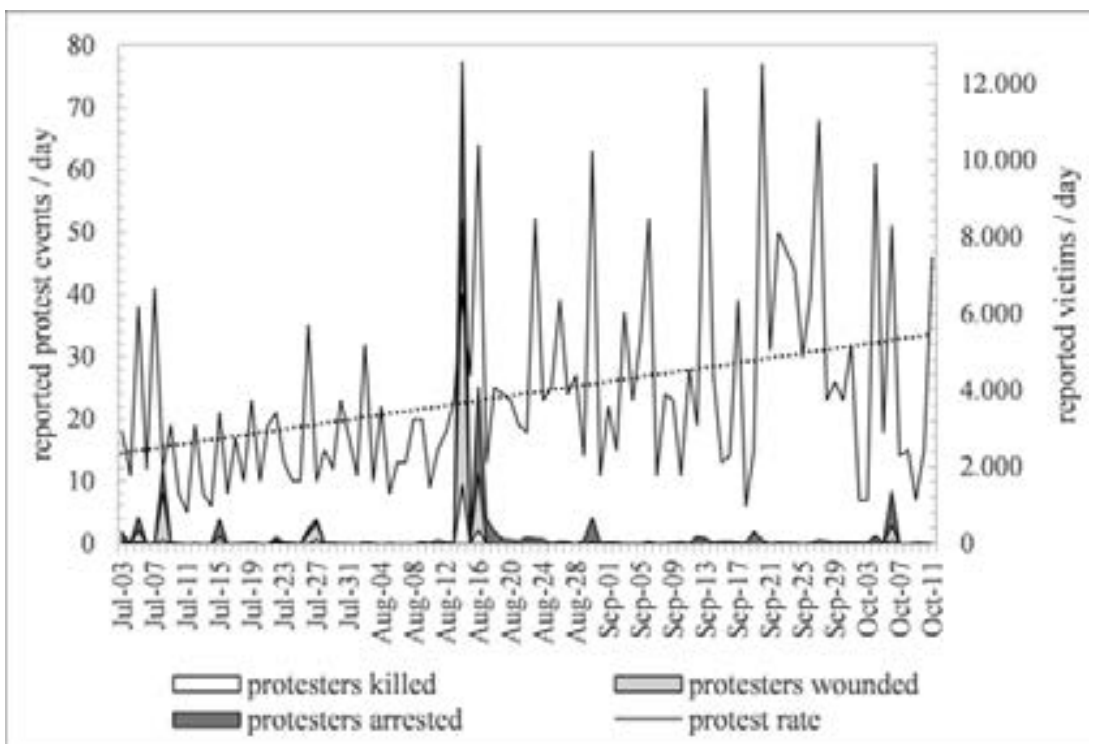


Until mid-August 2013, the protest camps of Rabaa and Al-Nahda had geographically concentrated the majority of the unseated president's supporters and served as hubs for protest marches. They had also formed spaces where innovative tactics could be developed, tested, and diffused (McCurdy et al., 2016, p. 98). By asserting territorial control over these spaces, the security forces reproduced a known tactic from the Mubarak era: ahead of important dates, the former regime had often fenced off symbolic public spaces into small plots, thereby impeding street mobilization (Shokr, 2015). These restrictions had crumbled when protesters claimed Tahrir and removed these crowd barriers in 2011, transforming the plaza into a central urban "space of resistance" (Soudias, 2015, p. 173).

Determined not to allow history to repeat itself, the authorities moved swiftly after clearing Rabaa Square and Al-Nahda Square from protesters. To prevent new occupations, police forces took control of urban landmarks, barred access to infrastructural hubs, and increased their presence in the center of all provincial capitals. In anticipation of the protest, authorities had cordoned off most ministries, administrative buildings, and military installations with razor wire and anti-vehicle barriers since Mursi's ouster. After Rabaa, these blockades were extended to strategic junctions and potential gathering points for protesters, including mosques and prayer rooms. From mid-August, the most symbolic squares, streets, and bridges including the surroundings of Rabaa and Tahrir Square were sealed off. On weekends, even metro stations in the vicinity of the squares were put out of service.

The country's mosques and Qur'an schools faced restrictions, too, as the government re-established territorial control over potential gathering points. After the nationwide close-down of all FJP-offices, they had often functioned as meeting points for protest marches. In early September 2013, the Ministry of Religious Endowments compiled a set of provisions that were intended to curtail the Brotherhood's control over these spaces (see Morsy \& Brown, 2013). Closing ranks with the Grand Imam Ahmed Tayyeb, who had welcomed the coup against Mursi in the name of the Al-Azhar institution, Minister Mohamed Mukhtar Gomaa declared illegal all prayers outside of officially licensed mosques. His decree restricted the weekly Friday prayers to licensed mosques of at least 80 square meters. In the context of decades of repressions against Islamists in the Arab world, these provisions were not a first: just as during the campaign against the Gama'a al-Islamiya in the 1980s, they aimed at regaining the state's control over the content of the Friday prayers and the distribution of the Sadaqat [voluntary donations]. These had served as efficient mobilization mechanisms for the Brotherhood and its allies (S. Ismail, 20o6, pp. 31, 71-77). 
In the weeks after, the countless smaller and privately funded mosques and local Zawiyat [rooms of religious retreat], which were among the Brotherhood's traditional centers of recruitment and influence (see Gaffney, 1991), were progressively closed down. Besides, Gomaa's decree also implied a general ban on all gatherings inside or outside of mosques. This heavy regulation of the public space complicated the task of organizing the musira khashida [mass demonstration] that was characteristic of the Anti-Coup campaign's inaugural phase. Nearly 40 percent of all Anti-Coup protests had started from these locations; as Ketchley (2013, p. 16) showed, the comparatively high density of protest in specific quarters of Cairo and Alexandria even correlated with the higher concentration of mosques in these areas. However, rather than curbing protest rates, the progressive closure of public spaces only promoted the tactical diversification of the Anti-Coup repertoire.

The restriction of public space provoked a spatial decentralization of the Anti-Coup campaign, as events with hundreds of thousands of participants were deprived of their spatial basis. This evidence is substantiated by the trajectory of the average protest size, which swiftly dropped in mid-August and settled substantially below 10,000 participants, with around 220,000 average reported protest participants per week. However, this considerable drop in daily turnouts and the average size of Anti-Coup events did not denote a reduction of mobilizing power: realizing that its centralized way of operating predisposed it to fail, the movement replaced mass events with smaller and more dispersed protests in byroads. Consequently, the event data documents a surge of smaller protests following the mass killings (see Table 1). Most of the locations where violent encounters had taken place were avoided - as were larger squares. This constrained the police forces' ability to target and weaken the movement in a single blow.

Events involving tens of thousands of participants became less frequent and concentrated on important key dates, such as the regular miliuniya after the Friday prayer. As the regular weekly peaks on Friday show, these demonstrations were less affected by the declining turnout on weekdays. They attracted up to a million protesters even after the August 14 massacres (see Table 1). Fridays in the immediate Rabaa aftermath even witnessed a surge of participants, and some of the vigils for its victims, including on the Friday of Rage two days later and the Friday of Martyrs one month later, were among the largest reported Anti-Coup protest events during the entire investigation period. ${ }^{14}$

14 The twin peaks at the beginning of October can be attributed to Armed Forces Day. This national holiday had a strong mobilizing effect on the Anti-Coup protesters due to its symbolic 
Table 1 List of Anti-Coup miliuniya protests, Fridays highlighted

\begin{tabular}{|c|c|c|c|}
\hline Date & Motto of the miliuniya & $\begin{array}{l}\text { Reported } \\
\text { protests }\end{array}$ & $\begin{array}{l}\text { Extrapolated } \\
\text { turnout }\end{array}$ \\
\hline 5 July & Day of rejection & 38 & 990.000 \\
\hline 9 July & The first night of Ramadan & 19 & 330.000 \\
\hline 12 July & Together against the bloody coup & 19 & 900.000 \\
\hline 15 July & Remember the martyrs & 21 & 450.000 \\
\hline 19 July & $\begin{array}{l}\text { Resistance in order to break the coup / 10th of } \\
\text { Ramadan }\end{array}$ & 23 & 885.000 \\
\hline 22 July & Right of martyrs & 21 & 510.000 \\
\hline 26 July & Breaking the coup & 35 & $1,210,000$ \\
\hline 30 July & Martyrs of the coup & 23 & 545.000 \\
\hline 2-Aug & Overcoming the coup & 32 & 835.000 \\
\hline 4-Aug & Laylat al Qadr & 22 & 550.000 \\
\hline 8-Aug & Aid el Fitr & 20 & 595.000 \\
\hline 9-Aug & Steadfastness against the coup & 20 & 410.000 \\
\hline 14-Aug & Rabaa Massacre & 40 & 985.000 \\
\hline 16-Aug & Friday of rage & 64 & 910.000 \\
\hline 23-Aug & Friday of martyrs & 52 & 830.000 \\
\hline 25-Aug & Start of the "people leading the revolution" week & 25 & 125.000 \\
\hline 30-Aug & The people reconquer the revolution & 63 & 865.000 \\
\hline 3-Sep & The coup is terrorism & 37 & 265.000 \\
\hline 6-Sep & The people protect their revolution & 52 & 685.000 \\
\hline 13-Sep & Loyalty to the blood of the martyrs & 73 & 985.000 \\
\hline 20-Sep & The youth continue the revolution & 77 & 765.000 \\
\hline 27-Sep & The youth is the pillar of the revolution & 68 & 670.000 \\
\hline 5 October & The people restore the spirit of 6 October & 61 & 970.000 \\
\hline 11 October & Tahrir for all Egyptians & 46 & 330.000 \\
\hline
\end{tabular}

Lower turnouts on weekdays are partly explained by protesters' need to return to their jobs and provide for their families (Ketchley, 2017a, p. 134). For many protesters, engaging in daily street demonstrations came with severe neglect of their businesses and working routines. This also explains why the starting time of protest marches on workdays gradually moved into the night, after shop closing time (see Figure 15). Additionally, the temporal concentration of contentious collective actions can be attributed to the better protection offered by the Friday events because of their large size. Over the summer of

character. October 6 honors the Egyptian army for its crossing of the Suez Canal and capture of the Israeli Bar-Lev defense line on Sinai in 1973. To raise awareness for the army's involvement in recent massacres, the Anti-Coup Alliance organized numerous counter-events to the October 6 celebrations and on Friday before the anniversary. 
Figure 15 Timing of the Anti-Coup protests

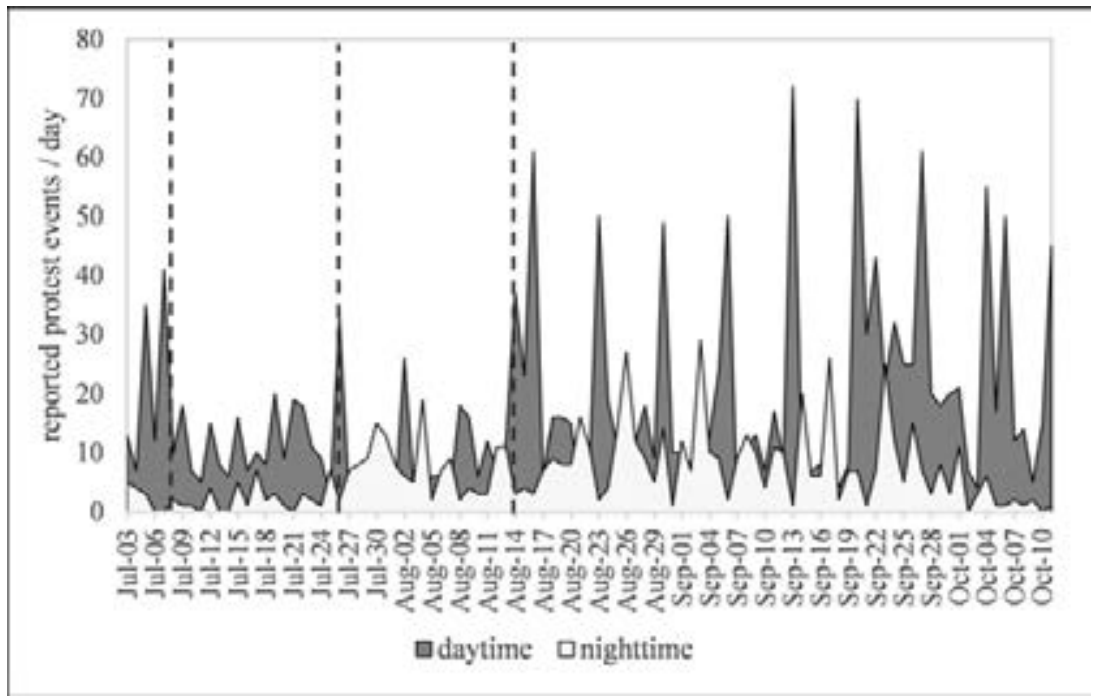

2013, the use of deadly force became a routine policing practice as the police took previous violent encounters with Anti-Coup protesters as a pretext to operate a shoot-to-kill policy. During the dispersion of the Rabaa and Nahda camps, for every five injured demonstrators, there was one who died of his wounds. Against this backdrop, the large crowds on Friday, at least, raised the repression costs for the CSF units charged with dispersing the protests.

The interim government aimed to lower these costs not only by legalizing the use of live ammunition against protesters but also by imposing a nationwide state of emergency in the month after the Rabaa clearing. The decree endowed the security forces with far-reaching competencies and remained in effect until the end of our investigation period, including curfews in 14 provinces. The Friday protests eventually became a way to circumvent these curfews as attending the Friday sermon at the mosque provided a pretext for political gatherings. To counter this recurrent mobilization, Egypt's Ministry of Religious Endowments, in early September 2013, declared all Friday prayers a prerogative of imams trained by Al-Azhar whose sermons were to be approved by the state-controlled institution's council of elders (RNN, 2013d). De jure, this implied that more than 55,000 freelance imams were barred from preaching on Fridays or carrying out collections on behalf of the Anti-Coup coalition. De facto, however, this impacted little on participation rates. While individual marches grew smaller in size, their frequency somewhat increased throughout the investigated timeframe. 


\section{The Coalition Diversifies}

After several weeks of protest, many Anti-Coup coalition members returned to a regular working schedule, thus causing a shift of protest to non-business days. It was only due to functional shifts in the composition of the Anti-Coup coalition that the still relatively high frequency of collective actions could be sustained on weekdays throughout the investigation period. Above all, women, whose employment rate in Egypt lies significantly below that of men, increasingly took responsibility for organizing marches and human chains.

As Erika Biagini (2017) illustrates, the post-coup period saw the establishment of several women-only movements both, within and independent of the Muslim Brotherhood and the Anti-Coup coalition. Of these groups, Women Against the Coup was the most active in coordinating women's activities across Egypt, moving to the forefront of the NASL as more male coalition members were jailed or killed. Above all, members of the Muslim Sisterhood progressively replaced men in their positions, thus gradually emerging themselves as leading links in the organization of protest marches and the dissemination of new slogans and tactics. Their increased participation in the protests came with the significant advantage of greater tolerance from the side of the security forces. It seems police appeared "more hesitant to act against them than male Muslim Brotherhood members, giving them the freedom to join demonstrations and preserve group cohesion through regular meetings" (Noueihed, 2014).

These changes within the mobilizing structures of the alliance, however, did not necessarily reflect change within the organizational structures of the NASL's tributary movements. While the forced exile of NASL leaders and the jailing of Muslim Brothers thrust women within the coalition into the vanguard of its battle for survival, the leading ranks abroad remained foreclosed. By contrast, within the Brotherhood, the need to rely on womanpower to sustain the movement in Egypt provided leverage for the Muslim Sisters, slowly creating niches in the group's local hierarchies. This development reinforced a trend that started in the aftermath of the 2011 uprising when Muslim Sisters made use of the opening spaces to participate in Islamic activism and assume political offices - often aligning with the conservative male leadership for tactical purposes (see Biagini, 2020).

In a similar vein, collective actions organized by students and youth organizations established by Anti-Coup sympathizers compensated for the declining protest activity by the core members of the alliance. With the start of the academic winter semester in September, Egypt's governorates witnessed a rise of protests in educational institutions where the state's 
monopoly of power had been curtailed by a series of administrative court decisions since 2009 (Abdel Salam, 2013). These protests were mostly organized by the groups Students Against the Coup and Youth Against the Coup, two Anti-Coup youth chapters that successfully recruited fresh members for the campaign, mainly from the high schools and universities where they organized a series of decentralized rallies. Ketchley (2013, p. 13) also observed a surge of Anti-Coup activities at public schools. Many of the students and pupils who organized and mobilized for these protests had been politically inactive during earlier phases of the NASL's resistance and were compelled to partake in protest only by the victimization of their friends and relatives. Accordingly, the protests on schoolyards often took the shape of solidarity actions and advocated a release of political prisoners. Often they were even organized or joined by the sons and daughters of demonstrators who had been arrested earlier.

The emergence and success of the Anti-Coup youth chapters effected another shift in the composition of the Anti-Coup coalition. The bulk of their members hailed from the ranks of the Muslim Brotherhood, which is made up in no small part (around 210,000-245,000) of young men below the age of 35 (Tammam, 2012, p. 35). Since the 2005 Kefaya campaign against Mubarak's re-election, these younger Brothers regularly participated in anti-government demonstrations, albeit not under the official banner of the organization (Martini et al., 2012, p. 11f.). During the 2011 uprisings, too, many young Islamists joined the Change Youth Coalition and the Revolutionary Youth Coalition. They played a crucial role in defending the Tahrir camp against police forces (Al-Awadi, 2013, p. 541f.). These prior protest experiences provided the Brotherhood youth with expertise in contentious politics which they could now rely on despite the weakening organizational structure of the Anti-Coup coalition.

Within the youth movement, through further functional differentiation, several specialized subgroups realized an active division of labor in the implementation of the Anti-Coup protests under the roof of the Youth Against the Coup movement: A dedicated Anti-Coup women chapter, for instance, became the central organizing body for teenagers and schoolgirls, in addition to the newly founded $7 \mathrm{Al}$-Sobh [7 in the morning] movement, named after its early morning demonstration in the Roshdy neighborhood of Alexandria on October 31, 2013 (see Antoun \& Parietti, 2013). ${ }^{15}$ In turn, the 'Afarit did

15 The 7 a.m. movement became widely known for a series of mass trials against 21 young female Anti-Coup protesters, including several minors, who had been arrested in the group's first protest event. The hastily conducted trials ended on November 26, 2013, in a series of 
al-Inqilab [Afrits/Demons Against the Coup ${ }^{16}$ ] took charge of organizing the nightly protest marches. These specialized groups complemented the professional protest chapters that the Anti-Coup coalition had established from its outset in various segments of the labor market, such as the Doctors Against the Coup, Lawyers Against the Coup, or Engineers Against the Coup chapters. With this penetration of different social sectors, the NASL tried to imitate the winning formula of the 2011 uprisings which, according to common wisdom, had consisted in the successful coalition-building across the sectors with the largest mobilization potential in Egyptian society.

In sum, the interaction with repression agents not only led to a spatial but also a functional decentralization and differentiation of the Anti-Coup protests, markedly impacting the composition of the protesting coalition of contenders. What Rune Ellefsen (2016) has described as "leadership decapitation" (p. 449) contributed to this trend. Due to the Muslim Brotherhood's secretive and protectionist information policy and the non-transparent internal hierarchies of its party, it is hard to accurately identify the leading figures inside the group and its coalition partners. However, the data released by Wiki Thawra offer a rough overview of arrested Islamists believed to be part of the organization's cadres. The targeted arrests documented therein broadly match the counts by senior Ministry of Interior officials, according to which around three thousand Islamist cadres had been detained by March 2014, most after the protest camp raids in August 2013 (see Figure 16). Until then, the tent cities had offered Anti-Coup leaders a relatively safe harbor. Arrest rates stayed low because the police refrained from incursions into the inner circles of the camps.

This changed with the crackdown on the squares. The rapid neutralization of the alliance's highest echelons after the Rabaa and Al-Nahda raids required the constituent parts of the Anti-Coup movement to adopt decentralized and leaderless forms of organizing (El-Sherif, 2014, p. 7). The incarceration of leaders also complicated the regular feedback loops in the drafting process of the Anti-Coup statements. Consequently, a small group of editors gradually assumed almost exclusive authority over the NASL's editorial lines. Henceforth, disagreements over the presented narratives were not resolved

harsh verdicts against the defendants. Adults received prison sentences of 11 years on charges of vandalism, thuggery, rioting, illegal public gathering, and the use of weapons. Those below 18 were sentenced to juvenile detention. The Sidi Gaber Minor Offenses Court later commuted the sentences to probation sentences of three to twelve months (Human Rights Watch, 2013d). 16 The term 'Afarit is derived from Islamic mythology, where it denotes a powerful Jinn or demon that is usually identified with the spirit of someone who suffered a violent death and who roams the earth to take revenge on the ones responsible. 
Figure 16 Impact of leadership decapitation on protest frequency

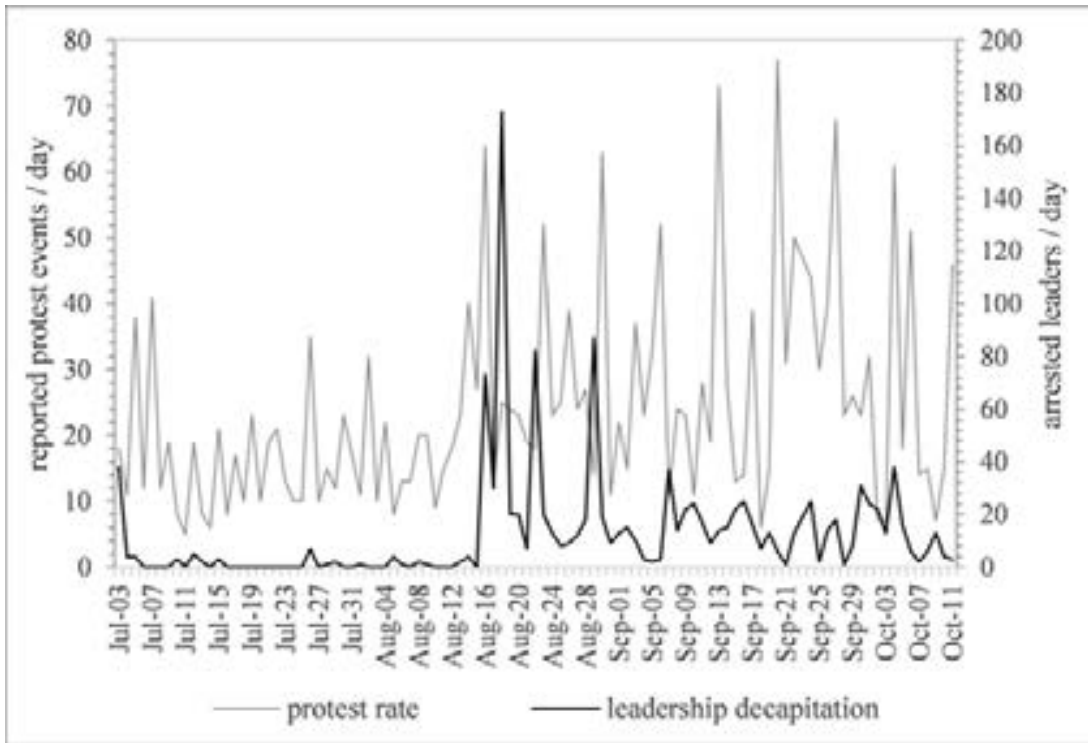

through lengthy drafting processes but through follow-up statements that corrected or restated certain formulations. ${ }^{17}$ Along with the trend towards decentralization and temporal concentration, the movement's contentious repertoire diversified in the interaction with the security state. Figure 17 illustrates how particularly after Rabaa, new protest tactics emerged as demonstrators pragmatically adapted to the destruction of their operational bases. Marches remained the most common protest form, but large-scale sit-ins were partly substituted by human chains, smaller hit-and-run protests, and creative tactics.

These flexible performances allowed for a more spontaneous organization and were better suited to evade state policing. With the emergence of Students Against the Coup and Youth Against the Coup particularly, schools and universities developed into hotbeds of resistance. They also gave rise to a range of innovative and often creative protest performances. The Anti-Coup students made use of their dorms, faculties, and schoolyards as stages for collective action, combining their local context with a globalized repertoire of creative tactics (Spiegel, 2016, p. 535). For example, in Mansoura students organized a series of public theater performances that re-enacted the massacres of Rabaa and Al-Nahda; in Port Said they released balloons with the 
Figure 17 Evolution of the Anti-Coup repertoire

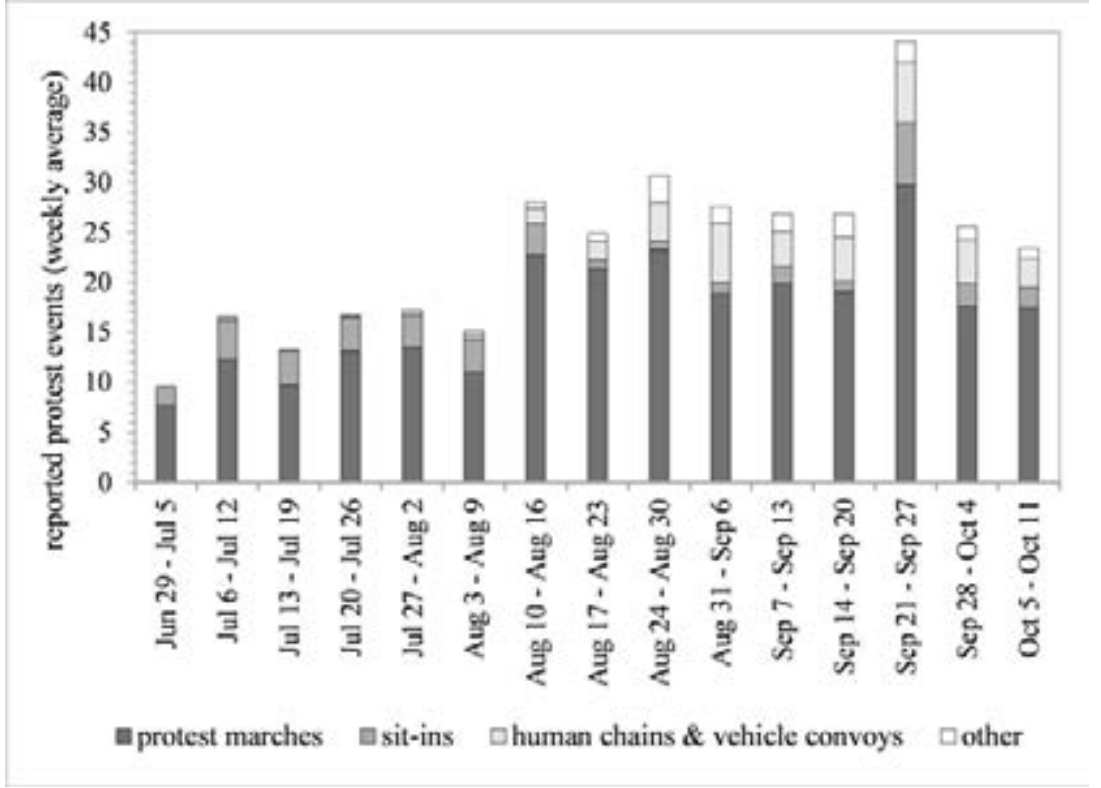

R4BIA imprint into the Suez Canal; and in Assiut, they commemorated the Rabaa martyrs with a series of soccer matches.

Inspired by the success of its youth chapters in generating resonance with their localized creative actions, the Anti-Coup Alliance adopted a civil disobedience campaign against the public sector and private enterprises that had supported Mursi's ouster. The alliance's August 20 statement called for a country-wide boycott and provided explicit instructions for the provincial chapters on how to respond to the destruction of the alliance's tent cities. Provincial Anti-Coup chapters were entreated to rejoinder with an escalating civil disobedience campaign and a new tactical repertoire that targeted newspapers, satellite channels, and websites that had supported the coup, incited hatred, and misled the public with their propaganda. The protesters were also asked to target businessmen who had supported the coup with a boycott of their products and services. This included companies run by the military and its associated enterprises.

Furthermore, train and metro traffic was affected by a rising number of blockades. In the countryside and alongside wide connecting roads, car convoys, motorcycle rallies, and human chains emerged as innovative tactics that circumvented structural repression. This proxy-targeting of the state was less hazardous than large sit-ins but caused significant disruption 
to public life, nevertheless. Because of this tactical diversification, the movement could make its presence felt in residential neighborhoods. As mainstream news coverage boycotted the protests and the Anti-Coup social media campaigns failed to reach most households, human chains and car convoys offered a comparative advantage to "protest camping" (McCurdy et al., 2016, p. 100). Taking place on the major commuter arteries and traffic nodes during rush hours, these decentralized performances were more salient in the urban public space and reached a broad audience as passers-by were inevitably confronted with the protesters' messages. Moreover, human chains and motorcades on thoroughfares were easy to organize and hard to disperse, while orchestrating large urban sit-ins and running entire tent cities posed significant logistical challenges (McCurdy et al., 2016, p. 101).

Following the same logic, so-called farasha [butterfly] protests spread in residential areas where security forces enacted a particularly restrictive curfew policy. The expression captures a variety of hit-and-run tactics that involved protesters changing their location in short intervals, or scattering after only a few minutes (Ketchley, 2017a, p. 144). The model of the butterfly protests was emulated across the entire country, with the newly formed Anti-Coup chapter Afrits Against the Coup working as a diffusion network. Just as the earlier protest camps in Nasr City and Gizah had been a model emulated by sit-ins in other parts of the country, the farasha tactics and other alternative protest performances quickly spread. A decisive advantage of the new protest forms compared to marches or sit-ins was that they circumvented the blockades and crowd barriers erected by the security forces in Egypt's urban centers after Mursi's ouster.

The diffusion of effective tactics was a recurrent phenomenon during the entire investigation period. Demonstrators in the protest epicenters mostly adapted their repertoire from known model cases where the envisioned tactics had been successfully applied by others. In Port Said, for instance, demonstrators occupied the Tawhid Mosque for several weeks mimicking the camps in the capital. In Alexandria, the Qaid Ibrahim Mosque became the site of several sit-ins. The butterfly protests, in turn, originated from the city of Assiut, where demonstrations were often attacked by hired thugs during curfew hours. In contrast, car convoys and motorcycle rallies made their way into the Anti-Coup repertoire from the Sinai and Fayoum governorates, where local Bedouin tribes traditionally employ motorcades to add weight to their political demands. All official attempts to prevent such diffusion processes - for example, by banning the use of motorcycles in Sinai - were unsuccessful. 


\section{Discursive Path Dependencies}

The body of statements issued by the National Alliance in Support of Legitimacy after the military ouster of Mursi on July 3, 2013, laid the basis for a protest campaign in the name of legitimacy which dominated Egyptian politics in the summer of 2013. It also strongly conditioned the trajectory of this very campaign - by restricting potential alliances with other political players, and by delimiting the horizon of thinkable repertoires of contention. As the Anti-Coup campaign suffered from unprecedented repression at the hands of the state, the NASL found itself in a quandary: At the Islamist base, the shared experience of victimization contributed to the stabilization of its oppositional identity and the antagonism between the supporters of deposed President Mursi and those who had supported his ouster. This political subjectivation was supported by discursive structures that portrayed the Brotherhood and its coalition partners as martyrs for both, democratic norms and religious values, as well as defenders of constitutional legitimacy and the rule of law. However, given the struggle over the definition of popular legitimacy in the months before Mursi's ouster, the NASL failed to appeal to a broader audience with this discourse.

In contrast to the 2005-2007 Kefaya campaign and the protests against Mubarak in 2011 (see Clarke, 2011, p. 406), the call to restore legitimacy (and, by extension, to reinstate Mursi) was no lowest common denominator that could be used for multi-partisan mobilization. Instead, it was an expression of the Muslim Brotherhood and its sympathizers' vested interests which, due to the erratic performance of the Mursi administration, was not met with a lot of enthusiasm outside of Islamist circles. As described in the third chapter of this book, large masses of Egyptians, including many players who had been key in mobilizing against Mubarak in 2011, had welcomed the removal of Mursi who, in their eyes, derived his only legitimacy from a narrow victory in a contentious election. Not realizing that "consent must be secured not just at the ballot box, but at every critical juncture," as the blogger Baheyya (2012) succinctly argued, Mursi had done little to placate his opponents' fears of the advent of an Islamic state in Egypt. Instead, the popular impression was that he had pursued an exclusivist winner-takes-all policy, alienating the revolutionary opposition along the way.

By the time that the Tamarod campaign filled Tahrir Square, his uncompromising stance had undermined Mursi to such a degree that any claims to his democratic legitimation held little credibility outside of his constituency. As illustrated in Chapters 4 and 5 , competing interpretations of the police operations against the Anti-Coup demonstrators further added to 
the polarization of Egypt's political arena. By excluding the army from its list of foes, the NASL initially sought to overcome this polarization and reproduce the solidarization effect of 2011. During the Tahrir uprising, according to John Chalcraft (2014), the demonstration of a united popular will had made it that much harder for the regime to resort to lethal violence for the risk that such a move would have sparked "disunity in the ranks and the rebellion of junior officers" (p. 176). But these attempts remained largely unsuccessful.

Instead, the fact that the Anti-Coup campaign failed to inspire even marginal support for its policies from within the military's ranks was indicative of the Muslim Brotherhood's political isolation by the time of Mursi's deposition. Faced with a strongly segmented and extremely polarized public (K. Hafez, 2015), and within the context of growing perceptions of insecurity, the Anti-Coup movement was unable to defend its version of events against the securitized frames of the administration.

Moreover, it failed to develop innovative frames that appealed to players beyond the Islamist oppositional spectrum, for instance, by building upon or modifying its legitimacy frame in a creative and inspiring way. Consequently, the Islamists' nonviolent protest campaign under the banner of legitimacy rather contributed to the stabilization and performative reproduction of the discursive frontier between the coup and the anti-coup forces. Over the course of the investigation, the Anti-Coup legitimacy discourse turned into an insurmountable obstacle for cross-ideological alliance-building because it placed the central players in post-coup Egypt within irreconcilable political camps.

As I have shown in this chapter, this precluded popular solidarity when civilian protesters were butchered in a series of brutal massacres. Even after Rabaa, the NASL failed to bind new supporters. The Anti-Coup Alliance's moral devaluation of all those who had initially supported the coup, and their branding as accomplices of previous massacres effectively forestalled a wave of solidarity with the victims of police repression. In addition, weakening organizational unity, brought about by the targeted arrests of leading cadres and the closure of public spaces, gave rise to violent eruptions from within the movement which the debilitated leadership was unable to contain. This only further cemented political antagonisms in post-coup Egypt.

While failing to extend the movement's support base, however, the principled nature of the Anti-Coup discourse on peaceful protest as the only legitimate way of resistance also ensured the movement's survival. It also prevented it from following the path of jihad that would inevitably have entailed a fragmentation of the contentious coalition and a discrediting of its political aims. The alliance was held together by a discourse that defined the Anti-Coup campaign as a popular movement that was peacefully resisting a violent, 
unconstitutional, and undemocratic counterrevolution. This discourse set the parameters for the NASL's contentious repertoire. Abandoning the nonviolent approach would have critically endangered the alliance's collective identity. Accordingly, instead of experiencing a gradual radicalization, the NASL adapted to the brutal crackdown with processes of decentralization and diversification.

The surge of contentious performances that did not depend on specific geographical points of assembly; the concentration of mass protest on Fridays; the postponement of protest marches to dusk; and the proxy-targeting of institutions seen as an extended arm of the regime all represented strategic substitutions of established performances by more effective tactics (Davenport \& Loyle, 2012, p. 80). They came along with personnel changes regarding the composition and organization of collective actions. Without these adaptations, particularly the Muslim Brotherhood would hardly exist anymore as an organization in Egypt today beyond the very atomized usra [family] level, the smallest organizational unit within the group. In this sense, the peaceful Anti-Coup campaign - which persists up to this date, albeit on a much smaller scale - became a self-serving survival mechanism for the Brotherhood and many of the players organized in the NASL. While unsuccessful regarding the goal of reinstating Mursi, their resilience after the defeating blow of Rabaa kept the disapproval of the military return to politics present in the public sphere (Schwedler, 2018, p. 83).

Ultimately, the contentious episodes in the summer of 2013 caused a two-sided backlash. As the next chapters illustrate, particularly the Rabaa and Al-Nahda massacres marked not only a turning point for the Anti-Coup protesters, but also for their antagonist other. Neither the protesters nor the authorities could take a step back afterward and offer concessions to their opponent. To legitimize its violent crackdown, the regime resorted to vicious nationalist propaganda that rivaled the NASL's legitimacy discourse, branded the Brotherhood and its allies as terrorists, and securitized Egypt's protest arena as an illegitimate sphere of insurgent politics. The Rabaa massacre made this antagonizing narrative irreversible, thus cementing political polarization and paving the way for the restoration of authoritarian rule.

\section{References}

Abaza, M. (2016). Violence, dramaturgical repertoires and neoliberal imaginaries in Cairo. Theory, Culture \& Society, 33(7-8), 111-135. https://doi.org/10.1177/0263276416670729

Abdel Salam, M. (2013, December 20). Egyptian universities between the Brotherhood and the military [Carnegie Endowment for International Peace]. Sada. http://carnegieendowment. org/sada/index.cfm?fa=show\&article $=53998 \&$ solr_hilite $=$ 
Abdelbaseer, M. (2016, January 25). Cairo's Rabaa massacre: Between a murderous army and urban failure. FA: Failed Architecture. https://www.failedarchitecture.com/ cairos-rabaa-massacre-between-a-murderous-army-and-urban-failure/

Abdelbaseer, M., van Nes, A., \& Salheen, M. A. (2014). Space and protest: A tale of two Egyptian squares. Proceedings of the 1oth International Space Syntax Symposium, 110, 1-18.

Afsaruddin, A. (2016). Jihad and martyrdom in Islamic thought and history. In Oxford Research Encyclopedia of Religion. Oxford University Press. http://religion.oxfordre.com/view/10.1093/ acrefore/9780199340378.001.0001/acrefore-9780199340378-e-46

Al-Awadi, H. (2013). Islamists in power: The case of the Muslim Brotherhood in Egypt. Contemporary Arab Affairs, 6(4), 539-551. https://doi.org/10.1080/17550912.2013.856079

Ali, A., \& El-Sharnouby, D. (2014). Distorting digital citizenship: Khaled Said, Facebook, and Egypt's streets. In L. Herrera (Ed.), Wired citizenship: Youth learning and activism in the Middle East (pp. 89-103). Routledge.

Alimi, E. Y. (2009). Mobilizing under the gun: Theorizing political opportunity structure in a highly repressive setting. Mobilization, 14(2), 219-237. https://doi.org/10.17813/ maiq.14.2.u210745765568737

Alimi, E. Y., Bosi, L., \& Demetriou, C. (2012). Relational dynamics and processes of radicalization: A comparative framework. Mobilization, 17(1), 7-26. https://doi.org/10.17813/ maiq.17.1.u7rw348t8200174h

Amnesty International. (2013, August 2). Egypt: Evidence points to torture carried out by Morsi supporters. https://www.amnesty.org/en/press-releases/2013/o8/egypt-evidence-points-torturecarried-out-morsi-supporters/

Antoun, N., \& Parietti, L. (2013, December 6). Making an example. Mada Masr. https://madamasr. com/en/2013/12/o6/feature/politics/making-an-example/

Armbrust, W. (2013, May 8). The ambivalence of martyrs and the counter-revolution. Cultural Anthropology. https://culanth.org/fieldsights/213-the-ambivalence-of-martyrs-and-thecounter-revolution

Armbrust, W. (2015). The iconic stage: Martyrologies and performance frames in the January $25^{\text {th }}$ revolution. In R. Abou-El-Fadl (Ed.), Revolutionary Egypt: Connecting domestic and international struggles (pp. 43-64). Routledge.

Askanius, T. (2013). Protest movements and spectacles of death: From urban places to video spaces. In Nicole Doerr, Simon Teune, \& Alice Mattoni (Eds.), Advances in the visual analysis of social movements (pp. 105-136). Emerald Group Publishing Limited.

Baheyya. (2012, December 8). Death knell for an old political style. Baheyya: Egypt Analysis and Whimsy. http://baheyya.blogspot.co.uk/2012/12/death-knell-for-old-political-style.html

Barthes, R. (1993). Camera lucida: Reflections on photography (R. Howard, Trans.; New Ed). Vintage Classics.

Bayat, A. (2005). Islamism and social movement theory. Third World Quarterly, 26(6), 891-908. https://doi.org/10.1080/01436590500089240

Bedier, A. (2014, August 14). My brotherwas killed at Rabaa. Al-Jazeera English. https://www.aljazeera. com/indepth/opinion/2014/o8/my-brother-was-killed-at-rabaa-201481411280500550.html

Biagini, E. (2017). The Egyptian Muslim Sisterhood between violence, activism and leadership. Mediterranean Politics, 22(1), 35-53. https://doi.org/10.1080/13629395.2016.1230943

Biagini, E. (2020). Islamist women's activism under Morsi's government (2011-2013): Political inclusion, gender and discourse. Egypte/Monde Arabe, $n^{\circ}{ }_{21}(1)$, 37-55. https://doi.org/10.400o/ ema.11592

Birgün Daily. (2017, May 20). 'Rabia' işareti AKP tüzüğüne de girdi! BIRG ÜNDAILY. https://www. birgun.net/haber-detay/rabia-isareti-akp-tuzugune-de-girdi-160439.html 
Carr, S. (2013, August 17). An account of the Ramses violence. Jadaliyya. http://www.middleeastdigest.com/pages/index/13648/an-account-of-the-ramses-violence-

CBC Egypt. (2013, July 3). Hunna al-Asima -Statement of Sheikh Al-Azhar:Ahmed Tayeb. https:// www.youtube.com/watch?v=PAiVvXioqkg

Chalcraft, J. (2014). Egypt's 25 January uprising, hegemonic contestation, and the explosion of the poor. In F. A. Gerges (Ed.), The new Middle East: Protest and revolution in the Arab World (pp. 155-179). Cambridge University Press.

Chang, L. T. (2013, June 27). Egypt's petition rebellion. The New Yorker. https://www.newyorker. com/news/news-desk/egypts-petition-rebellion

Clarke, K. (2011). Saying 'enough': Authoritarianism and Egypt's Kefaya movement. Mobilization: An InternationalJournal, 16(4), 397-416. https://doi.org/10.17813/maiq.16.4.m728m673p734ol23

Cook, D. (2002). Suicide attacks or 'martyrdom operations' in contemporary jihad literature. Nova Religio: The Journal of Alternative and Emergent Religions, 6(1), 7-44. https://doi.org/10.1525/ nr.2002.6.1.7

Cook, D. (2007). Martyrdom in Islam. Cambridge University Press.

Cook, D. (2012). Martyrdom (Shahada) [Data set]. In Oxford Bibliographies. Oxford University Press. https://doi.org/10.1093/obo/9780195390155-0124

Davenport, C. (2007). State repression and the domestic democratic peace. Cambridge University Press.

Davenport, C., \& Loyle, C. (2012). The states must be crazy: Dissent and the puzzle of repressive persistence. International Journal of Conflict and Violence (IJCV), 6(1), 75-95. https://doi. org/10.4119/ijcv-2931

Della Porta, D. (2014). On violence and repression: A relational approach (the Leonard Schapiro memorial lecture, 2013). Government and Opposition, 49(2), 159-187. https://doi.org/10.1017/ gov.2013.47

Della Porta, D., \& Tarrow, S. (2012). Interactive diffusion: The coevolution of police and protest behavior with an application to transnational contention. Comparative Political Studies, 45(1), 119-152. https://doi.org/10.1177/0010414011425665

Demmelhuber, T. (2014). Kann ein Putsch demokratisch sein? Normativer Etikettenschwindel in Ägypten. Zeitschrift Für Politik, 6r(1), 42-60.

Di Donato, M. (2012). Understanding the Arab Uprisings through the analysis of the terms Intifada and Istishad [Paper presented at BRISMES Annual Conference London School of Economics and Political Science 26-28 March 2012 'Revolution and Revolt: Understanding the Forms and Causes of Change']. https://brismes2012.files.wordpress.com/2012/o2/marco-di-donatounderstanding-the-arab-uprisings.pdf

Dworkin, A., \& Michou, H. (2014). Egypt's unsustainable crackdown (ECFR Policy Brief No. 92). ECFR. http://www.ecfr.eu/page///ECFR92_EGYPT_MEMO.pdf

Earl, J. (2003). Tanks, tear gas, and taxes: Toward a theory of movement repression. Sociological Theory, 21(1), 44-68. https://doi.org/10.1111/1467-9558.00175

EIPR. (2014). The weeks of killing: State violence, communal violence and sectarian attacks in the summer of 2013. Egyptian Initiative for Personal Rights. https://eipr.org/sites/default/files/ reports/pdf/weeks_of_killing-en.pdf

El Gendi, Y. (2017). Coptic commemorative protests and discourses of Egyptian nationalism: A visual analysis. Middle East - Topics \& Arguments, 8, 45-57.

Ellefsen, R. (2016). Judicial opportunities and the death of SHAC: Legal repression along a cycle of contention. Social Movement Studies, 15(5), 441-456.

El-Sherif, A. (2014). The Muslim Brotherhood and the future of political Islam. Carnegie Endowment for International Peace. http://carnegieendowment.org/files/mb_future_egyptı.pdf 
Eren, S. (2017, August 21). The Rabaa story: Who created the iconic hand gesture? TRT World. https:// www.trtworld.com/opinion/the-rabaa-story-who-created-the-iconic-hand-gesture--9732

Eshhad: The Center for the Protection of Minorities. (2018). Database. Eshhad. https://eshhad. org/database/

Euben, R. L. (2002). Killing (for) politics: Jihad, martyrdom, and political action. Political Theory, $30(1), 4-35$.

Fahim, K., \& Sheikh, M. E. (2013, August 17). Soldiers storm a mosque in Cairo, as Egyptian leaders struggle for order. The New York Times. https://www.nytimes.com/2013/08/18/world/ middleeast/standoff-in-cairo-as-security-forces-surround-mosque.html

FJP. (2013a, August 15). FJP Condemns Attacks on Copts; Reaffirms Revolution Non-Violence. Ikhwanweb. https://archive.is/wip/JbjLA

FJP. (2013b, August 16). FJP Reiterates Denunciation of Attacks on Copts, Churches and Property - Ikhwanweb. Ikhwanweb. http://www.ikhwanweb.com/article.php?id=31246

FJP Helwan. (2013, August 16). FJP Helwan on the church attacks [Arabic]. Facebook. https://www. facebook.com/FJ.Helwan/posts/516124478472316

Francisco, R. A. (1995). The relationship between coercion and protest: An empirical evaluation in three coercive states. The Journal of Conflict Resolution, 39(2), 263-282.

Francisco, R. A. (2004). After the massacre: Mobilization in the wake of harsh repression. Mobilization: An International Quarterly, 9(2), 107-126.

Gaffney, P. D. (1991). The changing voices of Islam: The emergence of professional preachers in contemporary Egypt. The Muslim World, 81(1), 27-47. https://doi.org/10.1111/j.1478-1913.1991. tbo3510.x

Gold, Z. (2014, May 22). Egypt's war on terrorism [Carnegie Endowment for International Peace]. Sada. http://carnegieendowment.org/sada/2014/05/22/egypt-s-war-on-terrorism/hbdq

Gribbon, L. (2013). The commodification of Egypt's revolutionary martyrs: Interpretive frames, mediated narratives and imagined solidarities. In N. Belakhdar, I. Eickhof, A. E. Khawaga, O. E. Khawaga, A. Hamada, C. Harders, \& S. Sandri (Eds.), Arab revolutions and beyond:Change and persistence. Proceedings of the international conference in Tunis, 12-13 November 2013 (pp. 101-112). Center for North African and Middle Eastern Politics. https://refubium.fu-berlin. de/handle/fub188/19057

Gribbon, L., \& Hawas, S. (2012). Signs and signifiers: Visual translations of revolt. In S. Mehrez (Ed.), Translating Egypt's revolution: The language of Tahrir (pp. 103-142). Oxford University Press.

Hafez, K. (2015). Radically polarized publics and the demise of media freedom in Egypt. Égypte/ Monde Arabe, 12. https://doi.org/10.4000/ema.3397

Hafez, M. (2003). Why Muslims rebel: Repression and resistance in the Islamic world. Lynne Rienner Publishers.

Halverson, J. R., Ruston, S. W., \& Trethewey, A. (2013). Mediated martyrs of the Arab Spring: New media, civil religion, and narrative in Tunisia and Egypt. Journal of Communication, 63(2), 312-332. https://doi.org/10.1111/jcom.12017

Hamama, M. (2016, August 14). Q\&A: Turkish designer of Rabea symbol - it's still alive. Mada Masr. https://madamasr.com/en/2016/o8/14/feature/politics/qa-turkish-designer-of-rabeasymbol-its-still-alive/

Harders, C., \& König, C. (2013). Mobilization, repression and coalitions: Understanding the dynamics of the Arab Spring [Discussion Paper]. Center for Middle Eastern and North African Politics. https://www.polsoz.fu-berlin.de/polwiss/forschung/international/vorderer-orient/publikation/working_papers/dp_o6/index.html

Hawksley, H. (2013, July 21). A teenager killed in Alexandria. BBC World. https://www.bbc.com/ news/magazine-23380343 
Hess, D., \& Martin, B. (2006). Repression, backfire, and the theory of transformative events. Mobilization, $11(2)$, 249-267.

Holmes, A. A. (2013, August 16). Before the bloodletting: A tour of the Rabaa Sit-in. The Cairo Review of Global Affairs. https://www.thecairoreview.com/tahrir-forum/before-the-bloodletting-atour-of-the-rabaa-sit-in/

Human Rights Watch. (2013a, August 21). Egypt: Mass attacks on churches. https://www.hrw. org/news/2013/08/21/egypt-mass-attacks-churches

Human Rights Watch. (2013b, December 7). Egypt: Dangerous message for protesters. https:// www.hrw.org/news/2013/12/o7/egypt-dangerous-message-protesters

Human Rights Watch. (2014, August 12). All according to plan: The Rab'a massacre and mass killings of protesters in Egypt. https://www.hrw.org/report/2014/o8/12/all-according-plan/ raba-massacre-and-mass-killings-protesters-egypt

Hürriyet Daily News. (2017, June 22). Turkish municipality erects Rabia sign. http://www.hurriyetdailynews.com/turkish-municipality-erects-rabia-sign-statue-114635

Ibrahim, G. (2013, August 18). The poster that turned Facebook yellow. The Angry Egyptian: Tahrir \& Beyond. https://theangryegyptian.wordpress.com/2013/08/18/the-poster-thatturned-facebook-yellow/

Ismail, F. (2011, February 2). Ex-minister suspected behind Alex church bombing. Al-Arabiya. https:// web.archive.org/web/20130120182322/http://www.alarabiya.net/articles/2011/02/07/136723. html

Ismail, S. (2006). Rethinking Islamist politics: Culture, the state and Islamism. I.B. Tauris.

Jasper, J. M. (2018). The emotions of protest. The University of Chicago Press.

Jasper, J. M., \& Poulsen, J. D. (1995). Recruiting strangers and friends: Moral shocks and social networks in animal rights and anti-nuclear protests. Social Problems, 42(4), 493-512. https:// doi.org/10.2307/3097043

Jasper, J. M., Young, M. P., \& Zuern, E. (2020). Public characters: The politics of reputation and blame. Ketchley, N. (2013). The Muslim Brothers take to the streets. Middle East Report, 269, 12-17.

Ketchley, N. (2017). Egypt in a time of revolution: Contentious politics and the Arab Spring. Cambridge University Press.

Ketchley, N., \& Biggs, M. (2014, April 4). What is the Egyptian anti-coup movement protesting for? [Washington Post]. The Monkey Cage. http://www.washingtonpost.com/blogs/monkey-cage/ wp/2014/04/o4/what-is-the-egyptian-anti-coup-movement-protesting-for/

Ketchley, N., \& Biggs, M. (2015, August 14). Who actually died in Egypt's Rabaa massacre [Washington Post]. The Monkey Cage. https://www.washingtonpost.com/blogs/monkey-cage/ wp/2015/o8/14/counting-the-dead-of-egypts-tiananmen/

Khalili, L. (2009). Heroes and martyrs of Palestine: The politics of national commemoration (1st ed.). Cambridge University Press.

Khawaja, M. (1993). Repression and popular collective action: Evidence from the West Bank. Sociological Forum, 8(1), 47-71.

Khosrokhavar, F. (2018). Violence, social actors, and subjectivation in the Egyptian revolution. In F. Volpi \& J. M. Jasper (Eds.), Microfoundations of the Arab uprisings: Mapping interactions between regimes and protesters (pp. 159-182). Amsterdam University Press.

Kingsley, P. (2014, February 22). How did 37 prisoners come to die at Cairo prison Abu Zaabal? The Guardian. https://www.theguardian.com/world/2014/feb/22/ cairo-prison-abu-zabaal-deaths-37-prisoners

Kingsley, P., \& Chulov, M. (2013, July 4). Morsi supporters prepare to defend themselves as tide turns in Egypt. The Guardian. https://www.theguardian.com/world/2013/jul/o4/ morsi-supporters-egypt-muslim-brotherhood 
Kingsley, P., \& Green, L. (2013, July 18). Killing in Cairo: The full story of the Republican Guards' club shootings. The Guardian. http://www.theguardian.com/world/interactive/2013/jul/18/ cairo-republican-guard-shooting-full-story

Litvak, M. (2010). "Martyrdom is life": Jihad and martyrdom in the ideology of Hamas. Studies in Conflict \& Terrorism, 33(8), 716-734. https://doi.org/10.1080/1057610X.2010.494170

Luker, K. (2009). World views of pro- and anti-abortion activists. In J. Goodwin \& J. M. Jasper (Eds.), The social movements reader: Cases and concepts (2nd ed., pp. 146-160). Wiley Blackwell.

Martijn de Koning. (2013, September 1). R4bia - the symbolic construction of protest. CLOSER: An Anthropology of Muslims in Europe. https://religionresearch.org/closer/2013/og/o1/ rybia-the-symbolic-construction-of-protest/

Martini, J., Kaye, D. D., \& York, E. (2012). The Muslim Brotherhood, its youth, and implications for U.S. engagement. Rand.

McAdam, D. (1983). Tactical innovation and the pace of insurgency. American Sociological Review, 48(6), 735-754. https://doi.org/10.2307/2095322

McCurdy, P., Feigenbaum, A., \& Frenzel, F. (2016). Protest camps and repertoires of contention. Social Movement Studies, 15(1), 97-104. https://doi.org/10.1080/14742837.2015.1037263

Miller, C., \& Gulhane, J. (2013, August 14). Mohandessin clashes as sit-ins disperse. Daily News Egypt. https://www.dailynewsegypt.com/2013/08/14/mohandessin-clashes/

Mittermaier, A. (2015). Death and martyrdom in the Arab uprisings: An introduction. Ethnos, $80(5), 583-604$. https://doi.org/10.1080/00141844.2014.93809o

Moghadam, A. (2014). The globalization of martyrdom. Johns Hopkins University Press.

Morris, A. D. (1993). Birmingham confrontation reconsidered: An analysis of the dynamics and tactics of mobilization. American Sociological Review, $58(5), 621-636$. https://doi. org $/ 10.2307 / 2096278$

Morsy, A., \& Brown, N. (2013). Egypt's al-Azhar steps forward. Carnegie Endowment for International Peace. http://carnegieendowment.org/2013/11/o7/egypt-s-al-azhar-steps-forward/gtob

Mostafa, D. S. (2016). The Egyptian military in popular culture: Context and critique. Palgrave.

Muslim Brotherhood. (2013a, August 6). Anti-Coup Alliance statement affirms no invitation to dialogue received. Ikhwanweb. http://www.ikhwanweb.com/article.php?id=31233

Muslim Brotherhood. (2013b, August 14). Anti-Coup Alliance statement: Major massacre during crackdown against Rabaa and Al-Nahda sit-ins. Ikhwanweb. https://archive.is/wip/Cuuni

Muslim Brotherhood. (2013c, August 16). The police and the church shoot at the Haram march in Giza Tunnel and on Murad Street [Arabic, on file]. Ikhwanweb.

Nagi, M. (2013, July 14). Sinai checkpoint attacked. Daily News Egypt. http://www.dailynewsegypt. com/2013/o7/14/sinai-checkpoint-attacked/

NASL. (2013a, August 14). Regarding the great massacre which was committed in the dissolution of the two peaceful sit-ins of Rabaa al-Adawiya and Nahda Square [Arabic]. Facebook. https:// archive.is/wip/SBJqD

NASL. (2013b, August 16). Statement 64: On "Friday of Anger" [Arabic]. Facebook. https://archive. $\mathrm{vn} / 4 \mathrm{~W}_{4} \mathrm{Kn}$

NASL. (2013c, August 16). Statement 65 [Arabic]. Facebook. https://archive.vn/wip/7aSzo

NASL. (2013d, August 17). On 'Friday of Anger' murderous crimes by coup commanders [Arabic]. Facebook. https://archive.is/wip/eaMzT

NASL. (2013e, August 17). On the crimes of coup leaders 3 July on Friday of Anger [Arabic]. Facebook. https://www.facebook.com/AllianceSupportingLegitimacy/posts/293449520797418

NASL. (2013f, August 17). What after the slaughter of Egyptians and destruction of houses of worship? [Arabic]. Facebook. https://archive.vn/wip/5WcOS

NASL. (2013g, August 20). Assessment of position and vision for the future. Facebook. https:// archive.is/wip/8NefH 
NASL. (2013h, August 20). Statement 72: Assessment of the situation and a vision for the future [Arabic]. Facebook. https://archive.is/zczSw

NASL. (2013i, August 20). Statement 73: A Call to all the Free in Egypt [Arabic]. Facebook. https:// archive.vn/wip/Csnml

NASL. (2013j, August 25). Statement 78 [Arabic]. Facebook. https://archive.is/wip/S5L86

NASL. (2013k, September 5). Statement 93 [Arabic]. Facebook. https://archive.is/wip/SOOxQ

Nazra for Feminist Studies. (2013). The dispersion of the Rab'aa sit-in and its aftermath. Nazra. https://nazra.org/sites/nazra/files/attachments/report_on_police_treatment-with_women_protesters_en.pdf

Noueihed, L. (2014, December 15). Sisters in the vanguard. Reuters. https://www.reuters.com/ article/us-egypt-brotherhood-women-idUSKBNoJT1PD20141215

Perlmutter, D. (2013, September 8). A new Muslim Brotherhood symbol: R4BIA. Frontpage Mag. https://www.frontpagemag.com/fpm/203449/new-muslim-brotherhood-symbol-r4biadawn-perlmutter

Peterson, M. A. (2015a). In search of antistructure: The meaning of Tahrir Square in Egypt's ongoing social drama. In Á. Horváth, B. Thomassen, \& H. Wydra (Eds.), Breaking boundaries: Varieties of liminality (p. 164). Berghahn Books.

Peterson, M. A. (2015b, July 23). Martyrs without a cause? Egypt's revolutionary martyrs as empty signifiers. Connected in Cairo. https://connectedincairo.com/2015/07/23/ martyrs-without-a-cause-egypts-revolutionary-martyrs-as-empty-signifiers/

Pratt, N. (2020). Making sense of the politics of the Egyptian Revolution in and through popular culture. International Journal of Middle East Studies, 52(3), 531-535. https://doi.org/10.1017/ So02074382000069o

Pratt, N., Mostafa, D., Rezk, D., \& Salem, S. (2012, September 20). Port Said Martyrs. Politics, Popular Culture and the 2011 Egyptian Revolution; Suzee in the City. https://egyptrevolution2011. ac.uk/items/show/6o

R4bia. (2013, August 29). What is R4BIA? https://web.archive.org/web/20130829025501/http:// www.r4bia.com/en/content/what-r4bia

Ramzy, C. M. (2015). To die is gain: Singing a heavenly citizenship among Egypt's Coptic Christians. Ethnos, 8o(5), 649-670. https://doi.org/10.1080/o0141844.2014.94326o

Richter, C. (2017). Mobilize, justify, accuse: The Egyptian Muslim Brotherhood and changing media practices. In S. Foellmer, M. Lünenborg, \& C. Raetzsch (Eds.), Media practices, social movements, and performativity: Transdisciplinary approaches (pp. 100-113). Routledge.

RNN. (2013a, August 6). Erian: Thousands are ready to sacrifice for legitimacy [Arabic]. Rassd News Network. https://rassd.com/68722.htm

RNN. (2013b, September 11). Endowments prohibit any gatherings in mosques after prayer ends [Arabic]. Rassd News Network. https://rassd.com/71718.htm

Salbi, Z. (2013, August 27). Who Is Rabaa Adawiya? Huffington Post. https://www.huffingtonpost. com/zainab-salbi/who-is-rabaa-adawiya_b_3820109.html

Schielke, S. (2017). There will be blood: Expectation and ethics of violence during Egypt's stormy season. Middle East Critique, 26(3), 205-220. https://doi.org/10.1080/19436149.2017.1336023

Schwedler, J. (2018). Routines and ruptures in anti-Israeli protests in Jordan. In F. Volpi \& J. M. Jasper (Eds.), Microfoundations of the Arab uprisings: Mapping interactions between regimes and protesters (pp. 67-88). Amsterdam University Press.

Shadid, A., \& Kirkpatrick, D. D. (2011, February 10). Mubarak refuses to step down, stoking revolt's fury and resolve. The New York Times. https://www.nytimes.com/2011/02/11/world/ middleeast/11egypt.html

Shamni, N. (2013). Punitive measures against athletes for flashing four-finger 'pro-MB' sign spark controversy In Egypt (MEMRI Inquiry \& Analysis Series Report No. 1048). MEMRI. https:// 
www.memri.org/reports/punitive-measures-against-athletes-flashing-four-finger-pro-mbsign-spark-controversy-egypt

Sherlock, R., \& Samaan, M. (2013, August 15). Grief of Muslim Brotherhood leader's family at death of teenage daughter. Telegraph. https://www.telegraph.co.uk/news/worldnews/ africaandindianocean/egypt/10245865/Egypt-Grief-of-Muslim-Brotherhood-leaders-familyat-death-of-teenage-daughter.html

Shokr, A. (2015). The 18 days of Tahrir. Middle East Report, 41(258), 14-17.

Soudias, D. (2015). Policing January 25: Protest, tactics, and territorial control in Egypt's 2011 uprising. Middle East - Topics \& Arguments, 4(1), 170-182. https://doi.org/10.17192/meta.2015.4.2669

Spiegel, J. B. (2016). Performing "in the red": Transformations and tensions in repertoires of contention during the 2012 Quebec student strike. Social Movement Studies, 15(5), 531-538. https://doi.org/10.1080/14742837.2016.1196126

Tammam, H. (2012). The Muslim Brotherhood: Pre-revolution years. Dar al-Shorouq.

Telmissany, M. (2014). The utopian and dystopian functions of Tahrir Square. Postcolonial Studies, $17(1), 36-46$. https://doi.org/10.1080/13688790.2014.912194

Tharoor, I. (2016, July 15). Turkey's Erdogan always feared a coup. He was proved right. Washington Post. https://www.washingtonpost.com/news/worldviews/wp/2016/07/15/ turkeys-erdogan-always-feared-a-coup-he-was-proved-right/

Thornhill, M. T. (2006). Road to Suez: The battle of the canal zone. Sutton.

Tilly, C. (2008). Contentious performances. Cambridge University Press.

Van de Sande, M. (2013). The prefigurative politics of Tahrir Square: An alternative perspective on the 2011 revolutions. Res Publica, 19(3), 223-239. https://doi.org/10.1007/s11158-013-9215-9

Van de Sande, M. (2015). Fighting with tools: Prefiguration and radical politics in the twenty-first century. Rethinking Marxism, 27(2), 177-194. https://doi.org/10.1080/08935696.2015.1007791

Werbner, P., Webb, M., \& Spellman-Poots, K. (2014). The political aesthetics of global protest: The Arab Spring and beyond. Edinburgh University Press.

Zakarevičiūtè, I. (2015). Telling the stories of martyrs: The cases of the Egyptian and Lithuanian revolutions. Journal of Contemporary Central and Eastern Europe, 23(2-3), 213-23o. https:// doi.org/10.1080/0965156X.2015.1116793 


\title{
6 New Sheriff in Town
}

\author{
Nationalism and the return of autocracy
}

\begin{abstract}
The events of Rabaa heralded a swift authoritarian rollback. This chapter covers the post-Rabaa period and reconstructs the emergence of a new nationalist consensus that enabled the restoration of autocracy in Egypt. It illustrates how several players who had supported Mursi's ouster promoted a securitizing discourse centred on national defense to counterweigh the Islamists' claim to democratic legitimacy. After Rabaa, this discourse allowed for the rehabilitation of the armed forces as folk heroes and the ascension of a military General to the presidency. The nationalist underpinnings of this nascent constellation, at the same time, created the discursive conditions for an unprecedented restriction of public space, thus changing the rules and parameters of the principal arenas of contentious politics in Egypt.
\end{abstract}

Keywords: autocracy, counterrevolution, diaspora activism, nationalism, repression

Rabaa marked a turning point not only for the Brotherhood and its allies but also for the interim regime (see Pearlman, 2018). To protect national security it temporarily reinstated martial law, imposed curfews in 14 provinces, and authorized the Central Security Forces (CSF) to apply deadly force in case of transgression (Sly \& Al-Hourani, 2013). Security forces also stepped up their mass arrests against leading members of the Anti-Coup Alliance, often in cooperation with a politicized judiciary (Dunne \& Brown, 2014). Most importantly, on September 23, 2013, the Cairo Court for Urgent Matters declared the Muslim Brotherhood a terrorist organization, ordered the seizure of its funds and banned it from carrying out any activities in the country (Brooke, 2015, pp. 1-2). A legal committee was charged with investigating the Brotherhood's assets and compiling a list of its affiliated

Grimm, Jannis Julien, Contested Legitimacies: Repression and Revolt in Post-Revolutionary Egypt. Amsterdam: Amsterdam University Press 2022 DOI: 10.5117/9789463722650_CHo6 
social service organizations. These organizations were to be closed for their ties with the group. In October 2014, the political arm of the group, the Freedom and Justice Party, was banned as well (El-Sherif, 2014, p. 14).

These verdicts established the legal basis to move against the group's social and financial basis which consisted of a network of schools, medical facilities, and charities across the country. In the following months, the Ministry of Social Solidarity audited 1,055 NGOs for alleged links with the Brotherhood and froze their assets pending the results (El-Dabh, 2013b). By mid-2015, more than 430 of these organizations were closed and their funds were frozen. The newly created Inventory, Seizure, and Management Committee additionally imposed asset freezes on 1,133 NGOs, 104 schools, 69 hospitals, and 33 media outlets, claiming that they were damaging the national economy by smuggling foreign currency and supporting illicit Anti-Coup activities. Aside from these social service networks and charities, the committee also targeted leading Anti-Coup activists and their private business ventures. By September 2018, it had seized the assets of 1,589 alleged Brotherhood members (including those of former President Mursi, of the Brotherhood's acting supreme guide Mahmoud Ezzat and FJP SecretaryGeneral Mohamed al-Beltagy) and 118 companies, preventing the Anti-Coup Alliance's leadership from financially recovering from the crackdown in 2013.

This comprehensive legal persecution raised the stakes for the Brotherhood and the Freedom and Justice Party, the two largest players in the Anti-Coup Alliance, and the largest contributing organizations to the protest campaign. The repressive measures, on the one hand, targeted both groups' traditional social basis (see Brooke, 2013, 2015; Davis \& Robinson, 2012). On the other hand, the Brotherhood's designation as a terrorist group placed all activities by its members within the jurisdiction of the National Security Service (NSS). It allowed domestic intelligence agents to raid and seize Islamist charities and civic associations at will, under the pretext that they maintained ties to the group or its members. Moreover, it removed the need for authorities to find a pretext for putting Anti-Coup members on trial. After the designation as a terrorist group, affiliation with the Brotherhood put even those at risk who were not politically active but only passively supporting the campaign.

With the verdicts, the Anti-Coup struggle became a struggle for the basic political survival of the Muslim Brotherhood. Barred from retreating to its traditional terrain - the social service sector, the Anti-Coup Alliance transformed into a mechanism for self-preservation in the face of crumbling organizational structures. This transformed role was reflected by the group's protest activities, which increased towards the end of 2013. Protesters 
remained remarkably resilient against repression up until the end of the period covered in this book.

Even today, Anti-Coup protesters are demonstrating in Egypt, albeit intermittently and in considerably smaller frequency and scale. Several Anti-Coup chapters continue to organize small protests regularly. However, the gradual criminalization of all protests in the years since Mursi's ouster has curtailed the movement's room for maneuver (Bildt, 2015). Today, AntiCoup groups as well as their protests are scattered across the country and operate mostly on a local level, with little interdependence and coordination between different local groups. Often the coordinating bodies for the weekly Anti-Coup farasha demonstrations boil down to the usra cells, the smallest organizing units within the Muslim Brotherhood, which continue to exist as independent cells autonomously from the leadership across Egypt. ${ }^{1}$

The changing parameters of Egypt's protest arena crippled attempts to mobilize a broader cross-movement coalition on Egyptian soil. But they catalyzed a relocation of Anti-Coup resistance to the diaspora.

\section{Anti-Coup Resistance from Abroad}

The summer of 2013 marked a turning point in the Muslim Brotherhood's 90-year long history. For the first time, the group lost its main operating base in Egypt. Consequently, it was forced to follow the path that related organizations and offshoots of the movement, such as Hamas, had taken in the past when repression became too severe to continue operating in their home countries. Anti-Coup refugees fled to various destinations exiting Egypt first predominantly via the Sudanese Border, later through Jordan. Turkey received the bulk of the Brothers' rank and file as well as several leaders of the Egyptian Gama'a Islamiya and key members of the Anti-Coup organization who were not part of either organization. By the time the Muslim Brotherhood was dissolved in December 2013, several thousand formerly active members of the Brotherhood and other tributaries of the Anti-Coup Alliance had already fled the country, particularly to Doha, London, and Istanbul.

Given the ideological sympathies between the FJP and members of Turkey's governing Adalet ve Kalkınma Partisi [Justice and Development Party, AKP] (see Yilmaz et al., 2017), Turkish authorities provided the exiled

1 Khalil Al-Anani (2016, pp. 87f, 104-110) provides an excellent overview of the Muslim Brotherhood's internal organizational structures. 
Egyptians with different forms of support. ${ }^{2}$ This included the provision of a special iqama, a sort of humanitarian residence permit created specifically to grant asylum to wanted Anti-Coup members. A small group of FJP and Brotherhood functionaries arriving in Turkey in the immediate aftermath of July 3, 2013, were the first to receive this legal title. These few hundred people then compiled lists of names for other Anti-Coup fugitives in need of asylum. Subsequent waves of refugees were awarded visas when they found themselves on these lists. Through this snowball system, to date, between four and eight thousand Muslim Brothers, including their families, found asylum in Turkey, predominantly in the Yenibosna area, near Istanbul's Ataturk airport, which houses much of today's logistical infrastructure of the FJP and the NASL's remains. Despite the pending charges in Egyptian courts, Brotherhood members were furthermore allowed to congregate in Istanbul and Ankara, including after their expulsion from increasingly pressured Qatar in mid-September 2014 (see Sailer, 2016).

By August 2014, several of these actors realized the failure of their grassroots protest campaign in Egypt and explored new avenues for translocal political activism from exile. The newly founded Egyptian Revolutionary Council (ERC) became the main vehicle to coordinate these efforts. Founded in Istanbul as an anti-regime platform that embraced the January 25 Revolution principles, the ERC affirmed most of the Anti-Coup Alliance's founding principles and comprised some leading players of the Anti-Coup Alliance (Magued, 2018, p. 487). ${ }^{3}$ At the same time, however, the new advocacy association attempted to avoid past mistakes and presented itself - though with limited success - as a non-partisan entity that included liberals and Christians. Led by Maha Assam, this new expatriate organization helped to keep the Anti-Coup discourse of legitimate resistance as well as the memory of Rabaa alive by acting as political opposition from abroad (Richter, 2017).

2 Another reason for this support may have been the leverage that the guardianship over the Brotherhood's fate gave the Turkish authorities. Several exiled Anti-Coup activists in Istanbul highlighted that they felt like "Erdogan's bargaining chips." This impression was reinforced by the failed coup attempt in Turkey on July 15, 2016, which made it plain to the Egyptian fugitives how much their toleration depended on a favorable political climate (see Aydın-Düzgit, 2014). Several interview partners have described how they frantically packed their bags during the night of the coup attempt as they anticipated that their asylum status would be revoked in the case of a government change. In truth, the room for maneuver for the Brotherhood and its allies widened in the aftermath of the failed coup against Erdogan. As a leading member of the group in Istanbul highlighted, after the coup attempt, the AKP and the Brotherhood shared the experience of victimization at the hand of the armed forces.

3 The ERC's founding statement is available at http://normanfinkelstein.com/wp-content/ uploads/2015/02/statement-1.pdf. 
Furthermore, members of the Anti-Coup Alliance increased their efforts to multiply oppositional voices from Egypt through a new form of transnational media activism. From London, this was conducted mainly through a range of exile news portals, with Ikhwanweb.com, Ikhwanpress. org, and Ikhwanonline.info as the most important examples. In contrast, from Istanbul, the Anti-Coup discourse was kept alive through several multimedia platforms specialized in providing propaganda material for social media as well as offline protests (e.g., banners, logos, propaganda videos, picture portfolios), such as Rabaastory.net or Rabiaplatform.com. In addition to these Brotherhood-owned outlets, several new Brotherhoodfriendly think tanks (e.g., Al-Sharq Forum) and news agencies (e.g., World Bulletin, Huffington Post Arabic) provided platforms for Anti-Coup members to circumvent media censorship and comment on the ongoing events in Egypt. Many of these platforms operated from Istanbul and often from the same buildings where Anti-Coup expats opened their offices.

Moreover, Turkey provided financial and legal backing to the Muslim Brotherhood by allowing the establishment of several oppositional satellite TV channels from abroad, which compensated for the organization's closed networks in Egypt. ${ }^{4}$ In December 2013, the Rabaa network was launched from Istanbul as the first major foreign-based Brotherhood opposition channel. By summer 2014, the Brotherhood operated nearly half a dozen satellite networks from Turkey (Awad, 2017). While the most prominent of these channels, Rabaa al-Thawra was taken off air by its Jordanian host in May 2015, the channels Mekameleen TV, Al-Sharq, and Watan TV (formerly Misr Al-Aan) continue to broadcast from Istanbul to date.

Run by exiled Brotherhood members, these media channels enabled those organizers of the Anti-Coup Alliance who were not arrested in the weeks after Rabaa, to lobby for international support and maintain a certain degree of communication with supporters in Egypt through the broadcast of news feeds, protest calls and talk shows. In this sense, media advocacy from abroad compensated for lacking infrastructure in Egypt and introduced a new means of participation that bypassed state repression (see Magued, 2018, pp. 486, 490). However, it also contributed to the detachment of the Anti-Coup leadership from the movement's grassroots.

Championed by a few dozen activists with privileged access to funding, travel opportunities, media outlets, and Turkish officials, the transnational

4 After Mursi's deposition, Egypt's administrative courts had shut down all satellite channels sympathetic to President Mursi and his supporters. This included the Brotherhood-owned Misr 25 and the Islamist Al-Hafez, Amgad, and al-Nas. 
media activism contrasted with the dire conditions of those Anti-Coup members who continued to stage protests in Egypt. Moreover, it also starkly differed from the experience of most Anti-Coup refugees in Turkey. As many interview partners in Istanbul highlighted, over time, supporting their families including jailed family members in Egypt from exile became a significant challenge. Furthermore, several research participants described the difficulties of finding employment, childcare or arranging other daily necessities in a foreign, non-Arabic-speaking country as the main obstacles to their continued political engagement. For many exiled Anti-Coup members in Istanbul and Qatar, these bread-and-butter issues overshadowed their political aspirations. The burden of meeting days ends dampened their propensity to continue their political engagement beyond Egypt's borders. ${ }^{5}$

What is more, the transnationalization of the Anti-Coup activism also contributed to a radicalization of the coalition's discourse of resistance. Above all, the mediatization of prominent religious scholars as guest speakers in the Turkey-based TV studios contributed to an expansion of Islam as a frame of reference for the Anti-Coup struggle. ${ }^{6}$ As Shaima Magued (2018) noted, "many Islamic scholars advocated the end of the Egyptian regime, stigmatized its leadership, and accused it of apostasy (kufr) while labeling the army an 'occupier' that killed 'Muslim' citizens'” (p. 411f.). Back in Egypt, this reinterpretation of the political struggle as a test of faith, and the increasing presence of takfir-language that denounced the coup regime as infidels and non-believers, effectively fed into the discourses of Al-Sisi's consolidating regime.

\section{Victors' Justice}

In Cairo, the interim authorities worked hard to erase the memories of the week-long peaceful resilience of the Anti-Coup campaign, as well as any

5 Additionally, several interviewees report a certain unease about engaging in any type of street activism in Turkey. They claimed that their toleration by Turkish authorities depended on an unspoken agreement that activism confines itself to the sanctioned online and media activities by the movement's upper tiers as well as covert logistical support for the criminalized Muslim Brotherhood in Egypt from abroad, such as the transfer of funds or the delivery of medication that was scarce or rationed in Egypt.

6 Rabaa TV was shut down by Jordanian authorities, because of the hate speech by a Salafist cleric broadcasted on the channel. That same year, Turkish authorities closed the Watan TV precursor Misr Al-Aan after a talk show host had called for the assassination of Abdel Fattah al-Sisi. 
evidence of the massacres committed by security forces. Police violence against civilians was either categorically denied or reinterpreted as selfdefense against terrorist attacks and the legitimate restoration of law and order. On December 22, 2013, President Mansour tasked a fact-finding committee, which included law professors and former government executives, with the collection of evidence on "the events that accompanied the June 30 , 2013 protests" (Al-Dakhakhly, 2014). The committee lacked any judicial power but released an executive summary of its report on November 26 , 2014. ${ }^{7}$ Unsurprisingly, the report blamed mainly the protest leaders for the casualties in Rabaa.

A parallel investigation by the state-affiliated National Council for Human Rights (NCHR), released on March 6, 2014, noted the disproportionate and excessive use of force by security forces (NCHR, 2014). However, as with the fact-finding committee, the NCHR exonerated the interim government. Both reports concluded that security forces had been compelled to use lethal force by the armed resistance of Anti-Coup demonstrators. Consequently, those responsible for the bloody dispersals of Rabaa and Al-Nahda remained unfazed by legal repercussions. On the contrary, in February 2014, Abdel Fattah Al-Sisi was promoted to the top rank of Field Marshall. Only hours later, the Supreme Council of Armed Forces (SCAF) authorized his presidential candidacy.

In contrast, those arrested during the raids were viciously prosecuted in what became known as the "Rabaa sit-in dispersal trial" and the "Rabaa operation room trial" (see Shams El-Din, 2016; Zeinobia, 2018). The first of these two mass trials included 739 defendants, of which roughly half were held in pretrial custody for years. Initiated on the day after the Rabaa dispersal, the case concluded only five years after the events of August 14, 2013, due to delays and countless bureaucratic hurdles. On September 8, 2018, the Cairo Criminal Court confirmed the death sentences against 75 Anti-Coup leaders, including FJP Vice Chairman Essam al-Erian and FJP Secretary-General Mohamed Al-Beltagy as well as the former Minister of Youth Osama Yassin and the clerics Abdel-Rahman al-Barr and Safwat Hegazi. Another 47 defendants, including Brotherhood Supreme Guide Mohammed Badie, received life sentences; hundreds were sentenced from five to 15 years imprisonment.

All defendants were charged with participating in an unauthorized protest. Further charges included premeditated murder of security personnel, vandalizing private and public property, forcibly occupying buildings, 
obstructing traffic and restricting citizens' rights to freedom of movement and personal safety, membership in a banned organization, criminal incitement, and participation in an illegal gathering (see Amnesty International, 2018). The prosecution (unsuccessfully) demanded death sentences for all defendants.

A second lawsuit against more than 50 leading Muslim Brotherhood members, which also dragged on for years, concluded the same year when Egypt's Court of Cassation handed down the final ruling on the existence of a hidden control room, where Anti-Coup cadres had allegedly planned the sectarian violence that followed the Rabaa dispersals. In both cases, the solicited charges were built on the testimonies of residents of the Rabaa al-Adawiya and Al-Nahda neighborhoods as well as official police reports (see Shams El-Din, 2016). According to the prosecution, these evidenced that the sit-ins had served as a cover for detaining and torturing Egyptian citizens, for storing arms, and for organizing armed marches to terrorize the public.

The treatment of the Anti-Coup demonstrators stood in stark contrast to that of the security forces, who were not investigated, let alone prosecuted for their conduct. Egyptian law added another layer of impunity by shielding current or former officers from prosecution in a civil court. According to article 204 of the new constitution of 2014, ${ }^{8}$ military officials and officers of the General Intelligence Service can be tried only before military courts and by prosecutors who are part of the Ministry of Defense. As President Al-Sisi succeeded Adly Mansour in the presidential office in May 2014, he ensured that they would also remain untouched in the future. On July 26,2018 , he ratified Law 161/2018 on the treatment of senior military commanders. The law allowed the president to exempt members of the armed forces from prosecution for any events during the periods when the constitution was suspended and the parliament dissolved (see Rabia, 2018). It also granted diplomatic immunity to the designated officers while traveling abroad.

In parallel to insulating themselves against judicial prosecution, the dominant players in the post-coup order made substantial efforts to whitewash their human rights records. Attempts to establish exclusive interpretive authority over the events of Rabaa as a successful anti-terror operation included the censorship and removal of all visual indicators of the massacre. Not only was the R4BIA-salute criminalized (see Shamni, 2013), but also the location of the Anti-Coup sit-ins was rebuilt in line with

8 A commented English translation can be accessed at https://www.constituteproject.org/ constitution/Egypt_2014.pdf. 
the official version of what had happened on the squares. As Kareem Fahim and Mayy El-Sheikh (2018b) note, "the bloodied roads have been covered with fresh asphalt, and the charred Rabaa al-Adawiya Mosque that gives the square its name has been repainted in eggshell white. Paving stones that were hurled in protest have been replaced."

Midan Rabaa was remodeled in the spirit of Al-Sisi's mandate speech: Facing the Rabaa Mosque, a sculpture now commemorates the unity of armed forces and police in the war on terrorism. This army-built monument is today the only visible landmark reminiscent of the Rabaa sit-in. In a final effort to efface the massacre from public memory, even the name of the square was changed by executive decree in July 2015. Its new designation as Midan Hisham Barakat referenced Egypt's former Public Prosecutor who was killed by a car bomb on June 29, 2015, and who had authorized the deadly raids on August 14, 2013.

\section{The Rehabilitation of the Armed Forces}

Despite such efforts to advance a revisionist material history and the authorities' manifest attempts to re-appropriate the space claimed by the Anti-Coup Alliance, the legacy of Rabaa anything but disappeared. The massacre marked a point of no return for the interim regime as well (Shokr, 2014). To legitimize the police operation, it unleashed a wave of patriotic fervor. From the beginning of their crackdown against the Anti-Coup Alliance, Egyptian security forces sought to establish legitimacy for their actions by controlling the rhetoric surrounding key events, such as Mursi's ouster or the dispersal of Brotherhood and Anti-Coup demonstrations. The repression of Anti-Coup protesters continuously reproduced specific rhetoric structures that securitized the alliance as sources of disorder and chaos, outlaws, and thugs, and ultimately as terrorists that had to be held in check. As described in the previous chapter, this tactic created an "emergency mentality" among the general population (Abdelrahman, 2017, p. 9) and culminated in Al-Sisi's mandate speech on July 24, 2013.

The resort to such a polarizing discourse was akin to opening Pandora's Box. The nationalist narrative of a heroic fight by the Egyptian people and its army against Islamist terrorism succeeded in supplanting all competing depictions of the bloody weeks in the summer of 2013. Any discussion of potential wrongdoing by the state was thereby suppressed. Instead, a new narrative emerged in which Rabaa, as Shokr (2014) noted, crowned the state's "crusade to quell a terrorist campaign that began as early as 2011 when 
Muslim Brother operatives and allies allegedly stormed Egypt's prisons." Consequently, all solutions based on compromise and a balance of interests were discredited.

The securitization of the Anti-Coup protesters was furthermore accompanied by a nationalist discourse that revolved around the Egyptians national duty [al-wajib al-watani] to support the state and oppose all those who attempted to harm it, namely the Brotherhood and its allies. This effectively allowed for rehabilitation of the military, the prime object of contestation and the single most powerful player in Egypt's political arena, as representative of the people's will - and its inclusion into the ruling coalition.

After Mursi's ouster, the armed forces had first attempted to present the newly appointed transitional government as a civilian authority: new parliamentary elections were scheduled and the world-valued Nobel peace laureate Mohamed El-Baradei became interim vice-president. In contrast, Abdel Fatah al-Sisi, the commander-in-chief of the Egyptian army who had given the orders for Mursi's arrest, only assumed the position of minister of defense. But when El-Baradei stepped down after the Rabaa massacre, and after less than a month in office, the façade of civilian governance crumbled. ${ }^{9}$

Instead, the state of emergency was reinstated in reaction to country-wide unrest, and to legitimize the domestic deployment of military units. This return to martial law was not met with much resistance. On the contrary, while the disproportional level of state violence, as well as the restriction of public spaces, created an international stir, inside the country, it was strongly endorsed. Some voiced skepticism as to whether reports about the massacres were accurate, others blamed the Brotherhood for the violence. Representatives of the Tamarod movement aligned themselves with mainstream media and complimented Al-Sisi for his determination. The National Salvation Front staunchly toed the line.

It was particularly striking to witness revolutionary groups relativize and legitimize police brutality as well as military deployments across the country, who had just resisted the military rule of the SCAF the previous year, after Mubarak's ouster. As Nathan Brown (2013) observes, "every sin with which the opposition charged the Brotherhood - using force against demonstrators, trying to purge judges, denying and even applauding security-force abuses, harassing media - was a sin that the opposition embraced with unseemly enthusiasm in July 2013" (p. 51). Arguably their lacking criticism and outrage resulted from an entrenched conflict of interest: Many preferred a second chance for a democratic turnover to the 
perceived risk of a "Brotherhoodization" of the emergent post-revolutionary republic. Aside from such rational considerations, "hardened" affective orientations partially explain the lacking resentment among many social players and their loyalty to the security forces' course of action (see Jasper, 2018, p. 102f.).

\section{A New Sense of Belonging}

Key to the emergence of this strange bedfellow alliance between former revolutionaries and the army against the Brotherhood was that its political subjectivity was primarily articulated in nationalist terms. As Samuli Schielke (2017) has argued:

The conflict line that divided Islamists from supporters of a civil and/ or secular state never would have been sufficient to create the June 30 coalition. The most powerful and successful accusation against Morsi and the Muslim Brotherhood was not that they were fundamentalists or that they were incompetent, but that they were traitors to the nation. (p. 207)

This reproach dominated the emotional responses to the army's brutal handling of the Anti-Coup protests after Mursi's ouster. It connected to the nationalist political project that is deeply ingrained in Egyptian history (see Naeem, 2016) and reproduced the enduring affective orientations that are tied to this project. Moreover, it provided those players opposing the Brotherhood and its allies with a template for the apportion of trust, respect, blame, and resentment, which served as a background for the more immediate reflex emotions associated with the witnessed police brutality (Jasper, 2018, p. 103). The sense of belonging evoked by patriotism and the affective arrangements implied by a heavily nationalist discourse additionally responded to the need for a positive unifying denominator among Egypt's opposition.

Yannis Stavrakakis has underscored that the discursive production of "the people" as a potent political subject presupposes "the inability of an established system to respond effectively to social grievances and political demands" (see Economidou, 2018). This inability became obvious during Mursi's term in office: The government not only failed to respond to the allegations of partisanship with convincing policies but also aggressively side-lined the concerns of the opposition about the country's transition. The groups representing those unmet demands were linked to each other through their shared dissatisfaction with the status quo. In Ernesto Laclau's 
(2005) terms, an "equivalential chain" (p. 74) materialized in the shape of a populist discourse that catalyzed President Mursi's ouster.

The post-coup regime, in turn, galvanized this political orientation replete with negative clusters of feeling which had been confirmed and amplified by repeated experiences of humiliation, neglect, and insult during Mursi's rule - in a new nationalist discourse that described the military's actions, first during the January 25 uprising, then in response to the Tamarod protests on June 30, 2013, and finally to the Anti-Coup protests as a realization of the people's denied will. The army thereby managed to portray itself as "guardian of the revolution" (Monier and Ranko 2013: 112) and protector of the Egyptian nation.

This nationalist discourse initially functioned as a counterweight to the Muslim Brotherhood's claim to democratic legitimacy - derived from its victory at the ballot boxes. After July 3, 2013, it was repurposed to sanction the crackdown on the Brotherhood and its allies as a necessary evil to restore national security. The post-coup regime made its ability to defend the Egyptian homeland from internal and external foes an essential component of its haybat al-dawla [state prestige] (Baheyya, 2013; see also Khosrokhavar, 2018, p. 165). Over time, and especially after the massacres, this subtext became the dominant layer in all official communications: After Rabaa, there were no longer two camps of players contending in Egypt. Instead, there was only the Egyptian nation, on the one hand, and a group of extremists on the other.

\section{Authoritarian Regression in the Veil of Nationalism}

Egypt's modern conception of its national identity is to a large part based on the construction of a glorious legacy that spans back thousands of years until ancient pharaonic times - a heritage that is captured tellingly in a famous metaphor that describes the country as umm al-dunya [the Mother of the World]. How the Egyptian nation defines itself is nowhere more clearly articulated than in its constitution. The preamble of the document, which was adopted through a popular referendum in 2014, depicts Egypt as a gift to humanity at the heart of the world:

It is the meeting point of its civilizations and cultures and the crossroads of its maritime transportation and communications. It is the tip of Africa, [...] the dawn of human conscience, [...] the cradle of religions and the banner of glory of the revealed religions and the first centralized state. [Egypt] is the home of the best soldiers of the earth struggling in the path of God. 
Against this backdrop, the nationalist archive became a welcome resource for a military man such as General Al-Sisi to counter the Islamists' legitimizing strategies which were rooted either in their deeper knowledge of religious matters or their wins in democratic elections. The constitution traces the role of the national people's army as the pillar of the modern Egyptian state back to the Mohammed Ali Pasha, who ruled Egypt from 1805 to 1848 and whose political reforms and progeny rendered Egypt a de facto independent state. In this spirit, Al-Sisi portrayed the army's mandate and mission after the dissolution of Mursi's cabinet, as a project for the protection of the Egyptian nation and its free will, above formal electoral politics, and factional struggles.

It was this aura as a savior who would modernize the country and restore its glory, coupled with the "necessary fiction" (Jasper, 2018, p. 105) of an Egyptian nation with the duty to support these efforts that carried the general into the presidential office (in addition to the vicious repression of all meaningful opposition). As Samuli Schielke (2017) recounts, "love for the nation became heavily personalized in the figure of a venerated leader: Abdel Fattah el-Sisi, glorified as the savior of the nation in songs and posters that covered homes, public spaces, and businesses across the country" (p. 208).

The 2014 presidential election marked the seventh ballot for Egyptians since the fall of Husni Mubarak. It took place between May 26 and 28, 2014. Al-Sisi was elected with 96.9 percent of the popular vote. Significantly this tally was higher than the narrow margin of 1.24 percent by which Mursi had secured his majority in Egypt's first free elections and even surpassed the rigged 88.6 percent of Mubarak's last electoral victory in 2005. As Andrea Teti and his collaborators have argued, "Sisi's main objective was to outpoll Mursi so as to lend an air of legitimacy and popular approval to the ouster of the Muslim Brother some 11 months earlier" (Teti et al., 2014).

Amid widespread reports of empty voting stations (see Kirkpatrick, 2017), officials announced that also the overall voter turnout of 47.5 percent exceeded that of the 2012 elections. Though heavily contested and the result of a limited choice in a repressive setting, these tallies reinforced the impression that Al-Sisi had beaten the Anti-Coup Alliance at its own game. The Anti-Coup campaign had portrayed general elections as the only legitimate source of power. Al-Sisi's victory at the ballot now challenged this discourse from within. It also endowed the new president, who now embodied both, the popular will and the army's prestige, with a high degree of popular trust. Empowered by this dual role, Al-Sisi dedicated his first weeks in office to the construction of an exclusive notion of citizenship with no room for those criticizing or dissenting with the national project 
(see Pratt, 2015, p. 49). Through the construction of a dualistic friend-foe mindset, dissenters were successively flagged as enemies of the state.

At the same time, the new military-backed government strengthened its alliance with those players that the Anti-Coup Alliance or other oppositional forces had marked as their enemies (see Roll, 2016, p. 34). Particularly the Tamarod initiative was subsequently instrumentalized as a mechanism to co-opt the Egyptian youth and as a potential reservoir for a new basis of political power. Tamarod representatives were involved in drafting the new constitution, and loyal youth groups were offered state support. What is more, a new nationalist platform, Mustaqbal Watan [the Future of the Nation] was established to empower loyalists within Egypt's revolutionary youth (see N. Abdalla, 2016). Like Tamarod before, the Future of the Nation campaign joined Al-Sisi's presidential election effort.

The construction of clear-cut antagonisms and the affective registers they connoted followed a well-established rule and divide playbook and mirrored the mechanisms by which Egypt's rulers have traditionally manufactured consent for their authoritarian policies. (McManus, 2018, pp. 3-6). Since the times of Gamal Abdel Nasser, patriotic portrayals of the Egyptian nation as progressive and modern, in contrast to a degenerate other (often an Islamist fundamentalist one), have intended to bolster state-centric models of governance (see Khatib, 2006; Yohannes, 2001). This othering process justified a conquest of this figure - often through security means. For decades, nationalist discourses thus lent themselves to support authoritarian power structures. Dichotomous representations of Egyptian society as an unbridgeable $u$ s against them, by nature, seemed to suggest the limits of, and undermine the struggles for pluralism within the nation (Khatib, 2006, p. 76). As Adeed Dawisha (2003) writes, "Arab nationalism operated throughout its glory days in a sea of authoritarianism, and this happened not because of some unfortunate circumstance. Indeed, the very way Arab nationalism was defined and developed accounted for the absence of democracy" (p. 297).

Even Husni Mubarak used to portray himself as the guardian of a nationalist and secular state against Islamist extremism. Hence, Al-Sisi's adoption of a similar discourse was not without its risks. But against the backdrop of continued violence in Sinai, clashes across the country, and the bloody summer of 2013, his administration was more successful in building resonances for the idea of a "nation under threat" (Sobhy, 2015, pp. 806, 821). It was effectively this nationalist discourse and the "sense of groupness" (Jasper, 2018, p. 105) that it transported which elevated Al-Sisi from his initial status as a trustworthy officer and loyal protector of the masses to the level 
of a moral paragon with the right to adjudge, speak and act in the name of national interest and national security (see Hamzawy, 2016).

\section{Shrinking Spaces}

The successful articulation of a nationalist conception of legitimacy as a counter-weight to the Brotherhood's narratives expedited the emergence of a new hegemonic bloc. In this nascent constellation, the army was present as the principal revolutionary subject. But the construction of an antagonist frontier between the people and its enemies also created discursive opportunities for massive repression. The mechanisms of securitization deepened the military's agenda by including non-military threats such as mass demonstrations and political opposition. They also extended the security forces' room for maneuver on the domestic level and renewed their legitimacy in the eyes of the people. Consequently, the new security paradigm soon transcended the Islamist segment of society.

To justify the redefinition of ever more policy arenas as security-relevant spheres or national crises, subjects such as the labor dispute, the state of public health care and education, or the demise of the currency reserves, were all dramatized by rhetorical structures dominated by threat perceptions and militarized, securitized, and often gendered language (see Amar, 2013). The terrorism label proved particularly useful for extending the state's freedom of action by creating a sense of urgency and canalizing public fears into feelings of trust and loyalty towards the agents of law enforcement. After the break-up of the Rabaa sit-in, presidential adviser Mostafa Hegazi declared the fight against extremism a full-blown war on terror. This war metaphor was uncritically cited by most political camps and used to justify repression against all kinds of dissent. Dealing with a designated terrorist group, and thus a matter of national security, authorities no longer had to limit their response to police deployment.

\section{A War on Civil Society}

The new constitution of January 2014 contained an article that declared the fight against all manifestations of terrorism a national goal and endowed the security services with far-reaching powers. Since its adoption, however, the Al-Sisi administration repeatedly modified its terrorism definition, expanding it each time to include a new set of criminal offenses. As a result, not only the Brotherhood but all actors critical of the regime or contradicting 
its narratives can now be persecuted by the domestic security services as threats to public order or national unity - and prosecuted by special courts for terrorism-related felonies (see Wessel, 2016, p. 26).

Orwellian legislation from mid-August 2015 (law 94/2015) further expanded the list of offenses to be tried as terrorist crimes to include even private expressions of support for groups blacklisted by the judiciary as terrorist entities. Article 86 of this new terrorism law - symbolically ratified by President Al-Sisi on the second anniversary of the Rabaa massacre - also criminalized the distribution of materials, in writing or speech, pertaining to proscribed organizations or in service of their objectives. ${ }^{10}$

A new protest law had already barred all public shows of solidarity with such groups in November 2013 (see Grimm, 2015). This piece of legislation responded to the ongoing protests under the umbrella of the Anti-Coup Alliance in the weeks after Rabaa by limiting the freedom of assembly and subjecting all collective action to prior police authorization. The law specified, on pain of severe penalties, that the organizers of any demonstration had to present their planned itinerary, the expected number of participants, and the names of those in charge seven days in advance at the responsible police station. Violations of this procedure or the vague requirement not to impair the country's "productivity" through protests were to be prosecuted as criminal offenses."

A government decree that authorized military courts to prosecute all violations committed in the vicinity of vital military installations complemented the protest law on October 27, 2014. Tellingly, the decree categorized not only electricity plants, pipelines, railway stations, and bridges as vital infrastructure but also the Egyptian universities, which had become the hotbeds of resistance after the crackdown on the Anti-Coup street protests. Taken together, these legal provisions tantamounted to a de facto ban on all demonstrations since the authorities issued hardly any authorizations and since fines of 100,000 Egyptian pounds and a two-year prison sentence became the "new standard" for punishing those who defied authorities (Teti et al., 2014). The protest law also became one of the main legal pretexts to put arrested regime critics on trial. ${ }^{12}$ In addition, activists' room for maneuver

10 For a discussion see https://archive.vn/wip/ly8HC.

11 An English translation of the protest law was made available by EgyptJustice.com at https:// de.scribd.com/document/398648976/Protest-Law-English.

12 The number of persons arrested under the protest law is not publicly available. The Egyptian research center Daftar Ahwal, however, reports at least 37,059 cases of individuals stopped, arrested, or charged under the protest law between November 2013 and September 2016. While under Mubarak the number of political detainees peaked at around 14,00o, the Wiki Thawra 
was systematically restricted through a series of presidential decrees in the months after Rabaa. In July 2014, a coalition of the most important national human rights organizations referred to the progressive restriction of civil society as a "declaration of war by the government on freedom of association and the work of civil society organizations in Egypt" (CIHRS, 2014). This war first targeted the Brotherhood and its allies, but then expanded to liberal and leftist movements, such as April 6 or the Revolutionary Socialists.

It also affected those who had documented the repression and rights violations committed by the security apparatus after the July 3 coup. In the absence of any independent investigation of the massacres in mid-2013, human rights organizations had taken on the critical function of monitoring the executive. This crucial task turned these groups themselves into targets of repression. To regulate the work of these and other NGOs, Social Minister Ghada Waly announced a new NGO law in June 2014, which was intended to replace the Mubarak-era association law 84/2002. According to the draft, NGOs were to be prohibited from participating in political activities and from carrying out unauthorized field research, data collection, or publishing. A supervisory authority with veto power was to control the registration, funding, and personnel decisions of NGOs working in Egypt. A particular source of concern was the indication that representatives of the NSS and the Ministry of Interior would be part of this committee.

As a result of massive public criticism of these provisions, the new NGO law was initially held back. Nevertheless, NGOs were made to register at the Social Solidarity Ministry per the current legislation. ${ }^{13}$ At first glance a mere formality, this procedure placed their work content and structure under the auspices of the ministry and drastically curtailed the associational freedoms guaranteed by the constitution. The large amount of discretion that the vaguely worded association law afforded the authorities effectively enabled state institutions to control any registered organization's funds at will, to prohibit their political activities, and to hold potential asset freezes as a Damocles Sword over activists' heads.

The heavily criticized law was finally repealed in June 2017 - only to be replaced by new and even more restrictive legislation to regulate civil society. This new law 70/2017 extended the authorities' room for maneuver in the

file analyzed in this book indicates that security forces detained more than 41,000 people in the months after the coup. Current estimates put this figure at over 6o,ooo.

13 According to the Ministry, about 45,000 NGOs were registered nationwide. Among Egypt's large human rights groups only the Egyptian Initiative for Personal Rights has done so, in early 2015, avowedly to set a precedent for Egyptian human rights organizations. 
regulation of civil society organizations as well as their budget oversight to an unprecedented degree (see Mirshak, 2018). Consequently, several prominent civil society organizations discontinued their work just before the deadline to register as an NGO under the new law expired or moved their staff abroad. Other groups simply ignored the deadline hoping to slip through the ministry's net, or registered as media production companies, limited liability companies, or law firms - sectors where regulation was less restrictive.

\section{Extra-Legal Repression}

This legalized repression reshaped the parameters of Egypt's protest arena by penalizing social mobilization, restricting critical discourse, and foreclosing opportunities and venues for civic activism (Hamzawy, 2017). In addition, extrajudicial violence impaired the mobilizing structures and resources of key opposition players. Since 2014, and increasingly since mid-2015, security forces targeted the lower and mid-levels of activist collectives, NGOs, and social movements with enforced disappearances (Grimm 2015, 4f.), that is, abductions carried out by state officers in plainclothes and to places outside the protection of the law. ${ }^{14}$

These enforced disappearances, mostly from the street, but also from private flats or the campuses of state universities, marked a new dimension in the abuse of state power. Above all, they demonstrated the degree of cover enjoyed by the authorities because of their securitizing frames: Enforced disappearances usually marked the start of a detention process, as those disappeared often resurfaced after weeks within the penitentiary system. At the same time, the Ministry of Interior, which formally administers Egyptian prisons, routinely refused to comment or else denied that the kidnappings had taken place, at all.

The enforced disappearance also exemplified the increasing randomization of repression which was intended to cow activists and potential protesters into obedience by reducing certainty and shattering their previous expectations during interactions. As Jasper (2018) notes, "forces of order may try to paralyze protestors through fear. This is the definition of state terror and authoritarian regime" (p. 55). In this sense, the initially counter-intuitive fact that the kidnappings were not always targeted - victims included

14 The Egyptian Coordination for Rights and Freedoms (ECRF), a coalition of lawyers that investigated the whereabouts of disappeared Muslim Brothers, identified almost 1,00o people that went missing since the start of 2015 . 
members of the banned Anti-Coup student chapter but also Egyptians who could not be assigned to any banned group - fulfilled an important repressive function by producing "feelings much like those of the tortured: a sense of vulnerability, alertness, a feeling of powerlessness, and distorted perceptions of what is real and possible as opposed to imaginary" (Jasper, 2018, p. 55).

In a similar arbitrary way, those who disappeared varyingly remained missing, were declared deceased during an anti-terror operation, or found themselves in one of the Egyptian jails of Tora, al-Qanater, and al-Aqrab. Some were also released into freedom after varying periods. These outcomes followed no discernible pattern. In some cases, activists whose location had been discovered were brought before a magistrate on a litany of trumped-up charges to legitimize their arrests retroactively. In other cases, their pre-trial detention was indefinitely extended without any formal charges by the prosecution. Combined, all these different potential outcomes, much like the sadly long repertoire of torture that has also been a constant feature of authoritarian politics in Egypt, instilled fear and related emotions such as mistrust and anxiety. It aimed at cowing potential dissenters into the demobilizing role of passive victims.

Increasingly, physical repression was also backed up by humiliation, especially of those who failed to display proper deference. To this end, the Egyptian regime included religious and moralizing themes into its populist rhetoric which depicted Al-Sisi as a protector of dignified morals and values. As argued elsewhere (Grimm, 2014), raids against bathing houses and coffee shops, the proclamation of a national strategy to combat atheism, and the prosecution of gay men for "debauchery" were just the most visible symptoms of a concerted effort to restore the state's moral authority in the eyes of the public. This frame enabled the president to address divergent moral conceptions as inappropriate for Egyptian society. At the same time, this discursive strategy was intensively used to denunciate and repress rights activists and liberal civil society organizations by attacking their basic human dignity (see Hamzawy, 2017, p. 6).

\section{A Winning Formula for Popular Support}

Because of these shrinking spaces due to legalized, extra-legal, and discursive repression, social movements all but disappeared from Egypt's streets during Al-Sisi's first year in office. The new way of expressing dissent that was established during the 2011 Revolution never completely vanished: Students 
adopted protest marches and occupations as a contentious repertoire to mobilize at their universities and against the encroachment of the security state on campus (Sika, 2017, p. 160). Furthermore, in what has been discussed as a new "supply intifada" (Ketchley \& El-Rayyes, 2017), Egyptians took to the streets against the government's decision to cut bread subsidies in several rural cities of Upper Egypt and the Nile Delta in March 2017. But in the end, neither of these cycles was more than a scattered population of protest events. Nor were the discourses of those taking to the street marked by any visible challenge to the nationalist consensus that carried Al-Sisi into office.

Accordingly, Egypt's nationalist revival has been mostly interpreted as a mechanism that successfully cemented the autocratic order (see Adly, 2014; Sobhy, 2015). It not only enabled repression on an unprecedented scale. It also left traces on people's hearts and minds: As the Egyptian nation was increasingly viewed and accepted as "a project rather than a people" (Kurzman, 2018, p. 186), a new social contract emerged - one that Foucault (1977) would have aptly described as a "disciplinary society" (p. 201) and others have decried as a "fascist" society (a.o., Al-Anani, 2015b; Naeem, 2016; Shahin, 2015).

In an assessment of Al-Sisi's grip on power, Maha Abdelrahman (2017) concluded that the regime "struck a winning formula for guaranteeing popular support" (p. 14) by deriving its legitimacy from promises of restoring security, honor, as well as Egypt's lost leadership in the Arab world. However, at the same time, she also notes the downside of this policy. Above all, Abdelrahman cautions against the substantial costs of keeping up with the illusions of national grandeur. On the one hand, the eminent focus of security policies may imply that other, not security-relevant policy fields remain neglected which, in turn, may compound popular grievances. On the other hand, national authorities may be unable to deliver on their promises: The power of nationalist discourse ultimately lies in its projection of a glorious image of the nation. But what if it becomes evident that these projections are castles in the air? As Mohamed Naeem (2016) writes in his essay on the state of Egypt, the "Mother of the World," "believers in the nationalist ideal daily bear the weight of its greatness and swim in seas of arrogant pride, impervious to the daily reality that defies such a belief. How can the result be anything but perilous?"

As the next chapter illustrates, there is nothing determining or inevitable about the effects of nationalism. As Mark Beissinger (2002) has argued in his attempt to transcend the dichotomous view of nationalism as either a strategic instrument or a primordial phenomenon, nationalist projects can become vehicles for the exertion of power or support a "politics of 
emboldening in the face of institutional constraints" (p. 38). Either outcome depends on how nationalism is constructed by social players and how it is shaped by their interactions during tumultuous periods of contention. Once a wave of nationalism emerges, ex-ante structural or institutional factors lose much of their relevance, allowing for - more or less - extraordinary events. Structural opportunities and institutional constraints may set the initial stage for protests. But once contentious emerges, events can take on a life of their own and alter conceptions of the nation in ways that encourage protests against, or in support of a ruler.

\section{References}

Abdalla, N. (2016). Youth movements in the Egyptian transformation: Strategies and repertoires of political participation. Mediterranean Politics, 21(1), 44-63. https://doi.org/10.1080/13629 395.2015 .1081445

Abdelrahman, M. (2017). Policing neoliberalism in Egypt: The continuing rise of the 'securocratic' state. Third World Quarterly, 38(1), 185-202. https://doi.org/10.1080/01436597.2015.1133246

Adly, A. (2014, October 14). Egypt's conservative nationalism: Discourse and praxis of the new regime. Carnegie Middle East Center. http://www.jadaliyya.com/Details/31358/ Egypt $\%$ e2\%80\%99s-Conservative-Nationalism-Discourse-and-Praxis-of-the-New-Regime

Al-Anani, K. (2015, August 12). When murder becomes a national project. The New Arab. https:// www.alaraby.co.uk/english/comment/2015/8/12/when-murder-becomes-a-national-project

Al-Anani, K. (2016). Inside the Muslim Brotherhood: Religion, identity, and politics. Oxford University Press.

Al-Dakhakhly, F. (2014, August 1). Government decision to reshape fact-finding committee on the events of the 'June $3^{\circ}$ Revolution' today [Arabic]. Al-Masry Al-Youm. https://www.almasryalyoum.com/news/details/372591

Amar, P. (2013). The security archipelago: Human-security states, sexuality politics, and the end of neoliberalism. Duke University Press.

Amnesty International. (2018, September 8). Egypt: Death sentences and heavy prison terms handed down in disgraceful mass trial. https://bit.ly/2u4iZPp

Awad, M. (2017). The role of traditional and new media in the Egyptian Muslim Brotherhood's internal power struggle. Project on Middle East Political Science. https:/pomeps.org/2017/o1/23/ the-role-of-traditional-and-new-media-in-the-egyptian-muslim-brotherhoods-internalpower-struggle/

Aydın-Düzgit, S. (2014). The seesaw friendship between Turkey's AKP and Egypt's Muslim Brotherhood. Carnegie Endowment for International Peace. https://carnegieendowment.org/2014/07/24/ seesaw-friendship-between-turkey-s-akp-and-egypt-s-muslim-brotherhood-pub-56243

Baheyya. (2013, August 8). Fetishizing the state. Baheyya: Egypt Analysis and Whimsy. http:// baheyya.blogspot.com/2013/o8/fetishizing-state.html

Beissinger, M. R. (2002). Nationalist mobilization and the collapse of the Soviet state. Cambridge University Press.

Bildt, J. van de. (2015). The quest for legitimacy in postrevolutionary Egypt: Propaganda and controlling narratives. The Journal of the Middle East and Africa, 6(3-4), 253-274. https://doi. org/10.1080/21520844.2015.1087817 
Brooke, S. (2013). Doctors and brothers. Middle East Report, 269, $12-17$.

Brooke, S. (2015). The Muslim Brotherhood's social outreach after the Egyptian coup (Rethinking Political Islam Series). Brookings Institution.

Brown, N. J. (2013). Egypt's failed transition. Journal of Democracy, 24(4), 45-58.

CIHRS. (2014, July 24). Memo to Ibrahim Mahlab, Prime Minister. https://www.cihrs.org/wpcontent/uploads/2014/o7/Memo-to-Dr.-Ibrahim-Mahlab.pdf

Davis, N. J., \& Robinson, R. V. (2012). Claiming society for god: Religious movements and social welfare Egypt, Israel, Italy, and the United States. Indiana University Press.

Dawisha, A. (2003). Arab nationalism in the twentieth century: From triumph to despair. Princeton University Press. https://doi.org/10.2307/j.ctt7shc6

Dunne, M., \& Brown, N. (2014). Egypt's judges join in. Carnegie Endowment for International Peace. http://carnegieendowment.org/2014/04/o2/egypt-s-judges-join-in/h6tf

Economidou, M. (2018, February 13). Interview with Yannis Stavrakakis for the New Pretender, February 2018. The New Pretender. https://new-pretender.com/2018/02/13/interview-withyannis-stavrakakis/

El-Dabh, B. (2013, December 27). Freezing of assets of Islamic NGOs 'open door' to conversions of poor Muslims. Daily News Egypt. https://dailynewsegypt.com/2013/12/27/ freezing-of-assets-of-islamic-ngos-open-door-to-conversions-of-poor-muslims-brotherhood/

El-Sherif, A. (2014). The Muslim Brotherhood and the future of political Islam. Carnegie Endowment for International Peace. http://carnegieendowment.org/files/mb_future_egyptı.pdf

Fahim, K., \& Sheikh, M. E. (2018, October 19). Memory of a mass killing becomes another casualty of Egyptian protests. The New York Times. https://www.nytimes.com/2013/11/14/world/middleeast/memory-egypt-mass-killing.html

Foucault, M. (1977). Discipline and punish: The birth of the prison. Vintage Books.

Grimm, J. J. (2014, December 19). Sisi's moralism [Carnegie Endowment for International Peace]. Sada. http://carnegieendowment.org/sada/2014/12/19/sisi-s-moralism/hxnz

Grimm, J. J. (2015). Repressing Egypt's civil society: State violence, restriction of the public sphere, and extrajudicial persecution (SWP-Comments No. 41; p. 8). Stiftung Wissenschaft und Politik. http://www.swp-berlin.org/fileadmin/contents/products/comments/2015C41_gmm.pdf

Hamzawy, A. (2016, November 8). Egypt's Orwellian populisms [Carnegie Middle East Center]. Diwan. https://carnegie-mec.org/diwan/65051

Hamzawy, A. (2017). Legislating authoritarianism: Egypt's new era of repression. Carnegie Endowment for International Peace. https://carnegieendowment.org/2017/03/16/ legislating-authoritarianism-egypt-s-new-era-of-repression-pub-68285

Jasper, J. M. (2018). The emotions of protest. The University of Chicago Press.

Ketchley, N., \& El-Rayyes, T. (2017, March 29). On the breadline in Sisi's Egypt. Middle East Research and Information Project. http://www.merip.org/mero/meroo32917

Khatib, L. (2006). Nationalism and otherness: The representation of Islamic fundamentalism in Egyptian cinema. European Journal of Cultural Studies, 9(1), 63-80. https://doi. org/10.1177/1367549406060808

Khosrokhavar, F. (2018). Violence, social actors, and subjectivation in the Egyptian revolution. In F. Volpi \& J. M. Jasper (Eds.), Microfoundations of the Arab uprisings: Mapping interactions between regimes and protesters (pp. 159-182). Amsterdam University Press.

Kirkpatrick, D. D. (2017, December 20). Egypt scrambles to raise turnout in presidential vote. The New York Times. https://www.nytimes.com/2014/05/28/world/egypt-presidential-election. html

Kurzman, C. (2018). Conclusion: Unruly protest. In F. Volpi \& J. M. Jasper (Eds.), Microfoundations of the Arab uprisings: Mapping interactions between regimes and protesters (pp. 183-192). Amsterdam University Press. 
Laclau, E. (2005). On populist reason. Verso.

Magued, S. (2018). The Egyptian Muslim Brotherhood's transnational advocacy in Turkey: A new means of political participation. British Journal of Middle Eastern Studies, 45(3), 480-497. https://doi.org/10.1080/13530194.2017.1320975

McManus, A. (2018). Securitization in Egypt: Between discourse and reality. In I. El-Anis, N. Underhill, \& S. Joharchi (Eds.), Security and insecurity in the Middle East (pp. 1-22). Cambridge Scholars Publishing.

Mirshak, N. (2018, November 22). Rethinking resistance in post-uprisings Egypt. OpenDemocracy. https:/www.opendemocracy.net/nadim-mirshak/rethinking-resistance-in-post-uprisingsegypt

Monier, E. I., \& Ranko, A. (2013). The fall of the Muslim Brotherhood: Implications for Egypt. Middle East Policy, 20(4), 111-123. https://doi.org/10.1111/mepo.12050

Naeem, M. (2016, June 9). Mother of the world, against the world and outside of it. Mada Masr. http://www.madamasr.com/opinion/mother-world-against-world-and-outside-it

NCHR. (2014). Report of the National Council for Human Rights fact-finding mission about the disperse of Ra-ba'a Al-Adaweya sit-in [Arabic]. National Council for Human Rights. http:// www.nchregypt.org/demo/download_en_news.php?id=503_22125759.pdf

Pearlman, W. (2018). Contingency and agency in a turning point event: March 18, 2011, in Daraa, Syria. In F. Volpi \& J. M. Jasper (Eds.), Microfoundations of the Arab uprisings: Mapping interactions between regimes and protesters (pp. 111-134). Amsterdam University Press.

Pratt, N. (2015). After the 25 January Revolution: Democracy or authoritarianism in Egypt? In R. Abou-el-Fadl (Ed.), Revolutionary Egypt: Connecting domestic and international struggles. Routledge.

Rabia, R. (2018, July 3). 'Shorouk' publishes the text of the 'treatment of senior commanders of the armed forces' before the adoption. Al-Shorouq. https://www.shorouknews.com/news/view. aspx $?$ cdate $=03072018 \&$ id $=54153$ a 77 -bog $8-43$ b6-bbb4-9a6640226ed 8

Richter, C. (2017). Mobilize, justify, accuse: The Egyptian Muslim Brotherhood and changing media practices. In S. Foellmer, M. Lünenborg, \& C. Raetzsch (Eds.), Media practices, social movements, and performativity: Transdisciplinary approaches (pp. 100-113). Routledge.

Roll, S. (2016). Managing change: How Egypt's military leadership shaped the transformation. Mediterranean Politics, 21(1), 23-43. https://doi.org/10.108o/13629395.2015.1081452

Sailer, M. (2016). Changed priorities in the Gulf: Saudi Arabia and the Emirates rethink their relationship with Egypt (SWP Comments C 8; p. 8). Stiftung Wissenschaft und Politik. https:// www.swp-berlin.org/fileadmin/contents/products/comments/2016Co8_sil.pdf

Schielke, S. (2017). There will be blood: Expectation and ethics of violence during Egypt's stormy season. Middle East Critique, 26(3), 205-220. https://doi.org/10.1080/19436149.20 17.1336023

Shahin, E. (2015, June 9). The four traits Sisi, Hitler and Mussolini have in common. Middle East Eye. http://www.middleeasteye.net/columns/four-traits-sisi-hitler-and-mussolini-havecommon-1427651880

Shamni, N. (2013). Punitive measures against athletes for flashing four-finger 'pro-MB' sign spark controversy In Egypt (MEMRI Inquiry \& Analysis Series Report No. 1048). MEMRI. https:// www.memri.org/reports/punitive-measures-against-athletes-flashing-four-finger-pro-mbsign-spark-controversy-egypt

Shams El-Din, M. (2016, August 14). The Rabea sit-in dispersal: Who the state is blaming three years on. Mada Masr. https://madamasr.com/en/2016/o8/14/feature/politics/ the-rabea-sit-in-dispersal-who-the-state-is-blaming-three-years-on/

Shokr, A. (2014, August 16). The massacre one year later. Middle East Research and Information Project. http://www.merip.org/massacre-one-year-later 
Sika, N. M. (2017). Youth activism and contentious politics in Egypt: Dynamics of continuity and change. Cambridge University Press.

Sly, L., \& Al-Hourani, S. (2013, August 15). Egypt authorizes further use of live ammunition against pro-Morsi protesters. Washington Post. http://www.washingtonpost.com/world/scores-deadin-egypt-after-security-forces-launch-assault-on-protesters-camp/2013/o8/15/563c95ao0575-11e3-ao7f-49ddc7417125_story.html

Sobhy, H. (2015). Secular façade, neoliberal Islamisation: Textbook nationalism from Mubarak to Sisi. Nations and Nationalism, 21(4), 805-824. https://doi.org/10.1111/nana.12147

Teti, A., Matthies-Boon, V., \& Gervasio, G. (2014, June 10). Sisiphus. Middle East Research and Information Project (MERIP). http://www.merip.org/mero/meroo61014

Wessel, S. (2016). Grey-scales: Negotiating the civil state in post-revolutionary Egypt (CARPO Study: The Dawla Madaniyya Series No. 3). CARPO. https://carpo-bonn.org/wp-content/ uploads/2016/12/CARPO_Study_03_2016_Wessel.pdf?fbclid=IwAR1xw9-1dRRjp9wRIW_oxoPdhQK7Y2GoMo-id_V7MoslqGV5zRjKbWifoFw

Yilmaz, I., Barton, G., \& Barry, J. (2017). The decline and resurgence of Turkish Islamism: The story of Tayyip Erdoğan's AKP. Citizenship and Globalisation Studies, 1(1), 48-62. https://doi. org/10.1515/jcgs-2017-0005

Yohannes, O. (2001). Political economy of an authoritarian modern state and religious nationalism in Egypt. Edwin Mellen Press.

Zeinobia. (2018, September 8). Rabaa Sit-in dispersal trial: Death sentences, life sentences and Shawkan is free at last... somehow. Egyptian Chronicles. https://egyptianchronicles.blogspot. com/2018/og/rabaa-sit-in-dispersal-trial-death.html 


\title{
$7 \quad$ A Tale of Two Islands
}

Cross-movement alliances, nationalist mobilization, and the Tiran and Sanafir island protests

\begin{abstract}
The nationalist discourse that accelerated Al-Sisi's ascension to power, at the same time, placed him and his supporters in a cage, forged of commitments to national security. This became visible when the transfer of two Red Sea islands to Saudi Arabia revealed the disparities between official policy and discourse and gave rise to a new contentious player in the shape of a protest campaign against the island deal. Through this campaign, nationalist activists held a mirror up to the authorities and undermined the official legitimization of repression. In doing so, they reshaped the post-coup protest arena and created new windows for mobilization. This chapter thus demonstrates how players can harness the emotional dimensions of established discourse for alliance building and mobilization under the most repressive conditions.
\end{abstract}

Keywords: alliance-building, autocracy, backlash, iron cage, nationalism, protest

Recent studies of protest in the Middle East have shown that there is significant power "in the subversion of the very images that rulers have tried to project as evidence and instrument of their dominion" (Tripp, 2013 , p. 306). The emancipatory potential of appropriating the language of those in power for symbolic resistance was, for instance, illustrated in Turkey, where President Erdogan unintendedly gave rise to an oppositional campaign by declaring that he would step aside if the nation said: Tamam [enough]. This statement inspired a viral hashtag on social media, which was able to unite Turkey's fragmented opposition (Hintz, 2018a). Another recent example comes from Lebanon in 2019, where demonstrators subverted a recurrent trope of their president's discourse. In a jab to Michel Aoun, who

Grimm, Jannis Julien, Contested Legitimacies: Repression and Revolt in Post-Revolutionary Egypt. Amsterdam: Amsterdam University Press 2022 DOI: $10.5117 / 978946372265^{0} \_$CHO7 
is known for presenting himself as a paternal figurehead to an immature Lebanese state (see Lefort, 2019), protesters adopted the lines "not our father" in many of their chants. Incensed by the president's televised remarks that protesters were free to emigrate if they saw no decent people within the state institutions, they also revived the iconic "irhal!" [leave!] chant from the Arab Spring: "We won't go unless the 'father of all' leaves," protesters chanted, referring to Aoun by his self-given title.

These acts of symbolic resistance brought to light players' intimate familiarity with the ways in which power was exerted in their home countries. As Charles Tripp (2013) notes, regardless of their concrete forms and representations, "the very fact of their expression can both outline the contours of resistance and unsettle the arrogant complacency of established power" (p. 308). In both Turkey and Lebanon, protesters turned the words of their presidents against them, thus repurposing narratives, which meant to stabilize the acting government and prevent protest, for mobilization.

Years after the events of Rabaa, in April 2016, Al-Sisi found himself in a similar quandary. As illustrated in previous chapters, the general had struck gold with his nationalist discourse, which promoted the notion of a nation under threat. This perception was instrumental, above all, to legitimize far-reaching repression and a swift democratic rollback. But Al-Sisi's carefully curated image as protector of the nation, and the securitizing discourse that sustained it, also placed the president and his administration in a cage, forged of commitments to national security (Grimm, 2019, pp. 460-466; see also Ritter, 2014). This cage became visible when the Al-Sisi government admitted in April 2016 that it would transfer sovereignty over Tiran and Sanafir, a small Red Sea archipelago, to Saudi Arabia.

Situated at the gate of the Gulf of Aqaba, the archipelago of Tiran and Sanafir is mostly uninhabited. The few inhabitants consist of Bedouin fishermen, a garrison of Egyptian police forces, and a small division of an international peacekeeping mission, stationed on the islands in the aftermath of Camp David. Aside from these, it is mostly diving tourists from the resort town of Sharm el-Sheikh that are drawn to the islands' rare colorful coral reefs and vivid marine life. But despite their lack of demographic significance (and the fact that most Egyptians have never set foot on either of the islands), Tiran and Sanafir are deeply embedded in Egypt's nationalist archive. The islands played a central role in all three wars with Israel. Egypt resumed control over the islands only in 1980, after a lengthy diplomatic struggle, and as part of the Israeli withdrawal from the Sinai Peninsula. Hence the surprise and outrage when the Al-Sisi government 
came forward with a secretly negotiated maritime border agreement on April 8, 2016, which put Tiran and Sanafir under Saudi sovereignty. ${ }^{1}$

This border demarcation agreement became a critical juncture for Egypt's post-coup transition. It caused rifts in the prevalent consensus about Al-Sisi's legitimacy to rule in the nation's interest. And it created new openings for countervailing political projects to suture these rifts. The deal starkly highlighted the disparities between what the general and his administration claimed to stand for and how they acted. By debunking the hollow nationalist rhetoric of the Al-Sisi regime, it provided the ignition spark for contesting the state's securitization of contentious action, which had delegitimized protest since Mursi's deposition, with a new language of revolt that reclaimed the meaning of patriotism in a way that supported social protests. Outraged by the voluntary cession of Egyptian territory to a foreign power, thousands of protesters gathered in Alexandria, Cairo, Port Said, and a range of other provincial capitals to demonstrate against the agreement.

\section{Reshaping the Protest Arena}

What made these protests significant was not only that they were the largest non-Islamist demonstrations since the 2013 military coup, but also the diversity of their participants: An unlikely domestic alliance of "strange bedfellows" (Whittier, 2014, p. 175) took to the street which was neither associated with the Muslim Brotherhood and its goal of reinstating President Mursi, nor the military regime and its campaign against internal opposition. Opposition to Al-Sisi's dominion materialized most notably in the shape of the so-called Popular Campaign to Protect the Land - Egypt is not for sale! [hereafter referred to as PCPL] - a new coalition of old political players who jointly took to the street to oppose the island deal. Among the players that joined this coalition were the April 6 Youth Movement, the Youth Movement for Justice and Freedom, and the Revolutionary Socialists - leftist youth and labor rights groups who had been vital in the making of the 2011 revolution.

Additionally, many of the political parties founded in the aftermath of the uprising joined the coalition, including the Constitution Party, the Popular Current, the Strong Egypt Party, and the Bread and Freedom Party - the four parties created in the wake of the 2012 elections by the former presidential candidates Mohamed El-Baradei, Hamdeen Sabahi, Abdel

1 The full text of the maritime border delimitation agreement can be accessed at https:// perma.cc/AF6N-99DF. 
Moneim Aboul-Foutuh, and Khaled Ali. The outlawed Muslim Brotherhood also supported the protests. Even the Tamarod movement, which had paved the way for Al-Sisi's ascension to power, joined the rallying calls.

Some of these players had hitherto fervently opposed each other. Aside from partisan grievances and ideological cleavages between Islamists and some liberal opposition parties, their fragmentation had resulted primarily from the securitization of Egyptian politics in the aftermath of the 2013 military coup. The repressive socio-political context had made it difficult for civil society to articulate a shared political message. Amongst the mechanisms preventing the opposition to coalesce were the aggressively proclaimed nationalist discourse described in the previous chapters which delegitimized any dialogue with those designated as national enemies, in addition to long-standing identity issues and the fundamental controversy about whether or not to support the armybacked interim government.

Sporadically, some players had overcome these cleavages, for instance, to form electoral alliances in the 2014 presidential elections. However, massive disagreements about Al-Sisi's war on terrorism, the recognition of the massacres against pro-Mursi demonstrators, and the inclusion of the Islamist segment of society into the post-coup order prevailed. These rifts would have suggested equally polarized reactions to the announcement of the island deal. All the more surprising was the ability of Tiran and Sanafir to unite the opposition in a new "coalition of contenders" (McAdam et al., 2001, p. 7).

For the Al-Sisi administration, this type of cross-ideological and crossmovement resistance was a primer. The overall turnout of the countrywide demonstrations may have remained rather low. Nevertheless, they exerted a transformative effect on Egypt's protest arena - for reasons that have less to do with participation rates and protest size and more with their symbolic character - by opening the doors for contesting the regime's modus of governing the country on different terrain. Accordingly, it was not long before the protest chants shifted from condemnations of Al-Sisi's deal with the Saudi King to the iconic slogans which had echoed in Egypt's streets since the outset of the revolution.

Significantly, the regime found itself trapped in dealing with these protests: The nationalist window-dressing had allowed opponents to hold it accountable to its own standards. The risk of tainting its image further among the wider patriotic population, in turn, inhibited it from brutally repressing this dissent. In other words, the Tiran and Sanafir agreement decisively reshaped the arena of contentious politics in post-coup Egypt. 


\section{The Limits of Securitization}

The controversial agreement that ceded to Saudi Arabia sovereignty over the two Red Sea islands at the mouth of the Gulf of Aqaba was officially signed into effect by Egyptian Prime Minister Sherif Ismail and his Saudi counterpart on April 8, 2016. The ceremony coincided with King Salman's visit to Egypt. As part of the ceremony, the government also disclosed its intention to build a new 32-kilometer-causeway over the Gulf of Aqaba. Plans for the so-called King Abdullah Bridge, which would link Egypt and Saudi Arabia between Sharm al-Sheikh and Ras Hamid and pass through the Straits of Tiran and Sanafir, had been in discussion since 1988. During Mursi's presidency, the Binladin Group had announced its intentions to fund the project with an estimated volume of 3 billion USD in cooperation with Egypt's state-owned Arab Contractors company. But cautions by environmentalists and diplomatic tensions between Egypt and the Saudi kingdom had led to the project's postponement (K. Walker, 2013).

The fact that these concerns had now vanished contributed to the widespread impression that the land swap, ultimately, represented an exchange of Egyptian land for Saudi petrodollars and economic support. After Mursi's ouster, the Kingdom of Saudi Arabia had provided at least 25 billion USD in aid and investment to cash-strapped interim governments. Against this background, Egyptians accused Al-Sisi of repaying this debt with Egyptian soil. Tiran and Sanafir thus became symbols for Egypt's dependence on the credit checkbook of the Gulf States. The exiled satiric Bassem Yousef aptly summarized the prevailing public sentiment that Al-Sisi had sold an invaluable piece of the homeland to the highest bidder in an Arabic tweet that imitated the bargaining habits of street hawkers in Cairo's old town tourist souk: "Come, closer Pasha, a billion for an island, two for a pyramid, and on top some statues as a gift" (B. Youssef, 2016).

Regardless of possibly respectable legal claims on the Saudi side (see Dupont \& McGarry, 2016, pp. 3-5; Tahrir Institute for Middle East Policy, 2017, p. 9) and the Egyptian Council of Ministers' announcement that the islands were unmistakably Saudi territory, as a total of eleven rounds of negotiations over six years had determined, the ceding of the islands "struck a nerve among the public and even among the elite that revived the fearlessness of the revolutionary period [...] Even members of the usually supine elite were horrified" (Cole, 2016). This was compounded by the fact that the resounding governmental rhetoric since Al-Sisi's assumption of the presidency had been one of reclaiming the state's lands [aradi ad-dawla], as Sherif Gaber (2016, pp. 98-101) noted. In October 2014, Prime Minister 
Mahlab had announced that those who laid their hand on the state's land would have them "cut off" (Gaber, 2016, p. 99). The demarcation agreement contradicted such announcements.

\section{Routine Vilification}

The securitization of contentious issues had been so successful during the previous three years in quelling opposition that it was seemingly out of a routine that the Egyptian authorities framed all concerns regarding the agreement in security terms. On the morning of April 13, 2016, Al-Sisi assembled the editors-in-chief of several newspapers, some members of parliament, and around one hundred selected movement representatives for a special meeting on the island crisis. Announced as a conversation with the "Egyptian family" the meeting boiled down to a presidential monologue that revealed Al-Sisi's deep mistrust in, and contempt for the Egyptian opposition and independent media (see Elmeshad, 2016). Among the opposition, Al-Sisi's remarks were taken as proof of the president's disdain for the opinion of its constituency.

The president's 9o-minute-long speech was live televised and set the tone for how authorities viewed critics of the land swap: Al-Sisi claimed that Egypt was subject to a foreign conspiracy that aimed at isolating the country internationally. Against this backdrop, the calls for demonstrations against the agreement were not only undermining the people's will but amounted to a "national suicide" that threatened the country's security and stability. Furthermore, he indirectly referred to the opposition's mobilizing efforts via social media as elements of a "fourth-generation warfare" that was being waged by cyber-brigades on the Egyptian nation (Naeem, 2016). Warnings of "hellish schemes" to widen the cracks that already permeated Egyptian society dominated the larger part of the president's speech.

This rhetoric, which securitized all opposition to the border demarcation agreement, tied in with the threat scenarios that had legitimized Al-Sisi's presidency after the repression of the Anti-Coup campaign. The players who coalesced within the Popular Campaign to Protect the Land (PCPL) to oppose the island deal were thereby subsumed as antagonist forces into the camp of Egypt's national enemies. This relocation of established political frontiers aimed to reinvigorate Al-Sisi's claim to power and legitimacy, which was based first and foremost on the former general's ability to deal most effectively with any threats to national security. In his speech, Al-Sisi had also hinted at a greater plot to discredit the people's confidence in those 
very state institutions that were, in truth, defending Egyptians against domestic and foreign threats. In doing so, he reaffirmed the protector-ofthe-nation-frame that had been successful in mobilizing popular support ever since Mursi's ouster.

All subsequent official statements that mentioned the island controversy and the mounting opposition to the agreement had the same basic tenor, including Al-Sisi's addresses to the Organization of Islamic Cooperation on April 14, on the occasion of Judges Day on April 23, as well as on the 34th anniversary of Sinai Liberation on April 25, 2016. At each of these events, Al-Sisi doubled down on his conspiracy theory, warning of an enemy from within and lauding, above all, the army, the judiciary, and the police for their services:

All these institutions never did and never will give in one inch of the Egyptian soil. They take all measures and make all efforts for defending and developing Egyptian soil. This homeland which is cherished in the minds of all Egyptians is protected through the providence of Allah the Almighty and the efforts of its loyal sons who are sacrificing their lives for its dignity and progress (Al-Sisi, 2016b).

The Ministry of Interior subscribed to this rhetoric and dismissed all critics of the demarcation agreement as agents provocateurs. It thereby reproduced a discursive pattern that had developed during the crackdown on the Anti-Coup protests, and that had subsequently also marked the ministry's framing of labor strikes and collective actions by public sector employees and non-commissioned officers in 2014 and 2015 (see Abdelrahman, 2017, p. 8). While underscoring its "full appreciation and respect for the rights of citizens to freely express themselves," the ministry's statements had a hostile undertone and warned critics not to break the law (Egypt Interior Ministry, 2016a). Furthermore, the ministry dismissed the protest marches as the work of the Muslim Brotherhood and appealed to citizens not to fall prey to this Islamist incitement. It also reserved the right to take all necessary steps to confront this extremist threat and restore order in the street, invoking its constitutional responsibility to safeguard public safety.

In other words, both Al-Sisi and his administration deliberately framed the ongoing controversy over Tiran and Sanafir in polarizing terms - as a standoff between the Egyptian nation and those intent on spreading chaos and disturbing the public order. By contrast, attempts to legitimize the redrawing of Egypt's sea borders were less fervent and agitated. 


\section{Formalist Answers to a Symbolic Controversy}

The Egyptian government recognized the pitfalls of a discursive strategy primed on nationalism alone. From the disclosure of the agreement onwards, it thus downplayed the political significance of the demarcation agreement and sought refuge in technicalities to persuade the public of the due process that had preceded the signing of the deal. In his meeting with the "Egyptian family," Al-Sisi argued that the agreement did not imply a sale but a return of sovereignty to its rightful owner. In a direct appeal to mores, Al-Sisi went on to say that his mother had taught him not to take other people's things, hence, giving the islands back to Saudi was the right thing to do: "We did not sell our land. What happened is we gave the Saudi people their land back" (Al-Sisi, 2016a).

He furthermore stressed that the agreement had been prepared by and resulted from a professional demarcation process that had been initiated in 1990. This formalist narrative exemplified the authorities' double strategy in dealing with the crisis and followed the lead of earlier government statements that portrayed the border demarcation as the outcome of a simple and unambiguous technical process following established scientific and legal standards. Above all, it was symptomatic of the Al-Sisi administration's attempt to de-politicize the agreement and present it as a mere formality.

As Villumsen Berling (2011) confirms, the securitization of a policy issue is often supported by narrative structures that relativize the political element within decision-making and portray it as a purely technical procedure. In this process, surveys, academic reports, and expert opinions can become instrumental to authorities, because they invoke scientific authority, objectify the facts of a case and hence contribute to establishing interpretive authority (Villumsen Berling, 2011, pp. 389, 393f.). Al-Sisi's statement on the $34^{\text {th }}$ commemoration of the liberation of Sinai best exemplifies how the Egyptian government also tapped into this mechanism of knowledge construction. Melding scientism with his securitizing rhetoric, the president intended to appease his critics on April 25 by affirming that the government had adopted a scientific approach to disperse all public skepticism about the demarcation agreement.

The President thus pointed to the experts involved in the process to defend the opacity of the demarcation procedure. To underscore the risks posed by the opposition to the due process of political decision-making, he furthermore contrasted the irresponsible and disruptive character of the protesters with the hard work and professionalism of the maritime delimitation committee that had gone into finalizing the agreement. 
On April 9, 2016, the cabinet disclosed details on this process to discard the impression of a backroom deal and reassure the public of the government's diligence during the negotiations. In a press release, it stated that the technicians in the committee had resorted to the latest scientific methods to calculate the precise geographic location and course of the borderline between Saudi Arabia and Egypt in the Red Sea. ${ }^{2}$ The exact coordinates had been determined by a presidential decree on Egypt's territorial waters from the Mubarak-era (decree 27/1990). This decree had placed the two islands outside of Egypt's national borders and economic zone in the Southern Sinai. Intending to deflect criticism from the presidency, the cabinet assured that the content of the bilateral agreement would soon be presented to the House of Representatives, which would have the final say on its ratification.

To up the ante, a few days later, the government's Information and Decision Support Center (IDSC) published a potpourri of documents, which purportedly proved Saudi ownership over the islands. These documents included several diplomatic letters and classified cables, a thematicallyrelated essay by Mohamed El-Baradei, and a New York Times article on the delineation of the border between Israel and Egypt from January 1982. ${ }^{3}$ The accompanying statement indicated that "claims that a hurried decision has been made during King Salman's visit to Egypt" were untrue (IDSC, 2016). Instead, the IDSC explained the peculiar timing of the deal between Egypt and Saudi Arabia with the necessity to conclude the demarcation process before commencing construction of the planned bridge over the Gulf of Aqaba.

According to the historical diplomatic correspondence quoted in the published file, the occupation of Tiran and Sanafir in 1949 had never amounted to a full-fledged annexation of the territory. Instead, the center asserted, the occupation had been acquiesced by the Saudi kingdom temporarily by an agreement in 1950, and only to shore up its military capacities for confronting Israel in the Gulf of Aqaba.

\section{Desperate Moral Appeals}

This legal opinion echoed Al-Sisi's assertion, on April 13, 2016, that the government had never relinquished "a single grain of sand" from Egypt's land. Only that Al-Sisi's insistence on the due process was accompanied by an appeal to morals and attempts to demobilize his critics by arousing feelings of 
shame and guilt. Appeals to protesters' pride and honor - powerful "master emotions" that influence political action by shaping players' social ties to each other (see Jasper, 2018, pp. 132-135) - meant to reaffirm and bolster popular identification with Egypt's armed forces. At the same time, they intended to demobilize opposition by degrading dissent to the government as a defection from the nation's moral consensus and a violation of public norms. Combining this evocation of pride and action-based shame, Al-Sisi's one-hour-long speech in colloquial Egyptian Arabic meant to steer collective action towards socially approved paths and into support for a state-centric solution to the island crisis. Accordingly, the president framed any criticism of his policies as an insulting public show of mistrust and a personal offense: "The army has no patriots, and they are all willing to sell their country?", he asked ironically, chastising the public for its lack of faith in the country's leadership (Al-Sisi, 2016a). However, rather than raising a convincing argument for public trust in the institutional process, the president opted for expressing forgiveness and demanding the people's loyalty in return:

I brought you here to reassure you about the man you entrusted with your land and honor. I did not take the issue personally ... I did not let you down or desert you and never doubted your sincerity for one second, please treat me and the state the same way. (Al-Sisi, 2016a)

People should differentiate between the state's better assessment of a crisis and the less accurate assessment of individuals, he added. In a side note on human rights conditions, he remarked that societies were built through work, not unchecked freedom of opinion. This served as a warning to the national media against questioning or criticizing the state. Referring to the earlier announcements by the cabinet, the president highlighted that, as with other issues of national importance, the island deal would undergo a due process of legal revision under the auspices of the parliament. Contrasting the legitimate representative of the people's will with the illegitimate claims that had been voiced via street politics, he argued that it was ultimately in the hands of the parliament to "form a committee, or two, and do whatever it wants" to process and ratify the border demarcation (Al-Sisi, 2016a).

As a backdrop to the opaque policy-making process in the lead-up to the agreement, this rhetoric was perceived by those critical of the island deal as an implicit gag order. However, it was not only the government's derogatory tone, nor its questioning of Egyptians' sanity that backfired (throughout his speech, Al-Sisi repeatedly asked his audience what was wrong with it). Rather, the manner in which Al-Sisi aimed to end the discussion about the islands 
became the straw that broke the camel's back: At the end of his speech, he thanked his audience and closed the meeting with the declaration that he had now said enough on the island controversy and hoped he would never have to take it up again. When one of the attendees tried to pose a question, the president snapped that he had not granted anyone permission to speak. This was followed by an abrupt suspension of public broadcast.

Al-Sisi's address was aimed at putting an end to the contentious discourse around the topic, but it caused precisely the opposite. Though embedded in a long speech, his remarks on Tiran and Sanafir were reminiscent of the Mubarak regime's attempt to defuse popular anger towards the end of the 18 days of Tahrir in 2011 via a normalization strategy. These attempts reached a climax during Omar Suleiman's brief address on February 10, 2011 (see Holmes, 2012, p. 406f.). Protesters in Cairo's Tahrir Square had already reacted with fury when Mubarak had failed to announce his immediate resignation. But when Suleiman asked Egypt's youth to go home and back to work, demonstrators, instead of leaving the square, vowed to make Friday's protests the biggest so far. Suleiman's speech backfired because it revealed the regime's disdain for the public mood and its ignorance of the "moral battery" (Jasper, 2018, p. 138) by which the players who had occupied Tahrir successfully transformed authorities' attempts to shame their actions into a source of pride and affective solidarity.

Like Suleiman's address, Al-Sisi's call for silence seemed out of touch with the mood. His attempts to shame opponents of the border demarcation agreement, rather than arousing shame only angered protesters. It also put the disconnect between the government's rhetoric and its actions further into relief, thus strengthening the impression among critics of the island deal that they were being consciously humiliated for their righteousness because it contrasted with the moral obliquity of those in power. This emotional transformation turned into a resource for political action. It enabled protesters to deflect feelings of shame and, instead, blame Al-Sisi for his intentions. A widely shared protest call, released on April 14 by several youth groups, portrayed the president's gag order as an insult, not only to the heritage of the Egyptian martyrs in Sinai but also to the Egyptian laws and norms:

The people's sons have paid with their blood to defend the islands of Tiran and Sanafir against the Zionist enemy. Today we find Al-Sisi daring to sell them with the stroke of a pen, against the Constitution and all norms and laws. Then he addresses us after the sale is complete, saying 'I do not want any more talk on this subject'. (April 6 Youth Movement, 2016a) 
Throughout the following weeks, Al-Sisi's speech became engrained in the campaign's motivational framing as a symbol of disrespect for the protesters' legitimate concerns. At times, the protest calls directly quoted the president, and, at times, they just hinted at his words, such as the different versions of the hashtag "speech does not need permission" which began to trend on Twitter and Facebook. This hashtag mocked the fact that the president had invited the nation to an open debate in which, in the end, only he had voiced his opinion. Paired with the hashtag جمعة_الارض \# [Friday of the Land], it resonated not only in Egypt but became the second-highest trending hashtag globally on April 15, 2016.

\section{The Popular Campaign to Protect the Land}

Contention soon spread from the capital to all governorates. Between April 8 and May 24, 2016, Egyptians witnessed at least 79 protest events with thematic reference to Tiran and Sanafir. As shown by Figure 18, these events mostly concentrated on two dates, April 15 and 25, which divide the campaign against the island deal into several episodes of contentious interaction:

1 First, the signature of the border demarcation agreement on April 8, 2016, by Egyptian Prime Minister Sherif Ismail and Saudi Deputy Crown Prince Mohamed bin Salman in Cairo set in motion the wave of protests at the center of this chapter.

2 Second, the so-called Goma'a al-Ard wa-l-'Ard [Friday of Land and Honor] on April 15, 2016, showed the magnitude of discontent with the government's ceding of territory. For the first time in three years, Egypt's provincial capitals saw mass protests of several thousand, which did not originate from affiliates of the Anti-Coup Alliance.

3 Finally, Sinai Liberation Day on April 25, 2016, marked a second major climax of the island protests and was followed by a relocation of opposition from the streets to the courts.

As shown in Figure 19, these turning-point events coincided with a spike in political arrests. According to the Front to Defend Egyptian Protesters (FDEP), no less than 1,344 people were arrested over the course of the entire Egypt is not for sale!-campaign. ${ }^{4}$ Of these, 741 were detained by Egypt's 
Figure 18 PCPL protest rate and turnout

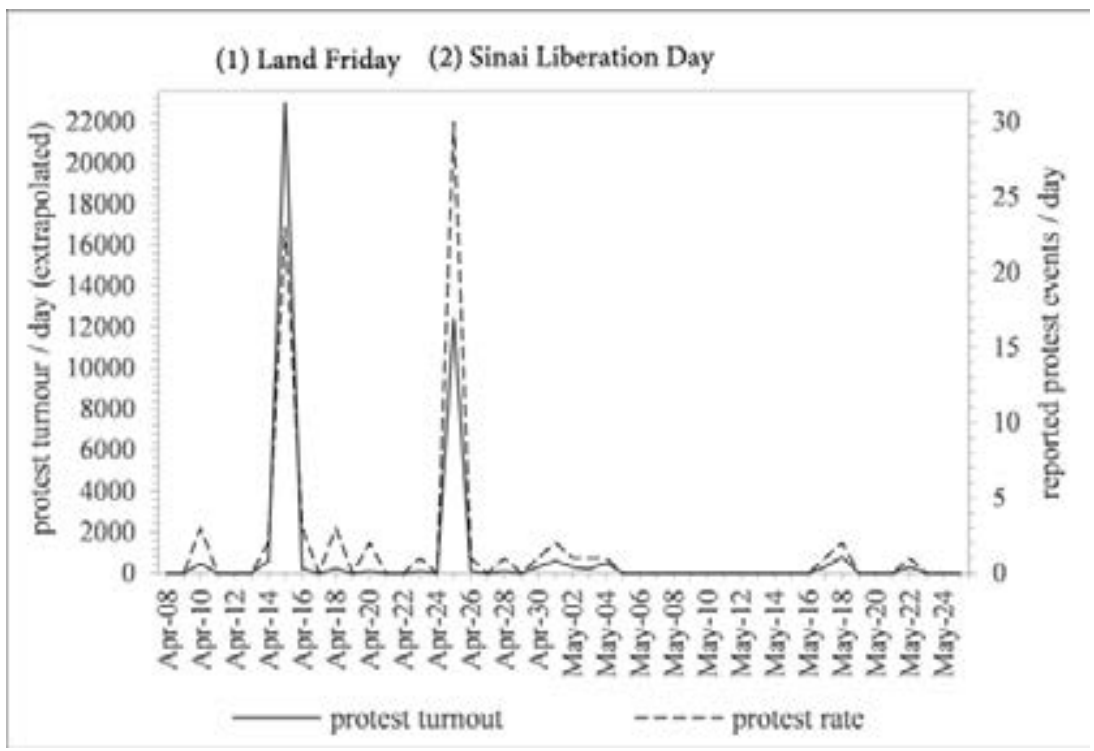

Figure 19 Repression of PCPL protest events

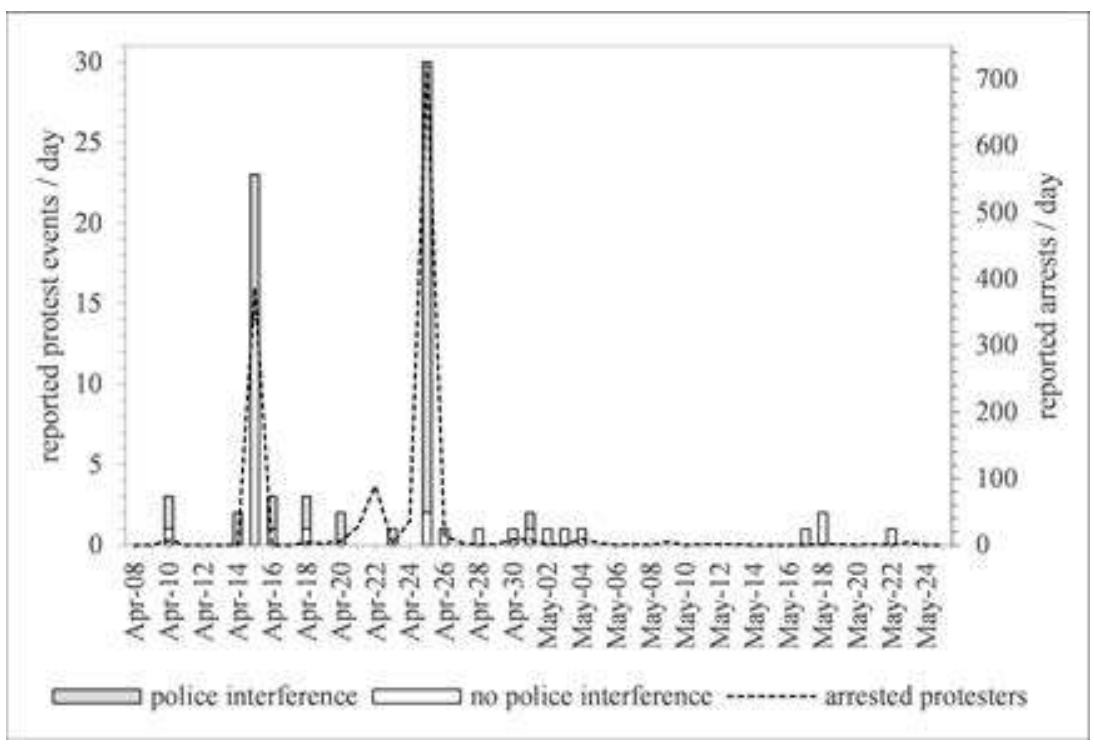


infamous state security service Amn Watany [Homeland Security]. ${ }^{5}$ The list issued by the NGO includes cases from 22 cities and the entire timeframe of the campaign. However, most arrests are documented on April 25, with 721 arrests, followed by April 15, with 387 arrested protesters. Besides, the diagram draws attention to the phase in the lead-up to Sinai Liberation day, which saw a spike in arrests on April 21 and 22 despite the absence of protest. This peak stems from a failed attempt by the security forces to prevent popular mobilization on the national holiday by arresting at least 116 people, often directly off the street or from their homes. Some were released at random shortly after the arrest. Others were released only when the Egyptian State Council declared the border demarcation with Saudi Arabia invalid on June 21, 2016 (see Dawoud, 2016a).

Arrests of protesters and activists accompanied the entire protest cycle. But how the PCPL protests were policed on the ground varied strongly across the major protest events: On April 15, more than half of the documented protests were unfazed by police interference; by contrast, on April 25, over 90 percent of collective actions were confronted by police forces. The protest repertoire also differed during both events, as the PCPL adapted to the closing space for public shows of dissent with a decentralization of the campaign: April 25 saw a substantial decline of centralized mass protests. Instead, it witnessed an increase in numerous smaller protests. Demonstrations and urban protest marches with a designated start and endpoint remained the most popular means of expressing dissent with the cession of the Red Sea islands. But as repression increased, especially in the countryside, the demonstrators also adopted human chains alongside busy thoroughfares and traffic junctions, as well as short-term "flash protest" tactics which resembled the Anti-Coup farasha [butterfly] protests described in Chapter 5 (see Figure 20).

These events provided resources for identity formation within the opposition and laid the foundation for a cross-ideological and cross-movement coalition. However, they were also significant as discursive events that dislocated the nationalist rhetoric upon which the Al-Sisi administration had carefully built its autocratic model of governance. For the first time since its reconfiguration in the aftermath of the July 3 coup d'état, the government's political legitimacy was seriously challenged by others than the demonized

5 A symbol of Mubarak's police oppression, the State Security Information Service (Mabahith Amn ad-Dawla) was nominally dissolved in March 2011. But in truth, the units were never disbanded but simply restructured in the newly founded National Security Service that continued to operate. The new NSS built on the networks of informants and resources acquired during the Mubarak era, with a high degree of personnel continuity (Abdelrahman, 2017, p. 7). 
Figure 20 PCPL protest repertoire

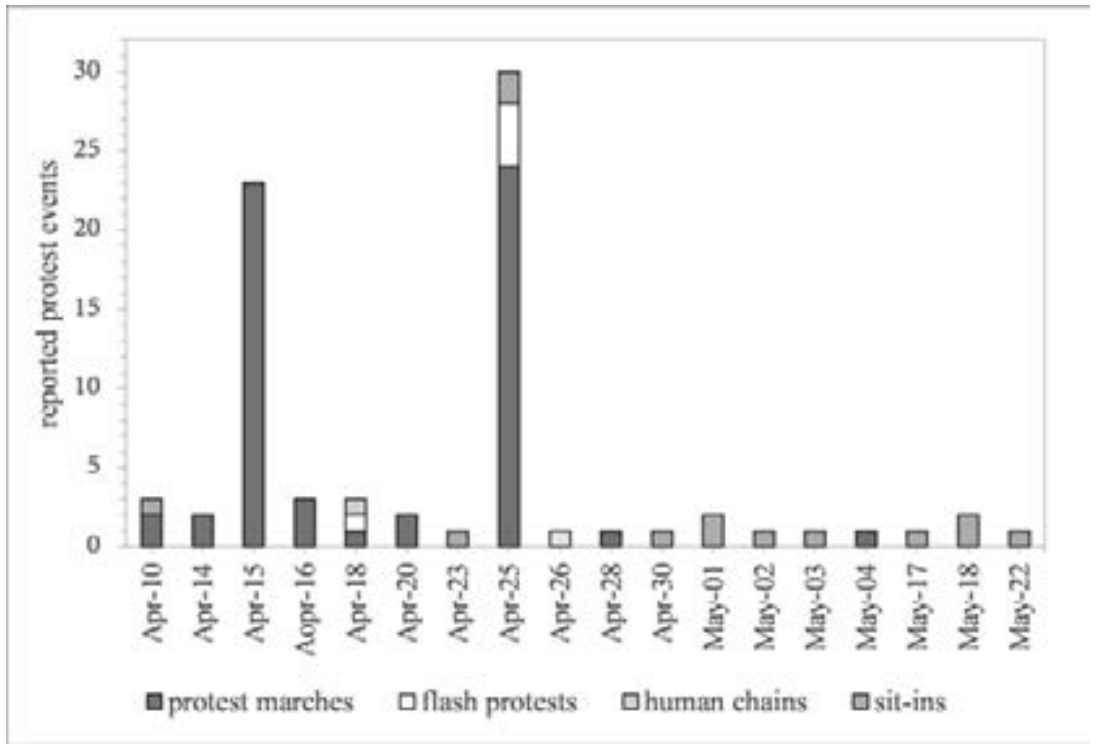

Islamists. For both authorities and contenders, the controversial border demarcation agreement came to symbolize the frontier in a struggle for interpretive predominance over political legitimacy, and thus the reference point for heady battles over the meaning of land and nation, security and stability, transparency and legality, as well as sovereignty and rights. These battles were fought with words on a discursive level, and with deeds in Egypt's streets.

\section{Land and Honor Friday}

Al-Sisi missed out on the sight of the revolutionary youth taking to the street for the first time during his presidency. Ironically, when the first protests erupted, the president was hosting a dialogue with selected members of the government's newly launched Youth Leadership Program at the Red Sea view Galala high plateau. There he acknowledged the public outrage over the Egyptian-Saudi agreement to the gathered loyalist youth representatives as a stab in the heart of the nation. These remarks echoed the Ministry of Interior's choice of words on the vigil of the marches. On social media, the ministry had claimed to possess information that the terrorist Muslim Brotherhood was behind the announced rallies, aiming to instigate chaos and civil strife. 
In truth, for the first time in three years and since the imposition of a restrictive protest law in November 2013, Cairo, Alexandria, Mansoura, Port Said, Qena, and a range of smaller provincial cities and villages was about to see mass protests which did not originate from Islamist groups. Different political organizations and parties supported and joined the protests on April 15, 2016. Among others, the Revolutionary Socialists, Strong Egypt, the Youth Movement for Justice and Freedom, the April 6 Youth Movement, and the Democratic Current declared their intention to oppose the land transfer in a newly founded alliance. Several of these parties were established in 2011 and 2012, often by long-standing opposition members, some of whom were interviewed for this book. Repeated collaborations before the uprising had consolidated relations of trust among these small but vocal opposition players (see Abdelrahman, 2009; Browers, 2007; Clarke, 2011). The successful toppling of Mubarak and then the SCAF in the aftermath of the 2011 uprising galvanized these affective ties (see Grimm, 2019, pp. 450-452).

As a result of state repression, none of these players could mobilize large constituencies individually when the border demarcation agreement was announced. Hence joining forces was a strategic step to appeal to a broader audience across ideological lines and thereby broaden the support for social protest. In its founding statement, the new issue coalition officially declared itself to be a "Popular Campaign to Protect the Land" - a designation vague enough to not alienate Egyptians without prior ties to either of its supporting groups. $^{6}$

On April 15, the coalition gathered on the steps of the Press Syndicate in downtown Cairo where most of the marches converged. The steps of the syndicate represented an iconic location for a demonstration. Under Mubarak's rule, they had become a sanctuary of sorts for the articulation of political demands that did not cross certain red lines (Fahmi, 2009, p. 101). ${ }^{7}$ Still, it came as a surprise that the protests were not met with the

6 The statement ends with a list of all PCPL founding members, including several political parties, such as the Socialist Popular Alliance, the Popular Current, the Constitution Party, the Justice Party, the Bread and Freedom Party, Karama, the Egyptian Social Democratic Party, Strong Egypt, the Egypt of Freedom Party, as well as a range of popular movements, such as the Revolutionary Socialists, the Free Front for Peaceful Change, the Freedom and Justice Youth and the Democratic Front - a chapter of the April 6 Youth Movement. Moreover, some nationalist movements, such as the National Partnership Current, the Land Campaign, and the Students Will Not Sell-campaign were among the signatories alongside dozens of prominent individual activists. The full list of PCPL founding members can be accessed at https://archive.vn/RziUM. 7 For an overview of Cairo's few "spaces of freedom" under the rule of Husni Mubarak see Samir Rafaat's map of downtown Cairo, modified and reprinted in Fahmi (2009, p. 100). 
lethal violence that had become the routine response from security forces to such public shows of dissent. When at least 1,500 people gathered in front of the Journalists Syndicate they remained relatively unfazed by Egypt's notorious riot police. Furthermore, the FDEP recorded no lethal violence during the entire investigation period.

At the outset of the protests in downtown Cairo, the Central Security Force (CSF) had deployed to the access routes to Tahrir Square and had closed off Mohammed Mahmoud, Talaat Harb, and Qasr El Nil Street. Moreover, they had blocked the entrances to Ramses Street to contain the marches to a controllable area. After creating a perimeter around the sit-ins, however, the riot police refrained, for the most part, from taking further action. Some teargassing and buckshot were reported from Al-Sayeda Zainab Square, and from Mustafa Mahmoud Square in Mohandessin, where approximately 2,00o protesters gathered following the Friday prayer. But the clashes between youth groups and police forces remained few and scattered. Figure 19 shows that more than half of all demonstrations recorded on April 15 remained completely unhindered. Arrests occurred only during the late evening hours. The PCPL organizers announced an ordered pull-back at around 7 pm, after having negotiated a truce with the police forces present at the journalist syndicate. Those who refused to leave the streets after this point were targeted for arrest.

However, when protesters left the steps of the syndicate it was only temporary. The retreat was a strategic withdrawal. A new protest call released on social media by members of the PCPL on April 16, 2016, showed that the coalition aimed to mobilize an even larger crowd ten days later, on April 25, the iconic national festive Sinai Liberation Day.

\section{Sinai Liberation Day}

After a range of small-scale rallies organized by the April 6 Youth Movement over the following ten days, Sinai Liberation Day brought a new surge of protest. On the very night of their retreat, the Revolutionary Socialists, April 6, and a range of independent public figures had announced protest marches on this national holiday to defend the achievements of the protests on April 15:|

[It is time] to complete the battle to overthrow the decision to forfeit the two islands, and to build on this fight to break this regime and overthrow the rule of the military. For we have created a mass protests joined by thousands today in a breakthrough for the mass movement. 
With the issue of the islands, closed doors have been opened on issues of economic exploitation and austerity, of political despotism, torture, arrests, and on the issue of the dirty alliance with the reactionary and counter-revolutionary kingdoms in the Gulf. (Revolutionary Socialists, 2016)

The following week, a leaflet was distributed in Egypt's streets which called upon Egyptians to overcome their fears, once more, and fulfill their national duty by defending the integrity of the Egyptian homeland on April 25, 2016 (see April 6 Youth Movement, 2016g). This second protest date was well-chosen. A highly symbolic national holiday, Sinai Liberation Day commemorates the departure of Israeli forces from the Sinai Peninsula in 1982. For many Egyptians, this event represented the restoral of national pride which had been hurt by the defeat of the Egyptian army in the 1976 war. The protest sites, in front of the Journalist Syndicate and the Doctors Syndicate in Downtown Cairo, and next to the Bohoos metro station in Dokki, were chosen wisely, too: The Future of the Homeland Party, one of the dominating nationalist blocs in the last parliamentary elections, had announced that it would celebrate Liberation Day, too, by marching in support of the government to downtown Cairo's Abdeen Square and Mohandessin's Mustafa Mahmoud Square, only a few blocks from the planned PCPL protest.

The geographical proximity between both camps raised the risk of clashes. But it also increased the chances of media coverage about the PCPL protests, as the Sinai Liberation Day celebrations would be televised by the national press. Nevertheless, contention remained fragmented on April 25. The number of protests was certainly higher than on April 15, with 29 individual protest events. But the size of individual collective actions was considerably smaller (see Figure 18). These individual marches failed to converge and assemble a critical mass. Consequently, the extrapolated overall turnout of 12,400 people across the country remained significantly below that of April 15.

This was partly a consequence of the little coverage that the PCPL's protest call had received in the Egyptian press. With the noteworthy exception of Al-Masry al-Youm and Al-Shorouk, most newspapers had opted to downplay the PCPL's importance. In doing so, they reproduced a pattern established during their coverage of the Anti-Coup protests. Moreover, a massive arrest campaign preceded Sinai Liberation Day (see Figure 19). Shortly before April 25, more than 100 people were picked up from their homes, offices, and from a range of downtown cafés by plain-clothed Amn Watany officers. This crackdown came as a surprise: Supporters of the PCPL had taken the 
restraint of the security apparatus on April 15 and the complete absence of the military as signs of encouragement. The April 6 Movement had even speculated that the army was "holding the stick from the middle" and might be willing to support the PCPL's cause (April 6 Youth Movement, 2016g). ${ }^{8}$ But these expectations remained unfulfilled.

Instead, in the aftermath of the Land and Honor Friday protests, both the army and the domestic security authorities announced a campaign to "bring back discipline in the street and straighten out what might affect public security" (Egypt Interior Ministry, 2016b). A heavy-handed arrest campaign aimed to suppress the new protests before they even began (Mughrabi, 2016). On the eve of Sinai Liberation Day, Egypt's general prosecutor additionally charged those in custody with violating the protest law, disrupting public transportation, blocking roads, and threatening security and public order. He also issued new detention orders against lawyers and journalists who continued to call for protests.

This crackdown was meant to deter supporters of the PCPL from taking to the street on April 25 and marked a major shift in the tactics of the security apparatus. ${ }^{9}$ To justify the pre-emptive arrest of activists, Interior Minister Magdy Abdel-Ghaffar stressed that the new Egyptian constitution tasked the security services with the protection of vital state institutions. The law would be applied firmly and decisively. Accordingly, there would be no further leniency and no compromise on the rights of all citizens to a safe and secure life. Public collective actions of any kind would not be tolerated. Then he appealed to Egypt's "honorable citizens" not to respond to attempts to instigate discord between the people and the police (Al-Bedaiah, 2016). ${ }^{10}$

8 The Egyptian proverb "to hold the stick from the middle" refers to someone who takes the position of a middleman or refuses to choose sides between two camps.

9 In a possible explanation for this change of strategy, the independent daily Al-Shorouk reported how the police's "soft approach" to the April 15 protests had been criticized by President Al-Sisi himself. Based on internal government sources, Al-Shorouk claimed that Al-Sis had ordered a different code of conduct for April 25. However, in a historic precedent, the president denied these accusations on April 21, 2016, in a post on his personal Facebook page (https://archive. is/tL4EP). Until then Al-Sisi hat refrained from issuing official statements via social media. It seems that by departing from protocol the presidency aimed at reaching a large share of the campaign's virtual followers who were, due to their nationalist background, also following the presidency on Facebook. In response, Al-Shorouk issued an official apology and took its article offline. An archived copy of the original article can be accessed at https://www.scribd.com/ document/399024037/Shorouk-Report?secret_password=lrRJ7VrnBopibUautB4H.

10 Given its routine use in the communiqués of the Supreme Council of the Armed Forces in 2012, the term "honorable citizens" has become a derogatory signifier, in oppositional circles, for all players who agree with any actions by the state and its institutions, while turning a blind eye to its crimes (see Andeel, 2014). 
Anyone involved in such activities would be crossing a red line and be dealt with accordingly. Reproducing the usual law-and-order frame, the minister highlighted that the police forces were responsible for safeguarding Egypt's stability and would not spare any sacrifices to keep its citizens safe.

Defense Minister Sedki Sobhi argued in the same vein in his honorific speech on the 34th anniversary of the liberation of Sinai. The general openly turned to domestic politics when he called on the people to unite their voices in the nation's interests. In a direct rebuke of the April 6 Movement, Sobhi warned that the army would not be blackmailed or pressured, thus crushing all hopes of military intervention on the side of the protesters (Sobhi, 2016). He also stressed that the armed forces would no longer tolerate those spreading chaos in the streets. This securitizing narrative was further streamlined as Sinai Liberation Day drew closer. Following a meeting between Al-Sisi and the heads of all security directorates, the military announced the deployment of troops to all major public buildings. The entrances and exits of Tahrir Square also saw the deployment of military vehicles.

In addition to the military deployment, riot police cordoned off the doctors' and journalist syndicates as well as other declared protest sites. Sadat Metro station was closed off to impede an influx of protesters to downtown. Moreover, the security forces arrested hundreds of citizens on the streets leading to the assembly areas, based on the suspicion that they were heading to the demonstrations. Many rallies were forced to relocate due to heavy police presence at the announced meeting points. An attempt to organize a convoy from the capital to plant an Egyptian flag on the islands was equally aborted given the government's announcement to block the tunnel that connects Sinai to the mainland. ${ }^{11}$

On the morning of April 25, nevertheless, the April 6 Movement posted a confident statement on social media that called Egyptians to the streets to join the protests without fear, asserting that the police forces were the ones who should be afraid. But as the first marches set out from Giza's Nahya neighborhood, riot police moved in. They prevented the individual protest marches from gaining pace and from converging and gathering larger masses. Throughout the afternoon, groups of around 100 people repeatedly tried to regroup at different assembly points, including on Midan Al-Mesaha

11 Among the main proponents of the convoy were the Revolutionary Socialists, the April 6 Youth Movement, the April 6 Democratic Front, and the Masr Party. To coordinate the convoy and the upcoming demonstrations, April 6 launched a Facebook social networking site entitled "Re-Liberation of Sinai." The statement announcing the convoy is available at https://archive. vn/wip/X9JMz. 
and Dokki Street in Giza, as well as in the Ard al-Liwa neighborhood. But these attempts were all thwarted by security forces who dispersed the demonstrations with teargas. The cat and mouse game between protesters and security forces culminated in a siege on the Karama Party headquarters at Al-Mesaha Square where many demonstrators had sought refuge from the riot police. This standoff ended late in the evening with a truce, negotiated by prominent leftist figures (Hidji, 2016).

The security services justified their crackdown with the PCPL's violation of the assembly law, according to which the marches would have been subject to prior authorization. At the same time, pro-government demonstrations, including even spontaneous ones, were widely tolerated. The very streets that remained barred to the PCPL saw major celebrations of the $34^{\text {th }}$ Sinai Liberation Day, particularly at Abdeen Palace, the presidential residence, where thousands convened to celebrate the army and their president. Convoys led by pick-up trucks with giant speakers drove around downtown Cairo blasting out the pro-military song Teslam al-Ayadi [Blessed are the hands, a reference to the fraternization slogan "the army and the people are one hand" during the 2011 uprising]. In the suburb of Maadi, dozens gathered outside the Maadi military hospital to salute Egypt's ousted president Husni Mubarak for his role in the consultations that led to the Israeli withdrawal from Sinai. There were also some minor counter-demonstrations in favor of the island deal. At these events in Mohandessin and Downtown, protesters not only carried banners honoring the army and its role in the liberation of Sinai. Some also carried Saudi flags. Albeit much smaller in size, these demonstrations were much more extensively covered by the media than the original PCPL protests. ${ }^{12}$

In summary, the odds were stacked against the PCPL on April 25. The protest arena was characterized by the authorities' hostile and vilifying discourse that aimed at undercutting the PCPL's support base. Its parameters were also shaped by mass arrests, roadblocks, and huge deployments of security forces. In response to the hard hand of the police and continued repression after Sinai Liberation Day, the protest campaign eventually abated. Realizing the limits of street politics under conditions of tightening repression, leading figures within the coalition refocused their mobilization efforts on the legal battle for Tiran and Sanafir, instead. As authorities shifted back to a zero-tolerance policy in dealing with demonstrations, resistance to the cessation of the two islands manifested on a new front: In Egypt's courts.

12 Impressions of these strange scenes were published by Al-Masry Al-Youm, see https:// archive.vn/ $\mathrm{xju}_{5} \mathrm{~N}$. 


\section{Shifting Protest Arenas}

After the abatement of street demonstrations, the legal battle waged by several PCPL lawyers in parallel to the street protest became the principal arena for opposing the Egyptian-Saudi border demarcation agreement. A significant arena for social movement strategy, courts represent an eminent symbolic site for the arbitration of contentious politics (see Doherty \& Hayes, 2015). They legitimize or delegitimize other political actions, including repression and resistance, thus challenging or reproducing the social meanings constructed by protest players and agents of repression. Accordingly, from the beginning, the resistance to the island deal centered on the solicitation of supporting legal evidence for several lawsuits against the border demarcation, in parallel to the campaign's street mobilization. After Sinai Liberation Day, these efforts experienced an additional boost and triggered an organic campaign by engaged citizens, both within the country and abroad.

This campaign saw activists taking to various international archives, colonial map repositories, and official documentation centers in search of documents supporting Egypt's historical ownership over Tiran and Sanafir. In the absence of a street movement to exert pressure on the political process, assisting the PCPL through historical and archival research became a significant action strategy for committed opposition activists, including for many in the diaspora. Early on, PCPL frontrunner and former presidential candidate Khaled Ali realized the potential of this international effort. As the AntiCoup campaign's continuation from Turkey had shown, the participation of the Egyptian diaspora could perpetuate the PCPL's resistance and prolong the political momentum from abroad, despite foreclosed opportunities for street mobilization in Egypt. Even before the first demonstrations on April 15, Ali had made use of his social media popularity to seek the assistance of a broader audience beyond Egypt's border. In a widely shared Facebook post, he stressed:

The case requires major research and legal effort at the historical, geographical, international, strategic, and constitutional levels. We thus call on everyone who can provide research assistance in this case not to withhold any knowledge or documents in his hands from us. (K. Ali, 2016)

For exiled Egyptians as well as those hesitant to join the island protest for fear of repercussions, Ali's call provided an alternative way to take part in 
the protest campaign anonymously, or from abroad. ${ }^{13}$ Not only committed activists answered the call, but also dozens of Egyptian citizens without prior ties to the players organized within the PCPL. Reportedly even civil servants within the Al-Sisi administration and state employees were thereby enabled to support the campaign without jeopardizing their safety (Kassab, 2016).

At a press conference led by the Egyptian Center for Economic and Social Rights, the team of lawyers presided over by Khaled Ali presented the collected historical documents: extracts from the official gazette, old maps, military atlases, several encyclopedias of Sinai, and historical diplomatic correspondences, amongst others. Based on these documents and against all odds, the State Council Commissioner Authority (SCCA) issued a verdict on June 7,2016 , which questioned the legality of the border demarcation procedure. Its report also quoted from article 32 of the constitution, according to which Egypt's natural resources belonged to the people, and recommended forming a committee of historians, geographers, and engineers to determine the sovereignty status of Tiran and Sanafir. Though not legally binding, the SCCA's recommendation represented, at least, a symbolic victory for the PCPL: It proved, for once, that the filed complaints against the land transfer were significant enough for the court to consider accepting it. Adding to that, it delegitimized the imprisonment of the renowned lawyers Malek Adly and Sayed al-Banna, members of the legal team who had filed the complaint against the demarcation agreement and who were arrested on May 6, 2016, on charges of plotting to overthrow the government, disseminating false news, and inciting anti-government protest.

This symbolic victory was soon followed by a tangible success in the courtroom: On June 21, 2016, after repeatedly postponing the case, the State Council's Administrative Court (SCAC) followed the SCCA's recommendations and nullified the maritime border agreement. In its verdict, the SCAC described the islands Tiran and Sanafir as sovereign Egyptian homeland, owned only by the people as the only source of authority. ${ }^{14}$ This judgment invalidated the prime minister's signature. Only hours later, the government filed an appeal at the Supreme Administrative Court. But the latter only confirmed the original verdict on January 16, 2017, effectively ruling against the government.

As the Supreme Administrative Court represented the highest authority in this branch of the judiciary, the government switched strategy and focused

13 Interviews with exiled opposition activists in Berlin, May and June 2016; Istanbul, September 2017; London, June 2018; Washington, May 2018.

14 The full 21-page report is on file and was uploaded to https://goo.gl/F22Smx. 
on challenging the arena of the legal dispute itself. A subsequent lawsuit centered no longer on the island deal but the legality of the lawsuit against the deal. A complex web of rulings issued by three different courts - the State Council (made up of Egypt's administrative courts), the Supreme Constitutional Court, and the Court of Urgent Matters - came to characterize the island case in the coming months. Several courts became embroiled as political players who took sides in the struggle over the Red Sea islands, denigrating each other and competing for jurisdiction (for a timeline see Mada Masr, 2017a).

For the Al-Sisi administration, the strategy of moving the lost case to a new legal arena, composed of different players adhering to different legal rationales proved successful: On April 2, 2017, the Cairo Court of Urgent Matters annulled the SCAC's ruling arguing that bilateral border agreements were a prerogative of the executive, not the judiciary. Albeit heavily contested, this verdict was the signal that the government had waited for to go ahead with the land swap proceedings. ${ }^{15}$ On April 10, 2017, the parliament referred the case to its constitutional affairs committee. On June 14, 2017, it took the final vote. A majority by the show of hands voted in favor of the islands' cession - despite 10 ongoing cases against it.

\section{The Last Stand}

The parliamentary vote on the island agreement prompted many members of the original protest coalition to call for mass protests for one last time. This was even though several rallying calls in the aftermath of Sinai Liberation Day had remained unanswered. Most notably, representatives of Karama, Dostour, the Justice Party, the Popular Alliance Party, and the Democratic Current had unsuccessfully tried to turn the headquarters of the Karama Party, which served as a refuge for protesters on April 25, into a center of resistance by making it the location of a sit-in for the release of political prisoners.

Nevertheless, on June 16, 2017, the players within the PCPL called upon the Egyptian citizens to express their rejection of the agreement one more time and to demand the release of all those arrested for their opposition to the island agreement. Moreover, the PCPL took the parliamentary vote in favor of the agreement as a sign of failing institutional checks and balances and advocated new elections:

15 The ruling paved the way for a new government appeal at the Supreme Constitutional Court (SCC) on the basis that now two contradictory rulings on the same case existed. As the SCC accepted this appeal, all previous rulings about the island deal were suspended. 
On this matter, we declare that we no longer recognize the legitimacy of the current House of Representatives, which has disregarded any political or constitutional legitimacy. Accordingly, we support all political and legal efforts on the dissolution of the current parliament. (PCPL, 2016e)

However, unlike after the disclosure of the deal the year before, this time, the PCPL was not given a pass for this harsh critique. Authorities initiated a widespread arrest campaign to pre-empt demonstrations (see Abdel Hafez et al., 2017). Many of the coalition's torchbearers were arrested or cowed into obedience by policing measures. Those arrested for disturbing the peace and calling for illegal protests included the leaders of the Social Democratic Party, the Bread and Freedom Party, and the Dostour Party. Additionally, many local PCPL leaders were detained on charges of incitement against the state apparatus. According to figures released by the activist campaign Freedom for the Brave, ${ }^{16}$ CSF raids of the offices and private residences of renowned opposition leaders and the main protest organizers led to the arrest of over 112 people, effectively forestalling any public show of dissent. Consequently, the protests on June 16, 2017, at the Journalist Syndicate remained insignificantly small.

Strengthened by these developments, President Al-Sisi went on to ratify the agreement with Saudi Arabia on June 24, 2017. His signature sparked even less resistance - partly because many websites that had previously published critical commentary had been shut down by the time of his signature (AFTE, 2018), and partly because it coincided with the start of the Eid al-Fitr holidays. A final SCC verdict on the matter was tellingly delivered during Saudi Crown Prince Mohamed Bin Salman's visit to Cairo on March 3 , 2018. It closed the lid on the case and confirmed the parliament's decision ex-post. The ruling was credited by Saudi Arabia with the announcement of a joint Egyptian-Saudi investment fund shortly after.

In principle, the SCC verdict only decided the struggle over jurisdiction, not the debate over the legality of the border demarcation per se. The agreement going into effect and being published in the Official Gazette thus could have paved the way for contesting its constitutionality in court. ${ }^{17}$ In practice, however, the PCPL was already too weakened to continue facing an uphill battle. The crucial street support of 2016 had lost momentum, and

16 For detailed figures on the arrests see https://archive.vn/jaaDB.

17 The full agreement, as included in the Official Gazette No. 33 from August 17, 2017, can be accessed at https://www.scribd.com/document/390296134/Official-Gazette-including-TiranSanafir-Agreement-No-33-17-August-2017-No-6o7-2016. 
the coalition against the agreement had crumbled. Moreover, when the SCC issued its verdict, Khaled Ali, one of the frontrunners of the Egypt is not for sale!-campaign had become embroiled in a sexual harassment scandal and refrained from any further public appearances. Ali resigned from his Bread and Freedom Party and his position as a lawyer at the ECESR. As a result, the opposition never took the next step to challenge the agreement at the SCC.

\section{Breaking through the Wall of Fear}

While successful in keeping a lid on the PCPL demonstrations, the combination of legal channeling and targeted repression was unable to stop the diffusion of protest. Albeit minor and short-lived, the island campaign became a progenitor of further contention. Already during the Egypt is not for sale!-campaign collective actions had spread to different social sectors where the push to abolish the island agreement encouraged other compound players, such as trade unions and professional syndicates, to champion more particularistic and sector-specific demands. Thereby, the PCPL opened the way to a series of contentious interactions that each would challenge the state in different arenas in the months following.

Emboldened by the PCPL's show of defiance, for instance, the so-called Tadamon [Solidarity] coalition, a civil society alliance of 36 syndicates and independent unions, announced its intention on May 30, 2016, to stage a public protest in front of the Doctors Syndicate (see El-Sheikh, 2016). Despite facing severe policing, this campaign against a controversial new civil service law continued for weeks in parallel to the PCPL, including sit-ins in front of the Ministry of Social Solidarity. These protests underscored the labor movement's demands for revisions to the civil service law with more general calls for transparency in political decision-making and the drafting of legislation - demands that were shared by the PCPL.

In a similar vein, hundreds of high school students gathered in front of the Education Ministry on June 27, 2016, to protest the cancellation of their exams after a series of exam leaks. In the following days, students also staged protests in Assiut, Alexandria, Cairo, and Suez, calling for the education minister's dismissal and the abolition of the infamously corrupted university admissions system. Many protesters carried banners and posters that likened the education system's corruption to the sellout of the Red Sea islands. As tear gas and heavy policing failed to disperse the students in downtown Cairo, at the end of the day, the student protest marches were the first ones to reach Tahrir Square against the will of authorities for years. 
The most significant example of the diffusion triggered by the PCPL, however, became known as the "standoff at the Journalist Syndicate" (see Dawoud, 2016b). On May 1, 2016, the PCPL seemed defeated when security forces took their crackdown one step too far and - in a historical precedent - raided Egypt's Press Syndicate. During this raid, plain-clothed officers arrested the journalists Mahmoud al-Sakka and Amr Badr who were involved in the PCPL mobilization efforts (see Suter, 2016). Their arrest sparked a new episode of contention that moved to become the gravest confrontation between the organized members of the national press and the Egyptian government in the country's modern history.

Tensions between representatives of both bodies had been building up gradually throughout the island protests, as members of the press were targeted by policing and faced arrest for covering the protests. On April 15, eight journalists were detained by police forces only briefly. But on April 25, the Committee to Protect Journalists registered over 33 arrests of local and foreign journalists (CPJ, 2016). These arrests concurred with a report by the monitoring group Journalists Against Torture Observatory which documented a total of 222 violations including assaults, arrests, kidnapping, torture, and censoring committed by the Egyptian government against media personnel in the first quarter of 2016 alone. ${ }^{18}$ The press syndicate's formal complaint about these incidents against the interior minister was simply ignored by the latter.

The police incursion onto the grounds of the Press Syndicate brought these mounting tensions to a climax. Less than 24 hours after Al-Sakka's and Badr's arrests on charges of joining an illegal organization that aimed at toppling the government, the syndicate's chairman Yehia Qallash convened an emergency general assembly. In this meeting on May 4, 2016, thousands of journalists gathered at the syndicate building and called for the minister of interior's deposition and an official apology from President Al-Sisi. Their sit-in would last for several weeks.

However, opposition to the island transfer also transcended the group of journalists, lawyers, and activists who had partaken, in some capacity, in the April 15 and April 25 demonstrations. The cause of Tiran and Sanafir gained momentum even within the Egyptian legislative. Like in Egypt's streets, also in the parliament a peculiar coalition emerged against the agreement. It was headed by MP Mohamed Abdelghani and the small parliamentary opposition

18 The report can be accessed at https://journagsttort.wordpress.com/2016/04/23/ quarterly-report2016/. 
of the 25-30 block, ${ }^{19}$ an informal electoral alliance of mostly unaligned or independent deputies, but also included some members of the Support Egypt block - a majoritarian parliamentary coalition that usually uncritically backed all government decisions. Several of these parliamentarians made their critique of the island agreement visible by wearing T-Shirts with the imprint "Tiran and Sanafir are Egyptian" to the parliamentary sessions; others expressed their concern about the deal only in closed session, out of fear for repercussions (Kassab \& Charbel, 2017).

These politics, in the end, did not halt the ratification of the agreement, but they showed the serious damage that the Tiran and Sanafir crisis and the protest campaign it sparked had done to the post-coup regime's legitimacy.

\section{Turning the Nationalist Discourse Inside Out}

The diffusion of protest illustrated the symbolic nature of the PCPL protests campaign. In this sense, the demonstrations that materialized around the islands controversy were highly successful in that they, as the April 6 Movement announced, managed to "break through the barrier of fear" which had successfully prevented major public shows of dissent since the forced change of government in 2013 (April 6 Youth Movement, 2016e). The PCPL can ultimately be read as an attempt to suture the rift in the social order created by the disjuncture between the ruling players' discourses and their actions on the ground.

Since the deposition of Mursi, the security state and its executing forces had been able to demand a high price from the Egyptian citizens for their promise to provide physical safety as well as moral guidance for the nation. This mechanism ultimately amounted to a protection racket scheme, which figured in the extension of security budgets and legal cover, increased arms buys, and the allocation of rents to senior officers (Abdelrahman, 2017, p. 9). Despite an economy in dire straits and a visible decline of social security and public safety, the bulk of Al-Sisi's constituency had grudgingly accepted this informal social contract, due to fears of a bellum omnium contra omnes and lacking alternatives. But ceding Egyptian islands proved a price too high to pay, creating what Jasper (2018) has referred to as an

19 The name references the uprisings on January 25, 2011, against Mubarak, and on June 30, 2013, against Muhamad Mursi. Coalition members have tried to position themselves as a third way between the two antagonist camps in the aftermath of the 2013 coup. 
obvious "indignation gap" (p. 158) between how things should be and how they were.

The Egyptian regime was eager to portray the demarcation agreement as a matter of honor. But even the Supreme Council of the Armed Forces, apparently concerned about upsetting public opinion, had warned the administration that conceding Tiran and Sanafir to Saudi Arabia in an agreement that coincided with the announcement of major Saudi investments made the sovereignty transfer look like a quid pro quo and would incur the risk of seriously wounding the national pride (Stratfor, 2016). The border demarcation agreement was simply an event that could not be convincingly symbolized in Al-Sisi's ruling discourse, thereby destabilizing it and creating opportunities for resistance. Tiran and Sanafir became empty signifiers that could be crafted into a counter-hegemonic web of meaning which challenged the regime's nationalist credentials as well as the modes of governing it had established since the military coup. This enabled the PCPL to appropriate the regime's securocratic discourse in a way that empowered anti-regime protests: as protesters reclaimed ownership over the meaning of national security, honor, and patriotism, the same nationalist ideology that had paved Al-Sisi's way to the presidency became a vehicle for successful alliance-building under conditions of severe repression.

The appropriation of the regime's nationalist garment was achieved via different discursive strategies and rhetorical devices, from the invocation of Egypt's historical archive and the legacy of Abdel Nasser to the use of familiar cultural narratives, patriotic metaphors, and borrowings from pop culture. These were creatively combined in a discourse of resistance that the opposition constructed around the nodal signifiers of Tiran and Sanafir. This discourse effectively drew the frontiers of the political struggle. Its main fault line concerned the support for the island agreement, with those opposing the agreement on one side of the political struggle and those supporting it on the other.

How the PCPL subverted the incumbent regime's securitizing logics manifested particularly on the diagnostic level. There the island coalition articulated the actions by which the government had betrayed its principles and thereby put its legitimacy in jeopardy. In the discursive web that sketched out the precise process by which the authorities had undermined their source of political legitimization, the rule of law, popular sovereignty, and treason against the nation assumed the role of nodal signifiers (see 
Figure 21 Meaning of the island deal in the PCPL discourse

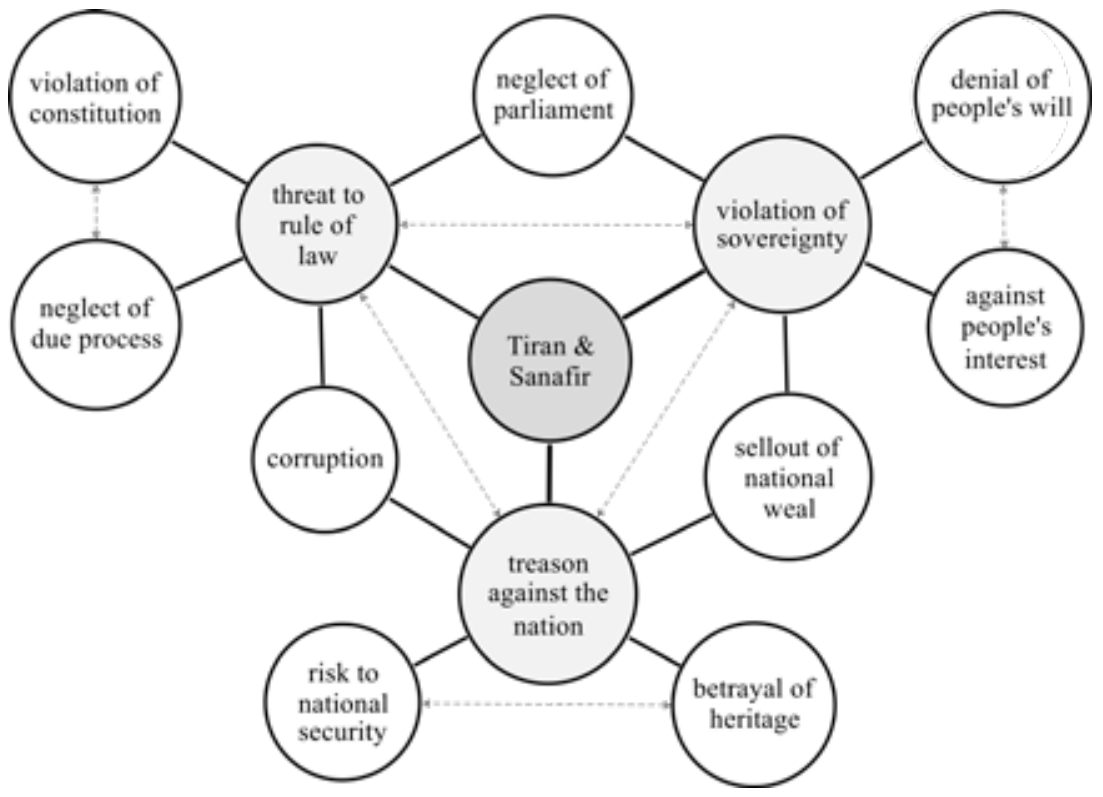

Figure 21). According to the PCPL, by ceding Tiran and Sanafir to Saudi, the government had:

1 violated the will of the people by denying the Egyptians sovereignty over their homeland,

2 violated the constitution, and committed a crime by negotiating and signing the border demarcation agreement without parliamentary oversight. The opaque and secretive way by which the deal had been prepared, in this sense, represented a threat to the rule of law.

3 Moreover, the government had betrayed the historical legacy of Egypt's struggle for independence. This amounted to treason against the nation and its weal.

Cementing an antagonist frontier in the political struggle, the PCPL's self-portrayal mirrored this image of the Egyptian authorities. According to its self-perception, the protesting coalition was acting on behalf of the people and defending the country's borders and national heritage when it took to the streets and called for the abolition of the Tiran and Sanafir island agreement. This diagnostic framing effectively challenged the legitimacy of the acting government by attacking the foundations of its nationalist credentials. It furthermore set the conditions for who could 
join the new coalition of contenders and who would be opposed as an accomplice of the unpatriotic forces who had given away parts of the Egyptian homeland.

\section{A Matter of Popular Sovereignty}

In what became the most prominent way of challenging the legitimacy of the regime's way of handling the crisis, the agreement was framed as a waste of the peoples' fortunes and sellout of the homeland, in return for investment commitments and credit loans for Egypt's ailing economy. The Egypt is not for sale!-campaign derived its name from a catchy slogan that the April 6 Movement coined in several press statements and social media posts at the outset of the island crisis: Speaking for the entire opposition and defying its judicial ban as a political organization (Farid, 2014), the youth movement released a widely shared statement titled "These things are not for sale!" and called for collective action all across Egypt. With a view to the Al-Sisi administration it claimed:

For the first time, we find a political system that seeks to prove that it lacks the right to the land it already controls, and that seeks to provide for those who pay the highest price. (April 6 Youth Movement, 2016a)

This rallying call set the tone for how the maritime border agreement would be framed by most of the forces opposing it. The Popular Campaign to Protect the Land picked up the cue from April 6. In its founding statement, the undersigning players agreed that they would refuse "the extension of the logic of selling public assets and wasting resources to the sale of the homeland" (PCPL, 2016b). But even before the official foundation of the protest coalition, the framing of the island agreement as a sellout was omnipresent, as mirrored by the viral hashtags in colloquial Egyptian Arabic \#بـاع_البلد_وحبس_الولد Egypt is not for sale] and the rhyming [مصرمش_للبيع [he sold the country and imprisoned the boy] which accompanied most opposition posts and referenced the perceived sale of the islands and the mass arrest of those opposing it.

The Muslim Brotherhood was the most vocal player in this regard. It issued a sharp condemnation of Al-Sisi's policy titled "What is left to waste, Al-Sisi?" immediately after the disclosure of the agreement, declaring that the president was not entitled to compromise on the fortune of the Egyptian people in return for "a handful of funds or support for the killing and arrests, violations and enforced disappearances and extrajudicial killings policies" 
(Muslim Brotherhood, 2016a). Shortly after, also the National Alliance in Support of Legitimacy (NASL) released a statement about the "traitor Sisi and his gang of thieves" who had sold off national territories in exchange for promises and cash (NASL, 2016). Both, the NASL and its student wing also announced their support for the Friday of Land protests.

To increase the resonance of this framing, and to inspire nationalist sentiments of solidarity, many statements also implicitly or explicitly touched upon other sensitive foreign policy issues that concerned Egypt's national sovereignty over its waters and borders. The Students Against the Coup movement linked the Red Sea island issue to the Nile Water Crisis warning the Egyptian people of a grim future if such deed went unpunished:

Today, the traitor gives Saudi Arabia the Egyptian islands of Tiran and Sanafir. Yesterday, he gave Ethiopia the rights of Egyptians in the Nile water. Tomorrow, he will sell off more of this homeland's resources to other countries. (Students Against the Coup, 2016)

Other, less explicit, references by signed members of the PCPL, who were less drastic in their critique than the already illegalized Brotherhood, included the perceived sellout of national gas to Israel; Egypt's weak bargaining hand in the diplomatic dispute with Cyprus about several newly found and substantial Mediterranean gas fields; as well as the government's passivity in the Egyptian-Sudanese border dispute about the so-called Hala'ib Triangle.

By placing their demand for an annulation of the island agreement in the historical trajectory of these disputes about Egypt's national resources, the opposition strengthened its claim that the Red Sea border agreement represented only the latest in a series of dismal political decisions which had not only caused harm to the nation but also demonstrated how the regime's legitimacy was based on hollow nationalist rhetoric.

\section{Protest and Pop Culture}

To increase their appeal within the nationalist segment of society and boost the resonance of the sellout framing, PCPL activists embedded their messages in famous patriotic metaphors and imagery and resorted to a range of familiar pop-culture narratives. Above all, the tale of taxi driver Awad who sold his share of the country's soil to raise money for his wedding with a belly-dancer became part and parcel of the PCPL's discourse and imagery. In the nationalistinspired film Ayez haqqi! [I want my right], released in 2002 based on a popular novel by Abdel Rahman al-Sharqawi, the struggling taxi-driver Awad played 
by comedian Hani Ramzy discovers by chance that the constitution grants him a share in the nation's public property. He thus collects power-of-attorney documents from his neighbors to sell his and their share of the land. In a powerful scene towards the film's finale, an elderly man appears - the father of a fallen soldier who died for Egypt's territorial independence. He admonishes the protagonist for attempting to sell his homeland to the highest bidder: "Awad sold his land, people" the old man says, creating an iconic line for Egyptian pop culture. This line was first adopted by political satirist Bassem Youssef in a tweet on the Tiran and Sanafir island deal. From there, references to the popular folktale made their way into the PCPL repertoire.

In an interesting twist, the Awad movie plot is based on a widely known nationalist radio soap that had been broadcast starting in the era of Gamal Abdel Nasser, through the Sadat tenure, up to the Mubarak era. The story of Awad and his land was part of Nasser's remodeling project to embed a new nationalist identity in the minds of Egyptians. The storyline was aimed at asserting the "bond between the land and the Egyptian people" (Mahmoud, 2016). Hence the tale of Awad was predestined to become part and parcel of the contentious discourse around the island deal. Images from the film became a constant feature of the mobilizing players' communications. In addition, different variations of the viral Twitter hashtags عواد_باع_ارضك [Awad sold his land / Awad sold your land] soon accompanied the press releases of all members of the protesting coalition, alongside the respective hashtag for the upcoming protest event.

Important for the island protesters, the inclusion of easily recognizable popular folk tales, such as that of Awad, awarded a certain "coolness factor" to their campaign, described by Lisel Hintz (2018b) as key in pop-culture's mobilizing effect. Lacking mobilizing structures beyond the inner-city neighborhoods of Cairo, the PCPL was thereby enabled to appeal to different publics outside their established networks of recruitment. Likewise, humorous social media posts that ridiculed $\mathrm{Al}$-Sisi for his attempts to deflect public attention from the agreement and, instead, project criticism on the unlawful protests became instrumental as a mobilizing tactic and were encouraged by members of the PCPL to reach new audiences (see Hintz, 2018b; Romanos, 2018). The power of resorting to simplified characters, such as that of the taxi driver Awad, to describe the Egyptian president and its policies derived from the fact that audiences immediately recognized how they were supposed to feel about them. They aroused strong emotions with the ability to shape political choices (see Jasper et al., 2020, p. 7).

Significantly, images and messages playing with pop-cultural tropes were often developed on social media but translated to contentious performances 
offline. In a sense, the writings on the walls of downtown Cairo interacted with the writing on social media walls. For instance, a stencil of Al-Sisi above the slogan "Awad sold you land" first appeared on social media. But it was adopted from there, printed out, and sprayed as graffiti on buildings near the announced protest sites. This stencil recalled prior creative protest performances in Egypt when graffiti sprayers had used the cut-out portraits of prominent Egyptians to connote specific subversive positions (see El Zein \& Ortiz, 2011). But it also referenced a now globalized cultural stock of imagery connoting resistance and counterculture.

The spray paint stencil of Al-Sisi's head (see Grimm, 2019, p. 454), for instance, mirrored Shepard Fairey's infamous “André the Giant"-sticker - a stylized portrait of a wrestler created in 1989 as part of a street art campaign. From its early adoption by the skater and street art community, the image was reproduced as a print on commercial products, clothing, décor, and as a stencil graffiti on billboards and buildings across the world, often paired with the slogan "OBEY." Originally devoid of any political meaning (see Fairey, 1990), the ironic "OBEY Giant" (Schulte, 2002) evolved into a global symbol of counterculture, with enough ambiguity to project a range of different subversive meanings, including the questioning of authority, the omnipresence of a "Big Brother"-like surveillance, and the ubiquity of corporate influence. By appropriating the style and coloring of this symbol to portray Al-Sisi - notably in suits, not in uniform - sympathizers of the PCPL evoked this iconology, translating it to the context of authoritarian rule in Egypt.

In a process that Hintz (2018b) describes as "one-upping others," sympathizers of the campaign shared and created countless such memes, trying to outdo one another by always adding cleverer, more subversive content. ${ }^{20}$ For instance, a sarcastic instruction to protesting youth - "If he asks you for your license to protest, tell him 'do you have a license for the sale of Egyptian soil?"' (PCPL, 2016d) - was widely shared. Social media users thereby unwittingly contributed to the incremental expansion of the protest campaign's outreach. At the same time, they enabled new audiences to reconstruct their own webs of meaning around the empty signifiers of Tiran and Sanafir.

For similar reasons, a process of tamsir al-lugha [Egyptianization of the language] could be observed in many of the PCPL's statements. While the official protest calls and many of the co-signed memoranda and press releases were redacted in modern standard Arabic, most of the shorter and more emotional statements - released above all by April 6 and Tamarod, but

20 For an impression of the satirical posts on the agreement see http://www.cairogossip.com/ gossip/life-style/14-hilarious-internet-reactions-to-the-tiran-sanafir-controversy/. 
at times also in the name of the entire PCPL - were published in Egyptian dialect. This adoption of colloquial language honored the historical underpins of nationalist rhetoric in Egypt, which replenish the lexical stock of the fusha [classical Arabic] with words and idioms of native origin to root nationalist sentiments in the everyday lives of Egyptians (Suleiman, 1996, p. 29f.). But it also stemmed from the PCPL's need to reach a broad audience. In this sense, the resort to colloquial Arabic aimed to create a bond between the campaign's core activists and the wider Egyptian public.

\section{Traitor to the Nation}

To increase the resonance of its "sellout"-frame, the PCPL furthermore aimed to establish the idea of an inalienable right of past, present, and future generations of Egyptians to their homeland. Against this backdrop, the campaign could claim that the president had committed treason against the nation by illegitimately signing a deal over property that he did not own in the first place. In the campaign's founding statement, the coalition asserted that forfeiting the islands to Saudi Arabia equaled compromising the country's sovereignty and the security of its borders. This represented a betrayal, "a violation of red lines that must not be crossed: the right of all the people and all future generations to this land" (PCPL, 2016b).

Until this date, the treason narrative had been championed primarily by members of the Muslim Brotherhood and the Anti-Coup Alliance who had pointed out crimes committed by the "coup regime" since Mursi's deposition. For the players in the island coalition, however, the reproach of treason was an escalation of their prior rhetoric. As with other nationalist movements, the PCPL thereby sought to "historicize a territory and territorialize a history" (Suleiman, 1996, p. 36), aiming to create in this process a historical unity between land and people. Soraya Morayef (2016) has demonstrated how this mechanism works to cement collective identity in her exploration of revolutionary street art and street performances inspired by pharaonic iconography. During and after the 2011 uprising, she stresses, this street art, on the one hand, subverted established and state-sanctioned art forms and asserted ownership over public spaces. On the other hand, the longue durée historical references embedded in graffiti, banners, and stencils symbolically empowered anti-regime protesters by invoking a foundational era of Egypt's national history whose legacy predated and would outlive the Mubarak-dominated years.

In a similar vein, the PCPL explored elements of the nationalist archive that were firmly established in Egypt's collective imaginary as a nation but 
predated the Al-Sisi era, to establish legitimacy for its protest campaign. The players united in the Egypt is not for sale!-campaign, for instance, began to adopt grainy footage of former president Gamal Abdel Nasser as well as historical pictures of the Egyptian army into their releases (PCPL, 2016a). Especially a video of Nasser warning of any violations of the Tiran waters was widely shared by social media users. Among others, the Tamarod movement was active in sharing the record under the hashtags السيسي_خاين [Al-Sisi is a traitor] and عبدالناهر_مات [Nasser died]. The second hashtag alluded to the Egyptian proverb "the men died in 1973" - a metaphor for the lack of braveness among more recent generations, compared to the valor of those who had died for Egypt in its wars with Israel over Sinai. The word of Nasser "belies that of al-Sisi and the government," Tamarod's corresponding statement read,

Abdel Nasser refused to forfeit one inch to maintain pressure against the enemy, Israel. Sisi, at this moment, sells her [the homeland] to Al-Saud, an ally of America and Israel, gives him [King Salman] the Necklace of the Nile, the highest medal of the Republic and a Ph.D. from the University of Cairo... etc. (Tamarod, 2016a)

This narrative juxtaposed Al-Sisi's dependence on his foreign backers with former President Abdel Nasser's emblematic stance for national independence (Brand \& Stacher, 2016, p. 38).

Invocations of Egypt's decades of anti-Zionist struggle were another avenue to challenge the nationalist prestige of the Al-Sisi administration. After all, the archipelago which gained strategic significance with the opening of the Suez Canal lies only three nautical miles ashore of the country's most contested territory, over which the Egyptian army fought a total of three wars during the last century. Due to their strategic location at the gate of the Gulf of Aqaba, Tiran and Sanafir played a central role in these conflicts, weaving themselves deeply into the cloth of Egypt's nationalist archive. Twice were the islands seized by Israel, twice were they "reconquered" by the Egyptian army.

As a result of the war that followed the establishment of the state of Israel in 1948, Egyptian troops first occupied Tiran and Sanafir in 1949, as Israeli forces were advancing on the northern end of the Red Sea. In 1955, when Israel first put into operation the port of Eilat at the head of the Gulf of Aqaba, the Egyptian Nasserite government insisted on its sovereignty over the Straits of Tiran as a bay inside of Egyptian territorial waters and on its sole authority for issuing permission to passing vessels (Hakim, 1979, 
p. 138). Threatened in its aspiration to ensure Israeli use of the gulf, the Ben Gurion government in Tel Aviv consequently occupied the islands in 1956 during the joint British-French-Israeli assault on Egypt, and only withdrew under the severe pressure of both, the US and USSR governments. After a period of relative quiet under the aegis of a United Nations Emergency Force overseeing the Egyptian-Israel armistice, the islands saw Israeli boots again in 1967 .

Before the invasion, Abdel Nasser had addressed air force officers in Sinai with the words "The Israeli flag shall not go through the Gulf of Aqaba. Our sovereignty over the entrance to the Gulf cannot be disputed" (Bowen, 2012; cit. in Comay, 2005, p. 28), providing Israel's Minister Levi Eshkol with a casus belli. Launching a series of pre-emptive strikes on Egyptian air force landing strips on June 5,1967 , the Israeli army left the country's military in shatters, and during the following Six-Day War it captured the entirety of the Sinai Peninsula including the contested archipelago. Only the Camp David Peace Treaty returned the archipelago to Egypt in March 1979. The treaty guaranteed Israeli ships freedom of passage through the Straits of Tiran and a UN peacekeeping force was stationed on the islands to ensure compliance. The Menachem Begin government finally handed over control over the island in 1982 .

This legacy was strongly present in collective memories about Tiran and Sanafir when the border agreement with Saudi Arabia became publicly known. Accordingly, the idea that Tiran and Sanafir are not Egyptian was difficult to sell to those "who lived all their lives with the story of the Straits of Tiran and the 1967 war as an integral part of their memory" (Mahmoud, 2016). This was compounded by the fact that the land transfer had required the approval of Israel, as any demarcation of maritime borders in the Gulf of Aqaba necessitated a modification of the military annex to the Camp David peace treaty. A case file passed to the Egyptian parliament established that the Egyptian government, to ensure Tel Aviv's acquiescence to the Egyptian-Saudi agreement, had assured its Israeli counterpart that it would guarantee the safety of the international peacekeepers on the islands, even after the transfer of sovereignty. On April 11, 2016, the Israeli newspaper Haaretz reported that Tel Aviv had consented to this proposal long before the deal was publicly announced (Ravid et al., 2016).

Against this backdrop, the alleged "hidden hand of Israel" played a significant role in the framing of opposition to the deal. Above all, the fact that the Israelis had learned of the land swap before the Egyptians was considered an affront by the PCPL. It nourished popular suspicions of an international plot, orchestrated by Israel and the US, to seize territory from Egypt. The 
head of Misr Qawiya [Strong Egypt], Abdel Moneim Aboul Foutuh, first made the baseless rumors of a Zionist plot respectable among the proponents of the PCPL. On April 10, 2016, the former presidential candidate tweeted:

The only ones who will benefit from tampering with Egypt's eastern borders will be the Zionists, Tiran and Sanafir are Egyptian the Strait of Tiran is Egyptian $100 \%$ and will be neither an international strait nor occupied Egyptian land as Al-Rishrash [Eilat]. (Aboul Foutuh, 2016)

In this narrative, the Egyptian nation was branded as the victim of an international plot, in which Egyptian authorities, as well as their Saudi counterparts, occupied merely the role of minions. The central villains, instead, were the state of Israel and the US. This characterization naturally elevated the PCPL and its allies to the level of heroes. A quote from the PCPL's founding declaration further illustrates the roles of Egypt, Israel, and Saudi Arabia in this narrative:

The agreement was even communicated to the Zionist entity and America before the Egyptians knew. This made clear that it is linked to regional arrangements which, in our view, aim to secure the Zionist enemy, favor the invasion of major powers in the region in the framework of Camp David and serve the American project in the Arab world. (PCPL, 2016b)

The parallels drawn between Egypt's historic struggle for territorial independence and the current episode of contention became most visible in the run-up to Sinai Liberation Day. The national holiday was the perfect fit. It not only enabled the PCPL to harness the historical significance of this date but also to attach a new prophetic connotation to it: "Come down and attend on April 25 and say no to the sale of Egypt," read the description of the public Facebook event created by April 6, "April 25 is the anniversary of Sinai's liberation from Israel. And the same date will be the liberation of the islands from Al-Saud" (April 6 Youth Movement, 2016f.). With this reinterpretation of Sinai Liberation Day, the PCPL effectively portrayed the island controversy as just another episode in a decade-long story of warfare over the integrity of Egypt's borders.

\section{A Threat to the Rule of Law}

By resorting to the confrontational framing that criminalized Al-Sisi and his administration as traitors to the homeland, the players in the opposition 
also attempted to counter the state's securitization of the Egypt is not for sale!-campaign, while at the same time admitting to the crime of patriotism. At the forefront of this framing were the Muslim Brotherhood and its allies who had been pointing to a litany of crimes committed by Al-Sisi over the last years. In the context of their established framing of the Al-Sisi administration as criminals and thugs, the reproach of corruption and selling off the nation's wealth was just another tile to add to the larger mosaic: "We are facing a group of criminals who commit the largest sale of Egyptian land and honor to date," the group's statement on April 14, 2016, read (Muslim Brotherhood, 2016b). It called for solidarity between all national forces against the military junta regime.

With an ironic undertone, the Brotherhood-affiliated Anti-Coup Alliance added that President Sisi was committing "the exact crime he falsely accused President Mohamed Mursi of" (NASL, 2016). This juxtaposition with the former president added an interesting twist to the Brotherhood's statements, as it recalled the rumors that the former president had plotted to hand over parts of the Sinai Peninsula to the Palestinian Hamas (Ezzat, 2013). The fears of such a disposal of the Egyptian homeland had even led to the inclusion of a clause into the new constitution, which significantly raised the legal prerequisites for any redraw of Egypt's borders (Walsh, 2016). ${ }^{21}$ Ironically, it was under the Al-Sisi administration that this constitution was put in place.

From the Brotherhood, the treason-framing was adopted by a range of public intellectuals, some of whom had ties to the group, who released a joint statement on April 14, 2016:

We call on every citizen to raise high the Egyptian flag to announce their commitment to the unity of Egyptian territory - from Tiran and Sanafir to Salloum and Farafra, from Alexandria and Matrouh to Rafah and the Sinai, and from this homeland's western borders to its eastern borders; not forgetting its rivers and seas. No one represents Egypt but its people. No one sells off Egypt's territory but a traitor. (Nafie et al., 2016)

21 According to article 151 of the 2014 constitution, "the President of the Republic represents the state in foreign relations and concludes treaties and ratifies them after the approval of the House of Representatives. They shall acquire the force of law upon promulgation under the provisions of the Constitution. With regards to any treaty of peace and alliance, and treaties related to the rights of sovereignty, voters must be called for a referendum, and they are not to be ratified before the announcement of their approval in the referendum. In all cases, no treaty may be concluded which is contrary to the provisions of the Constitution or which leads to a concession of state territories." 
In this context, the announcement that the agreement would still require parliamentary sanction, rather than alleviating the reproaches, only sparked further mistrust. As the deal had been kept secret for months and had side-lined all legislative bodies, the government's assurance that its implementation would go its due process held little credibility.

First, contenders to the deal argued, it would have been reasonable to assume that a public consultation with the parliament over the issue would have taken place before the finalization of an agreement with Saudi Arabia. Instead, the delegates would now be confronted only post-factum with a finalized deal, which the president had already signaled he would not tolerate further discussions on. The PCPL pointed out that the governmental institutions were treating the demarcation as a fait accompli, which added to the skepticism about the parliament's ability to fulfill a monitoring role:

Despite the declaration of the authorities' intention to submit the matter to the House of Representatives, however, some ministries and agencies have already changed the maps which indicated Egyptian ownership of Egypt over the islands. (PCPL, 2016b)

Al-Sisi's assertion that the public should simply trust in the fact that the presidency and his government were good patriots and fit to judge on the well of the nation, in this context, seemed to amount to a gag order not only for the street opposition but also for the parliamentarians. This impression was compounded by reports that the case file on the island deal, which had been passed by the government to the parliament, remained locked away in the office of parliamentary speaker and regime loyalist Ali Abdel Aal. Ordinary parliamentarians had been granted access to select documents only to placate their outrage over the lack of information (see Mada Masr, 2017b).

Second, and more importantly, activists questioned both the capacities and the loyalties of their MPs. Recent broadcasts from the House of Representatives had cast doubts on the parliament's allegiance: When King Salman addressed the Egyptian legislature on April 10, 2016, he had been received with standing ovations. Repeated applause had interrupted his only six-minute-long address. Some members of the 596 -seat chamber had even recited poetry praising the Saudi monarchy. ${ }^{22}$ Given this overwhelming show of allegiance by the elected representatives of the Egyptian people to a foreign leader, many activists saw their concerns warranted that the parliament would rubber-stamp the agreement without even considering

See the footage released on YouTube at https://www.youtube.com/watch?v=am8VQyKFirY. 
the widespread concerns. Many protesters who took to the streets on April 15 thus alluded that waiting for the parliament to decide negatively on the matter would equal waiting for Godot (Aman, 2016).

Adding to that suspicion was the fact that the regime imposed a gag order on media coverage of issues related to the island deal. Moreover, as the arrest campaigns expanded, even those who had only brought legal charges against the deal (and thus adhered to the proper procedure sketched out by Al-Sisi to oppose the island deal) were suddenly targets of persecution. This only substantiated the PCPL's critique of the government: The fact that famous lawyers who had challenged the deal in court now found themselves in detention cells vividly demonstrated the hypocrisy of the administration's insistence on due process.

Building upon the notion of a historical right that had been inherited by the Egyptian people to their land, the protest campaign consequently advanced its own conception of due process to counter the president's claims of rightfully restoring lost ownership to Saudi Arabia. From their first public statements onward, the players united in the PCPL pointed to the need of involving the people in significant decisions, such as the waiver of public land:

Those undersigning below affirm fully and unconditionally the right of the Egyptian people to express their opinion, and that the issue of land demarcation shall not pass into law without notice of the real holder of sovereignty and the real proprietor, which is the people. The matter of the Tiran and Sanafir islands is a matter for all Egyptians. (Strong Egypt Party, 2016a)

Calls for a popular referendum, as stated in Article 151 of the 2014 constitution, were thus widespread in the PCPL's political communication: "The Islands of Tiran and Sanafir are 100\% Egyptian [...] Egypt waived them without a referendum or referral to the Egyptian parliament, even though this is a formality (duty) according to the constitution after the signing of an agreement," read one of the many online petitions launched by the PCPL in the first days after the disclosure of the agreement (PCPL, 2016a).

\section{Harnessing the Memory of January 25 for Coalition Building}

The antagonist frontier drawn by the PCPL between its supporters and the disenfranchised Egyptian people, on the one hand, and those violating popular sovereignty, betraying the nation, and threatening its security 
sketched out the parameters of the protest arena. It also determined, to a certain extent, the conditions of possibility for different political players joining or opposing the street protests. A key factor for the evolution of the PCPL into a broader cross-ideological coalition was the successful bridging of nationalist and revolutionary rhetoric in a hybrid discourse of resistance that was reproduced by the players within the PCPL. This hybrid discourse appealed to the various political audiences who had previously been victimized by the Al-Sisi administration's weaponized nationalism. This included compound players such as Tamarod, which had previously articulated their collective identity along patriotic lines, as well as individual and collective actors who had supported the uprisings in January 2011 and June 2013 but were driven by social-liberal, democratic, or communitarian revolutionary ideals, rather than nationalist values.

In line with Benford and Snow's (2000, p. 624) assertion that the mobilizing power of collective action frames is strongly dependent on "the extent to which the frame taps into existing cultural values, beliefs, narratives," the prognostic frame adopted by the organizers within the PCPL drew heavily from the well-known and established vocabulary of the January 25 belief system. The key slogans, symbols, and signifiers of the Tahrir uprising made a spectacular comeback in the PCPL protest calls and chants, as footage from the major protest events reveals. As Samer Al-Atrush (2016) remarks, the chants on April 15 and 25, 2016 were "retro 2011" and often inspired by favorite themes from Tahrir Square or by football chants.

Some of these chants were reproduced by the PCPL protesters without modification. For instance, the signature slogans of the January 25 uprising against Mubarak ash-sha'ab yurid isqat an-nizam [the people want the fall of the regime], irhal [leave], and yasqut, yasqut hukm al-'askar [down, down with military rule] remained unchanged as they still fitted to the contemporary political realities. They evoked vivid collective memories about the revolutionary experience of 2011 and positive affective commitments of trust, solidarity, loyalty - hence a sense of groupness and belonging to a revolutionary people that endowed the protesters with a sense of purpose, comradeship, and commitment (see Jasper, 2018, pp. 105-120). But they also evoked negative commitments of hate and aversion towards the government and its oppressive practices. These identity markers became historicized during the Egyptian uprising and subsequent events, up until the coup against Mursi, only reinforced the boundaries they construed between the people and the regime. Reproduced within the frame of the PCPL, these affective commitments fed the reflex emotions of anger and fear about the loss of Tiran and Sanafir, transforming them into indignation and an urge for collective action. 
For a similar reason, also the famous bleep sound was adapted from the discursive repertoire of the January 25 Revolution (Gribbon \& Hawas, 2012, p. 116) and employed widely on both April 15 and April 25, 2016: An imitation of the sound used to blackout profanity on television, the bleep originates in the chants of the Egyptian Ultras soccer fans whom it enabled to swear in the soccer stadium without risking collective legal repercussions against their fan block. The adoption of the sound by the island protesters commemorated this collective act of resistance thus reinforcing the boundaries between the agents of law enforcement and agents of resistance. Within the frame of the PCPL, the bleep became a way to publicly curse President Al-Sisi without providing a pretext for legal prosecution under charges of "contempt for the president." By contrast, other chants were modified in ingenious ways and combined the references to the 18 days of Tahrir' with references to more recent events, such as the rhyming 'aish, hurriya, al-gaziraten masriya [bread, freedom, the two islands are Egyptian].

By adopting these slogans, the PCPL aimed to strategically harness the affective power of the "Midan Moments" (Ayata \& Harders, 2018) they referenced. As described by Bilgin Ayata and Cilja Harders, the bodily copresence, joint practices, and collective performances during the prolonged occupation of Tahrir Square in 2011 (and other squares in the region that witnessed large-scale occupations, such as Taksim Square in Istanbul) led to the emergence of complex affective dynamics. These included aspects of joy, fear, anger, and liberation. These affective dynamics served to catalyze processes of solidarization and, in their interplay, "enabled outright antagonistic actors to protest together" (Ayata \& Harders, 2018, p. 116). At the same time, they demarcated the state as the antagonist other. It is for this galvanizing effect on popular resistance that the players united in the Egypt is not for sale!-campaign aimed to discursively recreate the powerful "affective arrangements" of Tahrir (Slaby et al., 2019).

Furthermore, the narration of the Tiran and Sanafir crisis as the most recent episode in an ongoing revolutionary struggle against injustice aimed to recreate the conditions for coalition building across the organizational boundaries and ideological cleavages of Egypt's opposition - especially across the divide between the shabab ath-thawra [revolutionary youth] and nationalist movements, such as Tamarod, which had emerged during Mursi's government. ${ }^{23}$ To bridge this divide, the PCPL paired typical markers of identity of the players that had been at the forefront of the 2011

23 The narrative of the "revolutionary youth" emerged in 2011, as a frame that excluded competing readings of the uprising as an Islamic awakening or a popular coup. For different political 
Figure 22 Tiran and Sanafir as a bridge between revolutionary and nationalist discourses

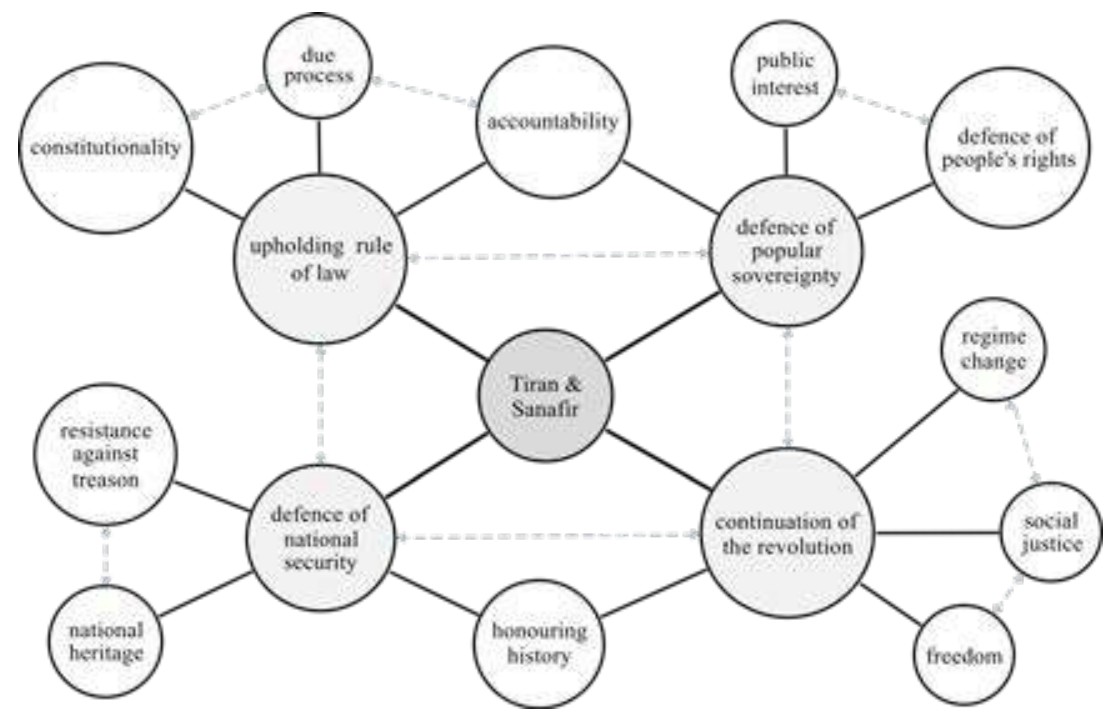

revolution (elements on the left side of Figure 22), with patriotic and legalistconstitutionalist discourses that followers of Tamarod and nationalist currents could subscribe to (elements on the right). The common reference to the nodal signifier of Tiran and Sanafir dissolved the differential relationship between both identity-establishing discourses - and effectively bridged the political divides between both groups.

Among the most active players championing this unifying effort was the Tamarod movement. Among all PCPL allies it first adopted the iconic repetition "yasqut, yasqut..." [down, down...] for President Al-Sisi. Since 2011, this slogan had reverberated throughout Egypt's streets whenever the political situation had become so unbearable that the people began to demand the government's resignation: first during the 2011 protests against Husni Mubarak; then during the interim rule of the Supreme Council of Armed Forces and its Field Marshall Mohammed Hussein Tantawi; and finally during the popular campaign against Egypt's first freely elected President Mohammed Mursi who had fallen out of the people's favor due to his partisan politics. It was highly symbolic that the movement whose campaign had enabled Al-Sisi to sweep Mursi from office now used the 
same chant against the general. In an Arabic post on April 13, Tamarod called for Al-Sisi's fall:

Down, down your ego; down, down your failure; down, down your speeches; down, down your deals; down, down your terror; down, down your suppression; down, down your regime; down, down Abdel Fattah al-Sisi. (Tamarod, 2016c)

However, the statements released by other activist groups including the Revolutionary Socialists or the April 6 Youth Movement were also full of Tahrir references and echoed its iconic vocabulary of resistance which, until the islands controversy, had all but disappeared from the public sphere. Several of these players explicitly stated that the island protests had opened a new chapter in the history of the popular revolution that started in January 2011 (see RNN, 2016). For instance, a statement by April 6 urged the Land and Honor-protesters:

Let today be a new beginning. More important than slogans, parties, political shouting, is that we go down today and say I am here. I am still here, and I have an opinion, a voice, and worth. The January revolution still lives, and its legacy is still within us, despite everything that has happened! (April 6 Youth Movement, 2016c)

The clashes between protesters and police on the evening of April 15 were also framed in analogy to the events of January 2011. Above all, two photographs taken at the standoff between CSF units and PCPL protesters in the vicinity of the Journalist Syndicate on April 15, went viral on Twitter and Facebook: a standoff between a wall of riot police and a single protester whose raised arms formed a V for victory (see Grimm, 2019, p. 456), and a young student ridiculing the security state by performing a longboard stunt in front of police cordons. These images captured scenes of popular defiance and were reminiscent of the imagery that traveled around the world during the mediatization of the Arab Spring.

In a similar vein, a picture of protesters kneeling for Friday prayer shielded by human chains from riot police on the street in front of Egypt's Judges Club on April 15, 2016, referenced the iconography of the Arab Spring (see April 6 Youth Movement, 2016b). During the 18 days of Tahrir, Coptic protesters had protected their praying Muslim comrades on Tahrir Square against baltagiya and police incursions by forming cordons around them. This highly mediatized ritual became a symbol of national unity and the 
anti-sectarian nature of the uprising. Its adoption by the PCPL was meant to evoke similar connotations and signal that the alliance was taking to the street on behalf of the entire nation.

\section{Lionizing the Prisoners of the Land}

Furthermore, the PCPL protests also saw the return of the martyr theme. On April 15, banners bore, for instance, the images of Coptic activist blogger Mina Daniel and Italian researcher Giulio Regeni. Daniel, an icon of the revolutionary youth, was killed by army forces in 2011 during the massacre of Maspero. His death became a symbol of the excesses of the post-revolutionary state and the army's betrayal of the Tahrir Revolution. In turn, Regeni, a Ph.D. student who was kidnapped, tortured, and murdered in January 2016 became a harbinger of the rise of an unaccountable security state.

Protesters who had been arrested during the island protests were also lionized by the PCPL as martyrs of the revolution and placed in the context of the authoritarian contraction and the growing number of political detainees since 2011. Alongside the annulment of the demarcation agreement, the release of the "prisoners of the land" soon became one of the central demands of the campaign, and their portraits featured strongly in the campaign's visual communication. In many PCPL press releases, the portraits were accompanied by a caption stating that if solidarity and the defense of the homeland were a crime, then the protesters admitted their guilt. Many statements ended by demanding freedom for the Land and Honor Friday prisoners. In a direct response to the arrest of protesters, the PCPL even extended its guiding slogan and reference to the Awad-folktale by a reference to the detention of Egypt's patriotic youth: The rhyming hashtag باع_البلد_وحبس_الولد and imprisoned the boy] blamed Al-Sisi personally for the arrest of many young demonstrators. It went viral on social media alongside depictions of the president as a jailor and prison warden.

Aside from the demand for a release of all political prisoners, the bridging of nationalist and revolutionary discourses also allowed for the articulation of more far-ranging goals in the frame of the island protests, such as a reformation of the assembly and information provision laws, as well as the dismissal of vital figures of the ruling coalition. Regarding this frame extension, there was notable disparage among the players in the PCPL. The Strong Egypt Party, for instance, was more explicit than other members of the coalition in its call for regime change. On April 23, it coupled the announcement of its participation in the marches on Sinai Liberation Day 
with a list of 15 reasons why Al-Sisi and his government should step down: Aside from the waiver of Tiran and Sanafir, the list enumerated a litany of alleged crimes including the repression and torture of citizens, the toleration of corruption and kleptocracy, and the prioritization of Israeli over Egyptian national interests (Strong Egypt Party, 2016c). In another statement, the party declared that defending Tiran and Sanafir was not enough:

We emphasize that our demands are greater and not only limited to the two islands - despite the significance of their issue - as our demands are still: state justice, freedom, democracy, rule of the people, the neutrality of the military and domestic security institutions, and the dignity of all citizens without distinction or discrimination. (Strong Egypt Party, 2016b)

As the protest cycle continued, demands for accountability and regime change were also adopted by most other PCPL members. Although the rallies continued to focus on the abolition of the island transfer, many began to air other grievances over the course of the protest cycle. Amongst these were the issues of political prisoners, physical repression, and the restriction of freedoms, the military coup of 2013, or other instances that were perceived as a sellout of Egyptian homelands, such as the demarcation of the maritime border with Cyprus, or the government's policy in the Nile Water Dispute with the country's southern neighbors. Eventually, the release of political prisoners became a particularly dominant motive of the PCPL. At the end of the protest cycle, calls for a presidential amnesty, the release of all prisoners of conscience, and an investigation into their unlawful arrest had replaced the abolition of the agreement as the protesters' central demand.

The effect of this scale shift in the aims of the PCPL was ambiguous: On the one hand, championing a plethora of political interests enabled the alliance to transcend the constraints of the strong nationalist frame on the social segments it appealed to. On the other, abandoning this unifying signifier eroded the PCPL's internal cohesion. The coalition statements, but also videos from the protest events reflect how some members realized the tensions that resulted from parts of its constituency embracing more particularistic demands. A clip from April 25, for instance, shows how some organizers attempted to prevent the protests from deviating from their primary objective with chants that called for unity among the demonstrators and a focus on Tiran and Sanafir as the common denominator. After April 25, the PCPL protest calls mirrored this effort on the grassroots level by carefully highlighting that the protest campaign was still essentially about the defense of Tiran and Sanafir. 
In the end, these calls failed to prevent fragmentation. Protest faded in response to the hard hand of the police and continued repression in the days following Sinai Liberation Day. Finally, the coalition dissolved as the debate was relocated to the judiciary, and opposition channeled into several lawsuits that questioned the constitutionality of the border demarcation procedure.

\section{Limits of Coalition Building}

In principle, the new antagonist frontier drawn by the PCPL, between those who had betrayed the nation and the true patriots who opposed the Tiran and Sanafir deal, could have functionally replaced the divide between coup and anti-coup that had shaped Egypt's protest arena since Mursi's deposition. The bridging of nationalist and revolutionary discourses allowed a broad spectrum of oppositional parties and movements from different sways to march jointly and rally around the same goal. Initial attempts to mobilize against the agreement and the growing thematic salience of the issue of political prisoners within the PCPL discourses seemed to point in this direction.

For instance, in its initial call for April 15, 2016, the April 6 Movement had asked protesters not to carry any signs displaying ideological or political affiliations or to raise any partisan slogans. This meant pre-empt attempts to discredit the campaign as factional instigation and enabled various political groups and parties to join the marches (see April 6 Youth Movement, 2016d). It also foreshadowed the emergence of a new broad anti-government coalition that could have included Islamist players, too, especially since revolutionary slogans, pictures, and chants were not only reproduced by the members of the PCPL but traveled across ideological boundaries. Most notably, the outlawed Muslim Brotherhood and its political arm at the grassroots level joined the calls for mass protests. On April 15, members of the Brotherhood and the NASL groups participated in the street protests, albeit individually and without carrying any of their banners. At some demonstrations in the countryside, scattered Rabaa-salutes were an indicator of the Islamist's presence. However, at the majority of the PCPL demonstrations, members of the Anti-Coup Alliance abstained from displaying their known insignia.

This visual abstinence of Rabaa-salute represented an attempt by the Anti-Coup Alliance to transcend polarization and open to some of its former enemies. The Anti-Coup statements pointed in this direction as well. Rather than repeating known Anti-Coup-tropes, they mirrored the PCPL's revolutionary-nationalist lingo. This is illustrated, among others, by 
a Brotherhood statement on Sinai Liberation Day which attempted to bridge the PCPL's sellout-frame with the Anti-Coup Alliance's legitimacy discourse:

The military coup leaders profaned Egyptian land, Egyptian honor, trampled the Egyptian citizens' dignity, and smeared the history, culture, and tradition of this dear homeland [...]. The only solution now is to defeat and end this illegitimate coup, to reinstate democratic legitimacy, and to put right all the ruinous coup's injustices and crimes. [...] Say it loud and clear: No compromise on an inch of Egyptian land. As President Mohamed Morsi said: 'The land of Egypt is forbidden to non-Egyptians'. It is not for sale, especially after it has been watered with the blood of the martyrs. (Muslim Brotherhood, 2016c)

These bridge-building attempts were largely unsuccessful. Certainly, the mere fact that former political adversaries, such as Tamarod and the AntiCoup Alliance mobilized their supporters for the same street protests was noteworthy. The two players had heretofore never rallied around a common goal and been exclusively antagonists in the formulation of their political aims. But it fell short of reviving the revolutionary unity coalition of 2011. Above all, liberal and leftist players within the PCPL rejected the thought of joining forces with the Islamists. They feared that the Brotherhood's participation would tarnish the image of the campaign. Furthermore, they rejected the distorted image of Mursi's presidency as the democratic antitype of Al-Sisi's rule. Instead, they pointed out the semblances between both presidents' authoritarian practices. The PCPL thus tolerated the individual participation of Anti-Coup supporters in the protests. But they were marginalized as organized players.

Instead, the PCPL discourse reproduced the dominant cleavage of Egypt's post-coup theater, which had dichotomized the political arena into supporters and opponents of Mursi's ouster. Rather than dissolving this antagonism, the PCPL asserted itself as an independent political player by disassociating itself both from the Anti-Coup and the regime camp. In addition to the established frontier between coup and anti-coup (line 1 in Figure 23), the PCPL communication carefully constructed a second internal frontier that split the pro-ouster camp into two (line 2 in Figure 23). In doing so, the PCPL asserted that its rejection of the Brotherhood did not equal uncritical support for the regime - and that opposition to government policies did not equal solidarity with the Islamists.

This strategic positioning as a third force is most clearly exemplified by a passage in the coalition's protest call for Sinai Liberation Day. Therein, the 
Figure 23 Antagonist frontier in the PCPL discourse

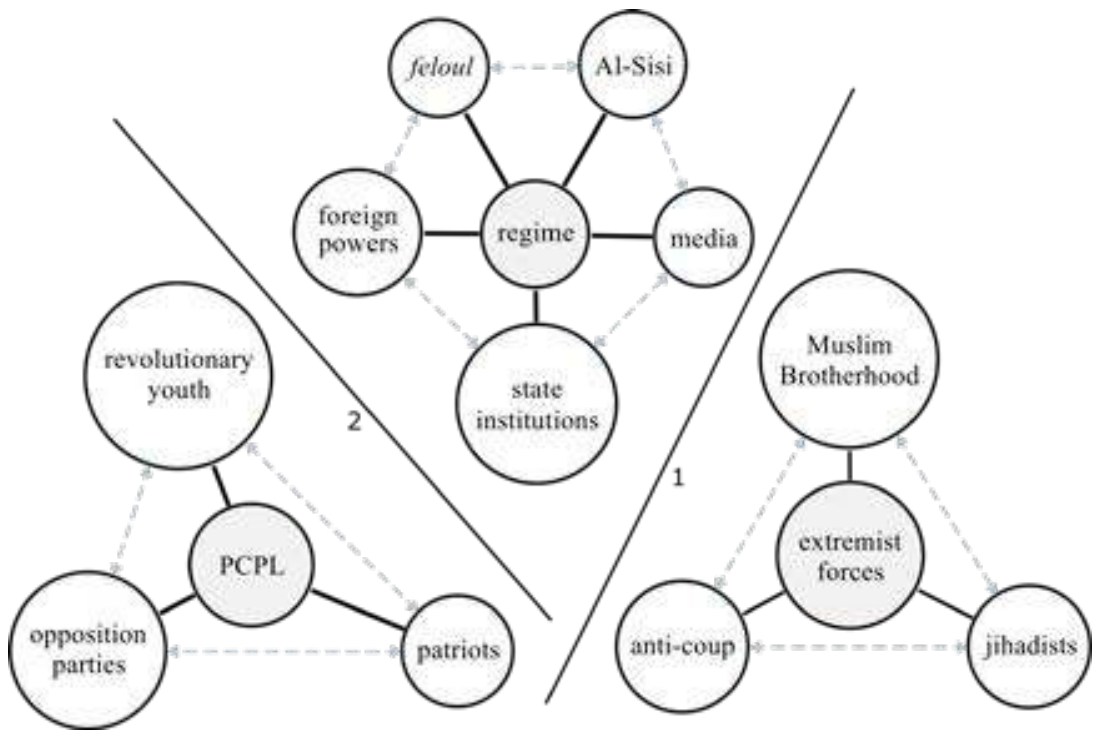

coalition categorically rejected any coordination with the Muslim Brotherhood. Instead, the group and its political arms were framed as reactionary players that promoted sectarianism and factionalism to destabilize the state:

There is no place for those who committed a crime against the nation and the people. We are confident that the Egyptian people - as they strive to overturn the forfeit of the two islands, refuse to subordinate to the Kingdom of Saudi Arabia, and confront a campaign of repression and threats of escalation from the side of authorities - won't allow the Brotherhood to exploit the issue, nor the coalition's name, nor its activities. (PCPL, 2016c)

The statement also stressed that all factions united in the PCPL had been at the forefront of the June 30 uprising against Mursi. This deliberately placed the island protests in a culture-bound narrative of the Egyptian uprising that excluded the possibility of a positive association with the Brotherhood. At the forefront of this effort was the Tamarod movement which cemented this political frontier as early as April 13, 2016:

On the revolutionary day of January 25, we took to the streets for this country. When we stood against the military council, it was for this country. When we stood against the Brotherhood on June 30, it was for this country. We have made sacrifices, some of us have died and some 
are in prison for our freedom, our dignity, and the future of our children in this country. Therefore, we will take to the streets again on Friday, April 15, for the sake of this country! (Tamarod, 2016b)

By placing the contentious struggle over the islands in the tradition of the June 30 uprising, Tamarod alienated the Muslim Brotherhood. But it also challenged Al-Sisi's interpretive authority. In the wake of the protests, the president had referred to June 30, 2013, to shore up his legitimacy.

Most other players within the PCPL soon followed suit. This forestalled a sustained positive identification of the Islamist opposition with the Egypt is not for sale!-campaign. In reaction to the hostility of Tamarod and other PCPL members, the players united in the NASL abandoned the idea of further rapprochement between both camps. Over the investigation period, both the Brotherhood and the NASL gradually returned to a discourse that placed the coup against Mursi at the center of their narrative. This prioritization of internal cohesion over alliance-building naturally antagonized most PCPL members.

\section{The Transformative Impact of the PCPL}

As the aftermath of the PCPL shows, the emergence of broad cross-movement mobilization provides no guarantee of success. The combination of legal channeling and targeted repression forestalled major public shows of dissent when President Al-Sisi ratified the agreement on 24 June 2017. But the ripple effects of the PCPL transcended the island controversy. Even though the PCPL eventually dissolved, the campaign was a catalyst for the contestation of the state on different fronts. By appropriating "something that had upheld the sanctity of the state" (Morayef, 2016, p. 200), the campaign managed to challenge the regime's claim to represent and protect the nation and her lands, thus transforming the conditions of possibility for collective action and leaving a lasting impact on the country's protest arena.

Through the articulation of a hybrid discourse that carried the marks of the "new political language" (Filali-Ansary, 2012, p. 10) of the Arab uprisings and the patriotic lingo of the Al-Sisi era, the PCPL successfully linked the signifiers of nationalism and revolution through their common relation to Tiran and Sanafir. Transcending prevalent differences and social divides, this enabled coalition-building between nationalist movements like Tamarod, moderate-Islamic groups like the Strong Egypt Party, and revolutionary youth movements like April 6 and the Youth Movement for Justice and Freedom. The Tiran and Sanafir issues enabled the re-emergence of revolutionary 
claims that had been virtually absent from Egyptian politics since the 2013 coup. But it nevertheless reinforced old antagonisms that had irrevocably split the Egyptian public into two camps since 2013. All the movements aligned with the PCPL - from the Revolutionary Socialists to Tamarod - out of fear or aversion explicitly set themselves apart from "extremist" Islamist forces, such as the Brotherhood and the NASL. This dynamic prevented the emergence of a more powerful coalition of contenders that could have posed an existential threat to the authoritarian order.

However, when investigating the transformative impacts of collective action, we should resist the temptation to discard all protests that fail to mobilize critical masses of tens of thousands of people or produce outright regime change. In this sense, it was highly symbolic that on April 15, hundreds of protesters gathered in the same squares and marched on the same thoroughfares that had witnessed the January 25 uprising in 2011, relatively unfazed by the massive deployment of Egypt's notorious riot police. Moreover, the island's controversy enabled opposition groups whose cadres and mobilizing goals had been largely discredited in the public sphere to come out of the closet and hold up a mirror to the nationalist elite. The Egyptian-Saudi land transfer, in this sense, was a transformative event for Egypt's post-revolutionary contentious dynamic.

The authorities grossly underestimated the prominent role of the homeland in their nationalist project. Therefore, attempts to integrate the controversial border demarcation agreement into the securitizing discourse that legitimized the authoritarian rule of the Al-Sisi administration in post-coup Egypt, effectively backfired. Although many Egyptians have no material relation to the country's ceded territory, with many having never traveled outside of their hometown, the two islands were deeply embedded in collective memory and identity. The link between land and nation grew strong over the fight against colonialism and the ensuing military and diplomatic battles with neighboring Israel - often driven by the question of sovereignty over Sinai (which recently also dominated the regime's narrative on the fight against jihadism in the peninsula). Consequently, the regime's framing of the demarcation agreement as an honorable restoration of historical rights became an easy target for the opposition.

As Laurie Brand and Joshua Stacher (2016) argue, in such moments of crisis, regimes usually attempt "a kind of re-scripting - a reinterpretation of national symbols or key events" (p. 38) to allow for policy innovation while maintaining control. But they suggest there are limits to which historical events can be sensibly incorporated into the hegemonic narrative and which elements of the dominant discourse may be modified short of a regime change. In this 
sense, the voluntary cession of Tiran and Sanafir was an event that could not reasonably be signified within the ruling players' discourses. Reinterpreting the transfer as a matter of national pride proved too great a challenge thus creating opportunities for resistance in an otherwise closed context.

The island deal evolved into an empty signifier that could be filled with different meanings. As such, it provided a powerful tool for the construction of a contentious coalition that united old political players in an innovative alliance. As protesters reclaimed ownership over the meaning of patriotism, the subversion of hegemonic discourse became a vehicle for successful alliance-building under conditions of severe repression: The forces that joined the PCPL claimed to represent the true patriots who would defend every single grain of their fathers' soil with their blood. They adopted the very same nationalist rhetoric by which the military-backed transitional government and its successors had legitimized their authoritarian modes of governing. Thereby, they seriously challenged the regime's self-legitimation, for the first time since the 2013 coup.

Ultimately, the Tiran and Sanafir crisis exemplifies the opportunities that arise from the disparities between what authorities claim to stand for (in terms of values and norms) and pursue (in terms of goals), and how they act. In an earlier exploration of such disparities, Brand (2014) noted that authoritarian leaders in the Middle East, at times, miscalculated by building on nationalist narratives, thereby inducing apathy or resistance in their target audience. The case study of Tiran and Sanafir complements her account by highlighting how such dissonance can also become a catalyst for innovative political alliances that cut across movement boundaries and ideological cleavages. By "harnessing hegemony" (Maney et al., 2005) and subverting nationalist discourse for mobilization by drawing upon its imagery, tropes, and established webs of meaning, activists not only bridged political divides but also undermine the official legitimization of repression against protesters. In doing so, activists themselves created and realized new opportunities for mobilization and reshaped the parameters of the protest arena.

\section{References}

Abdel Hafez, G., Abdel Rahman, H., Ibrahim, H., Al-Shazly, I., Al-Sheikh, O., Abu Al-Enein, M., \& Mulla, M. (2017, June 16). Tiran and Sanafir: Security forces detain dozens of protesters [Arabic]. Al-Masry Al-Youm. https://www.almasryalyoum.com/news/details/1149640

Abdelrahman, M. (2009). 'With the Islamists? - Sometimes. With the state? - Never!' Cooperation between the Left and Islamists in Egypt. British Journal of Middle Eastern Studies, $36(1), 37-54$. 
Abdelrahman, M. (2017). Policing neoliberalism in Egypt: The continuing rise of the 'securocratic' state. Third World Quarterly, 38(1), 185-202. https://doi.org/10.1080/01436597.2015.1133246

Aboul Foutuh, A. M. (2016, April 10). The only ones who will benefit from tampering with Egypt's eastern borders will be the Zionists [Tweet]. https://twitter.com/DrAbolfotoh/ status/719003541722046466

AFTE. (2018, February 1). A decision from an unknown party about the blocking of websites in Egypt. Association for Freedom of Thought and Expression. https://archive.vn/wip/9Mdxm

Al-Atrush, S. (2016, April 16). Chants are retro 2011. Bread freedom etc. And football inspired 'ooh ooh bleep Sisi your bleep' [Tweet]. @SameralAtrush. https://twitter.com/SameralAtrush/ status/720976017997881344

Al-Bedaiah. (2016, April 24). A day before the demonstrations of April 25, Interior Minister: We will deal firmly and firmly with attempts to 'disturb the security' [Arabic]. Al-Bedaiah. http:// albedaiah.com/news/2016/04/24/111758

Ali, K. (2016, April 21). Today I filed a lawsuit against the waiver of the islands [Arabic]. Facebook. https://www.facebook.com/khaled.ali.72/posts/822837647861595

Al-Sisi, A. F. (2016a, April 13). Text of Al-Sisi's speech to community representatives [Arabic, on file]. Al-Manassa. https://archive.vn/wip/Ghsoy

Al-Sisi, A. F. (2016b, April 24). Statement by H.E. President of the Arab Republic of Egypt Abdel Fattah El Sisi on the 34th anniversary of Sinai liberation [On file]. State Information Services.

Aman, A. (2016, April 17). Protesters return to Egypt's streets. Al-Monitor. http://www.al-monitor. com/pulse/originals/2016/o4/egypt-cairo-protests-sisi-islands-saudi-arabia.html

Andeel. (2014, February 3). Lexicon of a revolution's insults. Mada Masr. http://www.madamasr. com/sections/culture/lexicon-revolutions-insults

April 6 Youth Movement. (2016a, April 14). These things are not for sale [Arabic]. Facebook. https://bit.ly/2Hn2IwP

April 6 Youth Movement. (2016b, April 15). Now, in front of the Judges Club [Arabic]. Facebook. https://www.facebook.com/m6april/photos/a.119279621491044.29804.119276198158053/101 $4648468620817 /$ ?type $=3 \&$ theater

April 6 Youth Movement. (2016c, April 16). Comment on Facebook event: Over our bodies. Facebook. https://www.facebook.com/events/1586440928333688/

April 6 Youth Movement. (2016d, April 16). Protest call for April 15: Over our bodies [Arabic]. Facebook. https://www.facebook.com/events/1586440928333688/

April 6 Youth Movement. (2016e, April 16). The barrier offearwas not only broken, it was successfully obliterated [Tweet]. https://twitter.com/shabab6april/status/721264645789487105

April 6 Youth Movement. (2016f, April 16). The land of honour is not for sale [Arabic]. Facebook. https://www.facebook.com/events/584421871719292/

April 6 Youth Movement. (2016g, April 16). The people, the army and the demonstrations yesterday. Facebook. https://archive.vn/wip/EWCH6

Ayata, B., \& Harders, C. (2018). Midān moments: Conceptualizing space, affect and political participation on occupied squares. In B. Röttger-Rössler \& J. Slaby (Eds.), Affect in relation: Families, places and technologies (pp. 115-133). Routledge.

Benford, R. D., \& Snow, D. A. (2000). Framing processes and social movements: An overview and assessment. Annual Review of Sociology, 26, 611-639.

Bowen, J. (2012). Six days: How the 1967 war shaped the Middle East. Simon and Schuster.

Brand, L. A. (2014). Official stories: Politics and national narratives in Egypt and Algeria. Stanford University Press.

Brand, L. A., \& Stacher, J. (2016). Why two islands may be more important to Egyptian regime stability than billions in Gulf aid. In From mobilisation to counter-revolution (pp. 37-39). 
Project on Middle East Political Science. https://pomeps.org/wp-content/uploads/2016/o7/ POMEPS_Studies_2o_Mobilization_Web-REV.pdf

Browers, M. (2007). Origins and architects of Yemen's Joint Meeting Parties. International Journal of Middle East Studies, 39(4), 565-586.

Clarke, K. (2011). Saying 'enough': Authoritarianism and Egypt's Kefaya movement. Mobilization: An International Journal, 16(4), 397-416. https://doi.org/10.17813/maiq.16.4.m728m673p734ol23

Cole, J. (2016, April 11). Egyptian President Sisi is ridiculed for 'selling' islands to Saudi Arabia. The Nation. http://www.thenation.com/article/egypts-sisi-ridiculed-for-selling-islandsto-saudi-arabia/

Comay, N. (2005). Arabs speak frankly on the Arab-Israeli conflict: With original documents and comments by world leaders and writers. Printing Miracles Limited.

CPJ. (2016, April 25). Scores ofjournalists harassed, detained amid Egypt protests. Committee to Protect Journalists. https://cpj.org/2016/04/scores-of-journalists-harassed-detained-amidegypt.php

Dawoud, K. (2016a, May 20). A swift response to Egypt's April 25 dissent. Atlantic Council. http:// www.atlanticcouncil.org/blogs/menasource/a-swift-response-to-egypt-s-april-25-dissent

Dawoud, K. (2016b, June 23). Support for Egypt's press syndicate fades. Atlantic Council. http:// www.atlanticcouncil.org/blogs/menasource/support-for-egypt-s-press-syndicate-fades

Doherty, B., \& Hayes, G. (2015). The courts: Criminal trials as strategic arenas. In J. W. Duyvendak \& J. M. Jasper (Eds.), Breaking down the state: Protestors engaged (pp. 27-52). Amsterdam University Press. https://doi.org/10.2307/j.ctt196315k.4

Dupont, P.-E., \& McGarry, B. (2016). The Egypt-Saudi Arabia agreement on Tiran and Sanafir: Law of the sea and security issues. London Center of International Law Practice. http://www.lcilp. org/wp-content/uploads/2016/05/CILMB-Brief-April-2016-Egypt-Saudi-Arabia-Agreementon-Tiran-and-San....pdf

Egypt Interior Ministry. (2016a, April 14). Statement issued by the Ministry of the Interior [On file]. Egypt Ministry of Interior Official Website.

Egypt Interior Ministry. (2016b, April 15). Cairo security service is directing a large security campaign involving a number of streets and squares of the capital [On file]. Official Website.

El Zein, R., \& Ortiz, A. (Eds.). (2011). Signs of the times. The popular literature of Tahrir. Protest signs, graffiti, \& street art. ArteEast.

Elmeshad, M. (2016, April 29). Sisi sours on the media [Carnegie Endowment for International Peace]. Sada. http://carnegieendowment.org/sada/?fa $=63493$

El-Sheikh, S. (2016, May 30). Tadamon coalition to escalate actions against civil service draft law. Daily News Egypt. https://dailynewsegypt.com/2016/05/30/ tadamon-coalition-escalate-actions-civil-service-draft-law/

Ezzat, D. (2013, May 12). Wild rumors of Hamas interference in Egypt find an audience. Ahram Online. http://english.ahram.org.eg/News/71258.aspx

Fahmi, W. S. (2009). Bloggers' street movement and the right to the city: (Re)claiming Cairo's real and virtual 'spaces of freedom'. Environment and Urbanization, 21(1), 89-107. https://doi. org/10.1177/0956247809103006

Fairey, S. (1990). Manifesto. Obey Giant. https://obeygiant.com/propaganda/manifesto/

Farid, S. (2014, May 8). April 6: Egypt's latest outlawed group. Al Arabiya English. http://ara.tv/ vprop

Filali-Ansary, A. (2012). The languages of the Arab revolutions. Journal of Democracy, 23(2), 5-18. https://doi.org/10.1353/jod.2012.0035

Gaber, S. (2016). What word is this place? Translating urban social justice and governance. In M. Baker (Ed.), Translating dissent: Voices from and with the Egyptian Revolution (pp. 97-106). Routledge. 
Gribbon, L., \& Hawas, S. (2012). Signs and signifiers: Visual translations of revolt. In S. Mehrez (Ed.), Translating Egypt's revolution: The language of Tahrir (pp. 103-142). Oxford University Press. Grimm, J. J. (2019). Egypt is not for sale! Harnessing nationalism for alliance building in Egypt's Tiran and Sanafir island protests. Mediterranean Politics, 24(4), 443-466. https://doi.org/10 $.1080 / 13629395.2019 .1639024$

Hakim, A. A. (1979). The Middle Eastern states and the law of the sea. Manchester University Press. Hidji, A. (2016, May 8). How Cairo was able to stop the April 25 protests. Al-Monitor. http://www. al-monitor.com/pulse/originals/2016/05/egypt-security-thwart-demonstrations-protestsislands-saudi.html

Hintz, L. (2018a, May 11). How a hashtag and memes are uniting Turkey's opposition [Washington Post]. The Monkey Cage. https://www.washingtonpost.com/news/monkey-cage/wp/2018/05/11/ how-a-hashtag-and-memes-are-uniting-turkeys-opposition/

Hintz, L. (2018b). Bread, circus, and subversion: A framework for reading Turkish politics through pop culture [Paper presented at DC Area Comparative Politics Workshop].

Holmes, A. A. (2012). There are weeks when decades happen:Structure and strategy in the Egyptian revolution. Mobilization, 17(4), 391-410. https://doi.org/10.17813/maiq.17.4.905210228n564037

IDSC. (2016, April 12). Tiran and Sanafir islands belong to the kingdom of Saudi Arabia [Arabic, on file]. Information \& Decision Support Centre. http://www.idsc.gov.eg/idsc/News/View. aspx?ID=4269

Jasper, J. M. (2018). The emotions of protest. The University of Chicago Press.

Jasper, J. M., Young, M. P., \& Zuern, E. (2020). Public characters: The politics of reputation and blame.

Kassab, B. (2016, August 10). Nationalism and generosity fuel the defense of Tiran and Sanafir. Mada Masr. https://madamasr.com/en/2016/08/10/feature/politics/nationalism-and-generosityfuel-the-defense-of-tiran-and-sanafir/

Kassab, B., \& Charbel, J. (2017, January 11). Lawyers, MPs say Tiran and Sanafir are Egyptian. Mada Masr. https://madamasr.com/en/2017/o1/11/feature/politics/lawyers-parliamentarians-saytiran-and-sanafir-are-egyptian/

Lefort, B. (2019). The good, the bad and the ugly: Narrating social bonds and boundaries in contemporary Lebanon. British Journal of Middle Eastern Studies, 46(4), 663-680. https:// doi.org/10.1080/13530194.2018.1456903

Mada Masr. (2017a, January 15). A timeline of the Tiran and Sanafir islands legal contest. Mada Masr. https://madamasr.com/en/2017/01/15/feature/politics/a-timeline-of-the-tiran-and-sanafir-islands-legal-contest/

Mada Masr. (2017b, January 17). Tiran and Sanafir: Between Saudi pressure and a court ruling. Mada Masr. https://madamasr.com/en/2017/o1/17/feature/politics/tiran-and-sanafir-betweensaudi-pressure-and-a-court-ruling/

Mahmoud, N. (2016, April 28). Egypt and the land. Nervana. https://nervana1.org/2016/04/28/ egypt-and-the-land/

Maney, G. M., Woehrle, L. M., \& Coy, P. G. (2005). Harnessing and challenging hegemony: The U.S. peace movement after 9/11. Sociological Perspectives, 48(3), 357-381. https://doi.org/10.1525/ sop.2005.48.3.357

McAdam, D., Tarrow, S., \& Tilly, C. (2001). Dynamics of contention. Cambridge University Press.

Morayef, S. (2016). Pharaonic street art: The challenge of translation. In M. Baker (Ed.), Translating dissent: Voices from and with the Egyptian Revolution (pp. 194-217). Routledge.

Mughrabi, M. (2016, April 26). Egypt: Mass arrests in 'ruthlessly efficient' bid to block peaceful protest. Amnesty International. https:/www.amnesty.org/en/latest/news/2016/o4/ egypt-mass-arrests-in-ruthlessly-efficient-bid-to-block-peaceful-protest/

Muslim Brotherhood. (2016a, April 14). Statement on the signing of the convention on the demarcation of the sea border with Saudi Arabia [Arabic]. Ikhwanonline. https://archive.is/wip/avMzS 
Muslim Brotherhood. (2016b, April 14). The Muslim Brotherhood announces their participation in the protests against the sale of the islands of Tiran and Sanafir [Arabic]. Ikhwanweb. https:// bit.ly/2MIZOTS

Muslim Brotherhood. (2016c, April 24). Muslim Brotherhood statement on Sinai Liberation Day calling for protests on April 25. Ikhwanweb. http://www.ikhwanweb.com/article.php?id=32517

Naeem, M. (2016, June 9). Mother of the world, against the world and outside of it. Mada Masr. http://www.madamasr.com/opinion/mother-world-against-world-and-outside-it

Nafie, T., Abdel-Fattah, S., Youssef, A.-R., Azzam, H., Darrag, A., Ihab, S., \& Al-Zomar, T. (2016, April 14). Egypt national figures statement urging protests against handover of two islands [Arabic]. Ikhwanweb. http://www.ikhwanweb.com/article.php?id=32505

NASL. (2016, April 13). National Alliance urges mass protests Friday against junta selling out Egypt. Ikhwanweb. http://www.ikhwanweb.com/article.php?id=32503

PCPL. (2016a, April 10). Opponents to Egypt giving up Tiran and Sanafir: Sign to save the islands of Tiran and Sanafir [Arabic]. Avaaz. https://archive.is/wip/osfSs

PCPL. (2016b, April 22). Founding statement of the Popular Campaign to Protect the Land - Egypt is not for Sale [Arabic]. https://archive.vn/wip/RziUM

PCPL. (2016c, April 22). The Popular Campaign to Protect the Land calls for peaceful demonstrations in rejection of ceding the islands and to stop the repression of the security apparatus. https:// archive.is/cuLyp

PCPL. (2016d, April 24). And if they askyou about the license to demonstrate, ask them for their license to sell the land of Egypt [Arabic]. Facebook. https://archive.vn/wip/pCZep

PCPL. (2016e, June 16). Political parties, national forces, youth movements, and public figures announce their participation in a campaign to defend the land "Egypt is not for sale" [Arabic]. Facebook. https://archive.vn/wip/P577O

Ravid, B., Khoury, J., \& Cohen, G. (2016, April 11). Egypt informed Israel in advance of plan to hand over Red Sea islands to Saudis. Haaretz. http://www.haaretz.com/middle-east-news/1.713870

Revolutionary Socialists. (2016, April 15). Return to the street:Down with the military rule [Arabic]. The Revolutionary Socialists Official Website. http://revsoc.me/statements/36161/

Ritter, D. (2014). The iron cage of liberalism: International politics and unarmed revolutions in the Middle East and North Africa. Oxford University Press.

RNN. (2016, April 21). Politicians reveal to 'Al-Monitor' the reasons for the success of the April 25 demonstrations [Arabic]. Rassd News Network. https://archive.is/wip/bdfXp

Romanos, E. (2018). The strategic use of humor in the Spanish Indignados/15M movement. In B. Tejerina \& I. Perugorria (Eds.), Crisis and social mobilization in contemporary Spain: The 15 M Movement. Routledge.

Schulte, B. (2002, August 9). Obey Giant: The mandate that grabbed a generation. Washington Post. https://www.washingtonpost.com/archive/lifestyle/2002/08/og/ obey-giant-the-mandate-that-grabbed-a-generation/d2046ofc-e110-4e39-8ba4-69cogcd44686/

Slaby, J., Mühlhoff, R., \& Wüschner, P. (2019). Affective arrangements. Emotion Review, n1(1), 3-12. https://doi.org/10.1177/1754073917722214

Sobhi, S. (2016, April 21). Speech of the Commander-in-Chief of the Armed Forces, Minister of Defence and Military Production on the proceedings of the 22nd educational symposium [Arabic, on file]. Egypt Ministry of Defence Official Website.

Stratfor. (2016, April 15). Building bridges between Egypt and Saudi Arabia. https://www.stratfor. com/analysis/building-bridges-between-egypt-and-saudi-arabia

Strong Egypt Party. (2016a, April 14). Tiran and Sanafir belong to all Egyptians [Arabic]. Facebook. https://www.facebook.com/MisrAlQawia/photos/a.492672350759920.128763.478976282129 527/1362555427104937/?type =3\&theater

Strong Egypt Party. (2016b, April 23). Press release [Arabic]. Arabi21. https://archive.vn/eoqnP 
Strong Egypt Party. (2016c, April 23). Strong Egypt Party announces 15 reasons for the departure of Sisi [Arabic]. Arabi21. https://archive.is/wip/TyXC3

Students Against the Coup. (2016, April 13). Students Against the Coup to take part in Friday mass demonstrations across Egypt [Arabic]. Ikhwanweb. http://www.ikhwanweb.com/ article.php?id=32506

Suleiman, Y. (1996). Language and identity in Egyptian nationalism. In Y. Suleiman (Ed.), Language and identity in the Middle East and North Africa (pp. 25-38). Curzon Press.

Suter, M. (2016, May 11). Everything you need to know about the raid on Egypt's press syndicate. Atlantic Council. http://www.atlanticcouncil.org/blogs/menasource/everything-you-needto-know-about-the-raid-on-egypt-s-press-syndicate

Tahrir Institute for Middle East Policy. (2017). Tiran and Sanafir: Developments, dynamics, and implications. The Tahrir Institute for Middle East Policy. https://timep.org/wp-content/ uploads/2017/08/Tiran-and-Sanafir-Developments-Dynamics-and-Implications-web.pdf

Tamarod. (2016a, April 11). The word of Abdel Nasser belies Al-Sisi [Arabic]. Facebook. https:// www.facebook.com/watch/?v=1156772357696247

Tamarod. (2016b, April 13). Call for demonstrations on April 15, 2016. Facebook. https://www. facebook.com/TAMROUD/posts/1158333357540147

Tamarod. (2016c, April 13). Facebook post calling for the fall of the regime [Arabic]. Facebook. https://www.facebook.com/TAMROUD/posts/1158642677509215

Tripp, C. (2013). The power and the people: Paths of resistance in the Middle East. Cambridge University Press.

Villumsen Berling, T. (2011). Science and securitization: Objectivation, the authority of the speaker and mobilization of scientific facts. Security Dialogue, 42(4-5), 385-397. https://doi. org/10.1177/og67010611418714

Walker, K. (2013, February 3). Egypt-Saudi bridge: Is the government sacrificing natural resources for short-term gains? Egypt Independent. https://ww.egyptindependent.com/ egypt-saudi-bridge-government-sacrificing-natural-resources-short-term-gains/

Walsh, D. (2016, April 10). Egypt gives Saudi Arabia 2 islands in a show of gratitude. The New York Times. http://www.nytimes.com/2016/04/11/world/middleeast/egypt-gives-saudi-arabia2-islands-in-a-show-of-gratitude.html

Whittier, N. (2014). Rethinking coalitions: Anti-pornography feminists, conservatives, and relationships between collaborative adversarial movements. Social Problems, 6r(2), 175-193. https://doi.org/10.1525/sp.2014.12151

Youssef, B. (2016, April 9). Come closer Pasha, a billion for an island, two for a pyramid, and on top some statues as a gift [Tweet]. https://twitter.com/DrBassemYoussef/status/718914530823311361 


\title{
8 Conclusion and Implications
}

\author{
Prospects for popular resistance in a post-revolutionary \\ Egypt
}

\begin{abstract}
This concluding chapter discusses the findings of the previous chapters critically in light of ongoing theoretical debates on the power of nationalism, the role of affect and emotions, the imprint of violent events such as Rabaa on the collective memory of a people, and the resurgence of autocracy in the Middle East. It highlights the merits of a disaggregated and culture-sensitive interactionist approach to the study of protest and repression, reflects on the implications and limitations of this study, and offers points of contact for further comparative research. Finally, the concluding chapter assesses the prospects for popular resistance in contemporary Egypt.
\end{abstract}

Keywords: autocracy, discursive arenas, protest-repression dynamics, strategic interactionism, contentious politics

As Lisa Wedeen (1999) maintains in her political ethnography of Syrian authoritarianism, politics is "not merely about material interest but also about contests over the symbolic world, over the management and appropriation of meaning" (p. 30). The 2011 popular uprising effectively illustrated this process, demonstrating how the proliferation of a new vision of the Egyptian people was triggered by a dislocation of the discourse that had sustained Mubarak's rule. His claim to govern in the name, for the sake, and on behalf of the people had been undermined by years of negligence, unequal economic development, and barred access of Egyptian civil society to meaningful socio-economic and political participation. The performative disruption of this illusion on January 25, 2011, brought this latent crisis to the fore (Chalcraft, 2014, p. 175). The participants in the first mass protest were instrumental in physically breaking through the barrier of fear in that they

Grimm, Jannis Julien, Contested Legitimacies: Repression and Revolt in Post-Revolutionary Egypt. Amsterdam: Amsterdam University Press 2022 DOI: $10.5117 / 9789463722650$ _CHO8 
overpowered the deployed riot police and claimed ownership over public space by taking Tahrir Square. Moreover, through their protest, they also expanded the horizon of possibilities in terms of what was arguable with a view to the country's future. This opening discursive space - through the disruption and appropriation of meaning - impacted the potentials for subsequent mobilization and coalition building and culminated in the breakdown of the alliance of players that had ruled Egypt for several decades.

Countless new political projects originated from the dislocation of the hegemonic order: with the demise of Mubarak's regime, particularly the notion of "popular legitimacy" became a floating signifier that different factions wove into different discourses in their attempt to garner support for their political projects and shape the political transformation in the aftermath of the uprising. Their contending strategies, political competition, and ideological fragmentation have been described in several recapitulations of Egypt's democratic transition and the reasons for its failure (e.g., Abdelrahman, 2015; El-Sharnouby, 2018a; Marfleet, 2016; Rennick, 2015; Sika, 2017). Albeit rooted in different epistemological and theoretical paradigms, what these works have in common is that they underscore how the disruptions created by the Tahrir uprising left a vacuum in the political arena that different (revolutionary and reactionary) players attempted to fill with their projects. But rather than creating a shared vision for the revolutionary moment, these projects fell short of proposing a unifying "affirmative idea" (see Herrera \& El-Sharnouby, 2018) for a new participatory order. Instead, as Pratt (2015) argues, the January 25 Revolution marked only the beginning of "the next phase" in the ongoing efforts of civil society to resist authoritarianism.

This book has picked up where prior works left off and focused on this next phase and the events after the heavily studied Arab Spring. However, it has attempted to avoid reproducing the structuralist bias of earlier works, as well as the simplifying diagnosis of Egypt's transition as a return to square one which followed from normative assumptions of change as a gradual process towards democracy and evoked false connotations of stagnation and a halted political process. Instead, the eight chapters of this book portray the country's trajectory as the highly contingent outcome of dynamic interactions. By adopting a cultural interactionist perspective, politics in Egypt after the coup are conceived of as an ongoing struggle between various individual and compound players over the sources, meaning, and consequences of political legitimacy. This struggle manifested in a sequence of protest and repression events, of which some had a transformative impact on the composition of the political arena. And it took place in a discursive 
arena, too, where players interacted by wielding competing narratives about the unfolding events as discursive weapons against each other.

This book showed how these two "arenas" (Jasper \& Volpi, 2018, p. 15ff.), that is, street politics and the politics of signification, interrelated and informed the trajectory of the country's post-revolutionary order. Its results confirm those of Alberto Melucci (1996) who famously maintained that the ability of today's social movements to generate a serious challenge to prevailing structures of domination hinges on their symbolic capacity to subvert, reverse and redefine social meaning. Thereby they can demonstrate the arbitrariness of power and its manifold justifications. In a similar vein, I have argued throughout this book that in the case of post-revolutionary Egypt, discursive struggles determined the conditions of possibility for contentious interactions on the ground and thus the political opportunities for resistance or repression.

The discourses articulated in relation to contentious events crucially accounted for the observed variances in the (re)actions of the main contenders vis-à-vis each other. They conditioned which social movements formed coalitions, how authorities encountered mobilization, and how the broader public took in and evaluated the performances of the main political contenders. Depending on which rival interpretation about contentious events prevailed and affected people's hearts and minds, contentious interaction triggered a backlash, created opportunities for protest, or facilitated repression.

Particularly, the challenges posed by Tamarod and the Popular Campaign to Protect the Land (PCPL) to the rules of President Mursi and President Al-Sisi, respectively, testify to the power of discursive contestation from below. They evidence that, at times, "it is enough to structure reality using different words for the power monopoly over reality to crumble" (Melucci, 1996, p. 358). Over the course of the investigation period, the mismatch between how incumbents acted and what they claimed to stand for - and players articulating this disjuncture - caused the fall of one regime, triggered the emergence of another, and planted new seeds of resistance in the current order.

\section{Autocratic Restoration through the Lenses of Contentious Politics}

Considering these findings, this book makes several contributions to the body of research on contentious politics. First and foremost, it produces a new historical narrative about the exceptional and "eventful times" (Della Porta, 2017, p. 12) of the run-up, unfolding, and aftermath of the military 
coup. Egypt's post-revolutionary history is narrated as a sequence of several contentious episodes that were each structured by a series of transformative events. Their impact on the dynamics of contention, and consequently on the country's overall political trajectory - rather than clear-cut - was manifold, often ambiguous, and volatile, but always highly dependent on the outcome of the discursive battles fought over their interpretation.

This book starts by showing that the popular-backed military intervention against President Mursi, similarly to the 2011 uprising (see Khosrokhavar, 2018), represented a constitutive event that triggered a range of new political subjectivation processes, both in the Islamist spectrum and within the coalition of contenders who had joined forces to depose Mursi through their protest campaign. As a transformative event, the military coup of July 3, 2013, broke the political stalemate that had crippled Egyptian politics throughout the first half of the year. It reshuffled the cards and provided the leading political contenders with an opportunity to redefine both the boundaries of their collective identities and their stated goals for the country's political future. The coup effectively dislocated the precarious legitimacy discourse of the Mursi administration that had sustained the status quo, throwing it into open competition with the alternative political project that had been articulated in the frame of the June 30, 2013 protest.

As described in the third chapter, the president's standing had eroded throughout his first year in office. Above all, Mursi's insistence on his constitutional legitimacy proved to be a double-edged sword. First, the quiet entente between the SCAF and the Brotherhood, which had enabled Mursi's ascension to power, had tarnished his revolutionary credentials. Then, an exclusive constitutional drafting process cemented the image that the president and his Islamist base attempted to monopolize their grip on power. Lastly, a constitutional declaration that placed the executive beyond judiciary supervision also undermined his claim to constitutionality. The performative disruption of the hegemonic order on June 30 brought this latent crisis to the fore, demonstrating how the Mursi administration had never really managed to establish hegemony for its political project in Egypt's post-revolutionary public. In this context, the Tamarod campaign became the roof for a counter-hegemonic block that successfully bundled and mobilized the widespread grievances against Mursi.

As an event that could not be signified in the ruling discourse - primed on legitimizing Mursi's rule - the second popular uprising in Egypt within two years represented a transformative event that not only dislocated the incumbent regime's claim to legitimacy but also set in motion another military intervention that culminated in the deposition of Mursi on 
July 3, 2013. This "coup-volution" (Hamada, 2014, p. 37), however, did not result in the replacement of one precarious hegemony - that of the Mursi administration and its supporting Islamist base - by another. Rather, as my discussion of the post-coup dynamics in Chapter 4 shows, the coup dichotomized the public by delimiting the frontier between two opposing political projects. Their battle for hegemony dominated and polarized Egyptian society during the rest of the investigation period. This new societal conflict cut across the formerly salient division between the people and the regime by pitting an alliance of civic and state forces that supported Mursi's ouster, including representatives of the army, political parties, social movements, and state ministries, against another equally variegated coalition of anti-coup forces.

In this contest, both sides derived their legitimacy from competing conceptions of democracy, legality, and the country's revolutionary heritage; both sides claimed to speak for the people; and both sides engaged in vicious vilification of their respective other, depicting it "as an existential threat, yet paradoxically also as a minuscule fringe side-lined by their own clear majority" (Mogahed, 2013). After the massacre of Rabaa al-Adawiya, covered in Chapter 5 , the social polarization between these projects reached a fever pitch, "people didn't just hold different opinions about the same reality - they held different realities" (Mogahed, 2013). These different realities found their articulation in opposing discourses about the contentious dynamics that unfolded in the streets and, as my argument goes, set the conditions for the ensuing modes of conflict.

On the one hand, a coalition of mostly Islamist forces kept the deposed president's discourse alive. The myth of a "National Alliance" for the restoration of legitimacy effectively became the surface of inscription of a variety of political demands that found their expression in the most significant sequence of collective actions since the 2011 uprising. Within the frame of this Anti-Coup campaign, the central signifier of resistance in the name of legitimacy provided the principal reference point for protesters' collective identity. It also limited their radicalization in reaction to state repression, illustrating the conditioning impact of discourses on action repertoires: The strong intertwining of Anti-Coup conceptions of legitimacy with notions of nonviolent resistance prevented the Islamist protest coalition from turning to violence as an action strategy. Instead, adaptive decentralization and diversification ensured the movement's survival despite severe repression.

A question yet to be answered is how sustainable this survival mechanism was in the long term. Jillian Schwedler (2018, p. 72) noted that often the significance of innovations is only recognizable with time when routine 
practices come into sharp relief. In this sense, it remains to be seen whether the described short-term tactical substitution processes that made the AntiCoup campaign resilient against state repression have indeed established long-term path dependencies, for instance, for the Muslim Brotherhood as a group. Of equal concern remains the question of violence. In the immediate post-coup context studied in this book, the interim authority's deadly violence rather confirmed the protesters' moral superiority and strengthened their internal cohesion. But extending the analysis to a longer period might challenge the weak convergence of repression and protester violence observed in this book.

At the same time, the failure of the Anti-Coup Alliance to modify or extend its legitimacy discourse in an inspiring way also forestalled the creation of coalitions beyond the ideologically aligned opposition spectrum - it also precluded popular solidarity when civilian protesters were targeted in the massacres of Rabaa al-Adawiya and Al-Nahda. Not realizing that its discourse, by association with the former president's rhetoric, was perceived by most Egyptians as a hollow shell and a smokescreen for the Muslim Brotherhood's will to power, the NASL's insistence on constitutional, democratic, and revolutionary legitimacy only deepened the divide between the pro and the anti-coup camps.

On the other side of this divide, as I have argued, the events of July 3, 2013, also marked a point of no return. After all, the interim regime that assumed control over the country after Mursi's arrest needed to counter the Muslim Brotherhood's claim to power and the Anti-Coup Alliance's attempt to establish hegemony for its understanding of legitimacy. The interim regime, therefore, refuted these forces by promoting an alternative discourse primed on nationalism and the state's ability to protect the Egyptian people from external and internal threats. Within the frame of this discourse, the army's intervention against the acting president and its repression of the Anti-Coup protests was articulated as a realization of the popular will - and thus the origin of all political legitimacy. The army was thereby portrayed as the ultimate guardian of Egyptian democracy and rehabilitated as a political actor. On this side of the political divide, as within the NASL, the propagated official narrative set the conditions of possibility for how authorities acted vis-à-vis their opponents: as a consequence of the state's securitizing logic, all bottom-up challengers to the post-coup order were framed as potential threats to the nation. Brutal state repression, including several massacres, was signified as a necessary evil to restore national security. Especially after the liminal event of Rabaa, the crackdown against protesters was articulated as an undesired but reasonable policy to confront extremist threats. 
In the end, the discursive struggle for interpretive authority over social reality polarized public opinion so strongly that it became impossible for the main contenders - the supporters of the deposed president and those of the new transitional regime - to approach their antagonists or any other political players without losing face. Furthermore, in the bifurcated political arena, all other interpretations of the contentious dynamics in Egypt were unable to gain traction. Within the context of growing fears and perceptions of insecurity in the population - owing to the everyday violence on the streets - even formerly nonpartisan players were forced to take sides. Alternative political projects for the country's political future were thereby excluded from the horizon of possibilities. As discussed in Chapter 6, the emergence of a new autocratic order can thus be considered a by-product of this polarizing conflict over discursive hegemony.

To sum up, I contend that the authoritarian restoration under the auspices of General Al-Sisi should not be viewed as the result of the deep state's machinations. Instead, it was the outcome of an iterative process of discursive labor by different players, who strategically responded to unfolding events, starting with the legitimacy crisis of the Mursi administration. In other words, the emergence of a new ruling coalition whose discourse stresses national defense and the fight against terrorism, rather than self-determination and civilian rule, was highly contingent on the eventful interaction dynamics described in this book. Their outcome was hardly predetermined. Instead, each event altered the "constellation of possibilities in the future" (Alimi \& Meyer, 2011, p. 477).

In hindsight, it can be argued that the struggle between coup and AntiCoup was conclusively decided in favor of the former. However, contrary to Egypt's delusive self-portrayal as an "anchor of stability in the region," the new regime may not be as stable as it seems. Thus far, nationalist and securitizing discourses have mostly been understood as tools to co-opt popular pressure for reform into a state-centric model of governance (e.g., Amar, 2013; Brand, 2014). The potential of these discourses to serve as a magnet for contentious coalition building has been investigated only scarcely. But as Chapter 7 highlights there is nothing deterministic about nationalist ideology. It may support projects of domination, but also a "politics of emboldening in the face of institutional constraints" (Beissinger, 2002, p. 38). The case study of the Tiran and Sanafir Island protests exemplifies how activists may harness the emotional dimensions of established nationalist

1 See remarks Abdel Fattah Al-Sisi at the 71st session of the United Nations General Assembly on September 20, 2016 at https://gadebate.un.org/en/71/egypt. 
political discourse for mobilization and contentious alliance building. In this case, a controversial border demarcation agreement became the tipping point event that could not be symbolized in the nationalist discourse sustaining Al-Sisi's rule, thereby destabilizing it and creating opportunities for resistance. While failing to effect systemic change, the Egypt is not for sale!-campaign seriously challenged the post-coup regime's interpretational sovereignty. By undermining and subverting the Al-Sisi administration's image, the campaign effectively forced it into a discursive struggle over the meaning of political legitimacy and the appropriate modes of governance.

In this struggle, which is still ongoing, contentious players no longer attack the system and practices of authoritarian rule through frontal assaults, such as mass demonstrations, blockades, or strikes. Instead, they wage a discoursive war against and within the ideological complex that underpins and sustains Al-Sisi's rule. In this respect, the character of the resistance against Al-Sisi's dictatorship has assumed a form and shape that is faintly reminiscent of the decade-long opposition against the Husni Mubarak regime before the Arab Spring. At the same time, resistance, today, resembles that in the immediate aftermath of the 2011 uprisings. Described by Pratt (2015) as a war of position by civil society against military rule, its spirit is encapsulated in the phrase, "al-thawra mustamirra - the revolution continues" (p. 47).

\section{From a Relational to an Interactionist Perspective on Protest and Repression}

In addition to its historiographic value, this book highlights the opportunities for theoretical advancement offered by cultural interactionist studies of contentious politics. Approaches that are attuned to the interaction processes of key political players not only provide detailed insights into the mutual adaptation processes that take place between protesters and their counterparts in situations of contention. They also allow conceptualizing social relations - for instance, between state institutions, such as the military, and protest movements, such as the Anti-Coup coalition - as dynamic networks that are not static or predetermined but reproduced and modified through the interactions of responsive individual and compound players.

This perspective emphasizes the role of agency, leaving room for investigating the "historical contingency" of the social fabric (Jasper, 2019, p. 132), rather than taking the antagonisms, alliances, or competition between certain actors for granted as consequences of their structural disposition. Furthermore, it helps to identify and to give focus to the contestation 
processes that occur below the threshold of uprisings, which are crucial for broader social transformation but often overshadowed by episodes of mass protest that monopolize scholarly attention. Charles Kurzman (2018) warned that:

Social scientists who privilege the mass scale may dismiss small-scale disruptions as statistical noise in the signal, but for the people living through these periods of unrest, they may be the signal itself. These small-scale perturbations can come to define the historic moment. They may be the iconic feature that people latch on to as they work out which institutions are finished and which ones remain intact. (p. 190)

Particularly in contexts of authoritarian closure, small-scale mobilizations can signal rifts in the status quo and foreshadow more sweeping change. As Vince Boudreau (2005) noted: "Challenges [posed by protests to elites] are not intense objectively, but in their relationship to capacities possessed by states" (p. 53). This point is exemplified by the case of the PCPL: As described in Chapter 5 , it required no mass uprising to expose the hollow nationalist rhetoric of the dominant regime players. Albeit small in scale, the protests were highly symbolic in that the protesters gathered in the same streets they had occupied during the 2011 uprising to defend the two Red Sea islands. Event catalogs provide a useful heuristic device to detect such small-scale disruptions by disaggregating social movements into sequences and cascades of individual events. Even within the relatively short timeframe covered in this book, the analysis of contentious interactions during these events, along with the communications of political contenders about these events, reveal a number of situational linkages that would have remained obscure to analysts were they to rely uniquely on aggregate data.

For instance, the trajectory of the Anti-Coup campaign suggests that state violence may not necessarily be the most effective tool to control social players. Rather than successfully suppressing contenders, state violence triggered mechanisms of adaptation in the Anti-Coup movement that ensured its resilience; it even produced backlash effects as evidenced in mobilization rates. The results of this disaggregated analysis caution against misinterpreting strategic substitution as behavioral reduction. As I show in this book, the perceived "defeat" of the Anti-Coup Alliance was more a consequence of its failure to detach itself from a problematic and partisan conception of legitimacy that reinforced the antagonism between the protest movement and the public, rather than enabling a broader coalition of contenders. 
The resulting analysis presented in this book needs to be interpreted with caution, however, given that the data allow for some ambivalence. Above all, they do not lend themselves to a general empirical argument. Overall, I find that over the lifespan of a movement the interactional effects of protest performances and repression on contenders, rather than clear-cut, tend to be inconsistent and punctual. Also, in empirical reality, there is usually no clear-cut dichotomy between dissenters and incumbents, such as the one investigated in this book. The binary between state and street is an elusive construct that serves simplification but does not account for the variety of players' motives.

Bearing these caveats in mind, it seems fair to state that the methodological dualism of this study does, nevertheless, reflect the central antagonism in post-coup Egypt. The June 30 uprising boosted political polarization and effectively split Egyptian society in two. In this context, most political forces uncritically welcomed the state-led crackdown on the NASL and the return of the generals to the political stage. Others felt compelled to side with the interim authorities despite their criticism of the state violence, lest they risked victimization themselves (Hamzawy \& Dunne, 2017). Few non-aligned forces, such as the Bread and Freedom Party or the moderate Islamic Strong Egypt Party of former Brotherhood Guidance Bureau member Abdel Moneim Aboul Foutuh, attempted to resist the political binary and establish themselves as a third way between the army and the Brotherhood. But they were too weak to articulate and promote their alternative visions of popular legitimacy and a post-coup order. Their voices have thus not been explored with the same level of detail as those of the leading contenders.

While outside the scope of this book, it remains worthwhile to explore these "silences" in future research. Such an investigation would not only contribute to a more nuanced picture of the dynamics that caused Mursi's fall and Al-Sisi's rise to power. In light of the autocratic restoration in Egypt and the bleak prospects for national reconciliation, returning to these early attempts to resist securitization and to offer an alternative to the two hegemonic projects portrayed in this book might also produce a new positive vision for the country and harbor the potential for resistance to the authoritarian status quo.

Related to this unexplored external multiplicity of voices, is the understudied internal variety of the compound players covered in this book. As Jasper and Volpi (2018) argued, the unity attributed to players in the reconstruction of event history is but a necessary analytical device to cope with the otherwise impalpable "multiplicity in rapidly evolving political situations" (p. 16). Talking about Tamarod, the Anti-Coup Alliance, the 
Brotherhood, or the Popular Campaign to Protect the Land may create an impression of these groups as unitary actors. But, in truth, coalitions of contenders constantly shift, expand and contract, dissolve and reassemble. These interaction processes are hinted at, for instance, when describing the changes in the composition of the NASL after the arrest of its leadership. But they harbor much more potential for further investigation. The NASL's internal rifts over violence are a case in point: In the months after the events covered in this book, radicalization at the movement's grassroots level jeopardized reconciliation in Egypt as much as the regime's crackdown.

The same is true when discussing actors such as regimes, states, and authorities, for instance. These are placeholder terms that blend over internal disagreements and power struggles experienced by these actors, and obscure the fact that the internal composition of those "on the other side" of the contentious struggle also constantly alternates (see Duyvendak \& Jasper, 2015). Such alternations often result from these actors' internal interactions and of those with other players, for instance when interim vice-president Baradei resigned in response to the state violence against the Rabaa protesters. I have endeavored to account for this fluid nature of social players by making the contingent character of cross-movement alliances the center of several sections of this book. But actually, most of the protagonists of this book could be analyzed as arenas themselves, where individual movement or regime components - down to the level of individual actors - interoperate and compete for authority over the aims, motifs, identity, and actions of the movement or the state.

The deficits as regards accounting for this multiplicity are engrained in the research aims and the methodology of this book. The act of reconstruction involved in the coding of events implies a range of simplifications that limit the ability to capture the multiplicity of protesting actors. As we face the task of determining whether and how actions converge into a single historical event, we also face the task of limiting it to the acts performed, for instance, on one day, by one group of people, in one space, or against one common target (see Wagner-Pacifici, 2010, p. 1352). This should, however, not prevent further engagement with and refinement of the proposed research design. On the contrary, future projects could attempt to develop this approach further to include an analysis of voices from within compound actors. This could be undertaken, for instance, by extending discourse analyses from official statements and joint movement positions to the examination of internal discussions - on social media or in group meetings - among the members of specific alliances; or by mapping the broader discursive context constituted by reporting and the mediated articulations of public figures 
and other political players, to assess whether it supports or undermines the principal contenders during a protest cycle.

Alternatively, subsequent studies could explore a comparative angle. The Turkish case, where an authoritarian contraction has prompted many observers to caution against a repetition of the "Egyptian model," is just one of many examples that lend themselves to such scrutiny. Comparativists have tended to view the military coups in both countries as a factor that set them apart - the coup successfully toppled a government in Egypt, while it failed to do so in Turkey. But thinking of coups as disruptive events that caused a reconfiguration of decision-making in both countries, similarities between the Egyptian and the Turkish case become apparent (see Grimm, 2017). The challenge of such investigations will be to avoid falling back to correlating a few structural variables and to develop ways to compare and contrast different sequences of micro-interactions across cases, without reducing their complex settings for the sake of horizontal comparability (see Jasper, 2019; Weipert-Fenner, 2021).

I am unable to follow these threads here because this book engages with a single case in-depth and only allows for longitudinal comparison across the discussed episodes. Nevertheless, its results seem to support the claim that a relational and bottom-up perspective - one that "acknowledges emotions along with other meanings and institutional context" (Jasper, 2018, p. 12) - may provide a more nuanced picture of the highly situational dynamics during cycles of contention. Most importantly, a picture that accounts for contenders' agency. As Jasper and Volpi (2018) noted: "Although we may focus on one player, the approach discourages us from reducing the other players to the status of structures or a static environment" (p. 16). Rather than seeking an overarching causal argument or refining threshold models for backlash, scholars investigating the mobilization-repression-nexus ought to direct their attention to interactive explanations that account equally for the material arena of contention - including protest spaces and tactics and the character of policing - and the interpretive arena where players attribute meaning to the unfolding events.

\section{Conceptualizing the Discursive Arena of Contentious Politics}

By placing attention on the link between contested discourses and contentious politics, this book demonstrates how strategic interactionist frameworks, such as the players and arenas approach developed by Jasper and Duyvendak (2015), can benefit from integration with discourse 
theory. Exploring the question "who acted how towards whom," but also how players experience these interactions emotionally, interpret them cognitively, and articulate them strategically in contending discourses can prove fruitful in reconciling the ambiguous findings that have pervaded the study of the effects of repression on social movements for decades. By systematically linking the discursive to the material in an analytical framework informed by both, post-foundationalist theories of discourse analysis and the more dynamic and agent-centric cultural interactionist perspectives on contentious politics, I have proposed a novel approach that provides a more complete picture of the dynamics of contention under conditions of authoritarianism - one that allows us to illustrate the "variety of exchanges and influences" (Jasper, 2019, p. 132) that occur through players' interactions, including the volatility of their goals and convictions, as well as their changing sympathies and enmities.

This approach complements existing strategic-interactionist perspectives in social movement studies by adding a discursive layer to them. To some degree, however, it also challenges these perspectives by highlighting the structuring effect of discursive formations on social interaction. Crucially, Jasper $(2015$ b) and his collaborators underscored the flexibility of social arenas, stressing that players and arenas were "always emerging, changing and recombining" (p. 13). With this rigorous abandonment of structure, however, they somewhat dismissed the potentially lasting and stable impact that norms and values, culturally mediated historical experiences and collective identities, and carefully forged self-images and antagonisms can have on actors' behaviors. Discursive hegemonies often reflect these rather stable social relations, thus determining the boundaries of political players as much as their arenas of engagement. As this book also shows, they can thereby indirectly structure, and thus condition, social interaction, by shaping players' expectations, their perception of opportunities for action, and their evaluation of the rules and parameters of the political arena.

Guy Accornero made a similar argument in his contribution to the "Authors Meet Critics"-symposium about the players-arenas approach. There he argued that "identities, strategies, and goals do not completely emerge through the interactions among players, they are also the result of the specific background of each of them" (Accornero in McGarry et al., 2016, p. 638; see also Duyvendak \& Fillieule, 2015; Polletta \& Kretschmer, 2015). Through discourses that articulate these specific backgrounds as reference points for the collective identities and antagonisms, "these histories are pertinent in the present" (Duyvendak and Jasper, in McGarry et al., 2016, p. 639). 
The identities that are constituted through players' discourses, ultimately, define how they can experience and feel about unfolding events. They delimit their horizon of possibilities in terms of what is thinkable, arguable, and doable. Therefore, to a degree, the approach proposed in this book pushes the boundaries of the players-arenas perspective by highlighting how the discursive arena and its parameters represent a superordinate arena of struggle that regulates players' room for maneuver in other social spaces. Sometimes it enables, sometimes it restrains contentious interactions. There is little that players can do to overcome the conditioning effect of the discursive arena but engage in a proactive politics of signification to change its parameters. Discourses reflect the rules of the political game. If these rules are devised to keep movements from the playing field, resistance must start by challenging these discourses. Narratives that successfully challenge hegemonic discourses by creating new social spaces for action can thus open up entirely new arenas of contentious politics, even more effectively than other forms of mobilization (see Siméant-Germanos, 2021, p. 142ff.).

By emphasizing the transformative potential of discursive struggles on the parameters of contentious arenas, the approach I propose also goes beyond the debate on what Stefania Vicari (2015) has termed the "interpretative dimension of transformative events." In a recent intervention, Della Porta (2018) argued that eventful protests can trigger critical junctures and thereby produce abrupt changes that develop contingently and become path-dependent. In this book, I argue that discourse represents the missing link between such junctures and their impact on the trajectories of protest as transformative events. As the case of Rabaa and the disclosure of the Tiran and Sanafir deal show, critical junctures such as a coup, a massacre, or blatant foreign policy decisions constitute moments of politicking. When taken for granted assumptions about the social come into question and the horizon of possibilities for the emergence and promotion of new meanings expands, whereby "old lines of thought are disrupted, older constellations displaced, and elements, old and new, are regrouped around a different set of premises and themes" (Hall, 1980, p. 33). Precisely, the power of such moments of rupture and crisis lies not in their concreteness and the clarity of their meaning, but their interpretive malleability. This is why they represent windows of opportunity for players to develop alternatives to the status quo.

This productive dimension of critical junctures is captured in Laclau and Mouffe's concept of dislocation. Engendered by a mismatch of unfolding events on the ground and the way these events are articulated, dislocation creates ambiguity. This ambiguity opens up the possibility for multiple meanings to be inscribed and thus for processes of contestation, by new 
political players or by existing ones, that are propelled into action by the emotional and cognitive dynamics of critical junctures.

Pulling the two theoretical threads together, I have thus argued that movements can profit from the dislocations created by transformative events as symbolic resources for resistance. Both the June 30-uprising and the tale of two insignificant Red Sea islands demonstrate that blatant gaps between discourses and government policies can backfire on their agents in the same ways as severe repression and outrageous police violence sometimes do. When critical junctures render it apparent that authorities do not walk their talk, social players are provided with an opportunity to subvert the discourse that sustains the status quo and gives rules and shape to the political arena. Often, the failure of dominant players to sensibly respond to grievances allows others to articulate solidarity and to forge a common oppositional identity based on shared dissatisfaction with the status quo.

In sum, a closer examination of the discursive arena can yield insights into such diverse social phenomena as repression backlash, the emergence of "strange bedfellow" coalitions, and the public toleration or even approval of mass killings, regardless of their violation of formerly shared social norms. Discourses can catalyze the acceptance of oppressive power relations or the emergence of projects of resistance that challenge the status quo. It is thus imperative to develop new methods to capture and analyze these discourses if we want to achieve a better understanding of the volatility and "eventfulness" (Della Porta, 2011) of contentious cycles.

In this book, I have suggested one potential way forward, in the shape of a multimethod approach that combines protest event analyses and discourse analyses. In this approach, described in detail in the Appendix, event catalogs function as heuristic tools to capture the "rhythm" of mobilization and to identify crucial turning points, whereas semantic networks provide the means to capture discursive shifts. The integration of discourse-theoretical considerations and event history approaches cannot explain why certain perceptions and interpretations of political reality spread and created political legitimacies (whereas others fail to do so). What it can do, however, is to shed some light on the ways in which social players construct their own discursive windows of opportunity for mobilization and alliance-building.

\section{Prospects for Resistance in Egypt}

Progressive activists, movements, and civil society associations are fighting an uphill battle in Egypt and, regrettably, this book provides no blueprint for 
more effective resistance. However, it does show that even when the physical parameters of the protest arena are unfavorable to social mobilization, there often remain discursive spaces in which to challenge the status quo. One promising path for sustaining resistance in the context of near-total authoritarian closure lies in the symbolic erosion of the images of those in power through the exposure of disjuncture in their professed discourses. In line with James Scott's (200o [1987]) notion of "weapons of the weak," I have illustrated how, at several instances of Egypt's post-revolutionary history, social players with little if any resources at their disposal successfully challenged their counterparts through diligent symbolic labor.

As Lisa Wedeen (1999) noted, "regimes attempt to control and manipulate the symbolic world, just as they attempt to control material resources or to construct institutions for enforcement and punishment" (p. 30). In this regard, showing how they perform actions inconsistent with their claims represents minor, yet often powerful rebellious acts that can dislocate hegemonic perceptions of social reality and undermine the legitimacy of a regime. One might expect that authorities would adapt to these discursive attacks by modifying their narrative to incorporate or co-opt pressure, in the same way as they modify their repressive repertoire in response to protests (see Della Porta \& Tarrow, 2012). However, this is easier said than done and such attempts often prove to be a real test for those in power: the discursive strategies that "work well" in generating support - which is why autocrats rely on them - are usually hard to abandon. They rely on clear-cut differences between what is right and wrong, what ought to be done, and who ought to be fought against. These categorizations cannot be changed easily without causing the entire order to sway. While nationalist or securitizing rhetoric may seem abstract, the consequences of making it the imperative for political action are thus substantial.

In this sense, the cases discussed in this book say something about the long-term prospects of Al-Sisi's autocratic rule in Egypt. They caution against overestimating the ability to govern the country by force and to draw legitimacy exclusively from a discourse centred on nationalism and the government's provision of security against domestic and foreign threats. While securitizing, nationalist discourses may work in the short-term to shore up regimes, in the long term, they must be sustained by real policies that positively affect their audience. This audience - in this case, the Egyptian public - continually evaluates their congruency, punishes the betrayal of proclaimed goals with dissent, and rewards congruence with loyalty. In the end, this balances the power of nationalism, because the emotional component that makes it effective, can also become its weak spot. 
As Khaled Abdalla (2016) stated, "scale the conceptual frameworks embedded in those narratives into buildings, institutions, laws, cultural norms, and suddenly the burden of a simple story can become overwhelming" (p. $36 \mathrm{f}$.)

Accordingly, the Tiran and Sanafir events represented just the first in a series of crises that opened windows for contestation by rendering visible the disparities between the Al-Sisi administration's professed values, and its actual conduct. The most significant of these mobilizations took place in September 2019, when across Egypt's provinces thousands of Egyptians took to the streets to protest state corruption and to demand Abdel Fattah el-Sisi's departure. What connected these protests with the Popular Campaign to Protect the Land (PCPL) was their trigger, the video messages of a former defense contractor that revealed government misconduct. From his exile in Spain, in the fall of 2019, the 45-year-old actor Mohamed Ali went public with details of the corrupt practices by which state contracts were awarded to military companies and private subcontractors owned by army generals. In a series of very deliberately crafted videos, Ali recounted his experience as a defense contractor - including with members of Al-Sisi's family and inner circle.

Notably, these anecdotes portrayed Al-Sisi's failure as a leader not as a result of poor choices but more generally as "a fundamental failure to appropriately prioritize the wellbeing of the people over himself" (Khamis \& Fowler, 2020, p. 40), thus tapping into the very narratives established by the PCPL to frame its nationalist resistance three years earlier. Like the PCPL, Ali used his media celebrity to call on Egyptians to take to the streets, claiming that the army and the police would stand with the people and that Al-Sisi's days in office were numbered. People heeded his call and took to the streets between September 20 and 27, 2019, in what were the largest demonstrations since the Egypt is not for sale!-campaign.

In the end, there was no show of solidarity on the part of the military, unlike Ali had promised. While the protests caught the authorities by surprise, the regime's reaction to them followed an established authoritarian playbook: telecommunications were disrupted, websites censored, and protesters arrested on sight or from their homes. In the northern industrial city of Suez, where the spark of the January 25-revolution was ignited, protesters battled the police for two days without any intervention by the armed forces. On the contrary, repression reached a new level when security forces resorted to kidnapping known dissidents and their lawyers, including some who had not even participated in the demonstrations. By September 27, 2019, the Ministry of Interior had deployed thousands of police and plainclothes officers to all major squares and rounded up over 4,00o protesters. 
Notwithstanding, the anti-corruption demonstrations were significant due to the discursive rifts they caused and the affective dynamics they triggered. Corruption is common knowledge among Egyptians. But for the public, it was still a different thing to learn that Al-Sisi's entourage had squandered billions of Egyptian pounds on luxurious palaces and dubious mega projects - especially in times of austerity measures when presidential statements regularly stressed the country's poverty. Like the PCPL a few years earlier, activists were able to capitalize on these inconsistencies, in a way that widened the horizon of possibility for contentious action and that reshaped the arena of protest. In light of this episode, it is far from certain that Al-Sisi will become Egypt's new "president-for-life" (R. Owen, 2012). A constitutional referendum may have extended the president's maximum term length until 2030. But several sensitive issues loom on the horizon that could test Al-Sisi's nationalist credentials well before then.

At Egypt's southern border, the popular uprising against President Omar Bashir and has placed Al-Sisi in a quandary between fears of a contagion effect and the need to accept the new realities and prevent soaring relations to its neighbor. Bashir's ouster and the repeated waves of mobilization against military rule in the years after demonstrated how civic aspirations for political and socio-economic participation have taken root in the region. They might resurface in Egypt as well, should its government fail to be more responsive to its citizens and their needs. In addition, Sudanese authorities in the past repeatedly called on their Egyptian counterparts to reopen negotiations to settle the dispute over the oil-rich Halaib and Shalatin Triangle, a disputed area of around 20,000 $\mathrm{km}^{2}$ at the Red Sea coast, in the borderlands between Egypt and Sudan. Since the deployment of military units in the mid-199os, Egypt has administered the area as part of the Red Sea province and categorically rejected any negotiation over its sovereignty (see Hassan, 2017). The border dispute remained unaddressed for several years. But as Sudan's transition proceeds, attempts to challenge Egypt on this front will likely resume. In March 2021, Al-Sisi's first official visit to Khartoum since Bashir's ouster foreshadowed a revival of the conflict. It was accompanied by countrywide demonstrations whose participants demanded a return of the disputed area to Sudan. In the following weeks, both military and civilian leaders in Khartoum commented on the contentious issue and called for a resolution of the border dispute. Should these efforts to reach a settlement over the Halaib triangle persist, this could spark new concerns among the Egyptian public over another cessation of national territories to a neighboring country - especially since Al-Sisi might be forced to make concessions in order to preserve Khartoum's strategic support in the Nile water conflict with Ethiopia. 
This conflict among the different riparian states of the Nile Basin has been going on for decades (see Cascão, 2011; Nicol \& Cascão, 2011). During most of this conflict period, Egypt sought cooperation rather than conflict, to maintain the lion's share of the river's waters that was awarded to Egypt through several colonial-era agreements. But in 2011, Ethiopia commenced the construction of the Grand Ethiopian Renaissance Dam (GERD) to harness the river's hydroelectric potential. This development dynamized the conflict, as it sparked fears in Cairo that the mega-dam in the headwaters of the Blue Nile would reduce the Nile's annual flow downstream (see Cascão \& Nicol, 2016; Lossow \& Roll, 2015). Today, Egypt is almost entirely dependent on the river, which supplies more than go percent of the country's water needs. Hence any reduction of this renewable water source is predicted to come with severe consequences downstream, above all, with a view to Egypt's agricultural production.

This scenario has been looming since the start of Al-Sisi's presidency, but it wasn't until recently that the completion of construction works on Africa's largest dam made the risk of changes in Egypt's water supplies imminent (F. H. Lawson, 2017). Though Al-Sisi has warned that any cutback of Egypt's water supplies would be treated as a direct threat to its national security, he has made little headway in deterring the project. Instead, Ethiopia implemented the first two phases of filling the GERD reservoir unilaterally in 2020 and 2021, without prior agreement from the southern riparians. The latter now fear that Ethiopia's rapid filling of the dam and its use of the Nile water for irrigation, paired with increased loss of water to condensation from the newly created reservoir, could cause a devastating water deficit downstream. Freshwater supplies could be reduced by more than one-third, if unmitigated - a deficit that would entail a considerable loss of Egypt's arable land (see Heggy et al., 2021). At the same time, Egypt's Ministry of Water Resources and Irrigation has yet to present any viable alternatives to confront the looming water crisis through effective resource management or innovative irrigation methods. Faced with this potentially destabilizing situation, the Egyptian government has shifted between bellicose rhetoric and attempts to resolve disputes over the operation of the dam through joint conflict mitigation mechanisms. But neither saber-rattling nor diplomatic protocol has worked, so far. In the face of Ethiopian intransigence, Al-Sisi's window for finding a resolution for the almost decade-long standoff appears to be closing.

To the west, the president faces an additional quandary in the Libyan civil war, between the need to project strength vis-à-vis his domestic audience, on the one hand, and the potential costs of further involvement in the conflict, 
on the other. This predicament was exacerbated by a Turkish military intervention on the side of the internationally recognized Government of National Accord in Tripoli, which turned the tides of war against Al-Sisi's ally General Haftar and tested President Al-Sisi's resolve. Al-Sisi's calls for a full retreat of all mercenaries and foreign fighters and his warnings that a permanent Turkish presence in Libya and would be viewed as a national threat (like in Addis Abeba) have thus far been ignored in Ankara. At the same time, Egypt's abilities to follow up on Al-Sisi's rhetoric through military action are questionable. The failure of Haftar's military campaign in 2020, instead, forced the Egyptian government to recalibrate its strategy and to withdraw its support for a confrontational policy in favor of diplomatic arrangements.

Finally, to the east, the Tiran and Sanafir islands controversy is likely to resurface again, should the Saudi crown prince move forward with his plans to build a metropolis and a 500 billion USD economic zone on the coast of the Red Sea - spanning across Jordanian and Egyptian territories, and including the recently conceded islands. It is uncertain whether the Al-Sisi administration will be able to keep a lid on all these highly symbolic issues. Should it fail to deliver on its promise to protect the nation's security and interest, this might once again drive Egyptians to the streets.

\section{References}

Abdalla, K. (2016). Changing frames and fault-lines. In M. Baker (Ed.), Translating dissent: Voices from and with the Egyptian Revolution (pp. 33-44). Routledge.

Abdelrahman, M. (2015). Egypt's long revolution: Protest movements and uprisings. Routledge. Alimi, E. Y., \& Meyer, D. S. (2011). Seasons of change: Arab Spring and political opportunities. Swiss Political Science Review, 17(4), 475-479. https://doi.org/10.1111/j.1662-6370.2011.02041.x

Amar, P. (2013). The security archipelago: Human-security states, sexuality politics, and the end of neoliberalism. Duke University Press.

Beissinger, M. R. (2002). Nationalist mobilization and the collapse of the Soviet state. Cambridge University Press.

Boudreau, V. (2005). Precarious regimes and matchup problems in the explanation of repressive policy. In C. Davenport, H. Johnston, \& C. Mueller (Eds.), Repression and mobilization (pp. 33-57). University of Minnesota Press.

Brand, L. A. (2014). Official stories: Politics and national narratives in Egypt and Algeria. Stanford University Press.

Cascão, A. E. (2011). Power relations, conflict, and cooperation in the eastern Nile river basin. In S. S. Elmusa (Ed.), The burden of resources: Oil and water in the Gulf Region and the Nile Basin (pp. 20-51). American University in Cairo Press.

Cascão, A. E., \& Nicol, A. (2016). GERD: New norms of cooperation in the Nile Basin? Water International, 41(4), 550-573. https://doi.org/10.1080/02508060.2016.1180763 
Chalcraft, J. (2014). Egypt's 25 January uprising, hegemonic contestation, and the explosion of the poor. In F. A. Gerges (Ed.), The new Middle East: Protest and revolution in the Arab World (pp. 155-179). Cambridge University Press.

Della Porta, D. (2011). Eventful protest, global conflicts: Social mechanisms in the reproduction of protest. In J. M. Jasper \& J. Goodwin (Eds.), Contention in context: Political opportunities and the emergence of protest (pp. 256-276). Stanford University Press.

Della Porta, D. (2017). Riding the wave: Protest cascades, and what we can learn from them. In D. Della Porta (Ed.), Global diffusion of protest: Riding the protest wave in the neoliberal crisis (pp. 9-30). Amsterdam University Press.

Della Porta, D. (2018). Protests as critical junctures: Some reflections towards a momentous approach to social movements. Social Movement Studies, 1-20. https://doi.org/10.1080/1474 2837.2018.1555458

Della Porta, D., \& Tarrow, S. (2012). Interactive diffusion: The coevolution of police and protest behavior with an application to transnational contention. Comparative Political Studies, 45(1), 119-152. https://doi.org/10.1177/0010414011425665

Duyvendak, J. W., \& Fillieule, O. (2015). Conclusion: Patterned fluidity: an interactionist perspective as a tool for exploring contentious politics. In J. W. Duyvendak \& J. M. Jasper (Eds.), Players and arenas: The interactive dynamics of protest (pp. 295-318). Amsterdam University Press. https://doi.org/10.2307/j.ctt16vj285.16

Duyvendak, J. W., \& Jasper, J. M. (Eds.). (2015). Breaking down the state: Protestors engaged. Amsterdam University Press.

El-Sharnouby, D. (2018). Youth subjectivity at a post-ideological turn: The 2011 revolution in Egypt and youth's political imaginary. A case study of the Bread and Freedom Party [Doctoral Dissertation at the Center of Middle Eastern and North African Politics]. Freie Universität Berlin.

Grimm, J. J. (2017, April 27). Convergent authoritarianisms in Egypt and Turkey [Carnegie Endowment for International Peace]. Sada. http://carnegieendowment.org/sada/68797

Halawa, H. (2021, October 11). Burning ambition: Egypt's return to regional leadership and how Europe should respond. European Council on Foreign Relations. https://ecfr.eu/publication/ burning-ambition-egypts-return-to-regional-leadership-and-how-europe-should-respond/

Hall, S. (1980). Cultural studies: Two paradigms. In Media, culture, and society: A critical reader (pp. 57-72). Sage.

Hamada, A. (2014). Understanding the military role in the Egyptian revolution: Comparing February 2011 and July 2013. In N. Belakhdar, I. Eickhof, A. el Khawaga, O. el Khawaga, C. Harders, \& S. Sandri (Eds.), Arab revolutions and beyond (pp. 29-40). Center for Middle Eastern and North African Politics.

Hamzawy, A., \& Dunne, M. (2017). Egypt's secular political parties: A struggle for identity and independence. Carnegie Endowment for International Peace. https://carnegieendowment. org/2017/03/31/egypt-s-secular-political-parties-struggle-for-identity-and-independencepub- 68482

Hassan, K. (2017, April 10). Land dispute continues to threaten Egypt-Sudan ties. Al-Monitor. http:// www.al-monitor.com/pulse/originals/2017/o4/sudan-expel-egyptians-halayeb-shalateentriangle.html

Heggy, E., Sharkawy, Z., \& Abotalib, A. Z. (2021). Egypt's water budget deficit and suggested mitigation policies for the Grand Ethiopian Renaissance Dam filling scenarios. Environmental Research Letters, 16(7), 1-17. https://doi.org/10.1088/1748-9326/acoac9

Herrera, L., \& El-Sharnouby, D. (2018, January 24). Alain Badiou on the Egyptian revolution, seven years later. OpenDemocracy. https://www.opendemocracy.net/north-africa-west-asia/ linda-herrera-dina-el-sharnouby/alain-badiou-on-egyptian-revolution-questions 
Jasper, J. M. (2015). Introduction: Playing the game. In J. M. Jasper \& J. W. Duyvendak (Eds.), Players and arenas: The interactive dynamics of protest (pp. 9-32). Amsterdam University Press. https://doi.org/10.2307/j.ctt16vj285.3

Jasper, J. M. (2018). The emotions of protest. The University of Chicago Press.

Jasper, J. M. (2019). Afterword: Comparative versus historical research. Social Movement Studies, 18(1), 130-136. https://doi.org/10.1080/14742837.2018.1540348

Jasper, J. M., \& Duyvendak, J. W. (Eds.). (2015). Players and arenas: The interactive dynamics of protest. Amsterdam University Press.

Jasper, J. M., \& Volpi, F. (2018). Introduction: Rethinking mobilization after the Arab uprisings. In F. Volpi \& J. M. Jasper (Eds.), Microfoundations of the Arab uprisings: Mapping interactions between regimes and protesters (pp. 11-40). Amsterdam University Press.

Khamis, S., \& Fowler, R. (2020). Arab resistance in the diaspora: Comparing the Saudi dissident and the Egyptian whistleblower.Journal of Arab \& Muslim Media Research, 13(1), 31-49. https:// doi.org/10.1386/jammr_oooo9_1

Khosrokhavar, F. (2018). Violence, social actors, and subjectivation in the Egyptian revolution. In F. Volpi \& J. M. Jasper (Eds.), Microfoundations of the Arab uprisings: Mapping interactions between regimes and protesters (pp. 159-182). Amsterdam University Press.

Kurzman, C. (2018). Conclusion: Unruly protest. In F. Volpi \& J. M. Jasper (Eds.), Microfoundations of the Arab uprisings: Mapping interactions between regimes and protesters (pp. 183-192). Amsterdam University Press.

Lawson, F. H. (2017). Egypt versus Ethiopia: The conflict over the Nile metastasizes. The International Spectator, 52(4), 129-144. https://doi.org/10.1080/03932729.2017.1333272

Lossow, T. von, \& Roll, S. (2015). Egypt's Nile water policy under Sisi: Security interests promote rapprochement with Ethiopia (SWP Comments C 11). Stiftung Wissenschaft und Politik. https://www.swp-berlin.org/en/publication/egypts-nile-water-policy/

Marfleet, P. (2016). Egypt: Contested revolution. Pluto Press.

McGarry, A., Davidson, R. J., Accornero, G., Jasper, J. M., \& Duyvendak, J. W. (2016). Players and arenas: Strategic interactionism in social movements studies. Social Movement Studies, 15(6), 634-642. https://doi.org/10.1080/14742837.2016.1199320

Melucci, A. (1996). Challenging codes: Collective action in the information age. Cambridge University Press.

Mogahed, D. (2013, July 25). Deep runs the divide [Carnegie Endowment for International Peace]. Sada. http://carnegieendowment.org/sada/index.cfm?fa $=$ show\&article $=52493 \&$ solr_hilite $=$

Nicol, A., \& Cascão, A. E. (2011). Against the flow - new power dynamics and upstream mobilisation in the Nile Basin. Review of African Political Economy, 38(128), 317-325.

Owen, R. (2012). Rise and fall of Arab presidents for life. Harvard University Press.

Polletta, F., \& Kretschmer, K. (2015). Movement factions: Players and processes. In J. M. Jasper \& J. W. Duyvendak (Eds.), Players and arenas: The interactive dynamics of protest (pp. 35-54). Amsterdam University Press. https://doi.org/10.2307/j.ctt16vj285.4

Pratt, N. (2015). After the 25 January Revolution: Democracy or authoritarianism in Egypt? In R. Abou-el-Fadl (Ed.), Revolutionary Egypt: Connecting domestic and international struggles. Routledge.

Rennick, S. A. (2015). The practice of politics and revolution: Egypt's revolutionary youth social movement [Doctoral Dissertation, Lund University]. https://lup.lub.lu.se/search/ws/ files/5309346/5274498.pdf

Schwedler, J. (2018). Routines and ruptures in anti-Israeli protests in Jordan. In F. Volpi \& J. M. Jasper (Eds.), Microfoundations of the Arab uprisings: Mapping interactions between regimes and protesters (pp. 67-88). Amsterdam University Press. 
Scott, J. C. (2000). Weapons of the weak: Everyday forms of peasant resistance (Reprint). Yale University Press.

Sika, N. M. (2017). Youth activism and contentious politics in Egypt: Dynamics of continuity and change. Cambridge University Press.

Siméant-Germanos, J. (2021). Conceptualizing contexts or contextualizing concepts? On some issues of the modeling of relational spaces in the study of collective action. Social Movement Studies, 2o(2), 139-154. https://doi.org/10.1080/14742837.2019.1629899

Vicari, S. (2015). The interpretative dimension of transformative events: Outrage management and collective action framing after the 2001 anti-G8 summit in Genoa. Social Movement Studies, 14(5), 596-614. https://doi.org/10.1080/14742837.2014.995076

Wagner-Pacifici, R. (2010). Theorizing the restlessness of events. American Journal of Sociology, 115(5), 1351-1386. https://doi.org/10.1086/651299

Wedeen, L. (1999). Ambiguities of domination: Politics, rhetoric, and symbols in contemporary Syria. University of Chicago Press.

Weipert-Fenner, I. (2021). Go local, go global: Studying popular protests in the MENA post-2011. Mediterranean Politics. 



\title{
Appendix
}

\author{
A Mixed-Method Approach to the Study of Contentious \\ Interaction
}

Charles Tilly distinguished three camps of observers of violence and contention: ideas people, behavior people, and relation people (Tilly, 2003, p. 5f.). Whereas ideas people focus on ideology, behavior people understand collective phenomena as the sum of individual behaviors. Relation people, finally, give the transactions among persons and groups center stage, conceiving of collective actions as the visible symptoms of social relations and personal interchange. The methodology of this book is primarily embedded in the relational paradigm, but it also caters to the ideas and the behavior camp through its focus on discourses that are constitutive for players' actions and its view of movements as populations of contentious events.

It follows a two-step analytical process and combines a thorough mapping of contentious interactions as an event history with an in-depth examination of the discourses of those players involved in the witnessed events. This two-level investigation aims to illustrate how the narratives established around certain contentious key events - transformative or turning point events - crucially account for variances in the reaction of social players to each other: of social movements to regime action, of potentially mobilizable publics to both protest and repression, and of regime actors to social mobilization.

To reconcile the two analytical layers - a condensed retracing of contentious interaction on a day-to-day basis with an in-depth analysis of contested discourses - this study relies on process tracing as a research strategy. Ontologically, this method derives from the constructivist toolkit. It can be distinguished from other historical accounts by the focus it places on the interactive and configurative processes that lead to a particular outcome (e.g., the abatement of collective action or the modification of protest or policing tactics). The essential idea of process tracing as a research approach is that every phenomenon - mobilization and repression, for

Grimm, Jannis Julien, Contested Legitimacies: Repression and Revolt in Post-Revolutionary Egypt. Amsterdam: Amsterdam University Press 2022 DOI: 10.5117/9789463722650_appendix 
instance, but also the ways how contenders articulate the nature of their struggle - leaves traces that analysts can observe and reconstruct in terms of its attributes, elements, causes, and effects (Checkel, 2005). Hence what proponents of process tracing approaches do is look at "the observable implications of putative causal mechanisms in operation in a case, much as a detective looks for suspects and for clues linking them to a crime" (A. Bennett, 2004, p. 24).

Accordingly, process tracing can be thought of as a causal reconstruction of the "concatenation of generative events" (Della Porta, 2014b, p. 163) by which an investigated social phenomenon comes into being. The aim is not to establish a complete causal explanation for the trajectory of a protest cycle, but rather to identify the mechanisms that drive it (see Mahoney \& Goertz, 2006). These mechanisms and their consequences are not only visible and observable through the physical behavior of players, e.g., their protest performances, their tactical repertoires, or their changing attitude to violence. They also mark their discourses.

\section{Combining Protest Event and Discourse Analyses in a Nested Research Design}

From a methodological perspective, thinking historical hence implies tracing the relations between products of articulation (that is, the analyzed sources) and their eventful social context. The nested research design of this study gives due to this premise by interlinking the statistical analysis of protest events, which are coded from newspaper and social media reports, with an in-depth analysis of competing discourses surrounding these events. This multimethod research strategy caters to calls for methodological pluralism in the field of social movement research (e.g., Della Porta, 2014c; Tarrow, 2010) and for an integrated approach to the study of historical data (A. Bennett, 2002; Goertz, 2017; Lieberman, 2005, 2010). It also combines two different datasets with the necessary detail for micro-level analysis.

The essential idea behind such an integrated approach is to combine the complementary strengths of large- $\mathrm{N}$ designs for identifying empirical trends with those of in-depth case studies for revealing the driving forces behind such distinctive patterns (Fearon \& Laitin, 2008, p. 758). Recognizing this synergistic value, Evan Lieberman (2005) has pointed out the benefits of triangulating different methodologies in a "nested analysis" (p. 435) Combining small and large-N-analysis in a single framework, the nested analysis allows for examining a phenomenon, in this case, the shifting dynamics 
Figure 24 Nested research design

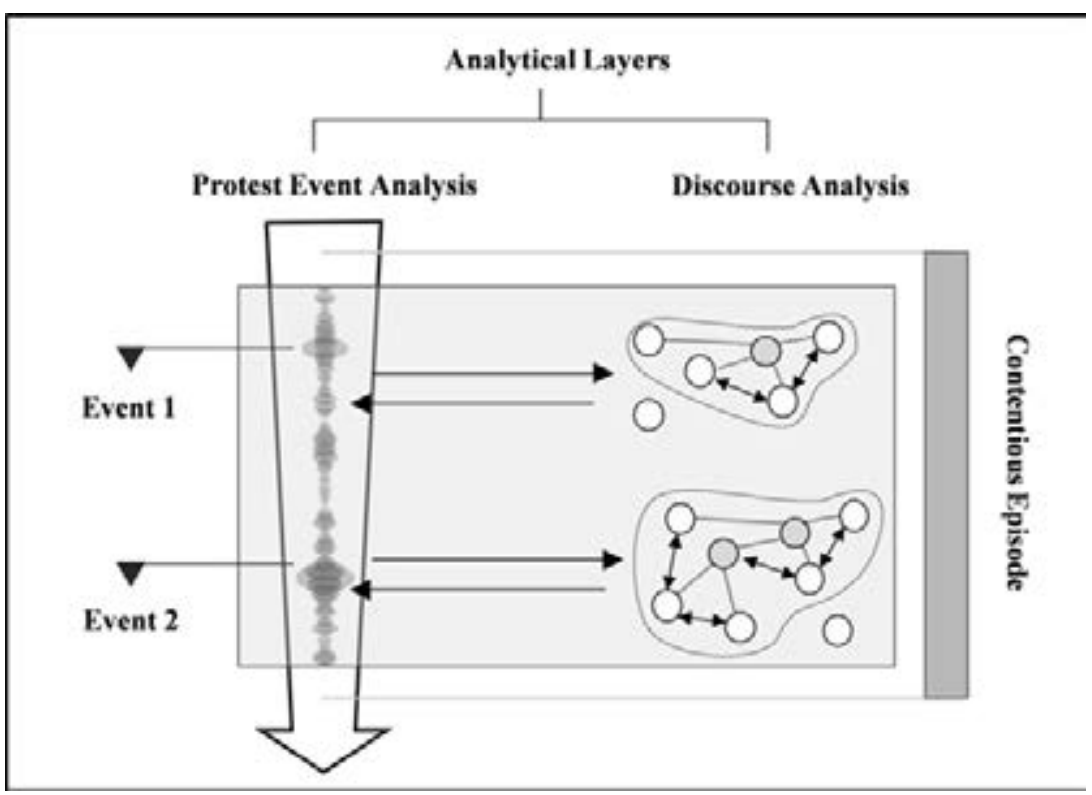

of contention in post-revolutionary Egypt, on different levels and to zoom in on causal mechanisms that drive it (see Fearon \& Laitin, 2008, p. 756).

In addition to providing orientation, the triangulation of methods also facilitates the verification of results, increasing the overall analytic payoff. Each level of analysis informs the other and thus contributes to an integrated understanding of the process under investigation and the reduction of potential sources of error. Time series may serve as a point of departure by drawing attention to moments of visibility and latency and to turning points in mobilization processes. In turn, close qualitative analysis of a limited set of events may provide more nuanced insights and explain transitions and nonlinearities that have been discovered through quantitative analysis (Tarrow, 2010, p. 104). The gain of reliability that results from such a second qualitative layer of analysis is convincingly expressed by Norman Denzin and Yvonna Lincoln (2000) who note that "qualitative researchers study things in their natural settings attempting to make sense of, or to interpret, phenomena in terms of the meanings people bring to them" (p. 3).

In essence, the integration of Protest Event Analysis (PEA) and Political Discourse Analysis (PDA) in a nested research design comprises two analytical stages: The first step consists of a quantitative mapping of contention in Egypt within the investigation period based on transparent and verifiable 
coding procedures. This catalog serves as a guide for the identification of intriguing events and historical turning points for in-depth study (see Lieberman, 2005, pp. 438-440). In a second step, this subset of events is explored in-depth, both in its effects on the character of protest and in its discursive effects. In this second step of the analysis, I examine how different narratives about the witnessed events are wielded by contenders as discursive "weapons" (Hoffmann \& König, 2013, p. 18) against each other. The analyzed discursive sample is necessarily limited to the communication of the prime contenders in each contentious episode identified via PEA. The results of these analyses can be conceived of like a cross-section of contenders' discourses at these specific instants of the protest cycle. Longitudinal comparison of these snapshots over time makes it possible to identify how certain events dislocated and altered discourses with varying effects.

\section{Event Data and their Limitations}

At the core of process tracing is the continuous description of a historical sequence. However, in practice, one cannot capture every step in a sequence of interactions. The presentation of empirical facts thus has to be pragmatically reduced to the "bare bones" (Richards, 2011, p. 212) of the interaction process, that is, to key events that are relevant for the construction of a coherent historical narrative. At the same time, one has to avoid "cherrypicking," that is, selecting only those interactions that are most aligned with a favored hypothesis (see Lieberman, 2010, p. 39). What is required, is "purposeful" (Rihoux \& Lobe, 2009) case selection. Event catalogs provide an excellent tool for this. Visualized in time series diagrams, they allow for confidently identifying the hot phases of contentious episodes. Sharp drops, fluctuation, or a sudden peak in an event sequence can point us to the transformative phases of a protest cycle.

Over the past decades, protest event analysis (PEA) has become a routine practice in the study of social movements (see Hutter, 2014). But only recently have scholars started to employ event catalogs in studies of the Arab World (see Weipert-Fenner, 2021, pp. 13-15). Within the method of PEA, the analytical focus shifts from the individual attitudes of activists and the ideological or organizational specificities of certain movements to a meso-level observation of discrete episodes in a movement's lifecycle (see Tilly, 2005, p. 212). Contentious episodes are the unit of analysis, while discrete contentious events - temporally and spatially circumscribable actions that are carried 
out by specific players and captured within the event database - function as the unit of observation within the examined episodes.

By the time of writing, no protest event dataset on the 2013 Anti-Coup protests in Egypt was readily available that offered the necessary depth of detail for investigating protest campaigns in the post-coup period. Therefore, a new event catalog covering the investigation period was hand-coded for this book from social media posts and press articles. To reduce reporting bias (e.g., newspapers over-reporting large and violent events and neglecting smaller and peaceful protests) and the effects of authoritarian censorship (see Earl et al., 2004; Ortiz et al., 2005), the coded sources include local print and online media of different political affiliations as well as social media posts and crowdsourcing data.

Before coding, samples of different sources were evaluated for a test period, the week following the so-called Mandate Friday on July 26, 2013, to probe their coverage of contentious collective actions. This pilot study showed that particularly those events that happened in the social or geographical periphery attracted significantly less media attention than those in the capital, which is characterized by a higher press density. Moreover, many outlets had political affinities that impacted the reliability of their reporting (see Ball, 2005, p. 189). Big Egyptian national dailies, such as the semi-official Al-Ahram and Al-Shorouq heavily underreported the Anti-Coup campaign due to their anti-Islamist stances or due to state interference in editorial lines. On top of that, censorship was at work (see Richter, 2015).

For this reason, the inclusion of opposition outlets, such as the Freedom and Justice Party's and the Anti-Coup Alliance's social media pages and the independent Rassd News Network, was indispensable for a reliable reconstruction of social mobilization. As "social newspapers" (Elsayed, 2013, p. 16), these sites took notice of smaller demonstrations, too, and were less affected by censorship. Articles were often linked to citizen reporter platforms, such as Bambuser, Ustream, or Livestream where demonstrators had uploaded geotagged live feeds and cell phone videos of the protests they attended. This enabled me to check samples for description bias and bolster the reliability of the collected data (see Ketchley, 2013). In the end, protest event reports were retrieved from a combination of the following sources:

- Al-Ahram. Print Edition. Cairo: Al-Ahram Publishing House. http://www.ahram.org.eg/pdf/ Zoom_1500/Index.aspx

- Al-Ahram Weekly. Online Edition. Cairo: Al-Ahram Publishing House. http://weekly.ahram. org.eg/Index.aspx

- Daily News Egypt. Section 'Politics'. http://www.dailynewsegypt.com/category/politics/ 
- Al-Dostor. Print Edition. Cairo: Dostor Publishing House. http://www.dostor.org/custom/ digital/

- Al-Shorouk. Print edition as PDF. Cairo: Shorouk News. http://www.shorouknews.com/pdf/

- Freedom and Justice Party. Freedom and Justice Gate. http://fj-p.net/category/news/

- Freedom and Justice Party. Official website in Arabic. http://www.fjponline.com/

- Freedom and Justice Party. Facebook. https://www.facebook.com/FJParty

- Ikhwanonline. The Muslim Brotherhood's Official Arabic Web Site. https://www.ikhwanonline. com/

- Ikhwanweb. The Muslim Brotherhood's Official English Web Site. http://www.ikhwanweb. com/index.php

- Mada Masr. Arabic Website. Sections: News, Politics, Society. https://madamasr.com/.

- National Alliance in Support of Legitimacy. Facebook. https://www.facebook.com/ AllianceSupportingLegitimacy/

- Rabaa Story. Remember Rabaa. https://rabaastory.net/

- Rassd News Network. Sections: Egypt, News from the provinces. http://rassd.com/cat-1.htm and https://rassd.com/cat-15.htm

The analyses in Chapter 7 additionally draw on the Africa dataset released by the Armed Conflict Location and Event Data Project at the University of Sussex (Raleigh et al., 2010). This dataset was checked for false positives before its merger with the catalog used in this book to eliminate duplicates as well as collective action events that were not related to the studied protest players.

In sum, these sources document 2,498 discrete protests during the investigation period. The indicators coded to qualify these events include meta-variables like location, time, and source as well as variables describing their size, composition, or repertoire. Protests were coded as violent whenever there were reports of violent confrontations; this did not include low-level forms of violent resistance, such as sporadic stone-throwing or scuffles, which were frequent at almost every larger protest event during the investigation period. Due to partially conflicting reports, protest size was coded on an imputed interval scale. Whenever sources did not explicitly specify numbers, I estimated the turnout according to available information, as suggested by Walker, Martin, and McCarthy (2008, p. 52). The daily country-wide turnout was extrapolated based on the sum of the categories' mean values.

Repression was measured by proxy through the data on the victims of state violence released by the activist crowdsourcing platform Wiki Thawra (2014). Its database arguably represents the most extensive effort to systematically catalog arrested, wounded, and killed protesters in Egypt. Launched by the Egyptian Center for Economic and Social Rights, the database is compiled mainly from the reports of human rights organizations. It meticulously documents who did what to whom, thus making it possible to distinguish victims of state violence from those of confrontations among 
Table 2 Comparison between official casualty figures and Wiki Thawra

\begin{tabular}{|c|c|c|c|c|c|c|c|c|}
\hline & \multirow{2}{*}{\multicolumn{2}{|c|}{$\begin{array}{l}\begin{array}{l}\text { Republican } \\
\text { Guard }\end{array} \\
8 \text { July } 2013\end{array}$}} & \multirow{2}{*}{\multicolumn{2}{|c|}{$\begin{array}{l}\text { Nasr Street } \\
27 \text { July } 2013\end{array}$}} & \multirow{2}{*}{\multicolumn{2}{|c|}{$\begin{array}{l}\text { Rabaa \& } \\
\text { Al-Nahda } \\
14 \text { August } 2013\end{array}$}} & \multirow{2}{*}{\multicolumn{2}{|c|}{$\begin{array}{l}\text { 6th October } \\
6 \text { October } 2013\end{array}$}} \\
\hline & & & & & & & & \\
\hline & $\begin{array}{l}\text { Wiki } \\
\text { Thawra }\end{array}$ & Official & $\begin{array}{l}\text { Wiki } \\
\text { Thawra }\end{array}$ & Official & $\begin{array}{l}\text { Wiki } \\
\text { Thawra }\end{array}$ & Official & $\begin{array}{l}\text { Wiki } \\
\text { Thawra }\end{array}$ & Official \\
\hline killed & 93 & 61 & 109 & 95 & 1516 & 719 & 83 & 53 \\
\hline wounded & 1237 & 1404 & 763 & 748 & 6986 & 3994 & 392 & 271 \\
\hline
\end{tabular}

civilians. Up to date, there exists hardly any comparable official data. Authorities have released body counts for a handful of events only, mostly to counter accusations that they were not properly investigating violent events. But as Table 2 illustrates, the discrepancy between these figures and those of Wiki Thawra is staggering.

By the time of the Tiran and Sanafir islands protests, the Wiki Thawra project had been discontinued. Repression during this episode was thus tracked through the statistics released by the Front to Defend Egyptian Protesters. ${ }^{1}$ The activist-lawyer collective regularly issues a disaggregated dataset on political arrests, detailing the demographic and geographic characteristics of the detainees.

In authoritarian settings, crowdsourcing platforms provide a valuable tool to keep track of human rights violations (Heinzelman \& Meier, 2013, p. 124). However, the explanatory potential of statistical data is limited: In reality, often the mere knowledge about the ruthlessness of police forces or prior experiences of victimization can discourage protests. Event catalogs offer no way to render such a climate of fear measurable. The analyses in this book, therefore, also include qualitative descriptions of control techniques, legal threats, and vilifying discourses and attempts of intimidation which are not captured by the event data.

\section{Political Discourse Analysis}

Whereas protest event analyses usually suffer from a scarcity of reliable sources, discourse analyses face the opposite problem: difficulties arise from the sheer quantity of commentary produced about protests. For instance, as

1 For a spreadsheet of all cases documented by the FDEP see https://goo.gl/DUp6Yn. 
regards the island crisis, a brief inquiry on the use of the two main hashtags associated with the Tiran and Sanafir island protests delivered more than 155,000 mentions on Facebook alone. This figure evidences the difficulty of reducing the pool of potential sources for analysis to a manageable sample while avoiding random selection and cherry-picking.

Adding to this difficulty is the fact that Laclau and Mouffe themselves never engaged with the question of how to operationalize their project. David Howarth and Yannis Stavrakakis (2000) have thus called upon discourse researchers to stay true to the post-foundational paradigm and "to articulate their concepts in each particular enactment of concrete research" (p. 7). Nevertheless, a lack of systematization pervades discourse theory as a field of study. The number of research projects claiming to be some kind of discourse analysis grows constantly (Van Dijk, 1990, p. 7). But only a handful are clear about their methods. This lack of transparency is partly responsible for the perception of discourse theoretical studies as lofty theorizing at the expense of systematic empirical engagement and has earned discourse theory the reputation of non-operationalizability (Müller, 2011, para. 5). Accordingly, I try to be as transparent as possible here, so readers can trace the logic behind my analysis - if only to dispute its results.

In this book, discursive interactions are analyzed with the help of semantic networks. A semantic network can be thought of as an organizing mechanism. It summarizes the structure of a discourse that conditions social interaction. Its elements correspond to the elements of a text or a body of texts and can represent recurrent words, themes, or meanings assigned by a coder. Competing discourses are hence the unit of analysis, the divergent structuration of different elements (signifiers) within these discourses functions as the unit of observation.

\section{Table 3 Key terminology of discourse theory}

\begin{tabular}{ll}
\hline Term & Definition \\
\hline Discourse & $\begin{array}{l}\text { An attempt to fix a web of meanings by articulating specific relations } \\
\text { between different signifiers to the exclusion of others. } \\
\text { The act of fixating the meaning of signifiers in a discourse. }\end{array}$ \\
$\begin{array}{l}\text { Articulation } \\
\text { Nodal signifiers }\end{array}$ & $\begin{array}{l}\text { A privileged signifier that bestows a specific relational meaning on all } \\
\text { signifiers ordered around it. }\end{array}$ \\
Floating signifier & $\begin{array}{l}\text { Signifiers whose meaning has not yet been fixed and which are open } \\
\text { to multiple possible meaning ascriptions. }\end{array}$ \\
Moment & $\begin{array}{l}\text { The relational meaning of a signifier in antagonism to a complex net } \\
\text { of differentiations of what the element does not mean. } \\
\text { The naturalisation of a particular social antagonism through } \\
\text { discourse. }\end{array}$ \\
\hline
\end{tabular}


In social movement studies, network analysis has primarily served as a method to grasp the relations among activists, mobilized groups, and social movement organizations, and to identify broker positions and overlaps in mobilizing structures and resources (Diani, 1992). But the network terminology (see Table 3) also dovetails with discourse theory, which is often described through the fishing net metaphor (see Andrade, 2015; Glasze, 2007). The following figures demonstrate this in two-dimensional network graphs. The two graphs illustrate how different discourses are constituted by the articulation of different relations among the same elements.

From a post-foundational perspective, terms are signifiers that draw their distinct meaning from their differential relation to each other. In Figure 25, elements A1-A6 represent such signifiers. They are connected to other elements that award them with a specific relational meaning. By contrast, B, C, and D are elements that have yet to be articulated. As floating signifiers without a fixed meaning, they are irrelevant for the depicted discourse. In this specific discourse, the signifier A assumes a unique role, because it occupies a nodal point. All differential elements A1-A6 are bound together by their common relation to this nodal signifier. Element A thus represents the entirety of the discourse by temporarily fixing the position of all its constituting elements and dissolving their differences in a chain of equivalence.

Discourses always emerge against a constitutive antagonist outside - in this case, elements B, C, D. By excluding what they are not through the construction of clear boundaries (this internal frontier is represented by a dotted black line), the players who entertain a certain discourse prevent the articulation of competing meanings, that is, of other possible configurations of the discursive field. Figure 26 shows just one alternative configuration of meaning through the articulation of the same signifiers in a different discourse. These two visualizations are hardly exhaustive of all possible relations. There is an infinite number of potential configurations that could include more or fewer elements.

The advantages of operationalizing discourses through networks are twofold: On a content level, it helps to discern the interrelation of topics in intertextual analyses. Studies of discourse should go beyond highlighting the broad red lines and touch upon the micro-topics discussed as well as underlying regularities that determine processes of meaning-making. In addition, semantic networks can visualize how discourses change with unfolding events. From a discourse theoretical perspective, often distinct clusters of equivalence characterize a specific tenet of a discourse. Converting a text (or a body of texts) into semantic networks helps to detect these clusters and trace how they are modified over periods of contention. 
Figure 25 Temporal fixation of meaning in a discourse

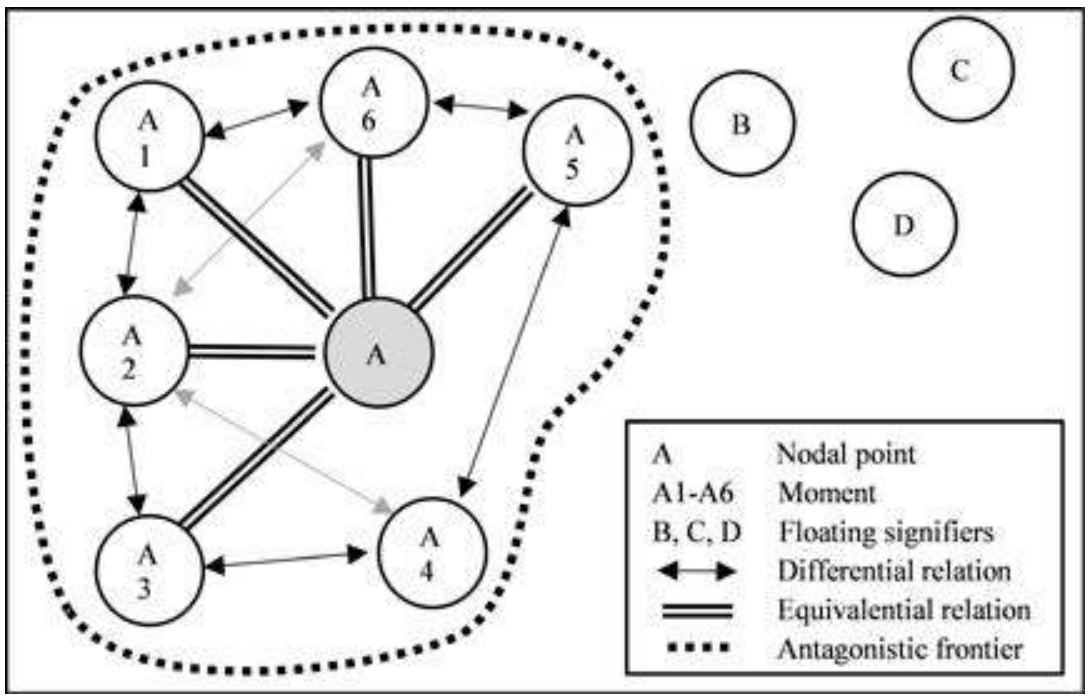

Figure 26 Alternative fixation of meaning based on identical signifiers

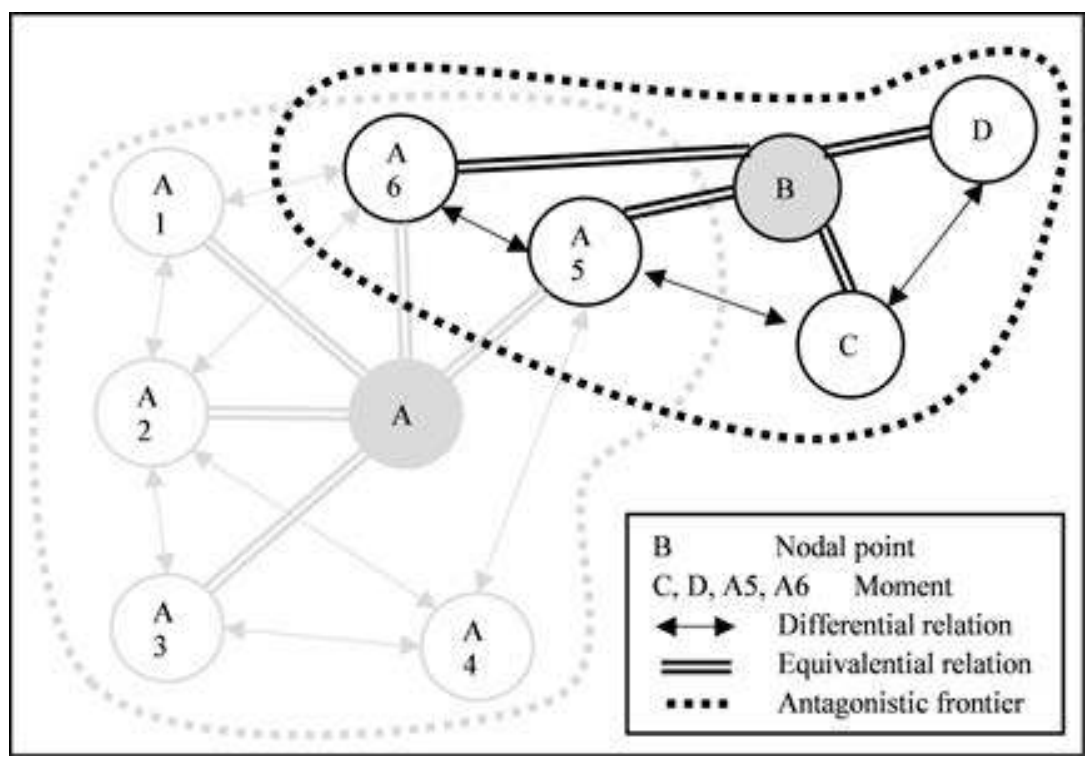




\section{Source Selection}

Johannes Angermüller (2001) has cautioned against superficial analyses of texts as "containers of self-referential meaning" (p. 8). To understand a discourse, it is not enough to merely analyze its internal structures. Instead, texts must be analyzed in relation to the social contexts in which they are produced and inserted. This entails analyzing the relation of the explications in statements to agents' practices and systems of signification (Wedeen, 2002, p. 714). Accordingly, my selection of sources for analysis was closely linked to the collected protest event data. I concentrated on sources that could be attributed to the main players in the political struggle. When we approach public discourse as an arena that is composed of players' contending practices of meaning-making, the explicit explanations and implicit assumptions in these statements are the most relevant reflections of the changing political culture (see Wessel, 2016, n. 2). Rather than discounting them for their partiality as unreliable sources for reconstructing eventful dynamics, these viewpoints can be taken as windows into the divergent perceptions of the unfolding events.

Based on these reflections, the sample analyzed in this book was compiled mainly from primary sources, such as the leaflets, press releases, and public statements of those players who participated in the events coded in the event catalog as well as those who were in charge of regulating and policing protest. Many of these sources were collected from blogs and social media websites. These platforms have effectively become alternative outlets for citizens' hopes, fears, and aspirations and changed the political game in favor of resource-poor players (W. L. Bennett \& Segerberg, 2013). They provide, in Nancy Fraser's (1990) words, "parallel discursive arenas where members of subordinated social groups invent and circulate counter-discourses to formulate oppositional interpretations of their identities, interests, and needs" (p. 67). For movements in Egypt, they also constituted a vehicle for circumventing censorship and exclusion from the public sphere. The analyzed sample was thus collected from the following sources:

\footnotetext{
April 6 Youth Movement. Facebook. https://www.facebook.com/shabab6april/ Egypt's Ministry of Defense. Official website. http://www.mod.gov.eg/ModWebSite/ Egypt's Ministry of the Interior. Official website. https://www.moi.gov.eg/home/index

- Egypt Presidency. Facebook. https://www.facebook.com/AlSisiofficial/. Records and transcripts were also partly available on YouTube and the State Information Service website; other transcripts were released by Al-Shourouk and BBC Arabic.

- Freedom and Justice Party. Freedom and Justice Gate. http://fj-p.net/category/news/

- Freedom and Justice Party. Official Arabic website. http://www.fjponline.com/
} 
- Freedom and Justice Party. Facebook page. https://www.facebook.com/FJParty

- Information Decision Support Center(IDSC). Officialwebsite. http://www.idsc.gov.eg/idsc/ News/View.aspx

- Muslim Brotherhood. Ikhwanonline. Official Arabic website. https://www.ikhwanonline.com/

- Muslim Brotherhood. Ikhwanweb. Official English website. http://www.ikhwanweb.com/ index.php

- Mursi, Mohammed. Speeches and public statements. Records and transcripts were released on Al-Jazeera, YouTube, Scribd, the State Information Service website, and several blogs.

- National Alliance in Support of Legitimacy. Official Arabic and English Facebook pages. https://www.facebook.com/AllianceSupportingLegitimacy/ and https://www.facebook. com/Egypt-Anti-Coup-Pro-Democracy-Alliance-222974781194704/

- Popular Coalition to Protect the Land. Facebook page. https://www.facebook.com/ Egyptisnotforsale/

- Rassd News Agency. New Website. https://rassd.com/

- Revolutionary Socialists. Official Website. http://revsoc.me/statements/

- State Information Service. Speeches and Statements by H.E. President of the Arab Republic of Egypt Abdel Fattah El Sisi. http://www.sis.gov.eg/En/Templates/Articles/

- Strong Egypt Party. Facebook page. https://www.facebook.com/MisrAlQawia/

- Students Against the Coup. Facebook page. https://www.facebook.com/SACMov/

- Tamarod.Facebook. https://www.facebook.com/TAMROUD/

- Wasat Party. Facebook page. https://www.facebook.com/alwasatparty/?ref=br_rs

- Youth Against the Coup. Facebook. https://www.facebook.com/Y.AntiCoup.Official/

Informal talks and interviews with activists with ties to the covered protest campaigns facilitated the selection of these sources. The elements collected from these sources for analysis are mostly of a textual nature or consist of a mix of text, graphics, and video elements, including TV records, banners, and photographs. For the first campaign discussed in Chapters 4 and 5 of this book, the protests after the ouster of President Mursi, they include a total of 154 mostly Arabic statements. Of these, 59 were released by affiliates of the Anti-Coup Alliance before the Rabaa massacre, another 66 in the timeframe after. By contrast, the reconstruction of the discourses that accompanied the Tiran and Sanafir controversy, the second major protest campaign analyzed in this book, is based on 68 speech transcripts and statements, mostly by supporters of the Popular Campaign to Protect the Land (PCPL) or the Muslim Brotherhood, in addition to 25 documents and records of public speeches that exemplify the regime's discursive strategy of dealing with the island issue.

All sources were coded deductively in four consecutive rounds with the help of the software MAXQDA (see, Kuckartz, 2010) and with special attention to the construction of antagonist frontiers by the players in focus. In addition, I coded how players defined themselves in terms of their actions and moral qualities vis-à-vis their antagonist others. In the semantic networks, which illustrate all chapters of this book, edges between the discursive elements are based on the co-occurrence of codes. Two elements are connected if they 
appear together frequently and not only as an idiosyncratic feature of one unit of text. The type of edge (straight line vs. dotted line with arrowheads) denotes the type of relation: a relation of difference or one of equivalence. The result of these coding rounds served as the basis for the reconstruction of players' discourses and the comparison of these cross-sections over time.

\section{Data Collection and Ethical Dilemmas}

Throughout this research, the deteriorating political conditions in Egypt, which are addressed in the sixth chapter of this book, heavily impacted my modes of data collection. This book has different types of sources collected during several phases of data collection, archival work, and field research. I conducted the first stage of this research in the spring and summer of 2013. During this period, I investigated Anti-Coup marches and countermobilization by groups affiliated with the NSF and Tamarod in the Cairene suburbs of Gizah, Helwan, Maadi, Nasr City, Sayeda Zeinab, and Shubhra al-Kheemas. The second stage of my data collection took place between December 2013 and May 2014 and centered on the systematic coding of Anti-Coup protest events in the aftermath of Mursi's deposition - mainly from Berlin but with intermittent field trips to Cairo. The data for the study of the Tiran and Sanafir island protests were recorded as the protests unfolded in April and May 2016. Additional interviews and documentary data were collected during field trips to Cairo (June and July 2015) and Istanbul (June 2016, August-December 2016). Whenever possible, I arranged follow-up discussions throughout 2016 and 2017; this last stage of data collection happened primarily from abroad.

Since early 2016, I conducted most background talks with activists via the encrypted online communication tool Jitsi Meet. By then, the re-emergence of the pre-revolutionary security state had drastically reshaped the red lines of what was doable, writable, thinkable in Egypt (see Kohstall et al., 2018). This affected my research in several respects: First, it effectively re-shifted my prior modes of data collection. The massacre of Rabaa al-Adawiya was a pivotal event in this regard. Before this outburst of violence, I had collected much of my primary data via semi-structured face-to-face interviews with protest organizers and activists. These same people were criminalized overnight and hunted down by the Egyptian police. As a result, I abandoned face-to-face talks in Egypt altogether and focused on interviews with exiled activists abroad, mainly in Athens, Berlin, Frankfurt, Rome, and Washington, DC. 
Additionally, I conducted two longer research stays in Turkey to interview former Anti-Coup protesters in exile. These conversations produced invaluable background knowledge for interpreting the findings of my discourse analyses. However, for fear of jeopardizing their safety now or after their potential future return to Egypt they are neither systematically analyzed nor quoted in this book. Some interview fragments are presented throughout the text to supplement the presentation of empirical data. But much more has been omitted for the stated concerns (see Wackenhut, 2018).

In general, the deteriorating security situation bore practical consequences for how interlocutors can be personally acknowledged and accredited in this study (see Grimm et al., 2020, p. 7off.). The full list of all activists, lawyers, journalists, and local researchers who were interviewed includes 37 mostly Egyptian informants. By the time I finished writing this book, some had been killed. Many more were still in jail. To not aggravate their already miserable situation, the names of all interviewees, the location where the interviews took place, and the dates of the interviews have been modified or obfuscated to ensure a maximum degree of confidentiality and anonymity, including for those who agreed to be cited by name at the time of our talk.

Behind this overly cautious approach to information security, including at the cost of losing detail, is the realization that many of the records that once would not have been deemed sensitive to law enforcement agencies in Egypt have today become highly sensitive. Who is to say that what was still relatively innocuous at the time of writing will remain so in the foreseeable future? Informed consent principles are indeed not enough to protect researchers and their interlocutors against the capriciousness of a police state. As Elisabeth Wood and Sarah Parkinson (2015) underscored, neither researchers nor their research participants are in a position to anticipate whether comments made to a scholar at one point in time may be used as evidence of criminality, sedition, or disloyalty later on. In this book, I have thus decided to rather err on the side of caution and prioritize risk avoidance over a transparent attribution of quotes.

\section{References}

Andrade, A. (2015, February 2). Illustrating Laclau and Mouffe's discourse theory with a social network approach. Models of Interaction, Reasoning and Learning. http://alandra.org/ laandrad/?p=108

Angermüller, J. (2001). Diskursanalyse: Strömungen, Tendenzen, Perspektiven. Eine Einführung. In J. Angermüller, K. Bunzmann, \& M. Nonhoff(Eds.), Diskursanalyse: Theorien, Methoden, Anwendungen (pp. 7-22). Argument Hamburg. 
Ball, P. (2005). On the quantification of horror: Notes from the field. In C. Davenport, H. Johnston, \& C. Mueller (Eds.), Repression and mobilization (pp. 189-208). University of Minnesota Press.

Bennett, A. (2002). Where the model frequently meets the road: Combining statistical, formal, and case study methods [APSA Proceedings].

Bennett, A. (2004). Case study methods: Design, use, and comparative advantages. In D. F. Sprinz \& Y. Wolinsky-Nahmias (Eds.), Models, numbers \& cases: Methods for studying international relations (pp. 19-55). The University of Michigan Press.

Bennett, W. L., \& Segerberg, A. (2013). The logic of connective action: Digital media and the personalization of contentious politics. Cambridge University Press.

Checkel, J. T. (2005). It's the process stupid! Process tracing in the study of European and international politics (Working Paper No. 26). ARENA. http://www.sv.uio.no/arena/english/research/ publications/arena-working-papers/2001-2010/2005/wpo5_26.pdf

Della Porta, D. (2014a). On violence and repression: A relational approach (the Leonard Schapiro memorial lecture, 2013). Government and Opposition, 49(2), 159-187. https://doi.org/10.1017/ gov.2013.47

Della Porta, D. (Ed.). (2014b). Methodological practices in social movement research. Oxford University Press.

Denzin, N. K., \& Lincoln, Y. S. (Eds.). (2000). The SAGE handbook of qualitative research (4th ed). Sage.

Diani, M. (1992). Analysing social movement networks. In M. Diani \& R. Eyerman (Eds.), Studying collective action (pp. 107-135). Sage Publications.

Earl, J., Martin, A., McCarthy, J. D., \& Soule, S. A. (2004). The use of newspaper data in the study of collective action. Annual Review of Sociology, 3o(1), 65-8o. https://doi.org/10.1146/annurev. soc.30.012703.110603

Elsayed, Y. (2013). Revolutionary media on a budget: Facebook-only social journalism. Arab Media and Society, 17, 1-27.

Fearon, J. D., \& Laitin, D. D. (2008). Integrating qualitative and quantitative methods. In J. M. Box-Steffensmeier, H. E. Brady, \& D. Collier (Eds.), Oxford Handbook of Political Methodology (pp. 756-776). Oxford University Press.

Fraser, N. (1990). Rethinking the public sphere: A contribution to the critique of actually existing democracy. Social Text, 25/26, 56-8o. https://doi.org/10.2307/466240

Glasze, G. (2007). Proposals for the operationalisation of the discourse theory of Laclau and Mouffe using a triangulation of lexicometrical and interpretative methods. Forum Qualitative Sozialforschung, 8(2). http://www.qualitative-research.net/index.php/fqs/article/view/239

Goertz, G. (2017). Multimethod research, causal mechanisms, and case studies: An integrated approach. Princeton University Press.

Grimm, J. J., Koehler, K., Lust, E., Saliba, I., \& Schierenbeck, I. (2020). Safer field research in the social sciences: A guide to human and digital security in hostile environments (1st ed). SAGE Publishing.

Heinzelman, J., \& Meier, P. P. (2013). Crowdsourcing for human rights monitoring: Challenges and opportunities for information collection and verification. In J. Lannon \& E. F. Halpin (Eds.), Human rights and information communication technologies: Trends and consequences of use (pp. 123-138). Information Science Reference.

Hoffmann, A., \& König, C. (2013). Scratching the democratic façade: Framing strategies of the 20 February movement. Mediterranean Politics, 18(1), 1-22. https://doi.org/10.1080/13629395 .2012 .761474

Howarth, D. R., \& Stavrakakis, Y. (2000). Introducing discourse theory and political analysis. In D. R. Howarth, A. Norval, \& Y. Stavrakakis (Eds.), Discourse theory and political analysis: Identities, hegemonies and social change (pp. 1-23). Manchester University Press. 
Hutter, S. (2014). Protest event analysis and its offspring. In D. Della Porta (Ed.), Methodological practices in social movement research (pp. 335-367). Oxford University Press.

Ketchley, N. (2013). The Muslim Brothers take to the streets. Middle East Report, 269, 12-17.

Kohstall, F., Richter, C., Dhouib, S., \& Kastner, F. (2018). Academia in transformation: Scholars facing the Arab uprisings. Nomos.

Kuckartz, U. (2010). Einführung in die computergestützte Analyse qualitativer Daten (3rd ed.). Springer VS.

Lieberman, E. S. (2005). Nested analysis as a mixed-method strategy for comparative research. American Political Science Review, 99(3), 435-452. https://doi.org/10.1017/Soo03055405051762

Lieberman, E. S. (2010). Bridging the qualitative-quantitative divide: Best practices in the development of historically oriented replication databases. Annual Review of Political Science, 13(1), 37-59.

Mahoney, J., \& Goertz, G. (2006). A tale of two cultures: Contrasting quantitative and qualitative research. Political Analysis, 14(3), 227-249. https://doi.org/10.1093/pan/mpjo17

Müller, M. (2011). Doing discourse analysis in critical geopolitics. L'Espace Politique. Revue en ligne de géographie politique et de géopolitique, 12. https://doi.org/10.400o/espacepolitique.1743

Ortiz, D., Myers, D. J., Walls, E. N., \& Diaz, M.-E. D. (2005). Where do we stand with newspaper data? Mobilization, $10(3)$, 397-419. https://doi.org/10.17813/maiq.10.3.836or76ok3277t42

Parkinson, S. E., \& Wood, E. J. (2015). Transparency in intensive research on violence: Ethical dilemmas and unforeseen consequences. Qualitative \& Multi-Method Research, 13(1), 22-27. https://doi.org/10.5281/zenodo.893081

Raleigh, C., Linke, A., Hegre, H., \& Karlsen, J. (2010). Introducing ACLED: An Armed Conflict Location and Event Dataset special data feature. Journal of Peace Research, 47 (5), 651-66o. https://doi.org/10.1177/0022343310378914

Richards, P. (2011). A systematic approach to cultural explanations of war: Tracing causal processes in two West African insurgencies. World Development, 39(2), 212-220. https://doi.org/10.1016/j. worlddev.2009.11.030

Richter, C. (2015). Ägypten: Paradox von Vielfalt und Gleichschaltung. In C. Richter \& A. Difraoui (Eds.), Arabische Medien (pp. 131-142). UVK.

Rihoux, B., \& Lobe, B. (2009). The case for qualitative comparative analysis (QCA): Adding leverage for thick cross-case comparison. In D. Byrne \& C. Ragin, The Sage handbook of case-based methods (pp. 222-242). SAGE.

Tarrow, S. (2010). Bridging the quantitative-qualitative divide. In H. E. Brady \& D. Collier (Eds.), Rethinking social inquiry: Diverse tools, shared standards (2nd ed., pp. 101-110). Rowman \& Littlefield Publishers.

Tilly, C. (2003). The politics of collective violence. Cambridge University Press.

Tilly, C. (2005). Repression, mobilization, and explanation. In C. Davenport, H. Johnston, \& C. Mueller (Eds.), Repression and mobilization (pp. 211-226). University of Minnesota Press.

Van Dijk, T. A. (1990). Discourse \& Society: A new journal for a new research focus. Discourse \& Society, 1(1), 5-16. https://doi.org/10.1177/0957926590001001001

Wackenhut, A. F. (2018). Ethical considerations and dilemmas before, during and after fieldwork in less-democratic contexts. The American Sociologist, 49(2), 242-257. https://doi.org/10.1007/ s12108-017-9363-z

Walker, E. T., Martin, A. W., \& McCarthy, J. D. (2008). Confronting the state, the corporation, and the academy: The influence of institutional targets on social movement repertoires. American Journal of Sociology, 114(1), 35-76.

Wedeen, L. (2002). Conceptualizing culture: Possibilities for political science. The American Political Science Review, 96(4), 713-728. 
Weipert-Fenner, I. (2021). Go local, go global: Studying popular protests in the MENA post-2011. Mediterranean Politics.

Wessel, S. (2016). Grey-scales: Negotiating the civil state in post-revolutionary Egypt (CARPO Study: The Dawla Madaniyya Series No. 3). CARPO. https://carpo-bonn.org/ wp-content/uploads/2016/12/CARPO_Study_03_2016_Wessel.pdf?fbclid=IwAR1xw91dRRjp9wRIW_oxoPdhQK $7 \mathrm{Y}_{2}$ GoMo-id_V7MoslqGV5zRjKbWifoFw

Wiki Thawra. (2014). Statistical Database of the Egyptian Revolution. Statistical Database of the Egyptian Revolution. https://wikithawra.wordpress.com/ 



\section{Bibliography}

Abaza, M. (2014). Post January revolution Cairo: Urban wars and the reshaping of public space. Theory, Culture \& Society, 31(7-8), 163-183. https://doi.org/10.1177/0263276414549264

Abaza, M. (2016). Violence, dramaturgical repertoires and neoliberal imaginaries in Cairo. Theory, Culture \& Society, 33(7-8), 111-135. https://doi.org/10.1177/0263276416670729

ABC/AFP. (2013, July 25). Egypt's military, Muslim Brotherhood call for protests. ABC News. https://www.abc.net.au/news/2013-07-25/egypts-defiant-muslim-brotherhood-leaderurges-27stand27-a/484470o

Abdalla, K. (2016). Changing frames and fault-lines. In M. Baker(Ed.), Translating dissent: Voices from and with the Egyptian Revolution (pp. 33-44). Routledge.

Abdalla, N. (2016). Youth movements in the Egyptian transformation: Strategies and repertoires of political participation. Mediterranean Politics, 21(1), 44-63. https://doi.org/10.1080/13629 $395 \cdot 2015 \cdot 1081445$

Abdel Ghaffar, A. (2013, August 7). Egypt's framing wars of June 3oth. OpenDemocracy. http:// www.opendemocracy.net/adel-abdel-ghafar/egypts-framing-wars-of-june-3oth

Abdel Hafez, G., Abdel Rahman, H., Ibrahim, H., Al-Shazly, I., Al-Sheikh, O., Abu Al-Enein, M., \& Mulla, M. (2017, June 16). Tiran and Sanafir: Security forces detain dozens of protesters [Arabic]. Al-Masry Al-Youm. https://www.almasryalyoum.com/news/details/1149640

Abdel Salam, M. (2013, December 20). Egyptian universities between the Brotherhood and the military [Carnegie Endowment for International Peace]. Sada. http://carnegieendowment. org $/$ sada/index.cfm?fa $=$ show\&article $=53998 \&$ solr_hilite $=$

Abdelbaseer, M. (2016, January 25). Cairo's Rabaa massacre: Between a murderous army and urban failure. FA: Failed Architecture. https://www.failedarchitecture.com/ cairos-rabaa-massacre-between-a-murderous-army-and-urban-failure/

Abdelbaseer, M., van Nes, A., \& Salheen, M. A. (2014). Space and protest: A tale of two Egyptian squares. Proceedings of the 1oth International Space Syntax Symposium, 110, 1-18.

Abdelrahman, M. (2009). 'With the Islamists? - Sometimes. With the state? - Never!' Cooperation between the Left and Islamists in Egypt. British Journal of Middle Eastern Studies, 36 (1), 37-54.

Abdelrahman, M. (2015). Egypt's long revolution: Protest movements and uprisings. Routledge.

Abdelrahman, M. (2017). Policing neoliberalism in Egypt: The continuing rise of the 'securocratic' state. Third World Quarterly, 38(1), 185-202. https://doi.org/10.1080/01436597.2015.1133246

Abedine, S., \& Abdelaziz, S. (2013, July 25). Pro-Morsy group calls for Egypt protests, warns of violence. CNN. https://edition.cnn.com/2013/07/24/world/africa/egypt-unrest/index.html

Aboul Foutuh, A. M. (2016, April 10). The only ones who will benefit from tampering with Egypt's eastern borders will be the Zionists [Tweet]. https://twitter.com/DrAbolfotoh/ status/719003541722046466

Abu-Lughod, L. (2014). Writing against culture. In H. L. Moore \& T. Sanders (Eds.), Anthropology in theory: Issues in epistemology (2nd ed., pp. 466-479). Wiley Blackwell.

Achcar, G. (2013). The people want: A radical exploration of the Arab uprising. University of California Press.

Adly, A. (2014, October 14). Egypt's conservative nationalism: Discourse and praxis of the new regime. Carnegie Middle East Center. http://www.jadaliyya.com/Details/31358/ Egypt\%e2\%80\%99s-Conservative-Nationalism-Discourse-and-Praxis-of-the-New-Regime

Afsaruddin, A. (2016). Jihad and martyrdom in Islamic thought and history. In Oxford Research Encyclopedia of Religion. Oxford University Press. http://religion.oxfordre.com/view/10.1093/ acrefore/9780199340378.001.0001/acrefore-9780199340378-e-46 
AFTE. (2018, February 1). A decision from an unknown party about the blocking of websites in Egypt. Association for Freedom of Thought and Expression. https://archive.vn/wip/9Mdxm Al-Anani, K. (2015a). Upended path: The rise and fall of Egypt's Muslim Brotherhood. The Middle East Journal, 69(4), 527-543.

Al-Anani, K. (2015b, August 12). When murder becomes a national project. The New Arab. https:// www.alaraby.co.uk/english/comment/2015/8/12/when-murder-becomes-a-national-project

Al-Anani, K. (2016). Inside the Muslim Brotherhood: Religion, identity, and politics. Oxford University Press.

Al-Atrush, S. (2016, April 16). Chants are retro 2011. Bread freedom etc. And football inspired 'ooh ooh bleep Sisi your bleep' [Tweet]. @SameralAtrush. https://twitter.com/SameralAtrush/ status/720976017997881344

Al-Awadi, H. (2013). Islamists in power: The case of the Muslim Brotherhood in Egypt. Contemporary Arab Affairs, 6(4), 539-551. https://doi.org/10.1080/17550912.2013.856079

Al-Bedaiah. (2016, April 24). A day before the demonstrations of April 25, Interior Minister: We will deal firmly and firmly with attempts to 'disturb the security' [Arabic]. Al-Bedaiah. http:// albedaiah.com/news/2016/04/24/111758

Al-Dakhakhly, F. (2014, August 1). Government decision to reshape fact-finding committee on the events of the 'June 3 o Revolution' today [Arabic]. Al-Masry Al-Youm. https://www.almasryalyoum.com/news/details/372591

Alexander, A., \& Aouragh, M. (2014). Egypt's unfinished revolution: The role of the media revisited. International Journal of Communication, 8, 890-915.

Ali, A., \& El-Sharnouby, D. (2014). Distorting digital citizenship: Khaled Said, Facebook, and Egypt's streets. In L. Herrera (Ed.), Wired citizenship: Youth learning and activism in the Middle East (pp. 89-103). Routledge.

Ali, K. (2016, April 21). Today I filed a lawsuit against the waiver of the islands [Arabic]. Facebook. https://www.facebook.com/khaled.ali.72/posts/822837647861595

Alimi, E. Y. (2009). Mobilizing under the gun: Theorizing political opportunity structure in a highly repressive setting. Mobilization, 14(2), 219-237. https://doi.org/10.17813/ maiq.14.2.u210745765568737

Alimi, E. Y., Bosi, L., \& Demetriou, C. (2012). Relational dynamics and processes of radicalization: A comparative framework. Mobilization, 17(1), 7-26. https://doi.org/10.17813/ maiq.17.1.u7rw348t8200174h

Alimi, E. Y., \& Meyer, D. S. (2011). Seasons of change: Arab Spring and political opportunities. Swiss Political Science Review, 17(4), 475-479. https://doi.org/10.1111/j.1662-6370.2011.02041.X

Almeida, P. (2003). Opportunity organizations and threat-induced contention: Protest waves in authoritarian settings. American Journal of Sociology, $109(2), 345-400$. https://doi. org/10.1086/378395

Alsharif, A., \& Saleh, Y. (2013, October 10). Special report: The real force behind Egypt's 'revolution'. Reuters. https://www.reuters.com/article/us-egypt-interior-specialreport/ special-report-the-real-force-behind-egypts-revolution-of-the-state-idUSBRE99908D20131010

Al-Sisi, A. F. (2016a, April 13). Text of Al-Sisi's speech to community representatives [Arabic, on file]. Al-Manassa. https://archive.vn/wip/Ghsoy

Al-Sisi, A. F. (2016b, April 24). Statement by H.E. President of the Arab Republic of Egypt Abdel Fattah El Sisi on the 34th anniversary of Sinai liberation [On file]. State Information Services.

Aman, A. (2016, April 17). Protesters return to Egypt's streets. Al-Monitor. http://www.al-monitor. com/pulse/originals/2016/o4/egypt-cairo-protests-sisi-islands-saudi-arabia.html

Amar, P. (2011). Turning the gendered politics of the security state inside out? International Feminist Journal of Politics, 13(3), 299-328. https://doi.org/10.1080/14616742.2011.587364 
Amar, P. (2013). The security archipelago: Human-security states, sexuality politics, and the end of neoliberalism. Duke University Press.

Amnesty International. (2013a, July 10). Egypt: Damning evidence points to security forces'failures. https://www.amnesty.org/en/press-releases/2013/o7/egypt-damning-evidence-pointssecurity-forces-failures/

Amnesty International. (2013b, August 2). Egypt: Evidence points to torture carried out by Morsi supporters. https://www.amnesty.org/en/press-releases/2013/o8/egypt-evidencepoints-torture-carried-out-morsi-supporters/

Amnesty International. (2018, September 8). Egypt: Death sentences and heavy prison terms handed down in disgraceful mass trial. https://bit.ly/2u4iZPp

Andeel. (2014, February 3). Lexicon of a revolution's insults. Mada Masr. http://www.madamasr. com/sections/culture/lexicon-revolutions-insults

Andrade, A. (2015, February 2). Illustrating Laclau and Mouffe's discourse theory with a social network approach. Models of Interaction, Reasoning and Learning. http://alandra.org/laandrad/?p=108

Angermüller, J. (2001). Diskursanalyse: Strömungen, Tendenzen, Perspektiven. Eine Einführung. In J. Angermüller, K. Bunzmann, \& M. Nonhoff(Eds.), Diskursanalyse: Theorien, Methoden, Anwendungen (pp. 7-22). Argument Hamburg.

Antoun, N., \& Parietti, L. (2013, December 6). Making an example. Mada Masr. https://madamasr. com/en/2013/12/o6/feature/politics/making-an-example/

Aoudé, I. G. (2013). Egypt: Revolutionary process and global capitalist crisis. Arab Studies Quarterly, 35(3), 241-254. https://doi.org/10.13169/arabstudquar.35·3.0241

April 6 Youth Movement. (2016a, April 14). These things are not for sale [Arabic]. Facebook. https://bit.ly/2Hn2IwP

April 6 Youth Movement. (2016b, April 15). Now, in front of the Judges Club [Arabic]. Facebook. https://www.facebook.com/m6april/photos/a.119279621491044.29804.119276198158053/101 $4648468620817 /$ type $=3 \&$ theater

April 6 Youth Movement. (2016c, April 16). Comment on Facebook event: Over our bodies. Facebook. https://www.facebook.com/events/1586440928333688/

April 6 Youth Movement. (2016d, April 16). Protest call for April 15: Over our bodies [Arabic]. Facebook. https://www.facebook.com/events/1586440928333688/

April 6 Youth Movement. (2016e, April 16). The barrier offearwas not only broken, it was successfully obliterated [Tweet]. https://twitter.com/shabab6april/status/721264645789487105

April 6 Youth Movement. (2016f, April 16). The land of honour is not for sale [Arabic]. Facebook. https://www.facebook.com/events/584421871719292/

April 6 Youth Movement. (2016g, April 16). The people, the army and the demonstrations yesterday. Facebook. https://archive.vn/wip/EWCH6

Archer, M. S. (2003). Structure, agency and the internal conversation. Cambridge University Press. Armbrust, W. (2013, May 8). The ambivalence of martyrs and the counter-revolution. Cultural Anthropology. https://culanth.org/fieldsights/213-the-ambivalence-of-martyrs-and-thecounter-revolution

Armbrust, W. (2015). The iconic stage: Martyrologies and performance frames in the January $25^{\text {th }}$ revolution. In R. Abou-El-Fadl (Ed.), Revolutionary Egypt: Connecting domestic and international struggles (pp. 43-64). Routledge.

Askanius, T. (2013). Protest movements and spectacles of death: From urban places to video spaces. In Nicole Doerr, Simon Teune, \& Alice Mattoni (Eds.), Advances in the visual analysis of social movements (pp. 105-136). Emerald Group Publishing Limited.

Atef, M., \& Frenkel, S. (2014, April 15). How Egypt's rebel movement helped pave the way for a Sisi presidency. BuzzFeed. https://www.buzzfeed.com/sheerafrenkel/how-egypts-rebelmovement-helped-pave-the-way-for-a-sisi-pre 
Awad, M. (2017). The role of traditional and new media in the Egyptian Muslim Brotherhood's internal power struggle. Project on Middle East Political Science. https://pomeps.org/2017/o1/23/ the-role-of-traditional-and-new-media-in-the-egyptian-muslim-brotherhoods-internalpower-struggle/

Ayata, B., \& Harders, C. (2018). Midān moments: Conceptualizing space, affect and political participation on occupied squares. In B. Röttger-Rössler \& J. Slaby (Eds.), Affect in relation: Families, places and technologies (pp. 115-133). Routledge.

Aydın-Düzgit, S. (2014). The seesaw friendship between Turkey's AKP and Egypt's Muslim Brotherhood. Carnegie Endowment for International Peace. https://carnegieendowment.org/2014/07/24/ seesaw-friendship-between-turkey-s-akp-and-egypt-s-muslim-brotherhood-pub-56243

Baheyya. (2012, December 8). Death knell for an old political style. Baheyya: Egypt Analysis and Whimsy. http://baheyya.blogspot.co.uk/2012/12/death-knell-for-old-political-style.html

Baheyya. (2013, August 8). Fetishizing the state. Baheyya: Egypt Analysis and Whimsy. http:// baheyya.blogspot.com/2013/o8/fetishizing-state.html

Bahgat, H. (2014, February 16). Who let the jihadis out? Mada Masr. https://www.madamasr.com/ en/2014/02/16/feature/politics/who-let-the-jihadis-out/

Bail, C. A. (2012). The fringe effect: Civil society organizations and the evolution of media discourse about Islam since the September 11th attacks. American Sociological Review, $77(6)$, 855-879. https://doi.org/10.1177/ooo3122412465743

Ball, P. (2005). On the quantification of horror: Notes from the field. In C. Davenport, H. Johnston, \& C. Mueller (Eds.), Repression and mobilization (pp. 189-208). University of Minnesota Press.

Barany, Z. (2011). Comparing the Arab revolts: The role of the military. Journal of Democracy, 22(4), 24-35.

Barthes, R. (1993). Camera lucida: Reflections on photography (R. Howard, Trans.; New Ed). Vintage Classics.

Bayat, A. (2005). Islamism and social movement theory. Third World Quarterly, 26(6), 891-908. https://doi.org/10.1080/01436590500089240

Bayat, A. (2010). Life as politics: How ordinary people change the Middle East. Stanford University Press.

Bedier, A. (2014, August 14). My brother was killed at Rabaa. Al-Jazeera English. https://www. aljazeera.com/indepth/opinion/2014/08/my-brother-was-killed-at-rabaa-201481411280500550. html

Beinin, J., \& Vairel, F. (2011). Social movements, mobilization, and contestation in the Middle East and North Africa. Stanford University Press.

Beissinger, M. R. (2002). Nationalist mobilization and the collapse of the Soviet state. Cambridge University Press.

Beissinger, M. R. (2009). Nationalism and the collapse of Soviet Communism. Contemporary European History, 18(3), 331-347.

Beissinger, M. R., Jamal, A. A., \& Mazur, K. (2015). Explaining divergent revolutionary coalitions: Regime strategies and the structuring of participation in the Tunisian and Egyptian revolutions. Comparative Politics, 48(1), 1-21.

Benford, R. D., \& Snow, D. A. (2000). Framing processes and social movements: An overview and assessment. Annual Review of Sociology, 26, 611-639.

Bennett, A. (2002). Where the model frequently meets the road: Combining statistical, formal, and case study methods [APSA Proceedings].

Bennett, A. (2004). Case study methods: Design, use, and comparative advantages. In D. F. Sprinz \& Y. Wolinsky-Nahmias (Eds.), Models, numbers \& cases: Methods for studying international relations (pp. 19-55). The University of Michigan Press. 
Bennett, W. L., \& Segerberg, A. (2013). The logic of connective action: Digital media and the personalization of contentious politics. Cambridge University Press.

Benski, T., \& Langman, L. (2013). The effects of affects: The place of emotions in the mobilizations of 2011: Current Sociology. https://doi.org/10.1177/0011392113479751

Benski, T., Langman, L., Perugorría, I., \& Tejerina, B. (2013). From the streets and squares to social movement studies: What have we learned? Current Sociology, 61(4), 541-561. https:// doi.org/10.1177/0011392113479753

Berriane, Y., \& Duboc, M. (2019). Allying beyond social divides: An introduction to contentious politics and coalitions in the Middle East and North Africa. Mediterranean Politics, 24(4), 399-419. https://doi.org/10.1080/13629395.2019.1639022

Biagini, E. (2017). The Egyptian Muslim Sisterhood between violence, activism and leadership. Mediterranean Politics, 22(1), 35-53. https://doi.org/10.1080/13629395.2016.1230943

Biagini, E. (2020). Islamist women's activism under Morsi's government (2011-2013): Political inclusion, gender and discourse. Egypte/Monde Arabe, $n^{\circ}{ }_{21}(1)$, 37-55. https://doi.org/10.400o/ ema.11592

Bildt, J. van de. (2015). The quest for legitimacy in postrevolutionary Egypt: Propaganda and controlling narratives. The Journal of the Middle East and Africa, 6(3-4), 253-274. https://doi. org/10.108o/21520844.2015.1087817

Birgün Daily. (2017, May 20). 'Rabia' işareti AKP tüzügüne de girdi! BİRG ̈̈NDAILY. https://www. birgun.net/haber-detay/rabia-isareti-akp-tuzugune-de-girdi-160439.html

Bishara, D. (2015). The politics of ignoring: Protest dynamics in late Mubarak Egypt. Perspectives on Politics, 13(4), 958-975. https://doi.org/10.1017/S153759271500225X

Blumer, H. (2009). Symbolic interactionism: Perspective and method. University of California Press.

Bolliger, R., Elmenshawy, M., \& Weilandt, R. (2016). The military, the media and public perceptions in Egypt: Communication and civil-military relations (Egypt Civil-Military Relations Conference Paper Series No. 3). Geneva Centre for the Democratic Control of Armed Forces. https:// www.dcaf.ch/sites/default/files/publications/documents/Egypt_Civil_Paper3_ENG.pdf

Boudreau, V. (2005). Precarious regimes and matchup problems in the explanation of repressive policy. In C. Davenport, H. Johnston, \& C. Mueller (Eds.), Repression and mobilization (pp. 33-57). University of Minnesota Press.

Bourdieu, P. (1987). What makes a social class? On the theoretical and practical existence of groups. Berkeley Journal of Sociology, 32, 1-17.

Bourdieu, P. (1993). The field of cultural production (R. Johnson, Ed.). Columbia University Press.

Bowen, J. (2012). Six days: How the 1967 war shaped the Middle East. Simon and Schuster.

Bradley, M. (2014, May 29). Egyptian TV swayed public against Morsi, in favor of Sisi. Wall Street Journal. http://www.wsj.com/articles/egyptian-tv-swayed-public-against-morsi-in-favorof-sisi-1401330765

Brand, L. A. (2014). Official stories: Politics and national narratives in Egypt and Algeria. Stanford University Press.

Brand, L. A., \& Stacher, J. (2016). Why two islands may be more important to Egyptian regime stability than billions in Gulf aid. In From mobilisation to counter-revolution (pp. 37-39). Project on Middle East Political Science. https://pomeps.org/wp-content/uploads/2016/o7/ POMEPS_Studies_2o_Mobilization_Web-REV.pdf

Brooke, S. (2013). Doctors and brothers. Middle East Report, 269, 12-17.

Brooke, S. (2015). The Muslim Brotherhood's social outreach after the Egyptian coup (Rethinking Political Islam Series). Brookings Institution.

Browers, M. (2007). Origins and architects of Yemen's Joint Meeting Parties. International Journal of Middle East Studies, 39(4), 565-586. 
Brown, G. (2014). Does framing matter? Institutional constraints on framing in two cases of intrastate violence. Mobilization, 19(2), 143-164. https://doi.org/10.17813/maiq.19.2.j13338h544l20720

Brown, J. (2013, July 18). On those protest numbers in Egypt: How many millions were we, my general? Counterpunch.https://www.counterpunch.org/2013/o7/18/on-those-protest-numbers-in-egypt/

Brown, N. (2013, July 17). Egypt's wide state reassembles itself. Foreign Policy. https://foreignpolicy. com/2013/07/17/egypts-wide-state-reassembles-itself/

Brown, N. J. (2013). Egypt's failed transition. Journal of Democracy, 24(4), 45-58.

Buzan, B., Wæver, O., \& Wilde, J. de. (1998). Security: A new framework for analysis. Lynne Rienner Pub.

Cambanis, T. (2013, July 21). What will give Egypt's ruler 'legitimacy'? Boston Globe. https://www. bostonglobe.com/ideas/2013/o7/2o/what-will-give-egypt-ruler-legitimacy/sNmW2ruHKkm8tFOuPTlg8H/story.html

Carr, S. (2013, August 17). An account of the Ramses violence. Jadaliyya. http://www.middleeastdigest.com/pages/index/13648/an-account-of-the-ramses-violence-

Cascão, A. E. (2011). Power relations, conflict, and cooperation in the eastern Nile river basin. In S. S. Elmusa (Ed.), The burden of resources: Oil and water in the GulfRegion and the Nile Basin (pp. 20-51). American University in Cairo Press.

Cascão, A. E., \& Nicol, A. (2016). GERD: New norms of cooperation in the Nile Basin? Water International, 41(4), 550-573. https://doi.org/10.1080/02508060.2016.1180763

CBC Egypt. (2013, July 3). Hunna al-'Asima - Statement of Sheikh Al-Azhar: Ahmed Tayeb. https:// www.youtube.com/watch?v=PAiVvXioqkg

Chalcraft, J. (2014). Egypt's 25 January uprising, hegemonic contestation, and the explosion of the poor. In F. A. Gerges (Ed.), The new Middle East: Protest and revolution in the Arab World (pp. 155-179). Cambridge University Press.

Chalcraft, J. (2016). The Arab uprisings of 2011 in historical perspective. In A. Ghazal \& J. Hanssen (Eds.), The Oxford handbook of contemporary Middle-Eastern and North African history. Oxford University Press. https://doi.org/10.1093/oxfordhb/9780199672530.013.13

Chalcraft, J., \& Noorani, Y. (2007). Counterhegemony in the colony and postcolony. Palgrave Macmillan. http://www.palgrave.com/us/book/9780230019188

Chang, L. T. (2013, June 27). Egypt's petition rebellion. The New Yorker. https://www.newyorker. com/news/news-desk/egypts-petition-rebellion

Chatterji, M. (2013). The globalization of politics: From Egypt to India. Social Movement Studies, 12(1), 96-102. https://doi.org/10.108o/14742837.2012.698132

Chayes, S. (2013, August 1). The Egyptian Restoration. Carnegie Endowment for International Peace. http://carnegieendowment.org/2013/o8/o1/egyptian-restoration/gh3o

Checkel, J. T. (2005). It's the process stupid! Process tracing in the study of European and international politics (Working Paper No. 26). ARENA. http://www.sv.uio.no/arena/english/research/ publications/arena-working-papers/2001-2010/2005/wpo5_26.pdf

CIHRS. (2014, July 24). Memo to Ibrahim Mahlab, Prime Minister. https://www.cihrs.org/wpcontent/uploads/2014/o7/Memo-to-Dr.-Ibrahim-Mahlab.pdf

Clarke, K. (2011). Saying 'enough': Authoritarianism and Egypt's Kefaya movement. Mobilization: An International Journal, 16(4), 397-416. https://doi.org/10.17813/maiq.16.4.m728m673p7340l23

Cole, J. (2016, April 11). Egyptian President Sisi is ridiculed for 'selling' islands to Saudi Arabia. The Nation. http://www.thenation.com/article/egypts-sisi-ridiculed-for-selling-islandsto-saudi-arabia/

Comay, N. (2005). Arabs speakfrankly on the Arab-Israeli conflict: With original documents and comments by world leaders and writers. Printing Miracles Limited. 
Cook, D. (2002). Suicide attacks or 'martyrdom operations' in contemporary jihad literature. Nova Religio: The Journal of Alternative and Emergent Religions, 6(1), 7-44. https://doi.org/10.1525/ nr.2002.6.1.7

Cook, D. (2007). Martyrdom in Islam. Cambridge University Press.

Cook, D. (2012). Martyrdom (Shahada) [Data set]. In Oxford Bibliographies. Oxford University Press. https://doi.org/10.1093/obo/9780195390155-0124

Cook, S. A. (2012, August 9). Brother knows best. Foreign Policy. https://foreignpolicy. com/2012/o8/og/brother-knows-best/

CPJ. (2016, April 25). Scores ofjournalists harassed, detained amid Egypt protests. Committee to Protect Journalists. https://cpj.org/2016/04/scores-of-journalists-harassed-detained-amidegypt.php

Cremer-Schäfer, H. (1992). Skandalisierungsfallen. Einige Anmerkungen dazu, welche Folgen es hat, wenn wir das Vokabular 'der Gewalt' benutzen, um auf gesellschaftliche Probleme und Konflikte aufmerksam zu machen. KriminologischesJournal, 24(1), 23-36.

Dakroury, N. (2013, July 29). National Defence Council closely monitoring Rabaa and Al-Nahda sit-ins. Daily News Egypt. https://www.masress.com/en/dailynews/207454

Davenport, C. (2005). Introduction: Repression and mobilization: Insights from political science and sociology. In C. Davenport, H. Johnston, \& C. Mueller (Eds.), Repression and mobilization (pp. vii-xli). University of Minnesota Press.

Davenport, C. (2007a). State repression and the domestic democratic peace. Cambridge University Press.

Davenport, C. (2007b). State repression and political order. Annual Review of Political Science, $10(1), 1-23$. https://doi.org/10.1146/annurev.polisci.10.101405.143216

Davenport, C., \& Loyle, C. (2012). The states must be crazy: Dissent and the puzzle of repressive persistence. International Journal of Conflict and Violence (IJCV), 6(1), 75-95. https://doi. org/10.4119/ijcv-2931

Davenport, C., \& Moore, W. H. (2012). The Arab Spring, winter, and back again? (Re)introducing the dissent-repression nexus with a twist. International Interactions, $38(5), 704-713$. https:// doi.org/10.1080/03050629.2012.726187

Davis, N. J., \& Robinson, R. V. (2012). Claiming society for god: Religious movements and social welfare Egypt, Israel, Italy, and the United States. Indiana University Press.

Dawisha, A. (2003). Arab nationalism in the twentieth century: From triumph to despair. Princeton University Press. https://doi.org/10.2307/j.ctt7shc6

Dawoud, K. (2016a, May 20). A swift response to Egypt's April 25 dissent. Atlantic Council. http:// www.atlanticcouncil.org/blogs/menasource/a-swift-response-to-egypt-s-april-25-dissent

Dawoud, K. (2016b, June 23). Support for Egypt's press syndicate fades. Atlantic Council. http:// www.atlanticcouncil.org/blogs/menasource/support-for-egypt-s-press-syndicate-fades

De Smet, B. (2015). A dialectical pedagogy of revolt: Gramsci, Vygotsky, and the Egyptian Revolution. Brill. https://doi.org/10.1163/9789004262669

De Smet, B. (2016). Gramsci on Tahrir: Revolution and counter-revolution in Egypt. Pluto Press.

Della Porta, D. (2006). Social movements, political violence, and the state. Cambridge University Press.

Della Porta, D. (2008). Eventful protest, global conflicts. Distinktion, 9(2), 27-56.

Della Porta, D. (2011). Eventful protest, global conflicts: Social mechanisms in the reproduction of protest. In J. M. Jasper \& J. Goodwin (Eds.), Contention in context: Political opportunities and the emergence of protest (pp. 256-276). Stanford University Press.

Della Porta, D. (2014a). Mobilizing for democracy: Comparing 1989 and 2011. Oxford University Press. 
Della Porta, D. (2014b). On violence and repression: A relational approach (the Leonard Schapiro memorial lecture, 2013). Government and Opposition, 49(2), 159-187. https://doi.org/10.1017/ gov.2013.47

Della Porta, D. (Ed.). (2014c). Methodological practices in social movement research. Oxford University Press.

Della Porta, D. (2016). Where did the revolution go? Contentious politics and the quality of democracy. Cambridge University Press.

Della Porta, D. (2017). Riding the wave: Protest cascades, and what we can learn from them. In D. Della Porta (Ed.), Global diffusion of protest: Riding the protest wave in the neoliberal crisis (pp. 9-30). Amsterdam University Press.

Della Porta, D. (2018). Protests as critical junctures: Some reflections towards a momentous approach to social movements. Social Movement Studies, 1-20. https://doi.org/10.1080/1474 2837.2018.1555458

Della Porta, D., \& Atak, K. (2017). The spirit of Gezi: A relational approach to eventful protest and its challenges. In Global diffusion of protest: Riding the protest wave in the neoliberal crisis (pp. 31-58). Amsterdam University Press. https://doi.org/10.1515/9789048531356-003

Della Porta, D., \& Tarrow, S. (2012). Interactive diffusion: The coevolution of police and protest behavior with an application to transnational contention. Comparative Political Studies, 45(1), 119-152. https://doi.org/10.1177/0010414011425665

Demmelhuber, T. (2014). Kann ein Putsch demokratisch sein? Normativer Etikettenschwindel in Ägypten. Zeitschrift Für Politik, 6r(1), 42-6o.

Denzin, N. K., \& Lincoln, Y. S. (Eds.). (2000). The SAGE handbook of qualitative research (4th ed). Sage.

Di Donato, M. (2012). Understanding the Arab Uprisings through the analysis of the terms Intifada and Istishad [Paper presented at BRISMES Annual Conference London School of Economics and Political Science 26-28 March 2012 'Revolution and Revolt: Understanding the Forms and Causes of Change']. https://brismes2012.files.wordpress.com/2012/o2/marco-di-donatounderstanding-the-arab-uprisings.pdf

Diani, M. (1992). Analysing social movement networks. In M. Diani \& R. Eyerman (Eds.), Studying collective action (pp. 107-135). Sage Publications.

DiMaggio, P. J., \& Powell, W. W. (1983). The iron cage revisited: Institutional isomorphism and collective rationality in organizational fields. American Sociological Review, 48(2), 147-16o. https://doi.org/10.2307/2095101

Doherty, B., \& Hayes, G. (2015). The courts: Criminal trials as strategic arenas. In J. W. Duyvendak \& J. M. Jasper (Eds.), Breaking down the state: Protestors engaged (pp. 27-52). Amsterdam University Press. https://doi.org/10.2307/j.ctt196315k.4

Dunne, M., \& Brown, N. (2014). Egypt's judges join in. Carnegie Endowment for International Peace. http://carnegieendowment.org/2014/04/o2/egypt-s-judges-join-in/h6tf

Dupont, P.-E., \& McGarry, B. (2016). The Egypt-Saudi Arabia agreement on Tiran and Sanafir: Law of the sea and security issues. London Center of International Law Practice. http://www.lcilp. org/wp-content/uploads/2016/o5/CILMB-Brief-April-2016-Egypt-Saudi-Arabia-Agreementon-Tiran-and-San....pdf

Durac, V. (2015). Social movements, protest movements and cross-ideological coalitions: The Arab Uprisings re-appraised. Democratization, 22(2), 239-258. https://doi.org/10.1080/13510 347.2015.1010809

Duyvendak, J. W., \& Fillieule, O. (2015). Conclusion: Patterned fluidity: an interactionist perspective as a tool for exploring contentious politics. In J. W. Duyvendak \& J. M. Jasper (Eds.), Players and arenas: The interactive dynamics of protest (pp. 295-318). Amsterdam University Press. https://doi.org/10.2307/j.ctt16vj285.16 
Duyvendak, J. W., \& Jasper, J. M. (Eds.). (2015). Breaking down the state: Protestors engaged. Amsterdam University Press.

Dworkin, A. (2013). The struggle for pluralism after the North African revolutions (ECFR Policy Brief No. 74). ECFR. http://www.ecfr.eu/page//ECFR74_PLURALISM_REPORT.pdf

Dworkin, A., \& Michou, H. (2014). Egypt's unsustainable crackdown (ECFR Policy Brief No. 92). ECFR. http://www.ecfr.eu/page/-/ECFR92_EGYPT_MEMO.pdf

Earl, J. (2003). Tanks, tear gas, and taxes: Toward a theory of movement repression. Sociological Theory, 21(1), 44-68. https://doi.org/10.1111/1467-9558.00175

Earl, J., Martin, A., McCarthy, J. D., \& Soule, S. A. (2004). The use of newspaper data in the study of collective action. Annual Review of Sociology, 3o(1), 65-80. https://doi.org/10.1146/annurev. soc.30.012703.110603

Earl, J., \& Soule, S. A. (2010). The impacts of repression: The effect of police presence and action on subsequent protest rates. In P. G. Coy (Ed.), Research in social movements, conflicts and change (pp. 75-113). Emerald Group Publishing Limited.

Economidou, M. (2018, February 13). Interview with Yannis Stavrakakis for the New Pretender, February 2018. The New Pretender. https://new-pretender.com/2018/o2/13/interview-withyannis-stavrakakis/

Egypt Interior Ministry. (2016a, April 14). Statement issued by the Ministry of the Interior [On file]. Egypt Ministry of Interior Official Website.

Egypt Interior Ministry. (2016b, April 15). Cairo security service is directing a large security campaign involving a number of streets and squares of the capital [On file]. Official Website.

EIPR. (2014). The weeks of killing: State violence, communal violence and sectarian attacks in the summer of 2013. Egyptian Initiative for Personal Rights. https://eipr.org/sites/default/files/ reports/pdf/weeks_of_killing-en.pdf

El Chazli, Y. (2018). It takes two (or more) to tango. In F. Volpi \& J. M. Jasper (Eds.), Microfoundations of the Arab uprisings: Mapping interactions between regimes and protesters (pp. 135-158). Amsterdam University Press.

El Gendi, Y. (2017). Coptic commemorative protests and discourses of Egyptian nationalism: A visual analysis. Middle East - Topics \& Arguments, 8, 45-57.

El Zein, R., \& Ortiz, A. (Eds.). (2011). Signs of the times. The popular literature of Tahrir. Protest signs, graffiti, \& street art. ArteEast.

El-Amrani, I. (2011). Popular protest in North Africa and the Middle East (I): Egypt victorious? (Middle East/North Africa Report No. 101). International Crisis Group. http://www.crisisgroup. org/en/regions/middle-east-north-africa/north-africa/egypt/101-popular-protest-in-northafrica-and-the-middle-east-i-egypt-victorious.aspx

El-Amrani, I. (2013). Marching in circles: Egypt's dangerous second transition (Middle East/North Africa Briefing No. 35). International Crisis Group. http://www.crisisgroup.org/ /media/ Files/Middle\%2oEast\%2oNorth\%2oAfrica/North\%2oAfrica/Egypt/bo35-marching-incircles-egypts-dangerous-second-transition.pdf

El-Dabh, B. (2013a, July 8). Sorrow and anger at Rabaa Al-Adaweya. Daily News Egypt. https:// dailynewsegypt.com/2013/07/08/sorrow-and-anger-at-rabaa-al-adaweya/

El-Dabh, B. (2013b, December 27). Freezing of assets of Islamic NGOs 'open door' to conversions of poor Muslims. Daily News Egypt. https://dailynewsegypt.com/2013/12/27/freezing-of-assetsof-islamic-ngos-open-door-to-conversions-of-poor-muslims-brotherhood/

El-Ghobashy, M. (2011). The praxis of the Egyptian revolution. Middle East Report (MER), 41(258). http://www.merip.org/mer/mer258/praxis-egyptian-revolution 
El-Issawi, F. (2014). The role of Egyptian media in the coup. In IE Med. Mediterranean Yearbook 2014 (pp. 299-304). http://www.iemed.org/observatori/arees-danalisi/arxius-adjunts/anuari/ anuari-2014/ElIssawi_egypt_media_military_coup_IEMed_yearbook_2014_EN.pdf

Ellefsen, R. (2016). Judicial opportunities and the death of SHAC: Legal repression along a cycle of contention. Social Movement Studies, 15(5), 441-456.

El-Mahdi, R. (2009). The democracy movement: Cycles of protest. In R. El-Mahdi \& P. Marfleet (Eds.), Egypt: The moment of change. Zed Books.

Elmeshad, M. (2016, April 29). Sisi sours on the media [Carnegie Endowment for International Peace]. Sada. http://carnegieendowment.org/sada/?fa $=63493$

El-Rashidi, S. (2013, June 27). Egyptian police divided in run-up to zo June anti-Morsi rallies. Ahram Online. http://english.ahram.org.eg/NewsContent/1/64/74399/Egypt/Politics-/ Egyptian-police-divided-in-runup-to--June-antiMors.aspx

Elsayed, Y. (2013). Revolutionary media on a budget: Facebook-only social journalism. Arab Media and Society, 17, 1-27.

El-Sharnouby, D. (2018a). Youth subjectivity at a post-ideological turn: The 2011 revolution in Egypt and youth's political imaginary. A case study of the Bread and Freedom Party [Doctoral Dissertation at the Center of Middle Eastern and North African Politics]. Freie Universität Berlin.

El-Sharnouby, D. (2018b). New social movements: The case of youth's political project in Egypt. Middle East Law and Governance, $10(3), 264-290$. https://doi.org/10.1163/18763375-01003003

El-Sheikh, S. (2016, May 30). Tadamon coalition to escalate actions against civil service draft law. Daily News Egypt. https://dailynewsegypt.com/2016/05/3o/tadamon-coalition-escalateactions-civil-service-draft-law/

El-Sherif, A. (2014). The Muslim Brotherhood and the future of political Islam. Carnegie Endowment for International Peace. http://carnegieendowment.org/files/mb_future_egypti.pdf

Elyachar, J. (2014). Upending infrastructure: 'Tamarod', resistance, and agency after the January 25th Revolution in Egypt. History and Anthropology, 25(4), 452-471. https://doi.org/10.1 080/02757206.2014.93046o

Eren, S. (2017, August 21). The Rabaa story: Who created the iconic hand gesture? TRT World. https:// www.trtworld.com/opinion/the-rabaa-story-who-created-the-iconic-hand-gesture--9732

Escobales, R., Holpuch, A., \& Weaver, M. (2013, July 5). Egypt's ‘day of rejection' - Friday 5 July as it happened. The Guardian. https://www.theguardian.com/world/middle-east-live/2013/ jul/o5/egypt-braced-day-of-rejection-live

Eshhad: The Center for the Protection of Minorities. (2018). Database. Eshhad. https://eshhad. org/database/

Euben, R. L. (2002). Killing (for) politics: Jihad, martyrdom, and political action. Political Theory, 3o(1), 4-35.

Eyadat, Z. (2015). A transition without players: The role of political parties in the Arab revolutions. Democracy and Security, n(2), 160-175. https://doi.org/10.1080/17419166.2015.1043080

Ezzat, D. (2013, May 12). Wild rumours of Hamas interference in Egypt find audience. Ahram Online. http://english.ahram.org.eg/News/71258.aspx

Fadel, M. (2014, January 8). What killed Egyptian democracy? Boston Review. https://bostonreview. net/forum/mohammad-fadel-what-killed-egyptian-democracy

Fahim, K. (2012, August 8). Morsi fires intelligence chief and Sinai governor over soldiers' killings. The New York Times. https:/www.nytimes.com/2012/o8/og/world/middleeast/egypt-sinaiattacks.html

Fahim, K., \& Sheikh, M. E. (2013, August 17). Soldiers storm a mosque in Cairo, as Egyptian leaders struggle for order. The New York Times. https://www.nytimes.com/2013/o8/18/world/ middleeast/standoff-in-cairo-as-security-forces-surround-mosque.html 
Fahim, K., \& Sheikh, M. E. (2018a, October 19). Egyptian general calls for mass protests. The New York Times. https://www.nytimes.com/2013/07/25/world/middleeast/egypt.html

Fahim, K., \& Sheikh, M. E. (2018b, October 19). Memory of a mass killing becomes another casualty of Egyptian protests. The New York Times. https://www.nytimes.com/2013/11/14/world/middleeast/memory-egypt-mass-killing.html

Fahmi, W. S. (2009). Bloggers' street movement and the right to the city: (Re)claiming Cairo's real and virtual 'spaces of freedom'. Environment and Urbanization, 21(1), 89-107. https://doi. org/10.1177/0956247809103006

Fairey, S. (1990). Manifesto. Obey Giant. https://obeygiant.com/propaganda/manifesto/

Farid, S. (2014, May 8). April 6: Egypt's latest outlawed group. Al Arabiya English. http://ara.tv/ vprop

Fayed, S., \& Saleh, Y. (2013, June 30). Millions flood Egypt's streets to demand Mursi quit. Reuters. https://www.reuters.com/article/us-egypt-protests-idUSBRE95QoNO20130630

Fearon, J. D., \& Laitin, D. D. (2008). Integrating qualitative and quantitative methods. In J. M. Box-Steffensmeier, H. E. Brady, \& D. Collier (Eds.), Oxford Handbook of Political Methodology (pp. 756-776). Oxford University Press.

Feldman, N. (2012, November 27). Egypt's Mursi turns tyrant to save democracy. Bloomberg Opinion. https://www.bloomberg.com/opinion/articles/2012-11-26/egypt-s-mursi-turnstyrant-to-save-democracy

Filali-Ansary, A. (2012). The languages of the Arab revolutions. Journal of Democracy, 23(2), 5-18. https://doi.org/10.1353/jod.2012.0035

FJP. (2013a, August 15). FJP Condemns Attacks on Copts; Reaffirms Revolution Non-Violence. Ikhwanweb. https://archive.is/wip/JbjLA

FJP. (2013b, August 16). FJP Reiterates Denunciation of Attacks on Copts, Churches and Property - Ikhwanweb. Ikhwanweb. http://www.ikhwanweb.com/article.php?id=31246

FJP Helwan. (2013, August 16). FJP Helwan on the church attacks [Arabic]. Facebook. https://www. facebook.com/FJ.Helwan/posts/516124478472316

Fligstein, N., \& McAdam, D. (2015). A theory of fields (First issued as an Oxford University Press paperback). Oxford University Press.

Foran, J., \& Goodwin, J. (1993). Revolutionary outcomes in Iran and Nicaragua: Coalition fragmentation, war, and the limits of social transformation. Theory and Society, 22(2), 209-247.

Foucault, M. (1977). Discipline and punish: The birth of the prison. Vintage Books.

Francisco, R. A. (1995). The relationship between coercion and protest: An empirical evaluation in three coercive states. The Journal of Conflict Resolution, 39(2), 263-282.

Francisco, R. A. (2004). After the massacre: Mobilization in the wake of harsh repression. Mobilization: An International Quarterly, 9(2), 107-126.

Fraser, N. (1990). Rethinking the public sphere: A contribution to the critique of actually existing democracy. Social Text, 25/26, 56-80. https://doi.org/10.2307/466240

Gaber, S. (2016). What word is this place? Translating urban social justice and governance. In M. Baker (Ed.), Translating dissent: Voices from and with the Egyptian Revolution (pp. 97-106). Routledge.

Gaffney, P. D. (1991). The changing voices of Islam: The emergence of professional preachers in contemporary Egypt. The Muslim World, 81(1), 27-47. https://doi.org/10.1111/j.1478-1913.1991. tbo3510.x

Gamson, W. A. (1992). The social psychology of collective action. In A. D. Morris \& C. Mueller (Eds.), Frontiers in social movement theory (pp. 53-76). Yale University Press.

Ghanem, T. (2016, May 30). O brother, what is prison? On Malek Adly. Mada Masr. http://www. madamasr.com/opinion/o-brother-what-prison-malek-adly 
Giugni, M. (2009). Political opportunities: From Tilly to Tilly. Swiss Political Science Review, 15(2), 361-367. https://doi.org/10.1002/j.1662-6370.2009.tboo136.x

Glasze, G. (2007). Proposals for the operationalisation of the discourse theory of Laclau and Mouffe using a triangulation of lexicometrical and interpretative methods. Forum Qualitative Sozialforschung, 8(2). http://www.qualitative-research.net/index.php/fqs/article/view/239

Glynos, J., Howarth, D., Norval, A., \& Speed, E. (2009). Discourse analysis: Varieties and methods (ESRC National Centre for Research Methods Review Paper No. 14). http://eprints.ncrm. ac.uk/796/1/discourse_analysis_NCRM_014.pdf

Goertz, G. (2017). Multimethod research, causal mechanisms, and case studies: An integrated approach. Princeton University Press.

Goffman, E. (1986). Strategic interaction (3rd ed.). University of Pennsylvania Press.

Gold, Z. (2014, May 22). Egypt's war on terrorism [Carnegie Endowment for International Peace]. Sada. http://carnegieendowment.org/sada/2014/05/22/egypt-s-war-on-terrorism/hbdq

Goldstone, J. A. (2009). Rethinking revolutions: Integrating origins, processes, and outcomes. Comparative Studies of South Asia, Africa and the Middle East, 29(1), 18-32.

Goldstone, J. A. (2011). Cross-class coalitions and the making of the Arab revolts of 2011. Swiss Political Science Review, 17(4), 457-462.

Goodwin, J., Jasper, J. M., \& Khattra, J. (1999). Caught in a winding, snarling vine: The structural bias of political process theory. Sociological Forum, 14(1), 27-54.

Gramsci, A. (1971). Selections from prison notebooks. Lawrence and Wishart.

Grewal, S. (2018). Explaining military defection and loyalty in the Mediterranean. Mediterranean Politics, 23(3), 427-432. https://doi.org/10.1080/13629395.2017.13060oo

Gribbon, L. (2013). The commodification of Egypt's revolutionary martyrs: Interpretive frames, mediated narratives and imagined solidarities. In N. Belakhdar, I. Eickhof, A. E. Khawaga, O. E. Khawaga, A. Hamada, C. Harders, \& S. Sandri (Eds.), Arab revolutions and beyond: Change and persistence. Proceedings of the international conference in Tunis, 12-13 November 2013 (pp. 101-112). Center for North African and Middle Eastern Politics. https://refubium.fu-berlin. de/handle/fub188/19057

Gribbon, L., \& Hawas, S. (2012). Signs and signifiers: Visual translations of revolt. In S. Mehrez (Ed.), Translating Egypt's revolution: The language of Tahrir (pp. 103-142). Oxford University Press.

Grimm, J. J. (2013, August 26). Riding the tiger [Carnegie Endowment for International Peace]. Sada. http://carnegieendowment.org/sada/2013/o8/26/riding-tiger/gkgr

Grimm, J. J. (2014, December 19). Sisi's moralism [Carnegie Endowment for International Peace]. Sada.http://carnegieendowment.org/sada/2014/12/19/sisi-s-moralism/hxnz

Grimm, J. J. (2015). Repressing Egypt's civil society: State violence, restriction of the public sphere, and extrajudicial persecution (SWP-Comments No. 41; p. 8). Stiftung Wissenschaft und Politik. http://www.swp-berlin.org/fileadmin/contents/products/comments/2015C41_gmm.pdf

Grimm, J. J. (2017, April 27). Convergent authoritarianisms in Egypt and Turkey [Carnegie Endowment for International Peace]. Sada. http://carnegieendowment.org/sada/68797

Grimm, J. J. (2019). Egypt is not for sale! Harnessing nationalism for alliance building in Egypt's Tiran and Sanafir island protests. Mediterranean Politics, 24(4), 443-466. https://doi.org/10 $.1080 / 13629395.2019 .1639024$

Grimm, J. J., \& Harders, C. (2018). Unpacking the effects of repression: The evolution of Islamist repertoires of contention in Egypt after the fall of President Morsi. Social Movement Studies, $17(1), 1-18$. https://doi.org/10.1080/14742837.2017.1344547

Grimm, J. J., Koehler, K., Lust, E., Saliba, I., \& Schierenbeck, I. (2020). Safer field research in the social sciences: A guide to human and digital security in hostile environments (1st ed). SAGE Publishing. 
Haenni, P. (2016). The reason for the Muslim Brotherhood's failure in power. In B. Rougier \& S. Lacroix (Eds.), Egypt's revolutions: Politics, religion, and social movements (pp. 19-40). Palgrave Macmillan.

Hafez, K. (2015). Radically polarized publics and the demise of media freedom in Egypt.Égypte/ Monde Arabe, 12. https://doi.org/10.4000/ema.3397

Hafez, M. (2003). Why Muslims rebel: Repression and resistance in the Islamic world. Lynne Rienner Publishers.

Haines, H. H. (2013). Radical flank effects. In D. A. Snow, D. D. Porta, P. G. Klandermans, \& D. McAdam (Eds.), The Wiley-Blackwell encyclopedia of social \& political movements (pp. 10481049). Wiley-Blackwell. https://doi.org/10.1002/9780470674871

Hakim, A. A. (1979). The Middle Eastern states and the law of the sea. Manchester University Press.

Halawa, H. (2021, October 11). Burning ambition: Egypt's return to regional leadership and how Europe should respond. European Council on Foreign Relations. https://ecfr.eu/ publication/burning-ambition-egypts-return-to-regional-leadership-and-how-europeshould-respond/

Hale, S. (2014). The new Middle East insurrections and other subversions of the modernist frame. Journal of Middle East Women's Studies, 10(3), 40-61. https://doi.org/10.2979/ jmiddeastwomstud.10.3.40

Hall, S. (1980). Cultural studies: Two paradigms. In Media, culture, and society: A critical reader (pp. 57-72). Sage.

Hall, S. (1982). The rediscovery of 'ideology': Return of the repressed in media studies. In M. Gurevitch, T. Bennett, J. Curran, \& J. Woollacott (Eds.), Culture, society, and the media (pp. 56-9o). Methuen.

Hall, S. (1988). The toad in the garden: Thatcherism among the theorists. In C. Nelson \& L. Grossberg (Eds.), Marxism and the interpretation of culture (pp. 35-57). Macmillan Education UK.

Halverson, J. R., Ruston, S. W., \& Trethewey, A. (2013). Mediated martyrs of the Arab Spring: New media, civil religion, and narrative in Tunisia and Egypt. Journal of Communication, 63(2), 312-332. https://doi.org/10.1111/jcom.12017

Hamada, A. (2014). Understanding the military role in the Egyptian revolution: Comparing February 2011 and July 2013. In N. Belakhdar, I. Eickhof, A. el Khawaga, O. el Khawaga, C. Harders, \& S. Sandri (Eds.), Arab revolutions and beyond (pp. 29-40). Center for Middle Eastern and North African Politics.

Hamama, M. (2016, August 14). Q\&A: Turkish designer of Rabea symbol - it's still alive. Mada Masr. https://madamasr.com/en/2016/o8/14/feature/politics/qa-turkish-designer-of-rabeasymbol-its-still-alive/

Hamzawy, A. (2016, November 8). Egypt's Orwellian populisms [Carnegie Middle East Center]. Diwan. https://carnegie-mec.org/diwan/65051

Hamzawy, A. (2017). Legislating authoritarianism: Egypt's new era of repression. Carnegie Endowment for International Peace. https://carnegieendowment.org/2017/03/16/ legislating-authoritarianism-egypt-s-new-era-of-repression-pub-68285

Hamzawy, A., \& Dunne, M. (2017). Egypt's secular political parties: A struggle for identity and independence. Carnegie Endowment for International Peace. https://carnegieendowment.org/2017/03/31/ egypt-s-secular-political-parties-struggle-for-identity-and-independence-pub-68482

Hanafi, A. (2015). Qamos Al-Thawra: A dictionary of the revolution. http://qamosalthawra.com/en Hanieh, A. (2013). Lineages of revolt: Issues of contemporary capitalism in the Middle East. Haymarket Books.

Haraway, D. (1988). Situated knowledges: The science question in feminism and the privilege of partial perspective. Feminist Studies, 14(3), 575-599. https://doi.org/10.2307/3178066 
Harders, C. (2009). Politik von unten - Perspektiven auf den autoritären Staat in Ägypten. In M. Beck, C. Harders, A. Jünemann, \& S. Stetter (Eds.), Der Nahe Osten im Umbruch (pp. 299-323). Springer VS.

Harders, C. (2015). "State analysis from below" and political dynamics in Egypt after 2011. International Journal of Middle East Studies, 47(1), 148-151.

Harders, C., \& König, C. (2013). Mobilization, repression and coalitions: Understanding the dynamics of the Arab Spring [Discussion Paper]. Center for Middle Eastern and North African Politics. https://www.polsoz.fu-berlin.de/polwiss/forschung/international/vorderer-orient/publikation/working_papers/dp_o6/index.html

Hassan, K. (2017, April 10). Land dispute continues to threaten Egypt-Sudan ties. Al-Monitor. http:// www.al-monitor.com/pulse/originals/2017/04/sudan-expel-egyptians-halayeb-shalateentriangle.html

Hassanpour, N. (2011). Media disruption exacerbates revolutionary unrest: Evidence from Mubarak's quasi-experiment (SSRN Scholarly Paper ID 1903351). Social Science Research Network. http:// papers.ssrn.com/abstract $=190335^{1}$

Hawksley, H. (2013, July 21). A teenager killed in Alexandria. BBC World. https://www.bbc.com/ news/magazine-23380343

Hay, C. (1996). From crisis to catastrophe? The ecological pathologies of the liberal-democratic state form. Innovation: The European Journal of Social Science Research, 9(4), 421-434. https:// doi.org/10.1080/13511610.1996.9968500

Hay, C. (2013). Treating the symptom not the condition: Crisis definition, deficit reduction and the search for a new British growth model. The British Journal of Politics \& International Relations, 15(1), 23-37. https://doi.org/10.1111/j.1467-856X.2012.00515.X

Hegel, G. W. F. (1910). Vorlesungen über die Philosophie der Geschichte. Philipp Reclam jun.

Heggy, E., Sharkawy, Z., \& Abotalib, A. Z. (2021). Egypt's water budget deficit and suggested mitigation policies for the Grand Ethiopian Renaissance Dam filling scenarios. Environmental Research Letters, 16(7), 1-17. https://doi.org/10.1088/1748-9326/acoac9

Heinzelman, J., \& Meier, P. P. (2013). Crowdsourcing for human rights monitoring: Challenges and opportunities for information collection and verification. In J. Lannon \& E. F. Halpin (Eds.), Human rights and information communication technologies: Trends and consequences of use (pp. 123-138). Information Science Reference.

Herrera, L., \& El-Sharnouby, D. (2018, January 24). Alain Badiou on the Egyptian revolution, seven years later. OpenDemocracy. https://www.opendemocracy.net/north-africa-west-asia/ linda-herrera-dina-el-sharnouby/alain-badiou-on-egyptian-revolution-questions

Herrera, L., \& Mirshak, N. (2018, August 11). Hegemony is never complete: Using Gramsci to understand the Arab uprisings. Truthout. https://truthout.org/articles/hegemony-is-nevercomplete-using-gramsci-to-understand-the-arab-uprisings/

Hess, D., \& Martin, B. (2006). Repression, backfire, and the theory of transformative events. Mobilization, $11(2), 249-267$.

Hidji, A. (2016, May 8). How Cairo was able to stop the April 25 protests. Al-Monitor. http://www. al-monitor.com/pulse/originals/2016/05/egypt-security-thwart-demonstrations-protestsislands-saudi.html

Hill, E., \& Mansour, M. (2013, April 10). Egypt's army took part in torture and killings during revolution, report shows. The Guardian. http:/www.theguardian.com/world/2013/apr/10/ egypt-army-torture-killings-revolution

Hintz, L. (2018a, May 11). How a hashtag and memes are uniting Turkey's opposition [Washington Post]. The Monkey Cage. https://www.washingtonpost.com/news/monkey-cage/wp/2018/05/11/ how-a-hashtag-and-memes-are-uniting-turkeys-opposition/ 
Hintz, L. (2018b). Bread, circus, and subversion: A framework for reading Turkish politics through pop culture [Paper presented at DC Area Comparative Politics Workshop].

Hoffmann, A., \& König, C. (2013). Scratching the democratic façade: Framing strategies of the 20 February movement. Mediterranean Politics, 18(1), 1-22. https://doi.org/10.1080/13629395 .2012 .761474

Holmes, A. A. (2012). There are weeks when decades happen: Structure and strategy in the Egyptian revolution. Mobilization, 17 (4), 391-410. https://doi.org/10.17813/maiq.17.4.905210228n564037

Holmes, A. A. (2013, August 16). Before the bloodletting: A tour of the Rabaa Sit-in. The Cairo Review of Global Affairs. https://www.thecairoreview.com/tahrir-forum/before-the-bloodletting-atour-of-the-rabaa-sit-in/

Holmes, A. A., \& Koehler, K. (2020). Myths of military defection in Egypt and Tunisia. Mediterranean Politics, 25(1), 45-70. https://doi.org/10.1080/13629395.2018.1499216

Howarth, D. R. (1998). Discourse theory and political analysis. In E. Scarbrough \& E. Tanenbaum (Eds.), Research Strategies in the Social Sciences (pp. 268-310). Oxford University Press.

Howarth, D. R. (2013). Poststructuralism and after: Structure, subjectivity and power. Palgrave Macmillan UK.

Howarth, D. R., Norval, A., \& Stavrakakis, Y. (Eds.). (2000). Discourse theory and political analysis: Identities, hegemonies and social change. Manchester University Press.

Howarth, D. R., \& Stavrakakis, Y. (200o). Introducing discourse theory and political analysis. In D. R. Howarth, A. Norval, \& Y. Stavrakakis (Eds.), Discourse theory and political analysis: Identities, hegemonies and social change (pp. 1-23). Manchester University Press.

Howarth, D. R., \& Torfing, J. (Eds.). (2005). Discourse theory in European politics: Identity, policy, and governance. Palgrave Macmillan.

Human Rights Watch. (2013a, July 5). Egypt: Deadly clashes at Cairo University. https://www. hrw.org/news/2013/07/05/egypt-deadly-clashes-cairo-university

Human Rights Watch. (2013b, August 19). Egypt: Security forces used excessive lethal force. https:// www.hrw.org/news/2013/o8/19/egypt-security-forces-used-excessive-lethal-force

Human Rights Watch. (2013c, August 21). Egypt: Mass attacks on churches. https://www.hrw. org/news/2013/o8/21/egypt-mass-attacks-churches

Human Rights Watch. (2013d, December 7). Egypt: Dangerous message for protesters. https:// www.hrw.org/news/2013/12/o7/egypt-dangerous-message-protesters

Human Rights Watch. (2014, August 12). All according to plan: The Rab'a massacre and mass killings of protesters in Egypt. https://www.hrw.org/report/2014/o8/12/all-according-plan/ raba-massacre-and-mass-killings-protesters-egypt

Hunt, S. A., Benford, R. D., \& Snow, D. A. (1994). Identity fields: Framing processes and the social construction of movement identities. In E. Laraña, H. Johnston, \& J. R. Gusfield (Eds.), New social movements: From ideology to identity (pp. 185-208). Temple University Press.

Hürriyet Daily News. (2017, June 22). Turkish municipality erects Rabia sign. http://www.hurriyetdailynews.com/turkish-municipality-erects-rabia-sign-statue-114635

Hutter, S. (2014). Protest event analysis and its offspring. In D. Della Porta (Ed.), Methodological practices in social movement research (pp. 335-367). Oxford University Press.

Ibrahim, G. (2013, August 18). The poster that turned Facebook yellow. The Angry Egyptian: Tahrir \& Beyond. https://theangryegyptian.wordpress.com/2013/o8/18/the-poster-thatturned-facebook-yellow/

IDSC. (2016, April 12). Tiran and Sanafir islands belong to the kingdom of Saudi Arabia [Arabic, on file]. Information \& Decision Support Centre. http://www.idsc.gov.eg/idsc/News/View. aspx?ID=4269 
Imad, A. G. (2014). Islamists between revolution and the state: An epilogue. Contemporary Arab Affairs, $7(2), 283-298$.

Ismail, F. (2011, February 2). Ex-minister suspected behind Alex church bombing. Al-Arabiya. https:// web.archive.org/web/20130120182322/http://www.alarabiya.net/articles/2011/02/07/136723.html

Ismail, S. (2006). Rethinking Islamist politics: Culture, the state and Islamism. I.B. Tauris.

Ismail, S. (2013, July). Mathematics and Egyptians don't mix: June 30 protests figures. The Revolution Fails. https://therevolutionfails.tumblr.com/post/56565464162/mathematicsand-egyptians-dont-mix-june-30

Jasper, J. M. (2008). Getting your way: Strategic dilemmas in the real world. University of Chicago Press.

Jasper, J. M. (2010). Social movement theory today: Toward a theory of action? Sociology Compass, 4(11), 965-976. https://doi.org/10.1111/j.1751-9020.2010.00329.x

Jasper, J. M. (2012). Introduction: From political opportunity structures to strategic interaction. In J. Goodwin \& J. M. Jasper (Eds.), Contention in context: Political opportunities and the emergence of protest (pp. 1-36). Stanford University Press.

Jasper, J. M. (2015a). Introduction: Players and arenas formerly known as the state. In J. M. Jasper \& J. W. Duyvendak (Eds.), Breaking down the state: Protestors engaged (pp. 9-24). Amsterdam University Press. https://doi.org/10.2307/j.ctt196315k.3

Jasper, J. M. (2015b). Introduction: Playing the game. In J. M. Jasper \& J. W. Duyvendak (Eds.), Players and arenas: The interactive dynamics of protest (pp. 9-32). Amsterdam University Press. https://doi.org/10.2307/j.ctt16vj285.3

Jasper, J. M. (2018). The emotions of protest. The University of Chicago Press.

Jasper, J. M. (2019). Afterword: Comparative versus historical research. Social Movement Studies, 18(1), 130-136. https://doi.org/10.1080/14742837.2018.1540348

Jasper, J. M., \& Duyvendak, J. W. (Eds.). (2015). Players and arenas: The interactive dynamics of protest. Amsterdam University Press.

Jasper, J. M., \& Poulsen, J. D. (1995). Recruiting strangers and friends: Moral shocks and social networks in animal rights and anti-nuclear protests. Social Problems, 42(4), 493-512. https:// doi.org/10.2307/3097043

Jasper, J. M., \& Volpi, F. (2018). Introduction: Rethinking mobilization after the Arab uprisings. In F. Volpi \& J. M. Jasper (Eds.), Microfoundations of the Arab uprisings: Mapping interactions between regimes and protesters (pp. 11-40). Amsterdam University Press.

Jasper, J. M., Young, M. P., \& Zuern, E. (2020). Public characters: The politics of reputation and blame.

Johanson, M. (2013, August 7). 'Rabaa tours' seeks brave tourists for trips into Cairo's Pro-Morsi Protest Camp. International Business Times. https://www.ibtimes.com/ rabaa-tours-seeks-brave-tourists-trips-cairos-pro-morsi-protest-camp-1374953

Johnston, H. (2012). State violence and oppositional protest in high-capacity authoritarian regimes. International Journal of Conflict and Violence, $6(1)$, 55-74.

Jørgensen, M., \& Phillips, L. (2002). Discourse analysis as theory and method. Sage.

Joya, A. (2011). The Egyptian revolution: Crisis of neoliberalism and the potential for democratic politics. Review of African Political Economy, 38(129), 367-386. https://doi.org/10.1080/03056 244.2011 .602544

Kamrava, M. (2014). Beyond the Arab Spring: The evolving ruling bargain in the Middle East. Oxford University Press.

Kassab, B. (2016, August 10). Nationalism and generosity fuel the defense of Tiran and Sanafir. Mada Masr. https://madamasr.com/en/2016/o8/10/feature/politics/nationalism-and-generosityfuel-the-defense-of-tiran-and-sanafir/ 
Kassab, B., \& Charbel, J. (2017, January 11). Lawyers, MPs say Tiran and Sanafir are Egyptian. Mada Masr. https://madamasr.com/en/2017/o1/11/feature/politics/lawyers-parliamentarians-saytiran-and-sanafir-are-egyptian/

Kerton, S. (2012). Tahrir, here? The influence of the Arab uprisings on the emergence of Occupy. Social Movement Studies, 11(3-4), 302-308. https://doi.org/10.1080/14742837.2012.704183

Ketchley, N. (2013). The Muslim Brothers take to the streets. Middle East Report, 269, 12-17.

Ketchley, N. (2014). "The army and the people are one hand!" Fraternization and the 25th January Egyptian Revolution. Comparative Studies in Society and History, 56(1), 155-186. https://doi. org/10.1017/Soo10417513000650

Ketchley, N. (2017a). Egypt in a time of revolution: Contentious politics and the Arab Spring. Cambridge University Press.

Ketchley, N. (2017b, July 3). How Egypt's generals used street protests to stage a coup [Washington Post]. Monkey Cage. https://www.washingtonpost.com/news/monkey-cage/wp/2017/07/03/ how-egypts-generals-used-street-protests-to-stage-a-coup/

Ketchley, N., \& Biggs, M. (2014, April 4). What is the Egyptian anti-coup movement protesting for? [Washington Post]. The Monkey Cage. http://www.washingtonpost.com/blogs/monkey-cage/ wp/2014/04/04/what-is-the-egyptian-anti-coup-movement-protesting-for/

Ketchley, N., \& Biggs, M. (2015, August 14). Who actually died in Egypt's Rabaa massacre [Washington Post]. The Monkey Cage. https://www.washingtonpost.com/blogs/monkey-cage/ wp/2015/08/14/counting-the-dead-of-egypts-tiananmen/

Ketchley, N., \& El-Rayyes, T. (2017, March 29). On the breadline in Sisi's Egypt. Middle East Research and Information Project. http://www.merip.org/mero/meroo32917

Keucheyan, R., \& Elliott, G. (2013). Left hemisphere: Mapping critical theory today (2nd ed.). Verso.

Khalili, L. (2009). Heroes and martyrs of Palestine: The politics of national commemoration (1st ed.). Cambridge University Press.

Khamis, S., \& Fowler, R. (2020). Arab resistance in the diaspora: Comparing the Saudi dissident and the Egyptian whistleblower.Journal of Arab \& Muslim Media Research, 13(1), 31-49. https:// doi.org/10.1386/jammr_oooo9_1

Khatib, L. (2006). Nationalism and otherness: The representation of Islamic fundamentalism in Egyptian cinema. European Journal of Cultural Studies, 9(1), 63-8o. https://doi. org/10.1177/136754940606o808

Khawaja, M. (1993). Repression and popular collective action: Evidence from the West Bank. Sociological Forum, 8(1), 47-71.

Khosrokhavar, F. (2018). Violence, social actors, and subjectivation in the Egyptian revolution. In F. Volpi \& J. M. Jasper (Eds.), Microfoundations of the Arab uprisings: Mapping interactions between regimes and protesters (pp. 159-182). Amsterdam University Press.

Kingsley, P. (2014, February 22). How did 37 prisoners come to die at Cairo prison Abu Zaabal? The Guardian. https://www.theguardian.com/world/2014/feb/22/cairo-prison-abu-zabaaldeaths-37-prisoners

Kingsley, P., \& Chulov, M. (2013, July 4). Morsi supporters prepare to defend themselves as tide turns in Egypt. The Guardian. https://www.theguardian.com/world/2013/jul/o4/ morsi-supporters-egypt-muslim-brotherhood

Kingsley, P., \& Green, L. (2013, July 18). Killing in Cairo: The full story of the Republican Guards' club shootings. The Guardian. http://www.theguardian.com/world/interactive/2013/jul/18/ cairo-republican-guard-shooting-full-story

Kirkpatrick, D. D. (2017, December 20). Egypt scrambles to raise turnout in presidential vote. The New York Times. https://www.nytimes.com/2014/o5/28/world/egypt-presidential-election.html

Kohstall, F., Richter, C., Dhouib, S., \& Kastner, F. (2018). Academia in transformation: Scholars facing the Arab uprisings. Nomos. 
Koopmans, R., \& Olzak, S. (2004). Discursive opportunities and the evolution of right-wing violence in Germany. American Journal of Sociology, no(1), 198-23o. https://doi.org/10.1086/386271

Kriesi, H. (2004). Political context and opportunity. In D. A. Snow, S. A. Soule, \& H. Kriesi (Eds.), The Blackwell Companion to Social Movements (pp. 67-9o). Blackwell.

Kuckartz, U. (2010). Einführung in die computergestützte Analyse qualitativer Daten (3rd ed.). Springer VS.

Kurzman, C. (2012). The Arab Spring uncoiled. Mobilization: An International Quarterly, 17(4), 377-39o. https://doi.org/10.17813/maiq.17.4.10326742no556v15

Kurzman, C. (2018). Conclusion: Unruly protest. In F. Volpi \& J. M. Jasper (Eds.), Microfoundations of the Arab uprisings: Mapping interactions between regimes and protesters (pp. 183-192). Amsterdam University Press.

Laclau, E. (1990). New reflections on the revolution of our time. Verso.

Laclau, E. (2005). On populist reason. Verso.

Laclau, E. (2006). Why constructing a people is the main task of radical politics. Critical Inquiry, 32(4), 646-68o. https://doi.org/10.1086/508086

Laclau, E., \& Mouffe, C. (2001). Hegemony and socialist strategy: Towards a radical democratic politics (2nd edition). Verso.

Lawson, F. H. (2017). Egypt versus Ethiopia: The conflict over the Nile metastasizes. The International Spectator, 52(4), 129-144. https://doi.org/10.1080/03932729.2017.1333272

Lawson, G. (2016). Within and beyond the "fourth generation" of revolutionary theory. Sociological Theory, 34(2), 106-127. https://doi.org/10.1177/0735275116649221

Lefort, B. (2019). The good, the bad and the ugly: Narrating social bonds and boundaries in contemporary Lebanon. British Journal of Middle Eastern Studies, 46(4), 663-680. https:// doi.org/10.1080/13530194.2018.1456903

Lichbach, M. I. (1987). Deterrence or escalation? The puzzle of aggregate studies of repression and dissent. Journal of Conflict Resolution, 31(2), 266-297.

Lieberman, E. S. (2005). Nested analysis as a mixed-method strategy for comparative research. American Political Science Review, 99(3), 435-452. https://doi.org/10.1017/Sooo3055405051762

Lieberman, E. S. (2010). Bridging the qualitative-quantitative divide: Best practices in the development of historically oriented replication databases. Annual Review of Political Science, 13(1), 37-59.

Litvak, M. (2010). "Martyrdom is life": Jihad and martyrdom in the ideology of Hamas. Studies in Conflict \& Terrorism, 33(8), 716-734. https://doi.org/10.1080/1057610X.2010.494170

Liu, J. (2011, February 20). Roundabouts and revolutions: The "Arab street" begins and ends in a circle.https://www.vice.com/en_us/article/788d7e/roundabouts-and-revolutions-the-"arabstreet"-begins-and-ends-in-a-circle

Lossow, T. von, \& Roll, S. (2015). Egypt's Nile water policy under Sisi: Security interests promote rapprochement with Ethiopia (SWP Comments C 11). Stiftung Wissenschaft und Politik. https://www.swp-berlin.org/en/publication/egypts-nile-water-policy/

Luker, K. (2009). World views of pro- and anti-abortion activists. In J. Goodwin \& J. M. Jasper (Eds.), The social movements reader: Cases and concepts (2nd ed., pp. 146-160). Wiley Blackwell.

Mada Masr. (2017a, January 15). A timeline of the Tiran and Sanafir islands legal contest. Mada Masr. https://madamasr.com/en/2017/01/15/feature/politics/a-timeline-of-the-tiran-andsanafir-islands-legal-contest/

Mada Masr. (2017b, January 17). Tiran and Sanafir: Between Saudi pressure and a court ruling. Mada Masr. https://madamasr.com/en/2017/o1/17/feature/politics/tiran-and-sanafir-betweensaudi-pressure-and-a-court-ruling/ 
Magued, S. (2018). The Egyptian Muslim Brotherhood's transnational advocacy in Turkey: A new means of political participation. British Journal of Middle Eastern Studies, 45(3), 480-497. https://doi.org/10.1080/13530194.2017.1320975

Mahmoud, N. (2016, April 28). Egypt and the land. Nervana. https://nervana1.org/2016/o4/28/ egypt-and-the-land/

Mahoney, J., \& Goertz, G. (2006). A tale of two cultures: contrasting quantitative and qualitative research. Political Analysis, 14(3), 227-249. https://doi.org/10.1093/pan/mpjo17

Malfait, S. (2014). An Islamist Caesar in Egypt's passive revolution? A discourse theoretical analysis of Morsi's hegemonic project [Master Thesis in Conflict and Development]. Universiteit Gent.

Maney, G. M., Woehrle, L. M., \& Coy, P. G. (2005). Harnessing and challenging hegemony: The U.S. peace movement after 9/11. Sociological Perspectives, $48(3)$, 357-381. https://doi.org/10.1525/ sop.2005.48.3.357

Marchart, O. (2014). Institution and dislocation: Philosophical roots of Laclau's discourse theory of space and antagonism. Distinktion:Journal of Social Theory, 15(3), 271-282. https://doi.org /10.1080/1600910X.2014.966272

Marfleet, P. (2016). Egypt: Contested revolution. Pluto Press.

Martijn de Koning. (2013, September 1). R4bia - the symbolic construction of protest. CLOSER: An Anthropology of Muslims in Europe. https://religionresearch.org/closer/2013/og/o1/ rubia-the-symbolic-construction-of-protest/

Martin, J. L. (2003). What is field theory? American Journal of Sociology, $109(1), 1-49$. https://doi. $\operatorname{org} / 10.1086 / 375^{201}$

Martini, J., Kaye, D. D., \& York, E. (2012). The Muslim Brotherhood, its youth, and implications for U.S. engagement. Rand.

Mason, T. D., \& Krane, D. A. (1989). The political economy of death squads: Toward a theory of the impact of state-sanctioned terror. International Studies Quarterly, 33(2), 175-198. https:// doi.org/10.2307/2600536

McAdam, D. (1983). Tactical innovation and the pace of insurgency. American Sociological Review, 48(6), 735-754. https://doi.org/10.2307/2095322

McAdam, D., \& Sewell, W. H. (2001). It's about time: Temporality in the study of social movements and revolutions. In R. Aminzade, D. McAdam, E. Perry, W. H. Sewell, S. Tarrow, \& C. Tilly (Eds.), Silence and voice in the study of contentious politics (pp. 89-125). Cambridge University Press.

McAdam, D., Tarrow, S., \& Tilly, C. (2001). Dynamics of contention. Cambridge University Press.

McCarthy, J. D., \& McPhail, C. (2005). Protest mobilization, protest repression, and their interaction. In C. Davenport, H. Johnston, \& C. Mueller (Eds.), Repression and mobilization (pp. 3-32). University of Minnesota Press.

McCurdy, P., Feigenbaum, A., \& Frenzel, F. (2016). Protest camps and repertoires of contention. Social Movement Studies, 15(1), 97-104. https://doi.org/10.1080/14742837.2015.1037263

McGarry, A., Davidson, R. J., Accornero, G., Jasper, J. M., \& Duyvendak, J. W. (2016). Players and arenas: Strategic interactionism in social movements studies. Social Movement Studies, 15(6), 634-642. https://doi.org/10.1080/14742837.2016.1199320

McManus, A. (2018). Securitization in Egypt: Between discourse and reality. In I. El-Anis, N. Underhill, \& S. Joharchi (Eds.), Security and insecurity in the Middle East (pp. 1-22). Cambridge Scholars Publishing.

Melucci, A. (1996). Challenging codes: Collective action in the information age. Cambridge University Press.

Miller, C., \& Gulhane, J. (2013, August 14). Mohandessin clashes as sit-ins disperse. Daily News Egypt. https://www.dailynewsegypt.com/2013/o8/14/mohandessin-clashes/ 
Mirshak, N. (2018, November 22). Rethinking resistance in post-uprisings Egypt. OpenDemocracy. https://www.opendemocracy.net/nadim-mirshak/rethinking-resistance-in-post-uprisingsegypt

Mittermaier, A. (2015). Death and martyrdom in the Arab uprisings: An introduction. Ethnos, $80(5), 583-604$. https://doi.org/10.1080/00141844.2014.93809o

Mogahed, D. (2013, July 25). Deep runs the divide [Carnegie Endowment for International Peace]. Sada.http://carnegieendowment.org/sada/index.cfm?fa $=$ show\&article $=52493 \&$ solr_hilite $=$

Moghadam, A. (2014). The globalization of martyrdom. Johns Hopkins University Press.

Mohsen, A. A. (2013, July 9). The killing of Islamist protesters: State censorship or self-censorship? Mada Masr. https://madamasr.com/en/2013/o7/og/news/u/the-killing-of-islamist-protestersstate-censorship-or-self-censorship/

Mohsen, M. (2013, July 10). Arrest warrants for Badie and nine others for Republican Guard clashes. Daily News Egypt. /node/1542?language=en

Monier, E. I., \& Ranko, A. (2013). The fall of the Muslim Brotherhood: Implications for Egypt. Middle East Policy, 20(4), 111-123. https://doi.org/10.1111/mepo.12050

Morayef, S. (2016). Pharaonic street art: The challenge of translation. In M. Baker(Ed.), Translating dissent: Voices from and with the Egyptian Revolution (pp. 194-217). Routledge.

Morris, A. D. (1993). Birmingham confrontation reconsidered: An analysis of the dynamics and tactics of mobilization. American Sociological Review, $58(5), 621-636$. https://doi. org/10.2307/2096278

Morsy, A., \& Brown, N. (2013). Egypt's al-Azhar steps forward. Carnegie Endowment for International Peace. http://carnegieendowment.org/2013/11/07/egypt-s-al-azhar-steps-forward/gtob

Moss, D. M. (2014). Repression, response, and contained escalation under 'liberalized' authoritarianism in Jordan. Mobilization, 19(3), 261-286. https://doi.org/10.17813/ maiq.19.3.9508v72264766ug2

Mostafa, D. S. (2016). The Egyptian military in popular culture: Context and critique. Palgrave.

Mughrabi, M. (2016, April 26). Egypt: Mass arrests in 'ruthlessly efficient' bid to block peaceful protest. Amnesty International. https://www.amnesty.org/en/latest/news/2016/o4/ egypt-mass-arrests-in-ruthlessly-efficient-bid-to-block-peaceful-protest/

Müller, M. (2011). Doing discourse analysis in critical geopolitics. L'Espace Politique. Revue en ligne de géographie politique et de géopolitique, 12. https://doi.org/10.400o/espacepolitique.1743

Mursi, M. (2013a, June 26). Address to the nation on the anniversary of his inauguration [Arabic, on file].

Mursi, M. (2013b, June 26). Address to the nation on the occasion of the anniversary of his inauguration [Arabic, on file].

Mursi, M. (2013c, July 2). Urgent statement by the presidency of the republic [Arabic, on file].

Muslim Brotherhood. (2011, January 26). Statement from the Muslim Brotherhood regarding the events ofJanuary 25 and their aftermath [Arabic]. IkhwanWiki. https://bit.ly/11 1oDUj

Muslim Brotherhood. (2013a, June 29). National Alliance in Support of Electoral Legitimacy's speech to the Egyptian people on the eve of 3 June. Ikhwanweb. http://www.ikhwanweb. com/article.php?id $=31062$

Muslim Brotherhood. (2013b, July 25). Statement by the Anti-Coup Alliance in response to Al-Sisi's speech. Ikhwanweb. https://archive.vn/wip/uVAHa

Muslim Brotherhood. (2013c, August 3). Anti-Coup Alliance statement condemns security forces attack on Friday 2 August. Ikhwanweb. http://www.ikhwanweb.com/article.php?id=31211

Muslim Brotherhood. (2013d, August 6). Anti-Coup Alliance statement affirms no invitation to dialogue received. Ikhwanweb. http://www.ikhwanweb.com/article.php?id=31233

Muslim Brotherhood. (2013e, August 14). Anti-Coup Alliance statement: Major massacre during crackdown against Rabaa and Al-Nahda sit-ins. Ikhwanweb. https://archive.is/wip/Cuuni 
Muslim Brotherhood. (2013f, August 16). The police and the church shoot at the Haram march in Giza Tunnel and on Murad Street [Arabic, on file]. Ikhwanweb.

Muslim Brotherhood. (2016a, April 14). Statement on the signing of the convention on the demarcation of the sea border with Saudi Arabia [Arabic]. Ikhwanonline. https://archive.is/wip/avMzS

Muslim Brotherhood. (2016b, April 14). The Muslim Brotherhood announces their participation in the protests against the sale of the islands of Tiran and Sanafir [Arabic]. Ikhwanweb. https:// bit.ly/2MIZOTS

Muslim Brotherhood. (2016c, April 24). Muslim Brotherhood statement on Sinai Liberation Day calling for protests on April 25. Ikhwanweb. http://www.ikhwanweb.com/article.php?id=32517

Nabers, D. (2017). Crisis as dislocation in global politics. Politics, 37(4), 418-431. https://doi. org/10.1177/0263395716661341

Naeem, M. (2016, June 9). Mother of the world, against the world and outside of it. Mada Masr. http://www.madamasr.com/opinion/mother-world-against-world-and-outside-it

Naeem, M. (2019). In Egypt, nothing has changed - But perhaps everything has. Mada Masr. https:/www.madamasr.com/en/2019/11/13/opinion/u/in-egypt-nothing-has-changed-butperhaps-everything-has/

Nafie, T., Abdel-Fattah, S., Youssef, A.-R., Azzam, H., Darrag, A., Ihab, S., \& Al-Zomar, T. (2016, April 14). Egypt national figures statement urging protests against handover of two islands [Arabic]. Ikhwanweb. http://www.ikhwanweb.com/article.php?id=32505

Nagi, M. (2013a, July 14). Sinai checkpoint attacked. Daily News Egypt. http://www.dailynewsegypt. com/2013/07/14/sinai-checkpoint-attacked/

Nagi, M. (2013b, July 15). No meetings between military and Muslim Brotherhood:FJP spokesperson. Daily News Egypt. http://www.dailynewsegypt.com/2013/o7/15/no-meetings-betweenmilitary-and-muslim-brotherhood-fjp-spokesperson/

Nagi, M. (2013c, July 26). Pro-Morsi march jovial at Al-Nahda Square. Daily News Egypt. https:// dailynewsegypt.com/2013/07/26/pro-morsi-march-jovial-at-al-nahda-square/

NASL. (2013a, July 2). The text of the statement of the National Alliance in response to the statement of the army. https://alaam25o.blogspot.de/2013/o7/blog-post.html

NASL. (2013b, July 3). Statement 4 [Arabic, on file].

NASL. (2013c, July 4). From the field command of the sit-ins to our brothers in the armed forces [Arabic, on file].

NASL. (2013d, July 4). Statement 6 [Arabic, on file].

NASL. (2013e, July 5). On the events of the Friday miliuniya [Arabic]. Facebook. https://archive. vn/wip/ZeiXt

NASL. (2013f, July 7). Statement 9 [Arabic, on file].

NASL. (2013g, July 7). To the Egyptian people [Arabic]. https://archive.vn/wip/XcvSh

NASL. (2013h, July 8). Statement 10 [Arabic]. https://archive.vn/wip/R39Gf

NASL. (2013i, July 11). Statement 12: Principles of the January 25 revolution [Arabic]. Facebook. https://archive.is/wip/lHSRE

NASL. (2013j, July 15). National Alliance in Support of Legitimacy statement condemns coup; calls for peaceful protests. Ikhwanweb. http://www.ikhwanweb.com/article.php?id=31144

NASL. (2013k, July 16). On the formation of the fake government [Arabic]. Facebook. https:// archive.vn/wip/jVhUC

NASL. (2013l, July 16). To the armed forces [Arabic]. Facebook. https://archive.vn/wip/ ${ }_{7} \mathrm{H}_{4} \mathrm{QE}$

NASL. (2013m, July 26). On the massacre of Rabaa al-Adawiya [Arabic]. Facebook. http://bit. ly/2PZfxD6

NASL. (2013n, July 26). Statement 37 [Arabic]. Facebook. https://archive.vn/wip/MuACe 
NASL. (20130, July 27). Regarding the efforts and initiatives put forward within the framework of constitutional legitimacy [Arabic]. Facebook. http://bit.ly/2Q1RaVi

NASL. (2013p, July 29). Statement 42: The National Alliance responded to the allegations of the National Defence Council [Arabic]. Facebook. https://archive.vn/bItCH

NASL. (2013q, August 1). Statement 47 [Arabic]. Facebook. http://bit.ly/2Q1Lvio

NASL. (2013r, August 3). Anti-Coup Alliance statement on US delegation meeting on Saturday.

Ikhwanweb. http://www.ikhwanweb.com/article.php?id=31215

NASL. (2013s, August 3). Statement 49: On the meeting with the US delegation [Arabic]. Facebook. https://archive.vn/wip/2iK3m

NASL. (2013t, August 6). Come join the Rabaa sit-in tour bus [Arabic]. Facebook. https://archive. vn/wip/rgDp3

NASL. (2013u, August 14). Regarding the great massacre which was committed in the dissolution of the two peaceful sit-ins of Rabaa al-Adawiya and Nahda Square [Arabic]. Facebook. https:// archive.is/wip/SBJqD

NASL. (2013v, August 16). Statement 64: On "Friday of Anger" [Arabic]. Facebook. https://archive. $\mathrm{vn} / 4 \mathrm{~W}_{4} \mathrm{Kn}$

NASL. (2013w, August 16). Statement 65 [Arabic]. Facebook. https://archive.vn/wip/7aSzo

NASL. (2013x, August 17). On 'Friday of Anger' murderous crimes by coup commanders [Arabic]. Facebook. https://archive.is/wip/eaMzT

NASL. (2013y, August 17). On the crimes of coup leaders 3 July on Friday of Anger [Arabic]. Facebook. https://www.facebook.com/AllianceSupportingLegitimacy/posts/293449520797418

NASL. (2013z, August 17). What after the slaughter of Egyptians and destruction of houses of worship? [Arabic]. Facebook. https://archive.vn/wip/5WcOS

NASL. (2013aa, August 20). Assessment of position and vision for the future. Facebook. https:// archive.is/wip/8NefH

NASL. (2013ab, August 20). Statement 72: Assessment of the situation and a vision for the future [Arabic]. Facebook. https://archive.is/zczSw

NASL. (2013ac, August 20). Statement 73: A Call to all the Free in Egypt [Arabic]. Facebook. https:// archive.vn/wip/Csnml

NASL. (2013ad, August 25). Statement 78 [Arabic]. Facebook. https://archive.is/wip/S5L86

NASL. (2013ae, September 5). Statement 93 [Arabic]. Facebook. https://archive.is/wip/SOOxQ

NASL. (2016, April 13). National Alliance urges mass protests Friday against junta selling out Egypt. Ikhwanweb. http://www.ikhwanweb.com/article.php?id=32503

Nassauer, A. (2016). From peaceful marches to violent clashes: A micro-situational analysis. Social Movement Studies, 15(5), 515-530. https://doi.org/10.1080/14742837.2016.1150161

Nassauer, A. (2019). Situational breakdowns: Understanding protest violence and other surprising outcomes. Oxford University Press.

Nazra for Feminist Studies. (2013). The dispersion of the Rab'aa sit-in and its aftermath. Nazra. https://nazra.org/sites/nazra/files/attachments/report_on_police_treatment-with_women_protesters_en.pdf

NCHR. (2014). Report of the National Council for Human Rights fact-finding mission about the disperse of Ra-ba'a Al-Adaweya sit-in [Arabic]. National Council for Human Rights. http:// www.nchregypt.org/demo/download_en_news.php?id=503_22125759.pdf

Nepstad, S. E. (2011). Nonviolent resistance in the Arab Spring: The critical role of military-opposition alliances. Swiss Political Science Review, 17(4), 485-491. https://doi. $\operatorname{org} / 10.1111 / \mathrm{j} .1662-6370.2011 .02043 \cdot \mathrm{x}$

Nepstad, S. E. (2013). Mutiny and nonviolence in the Arab Spring: Exploring military defections and loyalty in Egypt, Bahrain, and Syria.Journal of Peace Research, 5o(3), 337-349. https:// doi.org/10.1177/0022343313476529 Article information 
Nicol, A., \& Cascão, A. E. (2011). Against the flow - new power dynamics and upstream mobilisation in the Nile Basin. Review of African Political Economy, 38(128), 317-325.

Noakes, J. A., \& Johnston, H. (2005). Frames of protest: A road map to a perspective. In H. Johnston \& J. A. Noakes (Eds.), Frames of protest: Social movements and the framing perspective (pp. 1-29). Rowman \& Littlefield Publishers.

Noueihed, L. (2014, December 15). Sisters in the vanguard. Reuters. https:/www.reuters.com/ article/us-egypt-brotherhood-women-idUSKBNoJT1PD20141215

Olesen, T. (2009). Social movement theory and radical Islamic activism. In Islamism as social movement (pp. 7-33). CIR Aarhus Universität.

Opp, K.-D., \& Roehl, W. (1990). Repression, micromobilization, and political protest. Social Forces, 69(2), 521. https://doi.org/10.2307/2579672

Ortiz, D., Myers, D. J., Walls, E. N., \& Diaz, M.-E. D. (2005). Where do we stand with newspaper data? Mobilization, $10(3)$, 397-419. https://doi.org/10.17813/maiq.10.3.836or76ok3277t42

Osman, M. (2013a). Press Release on the poll conducted by the Egyptian Center for Public Opinion Research (Baseera) on the 'Rebellion' Campaign. Baseera. http://baseera.com.eg/EN/ PressPoll-Ar/22_En.pdf

Osman, M. (2013b). Baseera public opinion poll on Egyptians'living conditions and their expectations for the future. Baseera. http://baseera.com.eg/baseera/pdf_poll_file_en/Expectations\%2o for $\% 20$ the $\% 20$ Future-en.pdf

Owen, P., \& McCarthy, T. (2013, July 8). $5^{1}$ Morsi supporters killed in shooting at Republican Guard compound. The Guardian. http://www.theguardian.com/world/middle-east-live/2013/ jul/o8/egypt-34-killed-in-shooting-at-compound-where-morsi-is-being-held-live-coverage

Owen, R. (2012). Rise and fall of Arab presidents for life. Harvard University Press.

Pargeter, A. (2010). The Muslim Brotherhood: The burden of tradition. Saqi Books.

Parkinson, S. E., \& Wood, E. J. (2015). Transparency in intensive research on violence: Ethical dilemmas and unforeseen consequences. Qualitative \& Multi-Method Research, 13(1), 22-27. https://doi.org/10.5281/zenodo.893081

PCPL. (2016a, April 10). Opponents to Egypt giving up Tiran and Sanafir: Sign to save the islands of Tiran and Sanafir [Arabic]. Avaaz. https://archive.is/wip/osfSs

PCPL. (2016b, April 22). Founding statement of the Popular Campaign to Protect the Land-Egypt is not for Sale [Arabic]. https://archive.vn/wip/RziUM

PCPL. (2016c, April 22). The Popular Campaign to Protect the Land calls for peaceful demonstrations in rejection of ceding the islands and to stop the repression of the security apparatus. https:// archive.is/cuLyp

PCPL. (2016d, April 24). And if they ask you about the license to demonstrate, ask them for their license to sell the land of Egypt [Arabic]. Facebook. https://archive.vn/wip/pCZep

PCPL. (2016e, June 16). Political parties, national forces, youth movements and public figures announce their participation in a campaign to defend the land "Egypt is not for sale" [Arabic]. Facebook. https://archive.vn/wip/ $\mathrm{P}_{577} \mathrm{O}$

Pearlman, W. (2013). Emotions and the microfoundations of the Arab Uprisings. Perspectives on Politics, 11(2), 387-409. https://doi.org/10.1017/S1537592713001072

Pearlman, W. (2018). Contingency and agency in a turning point event: March 18, 2011, in Daraa, Syria. In F. Volpi \& J. M. Jasper (Eds.), Microfoundations of the Arab uprisings: Mapping interactions between regimes and protesters (pp. 111-134). Amsterdam University Press.

Perlmutter, D. (2013, September 8). A new Muslim Brotherhood symbol: R4BIA. Frontpage Mag. https://www.frontpagemag.com/fpm/203449/new-muslim-brotherhood-symbol-r4biadawn-perlmutter 
Peterson, M. A. (2015a). In search of antistructure: The meaning of Tahrir Square in Egypt's ongoing social drama. In Á. Horváth, B. Thomassen, \& H. Wydra (Eds.), Breaking boundaries: Varieties of liminality (p. 164). Berghahn Books.

Peterson, M. A. (2015b, July 23). Martyrs without a cause? Egypt's revolutionary martyrs as empty signifiers. Connected in Cairo. https://connectedincairo.com/2015/07/23/ martyrs-without-a-cause-egypts-revolutionary-martyrs-as-empty-signifiers/

Pioppi, D. (2013). Playing with fire: The Muslim Brotherhood and the Egyptian Leviathan. The International Spectator, 48(4), 51-68. https://doi.org/10.1080/03932729.2013.847680

Polletta, F., \& Kretschmer, K. (2015). Movement factions: Players and processes. In J. M. Jasper \& J. W. Duyvendak (Eds.), Players and arenas: The interactive dynamics of protest (pp. 35-54). Amsterdam University Press. https://doi.org/10.2307/j.ctt16vj285.4

Pratt, N. (2012, May 25). Old state, new rules: From war of manoeuvre to war of position [University of Oxford Podcast]. https://podcasts.ox.ac.uk/panel-4-old-state-new-rules-war-manoeuvrewar-position?qt-media_player=o\#qt-media_player

Pratt, N. (2015). After the 25January Revolution: Democracy or authoritarianism in Egypt? In R. Abouel-Fadl (Ed.), Revolutionary Egypt: Connecting domestic and international struggles. Routledge.

Pratt, N. (2020). Making sense of the politics of the Egyptian Revolution in and through popular culture. International Journal of Middle East Studies, 52(3), 531-535. https://doi.org/10.1017/ So02074382000069o

Pratt, N., Mostafa, D., Rezk, D., \& Salem, S. (2012, September 20). Port Said Martyrs. Politics, Popular Culture and the 2011 Egyptian Revolution; Suzee in the City. https://egyptrevolution2o11. ac.uk/items/show/6o

R4bia. (2013, August 29). What is R4BIA? https://web.archive.org/web/20130829025501/http:// www.r4bia.com/en/content/what-r4bia

Rabia, R. (2018, July 3). 'Shorouk' publishes the text of the 'treatment of senior commanders of the armed forces' before the adoption. Al-Shorouq. https://www.shorouknews.com/news/view. aspx?cdate $=03072018 \&$ id $=54153$ a77-bog8-43b6-bbb4-9a6640226ed 8

Rahin, A. (2013, July 17). Al-Arian told Al-Hayat: The army contacted us and al-Sisi refused to negotiate with Qandil [Arabic]. Al-Hayat. https://bit.ly/2HhısLD

Raleigh, C., Linke, A., Hegre, H., \& Karlsen, J. (2010). Introducing ACLED: An Armed Conflict Location and Event Dataset special data feature. Journal of Peace Research, 47(5), 651-66o. https://doi.org/10.1177/0022343310378914

Ramzy, C. M. (2015). To die is gain: Singing a heavenly citizenship among Egypt's Coptic Christians. Ethnos, 8o(5), 649-670. https://doi.org/10.1080/o0141844.2014.94326o

Ravid, B., Khoury, J., \& Cohen, G. (2016, April 11). Egypt informed Israel in advance of plan to hand over Red Sea islands to Saudis. Haaretz. http://www.haaretz.com/middle-east-news/1.713870

Rear, D. (2013). Laclau and Mouffe's discourse theory and Fairclough's critical discourse analysis: An introduction and comparison. Critical Policy Studies, 7(4), 375-394.

Rear, D., \& Jones, A. (2013). Discursive struggle and contested signifiers in the arenas of education policy and work skills in Japan. Critical Policy Studies, 7(4), 375-394. https://doi.org/10.1080 /19460171.2013.843469

Rennick, S. A. (2015). The practice of politics and revolution: Egypt's revolutionary youth social movement [Doctoral Dissertation, Lund University]. https://lup.lub.lu.se/search/ws/ files/5309346/5274498.pdf

Reuters. (2013, July 1). Egyptian armed forces chief sets ultimatum. https://www.reuters.com/ article/us-egypt-protests-army-text-idUSBRE96014420130701

Revolutionary Socialists. (2016, April 15). Return to the street: Down with the military rule [Arabic]. The Revolutionary Socialists Official Website. http://revsoc.me/statements/36161/ 
Richards, P. (2011). A systematic approach to cultural explanations of war: Tracing causal processes in two West African insurgencies. World Development, 39(2), 212-220. https://doi.org/10.1016/j. worlddev.2009.11.030

Richter, C. (2015). Ägypten: Paradox von Vielfalt und Gleichschaltung. In C. Richter \& A. Difraoui (Eds.), Arabische Medien (pp. 131-142). UVK.

Richter, C. (2017). Mobilize, justify, accuse: The Egyptian Muslim Brotherhood and changing media practices. In S. Foellmer, M. Lünenborg, \& C. Raetzsch (Eds.), Media practices, social movements, and performativity: Transdisciplinary approaches (pp. 100-113). Routledge.

Rihoux, B., \& Lobe, B. (2009). The case for qualitative comparative analysis (QCA): Adding leverage for thick cross-case comparison. In D. Byrne \& C. Ragin, The Sage handbook of case-based methods (pp. 222-242). SAGE.

Ritter, D. (2014). The iron cage of liberalism: International politics and unarmed revolutions in the Middle East and North Africa. Oxford University Press.

Rivera Celestino, M. (2012). Violence breeds violence: How violent crime affects repression in democratic regimes [Paper presented at the Workshop 'Advancing the Scientific Study of Conflict and Cooperation: Alternative Perspectives from the UK and Japan', 20-21 March 2012]. http://privatewww.essex.ac.uk/ ksg/esrcjsps/Rivera.pdf

RNN. (2013a, July 24). National Alliance: Al-Sisi speech is a call for civil war [Arabic]. Rassd News Network. https://archive.vn/wip/hmZxy

RNN. (2013b, August 6). Erian: Thousands are ready to sacrifice for legitimacy [Arabic]. Rassd News Network. https://rassd.com/68722.htm

RNN. (2013c, August 7). Al-Beltagy states three demands after the return of Morsi [Arabic]. Rassd News Network. https://archive.vn/wip/NodXo

RNN. (2013d, September 11). Endowments prohibit any gatherings in mosques after prayer ends [Arabic]. Rassd News Network. https://rassd.com/71718.htm

RNN. (2016, April 21). Politicians reveal to 'Al-Monitor' the reasons for the success of the April 25 demonstrations [Arabic]. Rassd News Network. https://archive.is/wip/bdfXp

Roccu, R. (2013a). The political economy of the Egyptian revolution: Mubarak, economic reforms and failed hegemony. Palgrave Macmillan.

Roccu, R. (2013b). David Harvey in Tahrir Square: The dispossessed, the discontented and the Egyptian revolution. Third World Quarterly, 34(3), 423-440. https://doi.org/10.1080/0143659 7.2013 .785338

Roll, S. (2010). 'Finance matters!' The influence of financial sector reforms on the development of the entrepreneurial elite in Egypt. Mediterranean Politics, 15(3), 349-37o. https://doi.org/ 10.1080/13629395.2010.517098

Roll, S. (2016). Managing change: How Egypt's military leadership shaped the transformation. Mediterranean Politics, 21(1), 23-43. https://doi.org/10.1080/13629395.2015.1081452

Romanos, E. (2018). The strategic use of humor in the Spanish Indignados/15 M movement. In B. Tejerina \& I. Perugorria (Eds.), Crisis and social mobilization in contemporary Spain: The 15 M Movement. Routledge.

Said, A. (2014, December 10). Regimes and movements: Thoughts on contentious politics and the Arab Spring. Mobilizing Ideas. https://mobilizingideas.wordpress.com/2014/12/10/ regimes-and-movements-thoughts-on-contentious-politics-and-the-arab-spring/

Said, A. (2015). We ought to be here: Historicizing space and mobilization in Tahrir Square. International Sociology, 3o(4), 348-366.

Sailer, M. (2016). Changed priorities in the Gulf: Saudi Arabia and the Emirates rethink their relationship with Egypt (SWP Comments C 8; p. 8). Stiftung Wissenschaft und Politik. https:// www.swp-berlin.org/fileadmin/contents/products/comments/2016Co8_sil.pdf 
Salbi, Z. (2013, August 27). Who Is Rabaa Adawiya? Huffington Post. https://www.huffingtonpost. com/zainab-salbi/who-is-rabaa-adawiya_b_3820109.html

Saleh, Y. (2013, July 24). Egypt's Tamarud youth group backs army call for protests. Reuters. https:// www.reuters.com/article/us-egypt-protests-youth-idUSBRE96NoHV20130724

Sayigh, Y. (2012). Above the state: The officers' republic in Egypt. Carnegie Endowment for International Peace. http://carnegieendowment.org/2012/o8/o1/above-state-officers-republic-in-egypt/d4l2

Schielke, S. (2017). There will be blood: Expectation and ethics of violence during Egypt's stormy season. Middle East Critique, 26(3), 205-220. https://doi.org/10.108o/19436149.2017.1336023

Schulte, B. (2002, August 9). Obey Giant: The mandate that grabbed a generation. Washington Post. https:/www.washingtonpost.com/archive/lifestyle/2002/o8/og/obey-giant-the-mandatethat-grabbed-a-generation/d2046ofc-e110-4e39-8ba4-69cogcd44686/

Schwedler, J. (2016). Taking time seriously: Temporality and the Arab uprisings. Project on Middle East Political Science. https://pomeps.org/2016/o6/10/taking-time-seriously-temporalityand-the-arab-uprisings/

Schwedler, J. (2018). Routines and ruptures in anti-Israeli protests in Jordan. In F. Volpi \& J. M. Jasper (Eds.), Microfoundations of the Arab uprisings: Mapping interactions between regimes and protesters (pp. 67-88). Amsterdam University Press.

Schwedler, J., \& Harris, K. (2016). What is activism? Middle East Report, 281, 2-5.

Scott, J. C. (2000). Weapons of the weak: Everyday forms of peasant resistance (Reprint). Yale University Press.

Sewell, W. H. (1996a). Historical events as transformations of structures: Inventing revolution at the Bastille. Theory and Society, 25(6), 841-881. https://doi.org/10.1007/BFoo159818

Sewell, W. H. (1996b). Three temporalities: Toward an eventful sociology. In T. J. McDonald (Ed.), The historic turn in the human sciences (pp. 245-248). University of Michigan Press.

Sewell, W. H. (2009). Logics of history: Social theory and social transformation. University of Chicago Press.

Shadid, A., \& Kirkpatrick, D. D. (2011, February 10). Mubarak refuses to step down, stoking revolt's fury and resolve. The New York Times. https://www.nytimes.com/2011/02/11/world/ middleeast/11egypt.html

Shahin, E. (2015, June 9). The four traits Sisi, Hitler and Mussolini have in common. Middle East Eye. http://www.middleeasteye.net/columns/four-traits-sisi-hitler-and-mussolini-havecommon-1427651880

Shamni, N. (2013). Punitive measures against athletes for flashing four-finger 'pro-MB'sign spark controversy In Egypt (MEMRI Inquiry \& Analysis Series Report No. 1048). MEMRI. https:// www.memri.org/reports/punitive-measures-against-athletes-flashing-four-finger-pro-mbsign-spark-controversy-egypt

Shams El-Din, M. (2016, August 14). The Rabea sit-in dispersal: Who the state is blaming three years on. Mada Masr. https://madamasr.com/en/2016/o8/14/feature/politics/ the-rabea-sit-in-dispersal-who-the-state-is-blaming-three-years-on/

Shantz, J. (2000). A post-Sorelian theory of social movement unity: Social myth reconfigured in the work of Laclau and Mouffe. Dialectical Anthropology, 25(1), 89-108.

Shenker, J. (2016). The Egyptians: A radical story. Penguin.

Sherlock, R., \& Samaan, M. (2013, August 15). Grief of Muslim Brotherhood leader's family at death of teenage daughter. Telegraph. https://www.telegraph.co.uk/news/worldnews/ africaandindianocean/egypt/10245865/Egypt-Grief-of-Muslim-Brotherhood-leaders-familyat-death-of-teenage-daughter.html

Shokr, A. (2014, August 16). The massacre one year later. Middle East Research and Information Project. http://www.merip.org/massacre-one-year-later

Shokr, A. (2015). The 18 days of Tahrir. Middle East Report, 41(258), 14-17. 
Sika, N. M. (2017). Youth activism and contentious politics in Egypt: Dynamics of continuity and change. Cambridge University Press.

Siméant-Germanos, J. (2021). Conceptualizing contexts or contextualizing concepts? On some issues of the modeling of relational spaces in the study of collective action. Social Movement Studies, 2o(2), 139-154. https://doi.org/10.1080/14742837.2019.1629899

Slaby, J., Mühlhoff, R., \& Wüschner, P. (2019). Affective arrangements. Emotion Review, n1(1), 3-12. https://doi.org/10.1177/1754073917722214

Sly, L., \& Al-Hourani, S. (2013, August 15). Egypt authorizes further use of live ammunition against pro-Morsi protesters. Washington Post. http://www.washingtonpost.com/world/scores-deadin-egypt-after-security-forces-launch-assault-on-protesters-camp/2013/08/15/563c95ao0575-11e3-ao7f-49ddc7417125_story.html

Smaldone, T. (2015). The Arab uprisings and the blossoming of a 'global imaginary'. Inquiries Journal, $7(6), 1-3$.

Sobhi, S. (2016, April 21). Speech of the Commander-in-Chief of the Armed Forces, Minister of Defence and Military Production on the proceedings of the 22nd educational symposium [Arabic, on file]. Egypt Ministry of Defence Official Website.

Sobhy, H. (2015). Secular façade, neoliberal Islamisation: Textbook nationalism from Mubarak to Sisi. Nations and Nationalism, 21(4), 805-824. https://doi.org/10.1111/nana.12147

Soudias, D. (2015). Policing January 25: Protest, tactics, and territorial control in Egypt's 2011 uprising. Middle East - Topics \& Arguments, 4(1), 170-182. https://doi.org/10.17192/meta.2015.4.2669

Spiegel, J. B. (2016). Performing "in the red": Transformations and tensions in repertoires of contention during the 2012 Quebec student strike. Social Movement Studies, 15(5), 531-538. https://doi.org/10.1080/14742837.2016.1196126

Springborg, R. (2018). Egypt. Polity.

Stein, E. (2012). Revolution or coup? Egypt's fraught transition. Survival, 54(4), 45-66. https://doi. org/10.1080/00396338.2012.709388

Stratfor. (2016, April 15). Building bridges between Egypt and Saudi Arabia. https://www.stratfor. com/analysis/building-bridges-between-egypt-and-saudi-arabia

Strong Egypt Party. (2016a, April 14). Tiran and Sanafir belong to all Egyptians [Arabic]. Facebook. https://www.facebook.com/MisrAlQawia/photos/a.492672350759920.128763.478976282129 527/1362555427104937/?type=3\&theater

Strong Egypt Party. (2016b, April 23). Press release [Arabic]. Arabi21. https://archive.vn/eoqnP

Strong Egypt Party. (2016c, April 23). Strong Egypt Party announces 15 reasons for the departure of Sisi [Arabic]. Arabi21. https://archive.is/wip/TyXC3

Students Against the Coup. (2016, April 13). Students Against the Coup to take part in Friday mass demonstrations across Egypt [Arabic]. Ikhwanweb. http://www.ikhwanweb.com/article.php?id=32506

Suleiman, Y. (1996). Language and identity in Egyptian nationalism. In Y. Suleiman (Ed.), Language and identity in the Middle East and North Africa (pp. 25-38). Curzon Press.

Suter, M. (2016, May 11). Everything you need to know about the raid on Egypt's press syndicate. Atlantic Council. http://www.atlanticcouncil.org/blogs/menasource/ everything-you-need-to-know-about-the-raid-on-egypt-s-press-syndicate

Svendsen, K. D. (2014). The articulation of resistance and the Arab 'Spring': A post-structuralist perspective [Thesis in global studies]. Roskilde University.

Tahrir Institute for Middle East Policy. (2017). Tiran and Sanafir:Developments, dynamics, and implications. The Tahrir Institute for Middle East Policy. https://timep.org/wp-content/ uploads/2017/08/Tiran-and-Sanafir-Developments-Dynamics-and-Implications-web.pdf

Tamarod. (2016a, April 11). The word of Abdel Nasser belies Al-Sisi [Arabic]. Facebook. https:// www.facebook.com/watch/?v=1156772357696247 
Tamarod. (2016b, April 13). Call for demonstrations on April 15, 2016. Facebook. https://www. facebook.com/TAMROUD/posts/1158333357540147

Tamarod. (2016c, April 13). Facebook post calling for the fall of the regime [Arabic]. Facebook. https://www.facebook.com/TAMROUD/posts/1158642677509215

Tammam, H. (2012). The Muslim Brotherhood:Pre-revolution years. Dar al-Shorouq.

Tarrow, S. (2001). Silence and voice in the study of contentious politics: Introduction. In R. Aminzade, D. McAdam, E. Perry, W. H. Sewell, S. G. Tarrow, \& C. Tilly (Eds.), Silence and voice in the study of contentious politics (pp. 1-10). Cambridge University Press.

Tarrow, S. (2010). Bridging the quantitative-qualitative divide. In H. E. Brady \& D. Collier (Eds.), Rethinking social inquiry: Diverse tools, shared standards (2nd ed., pp. 101-110). Rowman \& Littlefield Publishers.

Telmissany, M. (2014). The utopian and dystopian functions of Tahrir Square. Postcolonial Studies, 17(1), 36-46. https://doi.org/10.1080/13688790.2014.912194

Teti, A., \& Gervasio, G. (2011). The unbearable lightness of authoritarianism: Lessons from the Arab uprisings. Mediterranean Politics, 16(2), 321-327. https://doi.org/10.1080/13629395.2011.583758

Teti, A., Matthies-Boon, V., \& Gervasio, G. (2014, June 10). Sisiphus. Middle East Research and Information Project (MERIP). http://www.merip.org/mero/meroo61014

Tharoor, I. (2016, July 15). Turkey's Erdogan always feared a coup. He was proved right. Washington Post. https://www.washingtonpost.com/news/worldviews/wp/2016/o7/15/ turkeys-erdogan-always-feared-a-coup-he-was-proved-right/

Thornhill, M. T. (2006). Road to Suez: The battle of the canal zone. Sutton.

Tilly, C. (2003). The politics of collective violence. Cambridge University Press.

Tilly, C. (2005). Repression, mobilization, and explanation. In C. Davenport, H. Johnston, \& C. Mueller (Eds.), Repression and mobilization (pp. 211-226). University of Minnesota Press.

Tilly, C. (2008). Contentious performances. Cambridge University Press.

Torfing, J. (1999). New theories of discourse: Laclau, Mouffe, and Z̆ ižek. Blackwell Publishers.

Tripp, C. (2013). The power and the people: Paths of resistance in the Middle East. Cambridge University Press.

Underhill, H. (2016). Translating and diaspora politics: Narrating the struggle at 'home' and 'abroad'. In M. Baker (Ed.), Translating dissent: Voices from and with the Egyptian Revolution (pp. 45-59). Routledge, Taylor \& Francis Group.

Valbjørn, M., \& Volpi, F. (2014). Revisiting theories of Arab politics in the aftermath of the Arab uprisings. Mediterranean Politics, 19(1), 134-136. https://doi.org/10.1080/13629395.2013.856185

Van de Sande, M. (2013). The prefigurative politics of Tahrir Square: An alternative perspective on the 2011 revolutions. Res Publica, 19(3), 223-239. https://doi.org/10.1007/s11158-013-9215-9

Van de Sande, M. (2015). Fighting with tools: Prefiguration and radical politics in the twenty-first century. Rethinking Marxism, 27(2), 177-194. https://doi.org/10.1080/08935696.2015.1007791

Van Dijk, T. A. (1990). Discourse \& Society: A new journal for a new research focus. Discourse \& Society, 1(1), 5-16. https://doi.org/10.1177/0957926590001001001

Van Dyke, N., \& McCammon, H. J. (Eds.). (2010). Strategic alliances: Coalition building and social movements. University of Minnesota Press.

Van Leuven, D. (2014, May 25). Morsi and transitional justice: Peace vs. justice \& implications for a post-Brotherhood Egypt. Al Nakhlah. https://alnakhlah.org/2014/05/25/morsi-and-transitionaljustice-peace-vs-justice-implications-for-a-post-brotherhood-egypt-by-dallin-van-leuven/

Verhoeven, I., \& Bröer, C. (2015). Contentious governance: Local governmental players as social movement actors. In J. W. Duyvendak \& J. M. Jasper (Eds.), Breaking down the state: Protestors engaged (pp. 95-110). Amsterdam University Press. https://doi.org/10.2307/j.ctt196315k.7 
Vicari, S. (2015). The interpretative dimension of transformative events: Outrage management and collective action framing after the 2001 anti-G8 summit in Genoa. Social Movement Studies, 14(5), 596-614. https://doi.org/10.1080/14742837.2014.995076

Villumsen Berling, T. (2011). Science and securitization: Objectivation, the authority of the speaker and mobilization of scientific facts. Security Dialogue, 42(4-5), 385-397. https://doi. org/10.1177/0967010611418714

Volpi, F. (2014). Framing political revolutions in the aftermath of the Arab uprisings. Mediterranean Politics, 19(1), 153-156. https://doi.org/10.1080/13629395.2013.856186

Volpi, F., \& Clark, J. A. (2019). Activism in the Middle East and North Africa in times of upheaval: Social networks' actions and interactions. Social Movement Studies, 18(1), 1-16. https://doi.or g/10.1080/14742837.2018.1538876

Volpi, F., \& Jasper, J. M. (Eds.). (2018). Microfoundations of the Arab uprisings: Mapping interactions between regimes and protesters. Amsterdam University Press.

Wackenhut, A. F. (2018). Ethical considerations and dilemmas before, during and after fieldwork in less-democratic contexts. The American Sociologist, 49(2), 242-257. https://doi.org/10.1007/ s12108-017-9363-Z

Wacquant, L. J. D. (2019). Making class: The middle class(es) in social theory and social structure. In S. G. McNall (Ed.), Bringing class back in: Contemporary and historical perspectives. Routledge. https://doi.org/10.4324/9780429033612

Waever, O. (1995). Securitization and desecuritization. In R. D. Lipschutz (Ed.), On security (pp. 46-86). Columbia University Press.

Wagner-Pacifici, R. (2010). Theorizing the restlessness of events. American Journal of Sociology, 115(5), 1351-1386. https://doi.org/10.1086/651299

Wahba, D. (2017). Rabea: How do we live with ourselves after witnessing a massacre? Mada Masr. https://www.madamasr.com/en/2017/08/17/opinion/u/rabea-how-do-we-live-with-ourselvesafter-witnessing-a-massacre/

Wahba, D. (2020). A thug, a revolutionary or both? Negotiating masculinity in post-revolutionary Egypt. Middle East - Topics \& Arguments, 14, 56-65. https://doi.org/10.17192/meta.2020.14.8265

Walker, E. T., Martin, A. W., \& McCarthy, J. D. (2008). Confronting the state, the corporation, and the academy: The influence of institutional targets on social movement repertoires. American Journal of Sociology, 114(1), 35-76.

Walker, K. (2013, February 3). Egypt-Saudi bridge: Is the government sacrificing natural resources for short-term gains? Egypt Independent. https://ww.egyptindependent.com/ egypt-saudi-bridge-government-sacrificing-natural-resources-short-term-gains/

Walsh, D. (2016, April 10). Egypt gives Saudi Arabia 2 islands in a show of gratitude. The New York Times. http://www.nytimes.com/2016/04/11/world/middleeast/egypt-gives-saudi-arabia2-islands-in-a-show-of-gratitude.html

Wedeen, L. (1999). Ambiguities of domination: Politics, rhetoric, and symbols in contemporary Syria. University of Chicago Press.

Wedeen, L. (2002). Conceptualizing culture: Possibilities for political science. The American Political Science Review, 96(4), 713-728.

Weipert-Fenner, I. (2021). Go local, go global: Studying popular protests in the MENA post-2011. Mediterranean Politics.

Weizman, E., Fisher, B., \& Moafi, S. (2015). The roundabout revolutions. Sternberg Press.

Werbner, P., Webb, M., \& Spellman-Poots, K. (2014). The political aesthetics of global protest: The Arab Spring and beyond. Edinburgh University Press.

Wessel, S. (2016). Grey-scales: Negotiating the civil state in post-revolutionary Egypt (CARPO Study: The Dawla Madaniyya Series No. 3). CARPO. https://carpo-bonn.org/ 
wp-content/uploads/2016/12/CARPO_Study_03_2016_Wessel.pdf?fbclid=IwAR1xw91dRRjp9wRIW_oxoPdhQK $7 \mathrm{Y}_{2} \mathrm{GoMo}$-id_V7 MoslqGV5zRjKbWifoFw

Wessel, S. (2017). The making of political representation. Processes of claim-making and receiving during the Egyptian transformations (2011-2014) [Doctoral Dissertation]. Universität Hamburg.

Wessel, S. (2018). The 'third hand' in Egypt. Middle East Law and Governance, 10(3), 341-374. https://doi.org/10.1163/18763375-01003006

Westall, S., \& Perry, T. (2013, March 13). Food price rises put restive Egypt on edge. Reuters. https://www.reuters.com/article/us-egypt-food/food-price-rises-put-restive-egypt-onedge-idUSBRE92CoPW20130313

Whittier, N. (2014). Rethinking coalitions: Anti-pornography feminists, conservatives, and relationships between collaborative adversarial movements. Social Problems, 6r(2), 175-193. https://doi.org/10.1525/sp.2014.12151

Wickham, C. R. (2013). The Muslim Brotherhood: Evolution of an Islamist movement. Princeton University Press.

Wiki Thawra. (2014). Statistical Database of the Egyptian Revolution. Statistical Database of the Egyptian Revolution. https://wikithawra.wordpress.com/

Yates, L. (2015). Rethinking prefiguration: Alternatives, micropolitics and goals in social movements. Social Movement Studies, 14(1), 1-21. https://doi.org/10.1080/14742837.2013.870883

Yilmaz, I., Barton, G., \& Barry, J. (2017). The decline and resurgence of Turkish Islamism: The story of Tayyip Erdoğan's AKP. Citizenship and Globalisation Studies, $1(1), 48-62$. https://doi. org/10.1515/jcgs-2017-0005

Yohannes, O. (2001). Political economy of an authoritarian modern state and religious nationalism in Egypt. Edwin Mellen Press.

Youssef, B. (2016, April 9). Come closer Pasha, a billion for an island, two for a pyramid, and on top some statues as a gift [Tweet]. https://twitter.com/DrBassemYoussef/status/718914530823311361

Youssef, M., Arafa, H., \& Kumar, A. (2014). Arab revolutions: Breaking fear: Mediating discourse of democratic uprising in Egypt: Militarized language and the "battles" of Abbasiyya and Maspero. International Journal of Communication, 8(1), 871-889.

Zakarevičiūtè, I. (2015). Telling the stories of martyrs: The cases of the Egyptian and Lithuanian revolutions. Journal of Contemporary Central and Eastern Europe, 23(2-3), 213-230. https:// doi.org/10.1080/0965156X.2015.1116793

Zeinobia. (2018, September 8). Rabaa Sit-in dispersal trial: Death sentences, life sentences and Shawkan is free at last... somehow. Egyptian Chronicles. https://egyptianchronicles.blogspot. com/2018/og/rabaa-sit-in-dispersal-trial-death.html 


\section{Index}

Abdeen Palace 233

Abdel Aal, Ali $\quad 252$

Abdel-Ghaffar, Magdy 231

Abdelghani, Mohamed 239-40

Aboul-Foutuh, Abdel Moneim $\quad 215-6,250,280$

Abu Ismail, Hazen Salah 82

accountability $\quad 33,82,98,112-3,216,259$

al-Adly, Habib $\quad 72,162$

Adly, Malek 235

adversarial framing 60

'Afarit did al-Inqilab $174-5,178$

affective dynamics $\quad 52-4,61,99,119,121,136-7$, $151,199,254-5,288$

agency $47,62,99,145^{-6}, 278,282$

agents provocateurs $\quad 52,219$

Alexandria $51,54,80,108,135,162,166,170$, $174,178,215,228,238$

Algeria 164

Ali, Khaled $\quad 216,234-5,238$

Ali, Mohamed 287

alliances see coalition-building

Amn Watany $126,190,205,224-6,230-1$

Amnesty International $\quad 141,166$

Anan, Sami $\quad 71,74$

ancient Egypt $149-50,200,247$

antagonism $27,48,58-63,76,85,94-6,100-7$,

$114,119,179,202-3,242,253-5,260-4,279,283$

Anti-Coup Alliance

activism from abroad $191-4,234$

collective identity $91,94,96-8,114,134$, $137-9,143,181,275$

constitution as political player $\quad 93-6$

construction of antagonist other 100-7, 110-4, 179

decentralization $\quad 167-72,175,178,181,275^{-6}$

deep state discourses $\quad 96,110-4$

depictions of coup regime $\quad 154-9$

depictions of the media $101,105^{-6}, 108$

depictions of the military $102-6,108,110-2$, $124,157,180$

depictions of the police $102-6,108,179-80$

depictions of al-Sisi $112,115,120,251$

diversification $167,173-8,181,275-6$

establishment of 82

exile 191-4

extremist elements $\quad 160-2$

female mobilization $\quad 167,173-4$

geographical spread of protests $93,167-9$, 191

involvement in PCPL protests $\quad 243-4,247$, $251,260-4$

judicial proceedings against 117

leadership decapitation $\quad 175^{-6}, 180,281$

legitimacy $90-4,97-100,106,119,134,163$, 166, 179-81, 200-1, 261, 275-6, 279 martyrs $127,134,137,141,143,145^{-} 6,149^{-} 5^{1}$, $154-6,159,163,170,177$

moral discourses $\quad 111,126-7,150-9,180$

nonviolence $14,17,98,100,108,110,115,123$, $127,134,144,151-3,161-6,180-1,275$

protests $13-4,17,19,34,81-3,90-3,107-27$, 133-81, 190-4, 204, 275, 279

protest frequency $\quad 92-3,168-73,191$

protest turnout $92-3,159,167,170-2$

repression $14,16-8,34,92-3,99,103,107-27$, 133-81, 189-99, 206-7, 275-6, 279-8o

responses to Rabaa al-Adawiya massacre $\quad 133-81$

self-defense units $\quad 164$

tactical adaptations $\quad 167-78,181,275^{-6}$, 279

trials of arrested protesters $\quad 195^{-6}$

violence $108,117,160-6,196,281$

youth mobilization $\quad 167,173-4,176-7$

anti-corruption protests $\quad 287-8$

anti-Islamist units $\quad 126$

Aoun, Michel 213-4

April 6 movement 120, 205, 215, 228-30, 232, $240,243,246-7,257,260,263$

Arab Contractors company 217

Arab Spring $16,19-24,45^{-6}, 5^{0-1}, 61,113,137$,

$143,147,214,257,272$

arenas $22-3,31-3,35,46-9,56-7,62,233-6,254$, $272-3,281-4$

armed forces see military

arson 103-4, 160-3

articulation $29,56-8,62$

Askar Kazeboon 79

al-Assad, Bashar 120

asset freezes 189-90, 205

Assiut $160,177-8,238$

authoritarianism $13,19-21,24,29,34-5,46,85$, $97,99,112-4,158,181,200-8,258,261,264-5$,

$272,277-83,286$

Awad sold your land $\quad 244-6,258$

Ayez haqqi! (2002) 244-5

Al-Azhar University 90-1, 124-5, 169, 172

Aziz, Mohammed Abdel 79

backfire effects $22,134,159,223,264,285$

backlashes $17-8,22,50-4,114-5,134,153$,

$159-62,181,273,279,285$

Badeen Hamdy 71

Badie, Mohammed $\quad 107,156,195$

Badr, Amr 239

Badr, Mahmoud $79,9^{\circ}$

Bahrain $5^{2}$

baltagiya $101,104,108,117,165,257$

al-Banna, Hassan 140,156

al-Banna, Sayed 235 
el-Baradei, Mohamed 79, 90, 113, 198, 215, 221, 281

Barakat, Hisham $\quad 117,197$

barricades 54, 135-6, 164

Bashir, Omar 288

batil $\quad 157-8$

Battle of the Camel $\quad 52,99,149$

el-Beblawi, Hazem $\quad 113,126$

Bedouin 178, 214

al-Beltagy, Asmaa $\quad 140,15^{6}$

al-Beltagy, Mohamed 121-2, 124, 140, 156, 161, 190, 195

Beni Suef 108

bin Salman, Mohamed 224, 237

black banner 144, 166

Black Lives Matter movement $\quad 141$

border demarcation agreement $\quad 215,218-28$, 234-8, 241-4, 249, 252-3, 258, 263-4, 278

Bouazizi, Mohamed 51,147

boundary framing 60

boycotts 78,177

Bread and Freedom Party $215,237-8,280$

Building and Development Party 82

butterfly protests $178,191,226$

Cairo see individual locations

Cairo University $\quad$ 92, 99, 104, 248

Camp David peace treaty $214,249-50$

capitalism $\quad 25,55-6,58-9,141$

censorship $116,122,193,196,239,287$

Central Security Forces (CSF) 109-10, 115, 121,

$135^{-6}, 172,189,229,237,257$

Chahine, Yousef $157-8$

Change Youth Coalition 174

chants $123,152,158,214,216,254-7,259-60$

characterization $\quad 85,96,110-11$

charities 190

checks and balances $\quad 70,236-7$

child casualties $110,115,15^{2}$

Christianity $90,117,123,149-50,160-2,192$, 257-8

citizenship $\quad 51,95,97,201-2$

civil disobedience 167,177

civil rights 139,141

civil service law 238

civil society $\quad 28-9,203-7,216,238,272,278,285$

class $26-8,48-9,55-6,61,85,137-8$

coalition-building $19,22,27-8,31,35,45-6,60$ $3,76-7,82,85^{-6}, 97,134,155,175,180,215^{-16}$, 226, 228, 253-65, 272-3, 276-8, 280-1, 285

collective identity $\quad 26-7,60-1,91,93,96-8,114$, 134, 137-9, 143, 181, 226, 247, 254, 264, 274-5, 283-4

collective memory $99,123,136-7,145,150,249$, 254,264

colloquial language $\quad 79,222,243,246-7$

colonialism $148,264,289$

commemoration $91,145,148-50,154,177,230$

Committee to Protect Journalists 239 community $\quad 137-9$

comparative analysis $\quad 45,282$

compound players $44,47-9,61,77,96,238$, $254,272-3,278,280-2$

consensus $16,19,26,34,56,90,94,215$

consent $25-6,30,34,55,179,202$

constitution $75^{-8}, 200-3,231,242,244,251$,

253,274

Constitution Party $\quad 215,236-7$

Constitutional Assembly $\quad 75^{-6}, 78$

constitutional declaration $75-8,85,274$

constitutionality $76,97,106-7,223,237,242$,

274

constructivist approaches 44

contentious events $29,32,50,273-4$

contentious interactions $45,49-52,92-3,224$, $238,273,279,284$

contingency $22,35,46,47,50,55,59,94,278$

convoys $177-8,232-3$

Coptic Christianity 9o, 117, 123, 149-50, 160-2, $257-8$

corruption $51,96,99,238,251,259,287-8$; see also moral corruption

counter-hegemony $\quad 24-6,62,241,274$

counter-narratives $119,123-4$

counterrevolution $18-9,45,101,105-7,109$, $157-8,181$

coups d'état

195291

2013 13-4, 19, 33-4, 86, 89-90, 100-1, 256-7, $262,273-5,282$

2016 Turkish coup attempt $\quad 142,282$ courts

Cairo Criminal Court 195

Court of Cassation $\quad 196$

Court of Urgent Matters 189, 236

International Criminal Court 122

military courts $71,74,196,204$

State Council Administrative Court (SCAC) $\quad 235^{-6}$

Supreme Administrative Court (SAC) $\quad 235^{-6}$

Supreme Constitutional Court (SCC) 70, $78,89,236-8$

crimes against humanity $17,122,139,155$

critical junctures $16,31,49-52,54,59,62,179$,

$215,284-5$

cross-class mobilization $\quad 27-8,46,61,85,137-8$ cross-ideological mobilization $27,46,61,85$,

$137-8,145,150,180,216,226,228,254-6,260-5$ cross-movement coalitions $\quad 27,31,191,216$,

226, 228, 255-6, 260-5, 281

curfews $\quad 172,178,189$

Cyprus $\quad 244,259$

Damanhur 108

Damietta 159

Daniel, Mina $\quad 258$

death sentences $195^{-6}$ 
decentralization $\quad 167-72,175,178,181,226,275^{-6}$ deep state $\quad 35,73,80,96,110-4,277$ de-escalation 134,167

defections 23

democracy $14,20,45-6,69,76,90,94,97,113$, 159, 200-1, 259, 272, 275-6

Democratic Current Party $\quad 228$

democratization $\quad 20,45^{-6}$

demographic change $\quad 25$

detention see imprisonment

diagnostic framing $60,105^{-6}, 242$

diaspora 191-4, 234-5

difference, relations of $\quad 58-63,95-6$

disappearances $72,206-7,243,287$

discourse analysis $\quad 301-4$

discourse theory $31-3,44,55-60,62-3,282-5$, 301-4

disinformation see misinformation

dislocations $\quad 58-9,62,110,271-2,284-5$

diversification $\quad 167,173^{-8}, 181,275^{-6}$

Doctors Against the Coup 175

Doctors Syndicate $\quad 230,232,238$

Doss, Moheb 79

Dostour Party see Constitution Party

economic liberalization $\quad 25$

Egypt is not for sale! Campaign 35,215 , 224-65, 277-9, 287

Egyptian Center for Economic and Social Rights 235

Egyptian Initiative for Personal Rights 135 Egyptian Islamic Jihad $82,147-8$

Egyptian Revolutionary Council (ERC) 192 empty signifiers $94,112,141,241,246,265$

Engineers Against the Coup 175

equivalence, relations of $58,60-3,95-6,102$, 200

Erdogan, Recep Tayyip 141-2, 213

el-Erian, Essam 161, 195

escalation $\quad 92-3,117,126-7,134,167$

Essex School 31-2, 55

ethics $307-8$

Ethiopia 244, 288-9

European Union $\quad 125$

event data 298-301

exile 191-4

extrajudicial violence $\quad 206-7,243$

Ezzat, Mahmoud 190

Facebook see social media

Factions $47,94,138,260,262$

Fairey, Shepard 246

false flag operations 108,162

farasha protests $178,191,226$

Al-Fateh Mosque $\quad 154-6$

Fayoum 160,178

female casualties $115,117,145,15^{2}$

female mobilization $167,173-4$; see also

Muslim Sisterhood fifth column $\quad 101,104-5,113$

film $157-8,244-5$

floating signifiers $84-5,94,272$

folk tales $244-5,25^{8}$

food prices 80,208

framing $50,54-5,60,63,90,94-5,102,105-6$, $112,124,146,154,180,206-7,218-9,224,232$, 241-4, 250-1, 254, 261

Freedom and Justice Party (FJP) 14, 69-70, 74, $77,81-2,86,90,103,105-6,117,121,124,138$, 161-2, 169, 190-2

Freedom for the Brave 237

freedom of assembly $\quad 204-5,258$

freedom of speech $\quad 25$

French Revolution $\quad 5^{0-1}$

Friday of Anger

$201121,73,153,159$

$2013153-4,159-60,170$

Friday of Land and Honor 224, 227-9, 231, $244,257-8$

Friday of Martyrs $\quad 170$

Friday of Rejection $\quad$ 107-9

Front to Defend Egyptian Protesters

(FDEP) 224-6, 229

fuel shortages $80-1$

Future of the Homeland Party 230

Gama'a al-Islamiya $\quad 72,82,114,160,169,191$

General Intelligence Service $\quad 196$

Giza $81,92,100,178,232-3$

Gomaa, Mohamed Mukhtar 169-70

graffiti 142, 149-50, 245-7

Grand Ethiopian Renaissance Dam (GERD) $\quad 289$

grassroots mobilization $\quad 25,78-9,100,117-8$ $138,160,162,192,259-60,281$

grey wolf salute 142

grievances 20, 26, 28, 121, 146, 149-50, 199-200, 208, 216, 259, 285

hadith 147,154

Haftar, Khalifa 290

Hala'ib Triangle 244,288

Hamas $120,147,163,191,251$

Hashtags $\quad 213,224,243,245,248,25^{8}$

hate speech 160-1

Hegazi, Safwat 195

hegemony $19,24-6,30,34,55,59,94,203$, $264-5,272,274-7,280,283-4,286$

heroism $60,96,111,134,137,140,143,146,148$, 159

hired thugs $\quad 52,77,99-101,103-4,178$

historical events $15-19,30-1,49-50,62,264-5$; see also transformative events

Hizbullah 147

Homeland Security see Amn Watany

human chains $173,176-8,226,257$

human dignity $27,139,207,259$

Human Rights Campaign 141 
human rights organizations $17,71,121,124$,

$$
134-5,166,195,205-6
$$

Human Rights Watch 135

humiliation $149,200,207,223$

Ibrahim, Mohamed 101, 126

iconography $99,139-44,146,149-50,246-7,257$ imprisonment $72,135,174-6,195-6,204,206-7$, 224-6, 230-1, 235, 253, 258-6o

Information and Decision Support Center (IDSC) 221

intelligence services $24,71,75,190,196$; see also Amn Watany, General Intelligence Service

interactionist approaches $\quad 20-3,31-3,44-5$, 61-2, 272, 278-84

international organizations 122

internet shutdown 21

interviews $35,80,109,306-8$

Inventory, Seizure, and Management Committee 190

Islamic State 166

Islamism $14,17-8,34,72-5,78,81-2,85,90-1$, $102-6,120,126-7,133,137,145,154,160-4,169$, 174-5, 179-8o, 19o, 197-203, 216, 219, 26o-4, 274-5; see also Anti-Coup Alliance; Muslim Brotherhood

Ismailiya 148,159

Israel $53,148,214,221,230,233,244,248-5^{\circ}$, 259,264

Istanbul $\quad 52,191-4$

Ittihadiya palace protests $\quad 76-8,103$

jihadism $71-2,82,117,124,144,147-8,166,180$, 264

Jordan 53, 191, 193, 290

Journalists Against Torture Observatory 239 Journalists Syndicate see Press Syndicate Judiciary $\quad 70^{-1}, 75^{-6}, 121,189,219,235^{-6}, 260,274$ Justice and Development Party (AKP) 142, 191-2

Karama Party $\quad 233,236$

Kefaya movement $\quad 26,28,79,174,179$

Kerdasa 160

kidnapping see disappearances

King Abdullah Bridge $\quad 217,221$

Land, The (1968) $\quad 157-8$

Lawyers Against the Coup 175

leadership decapitation $\quad 175^{-6}, 180,281$

Lebanon 213-4

legal battles $233-8,253,260,263$

liberalism $35,71,75,77-8,138,192,205,261$

Libya $\quad 289-90$

liminality $15,17,5^{0}, 59$

London 191, 193

looting $103-5,160-2$

Luxor 108
Maadi 159, 233

machine guns $115,121,156$

Mahlab, Ibrahim 217-8

Mahmoud, Abdel Meguid $\quad 76$

Mandate Friday $120-3,165$

Mansour, Adly $\quad 89,113,118,126-7,195,196$

Mansoura $117-8,176,228$

al-Maqdis, Ansar Bayt 166

martial law $166,189,198$

martyrdom $53,99,110,121,127,134,137,140-1$, $143-59,163,170,177,179,25^{8}$

Marxism $55^{-6}$

massacres

Andijan massacre 133

Bloody Sunday Massacre 52

Minassa massacre $121-4,126$

Maspero massacre $123,150,258$

Piazza Fontana massacre $\quad 136-7$

Rabaa massacre $11,16-9,30,34,93,133-9$, $143,145^{-6}, 150-2,155,158-9,171,175,180-1$, $189,193,195^{-8}, 204,275^{-6}, 284,301,306-7$

Republican Guard massacre $\quad 93,107$, 109-12, 114-7, 121, 134, 146, 164-5

Sharpeville Massacre $\quad 5^{2}$

Tiananmen Square massacre 133

mass trials $195^{-6}$

meaning $23,30,32-3,44,53-8,61-2,141,241-2$, $265,271-3,284-5$

media $14,17,83-6,89,100-8,113,115-20,123$, $136,150,161,177-8,190,193-4,198,218,222$, 230, 233, 239, 253

memes $245^{-6}$

Al-Mesaha Square $\quad 232-3$

methodology $11,32-5,49,53,280-1,285$, 295-304

micro-level approaches $\quad 21,31,46-7,53$

Midan moments 61,255

military

Anti-Coup depictions of $102-6,108,110-2$,

$$
124,157,180
$$

associations with Nasr City 91

attacks on $160,165^{-6}$

boycott of associated enterprises 177 commemoration of fallen personnel 148 cooperation with media 84

corruption 287

coups see coups d'état

declare nationwide state of alert $\quad 120$

dissolution of Parliament 70

increased powers against protesters $\quad 126-7$

issues ultimatum to Mursi 84,86

leadership purged and reshuffled by

Mursi 71-2, 74-5

martial law $166,189,198$

military courts $71,74,196,204$

military intelligence 71,75

military police 71

as a people's army $34,102-5,110,118$, 198-203, 276 
propaganda $116-7$

quiet entente $73-5,112,274$

rehabilitation of $34,197-203,276$

repression of PCPL protests $\quad 231-3$

Republican Guard 107, 109-10, 112

role in Mubarak regime 24,74

shielded from prosecution 196

support for Tamarod campaign $80,83-6$,

109

Supreme Council of Armed Forces

(SCAF) 70-2, 74-5, 84, 117, 124, 150, 195, $198,228,241,256,274$

violence $16-7,92-3,109-12,114-5,121-3$, $135^{-6}, 157,199$

Minassa massacre 121-4, 126

Ministry of Defense 136,196

Ministry of Education $\quad 238$

Ministry of Interior $\quad 73,80,85,95,101,103$, 116-7, 120, 126, 175, 205-6, 219, 227, 231, 287

Ministry of Religious Endowments $\quad 169,172$

Ministry of Social Solidarity $190,205,238$

misinformation $\quad 72,106,117$

Misr Qawiya $110,215,228,250,25^{8-9}, 263,280$

mixed methods $\quad 32-3,35,285,295-304$

modernization 24,112

Mohamed Mahmoud Street $\quad 75,149,229$

Mohammed, Prophet 124,154

Mohammed Ali Pasha 201

Mohandessin 159, 229-30, 233

molotov cocktails $\quad 105,109,136,166$

moral discourses $57,60,111,126-7,150-9,180$, 207, 221-4

moral corruption $\quad 60,111,147,152,154-9,180$

moral shock $18,51,139$

moral superiority $29,57,60,111,126-7,150-4$, $157,180,276$

mosques $105,114-5,154-5,169-70,172,178$

motivational framing 60

Mouwafi, Mourad 71

Mubarak, Husni

assassination attempts $\quad 72$

declares National Police Day 148

electoral margins 201

final public speech $\quad 149$

handling of Tahrir protests 158,223

legitimacy $16,24-6,98,271-2$

nationalist discourses 202

ousting of $14-6,23,5^{2-3}, 70,73-4,158,228$, 271-2

policies 25

retrial ordered by Mursi 72

role in Israeli withdrawal from Sinai 233

succession crisis 25

Mubarak regime $14,24-6,52,61,74,101,112$, $126,156,158,223$

murals see graffiti

Mursi, Mohamed

arrest $89-90,103,107,112,198$

Cairo stadium speech $\quad 82,86$ characterizations of 85

charged with murder and conspiracy $\quad 120$

constitutional declaration $75-8,85,274$

coup against $13-4,19,33-4,86,89-90,100-1$, $256-7,262,273-5,282$

defiance of military and judiciary $\quad 7^{0-1}$

election 14, 19, 79, 85-6, 179, 201

final presidential address 100-1, 105

inauguration and presidential oath 69-70

legitimacy $14,71,75-8,81-2,84-6,93-4$, $97-8,119,179,274-5,277$

military issues ultimatum to 84,86

Muslim Brotherhood membership $\quad 13,85$

policies 14, 19, 70-3, 179, 199-200

presidential pardons $\quad 72$

purges and reshuffles military leadership $71-2,74-5$

resignation of cabinet members 83

seizure of assets 190

transitional justice measures $\quad 71-2,76$

Muslim Brotherhood

activism from abroad $\quad 191-4$

affiliation with Hamas 163

Anti-Coup Alliance involvement 13-4, 34, 81-4, 91, 96-7, 107-8, 114-22, 138, 143-4, 161-3, 169-70, 173-81, 189-94, 196, 198-205, 243-4, 251, 26o-4, 276

collusion with military $\quad 72-5,274$

counter-demonstrations $\quad 77-8$

designated as terrorist organization 120 , $143,189-90,203-5,227$

dominance of governing institutions 69 71,75

exile 191-4

female mobilization $\quad 173$

looting and arson of premises $\quad 77,103$

media outlets $116,122,161,193$

political arm see Freedom and Justice Party

recruitment $169-70$

repression of $14,63,90,103-4,107,116$, 120, 122, 143, 169-70, 173-6, 189-94, 196, 198-205

rise to power with Mursi $69-75,84-6$

support for the PCPL $\quad 216,243^{-4}, 247,25^{1}$, 260-4

and the 2011 Tahrir protests

violence $77-8,161-2$

youth mobilization 174

Muslim Sisterhood 173

Mustafa Mahmoud Square $\quad$ 159, 229-30

Mustaqbal Watan 202

myths $53,90-1,94,118,127,145,15^{2}$

al-Nahda Square $\quad 16-7,81-2,92-3,100,103,118$, $126,134,137-9,153,160,167-8,175,181,195$, 276

narratives $24,29,51-5,60-2,73,84-5,93-6$, $110-6,119,123-6,143,148,15^{8-9}, 214,220,273$, 284-7 
Nasr City $\quad 17,81-2,91,126,178$

Nasr Street $\quad 93,121,126,134-6,164-5$

Nasser, Gamal Abdel $\quad$ 91, 142, 202, 241, 245, 248-9

National Alliance in Support of Legitimacy (NASL) see Anti-Coup Alliance

National Council for Human Rights (NCHR) 195

National Day of the Martyr 148

National Defence Council (NDC) $\quad$ 126-7

National Democratic Party (NDP) 74, 101, 105

national identity $16,150,200-1,247$

National Police Day $\quad 148-9$

National Salvation Front (NSF) $\quad 76-7,83,85$, $90,101,105,108,110,113,120,198$

national security $18,34,97-8,100,106-7,126-7$, 189-90, 200, 203-4, 208, 214-19, 240-2, 276-7, 286, 289; see also securitization

National Security Service (NSS) see Amn Watany

national sovereignty $76,148,214,217,220$, 241-2, 244, 247-9, 264, 288

nationalism $34-5,53,93,98,105,142,148-50$, 153-4, 165, 181, 197-203, 208-9, 214-9, 226, 230, 240-65, 276-9, 286-7

Nazra for Feminist Studies 135

neoliberalism 25

nested analysis see mixed methods

NGO law 205-6

Nile Water Crisis $\quad$ 244, 259, 288-9

No to Military Trials coalition 71

nodal signifiers $\quad 58-9,91,93-5,100,106,123$, 241,256

non-governmental organizations (NGOs) 190, 205-6; see also human rights organizations

nonviolence $14,17,98,100,108,110,115,123$, $127,134,144,151-3,161-6,180-1,275$

Northern Ireland $\quad 5^{2}$

Nour Party $74,86,90,110,120$

OBEY giant 246

Occupy movement $\quad 5^{1}$

Organization of Islamic Cooperation $\quad 219$

outrage $17-8,51-3,60,151,214-5,227$

Palestine $\quad 120,140,150,163,251$

path dependencies $19,50,77,93,179-81,276$, 284

Parliament $\quad 70,75^{-6}, 97,196,222,236-7$, $239-40,242,252-3$

patriotism $84,148-9,151,153,157,197,199,202$, $215,241-4,251,254,256,263,265$

peacefulness see nonviolence

peacekeeping 214, 249

Pearl Roundabout, Manama $\quad 5^{2}$

petitions $\quad 78-81,103,253$

pharaonic imagery $149-50,247$

players $22-3,28-32,35,44,46-9,62,94-6,236$, $254-6,272-3,278,280-4$ polarization $34,71-3,77,90,114,162-4,179-81$, $197,219,260-4,275,277,280$

police

Anti-Coup depictions of $102-6,108,179-80$ attacks on $117-8,160,162,165-6$

authorization of protests 204

handling of Tahrir Square protests 21, 26,272

increased powers against protesters $\quad 126-7$ interactions with protesters $\quad 20-3,29$

prevent Anti-Coup occupation of new squares 159,170

repression of PCPL protests 226,229 , 232-3, 257

riot police $22,26,78,103,107-9,156,229$, $232-3,257,264,272$

support for Tamarod campaign $\quad 80,84,103$ taking sides against the Brotherhood and FJP $77-8,103,159,170$

targeting of journalists $\quad 239$

violence $14,16-8,52,54,92-3,103-4,107-8$, $121-3,133-6,147,152,156-7,172,195,198-9$

political opportunity structures $20,46,273$

political prisoners $71,174,236,258-60$; see also imprisonment

political process theory 46

political subjectivation $26-8,44,49,58-61,63$, $110,119,133,150,179,199,274$

pop culture $158,241,244-7$

Popular Campaign to Protect the Land

(PCPL) 215, 218, 224-65, 273, 277-9, 281, 287

Popular Current Party $\quad 215$

popular legitimacy $179,272,280$

popular sovereignty $70,94,119,241-2,253-4$

popular will $34,85-6,90,94,97-8,106,119$, $180,198-202,241-4,276$

populism 25, 58, 200, 207

Port Said $176,178,215,228$

Poststructuralism 26, 29, 31

power outages 80

prayer 110, 115, 146, 154, 169, 172, 257-8

presidential pardons 72

Press Syndicate $\quad 228-30,232,237,239,257$

production, relations of $55^{-} 6,5^{8}$

prognostic framing $60,100,166,254$

propaganda $116-7,148,177,181,193$

protest cycles $31,49,53,259,282$

protest event analysis $33,35,164,279,285$, 298-301, 305

protest frequency $\quad 92-3,168-73,191,224-5$

protest law 204-5, 228, 231, 233

protest turnout $21,83,86,92-3,119,159,167$, 168-72, 224-5, 230, 237

public space restrictions $107,166,169-70,180$, 198, 226, 229, 232

Al-Qaeda 166

Qandil, Hazem 110

Qatar 191-2, 194 
Qena 228

quiet entente $73-5,112,274$

Qur'an 124, 147, 154, 157

Qur'an schools 169

Rabaa Al-Adawiya

martyrs $127,134,137,141,143,145^{-6}, 149-51$, $154-6,159,163,170,177$

massacre $11,16-9,30,34,93,127,133-9,143$, $145^{-6}, 150-2,155,158-9,171,175,180-1,189$, $193,195-8,204,275^{-6}, 284,301,306-7$

mosque $81,136,145,155,197$

saint $139,142-3$

salute $139-44,196,260$

square $16-9,30,34,81-2,91-3,96,103,108$, $117-8,120-6,133^{-} 81,189,195^{-8}, 275^{-6}, 281$ trials $195^{-6}$

radio 245

Ramadan $71,114,127,139$

Ramadan amnesty 71

Ramses Square $154-5,159,229$

reconciliation initiatives $117-8,125,153$

recruitment $18,50-1,60,170,245$

Red Sea islands protests $19,34-5,215^{-6}, 223^{-}$ 65, 277-9, 287; see also Tiran and Sanafir referenda $74,78,86,97,200,253,288$

Regeni, Giulio $\quad 25^{8}$

regime change $\quad 258-9,264$

relational approaches $\quad 21,32-3,46,282$

repertoires of action $\quad 29,35,91,97,133,159$, $162-79,181,207-8,226-7,275^{-6}$

repression

of anti-corruption protests 287

of the Anti-Coup Alliance 14, 16-18, 34, 92-3, 99-100, 103, 107-27, 133-81, 189-99, 206-7, 275-6, 279-80

backlashes against $\quad 17-8,22,50-4,114-5$, $134,153,159-62,181,273,279,285$

discursive aspects $\quad 29-30,43,197-200,203$

excessive levels of $18,5^{2}, 114-5,121,127$, $133,162,195,198$

of human rights organizations $\quad 205^{-6}$

of Islamism $\quad 73,169$

indiscriminate and reactive use $14,18,31$, $52,114-5,122-3,127,134-5$

investigations into $108,115,134-5,195,205$

of the PCPL $\quad 224-6,228,230-2,237-9,253$, $257,260,263$

popular mandate for $118-20,123$

randomization of 206-7

relation to mobilization $17-20,22,31,51-4$, $114-5,121-3,134,136-7,159,279,282$

relation to oppositional violence $163-6,276$

of Tahrir Square protests $15-6,52,71$, 99-100, 158, 257

see also violence

Republican Guard 107, 109-10, 112

Republican Guard massacre $\quad 93,107,109-12$, $114-17,121,134,146,164-5$
Revolutionary Socialists $\quad 205,215,228-30$, 257,264

Revolutionary Youth Coalition 174

riot police $22,26,78,103,107-9,156,229$, $232-3,257,264,272$

Riyad, Abdel Moneim 148

rule of law $70,97,106-7,123,179,241-2,25^{0-3}$

ruptures $53,5^{8-9}, 284$; see also critical junctures; dislocations

Sabahi, Hamdeen 215

Sadat, Anwar $91,112,142,245$

Said, Khaled $\quad 51,54,146-7$

al-Sakka, Mahmoud 239

Salafism 74, 82, 86, 9o, 110, 144, 16o, 166

Salah Salem Street $\quad 93,107,109-10$

Salman, King of Saudi Arabia 217, 221, 248, $25^{2}$

Salvation and Development Party 82

satellite channels $120,177,193$

Saudi Arabia $19,34-5,214-27,233-4,237,241-4$ 247-53, 262, 290

Sawt al-Shahid magazine $\quad 151$

Al-Sayeda Zainab Square $\quad 229$

scientism 220-1

Scott, James $\quad 286$

sectarianism $96-7,101,117,160-2,196,262$

secularism, 44, 138

securitization $18-9,34,113,116-7,123-7,143-4$ 180-1, 189-90, 197-200, 203-8, 214-24, 232, 240-2, 251, 276-7, 28o, 286; see also national security

semantic networks $\quad 35,95$

separation of powers 76,112

Shafik, Ahmed 85

shahada 144,147

shahid $146-8$

Sharm el-Sheikh 214, 217

shoot-to-kill policies $114-5,121,135,172$

Shura Council 70

signification, politics of 29

Sinai $71,103,117,148,166,178,202,214,223$, 230, 232-3, 248-9, 251, 264

Sinai Liberation Day $\quad 219,224,226,229-33$, 250, 258-62

al-Sisi, Abdel Fattah announces Mursi's arrest and transitional measures 89-90,100, 198

Anti-Coup depictions of $112,115,120,251$

as Defense Minister $74,83,93,101,118-20$, 198

election $\quad 201$

future prospects $19,286-90$

introduces protest and NGO laws $204-6$, 228

legitimacy $119-20,201,208,215,218-9$, 226-7, 263, 278, 286-7

mandate speech $\quad 118-20,123,197$

military intelligence role 75 
moral discourses $\quad 207,221-4,226$ nationalist discourses $201-3,208,214-6$, 218-9, 240-54, 264-5, 277-9, 286-7 presidency $19,196,201-8,214-65,286-90$ promotion to Field Marshall 195 Red Sea islands speech 218-24 transfers Red Sea islands to Saudi Arabia $\quad 214-65,277-8,287$ war on terror $18,119-20,124,126,197$, 203-4, 216, 277

Six-Day War 249

slogans $18,57,61,82-3,97,123,143-4,216,243$, $246,254-6,25^{8}, 260$

small-scale mobilization $\quad 279$

snipers $\quad 115,121,124-5,135^{-6}, 15^{2}$

Sobhi, Sedki 74, 232

social contract $\quad 24-5,107,208,240$

Social Democratic Party 237

social media $\quad 17,79,116,123,141,144,150-1$, $161,164,178,193,213,218,224,227,232,234$, $243-6,248,250,257-8,281$

social movement studies $18,20-3,31-3,45-6$, $54,60,283$

social service organizations 190

social transformation $\quad 25,28,33,279$

socialism 77,205

solidarity $14,35,52,59-61,97,134,137,140-3$, $146,151,174,180,204,223,244,254-5,276$, 285,287

sources $\quad 299-300,302,305-7$

sovereignty see national sovereignty; popular sovereignty

State Council Administrative Court (SCAC) $\quad 235^{-6}$

State Council Commissioner Authority (SCCA) 235

state media $84,101,113,116-20,123$

state of emergency 172,198

State Security Service see Amn Watany

state terrorism $\quad 107,124,206-7$

state violence $14-8,30,34,51-4,92-3,99-100$, 107-2, 121-7, 133-9, 145-59, 172, 195-9, 206-7, $243,276,279-80$; see also repression

status quo $19,24,28,59,86,113,118,199,274$, $280,285^{-6}$

stone-throwing $\quad 54,109,116,136,166$

strategic interaction $\quad 22-3,28,31-3,47-9,56-7$, 282-3

street art 142, 149-50, 245-7

Strong Egypt Party see Misr Qawiya

structuralist approaches $\quad 45-6,55,272$

Students Against the Coup 174, 176, 244

subversion 19, 54, 84-5, 124, 213-4, 226, 240-53, $265,273,278,285$

Sudan $191,244,288$

Suez 238,287

Suez Canal 177,248

Sufism 142-3

Suleiman, Omar 223
Supreme Administrative Court (SAC) $\quad 235^{-6}$ Supreme Constitutional Court (SCC) 70, 78, $89,236-8$

Supreme Council of Armed Forces (SCAF) 70$2,74-5,84,117,124,150,195,198,228,241$, 256,274

symbolism 24, 29-30, 50-5, 96, 99, 139-44, 148, $154,158,213-6,247,254-7,271,279,286$

Syria $115,120,140,271$

Tadamon coalition $\quad 238$

Tahrir Square

Battle of the Camel $\quad 52,99,149$

commemorations of 1952 coup 91

inauguration of Mursi $\quad 69-70$

Tamarod protests $14,81-5,91,142,179$

2011 protests $14-6,19,21,23-7,46,51-2,61$, $71,73,85,98-100,137,143,149,158,169$, $174,180,223,254-8,261,271-2$ 2016 student protests $\quad 238$

takfir 156,194

Taksim Square, Istanbul $\quad 5^{2}$

Tamarod movement $\quad 14,19,78-86,90-1,95$, 101-5, 108-10, 120, 142, 163, 179, 198, 200, 202, 216, 246-8, 254-7, 261-3, 273-4, 280-1

tamsir al-lugha $\quad 246-7$

Tantawi, Mohammed Hussein $\quad 71,74,256$

Tawadros II 90, 16o

Tayaran Street $\quad 135^{-6}$

Al-Tayyeb, Ahmed 9o, 124-5, 169

teargas $54,121,152,159,229,233,238$

television $17,84,90,101,105,113,116-20,177$, 193-4, 218, 230; see also media

terrorism 18, 34, 59, 93, 117-20, 123-6, 143-4, $161,167,181,189-90,195-8,203-4,216,227$,

277

theocracy 75,85

third hand $104-5,113$

Tiran and Sanafir $19,34-5,214-65,277-9,287$, 290; see also Red Sea islands protests

torture $51,54,72,117,123,166,196,207,239$, $25^{8-9}$

tourism 214

transformative events $\quad 30-3,49-55,58-9,62$, $77,93,107,167,181,197,224,264-5,272-5$, 284-5; see also historical events

transitional justice $\quad 71-2,76,121-2$

treason against the nation $199,241-4,247-51$, $253-4$

Tunisia $\quad 51,147$

Turkey $52,141-2,191-4,213,234,282,290$

turning-point events see transformative events

Twitter see social media

Two Saints Church, Alexandria 162

United Kingdom $\quad 191,193,249$

United Nations $\quad 122,249$

United States $\quad 59,125,248-50$ 
unity $48,104,107,144,180,257-8,261,280-1$ usra cells 181,191

utopic experiences $\quad 137-8$

victimhood $28,60,94-7,99,110,145^{-6}, 179$ violence

by the Anti-Coup Alliance $108,117,160-6$, 196,281

extrajudicial violence $\quad 206-7,243$

by hired thugs $\quad 52,77,99-101,103-4,178$

by the military $16-7,92-3,109-12,114-5$, 121-3, 135-6, 157, 199

by police $14,16-18,5^{2}, 54,92-3,103-4$, $107-8,121-3,133-6,147,152,156-7,172$, $195,198-9$

sectarian violence $117,160-2,196$

state violence $14-8,30,34,51-4,92-3$,

99-100, 107-12, 121-7, 133-9, 145-59, 172,

195-9, 206-7, 243, 276, 279-80 and transformative events $15-7,51-4,181$ see also repression

war on terror $18,119-20,124,126,197,203-4$, 216, 277

Wasat Party 82,306

Wiki Thawra 92, 121, 175

Women Against the Coup 173

Youssef, Bassem $\quad$ 217, 245

Youth Against the Coup 174,176

Youth Leadership Program 227

youth mobilization $\quad 22,35,71,76,78-9,97,149$, $167,173-7,215,223,227-9,238,263$

Youth Movement for Justice and Freedom 215, 228,263

zero-sum game discourses 114,124

Zionism 105, 141, 223, 248-50 
